Szegedi Tudományegyetem

Természettudományi és Informatikai Kar

Földtudományok Doktori Iskola

Gazdaság- és Társadalomföldrajz Tanszék

\title{
A KÖRNYEZETI IGAZSÁGOSSÁG TÉRBELI VIZSGÁLATÁNAK LEHETŐSÉGEI MAGYARORSZÁGON
}

\author{
Doktori (Ph.D.) értekezés
}

\author{
Nagy Gyula \\ Témavezető \\ Dr. Boros Lajos \\ egyetemi docens
}

Szeged

2019 


\section{Tartalomjegyzék}

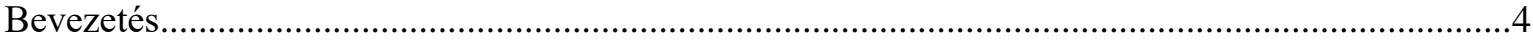

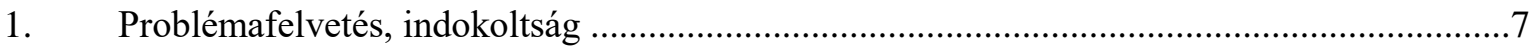

2. A dolgozat célkitüzései és hozzá kapcsolódó fó kérdései ...................................................14

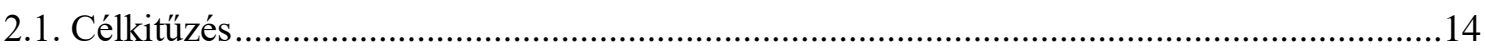

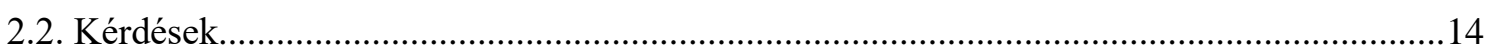

2.3. A kutatás során alkalmazott módszerek ............................................................... 16

2.3.1. A környezeti igazságosság mérése főkomponens analízis módszerével ..................16

2.3.2. Kérdőíves, interjús felmérés, dokumentumelemzés ............................................19

3. A környezeti igazságtalanság földrajztudományi elméleti keretbe illeszkedése ................21

4. A környezeti igazságosság kialakulása ..................................................................24

5. Környezeti igazságosság a posztszocialista országokban ....................................................27

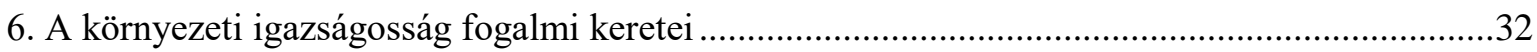

6.1. Környezet fogalom értelmezési lehetőségei a környezeti igazságosságban ......................34

6.2. Az igazságosság értelmezési aspektusai a környezeti igazságosság-kutatásokban..............36

6.3. A döntési mechanizmus szerepe a környezeti igazságtalanság kialakulásában, top-down és bottom-up megközelítések .......................................................................... 41

6.4. A környezeti igazságtalanság érintettjeinek attitüdjei................................................44

6.5. A kockázatok lakossági értékelése és érzékelése ......................................................47

6.6. A környezeti igazságtalanság időbelisége, ex ante és ex post igazságtalanságok...............48

6.7. A lépték szerepe a környezeti igazságtalanságok vizsgálatában.....................................51

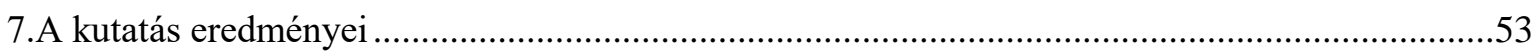

7.1. Környezeti igazságtalanságokkal potenciálisan érintett területegységek lehatárolása..........53

7.2. A disszertáció kiválasztott mintaterületeinek a bemutatása .............................................58

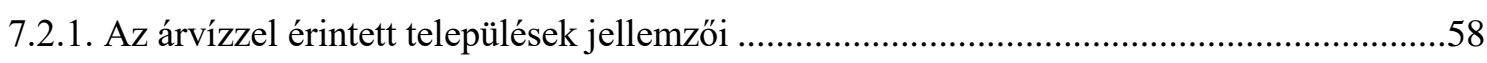

7.2.1.1. Boldvai árvizes mintaterület bemutatása és a felvételezés módszertana......................58

7.2.1.2. A beregi Tiszamente és borsodi Sajó- és Bódvavölgy mintaterület módszertani jellemzői 60

7.2.2. A belvízzel érintett területek jellemzői, Szeged-Baktó és Domaszék 62

7.2.3. A vörösiszappal érintett Kolontár-Devecseri mintaterület felmérésének módszertana .....65

7.3. A kutatás során vizsgált mintaterületek környezeti igazságosság-szempontú összehasonlító

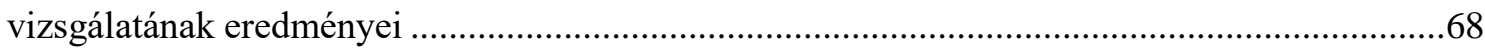

7.3.1. A félelem-érzet hasonlóságai és különbségei a mintaterületeken .................................68

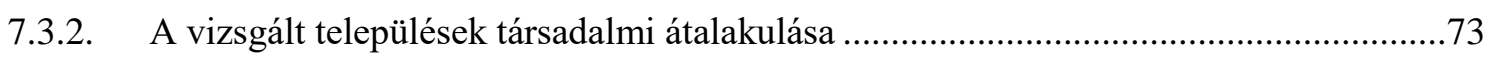

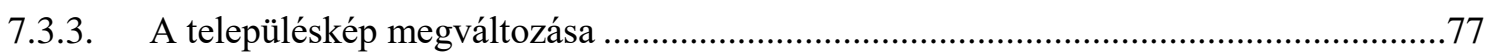

7.3.4. A katasztrófákat követő segítségnyújtás szubjektív értékelése, az érdekérvényesítő-

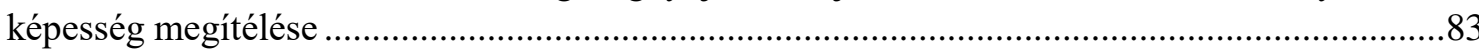

7.3.5. Érdekérvényesítő képesség megítélése ...........................................................91 
7.3.6. Tájékoztatás és információ-hozzáférés a mintaterületeken .......................................92

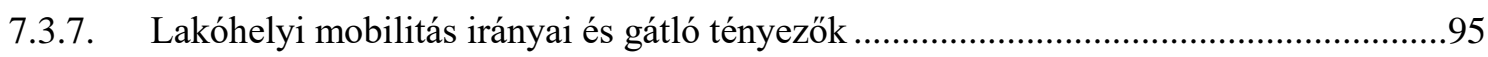

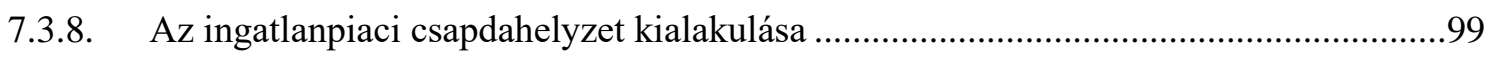

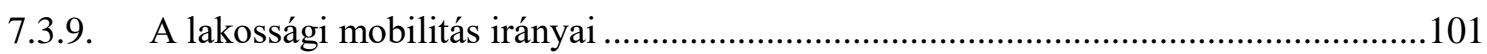

7.3.10. A katasztrófák egészségügyi vonatkozásai az érintettek szemszögéből ......................107

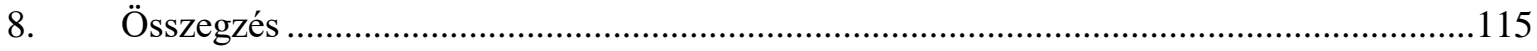

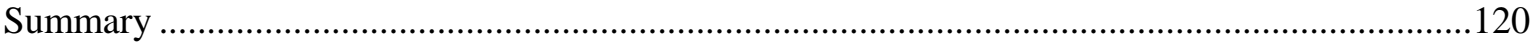

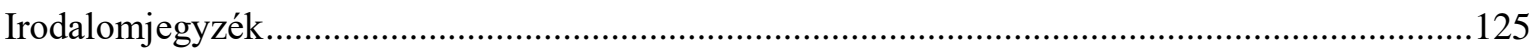

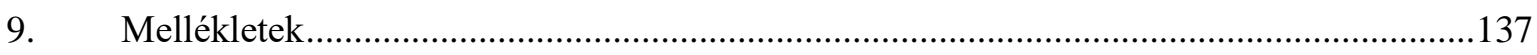

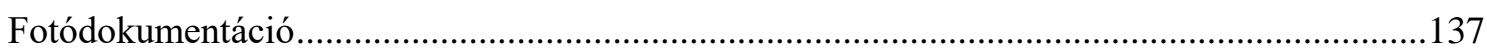

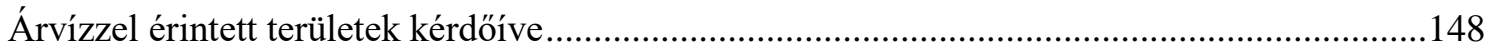

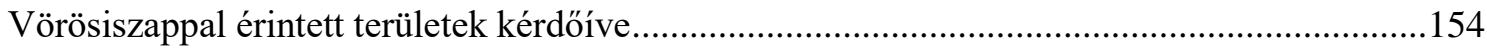

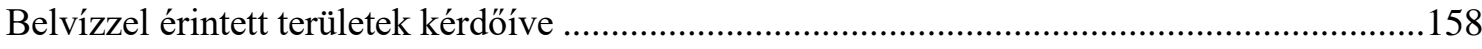

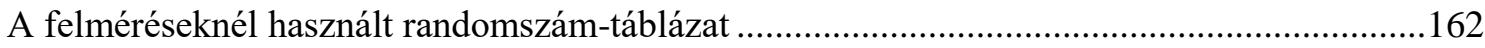




\section{Bevezetés}

Az elmúlt évtizedekben a nemzetközi környezeti kutatások, a politikai viták és az aktivizmus egyik meghatározó elemévé vált a környezeti igazságosság kérdésköre. Olyan, a földrajzi kutatásokban is megfogalmazott kérdéseket fogalmaznak meg, mint például: milyen módon befolyásolja a különböző társadalmi csoportok, emberek életét az öket körülvevő környezet, van-e különbség az egyes csoportok sérülékenysége vagy érzékelése között a környezeti hatások tekintetében, vagy éppen a globális klímaváltozással kapcsolatosan milyen lokális hatások és reakciók érhetők tetten. A környezeti igazságosság kutatások alapvetően a társadalmi igazságosság elméletein alapulnak, a környezeti ártalmak, kockázatok egyenlőtlen elosztására és azok társadalmi következményeire összpontosítanak. Azt kívánják feltárni, hogy milyen, környezetükből adódó, gazdasági, társadalmi, egészségügyi, jogi különbségekkel kell megküzdeniük az érintetteknek, és hogy ehhez milyen döntéshozatali, jogalkalmazási gyakorlatok kapcsolódnak, melyek az egyenlőtlenségek felszámolása mellett, vagy éppen ellenében hatnak. A környezeti igazságosság kutatások kialakulása az Amerikai Egyesült Államokbeli polgárjogi mozgalmak kibontakozásához és kiteljesedéséhez kapcsolódik, így a kutatások gyakran összefonódnak a politikai aktivizmussal is. Így a fogalom magában foglalja a környezeti kockázatok és lehetőségek eloszlásában tapasztalható egyenlötlenségek elleni küzdelmet is.

A klímaváltozás egyre jelentősebb és kártékonyabb következményeinek hatására, a korábbi, főként kisebbségeket érintő kutatási fókusz egyre szélesebbé vált, kibővült, és a globális klímaváltozás okozta folyamatok és események feltárása is a kutatások középpontjába került. A környezeti igazságosság kutatások olyan környezeti eseményekhez vagy körülményekhez kapcsolódnak, melyek hatással vannak az ökoszisztémákra, a gazdasági ágazatokra, az épített környezetre és az emberi egészségre és a jóllétre.

A környezeti igazságosság kutatások célja, hogy felhívják a figyelmet az élhető és egészséges környezet szükségességére, és arra a mindenki számára biztosítandó jogra, mely szerint biztosítani kell, hogy ugyanolyan, jó minőségü, élhető környezetben éljenek, nemcsak a ma generációi, de a jövő nemzedékei is. Az elmúlt bő két évtizedben a nemzetközi jogrendszerbe is beépültek a környezeti igazságosság kutatói és aktivistái által meghatározott célok, úgynevezett harmadik generációs jogként, melyek globális és környezeti jogoként azonosíthatók. Amennyiben ezek az élhetö környezettel kapcsolatos alapvető követelmények nem teljesülnek környezeti igazságtalanságok alakulnak ki, mely az egyenlötlen társadalmi és gazdasági rendszeren alapuló környezeti kockázatviselésböl, terhelésből adódik. Ebben az esetben, meg kell próbálni biztosítani, hogy a környezetben tapasztalt egyenlőtlenségeket tisztességesen, igazságosan legyenek felszámolva, vagy legalább elérni, hogy méltányosan oszoljanak meg az érintettek között. Ez mind elméleti, mind gyakorlati síkon számos kritikát vet fel. Az egyik leggyakrabban kritizált elméleti elem az igazságosság fogalma, mely normatív, a másik pedig a környezet definíciója, melynek észlelése akár végletekig eltérő is lehet bizonyos csoportok és egyének között.

A környezeti igazságosság kutatások normatív gondolkodási keretet nyújtanak az igazságtalanságok értékelésére, mely nagyban kapcsolódnak az egyének szubjektív megítéléséhez és az igazságtalanságok különböző szereplők által történő percepciójához. Az így fellépő érzékelés, értékeléshez kapcsolható eltérések további tisztességtelen, egyenlötlen helyzetek kialakulásához, igazságtalanságok különböző formáinak megjelenéséhez vezethetnek. Tehát a környezeti igazságosság kutatások esetében a fogalmak és definíciók kontextus alapú megközelítést igényelnek, és mivel az igazságtalan helyzetek megértése emberi kapcsolatban áll az érintettek részvétele és véleményük megismerése elengedhetetlen az igazságtalanság felismeréséhez, kezeléséhez és megszüntetéséhez.

Eddig viszonylag kis számú kutatás foglalkozott a környezeti igazságossággal hazánkban, így korlátozott mennyiségü információ áll rendelkezésre a környezeti igazságtalanságok által érintett lakosság attitűdjeiről és környezeti igazságtalanságok észleléséről, azok feltárási lehetőségeiről. 
Így a disszertáció egyik célja, hogy az egyre széleskörübbé váló nemzetközi szakirodalmi előzményeket összegezze, potenciálisan környezeti igazságtalanságokkal érintett hazai mintaterületeket azonosítsa, majd azok igazságtalanságait feltárja, ezáltal adaptálva a nemzetközi szakirodalmi gondolati kereteket. A disszertáció két fö kérdést fogalmaz meg. Az egyik fő kérdése elméleti jellegü, arra vonatkozik, hogy mit értünk környezeti igazságosság fogalom alatt, a definíciónak milyen elemei és azonosítható megnyilvánulási formái vannak. Ehhez kapcsolódóan a másik fő kérdés gyakorlati jellegü, és arra irányul, hogy milyen mérési módszerek segítségével tárhatók fel a környezeti igazságtalanságok és ezen módszerek alapján milyen jellemzői vannak a vizsgált hazai példáknak, azok a nemzetközi szakirodalmakban leírtakhoz hogyan viszonyulnak. A doktori dolgozat térbeli fókuszú, mely egyrészt az egész országra terjed ki és települési szintü adatok segítségével keres potenciális környezeti igazságtalansággal érintett területeket. Másrészt három, az elmúlt évtizedben a sajtó és a közbeszéd által is felkapott tématerületre koncentrál, melyek közül kettő a klímaváltozáshoz, egy pedig a méltánytalan és igazságtalan társadalmi-gazdasági müködéshez köthető. Így a dolgozat az országot érintő árvizekre, az időszakosan kialakult belvízhelyzetre, valamint a vörösiszap katasztrófára épít, melyek felmérése kvantitatív és kvalitatív módon, kérdőíves és azt kiegészítő jelleggel kis elemszámú interjús felméréssel történt, és föként a települési szint alatti folyamatok feltárására szolgál.

A kérdések megválaszolása érdekében a vonatkozó szakirodalmat áttekintettem és feldolgoztam. A hazai és nemzetközi szakirodalom alapján felállítottam egy területi adatbázist, mely segítségével lehatároltam az ország azon térségeit, amelyek környezeti igazságtalansággal érintettek lehetnek. Azonban nem csupán a térbeliséget, de az időbeliséget is vizsgáltam, középtávú elemzést készítettem a 2010-2017-es időszakra vonatkozóan kiválasztott mutatók segítségével.

A disszertáció három fô részre tagolódik. A dolgozat első felében a kutatás indokoltságát, problémafelvetését, célját, kérdéseit mutatom be. Ezt követően a kérdésekhez kapcsolódva ismertetem az alkalmazott módszereket. Ebben a részben bemutatom azt a hazai és globális kontextust, melynek megismerése a környezeti igazságtalanságok megértéséhez és értelmezéséhez szükséges. Kitérek egyrészt a posztszocialista környezetre, melyben a neoliberális és neokonzervatív politikák a társadalom polarizációjához és marginalizációjához vezettek, meglévő hatalmi viszonyokat konzerváltak, újabb függési viszonyokat alakítottak ki, melyeknek sajátos térbeli mintázata is van. Továbbá bemutatom a globális klímaváltozás lokálisan érzékelhető folyamatait, melyek hazánkat és közép-európai régiónkat mind természeti, mind pedig humán-egészségügyi szempontból fokozottan és negatívan érintik. Ehhez a két gondolatkörhöz kapcsolódva bemutatom, hogy a változó természeti, társadalmi és gazdasági környezet átformálja az egyének, csoportok és a társadalom környezethez való viszonyát. Több esetben sokkal nagyobb kockázatvállalási hajlamot indukálva, mely a létezö társadalmi különbségek és hatalmi viszonyok között egy speciális és komplex környezeti-társadalmi problémakört eredményez.

A dolgozat második részében a szakirodalmi elemzés eredményeit, a környezeti igazságosság elméleti kereteit mutatom be. A disszertáció elméleti részében elsődlegesen a környezeti igazságosság és a földrajz gondolatvilágának kapcsolódási pontjait mutatom be, majd a nemzetközi szakirodalom alapján a környezeti igazságosság kutatások kialakulásának folyamatát ismertetem, kitérve a gondolkodási keretnek a posztszocialista irányvonalaira is. Az ezt követő részben definiálom a környezeti igazságosság fogalmát, annak két fö összetevőjét, az igazságosságot és a környezetet. A fejezeten belül bemutatom a környezeti igazságosság kutatások vizsgálati aspektusait, a döntési mechanizmusok szerepét, az érintettek és a nem érintettek különböző attitüdjeit, a kockázat érzékelését, az igazságtalanságok kialakulásának időbeliségét, végül pedig a lépték megválasztásának fontosságát hangsúlyozom.

A dolgozat harmadik nagy egységében az elméleti eredmények alapján bemutatom egyrészt az országos léptékű, települési szintű kutatási eredményeimet, lehatárolva a környezeti igazságtalansággal lehetségesen érintett területeket. Ezután, a kiválasztott mintaterületeket elemzem és hasonlítom össze az elméleti részben meghatározott szempontok alapján. Kitérek az igazságtalanságok érzékelésének különbségeire, a félelem, illetve a változás fökomponensek vizsgálata segítségével, az érdekérvényesítő képeség meglétére, illetve meg-nem-létére, a kompenzáció 
módjára. Bemutatom a tájékoztatás és a közösségi bevonás szerepét a katasztrófa utáni helyreállítás későbbi megítélésében, a lakosság mobilitási hajlandóságát, irányait, az azt gátló tényezőket és az ehhez kapcsolódó ingatlanpiaci csapdahelyzetet. Végül pedig humán egészségügyi kitekintést is teszek, mely a lakosság szemszögéböl vélt vagy valós félelmeken, önbevalláson és statisztikailag rögzített megbetegedéseken alapul. 


\section{Problémafelvetés, indokoltság}

A társadalmi-térbeli egyenlötlenségeket, azok környezeti vonatkozásait különböző tudományterületek kutatói számos aspektusból vizsgálják. Dolgozatomban a hazai vonatkozások értelmezéséhez a környezeti igazságosság gondolati keretét alkalmazom, mert véleményem szerint ezen keresztül korábban nem alkalmazott módszerekkel azonosíthatók, problematizálhatók a társadalmi-térbeli egyenlőtlenségek és ezek újratermelödésének folyamatai. Egyrészt, a dolgozatban vizsgálom azt, hogy milyen társadalmi és gazdasági problémák vezetnek a környezeti igazságosság vizsgálatához, vagy az említett problémák környezeti szempontú újraértelmezéshez. A téma posztszocialista és perifériás kapitalista kontextusának kifejtése pedig kiegészíti a kérdéskört, véleményem szerint érthetőbbé teszi azt. Másrészt, a téma kontextusfüggősége miatt fontosnak találom röviden kifejteni, hogy az elmúlt évtizedekben milyen indíttatásból kezdtek ezzel a kérdéskörrel foglalkozni a kutatók, illetve, hogy az adott korszakokban milyen kutatási fókuszt fogalmaztak meg. Mivel a környezeti igazságosság interdiszciplináris szemléletü gondolati keret szükségesnek tartom bemutatni, hogy mi a kutató geográfus feladata ebben a kérdéskörben, hogyan kapcsolódik a környezeti igazságosság a geográfiához.

A dolgozat problémafelvetésében két fö témakörre helyezem a hangsúlyt, az egyik, az, az átöröklött és jelenleg is formálódó térbeli társadalmi-gazdasági egyenlőtlenség és intézményi struktúra, amely a kereteit jelenti a fennálló igazságtalanságoknak. A másik témakör ehhez szorosan kapcsolódó globális klímaváltozás és annak lokális hatásai, azokra adott válaszok.

\section{A társadalmi problémák és különbségek egyre növekednek, marginalizációs és polarizációs folyamatok új térbeli mintázatot hoznak létre és emellett korábbiakat konzerválnak, ennek közvetle- nül és áttételesen is hatása van a környezet folyamataira, az egyénekre és közösségekre.}

A rendszerváltozás óta elmúlt bő két és fél évtized számos változást hozott Magyarország életében mind politikai, mind gazdasági, mind társadalmi szempontból. A gazdaságszerkezet átalakult, a globális gazdaság vérkeringésébe bekapcsolódott az ország, azonban az új gazdasági környezetben az egyes térségek eltérö versenyképességgel, melynek hátterében az endogén és exogén tényezők egyaránt szerepet játszanak. A kialakult területi különbségekröl és azok okairól számos tanulmány született települési, térségi, megyei, régiós és országos léptékekben.

Míg az ország egyes részein lassan vagy egyáltalán nem történt lényegi átalakulás, átstrukturálódás addig máshol igen dinamikusan lezajlott a folyamat, mely az egyenlőtlenségek növekedéséhez vezetett. TÓTH I. GY. - SZELÉNYI I. (2018) megállapítása szerint az elmúlt évtizedekben nöttek a jövedelmi különbségek és ennek következtében a társadalmi távolságok is, ráadásul bizonyos társadalmi rétegek közötti mobilitás nehezebb. KOLOSI T. - KELLER T. (2010) szerint a rendszerváltozást követő években egy széles de igen heterogén középosztály alakult ki, amelyből azonban „,megnyílt a társadalmi felemelkedés és lesüllyedés lehetősége is" (KOLOSI T- KELLER T. 2010 P. 105). Az egyre növekvő társadalmi polarizáció során bizonyos társadalmi csoportok egyre inkább marginalizált helyzetbe kerültek, ráadásul ez a folyamat együtt járt a térségek periferizációjával is, mely részben következménye, de kiváltója is az említett folyamatoknak (ENYEDI GY. 1996; 2004; 2010A; 2010B; SzOBOSZLAI Zs. 2006). Így kialakultak olyan állandósult válságtérségek Magyarországon, amelyek kiilleszkednek a globális gazdasági folyamatokból, VÁRADI M. M (2014) szerint ráadásul újratermelődnek az ezeket a folyamatokat kialakító, fenntartó strukturális okok. ENYEDI GY. 2004-es tanulmányában ezeket a térségeket hálózatokból kimaradó, a dinamikus tengelyek közé szorult elmaradott térségekként aposztrofálja (ENYEDI GY. 2004).

Szükségszerüen a településhálózat is átalakult a rendszerváltozást követően, megváltoztak az egyes települések által betöltött szerepek, átalakultak a jelentőségtöbblet relációi, elindult egy újraiparosodási folyamat (LENGYEL I. ET AL. 2016; NAGY B. 2016; NAGY E. ET AL. 2015; VELKEY G. 2014,) az ország nyugati és fővárosi térségében, a „vidék Magyarországán” csak egy-egy föbb vonzásközpont emelkedik ki szigetszerúen gazdaságát tekintve (KOLTAI Z. 2016). Ezek a települések és az általuk meghatározott térségek versenyképességének és versenyképtelenségének kérdése állandósult témájává 
vált a térkutatásoknak, hiszen a települések és ezáltal annak lakói, a rendszerváltás vesztesei lettek (LENGYEL I. 2016; 2012; VIDA GY. 2016.). A hátrányos helyzetü térségek elhelyezkedése, amelyek már az 1960-es években is ismertek voltak (BARTKE, I. 1967; LACKÓ L. 1975; PÉNZES J. 2011; ORMOSY V. 2013; LuX G. 2016). nagyvonalakban mit sem változott, ráadásul a térségek közötti mérhető, számszerüsíthető társadalmi-gazdasági különbségek azóta csak növekedtek. (PÉNZES J. 2011, PAPP S. ET AL 2016, NAGY G. 2006). A jelenség modellszerü és nem egyedi magyarországi vagy posztszocialista sajátosság, hanem a tőke logikájából eredeztethető negatív következmény, és egyben egy rendszerszintü elem is, mely müködésben tartja, gyakran mozgatja azt, hiszen a töke kihasználja ezen egyenlötlenségeket. Ennek következtében az egyenlötlenségek gyakran térben újratermelődnek.

Az elmúlt években a rendszerváltozást, annak társadalmi-gazdasági aspektusait tanulmányozó kutatások kiegészülni látszanak olyan diskurzusokkal, melyek az említett változásokat új hatalmi függési viszonyokként, a meglévő interdependenciák elmélyüléseként, átstrukturálódásaként értelmezik (VÁRADI M. M. - VIRÁG T. 2015) akár kolonialista és poszkolonialista szempontból (GINELLIZ. 2018). Ezen elképzelések alapján a rendszerváltással a korábbi hatalmi függőség nem szünt meg, csak a keretei és tartalma, megjelenési formái változtak meg. Ez a folyamat a földrajzi hely és a helyzet felértékelődésével, korábbi polarizált társadalmi csoportok fokozott leszakadását idézte és idézi elő napjainkban is (BLOMLEY, N.K. 1994, BLACKSELL, M. ET AL. 1986). A földrajzi helyzet a korábbi szocialista rendszerben a tér értékének hiányához képest felértékelődött, a centrum-periféria relációk új, gazdasági alapokon nyugvó értelmet kaptak (ENYEDI GY. 1996; SIMON S. 2006; LÖCSEI H. - SZALKAI G. 2008; PÉNZES J. 2011).

A pártállami diktatúra korában elsősorban a gazdasági és gazdaságossági szempontok élveztek elsőbbséget, valamint a szovjet példa követése, így a földrajzi nihilizmuson alapuló természetátalakítási folyamatok (HAJDÚ Z. 2006) nagymértékben befolyásolták a környezetvédelem kérdését. Még a rendszerváltozás elött is a környezetvédelmi kérdésekben az elsődleges megoldandó tudományos feladatként azonosították ,a természethasznosítás szocialista tervezési, valamint a természeti erőforrások és a környezet állapotára vonatkozó gazdasági értékelés módszerének kidolgozását" (FODOR I. 1987 P.106). Az 1980-as évek végén megállapították, hogy „,nincs érdemleges viszony a környezetvédelem és a piaci mechanizmusok között" (FODOR I. 1987 P.107), és nem állnak rendelkezésre a környezetvédelem szabályozhatósága érdekében megfelelő eszközök, ösztönzők. Ráadásul a szocializmus idején kifejezetten elhanyagolt környezet állapotváltozásának rendszerváltás utáni társadalomföldrajzi feldolgozása is elhanyagolhatónak tekinthető (ŠPIRIĆ, J. 2017). A környezetvédelmi beavatkozások technokrata szemléletüek voltak, föként már bekövetkezett károk enyhítésére szolgáltak, és a szennyezés megszüntetése nem is volt igazán cél (RABÓCZKY L. ET AL 1990). Nem született meg az igény a környezeti károk és annak rövid-hosszútávú következményeinek társadalomföldrajzi szempontú értékelésére. Éppen ezért az államszocialista térségben kodifikált, környezetvédelmi tételes jog nem alakult ki (PRUGBERGER T .2001), hiszen az másodrendủ és elhanyagolt szempont volt. De a rendszerváltás után is a privatizáció és a gazdaság céljait szolgálta, hogy nem támasztottak remediációs követelményeket (PRUGBERGER T. 2001). Ennek következtében a környezet állapota Magyarországon a rendszerváltozást követően sem javult olyan mértékben, mint ahogy az az EU véleménye szerint elvárható lett volna (PRUGBERGER T 2001). Ez pedig a további, későbbiekben kialakuló környezeti kockázatok és veszélyek alapjául szolgál majd, esetlegesen egymást erősítő negatív folyamatokat generálva. Mindezen tényezők igényt támasztanak a környezetben tapasztalható egyenlőtlenségek, azok által előidézett igazságtalanságok társdalomföldrajz szempontú vizsgálatára.

\section{Az éghajlatváltozás feltételei nagymértékben összekapcsolódnak az átöröklött térbeli egyenlöt- lenségekkel, a meglévö társadalmi-gazdasági rendszerekkel és az azokat formáló, alakító intézményi struktúrákkal.}

A nemzetközi szakirodalom szerint a környezeti igazságtalanságok a komplex társadalmi-gazdasági-természeti környezetben bekövetkezett változások révén alakulnak ki, és az egészséges és minőségi környezethez való jogot korlátozzák. A környezeti igazságtalanságok gyakran a fennálló felté- 
telrendszer hirtelen változását okozzák, melyek kihatnak a közvetlenül és közvetetten érintettek életminőségére és növelik a társadalmi különbségeket. A környezeti igazságosság elmélete alapján tehát az egyre növekvő emberi befolyás a természeti rendszerekben léptékeken átívelő, komplex problémákat generál, melyek politikai, jogi, társadalmi és gazdasági következményekkel jár.

Az elmúlt évtizedek során egyre élénkebbé vált a környezetvédelemmel kapcsolatos érdeklődés, mind közéleti, mind tudományos szempontból, ennek egyik kulcsfontosságú dokumentuma a Bruntland-jelentés volt, amely a globális klímaváltozás, és negatív hatásainak feltárásának igényét is megfogalmazta. Az extrém időjárási események számának növekedése, az ehhez kapcsolódó megbetegedések és halálozások számát statisztikailag is növeli, másrészt hozzájárul a jelenlegi környezeti kockázatok és az ezek által érintettek növekedéséhez is (WHO 2010, 2011). Tehát a fentebb említett elhanyagolt környezeti állapot, a társadalmi és gazdasági struktúra egyfajta kiindulási alapot jelent a globális klímaváltozás okozta lokálisan is érzékelhető folyamatai számára. A klímaváltozás hatásait alapvetően „egyéb tényezők” (például a lakás-viszonyok, felkészültség, orvosi ellátás színvonala stb.) is befolyásolják, melyek a társadalmi-gazdasági viszonyok függvényei, tehát a probléma komplex és sokrétü. A kontextus ismerete éppen ezért elengedhetetlen a globális klímaváltozás értelmezéséhez, hiszen maga a kontextust kitermelő szakpolitikák, társadalmi gyakorlatok, gazdasági tevékenységek, döntések és intézményi struktúrák azok, amelyek hozzájárulnak a globális klímaváltozás eszkalálódásához újabb és újabb intézményi gyakorlatok bevezetésével.

A kontextus ismerete és megértése nélkül előfordulhat, hogy az emberek életminőségének mindennapi romlása nem olyan típusú intézményi átalakításokat hoznak magukkal, amelyek a változásokra reagálnak, hanem épp ellenkezőleg, olyan válaszok jönnek létre, melyek nem hoznak gyökeres változást, ezáltal konzerválják a nem fenntartható rendszert. Ráadásul a leginkább szélsőséges válaszok bevezetése a periféria országaira lesz a jellemző, ahol igen nagy a marginalizált, periférián élö lakosság aránya. A fennálló kockázatok és veszélyek értékelése és felmérése kérdéses, hiszen a klímaváltozás tényleges jövőbeli hatásaival kapcsolatosan sok a bizonytalanság, ráadásul nem csupán az a kérdés, hogy milyen következményekkel kell majd számolni, hanem az is, hogy az ellene eszközölt beavatkozásnak kik lesznek a teherviselői, kik lesznek azok, akik e negatív folyamatban is hátrányos helyzetbe kerülnek a többi érintetthez képest.

A klímaváltozás megváltoztatja a strukturális feltételeket, cselekvővé téve a környezetet. A hatások különböző közvetítőkön keresztül jutnak el a társadalom rendszerébe, melyek maguk képzik a strukturális feltételeket is. Ebben a cselekvő helyzetben a különböző ágensek, szereplök léteznek, a változásokra válaszokat adnak. A szereplök között a társadalom és annak egyes tagjai, az állam és a tőke is hangsúlyos szerepet kap.

A hatásokkal kapcsolatban felmerül több kérdés is. Az egyik ilyen, hogy a klímaváltozás közvetett és közvetlen hatásaira az egyes szereplök milyen módon tudnak választ adni, melyik az az ágens, melynek egyáltalán van mozgástere reagálni. Ez viszont annak függvénye, hogy a szereplőkben a hatások, problémák milyen módon képződnek le, ez pedig a klímaváltozás és az egyes szereplők közötti viszonyrendszertől is függ. Bizonyos strukturális feltételek megváltozásával, mint például a müszaki infrastruktúra átalakulásával szemben, az egyes szereplők különböző mértékben cselekvőképesek. Az egyén például korlátozottan cselekvőképes, hiszen a viszonyrendszer kiegyensúlyozatlan, az egyén a nagy infrastrukturális rendszerekre nincs hatással, míg a tőke és az állam annál inkább (1. ábra).

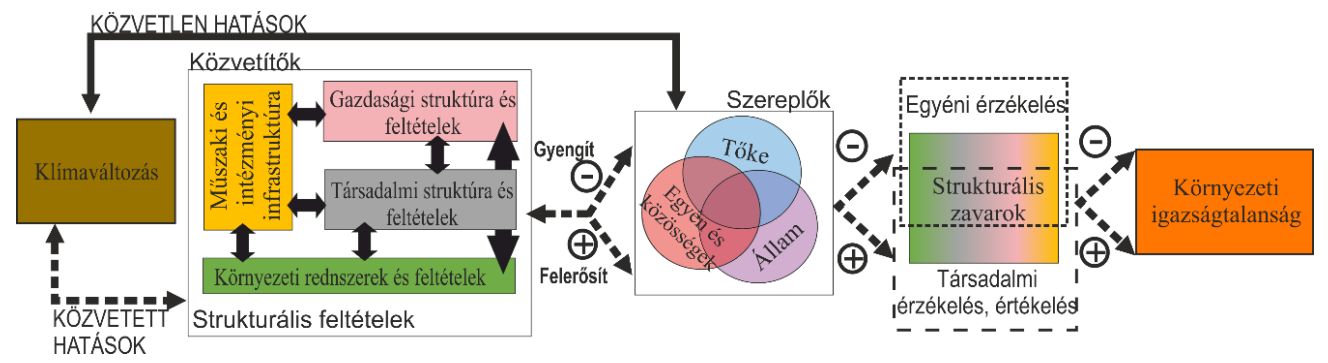

1. ábra: a klímaváltozás és a környezeti igazságtalanságok kapcsolódása. Forrás: saját szerkesztés 
A klímaváltozás okozta cselekvési helyzetek a szereplők közötti egyensúly megbomlásához vezethetnek, sturkturális zavarokat, végső soron pedig környezeti igazságtalanságokat előidézve. SWYNGEDOUW szerint a klímaváltozás, a globális tőke térformáló szerepe és a környezeti igazságtalanságok egyértelmüen kapcsolatban álnak, melyet lokális léptékben a helyi politikai-hatalmi viszonyok átalakítanak a társadalmi-környezeti feltételek szabályozása révén. A környezet alakítása pont annyira ellenőrzött, manipulált, kirekesztő, ahogyan az a kulturális, politikai, társadalmi vagy gazdasági kontextus, melybe beágyazódik (SWYNGEDOUW, E-HEYEN, N.C. 2003). Ezért a társadalom szereplöi környezetük kialakításáért és védelméért szüntelenül küzdenek (HARVEY, D. 1996), a természet folyamatos átalakítása egyes csoportokat negatívan, míg másokat pozitívan érint (SWYNGEDOUW, E-HEYEN, N. C. 2003). A környezet átalakulása hatalmi struktúráktól függ, így a globális klímaváltozás hatásai is részben kapcsolódnak a meglévő viszonyrendszerhez, részben azt átalakítva, másrészt konzerválva, vagy éppen azt felerösítve. A világ jelenlegi gazdasági-hatalmi berendezkedéséből adódóan a környezet növekvő károsítása, privatizációja egyre nyilvánvalóbb egyenlőtlenségek és igazságtalanságok kialakulásához vezet, mely mind a környezeti fenntarthatóságot, mind az egyének és csoportok élhető és minőségi környezethez való jogát csorbítják (SWYNGEDOUW, E. 2004). Az egészséghez környezethez való jog olyan alapjog, mely nem csak a testi és lelki egészség legmagasabb szintjének elérhetőségét (CHEESEMAN S. J. 2011), hanem a jólétet, és a társadalom jól létét, egészségi állapotát, annak testi, lelki és társas dimenzióit is jelenti (PIKÓ B. 1999). Mivel az egészség a környezettel kapcsolatban áll, így a környezetvédelem és az egészséghez való jog az egészséges környezethez való jogban egyesül, melynek garantálását az állam vállalja.

Magyarországon mind az 1989-es Alkotmány, mind pedig a 2011-es Alaptörvény elismeri és érvényesíti az egyén jogát az egészséges környezethez, utóbbi azonban már nem csak jogokat, de kötelességeket is megfogalmaz a környezetvédelemmel kapcsolatban (NÉMETH L. 2011). Mindezt annak ellenére teszi, hogy az Alkotmánybíróság szerint egészséges környezethez való jog a korábbi szabályozások eredményeként kialakult egyenlőtlenségek és igazságtalanságok miatt nem lehet alanyi alapjog, csak elérendő cél, az egészséges élet feltételeinek biztosítása mégis alkotmányos kötelezettség. Tehát minden olyan környezetből származó egészséget érő negatív hatás, mely esetlegesen környezeti vagy civilizációs katasztrófa folyománya nem csak morális értelemben igazságtalan, egyenlötlen, de jogi szempontból is aggályos, melynek megszüntetéséért részben az állam felelős, hiszen alkotmányos garanciát vállal a környezet meghatározott minőségének és az egészség és annak dimenzióinak biztosítására.

Az az elméleti ideálállapot, melyben a különböző igazságtalan helyzetek esetében a keletkezett költségek, előnyök és hátrányok egyenlően oszlanak meg az érintettek között, nem csak társadalmi, de területi dimenzióban is figyelmen kívül hagyja, hogy az egyes környezeti problémák egyediek, kontextus függően értelmezhetők (CHUKWUMERJE, 2005). Szükséges figyelembe venni, olyan tényezöket, melyek történelmi folyamat szerves eredményeként, vagy éppen korábbi gazdasági/politikai rendszer öröklött tulajdonságaiként állnak elő. Vannak csak az adott területre jellemző statikus vagy dinamikus sajátosságok, melyek pozitív vagy negatív irányban befolyásolják a térség fejlődését, egyfajta kiindulási állapotot jelölnek.

A boldogság és a jólét elérése, a környezetböl adódó hasznok közös felhasználása egyre fontosabbá válik, és gyakran az egyenlő jogok biztosítása csak a hátrányos helyzetben lévők kompenzálásával lehetséges, nem pedig a hátrányt előidéző probléma megszüntetésével. Az egyenlőtlen fejlődés elmélete ráadásul a fennálló rendszer fenntartását, illetve további kihasználását kívánná meg. Ezeket mérlegelve számos alkalommal elöfordulhat olyan eset is, ahol az igazságtalanság szinte megváltoztathatatlan, esetleg csak kismértékben csökkenthető. A társadalmi-gazdasági folyamatok hatására megváltozik a környezeti igazságtalanságokkal kapcsolatos egyéni és társadalmi hozzáállás, egyes folyamatok általánossá, a kompenzáció pedig legitimmé válik, mely a problémákat nem oldja meg, csupán mérsékeli azok negatív hatásait.

Mivel az állami kompenzációs rendszerek nagyon drágán tarthatók fenn, és azok sem hosszú ideig, a piac az, mely szerepet vállalhatna az egyének és csoportok jólétének emelésében, azonban ez nem történik meg, hiszen nem füzi hozzá profitérdek. A környezeti igazságosság vizsgálatnak ilyen esetekben nem az egyenlőtlen földrajzi- társadalmi- természeti teherviselést, vagyis annak hiányát kell 
vizsgálnia, hanem inkább a folyamatot magát. Mivel csökkenthető a kockázat a minimális szintre, és az ehhez szükséges erőforrásokhoz hogyan lehet hozzájutni. Szükséges megérteni az okokat és a következményeket, közös együttmüködésre kell sarkallni a döntéshozókat (politikusok, gazdasági szereplök), a kockázatviselőket (lakosság, marginalizálódó csoportok) és a megvalósítókat (önkormányzat, gazdasági szereplők, lakosok) (FABER, D. - MCCARTHY, D. 2002).

A hatalmi viszonyok kapcsolódnak a társadalmi különbségekhez, melyek a természet és társadalom viszonyában, így a környezetben is megmutatkoznak, tehát a környezeti igazságtalanságok nem függetleníthetők azoktól a társadalmi tényezőktől, melyek az egyenlötlenségeket elöidézik, így a jövedelmi viszonyoktól, nemtől, kortól, etnikai hovatartozástól, iskolázottságtól stb. (CUTTER S. L 1995). Így a környezetben zajló folyamatok nem mindenki számára hoznak egyaránt hasznot, gyakran bizonyos csoportoknak hátránya is származik belőle. A környezeti igazságossággal foglalkozó szakirodalomban általánosan megállapított, hogy a deprivált népességet a hátrányok nagyobb arányban érintik (BULLARD, R. D. 1990; BROWN, P. 1995; WILliams, R. W. 1999A; FABER, D. - MCCARTHY, D. 2001; OKEREKE, C. 2006; FilČAK, R. 2007; NeWton, D. E 2009; SoJA, E. W 2010; WALKeR, G. 2010). A hátrányoknak számos megnyilvánulási formája van, nem csak anyagi, de például egészségügyi, életminőségbéli, melyet elöidézhet gazdasági tevékenység, törvényalkotás vagy éppen politikai döntés (CUTTER, S. L. 1995; WILLIAMS, R. W. 1999B) és léptékeken átívelő folyamatként nem csupán az egyénekre, de azok csoportjaira, de visszahatólag a környezetre is hatással vannak. A klímaváltozás illetve az állam - egyén - tőke kapcsolatának relációjában környezeti igazságosság szempontú munka még nem készült hazánkban. A disszertáció a rendszer megértését és esetlegesen az alakítását szolgálja empirikus eredmények segítségével.

A globális klímaváltozás hatásai lokálisan érzékelhetö folyamatokat eredményeznek egyre nagyobb számú környezeti katasztrófát és egyre nagyobb értékü környezeti kárt okozva. Mindez az emberek mindennapi életére, életminőségére, egészségi állapotára is hatással van.

A 2007-ben kiadott Európa klímaváltozásról szóló tanulmány (ALCAMO, J. ET AL. 2007) öt fó területet és 12 lehetséges hatást különít el, ahol a klímaváltozás érezhető változásokat fog okozni (1. táblázat).

1. táblázat: A klímaváltozás hatásai a Kelet-Európa régióra. (-) negatív (+) pozitív (?) kérdéses (Forrás: Alcamo J. et al alapaján saját szerkesztés)

\begin{tabular}{|c|c|c|}
\hline Terilet & Hatás & Kelet-Európa \\
\hline \multirow[t]{3}{*}{ Felszíni és felszín alatti vízkészlet } & Árvizek & --- \\
\hline & Víz elérhetősége & -- \\
\hline & „Víz stressz” & -- \\
\hline \multirow[t]{2}{*}{ Tengeri és tengerparti rendszerek } & Alacsony fekvésü területek eróziója & -- \\
\hline & Tengerszint-emelkedés, viharok okozta áradások & --- \\
\hline \multirow[t]{2}{*}{ Ingatlan } & Árvízi károk & $? ?$ \\
\hline & Viharkárok & $? ?$ \\
\hline Ökoszisztéma & Tüzek & -- \\
\hline \multirow[t]{4}{*}{ Humán egészségügy } & Hőhullámok okozta megbetegedés/halálozás & -- \\
\hline & Hideg időjárás okozta megbetegedés/halálozás & +++ \\
\hline & Árvizek egészségügyi kockázata & -- \\
\hline & Élelmiszerbiztonság, árvíz okozta megbetegedések & -- \\
\hline
\end{tabular}

A tanulmány alapján az éghajlatváltozás egyik legerőteljesebben térségünket, Kelet-Európát, vagyis az európai periféria országait fogja érinteni. Például, a felszíni vizeket fogja érinteni térségünkben, 2050-ig akár 100 ezer föről 320 ezer fővel is megnőhet Kelet-Európában az árvíz negatív hatásai által érintett népesség száma (FEYEN, L. 2009). Az egyre extrémebbé váló időjárás több szempontból is sebezhetővé teszi a közösségeket hiszen hirtelen bekövetkezésü, gyors lefolyású, előre nehezen megjósolható időjárási események alakulnak ki, melyeknek a társadalomra nézve súlyos következmények- 
kel járhatnak. Egyre több hőhullámmal, forró nappal kell számolni, emellett egyre intenzívebb csapadékozásra lehet majd számítani, mely villámárvizek kialakulásához vezet (CZIGÁNY S. ET AL. 2008; GRUNDFEST, E. - RIPPS, A. 2000). A klímaváltozás negatív hatásai nagy népesség-koncentráció miatt az urbánus térségekben fokozottan jelentkeznek majd.

A Kárpát-medencében az elmúlt két évszázadban számos, környezetbe való emberi beavatkozás történt, a vízrendszer szabályozása alapvetően formálta át a térséget. A Kárpátok béli fakitermelés következtében felgyorsuló erózió ártereinket feltöltötte, a hullámtérben elburjánzó növényzet pedig elösegítette ezt a folyamatot (KISS T. ET AL 2008; NAGY J. ET AL. 2017). A szabályozásokkal a folyók lefolyása is felgyorsult, így fordulhat elö, hogy a mértékadó árvízszintek az elmúlt évtizedekben mind magasabbak lesznek (RAKONCZAI, J. 2008). Mindemellett a Trianoni békediktátum hatására hazánk alvízi ország lett, így mind vízkészlet-gazdálkodásában, mind a folyóvízi szennyezések megakadályozásában szomszédjainak együttmüködésére szorul. Az egyre szélsőségesebb időjárás tovább növeli a térségben az árvízi kockázatot.

A belvíz - mely az elmúlt évtizedben hasonlóan nagy problémát okozott hazánkban - kialakulásában szintén szerepet játszanak az éghajlati változások (RAKONCZAI J. ET AL. 2011). A villámárvizek eredményéhez hasonló, kialakulásában azonban eltérő, úgynevezett városi árvizek kialakulása is, mely egyre gyakrabban megfigyelhető, Magyarországon is (LÓCZY D. - GERESDI I. 2010). A megváltozott és nagyon korlátozott felszíni beszivárgás a felszíni lefolyás megnövekedését eredményezi, mely a városi csatornahálózat kapacitásának korlátozottsága miatt áradásokat okoz a városokban (LÓCZY D- GERESDI I. 2010; STEVAUX, J.C. - LATRUBESSE, E. 2010). Az árvíz nem csupán az egyén vagy csoportjainak jelent veszélyforrást és kockázatot, de nagymértékü károkat okozhat az infrastruktúrában és a gazdaság számára is (KÁTAY Á. ET AL. 2013). Magyarországon nem csak a városi lakosság, de a vidéki népesség helyzete kritikussá válhat többek között a mezőgazdasági termelés ellehetetlenülése révén, melyet nem csupán az elsivatagosodás, de egy tartós belvizes és árvizes borítás is elöidézhet. Mindez annak fényében, hogy a hazai folyó menti települések döntő része országos viszonylatban hátrányos helyzetünek mondható (TÓTH G. ET AL. 2010; PÉNZES J. 2010) komplex módon kezelendő problémakör.

Az éghajlatváltozás azonban nem csak a természeti környezet destabilizációját okozza, de kényszerüen megváltoztathatja az egyén és a környezet viszonyát is (SACHS, W. 2008), mely társadalmi konfliktusokhoz és áttételesen környezeti igazságtalansághoz vezethet. A szegények és a kisebbségek nem csak azért kerülnek hátrányos helyzetbe, mert feltehetőleg az ő természeti környezetük sérül a legjobban, de ennek következményeként fellépő káros hatások is őket sújtják majd (SACHS, W. 2008).

Hazai kontextusban az elmúlt években a rendszerváltozást követő társadalmi-gazdasági átalakulási folyamat, a 2008-as gazdasági válság, a szociális intézményrendszer átalakulása, lakosság marginalizálódása stb. is több szempontból kihívások elé állította a lakosságot, melyekre eltérő válaszok érkeztek a különböző társadalmi csoportokból, gazdasági és politikai szereplőktől, eltérő földrajzi léptékben. Ezek a reakciók alapvetően a változásokhoz való alkalmazkodást, vagy az arra tett kísérletet jelentették. GORDDARD ET AL. (2016) szerint az adaptáció döntési mechanizmusoktól függ, melyek azonban számos személyes vagy társadalmi tényezőtől függnek, mint például érték- és normarendszer, elvek, szabályok és egyéni és társadalmi tudás.

Annak ellenére, hogy jelenleg Európa gazdaságilag legdinamikusabban fejlődő térségei közé tartozik hazánk, a rendszerváltás óta mégis úgynevezett egészségparadoxon figyelhető meg (KOPP M. SKRABSKI Á, 2009), vagyis a gazdasági növekedés nem eredményezi a várható ütemben az élettartam növekedését és a halálozási ráta csökkenését (UzzOLI A. 2013). Ennek hátterében áll egyrészt az önkárosító magatartásformák viszonylagos gyakorisága, másrészt, hogy a pszichoszociális környezet erősíti ezeket a folyamatokat. A gazdasági fejlődés térbeli egyenlötlensége, a részben gátolt horizontális és vertikális mobilitás főként a deprivációval veszélyetetett társadalmi csoportok esetében reményvesztettséget, kaotikus, kilátástalan élethelyzetet teremt. Az OECD kutatásai alapján minél nagyobbak az országon és a társadalmon belüli különbségek, annál magasabbak a halálozási arányok (KoPP M SKRABSKI Á. 2009).

A rendszerváltozás egyértelmü vesztesei a munkaerőpiacon és az életkilátásokban is a legalacsonyabb iskolai végzettségüek és az alacsony jövedelmüek voltak (HABLICSEK L - KovÁCs K. 2004), 
akik egészségi állapotát közvetetten befolyásolják a jövedelemegyenlötlenségek, a térségi fejlettségi viszonyok (DARÓCZI E.- KOVÁCS K. 2004). Ehhez kiemelten kapcsolódik, hogy a katasztrófák következtében hasonlóan negatív pszichoszociális környezet alakul ki, ráadásul, ha a katasztrófa egy elmaradott térséget érint, akkor a kockázati tényező sokkal nagyobb. Hiszen a helyzetet korrigáló-mérséklő gazdasági-politikai-társadalmi környezet nem adott. Egyrészt hiányos vagy elégtelen, térben és időben is nehezen megközelíthető a térségi szociális és egészségügyi ellátórendszer (UZZOLI A. ET AL. 2011), másrészt a fizikai és társas környezet sem elégséges, a társadalmi érdekérvényesítö képesség gyenge. A válságok és krízishelyzetek hosszútávon negatív egészséghatásokat fejtenek ki, azonban ezek a népességet nem egyenlő mértékben érintik (UzzOLI A. 2013). A társadalmi egyenlötlenségek leképeződnek az egészségegyenlőtlenségben (SZILÁGYI D. - UZZOLI A. 2013), és fordítva, befolyásolják a társadalmi egyenlőtlenség alakulását, melynek térbeli vetülete helyzeti, fejlettségi és hatalmi centrum-periféria relációk (NEMES NAGY J. 2009) kialakulását, újratermelődését okozza. A különböző civilizációs és természeti katasztrófák következtében kialakuló földrajzi egyenlötlenségek a környezeti igazságosság vizsgálati kérdései közé tartoznak.

A klímaváltozás és az átmenet következtében a volt szocialista országokban, így hazánkban is a környezet és a társadalom viszonya átalakulóban van, ami megváltoztatja a lakosság életterével kapcsolatos elvárásait és prioritásait, ezzel együtt a kockázatvállalási hajlandóságát is. A rendszerváltozás okozta társadalmi-gazdasági folyamatok, a neoliberális és ezzel egyidőben gyakran jelentkező neokonzervatív fordulat, a fokozódó klímastressz, a megváltozó ember-környezet viszony a környezeti igazságtalanságok kialakulását eredményezhette Magyarországon, erről azonban teljeskörü vizsgálat még nem készült. A jelen környezeti igazságosság kutatás egyrészt célozza a környezet-ember viszony új, társadalmi és egyéni értelmezésének megértését, másrészt pedig ebben a kontextusban az igazságtalanságok feltárásával segíti a döntéshozókat a megfelelő stratégiai beavatkozásokhoz. 


\section{A dolgozat célkitüzései és hozzá kapcsolódó fó kérdései}

\subsection{Célkitüzés}

A disszertáció célja az igazságtalanságok kialakulásának „vezérlöit” (2. ábra) feltárni magyarországi környezetben a környezeti igazságosság gondolati keretein belül.

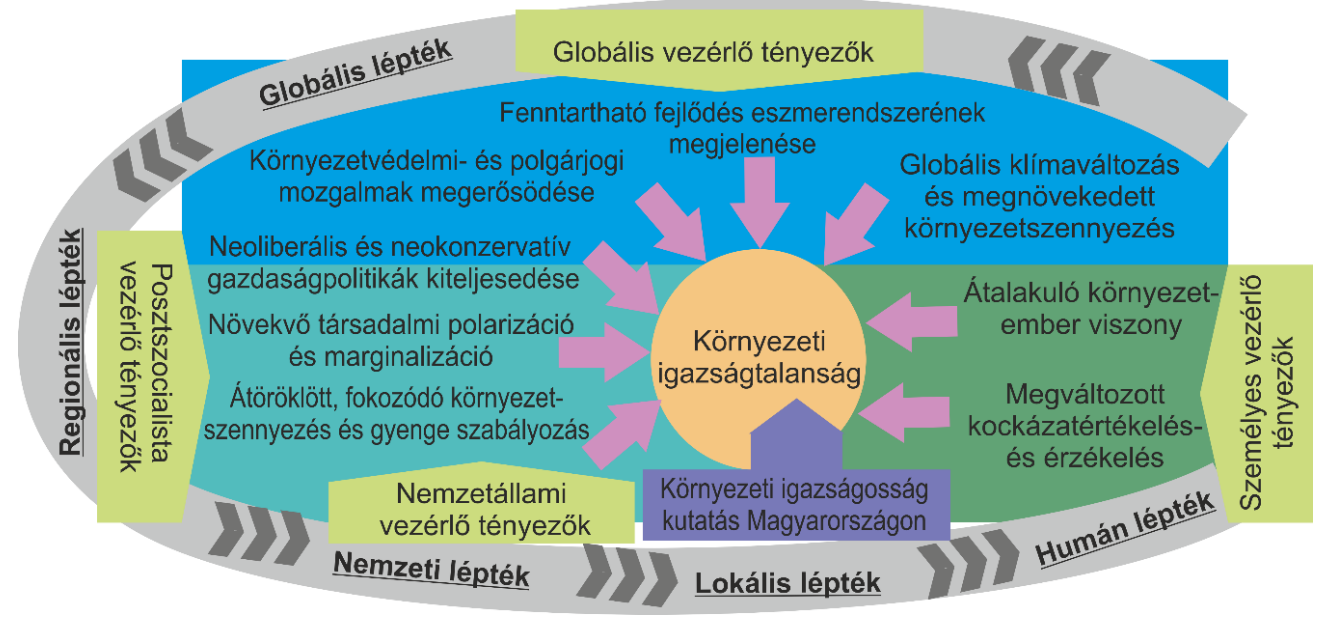

2. ábra: A dolgozat célkitüzésének kapcsolódása a dolgozat problémafelvetéséhez. Forrás: saját szerkesztés

A disszertáció tehát kettős céllal született meg. Egyrészt, olyan magyar nyelven megjelent elméleti összegzést kíván adni, mely feldolgozza az elmúlt három évtized környezeti igazságosság-kutatásainak szemléletbéli változását és földrajzi keretek között, annak sajátos térszemléletével értelmezi azt. A disszertációban összegzem az eddig megjelent legföbb környezeti igazságossággal foglalkozó tanulmányok elméleti megállapításait, és a környezeti igazságtalanságokat alkotó tényezőket. A dolgozatnak e célkitüzésébe tartozik, hogy megvizsgálja, hogy a posztszocialista kontextusba hogyan illeszkedik a környezeti igazságosság, mint kutatási keret. A diszszertáció másik célja, hogy hazai kutatáson alapuló gyakorlati példákon keresztül mutassa be a környezeti igazságtalanságok megvalósulását, annak számos aspektusát, illetve, hogy az elméleti részben kifejtett igazságtalanság-összetevők milyen módon nyilvánulnak meg.

\subsection{Kérdések}

A kutatás indokolságában és problémafelvetésében megfogalmazott vezérlő tényezők alapján két fő kérdést fogalmaztam meg, mely további alkérdésekre bontható. Az egyik fö kérdés elméleti, a másik pedig empirikus fókuszú, mely az elméleti eredményekre alapoz. A dolgozat tagolása követi a kérdésfelvetés kettősségét.

(1.) Hogyan definiálható a környezeti igazságosság, illetve hogyan értelmezhetőek a természeti és társadalmi-gazdasági környezet kölcsönhatásából eredö igazságtalan helyzetek, milyen megnyilvánulási formái és gyakorlati vonatkozásai vannak ezen folyamatok feltárásának?

A környezeti igazságosság fogalom definiálására azért van szükség, mert mint korábban említettem a témakörben csak kevés elméleti és feltáró jellegü publikáció született a posztszocialista országoka, hazánkra és szükebb régiójára. A létező szakirodalom két részre osztható: egyik fele a „nyugati világ"-ban tapasztalható környezeti igazságtalanságokkal foglalkozik, azoknak az elméleti keretét hozza létre, míg a másik fele „harmadik világ”-béli esettanulmányokat dolgoz fel, többnyire az előző elméleti eredményeit alkalmazva. Azonban a még napjainkban is fennálló kelet - nyugat megosztottság, a „nyugati” és a volt szocialista országokban kialakult sajátosságok, fejlődési utak és a markáns társadalmi, gazdasági és környezet-szemléletbeli eltérések miatt szükséges az elméleti keretek kiter- 
jesztése. Ehhez kapcsolódóan elsődlegesen arra keresem a választ, hogy (1.1.) a környezeti igazságosság, mint gondolati keret hogyan kapcsolódik a földrajztudományhoz, milyen kapcsolódási pontjai vannak a kritikai földrajzzal, hogyan illeszkedik a posztszocilista és periférikus kapitalista kontextushoz?

Ezt követően a környezeti igazságosság- kutatások történetével foglalkozom, azt vizsgálom, hogy (1.2.) az elmúlt évtizedekben milyen meghatározó momentumok voltak, melyek a környezeti igazságosság koncepció kifejlödéséhez vezettek, illetve mi a jelenleg egyezményesen elfogadott és alkalmazott logikai keret? Ehhez kapcsolódóan bemutatom, hogy a posztszocialista országokban milyen környezeti igazságosság kutatások születtek, azoknak milyen következtetései vannak.

Az elméleti megalapozás érdekében megvizsgálom a fogalom etimológiáját, (1.3.) arra keresem a választ, hogy a nemzetközi szakirodalomban milyen alkotóelemeket sorakoztatnak fel a fogalom tartalmával kapcsolatban. Elsődlegesen a fogalom két leglényegesebb elemére, a környezet és az igazságosság fogalmaira térek ki, megvizsgálom, hogy (1.4.) milyen szerepet játszik a döntési mechanizmus, a különbözö attitüd, az egyéni percepció, az idöbeliség és a lépték a környezeti igazságosság fogalomban.

A környezeti igazságosság több szempont alapján feltárt a szakirodalomban. Számos, főleg nyugat-európai megközelítés létezik, legtöbbjük a környezeti veszélyek és kockázatok egyenlötlen földrajzi eloszlásával és elosztásával foglalkozik. Mindemellett egyre nagyobb hangsúlyt kapnak a globális klímaváltozás negatív, társadalomra gyakorolt hatásai, az előidézett egyenlőtlenségek. De meghatározók az olyan hagyományos megközelítések is, mint a kisebbségek szerepének vizsgálata, a környezeti depriváció és a társadalmi státusz összefüggései, a döntéshozatali mechanizmus. A vizsgálatok túlnyomó többségében a közös összekapcsoló elem a földrajzi tér, mely keretet biztosít a folyamatok értelmezéséhez és megértéséhez. Ehhez kapcsolódik a második fő kérdésem.

(2) Magyarországon a javak, a környezeti kockázatok, katasztrófák hatásainak egyenlötlen elosztásához kapcsolódóan milyen módszerekkel azonosíthatók a potenciális hazai környezeti igazságtalanságok, azoknak milyen térbeli sajátosságai vannak az érintettek szempontjából, milyen mechanizmusok vezetnek kialakulásához, az egyenlötlen helyzetek fenntartásához?

Dolgozatom második, gyakorlati jellegü fő kérdése tehát területspecifikus. Elsődlegesen arra keresem a választ kiválasztott módszerek segítségével, hogy (2.1.) milyen magyarországi területek határolhatók le, melyen potenciálisan környezeti igazságtalanságok alakulnak ki a társadalmi és környezeti változások tükrében. A klímaváltozáshoz és természetkárosításhoz kapcsolódó három, potenciálisan környezeti igazságtalanságnak tartott jelenség, az árvíz, a belvíz és a vörösiszap-katasztrófa esetét vizsgálom esettanulmányokon keresztül. Számos dimenzió mentén tárom fel az egyén és a társadalom szempontjából a környezeti igazságtalanságokat. (2.2.) Elsődlegesen arra voltam kíváncsi, hogy a katasztrófák által közvetlenül és közvetetten érintett lakosság esetében vannak-e vélt vagy valós félelmek egy esetleges további katasztrófával kapcsolatban, valamint milyen változásokat észlelnek a társadalom vagy a települléskép esetében? A véleményekben esetlegesen mérhetö különbség eredeztethető abból, hogy milyen megoldási javaslatok születtek az igazságtalanság felszámolására, így második kérdésem arra vonatkozott, hogy (2.3.) a katasztrófákat követö segítségnyújtással, kompenzációval és az azzal kapcsolatos információ-ellátással mennyire elégedettek az érintettek?

A környezeti igazságtalanságok hosszútávon befolyásolhatják a térségről alkotott véleményt, gátolhatják a térségi mobilitást, így a kutatás azt is vizsgálja, hogy (2.4.) a háromtémakörben kiválasztott négy mintaterület esetében hogyan alakul a megkérdezett lakosság véleménye a helyben maradásról, elvándorlásról, a mobilitási lehetöségekröl, illetve, hogy a lokális egyenlötlenségek mérhetőek-e ingatlanpiaci adatokon keresztïl.

Végezetül, a környezeti igazságtalanságok számos esetben egészségkárosodáshoz vezetnek, melyek föként a kisebbségi, szegény, deprivált lakosságot érintik leginkább. Ehhez kapcsolódva a dolgozatomban megvizsgálom, hogy (2.5.) a különféle katasztrófákkal sújtott mintaterületek esetében az. egyének szempontjából tapasztalható-e bármiféle, egészségre káros hatás, illetve, hogy az ehhez kapcsolódó statisztikai adatok alapján igazolható-e egészségkárosodás. 
A dolgozat kérdésfelvetésének a fókuszában egy összehasonlító elemzés elkészítése áll. A négy esettanulmány függvényében vizsgálom, hogy mik azok a tényezők, melyek az igazságtalanságot elöidézhették, hogy miben különböznek, miben hasonlítanak, hol kapcsolódnak egymáshoz az említett esetek. Vizsgálom, hogy a helyzetekre adott a lokális döntések hogyan változtatták meg a lakossági attitüdöket, milyen társadalmi és politikai változások következtek be, illetve, hogy a kialakult helyzet köthető-e korábbi, vagy újonnan megjelenő hatalmi viszonyokhoz. Mindhárom téma nagy visszhangot kapott a sajtóban, azonban a környezeti igazságosság témakörén belül, földrajzi szempontokat figyelembe véve egyiket sem vizsgálták. A vizsgált területek közös jellemzöje, hogy évtizedek óta fennálló problémák következményeit viselik magukon, melyek részben a szocialista évtizedekre visszavezethető strukturális problémában gyökerezenek és, hogy egy gyors, természeti környezetben előállt változásra adott válasz (vagy annak hiánya) mozgatja, befolyásolja az események alakulását

\subsection{A kutatás során alkalmazott módszerek}

Ha elfogadjuk a környezeti igazságosság-kutatások alapvetését, miszerint a környezeti hátrányok a társadalmi csoportokat eltérő módon érintik, és ez területileg differenciáltan jelenik meg, (DAVIDSON, P. - ANDERTON, D.L. 2000; PELLETIER, N. 2010) akkor felmerül a kérdés, hogy ezek milyen módon mérhetőek, hogyan tárhatóak fel. MÁLOVICS számos munkájában arra hívja fel a figyelmet, hogy a környezeti fenntarthatóság, a környezet értéke, annak mérése igen szubjektív, közgazdaságtani szempontból kritikusan kezelendő (MÁLOVICS, GY. - BAJMÓCY Z. 2009; MÁLOVICS GY. 2016), így a környezeti igazságtalanságok disszertációban alkalmazott mérési módszereit is kritikával szükséges kezelni.

A disszertáció jelen fejezetében bemutatom a dolgozat kérdéseinek megválaszolásához alkalmazott kvantitatív és kvalitatív módszereket. A disszertáció elméleti hátterének összeállításához hazai és külföldi szakirodalom elemzését végeztem el, melyet a környezeti igazságosság gondolati keretébe illesztettem.

A környezeti igazságosság-vizsgálatok több léptékben és a környezetet alkotó elemek sokszínüsége okán több megközelítésben történhetnek. A környezeti igazságosság szakirodalmában - föként a kezdeti időszakban - az igazságtalanságok feltárására és mérésére leggyakrabban kvantitatív módszereket alkalmaztak, mely csak később egészült ki kvalitatív vizsgálati módszerekkel. A disszertáció mindkét nézőpontot alkalmazza.

\subsubsection{A környezeti igazságosság mérése fökomponens analízis módszerével}

Mivel a környezeti igazságtalanságok a térben sokféleképpen megjelenhetnek, szükséges lehatárolni azokat a potenciális területeket, melyek érintettek lehetnek környezeti igazságtalanságok által. Ezért elsődlegesen egy több társadalmi-gazdasági és környezeti indikátor figyelembevételével létrehozott, összetett, komplex mutatót képeztem, mely települési szintü adatok felhasználásával határolja le azokat a magyarországi térségeket, melyek potenciálisan környezeti igazságtalanságokkal érintettek. Ehhez a mutatókat a WHO vizsgálatainak tapasztalatai alapján választottam ki, mely három fő dimenziót vizsgál (lakáshelyzet, balsetek okozta, környezet-okozta egyenlőtlenségek) három megközelítésböl (nem, kor, jövedelem) (WHO 2010a, WHO2010b). Az indikátorok kiválasztását indokolja, hogy a környezeti egyenlötlenségek az élet számos területén érhetik az egyéneket, melyeket bizonyos élethelyzetek és státuszok nagymértékben befolyásolhatnak. Bár a nemzetközi összehasonlító vizsgálatokban a WHO több olyan mutatót is megállapított, mely segíthet a környezeti igazságtalanságok és egyenlőtlenségek feltárásában, ebböl több indikátor Magyarországon központi adatbázisból nem, vagy csak korlátozottan, más földrajzi léptékben érhetők el. Ezeket az adatokat egyéb mutatókkal pótoltam, melyek tartalmukban vagy jellegükben hasonlóak a WHO által meghatározotthoz. A dimenziók társadalmi-gazdasági szempontú bontása ebben a formájában kevésbé releváns, így ezeket egy újabb dimenzióként tünetettem fel. A vizsgálatomhoz a TEIR adatbázis elérhető legfrissebb adatait használtam fel. Ez egyrészt jelenti a kutatás megkezdésekor elérhető 2010-es adatokat, illetve az aktuális és a fo- 
lyamatok változásának monitoringja érdekében az empirikus kutatások időpontjaira elérhető legfrissebb adatokat (2013 és 2015 évekre). Az adatok könnyebb kezelhetösége érdekében a kiválasztott mutatókból települési szintre fökomponenseket képeztem az SPSS 22.0 statisztikai program segítségével.

A főkomponens-analízis elvégzése előtt a felhasznált mutatók kapcsolódását vizsgáltam, meghatároztam azokat a mutatókat melyek korrelálnak, együtt vagy ellentétesen mozognak, legalább 0,5es értékkel. Emellett további négy feltételt határoztam meg a létrejövő főkomponensekkel szemben, ezeket a feltételeket csak összefoglalóan és röviden ismertetem a következökben.

Első feltételként határoztam meg, hogy az egyes fökomponensek összetevői, melyek legalább 0,5-ös korrelációt mutatnak egymással, legalább 25\%-ban részt kell, hogy vegyenek a létrehozott új mutatóban, vagyis, értékük legalább 0,25-ös kommunalitási értékben kifejeződjön (1). A következő feltételem volt, hogy a létrehozott főkomponens az adattartalom legalább 50\%-át őrizze meg, vagyis a varianciája legalább 50\%-os értéket érjen el (2). A következő feltétel a sajátértékre vonatkozott. A fökomponens analízis adatredukciós eljárás során lineáris transzformációval csökkenti az adattartalmat, egy változószettből alacsonyabb számú változószettet hoz létre (SZÉKELYI, M-BARNA I. 2002), ahol a tömörítést és a változók helyettesítését a fơkomponensek végzik, és ezek sajátértékei nyújtanak információt a megfelelő variancia viszonyokról, vagyis a tömörítés sikerességéröl és mértékéről (HAJDU O. 2010). A főkomponens-analízis során a bevitt változók egyenként is sztenderdizált értékeket vesznek fel, hiszen lineáris transzformáción esnek át ezért varianciaértékük 1. Mivel a fökomponens elméletben több változó értékeit hordozza, ezért elvárható, hogy az eredeti változónál nagyobb magyarázóértékkel bírjon. A harmadik feltételem tehát az Eigenvalue, vagyis sajátérték értékére vonatkozott, mely legalább 1 kellett, hogy legyen, ahhoz, hogy a kapott fökomponenst teljes értékü fökomponensként figyelembe vegyem (3). Negyedik feltételként támasztottam, hogy a létrehozott fökomponensek legalább három indikátorból épüljenek fel, hiszem két adat esetén szinte szükségtelen az adatredukciós módszer (4).

Bár a WHO adataiban nem szerepel, de fontosnak találtam a mindennapi élet minőségét nagyban befolyásoló infrastrukturális ellátottságot is figyelembe venni, hiszen az infrastrukturális ellátottság vagy annak hiánya maga is egyenlőtlenségeket generál a térben (SZABÓ P. - FARKAS M. 2012; PÉNZES, J. 2014). Ezért elöállítottam egy összetett mutatót az intézményi ellátottságról, melynek oktatás-képzési, egészségügyi, ellátottsági és közszolgáltatási összetevői is vannak (2. táblázat). Az összesített intézményi ellátottsági mutatót a TeIR-ben elérhető Területi statisztika adatbázisban az Intézményi ellátottság fülben felsorolt mutatókból állítottam össze, 2011, 2013, 2015 közötti évek értékeit is megvizsgáltam. Az ellátottság egy abszolút szám, mely a meglévő ellátástípusok összegét jelenti, minél nagyobb volt ez az érték, annál pozitívabb a település ellátási helyzete.

\section{2. táblázat: az intézményi ellátottság mutató összetevői. Forrás: Saját szerkesztés}

\begin{tabular}{|c|c|c|c|}
\hline \multicolumn{4}{|c|}{ Intézményi ellátottság mutatói } \\
\hline Oktatás - képzés & Egészségügy & $\begin{array}{l}\text { Infrastrukturális ellátott- } \\
\text { ság - kereskedelem }\end{array}$ & Közszolgáltatás \\
\hline bölcsőde & gyógyszertár & bankfiók & munkaügyi központ \\
\hline családi napközi & $\begin{array}{c}\text { házi gyermekorvosi szol- } \\
\text { gálat }\end{array}$ & helyközi autóbusz-megálló & okmányiroda \\
\hline óvoda & háziorvosi szolgálat & szennyvíztisztító telep & posta \\
\hline általános iskola & járóbeteg szakellátás & szennyvízgyüjtő hálózat & rendőrörss \\
\hline $\begin{array}{l}\text { középiskolai feladat-ellá- } \\
\text { tási hely }\end{array}$ & kórház & $\begin{array}{l}\text { vegyesiparcikk-üzlet és } \\
\text { áruház }\end{array}$ & tüzoltóság \\
\hline közmüvelődési intézmény & fürdő & piac & \\
\hline könyvtár & & ruházati szaküzlet & \\
\hline sportcsarnok/sportpálya & & üzemanyagtöltő állomás & \\
\hline
\end{tabular}

A vizsgálat során az eredeti WHO alapján ajánlott társadalmi-gazdasági főkomponens előállításakor az indikátorok között mind korreláció, mind a fökomponens adattartalma tekintetében éles törésvonal alakult ki. Ezért úgy döntöttem, hogy külön gazdaság és külön társadalmi fökomponenst képzek. 
Így kialakult egy életkort és településméretet reprezentáló és egy gazdasági aktivitást, képzettséget és etnikai viszonyokat bemutató fökomponens (3. táblázat).

3. táblázat A főkomponens analízis alapján figyelembe vett, bővített indikátorlista a kialakított dimenziók mentén. Forrás: WHO alapján saját szerkesztés ${ }^{1}$

\begin{tabular}{|c|c|}
\hline Dimenzió & Mutató \\
\hline $\begin{array}{l}\text { Épített környezet di- } \\
\text { menziója, lakáshely- } \\
\text { zet és lakókörnyezet } \\
\text { biztonság }\end{array}$ & $\begin{array}{l}\text { Komfort nélküli és félkomfortos lakások aránya 2011(\%) } \\
100 \text { före jutó büncselekmények száma 2011, 2013, 2015 (db) } \\
1000 \text { foóre jutó balesetek száma 2011, 2013, 2015 (db) } \\
1000 \text { före jutó daganatos betegek száma, 2011, 2013, } 2015 \text { (fö) }\end{array}$ \\
\hline $\begin{array}{l}\text { Természeti környe- } \\
\text { zet dimenziója }\end{array}$ & $\begin{array}{l}\text { Árvízzel érintett terület (igen-nem) 2010, 2013, } 2015 \\
\text { Belvízzel érintett terület (igen-nem) 2010, 2013, } 2015 \\
\text { Az ivóvíz minőségére vonatkozó adatok (ammónium, arzén, bór) határértéken felül az } \\
\text { ivóvízben (\%) 2011, 2013, } 2015 \\
\text { Egy före jutó veszélyes hulladék értéke } 2011,2013,2015(\mathrm{~kg})\end{array}$ \\
\hline $\begin{array}{l}\text { Települési környezet } \\
\text { dimenziója }\end{array}$ & $\begin{array}{l}\text { Település lakónépessége - törpe- és aprófalvas térségek kimutatása } \\
\text { 0-14 éves korosztály aránya (\%) juvenilis szerkezet } \\
\text { Összesített intézményi ellátottsági mutató } 2011,2013,2015\end{array}$ \\
\hline $\begin{array}{l}\text { Gazdasági környezet } \\
\text { dimenziója }\end{array}$ & $\begin{array}{l}\text { Egy före jutó összevont személyi jövedelemadó alap (Ft/fö) 2011, 2013, } 2015 \\
\text { Roma és cigány lakosság aránya (\%) } 2011 \\
\text { Legfeljebb nyolc osztályt végzettek aránya a munkaképes korúak között } 2011 \text { (\%) } \\
\text { Nyilvántartott álláskeresők aránya a teljes népességen belül (\%) az országos átlagnál } \\
\text { rosszabb értékek 2011, 2013, } 2015 \\
\text { A legalacsonyabb és legmagasabb adókategóriába tartozó adófizetők arányának kü- } \\
\text { lönbsége, 2011, 2013, 2015 }\end{array}$ \\
\hline
\end{tabular}

A fökomponens-elemzés segítségével lehatárolhatóvá váltak azok a potenciális környezeti igazságtalansággal érintett települések, illetve térségek, melyek deprivált helyzetük miatt kevésbé vagy egyáltalán nem kerülnek a környezeti igazságossággal kapcsolatos kutatások homlokterébe. Ezekről a településekről és térségekről többnyire a sajtóban nem jelenik meg megfelelö mennyiségü vagy minőségü információ, illetve, ha megjelenik, akkor sem vált ki nagyobb érdeklődést a kutatók körében, így a problémák feltártalanok maradnak. Ezen eredmények a környezeti-igazságosság kutatásban a szelektív diskurzus vizsgálatára adnak lehetőséget, azonban a disszertációban ezt a tényezőt, jelenséget nem vizsgáltam.

A fökomponens-analízis segítségével meghatároztam azokat a területeket, melyek a kutatásom lehetséges mintaterületeit adták. A mintaterületek kiválasztásánál a meghatározó az volt, hogy olyan aktuális természeti-környezeti problémákhoz kapcsolódjanak, melyekröl általánosan a média is beszámolt, mindemellett az elvégzett fökomponens-elemzés eredményeinek is megfelel.

Kezdetben környezeti katasztrófákhoz szorosan kapcsolódó online elérhető médiatartalmakat tekintettem át, melyek alapján leszükítettem a lehetséges mintaterületek körét. A dolgozatomban így három különböző típusú környezeti igazságtalanságot, az árvíz, belvíz és a vörösiszap-katasztrófa eseteit vizsgáltam meg összesen négy mintaterületen (Bereg, Borsod, urbánus belvizes és rurális belvizes terület, vörösiszap területe) (3. ábra).

\footnotetext{
${ }^{1}$ Amennyiben nem volt az adott évekre adat, úgy azt a mintavétel évéhez legközelebbi adattal pótoltam.
} 


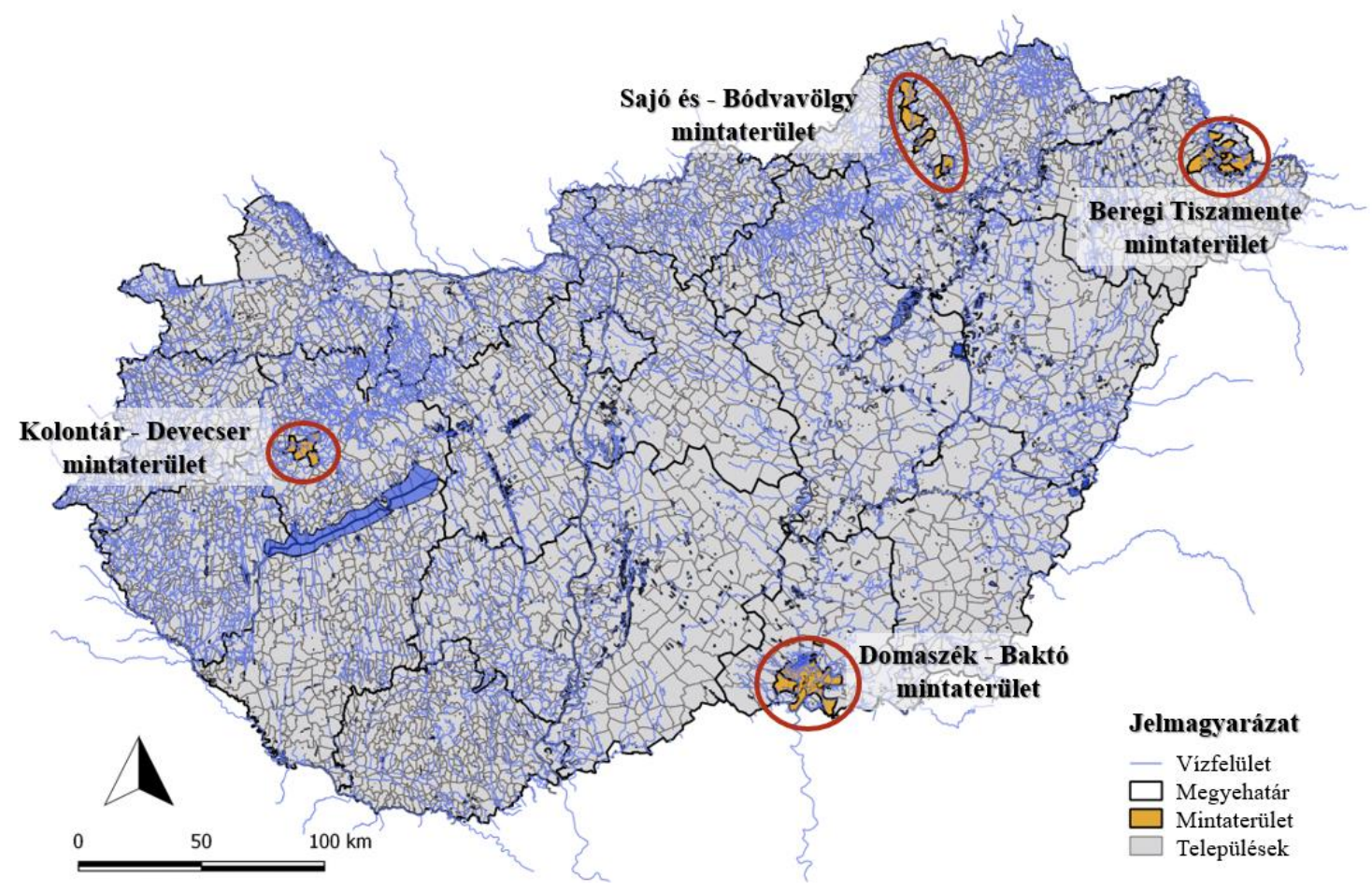

3. ábra: A mintaterületek elhelyezkedése (saját szerkesztés)

\subsubsection{Kérdőíves, interjús felmérés, dokumentumelemzés}

Mivel a környezeti igazságtalanságok települési szint alatti folyamatok eredményei, melyek országos statisztikai adatokkal bár összefüggést mutatnak, azok mégsem egyértelműen meghatározói. Ezért a településen belüli folyamatok feltárása érdekében kérdőíves felmérést végeztem, eredményeit minden esetben az MS Excel és az SPSS22.0 programokkal dolgoztam fel. A mintaterületeken összesen 5 időpontban zajlottak kérdezőbiztosok segítségével kérdöíves vizsgálatok. A kérdöívek kitöltését az adott mintaterület sajátosságaihoz legjobban alkalmazkodó módszer alapján (szakértői becslés, kvótás, randomszám segítségével stb.) végeztük. Összességében

Az összehasonlításhoz alapvető statisztikai eljárásokat alkalmaztam, a nominális és ordinális változók esetében Khí-négyzet próbát, míg a metrikus változók esetében t-próbát végeztem a szakirodalomban meghatározott feltételek alapján (SAJTOS L. - MiteV A. 2007; BARNA I. - SzÉKELY M. 2004; FREEDMAN, D. ET AL. 2005). Alkalmaztam haladó statisztikát is, csoportok lehatároláshoz a K-közép klaszter-elemzést végeztem, míg a döntési sorozatok vizsgálatára döntési fákat alkottam a rendelkezésre álló adatokból. A döntési fák alapvetően grafikus modellek, amit több rendelkezésre álló választási lehetőség alakít ki a legnagyobb valószínűség alapján. Általában ezt a statisztikai módszert a pénzügyi szektor hitelbírálat során alkalmazza (JÁNOSA A. 2011), azonban a kutatás szempontjából releváns módszer, hiszen ez jól feltárja az általános összhasznosságon alapuló értékítélet mögött meghúzódó véleménykülönbségeket (JÁNOSA A. 2011). A disszertációban használt döntési fák CHAID metódussal készültek ami a Khí-tesztet illetve az F-tesztet használja (TAN, P. 2012). A döntési fák esetében többnyire bináris és sorrendi attribútumokat használtam fel (nominális és ordinális mutatók), azonban a különböző fökomponens értékek esetében folytonos attribútumokat is beiktattam a vizsgálatba (metrikus adatok). Viszonylag kis mélységü döntési fákat építettem és a „szülő”, valamint a „gyermek” nódokat (JÁNOSA A. 2011) 25 és 15 fonnél határoztam meg.

A kérdőíves vizsgálat eredményeinek kiegészítéséhez $10 \mathrm{db}$ félig strukturált interjút készítettem, 6 fövel az árvizes mintaterületeken, 4 fövel a vörösiszappal érintett mintaterületeken. Az interjúk kérdései az adott katasztrófához és a kárpótláshoz kapcsolódtak. Főként a településen tapsztalható feszültségek milyenségének, okainak feltárását célozták. 
A kontextus értelmezéséhez jogszabály-elemzést végeztem. Áttekintettem a netjogtár segítségével az adott időszakban keltkezett kormányrendeleteket és kormányhatározatokat a jogi környezet tisztázásához, az esetleges anomáliák feltárásához. Továbbá megvizsgáltam az adott települések fejlesztési dokumentumait, koncepcióit, stratégiáit annak érdekében, hogy fentárjam, hogy az adott településen mekkora problémát jelent az általam igazságtalan helyzet kialakulásáért felelős esemény. Megjelenike a kérdéskör a fejlesztési dokumentumokban. Továbbá szisztematikusan áttekintettem a katasztrófákkal foglalkozó hazai online sajtót és folyóiratokat. Kulcsszavas kereséssel kerestem a legnagyobb hazai portálok cikkei között, ahol az összes releváns, témával foglalkozó cikket elolvastam. Mindez szükséges volt a téma átlátásához. Különösen hasznosnak találtam a hazai építészek egyik folyóiratát, az Országépítőt, melyben a települések képének megváltozásával kapcsolatos írásokat elemeztem, használtam fel a disszertáció megírásához.

A mintaterületeket, a hozzá kapcsolódó kérdöíves és kvalitatív felmérések módszereit részletesen az empirikus kutatás eredményei előtt mutatom be. A mintaterületek leírása már dolgozatom eredményét is képezi egyben, hiszen részletes mintaterülei profilt állítok fel, mely szervesen kapcsolódik az empirikus elemzésekhez. 


\section{A környezeti igazságtalanság földrajztudományi elméleti keretbe illesz- kedése}

A földrajztudományban az 1950-es években elinduló tudományelméleti viták az elmúlt évtizedekben számos új nézőpont, paradigma, gondolati keret, mint például a kvantitatív földrajz, behaviorista, feminista, neomarxista, vagy kritikai földrajz, kialakulását eredményezték (TóTH J. 2001, PEET, R. 2006, FARAGÓ L. 2018). Ezek ugyan késéssel, de a magyar földrajzi iskolákba is eljutottak és meghonosodtak. A megjelent új elméletek és nézőpontok föként a társadalomföldrajzi gondolkodásra voltak nagy hatással, mely egyre eltávolodott a természetföldrajzi kutatásoktól. Mindez annak ellenére történt, hogy számos negatív példa (szüz földek feltörése, néma tavasz, csernobili atomkatasztrófa hogy csak a legismertebbeket említsem) bizonyította az ember és környezetének szoros kapcsolatát.

Az 1960-as években megindult, és a 70-80-as években kiteljesedő környezetvédelmi mozgalmak szilárd alapot és hátteret biztosítottak az 1987-es évben kiadott Brundtland-jelentésnek. Már 1969-ben az ENSZ az egyre nyilvánvalóbb környezetszennyezést, túlnépesedést felismerve globális gondolkodásra sarkallta a szervezetet. 1972-ben az első környezetvédelmi konferenciát is megrendezték Stockholmban, a Római Klub gondozásában kiadták a Növekedés Határai címü jelentést (RAKONCZAI J. 2013). Mindezek felhívták a figyelmet az ember és környezetének összefüggéseire, és tevékenységünk Földünkre gyakorolt negatív hatásaira, a fenntartható fejlödés fontosságára, továbbá arra, hogy klímaváltozás globális problémája nem csak a jövő generációi, de főként napjaink kiszolgáltatott társadalmi csoportjai számára is egyre nagyobb kihívást jelentenek. Mindemellett ez az időszak az Egyesült Államokbeli polgári jogokért folytatott mozgalom kiteljesedésének időszaka, mely a színes bőrüek jogi emancipációját eredményezi. Részben ennek hatására a környezet és az ember viszonyának értelmezése a tudományban az elmúlt évtizedekben jelentősen átalakult. A fenntartható fejlődés elmélete, a negatív diszkrimináció és kirekesztés elleni közdelem a politikai irányelvek és a tudományterületek meghatározó momentuma lett. Az elképzelés szerint a jelen fejlődésünk nem késztetheti kompromiszszumra a jövőbeli generációkat szükségleteik kielégítésében. Mindehhez a társadalom, gazdaság és természet harmonikus fejlödése szükséges, nem csak ökológiai de pénzügyi fenntarthatóság mellett. Az általunk felhalmozott természeti, mesterséges, kulturális, társadalmi és humántőke az melyet átörökítünk, éppen ezért nem mindegy, hogy a tőkeakkumuláció milyen mértékben és módon történik (BELL, D. 2004; BERRY, B. 1999).

A fenntartható fejlödés elmélete a földrajztudományba is beépült (GUTTENSEN, R. 1996), eredményeként a szerves fejlödésen átment társadalomföldrajzi paradigmák és elméletek részben horizontális elemévévé vált, ismét középpontba helyezve a természet és a társadalom kapcsolatát, a természeti környezetben zajló emberi tevékenységek, a társadalmi csoportok müködésének, viselkedésének öszszefüggéseit, döntéshozatali mechanizmusainak folyamatait és az azok által létrehozott térbeli mintázatokat. Mindeközben a földrajztudomány is folyamatosan megújult, a nézőpontok statikusról dinamikusra változtak, a vizsgálatokat időben, térben és léptékeken átívelően is kiterjesztették (TIMÁR J. 2001). A modern társadalomföldrajz olyan környezet- ember kapcsolatokkal foglalkozik, melyek környezeti változásokat eredményeznek és ezek a változások különböző léptékben visszahatnak a társadalom müködésére (SNEDDON, C. 2009). Mindemellett nem csak feltárja a problémákat, hanem sarkall azok megváltoztatására is (PANELLi R. 2009, WiTHERICK ET AL 2001, TiMÁR J. 2001, KOVÁCs Z, 2001; TóTH J. 2001).

A társadalomföldrajzi irányzatok peeti értelemben vett egymás melletti párhuzamos, de egymástól nem független fejlődési folyamatát elfogadva (PEET, R. 2006; PEET ET AL 2010), ahogyan az ember hat a környezetére, úgy hatnak a kutatási irányok egymás fejlödésére is, újabb és újabb kérdéseket és kritikákat megfogalmazva. Ezen a teoretikai alapon jelenik meg a kritikai geográfia, mint társadalomföldrajzi irányzat, melynek kifejezett célja, hogy kritikát fogalmazzon meg a kialakult kutatási megközelítésekkel szemben és lépjen fel egy másfajta megközelítést alkalmazva (TIMÁR J. 2003; TIMÁR J. 2009). A kritikai geográfia definíciójának megfelelően a kapitalizmussal, a hatalmi relációk okozta társadalmi elnyomással és kizsákmányolással, azok ismételt és folyamatos újratermelési és termelődési folyamataival, a kirekesztéssel, a környezetszennyezéssel és az ezek által előidézett társadalmi-gazda- 
sági egyenlötlenségekkel foglalkozik, úgy, hogy azok ellen aktívan fel is lép. A kritikai geográfiai megközelítésben, számos esetben az elmélet az aktivizmussal és a cselekvéssel összekapcsolódik (TIMÁR J. 2003; SMITH, N. 2003), nemcsak a kutatások módszertanában és feltárási szakaszában, de az azt követö, a kutatások eredményét hasznosító beavatkozások tekintetében is. Az elmúlt évtizedekben új térbeli gondolkodásmód, kritikai személet kezdett elterjedni nem hagyományos tértudományokban, mint például jogtudomány, társadalomtudomány, gazdaságtudomány, ez a folyamat (BÖHM A. - PÁL L. 1988; MÉSZÁros R. 2000; TiMÁR J. 2005; NEMES NAGY J. 2009; WARF, B. - ARIAS, S. 2009; SoJA, E. W.2010) hangsúlyozza, hogy a tér, azaz szükebb és tágabb környezetünk nem csupán leíró tulajdonság, de aktív szereplő is mindennapi életünkben.

A térbeliség az igazságtalanságokat, egyenlőtlenségeket láthatóbbá és könnyebben kézzelfoghatóvá teszi (SMITH N. 2003), ezért a kritikai földrajzosok megfogalmazása szerint az igazságos és egyenlőségen alapuló társadalom kialakításának része a földrajzi folyamatok megértése és megfelelö, egyenlő, méltányos, igazságos földrajzi viszony megteremtése, a jelenlegi igazságtalan és egyenlötlen viszonyok megváltoztatása (HARVEY, D 1996; TIMÁR J. 2001, 2003, 2009). Az egyenlötlenség és igazságosság-szempontú megközelítés ellenére azonban nem szakít a földrajzi hagyományokkal, bár egyéb folyamatokat és tényezőket is kiemel elemzési keretként, megőrzi a kutatásokban a tér kiemelt szerepét, és hangsúlyozza a léptékeken átívelö folyamatok akár több tudományterület együttes munkájával történő feltárásának fontosságát. Ebbe illeszkedik bele a környezeti igazságosság gondolati világa. A térszemléletet kapcsolja össze az egyenlőtlenségeket a környezeti igazságosságban, mely elvezet a fogalom definíciójához kapcsolódó kérdésekhez és szakmai diskurzusokhoz. A földrajz többléptékü gondolkodása segít feloldani a lokális és a globális léptékek közötti ellentéteket és rámutat a különbözö léptékek egymással való összefonódására és a lokális folyamatok globális, nagyobb léptékü folyamatokba való beágyazódására. A lépték összefonódása mellett az időbeli kapcsolódás és a hosszabb időtávú aspektusok kiemelt szerepet kapnak a földrajzi munkákban, mely egyrészt utal a nemzedékeken átívelö folyamatok fontosságára is (BERRY, B. 1999; WESTON, H.B. 2008).

A környezeti igazságosság vizsgálati kerete a kritikai földrajzhoz hasonló kritikai szemléletet alkalmaz a fennálló társadalmi-gazdasági és politikai rendszerrel szemben, és igyekszik rámutatni az általa létrehozott egyenlötlenségekre és igazságtalanságokra. Vizsgálata annak ellenére, hogy szoros kapcsolatot feltételez a társadalomtudományok és a természettudományok között, mégis a kutatók inkább a társadalomtudományokhoz kapcsolják. A környezeti igazságosság azonban nem pusztán olyan társadalmi problémákkal foglalkozik, mint egészség-betegség, diszkrimináció, rasszizmus, politikai döntéshozatal, hanem természetföldrajzi kérdésekel is, mint például a fenntartható fejlődésben való elkötelezettség, talajszennyezés, vízszennyezés, árívíz, belvíz, a természeti és társadalmi folyamatokat összekapcsolja. Mindemellett nem csak a HARVEY és TIMÁR által felvetett földrajzi egyenlőtlenségek megfigyelését, de azok kiegyenlítését is célozza, ennek eléréséhez mindenki számára egyenlő és azonos elbánást kíván. Az egészséges környezet mindenki számára alapvető jogmely azonban nem különíthető el a társdalmi-gazdasági feltételektől és folyamatoktól, hiszen legtöbbször ezek azok, melyek az igazságtalan és egyenlőtlen folyamatokat előidézték (LEHTINEN, A. A. 2009).

A környezeti igazságosság nem vizsgálható komplex társadalmi-természeti szemlélet nélkül, mely megjeleníti földrajz kettősségét. Ezek alapján megfogalmazható, hogy a környezeti igazságosság vizsgálatok - amennyiben természethez köthető igazságtalanságok merülnek fel - alapvetően természetföldrajzi vizsgálati eredményeit felhasználva jutnak el a környezetben zajló természeti folyamatok társadalmi hatásainak megállapításaihoz. A hangsúly ezen kutatások esetében nem a természetföldrajzi folyamatokon, hanem azok emberre gyakorolt hatásán, illetve az emberek által a természetre gyakorolt hatásokon van. A környezetben zajló folyamatok környezeti igazságosság szempontú értékelései alkalmazzák a kritikai geográfia komplex értelmezéseit, megközelítését és fogalmi keretét, a társadalmi marginalizálódás, diszkrimináció folyamatának környezeti-térbeli megnyilvánulásait mutatják be. A környezeti igazságosság társadalomföldrajzi megközelítésnek is tekinthető, melyben ugyanakkor jelentős szerepet kap a természetföldrajz (LEHTINEN, A. A. 2009).

A környezetben fellépő igazságtalanságok direkt vagy indirekt módon befolyásolják társadalmigazdasági cselekedeteinket, vagy éppen a politikai döntéseinket, többléptékü földrajzi térben léteznek. 
Fenntartanak és felerősítenek olyan folyamatokat, mint kizsákmányolás, szegregáció, térbeli differenciáció. Hatására olyan struktúrák alakulnak ki, melyek az egyes környezetben zajló tevékenységek elönyeiből és hátrányaiból egyenlőtlen részesedést okonak gazdasági, politikai társadalmi döntések révén (WILLIAMS, R. W. 1999). A környezeti igazságosság-kutatások a kritikai geográfiai kutatásokon belül új térkategóriákat, mint például a környezeti periféria (KoVÁCS, A. D. 2004) is megteremtenek, melynek kialakulása a részvétel és az érdekképviselet hiánya, a mindennapi diszkriminatív gyakorlatok és rossz minőségi természeti-környezet indukálta negatív és tovagyürüző hatásainak eredménye. Mindez földrajzi keretek között mérhető és megérthető.

Bár a környezeti igazságosság-kutatások környezeti eseményekkel, folyamatokkal és azok rövidhosszútávú hatásaival foglalkoznak, mégis egyfajta társadalomkritikaként értelmezhetők, melyben a kritikai földrajz által is sokszor artikulált hatalmi viszonyokat minősíti és vizsgálja. Ez kapcsolódik össze azzal a folyamattal, melyet egyes szerzők a fentebb említett módon a tudományterületek ,területi öntudatra ébredéseként" definiálnak, vagyis a folyamatokat térbeli kontextusba emelik, így a környezeti igazságtalanságok vizsgálatában a földrajzi tér és a lépték alaptényezővé válik, vagyis a környezeti igazságosság vizsgálatok elsődlegesen földrajzi, ezen belül pedig másodlagosan kritikai földrajzinak tekinthetők az említett okok miatt. 


\section{A környezeti igazságosság kialakulása}

A környezeti igazságosság, mint kutatási keret egyre szélesebb körben alkalmazott interdiszciplináris megközelítése miatt. Egy olyan narratíva, melyet nem csak a társadalmi igazságosságot és esélyegyenlőséget zászlajukra tüző környezetvédelmi mozgalmak, de tudományos kutatások is egyaránt alkalmaznak. Ennek oka, hogy a tudományos igényü környezeti igazságosság kutatások a környezeti igazságosság mozgalomban (KIM) gyökerezik (MÁLOVICS, GY. 2012; MARTIN, A. ET AL. 2014). Egyaránt tükrözi a polgári jogokért folytatott küzdelem és mozgalom, az önkéntesség, az alulról szervezödés, a kiközösítés és a megkülönböztetés elleni küzdelem föbb eszméit, az egyenlő jogok biztosításának igényét. Éppen ezért a kezdeti környezeti igazságosság kutatások szorosan kapcsolódnak az Egyesült Allamokbeli polgári jogokért folytatott mozgalomhoz, melynek hagyományai megmutatkoznak az aktivizmus melletti elkötelezettségben is.

A környezeti igazságosság mozgalom kialakulásakor annak céljául tüzte ki, hogy feltárja, megértse, megszüntesse, vagy éppen megakadályozza az embereket érő környezeti ártalmakat. Ehhez azonban szükséges a helyiek, a civilek aktív részvétele, hiszen a helyben tapasztalt környezeti egyenlöséggel kapcsolatosan a helyiek tudnak releváns információt biztosítani. A környezeti igazságosság kutatások egyik alapvetése, hogy az úgynevezett fóáramú környezetvédelem (mainsream environmentalism) (MÁLOVICS, GY. 2012) döntéshozatából, intézményrendszeréböl, struktúráiból hiányzik a kisebbség, az alsóbb osztályok képviselete, így a döntésekben ezen csoportok érdekérvényesítése nem valósul meg. Ezáltal az így megalkotott környezetvédelmi döntések egyoldalúak és kirekesztőek lehetnek (FABER, D. - MCCARTHY, D. 2001; WALKER, G. 2006), és nem teljesül a széleskörü, alulról építkező megmozdulás és csupán bizonyos környezeti problémák kerülnek előtérbe. Éppen ezért a KIM kiáll a saját környezeti érdekeit önállóan képviselni képtelen csoportok mellett, segíti azok participációját, ezáltal a mozgalom aktivizmus útján érvényre juttatja az egészséges környezethez való alapjogokat (MÁLOVICS, GY. 2012).

A környezeti igazságosság mozgalmának történeti előzményeként tekinthetjük a Néma Tavasz (Silent Spring) címü könyv (CARSON R. 1962) megjelenését, mely egyben a civil és az állami környezetvédelem kezdetének is mondható (RAKONCZAI J. 2013). A második világháború után a szintetikus vegyszerek mezőgazdasági alkalmazása az egész fejlett világban elterjedté vált, azonban a leggyakrabban alkalmazott peszticid nem csak a kártevőkre nézve volt mérgező, de az ártalmatlan, gyakran hasznos egyéb élölényekre, illetve gyakran magára az emberre is. A könyv címét arról kapta, hogy a peszticidek megmérgezték a környék madarait, így abban az éven nem lehetett madárszót hallani. A Carson által publikált könyv hozzájárult a civilek és a kisebbségek környezeti öntudatra ébredéshez (NEWTON, D. 2009).

A navajo indiánok 1979-ben szervezetet alapítottak az új-mexikói Puerco-völgy tiszta vizének biztosítása érdekében, ahol uránt bányásztak az indián rezervátum területén. Az uránbányász cég kihasználta a helyiek témával kapcsolatos tájékozatlanságát, szándékosan nem fordított elegendő figyelmet a bányászat lehetséges következményeire. Ez komoly egészségügyi-kockázatot jelentett mind a területen élö indiánok illetve az indiánok által tartott állatokra is, komoly szervi elváltozásokat okozott. Egy hasonló katasztrófa ismételt bekövetkezése ellen a helyiek önképző rendszert indítottak, a közösség saját érdekében egységesen fellépett a bányászati vállalat ellen (NEWTON, D. 2009).

A környezeti igazságosságot kutatók szerint a meghatározó pillanat a környezeti igazságosságban az 1982. szeptember 15-i Észak-karolinai Warren megyei ellenálláshoz kötődik. Észak-Karolnia útjai mentén majd 120 ezer liter poliklorinált bifenilt (PBC) öntöttek ki, több mint $150 \mathrm{~m}^{3}$ szennyezett talajt hozva létre (NEWTON, D. 2009). Az állam úgy határozott, hogy a kármentesítési eljárás során felszedett talajt a Warren megyei Shocco község közelében helyezik el, azonban az eljárás nem felelt meg a szabványoknak, hiszen nem volt vízzáró réteg és az eltemetés sem a megfelelö mélységben történt. A többségében feketék által lakott, gazdaságilag az egyik legelmaradottabb, az ivóvizet föként felszín alatti vízből nyerő, kis politikai befolyással bíró Warren megye, illetve Shocco község lakói a források hiánya, illetve a megfelelő szakmai tudás híján keveset tehettek az ügy ellen, így hát saját testükkel próbálták megakadályozni a döntés végrehajtását. Ennek eredményeként több mint 500 tüntetőt letartóztattak, $\mathrm{s}$ bár a szennyezett talaj eltemetésre került, a történelemben először a szegény afro- 
amerikaiak összefogtak, és állami szinten álltak ki az egyenlő környezethez való jogért (NEWTON, D. 2009). Az eset rámutatott arra is, hogy a környezetterhelés nem érint mindenkit egyaránt, gyakran a szegényebbek, alacsonyabb státuszúak, kisebbségiek jobban ki vannak szolgáltatva a veszélyes és mérgező hulladékok általi kockázatnak, elégtelen munkakörülményeknek, szennyezett levegőnek, és egyéb környezeti sérelemnek, mint a gazdagabbak, vagy éppen a nem kisebbségiek (WILES, R. 1985).

Az egyre növekvő ellenállás következtében 1994. február 11-én az Egyesült Államokban beiktatják az Executive Order 12898-as számú törvényt, a Federal Action To Adress Environmental Justice in Minority Populations and Low-Income Populations címmel. A törvény elrendeli, hogy minden szövetségi fejlesztési és környezeti ügynökség építse bele politikájába a környezeti igazságosság eszméjét, illetve törekedjen annak megvalósulására, ráadásul a környezeti igazságosság nem csak a politikában, de az akciótervekben és a programokban is szerepeljen, és nem csak kisebbségi, de többségi népesség esetén is, ha az alacsony jövedelem, vagy a társadalmi státusz, esetleg a környezet állapota úgy kívánja. Az elsődleges cél a környezeti kockázatok csökkentésével az emberi egészség megóvása (NEWTON, D. 2009). A környezeti igazságosság törvénybe foglalása csak az első hivatalos elismerése volt a tudományterületnek. Az 1990-es évek során több ország alkotmányába foglalta a környezeti egyenlőség eszméjét.

A környezeti igazságosság kutatások kezdeti időszakában, föként az Egyesült Államokban, a kutatások fókuszában a kisebbségek környezeti ártalmakkal szembeni nagyobb kitettsége, a térbeli távolság, a társadalmi és térbeli elosztás egyenlőtlenségi álltak. A kutatások különböző környezetszennyező tevékenységek okozta egészségkárosodások, fokozott depriváció, ingatlanpiaci leértékelödés témakörben születtek (BRYANT, B. - MOHAI, P. 1992; BullaRD, R.D. 1990; BullaRD, R.D. 1993), föként statisztikai alapokon az igazságtalanságok egyszerü, eloszlási és elosztási aspektusait vizsgálták (FUNDERBURG, R. LAURIAN, L. 2015). A kutatások célja volt, hogy bizonyítékot szolgáltassanak az egyenlötlenségekre, és hogy a bizonyítékok birtokában beavatkozhassanak az igazságtalan folyamatokba, ezáltal biztosítva az egyenlő környezeti jogokat, azon a helyen, ahol az érintettek élnek, dolgoznak, játsszanak és iskolába járnak (MOHAI P. ET AL. 2009). Ezekben a kutatásokban a többrétü környezeti depriváció társadalmi státuszhoz, az etnikai hovatartozáshoz, demográfiai jellemzőkhöz kapcsolódó vonatkozásait, illetve a kockázatoknak való kitettséget vizsgálták (BOWEN, W. 2002, MORENO-JIMÉNEZ, A. ET AL. 2016).

Az igazságosság kutatás ezen időszakának erőteljes irányvonalává vált a környezeti rasszizmuskutatás, mely keretein belül a tisztességtelen, börszín és a gazdasági-társadalmi státusz szerinti telepítési gyakorlatokat vizsgálták, melyek egyenlötlen környezeti terhet rónak a színes bőrü (HAMILTON, T.J. 1995, PULIDO, L 2000), szegregált (CHAVIS, B.F. - LEE, C. 1987) közösségekre. Bebizonyították, hogy ezek a közösségek nagyobb környezeti kockázattal és egészségügyi problémákkal szembesülnek (CUSHING, L. ET AL. 2015). A kutatások megállapították, hogy a környezeti igazságtalanságok a legszegényebb, legkiszolgáltatottabb, kisebbségi helyzetü társadalmi rétegeket, csoportokat érintik a legjobban (BRAUBACH M. 2011; BRAUBACH, M-FAIRBURN J. 2010; SOJA, E. 2010; HIGGS, G. - LANGFORD, M. 2009; NewTON, D. E. 2009; CUTTER, S. L. 2002; BullaRD, R. 1994; BullaRD, R. 1990). Ezért a kezdeti kutatások föként az alacsonyabb minőségü környezetben élő csoportokat egy vagy esetleg több kiragadott társadalmi dimenzió mentén értékelték. A bizonyításhoz azonban eltérő elemzési egységeket használtak, melyek eltéró eredményeket hoztak, mindez elindította a területi-földrajzi szempontú megközelítések felértékelödését (MOHAI P. ET AL., 2009).

Mindemellett szakirodalmak azt is megállapították, hogy ily módon általánosítani és párhuzamot vonni a szegény, képzetlen és kisebbségi csoportok, valamint a környezeti igazságtalanságok között helytelen, túlságosan leegyszerüsítő, hiszen más-más csoportokra más-más hatást gyakorolnak egyes igazságtalan helyzet, melyekre az adott válaszok és reakciók is eltérőek. Kutatások felhívják a figyelmet, hogy a társadalmi-gazdasági státusz mellett az egyes vizsgált földrajzi egységekre jellemző infrastrukturális ellátottság, mint például a közszolgáltatási elérhetőség, de tágabb értelemben értelmezve a társadalmi rend és annak müködését befolyásoló tényezők és intézmények, folyamatok pl. bünözési mintázatok, katasztrófavédelmi szervezettség, kockázatkezelési módszerek és szokások jellegzetességei is hatással vannak az igazságtalanságok kialakulására, azok kezelésére (FISCHER J. B. ET AL. 2006). Mindazonáltal, mivel ezek a tényezők maguk is szervesen összefügghetnek a társadalmi helyzettel, jövedelemmel, így az egyéni/csoportos és területi jellemzők egymástól élesen nem elkülöníthetök. 
Mindezek miatt az egyén környezeti deprivációjára a negatív külső hatások fokozottan negatív irányba hatnak és egy lefelé tartó negatív spirál alakulhat ki. Tehát egyetlen környezeti igazságtalanság sem elkülöníthető a területegység (környezet) sajátosságaitól (WALKER, G. 2012).

Az 1990-es évektől kezdve a szakirodalomban egyre szélesedett a vizsgált igazságtalanságok köre, a tudatos és gyakran rasszista környezetszennyezés és annak hatásait feltáró kutatások mellett megjelentek a természeti katasztrófák következményeit vizsgáló tanulmányok is (CUTTER, S.L. (SZERK.) 2006; MAANTAY, J.-MAROKO, A. 2009; NAGY GY. 2012). Ezeket a tanulmányokat több ízben kritika érte a túlságosan leíró jellegük, valamint gyenge konceptualizáltságuk és statisztikai módszereik miatt (BOWEN, W. M. 2002). A kutatások által feltárt igazságtalanságok térben megnyilvánuló bizonyítékai sokszor egy igen egyoldalú, normatív és nem plurális igazság-fogalom alapján minősíttetett igazságtalanná.

Ennek hatására az elmúlt két évtized kutatásai az eloszlás vizsgálatáról egyre inkább az igazságtalanságok térbeli kialakulására, termelődésére helyeződött a hangsúly, melyek a kritikai földrajzi irányzathoz igen közel állnak. A kutatásokban nem csak a tér és a lokalitás válik hangsúlyosabbá, de mögöttes - globális vagy lokális - összefüggések feltárására is sor kerül. Így a bemutatás mellett a probléma vezérlöinek és azok következményeinek megértése is megtörténik. WALKER, G. (2012) szerint, ehhez három tényezőt kell egyidőben vizsgálni. Egyrészt az igazságosság fogalmát, melyről a későbbiekben részletesebben értekezek. Másrészt az általunk igazságtalanságnak tekintett folyamat, esemény, helyzet bizonyítékait, harmadrészt, a folyamatot, mely a kialakult helyzethez vezetett (4. ábra). A disszertációban a WALKER által megalkotott hármas nézőpontot alkalmazom a továbbiakban.

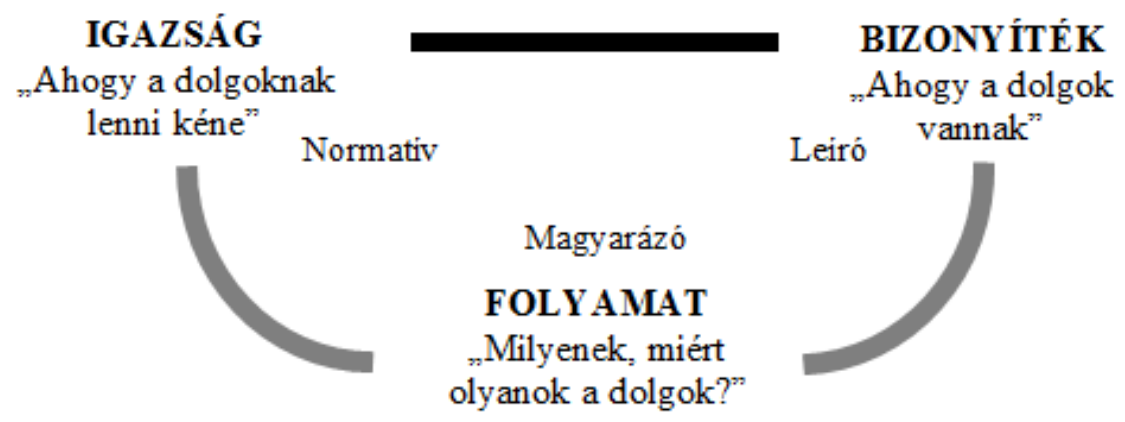

4. ábra: A környezeti igazságosság vizsgálatának elemei. Forrás: saját szerkesztés Walker, G. (2012) alapján 


\section{Környezeti igazságosság a posztszocialista országokban}

Az átmenet időszaka igen turbulensnek tekinthető intézményi, jogi és szabályozási szempontból is. Ezek a szabályozási folyamatok letisztultak az ugyan elmúlt időszakban, de az, hogy milyen módon tisztulnak le, és milyen trásadalmi tartalommal töltődnek fel, milyen érdekviszonyok állnak az átalakítások, az intézményi struktúrák és gyakorlatok mögött nem csak a posztszocialista örökség, de a jelenleg müködő rendszerek is tetten érhetők. Ezért nem csak posztszocialista, de perifériális kapitalista kontextusban is szükséges értelmezni a környezeti igazságosság kérdéskörét. Bár politikai és gazdasági értelemben megtörténik a rendszerváltozás, a müködési mechanizmusok, mind a társadalom mind pedig a joggyakorlat tekintetében átalakulnak, módosulnak, de az átmenet ideje alatt megmaradnak. Ezért a rendszerváltozás után hazánkban és a többi posztszocialista országban is a kialakult igazságtalanságok a korábbi szocialista rendszerben gyökereznek, de az átmenet időszakában sem szünnek meg (PRUGBERGER T. 2001). A kapitalizmus egy adaptált változata alakul ki, mely a korábbi hatalmi relációknak még mindig erős függvénye marad.

A környezeti igazságosság és társadalmi igazságosság kapcsolata mellett egyre hangsúlyosabb szerepet kap a tér és a lépték, és ebben az állami szerepvállalás is. A változó állami szerepek egyértelmüen összekapcsolódnak a társadalmi igazságosság vitákkal. Az államnak, mint az intézményrendszerek és ezáltal részben a társadalmi diskurzusok alakítójának felelössége van a társadalmi igazságtalanságok és térbeli egyenlötlenségek kialakulásában. Az állam a társadalmi, környezeti problémák megfogalmazásával - vagy éppen a meg nem fogalmazásával -, annak módjával befolyásolja a válaszokat, melyeket a felmerülő kérdésekre adnak.

A környezeti igazságosság kérdése így nem feltétlenül a szoros értelmezésben vett környezeti kockázatok és negatív externáliák egyenlő elosztásának, hanem a hatalmi viszonyoknak a függvénye, hiszen a kompenzáció hatalmi aktusként, döntéshozatali mechanizmus eredményeként azonosítható (BEGG, C. 2018). A hatalmi viszonyok alapján egy környezetileg igazságtalan helyzet is legitimációt nyerhet, abban az esetben, ha az egészséges környezethez való jogot az állam nem, vagy csak részben, a társadalom tekintetében szelektíven érvényesíti és garantálja - mint például a privatizációs időszakban (PRUGBERGER T. 2001). Az ilyen szelektív jogérvényesítés a profitmaximalizálás és költségminimalizálás elvének kedvező. A kevésbé szigorú szabályozást bevezető és alkalmazó országok esetében akár más országok környezetkárosító tevékenységei is áthelyeződnek ezekre a területekre, halmozott kitettséget előidézve (BOROS L. 2010). Erre számos példát találhatunk a fejlödő, periférikus országok esetében is. Mindezek következtében, egyes posztszocialista országokban vagy térségekben a környezeti igazságtalanságok maximális kompenzációja mellett a kockázatokat felszámolják, vagy viszonylag egyenlően elosztják, míg más térségek esetében a korábbi helyzet konzerválódik, vagy esetleg súlyosbodik.

A kapitalizmus kiépítése, illetve az 1990-es évek közepén kibontakozó neoliberális fordulat társadalmasítva van, úgynevezett közös elönyökre hivatkozva. E nézőpont szerint a piac profittermelésének következtében a növekvő bevételek növekvő jólétet hoznak, a globális és a lokális különbségek is csökkenthetők, a piac segítségével a fejlődő országok fejlettebbé válnak, felzárkózhatnak, míg a megfelelő elosztási rendszer mellett a térségi különbségek is nivellálódnak majd. Azonban a gyakorlat azt mutatja, hogy legtöbb esetben a neoliberális gazdaságpolitka okozta hátrányok kompenzációja nem, vagy csak részben történik meg, így kritikusok szerint a neoliberalizmus a legjobb eszköz az egyenlőtlenségek „új ruhába bújtatásához” (ÁGH A. 2018). Emellett az állami kompenzációs rendszerek nagyon drágán tarthatóak csak fenn, és azok sem hosszú ideig, ráadásul abban az esetben, ha például az anyagi kompenzáció meg is történik, akkor is viselni kell azokat a negatív hatásokat, melyekért kompenzálják a lakosságot vagy a térséget, mely ennek a révén legitimitást nyer. A kompenzációs folyamat önmagában egy rendszer hibáinak teljes kiküszöbölésére nem elég, csak mérsékeli annak hatásait hiszen a rendszer többelemü, és egy elem változtatása nem eredményezi feltétlenül a teljes müködési mechanizmus megváltozását. Főleg azért, mert a kompenzáció mint aktus nem a megváltoztatást, hanem a helyzet fenntartását, a rendszer változatlan tovább müködését segíti elő, ahol az egyszeres kompenzációt nagyságrendekkel meghaladja a kompenzáció által megtakarított pénz és a politikai haszon. A hazai neoliberális fordulat, de az ezzel párhuzamos neokonzervatív irányvonal sem szolgálja a környezetvédelmet, 
az értékvédelmet. Míg a neoliberalizmus a tőke társadalom feletti ellenőrzését kívánja, a neokonzervativizmus politikai ideológia, ami a neoliberális keretek kialakítását és fenntartását szolgálja. Az elmúlt években módszeresen építették le a természetvédelem intézményrendszerét hazánkban, mely nemcsak a környezet állapotának megóvását nehezíti meg, de a környezeti igazságtalanságokkal szembeni fellépést is. A környezetvédelem szempontjából sem a neoliberális sem a neokonzervatív fordulatok nem jelentettek pozitív irányú változást Magyarországon. Mindkettő különböző jelmondatok mellett - külföldi müködőtőke befektetés vagy éppen teljes foglalkoztatás - leginkább a gazdasági érdekeket helyezték és helyezik elötérbe.

A környezeti igazságtalanság kutatások több esetben kiemelik a környezetpolitika másodsorba helyezését mint igazságtalanságok kialakulásának indokát. A megfigyelt polarizációs és marginalizációs folyamatok, a periferizáció pedig meghatározó szerepü lehet azon társadalmi csoportok és terek kitermelésében, mely a környezettel kapcsolatos igazságtalan folyamatok alapját képezhetik (CLOUGH, E. 2018).

Bár azt mondhatjuk, hogy alapvetően a környezet és a környezeti folyamatok nem diszkriminatívak, nem válogatnak, nem jövedelem vagy az etnikai hovatartozás alapján érinti az egyéneket, mégis a környezetben bekövetkező katasztrofális változások mégis igazságtalanná válnak. Ennek oka pedig a társadalom és a gazdaság müködésében, a hatalmi relációkban keresendő. Nem a környezet igazságtalan, hanem a rendszer, mely a kontextust adja a környezeti változásokhoz, annak negatív következményeihez és az eszközölt aktusokhoz, például a kompenzációhoz.

A rendszerváltozáskor a társadalom - többek között a politikai kommunikációnak köszönhetően - úgy gondolta, hogy az új rendszerben mindenki egyenlő esélyekkel indul majd, azonban ahogyan az egyén születésétöl fogva egy adott közegben és körülmények közt nő fel, meghatározva ezzel eredeti helyzetét (original position) (RAWLS, J 2001), úgy a rendszerváltozáskor a korábbi társadalomban elfoglalt pozíció adta meg az egyének és csoportok eredeti pozícióját. Ez a környezeti igazságosság szempontjából azt jelenti, hogy a hátrányos helyzetüek, vagy a leromlott környezeti állapotú helyeken élők helyzete és környezete a kihirdetett rendszerváltozástól nem változott meg, ráadásul a fentebb leírt környezetvédelmi (alkotmányos és demokratikus) deficitek okán, több esetben még romlott is. A térbeli igazságtalanságok részei a rendszernek, hiszen a töke érdek diktálja az egyenlőtlenség fenntartását.

Az egyenlőtlen eredeti helyzet, a rendszerváltozás demokratikus deficitjei, a jogi hiányosságok, a marginalizációs és polarizációs társadalmi folyamatok, a konzerválódó hatalmi relációk a posztszocialista térséget, ezen belül Magyarországot a környezeti igazságosság szempontjából kiemelt kutatási területté teszi. Mindemellett a társadalmi-gazdasági és politikai folyamatokat felerősíthetik a természeti folyamatok, és azok közül is az egyik legégetőbb probléma a globális klímaváltozás és annak következményei.

Közép- és Kelet-Európában a környezeti igazságosság-mozgalom történeténél tárgyalt, egyenlötlen környezeti terheléshez kapcsolódó igazságtalansághoz hasonló folyamatok megfigyelhetők, mégis ezek feltárása azonban nem- vagy csak kezdetlegesen történt meg mindezidáig a térségben. Ennek egyik oka lehet a környezeti problémák relativizálása. Napjainkban a posztszocalista országok számos olyan egyéb, társadalmi-gazdasági helyzetet meghatározó problémával szembesülnek, mely mellett a környezeti degradáció és az ez okozta lakossági kockázatok többedrangú problémának tünhetnek.

A környezeti igazságosság-kutatások kibontakozását elősegítheti, hogy a keleti blokkban, a szocializmus időszaka alatt a gyakran nem racionális fejlesztések környezetkárosító hatásai az 1990-es évektől egyre súlyosabbá váltak. Ez föként a szocialista tömbben hiányzó vagy háttérbe szoruló környezetvédelem, és a nemtörödöm környezetpolitikának róható fel. Nehezítheti azonban, hogy, ha a környezetkárosodás szemmel látható és dokumentálható is volt, arról beszélni nem volt ildomos a szocializmus időszakában. A rendszerváltást követő években a neoliberális gazdaságpolitika adaptálásával, a várakozások ellenére, sikeres és átfogó környezetpolitika nem alakult ki (AGYEMAN J. - OGNEVAHIMMELBERGER Y. 2009). Ráadásul a környezetvédelmi mozgalmak lassan bontakoztak ki a rendszerváltozás után, melyek azonban sokak szerint napjainkban is igen gyenge lábakon állnak, mind Magyarországon, mind a többi posztszocialista országban. A magyarországi rendszerváltozás egyik legföbb környezetvédelmi megmozdulása a Bős-Nagymarosi gátrendszer ellen indult, mely inkább az előző 
rendszer nihilista és a közösség véleményét figyelmen hagyó környezetpolitikájának kritikája volt, mintsem valódi környezetvédelem (MúLT-KOR 2009).

Ennek fényében EMBER I. ET AL. (2002) kiemelik a volt szocialista országok társadalmának nagymértékü sérülékenységét és kitettségét a környezetszennyezéssel szemben, illetve a Kárpát-medencében meghúzott korábbi mesterséges határok természetvédelmi, környezetvédelmi és egészségügyi kockázatait. Ezáltal kívánják felhívni a figyelmet a környezeti igazságosság szükségességére a térségben. Magyarország kiemelt szerepet kap publikációjukban, melyben az ország medence-helyzetét említik mint környezeti igazságossággal kapcsolatos kockázati tényezőt. Ez a pozíció a vízfolyások szennyezésénél kifejezetten hátrányos, hiszen védekezni sem lehet a környezetkárosodás ellen, illetve szankcionálni sem lehet megfelelően a szennyezést (EMBER I. ET AL. 2002). SZABÓ M. (2004) hívja fel a figyelmet, arra, hogy az USA-ban akkor már 40 éve ismeretes ,régi-új” paradigma adaptálása elöremozdíthatná a környezetvédelem ügyét Magyarországon és Közép- és Kelet-Európában is (SzABó M. 2004). 2010-ben a Védegylet révén elindult hazánk első környezeti igazságosság-kutatása is. JULESZ M. (2012) a környezeti igazságosságot a társadalmi igazságosság speciális aleseteként azonosítja és példaként említi a borsodi romákat érő környezeti igazságtalanság okozta egészségügyi helyzet romlását. Felhívja a figyelmet, hogy a többség nem zsákmányolhatja ki a természeti értékeket, hiszen ennek rövid távon vagy hosszabb idő után is következményei lesznek, mely legtöbb esetben hátrányos helyzetü csoportokat érint majd, föként az érintett társadalmi csoport egészségromlása lesz megfigyelhető (JULESZ M. 2012). Jelenleg a magyar nyelven elérhető tanulmányok föként külföldi írók kutatásainak fordításai és esettanulmány jellegủek (MÁLOVICS, GY. 2012). A kutatások egyrészt feltárják a környezeti igazságtalanságok bizonyítékait és törekednek az okok feltárására is (MÁLOVICS GY. 2012). FODOR L. ET AL (2016) szerint a környezeti igazságtalanság, illetve rasszizmus jelenségével foglalkozni kell, azonban sem a kormányzat, sem az önkormányzatok nem érzékenyek problémára, utóbbiak annak ellenére, hogy a településrendezési eszközök segítségével javíthatnának a környezetileg deprivált csoportok helyzetén (FODOR L. ET AL. 2016).

Az USA-ban kisebbségekkel kapcsolatban leírt környezeti igazságtalanságok párhuzamosságot mutatnak a térség cigány és roma lakosságával kapcsolatos környezeti problémákkal, azonban teljes azonosság nem írható le. A Közép- és Kelet Európa posztszocialista országairól szóló környezeti igazságosság-kutatások egyik fő fókuszában a roma lakosság hátrányos helyzete áll (STEGER, T. - FILČÁK, R. 2008).

Hasonló a két folyamat egyrészt, mert a szocialista iparosítás hatására megindult a romák vidékről városba való áramlása - ahogyan az USA-ban is megindult a föként afroamerikai kisebbség városba áramlása - azonban a roma lakosság urbanizációjának mértéke nem érte el a nem roma lakosságét, a folyamat ellenére a cigányság területi elhelyezkedésének sajátossága maradt a falvakban való nagyobb koncentrálódás (HAVAS, G. 1999; PÉNZES, J. ET AL. 2018).

Másrészt, mert a romák és cigányok a történelem során folyamatosan szembesültek a diszkriminációval egész Európában, mely a legtöbb esetben területi szegregációval is párosult (LADÁNYI, J. VIRÁG, T. 2009; VIRÁG T. 2010). A romatelepek a falvak szélén, illetve a városokban elkülönülten jöttek létre, gyakran természetes vagy mesterséges tereptárgyakkal elválasztva a központi településrésztöl (STEGER, T- FILČÁK, R. 2008; HARPER, K. ET AL 2009; NAGY GY. 2011). A kutatások rávilágítanak, hogy négy fö irányvonala tárható fel a környezeti igazságtalanságoknak a térségben: a veszélyes vegyi anyagoknak és hulladéknak való kitettség (1), az árvizeknek való kitettség (2), az ivóvízhez és egyéb közszolgáltatásokhoz való egyenlötlen hozzáférés (3), a diszkriminatív hulladékelhelyezési gyakorlat (4) (STEGER, T. - FILČÁK, R. 2008). A lakóhelyi elkülönülés magával hozza a kulturális és társadalmi elválasztódást és marginalizálódást is okoz, gyakran többszörözi az adott területen élőkre néző kockázatokat.

Harmadrészt a roma lakosság elkülönülését és kirekesztését, csakúgy, mint az Egyesült Államok gettóiban tapasztalható, a közszolgáltatásokból való kirekesztése is segíti. A közszolgáltatások bevezetésére, az egyenlőtlenségek és igazságtalanság csökkentésére irányuló követeléseket a helyi vagy központi kormányzat pénzhiány miatt általában elutasítja (MELLÉKLET 9.1.5). Nem csupán a szolgáltatás vagy a védelem kiépítésre de az az utáni fenntartásra sincs pénz, így inkább nem biztosítják a hozzáférést a romák számára. Eredményként megosztott települések jönnek létre, melyben az embereket érhető 
kockázatok is nagyobbak (FILČÁK, R. 2007). A közmüvesítés, a vezetékes ivóvízellátás és gyakran az elektromos áram hiánya méltánytalan és embertelen körülményeket eredményez. Számtalan esetben a romák lakhelyei egy korábbi hulladéklerakaton, vagy ahhoz közel, szennyezett mezőgazdasági földön, vagy árvíznek legjobban kitett területen helyezkednek el. A romák lakóhelyét gyakran „határon túli” (beyond the pale) típusú területként kezelik ahol ennek következtében a higiénia és a természeti erőforrásokhoz való hozzáférés igen korlátozott (HARPER ET AL. 2009; MÁLOVICS GY. 2012; 2018).

Például a Kassán megjelenő hipermarketek hulladék-lerakója a roma-telep közelében épült fel 2005-ben. A hulladéklerakó legnagyobb kockázata, hogy a telep lakói a lerakóra ,járnak bevásárolni” ahol lejárt szavatosságú élelmiszerek, illetve egyéb hulladékok után kutatnak, ezzel óriási egészségügyi kockázatnak téve ki magukat és gyermekeiket is (FILČÁK R. 2007). Hasonló például szolgálhat Svinia község a Svinka folyó felső vízgyüjtőjénél, Kelet-Szlovákiában, Kassától 10 km-re. Az 1980-as évek elött két cigánytelep volt a településen, amit alsó és felső falucskának hívtak. A 80-as években a felső falucskát lerombolták, és az alsóba költöztették az összes romát, akiknek a rendszer által biztosítottak újonnan épült házakat. (STEGER, T. 2007) A romáknak nem csupán lakhelyük szünt meg, de a korábban két különálló közösség kényszerült együttélésre négy nagyobb épületben, melyekben 8-8 lakás található. Nagyjából 50 viskó pedig később épült a telephez. Annak ellenére, hogy nagyjából a település lakosságának fele roma, a választásokon egyetlen roma képviselő sem került be az önkormányzatba, mely példázza a romák depriváltságát. A helyzet javítására az EU PHARE és a kanadai Caribou egyetem közös programmal kívánt 70 új házat építeni a romáknak, azonban az önkormányzat döntése értelmében a program csak részlegesen valósult meg, annak ellenére, hogy a pénz már meg volt, csak az engedélyeket kellett volna kiadni (FILČÁK, R. 2007). 2009-ben Ostrovany településen a cigányok házai köré betonfalat építettek, mely bejárta a világsajtót is $[4,5,6]$ ebben az esetben sem a fennálló problémákat próbálták felszámolni, hanem egy látszatmegoldást kínáltak a település lakosai számára.

A szintén a Svinka folyó mentén található Jarovnice települést 1998. június 20-án árvíz öntötte el hatalmas esőzések következtében. A folyó korábban a felső szakaszokon szabályozva lett, a medrét kikövezték, így a lefolyási sebesség megnőtt, s hirtelen gyorsasággal tört az első laposabb területre, melyen a jarovnicei cigánytelep elhelyezkedik. Az árvíz alatt 35 épület rongálódott meg, és 47 halálos áldozatot követelt, akik közül 45 roma volt. A település legalacsonyabban fekvő területein elhelyezkedő cigánytelep az ár után még több napig vízben állt. Ezt követően a lerombolt házakat újraépítették, hiszen a romáknak nem biztosítottak más területen helyet az építkezésre (STEGER, T. ET AL. 2007, FILČÁK, R. 2007).

A lakóhelyi szegregáció mellett a munkaerö-piaci diszkrimináció is érinti a cigány népességet. A szocializmus alatt hivatalosan nem létező, azonban a kezdetektől fogva érzékelhető társadalmi-gazdasági különbségek alakultak ki a roma és nem roma emberek között. A korábbi tradicionális munkájukat és életmódjukat felhagyó romák alacsony státuszú munkához jutottak, mint favágók, napszámosok a TSZ-ben, bányászok, vagy ipari munkások (HARPER, K. ET AL. 2009). A rendszerváltás után az egykori nagy ipari fellegvárak és a szocialista újvárosok szerkezeti összeomlása következett, a privatizáció és a váltás nagy hatással volt az országokra, a racionális üzemszervezés, a költségminimalizálás stb. a korábbi maximális foglalkoztatottságról akár 20-30\%-os munkanélküliséget szült, melynek első szenvedő alanyai voltak az alacsonyan képzett romák (STEGER, T. - FILČÁK R. 2008; NAGY GY. 2011). Ahogyan a világ bármely válságrégiójában, úgy a rendszerváltozás következtében Magyarországon és Kelet-Közép Európában is megjelentek forráselvonások. Az így eszközölt városi szolgáltatások megkurtítása, szociális juttatások visszametszése, a fejlesztési akciócsoportok és tevékenységek juttatásainak elvonása legelsőként az alacsony státuszúakat érintette (DREIER, 1992, VIRÁG T. 2006), ami alacsony jövedelmet, szegényes jövőbeli kilátásokat és reménytelenséget teremtett ezekben a térségekben (RosLER, M. 1991). Az ipar felszámolásával gyakran az egyetlen munkalehetőség is megszünt a térségben és elindult a gettósodás folyamata, melyet tovább erősített a kormányzati szinten is támogatott pólus-fókuszú, központ és szuburbán térségeket fejlesztő gazdaságpolitikája (EITZEN, D.S.-ZINN, M.B 1994). Ezeken a területeken a gettósodás „ördögi köre” (CSÉFALVAI Z. 1994) a dolgozó középosztály kivándorlásával kezdődik, melynek hatására a településen csökken a befizetett adóalap, a beköltözők alacsony státuszuk miatt további segítségre szorulnak, így nem csak a „régi”, de az ,újdonsült szegényeket" is a település csökkent költségvetéséböl kell ellátni (EITZEN, D.S. - ZINN, M.B 1994). Mindez 
a spirál végén egy akut válságterület kialaulását jelenti, ahol nem csak a gazdaság strukturális problémaival, de az etnikailag összetett társadalom konfliktusaival is számolni kell.

A posztszocialista térségben a roma lakosság gyakran a környezetére káros csoportként van megbélyegezve (CSALOG Zs. 1994). Környezettudatosság teljes hiánya mutatkozik meg, mikor védett hóvirágot szednek az erdőben, hogy azt a városban értékesítsék, vagy a környező erdőkből lopják a fát a házaik fütéséhez, de a társadalmi környezetre is káros megnyilvánulásokkal (kábellopás, veteményesek meglopása) nem csak a sztereotípiákat erősítik, de a nem roma lakosság szemében csak ellenérzéseket keltenek (HARPER, K. ET AL. 2009). Mindez azonban nem csak az egyén döntéséböl kialakult helyzet, melynek fentebbi leírása eufemisztikus, azonban létező társadalmi diskurzus. A megbélyegzés mellett rendkívül nagy probléma húzódik a környezeti tudatosság hiányában, mely indirekt módon vezethet környezeti igazságtalanságok kialakulásához. A társadalmi kirekesztettséggel a környezeti természeti kitettség is nő, hiszen az érintettek sok esetben a a kirekesztettségnek köszönhetően, vagy a tudás hiányában kitettebbnek tekinthetőek a környezeti kockázatoknak, ami ezzel párhuzamosan megnöveli az egészségügyi kockázatokat, és emellett csökkenti a humánbiztonságot. Kimutatható, hogy összefüggés van az alacsony színvonalú életminőség, a környezeti degradáció, a szegénység és a rasszbeli elkülönülés között a cigányos településeken (MÁLOVICS GY. 2012).

Hazánkban és tágabb környezetében nem csupán a romák érintettek a környezeti igazságtalansággal, de a gyakran a közbeszédben ,cigány életünek” mondott nem roma és cigány, marginalizált csoportok, szegények is hasonló helyzetbe kerülnek. Éppen ezért disszertációmban egyaránt kitérek az alacsony jövedelmüek, romák és cigányok egyenlőtlen helyzetére is. A hazai kontextus sok esetben megegyezik a fentebb említett Közép- és Kelet-európaival, azonban a dolgozatomban kevésbé egyfókuszú, csak kisebbségekkel foglalkozó kutatás valósítottam meg. Ahhoz, hogy megfelelően tudjam értelmezni az igazságtalan helyzeteket a következőkben feltárom a környezeti igazságosság fogalmi kereteit. 


\section{A környezeti igazságosság fogalmi keretei}

A környezeti igazságosság fogalmát elsőízben az Egyesült Államokban fogalmazta meg az Environmental Protection Agency (EPA), ,mely az összes ember tisztességes bánásmódja és bevonása rassztól, börszintöl, nemzetiségtöl vagy jövedelemtöl függetlenül a környezetvédelmi törvények, rendeletek és politikák kidolgozása, végrehajtása és érvényesitése tekintetében. Mindez az egyének, a nemzeti közösségek és az egész nemzet számára biztositandó. Ez akkor érhetö el, ha mindenki ugyanolyan védelmet élvez a környezeti és egészségügyi veszélyekkel szemben, és egyenlö hozzáféréssel rendelkezik a döntéshozatali folyamathoz, hogy egészséges környezetet biztositson az élet, a tanulás és a munka terén [7]."

A környezeti igazságosság, mint vizsgálati keret a társadalmi és természeti különbségek viszonyában kívánja feltárni a környezeti egyenlőtlenségeket, melyek nem csupán egyenlőtlenek, de igazságtalanok és méltánytalanok is az egyénekre, csoportokra nézve. Ezek alapján a környezeti igazságosság megfogalmazható az emberek egyetemes jogaként az azonos állapotú és minőségü környezethez, melyben egészséges és teljes életet élhetnek (1), egyenlően viselve a társadalmi-gazdasági tevékenységekből illetve politikai döntésekből (2) vagy természeti folyamatokból (3) eredő kockázatokat és veszélyeket (5. ábra).

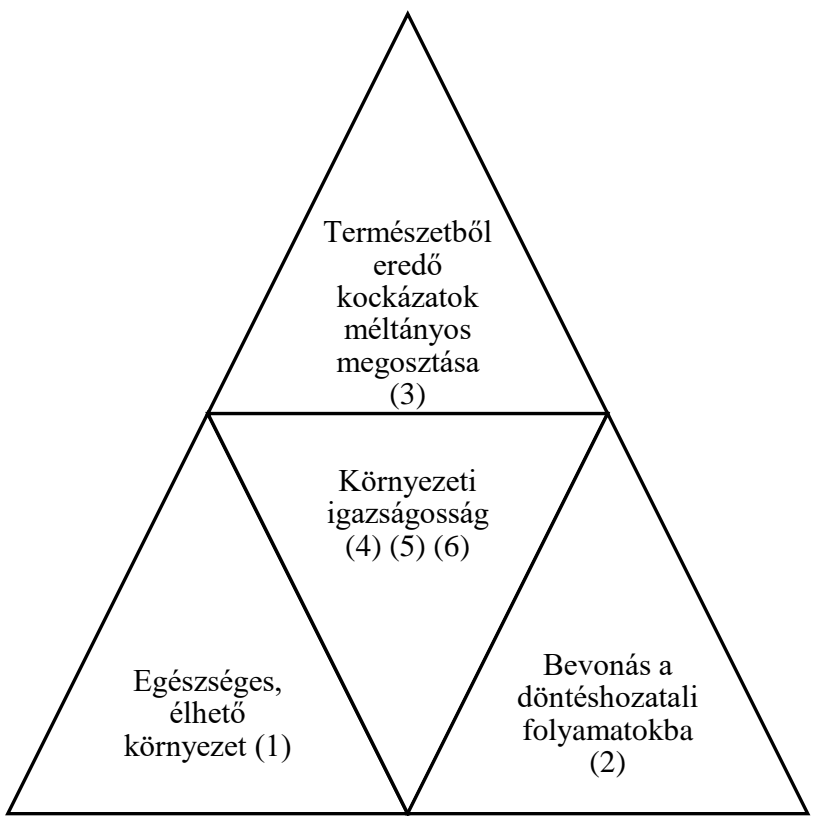

5. ábra: a környezeti igazságosság három alappillére az EPA megfogalmazása alapján. Forrás: saját szerkesztés

A kutatás alapfelvetésének megértéséhez fontosnak tartom, hogy a fentebb említett fogalmat két oldalról megközelítsem, az egyik a libertariánus, másik pedig a liberális (WESTON H.B 2008). Azért vélem szükségesnek a két álláspont bemutatását, mert a megfigyelhető igazságtalanságokra adott válaszokat, megoldási kísérleteket alapvetően befolyásolja a két nézőpont.

Először is a környezethez való joghoz kapcsolódóan (1) a két nézőpont másként vélekedik az egyéni szabadságjogokról. Míg előbbi az egyén szabadaságjogait a „szabad valamitől” elven, negatívan fogalmazza meg, addig utóbbi a „szabadsága van, hogy” elven pozitívan közelít az egyén jogaihoz (FEINBERG, J. 1999). A libertariánus nézőpont az állam legkisebb intervencióját sürgeti, azt is főként a magántulajdon védelme érdekében és az egyén jogait „negatív” módon fogalmazza meg, vagyis a jogokat a valamitől való mentességként, ellenpontjaként határozza meg (FEINBERG J. 1999). Ebből a szempontból tehát az embereknek joguk van a környezeti ártalmaktól mentes élethez. A másik nézöpont a liberális, mely pozitív oldalról közelíti a jogokat, azt fogalmazza meg, hogy az egyénnek, csoportjainak mihez van joga. Ebböl a szempontból tehát az egyéneknek, csoportoknak joguk van egy olyan környezethez, mely egészséges élethez való alapfeltételeket biztosítja. 
A döntésekhez (2) kapcsolódóan a liberális megközelítés elfogadja az állami beavatkozást a társadalmi-gazdasági és politikai jólét érdekében, azonban ez nem eredményezheti a jogok korlátozását. Úgy vélekedik, hogy a természet sebezhetősége és egyedi jellege miatt a jelenlegi technológia, beavatkozások, tevékenységek a jövőben nem várt hatásokat is generálthatnak, ehhez kapcsolódóan a korábbi álláspontunk változhat egy-egy beavatkozással, technológiával kapcsolatban (WESTON H. B. 2008; BECCHI, P. 2011) (pl. az atomenergiával kapcsolatos viták napjainkban), tehát azt sosem tekinthetjük állandónak és általános érvényünek. Ebben szükséges az állami szerepvállalás, hogy biztosítsa az emberek számára a közjót a változó kontextusban és környezetben is. Annak a kérdése azonban, hogy mi szolgálja a közjót és mi az, ami mindenki számára a jogok megfelelö biztosítását jelenti, többféle elképzelés létezik. Ezek az elképzelések a jogi és igazságosság helyi normáitól, az intézményrendszertől, a jellemző folyamatoktól egyaránt függnek. Szükség van egy úgynevezett társadalmi szerződésre, mely jogi és morális értelemben is meghatározza a jog által szolgáltatott igazság ideologikus koncepcióját (WESTON, H.B. 2007). A libertariánus felfogás szerint a lehető legkevesebb állami döntést kell hozni az egyenlőtlenség felszámolása érdekében, hiszen azt a piaci mechanizmusok megoldják. Bármely nézőpontot is fogadjuk el, megállapítható, hogy az igazságosság és az igazságtalanság, a vélt vagy valós környezeti veszély és kockázat felismerésének folyamata szubjektív. A döntéshozatali mechanizmusban a jó és a rossz megitélése egy társadalmi folyamat eredménye, az adott társadalmi-hatalmi-gazdasági állapotok lenyomata, mintsem egy általános érvényü igazság. Vagyis a jogszabályok által meghatározott igazság eltérhet a társadalmilag igazságosnak tartottól (BLACKSELL, M. ET AL. 1986; BLOMLEY N.K. 1994; BUTLER, C. 2009). Így a környezet- és társadalompolitika által meghatározott általános szabályok gyakran a környezeti periférián (KovÁcs A. D. 2004) másképpen értelmezhetők, hiszen kialakulhat az általánosan elfogadott fogalomrendszer lokális (át)értelmezése. Korábbi kutatások (BLOMLEY N.K. 1994; BLACKSELL, M. ET AL. 1986) alapján egyre inkább elfogadottá vált a nézöpont, hogy a jogi környezet és a térbeli egyenlötlenségek összefüggésben vannak, a jogi környezet is részt vesz a tér termelési folyamatában (BUTLER,C. 2009), a jogszabályok, jogalkotás- és a joggyakorlat folyamata alakítja a környezetünket, a helyeket, tereket (HARVEY, D. 1973; LEFEBVRE, H. 1991; MCAUSLAN, P. 1980). Ezért fontos a kutatásokban tisztázni, hogy mi az, ami szükségszerüen vagy elvártan (is) igazságosnak minősíthető, illetve mi ennek az elérési útja, hogyan lehet alkalmazni (HEFFRON R.J. - MCCAULEY D. 2018).

A környezeti igazságtalanságok egyoldalú megközelítése azok leegyszerüsítéséhez vezet éppen ezért nem lehetséges egyértelmüen kijelenteni csupán a környezeti hátrányok térbeli elosztása alapján, hogy az igazságos-e vagy sem, minden esetben szükséges az igazságosság fogalmát tisztázni, és lefektetni, hogy igazságtalanság bebizonyosodása esetén azt nem eredménynek, hanem inkább egy társadalmi diskurzus kezdetének szülkséges értelmezni, melyben használt fogalmaink elfogadott, társadalmilag legitim, nem önkényes értékválasztáson alapulnak, hanem az adott kontextushoz illök. (3). A környezeti igazságosság többrétüsége az együttesen alkalmazandó fogalmak sokszínűségből is ered.

Tágabb értelmezésben azonban szükséges kiterjeszteni a fenti állapotra és helyzetre vonatkozó fogalmat a folyamat-szempontú megfontolásokkal is. Erre azért van szükség, mert a környezeti események nem különülnek el a társadalomtól, azzal szoros kapcsolatban állnak. $\boldsymbol{A}$ környezeti igazságtalanság nem csak természeti, de társadalmi közeg-függö is, ahol kulcselem a non-human tényezó, egy olyan környezeti esemény vagy helyzet mely az egyéneket és csoportokat eltérõ módon érinti (4). Ezzel kapcsolatban két egymással szemben álló nézőpont alakult ki a kutatók körében, melyek a nonhuman szerepét nem, csak annak társadalommal való kapcsolatát más irányból közelíti meg (MURDOCH, J. 1997). A neomarxisták szerint a non-human alakulását a társadalmi tényezők bizonyos célok elérése érdekében befolyásolják és irányítják, melynek hatására alakulnak ki igazságtalan helyzetek (4a) (MuRDOCH, J. 1997; BOSCO, F. 2014). A társadalmi jellemzők, mint például a nem, a kor, az etnikai hovatartozás, a társadalmi és hatalmi viszonyok újratermelödési folyamata térbeli vetülettel rendelkezik, mely hatással van közvetetten vagy közvetlenül a környezeti eseményekre. És bár a környezeti igazságtalanságok környezeti eseményekkel foglalkoznak, mégis egyfajta társadalmi kritikaként is értelmezhetők, hiszen a fennálló rendszer hatással van az igazságtalanság kialakulására. A társadalmigazdasági különbségekkel számos esetben állnak kapcsolatban környezeti konfliktusok (MURDOCH, J. 1997; BosCO, F. 2014). Ezzel szemben a cselekvőhálózat elmélet megközelítése szerint a non-human, 
természeti faktorok bizonytalan változói a rendszernek, melyek hatására alakulnak ki a „cselekvők” és jönnek létre a cselekvő csoportok és azok hálózata, tehát a társadalom szerveződésében az igazságtalanságok kialakulása kulcstényezö lehet (4b) (MuRDOCH, J. 1997, BosCO, F. 2014). Például egy természeti katasztrófa következtében átalakulnak a települések társadalmi viszonyai, melyek új kapcsolatokat, eredményeznek a jobb érdekérvényesítés érdekében. A két nézőpont összevetésének a környezeti igazságosság szempontjából fontos üzenete, hogy a tér a társadalom konstrukciója, egy emberek által generált folyamat, azonban a tér és annak nonhuman tényezői is képesek a társadalom konstrukciójára, a környezeti igazságtalanság folyamata a társadalomban csoportképzöként jelenhet meg (MURDOCH, J. 1997, Bosco, F. 2014).

Ráadásul a különböző társadalmi viszonyok között és eltérö térbeli és időbeli léptékben (5) ugyanazon környezeti folyamatok másként jelennek meg. Az igazságtalan helyzetek felszámolása a térbeli szemlélet nélkül nem lehetséges, azért is, mert a környezeti közegek, a levegö, a talaj, a víz stb. más-más jellemzőkkel bírnak, így az egyes igazságtalanságok (szennyezések) terjedése is más, az okozott károk is másként nyilvánulnak meg. A térbeli helyzet mérsékeli vagy éppen erősíti a tapasztalt negatív folyamatokat, ezért a helyspecifikusság, környezet vizsgálata és az abból levont következtetések hozzájárulnak a megfelelő válaszlépések megfogalmazásához. Azonban a jelen állapotok feltárásával a társadalom egy pillanatnyi helyzete alapján határozzuk meg az igazságosság létét vagy hiányát, mely az időbeli kiterjedéssel nem foglalkozik, így a fejlödési folyamatok egy kiragadott helyzetét írja le. Ezért előfordulhat, hogy ami pillanatnyilag igazságos az történelmi vagy földrajzi kontextusban igazságtalanabb, mint a korábban tapasztaltak (CAPEHEART, L. - MILOVANOVIC, D. 2007). Ezek alapján a környezeti igazságosság és igazságtalanság kontextusfüggősége térhez és időhöz is kapcsolódik. Egyrészt statikusan értelmezett, a hol és a mikor, másrészt strukturálisan is értelmezett a miért és hogyan kérdésekre is választ ad, a mögöttes folyamatok, hatalmi viszonyok, történelmi beágyazottság alapján, melyek nagymértékben befolyásolják a társadalmi viszonyok térbeliségét.

Az igazságtalan állapot és helyzet megszüntetése vagy mérséklése feltételezi a lakosság tényleges bevonását a környezetét érintő jogi, politikai, szakpolitikai döntéshozatalba, megvalósításba és végrehajtásba, tekintet nélkül nemre, életkorra, származásra, identitásra, jövedelemre is (6). Az igazságosság össztársadalmi érdek, ezért megvalósulása a legszélesebb körben bevonást igényel. Az igazságosság akkor áll elő, ha közös nevező mentén kialakul a környezetileg biztonságos, egészséges és az igazságos és méltányos fogalma. Mindemellett szükséges „objektív” szempontokat és mérési eszközöket, módszereket is alkalmazni. A környezeti igazságosság az egyenlötlen, igazságtalan és méltánytalan állapotokat nem csak feltárja, de arra kíván megoldást alkotni, így egyfajta beavatkozási módszer is.

Összességében a környezeti igazságosság vizsgálata kiterjed: az egészséges környezethez kapcsolódó szabadságjog(ok) (1) bizonyos döntéseken (2) és folyamatokon (3) alapuló csorbulásának (igazságtalanság) feltárására, ahol figyelembe kell venni, hogy az alkalmazott fogalmak szubjektívek, így kontextus-alapú megközelítés szükséges azok vizsgálatára. A környezeti igazságtalanságok human és non-human tényezők egymást kölcsönösen befolyásoló és alakító rendszerében, (4) különböző térbeli és időbeli léptékben (5) jelentkezik. Az igazságtalanság megszüntetéséhez alapvető fontosságú a participáció és a bevonás (6). A környezeti igazságtalanságok tehát földrajzi tértől nem függetleníthető jelenségek, melyek kutatására a földrajz kettőssége és szintetizáló látásmódja kiváló keretet biztosít.

\subsection{Környezet fogalom értelmezési lehetőségei a környezeti igazságosságban}

A környezet fogalma az elmúlt évszázadokban nagy változáson ment keresztül. A darwinista, környezeti determinista, a modern, eröforrás-központú felfogások helyett napjainkban a környezet, mint társadalmi alkotóelem jelenik meg. Ezek alapján a környezet az embert körülvevő természetes és mesterséges összetevők összességeként értelmezhető, a természet azon része, mellyel az ember folyamatos interakcióban áll (ТóTH J.2001). A környezet nem csupán természeti feltételek és körülmények, melyek körülveszik az élölényeket vagy ökoszisztémákat, de olyan társadalmi és kulturális alkotók is, melyek befolyásolják az egyéneket és a társadalmat (DAVIES A. 2009). Sőt, az antropogén jelenlét, az emberi mentális és viselkedési tényezők alapján válik valami természetből környezetté (BÁRDOS GY. 2005). Ezek alapján mind a kultúra, mind az identitás meghatározó szereppel bír a társadalom és a 
környezet közötti kapcsolatban (SNEDDON, C. 2009). Így mind a természeti, mind a társadalmi tényezőket a környezet alkotóelemeként szükséges tekinteni (ENYEDI GY. 2000), mely mellett a harmadik, a társadalmi és környezeti tényezők együtteseként kialakult, a változásokhoz alkalmazkodó, vagy éppen az által generált viselkedés, mint mentális környezet-elem definiálása is szükséges (BÁRDOS GY. 2005). A viselkedésünket leíró mentális térben fenntartunk és felerösítünk olyan folyamatokat, melyek egyenlötlen helyzeteket okoznak, és nem csak vertikálisan, egyének és csoportok között, de horizontálisan, térben is differenciát okoznak. A tér, vagyis tágabb értelemben vett társadalmi-gazdasági és természeti környezetünk, vertikális és horizontális viszonyuk nem csupán egy leíró jellemzö, de aktív alakítója is létünknek (SoJA, E. W. 2010).

A földrajzi és a környezeti igazságosság szempontjából értelmezett környezet egy olyan sajátos tértípus, melyben a természeti és társadalmi szféra törvényei is hatnak, így ezek érvényesülése sajátos, a másik által befolyásolt (TÓTH J. 2002). Környezetünk egy szüntelen visszacsatolási rendszer eredménye, az ember környezetével dinamikus kölcsönhatásban él, melyet maga alakít, és eközben egyensúlyáért is felel (EMBER I. 2006). A kölcsönös függési viszony fennállása miatt a környezet szerkezete befolyásol(hat)ja a benne élők viselkedését és gondolkodását is (MÉSZÁROS R. 1994). A környezet észlelése lokális, helyhez kötött, így a környezeti problémák gyakran önmagukban helyileg jelentkezők, helyieket érintők. A lokális problémák összessége viszont regionális és globális folyamatokat eredményez. A lokális és globális, valamint más léptékben zajló folyamatok egyaránt szerepet játszanak és egymással szoros kölcsönhatásban vannak.

A környezet már nem csak a pozitivista nézőpontból tekintett természeti erőforrások lelőhelye, de a természet azon speciális része, mely életünk színtere, jólétünk és egészségünk záloga, mindemellett veszélyek és kockázati tényezők forrása is. A környezetben zajló eseményeknek alapvetően két nagy csoportját különíthetjük el, a természeti és az antropogén eredetüt. A környezeti események a valóság társadalmi konstrukciói és értelmezései melyek nem csupán egy válasz, de egy azonosítási, értelmezési, identifikációs folyamat eredményei. Ezek akkor válnak veszéllyé, ha az emberek életére negatív hatással vannak és azt annak megfelelően veszélyként is értelmezik. A negatív hatásokat tovább módosítja az emberek által az esemény ellen tett társadalmi, gazdasági, politikai vagy kulturális akciói, tevékenységei (ELLIOTT, S.J. 2009).

A környezet-fogalom a piacgazdaság kontextusában számos esetben annak kommodifikációja, privatizációja és termékként való értelmezése kapcsán kerül elö (EDEN, S. 2009; BOROS L. 2010). Az 1970-es évektől egyre inkább neoliberális gazdaságpolitika elemeként megjelenő „eladható környezet” fogalom számos konfliktus forrásává vált. A neoliberalizmus alapvetően vitákat generál mind az eszmerendszer értelmezésében, mind a kiteljesedő kapitalizmus szülte egyenlőtlenségek miatt (BOROs L. ET AL. 2007), mely számos esetben a haszonelvü nézőpontot helyezi előtérbe - akár a környezeti, akár a társadalmi igazságossághoz kapcsolódik (EDEN, S. 2009, BoROS L. 2010). Ebben a kontextusban a környezet értéke a profittermelő képességéhez kötődik, közgazdaságtani szempontból mérhető (MÁLOVICS, GY 2016) és a környezetre, egy eszköz, használati tárgy (EDEN, S. 2009). Emellett a környezetünk által nyújtott lehetőségek igénybevétele egyénenként és társadalmi csoportokként eltérő, mindez az egyének társadalmi-gazdasági helyzetétöl is függ, így a természet kiaknázása gyakran öszszekapcsolódik a hatalom birtoklásával és a befolyás gyakorlásával. Ez egyenlőtlenségeket okoz az élet számos területén, bizonyos csoportokat előnyhöz juttatva, ugyanakkor másokat hátrányos helyzetbe hozva (EDEN, S. 2009).

A környezet növekvő károsítása, privatizációja és az egyre nyilvánvalóbb egyenlőtlenségek és igazságtalanságok a történeti fejezetben kifejtett módon civil mozgalmakat indítottak útjukra, melyek a természet és az emberi kultúrák közötti kapcsolatból kialakult, az emberek által okozott negatív hatásokat vizsgálják etikai, politikai és egyéb aspektusokból (DAVIES, A. 2009). A kritikai megközelítés alapján a kialakult igazságtalanságok nem a természeti környezet kizsákmányolásából fakadó egyenlötlenségek, nem a természeti környezet határosságában, hanem a társadalmon belüli technológiai és igazságosságbeli hiányosságokban gyökereznek, melyek nem képesek az erőforrások megfelelő kiaknázására és a hátrányok és előnyök megfelelő elosztására (EDEN, S. 2009).

Ezen a gondolatmeneten tovább haladva a környezet negatív externáliák, kockázatok és veszélyek eloszlása, elosztása és hatása sem azonos. A kockázatok és veszélyek elosztása nem, vagy nem a 
társadalom számára megfelelő módon és mértékben irányított, ezért egyenlőtlenül oszlik meg a térben, melyeket részben a társadalmi különbségek is generálhatnak vagy elmélyíthetnek. A társadalmi helyzetböl, sérülékenységböl fakadó egyenlőtlenség tovább növelheti a kialakult különbségeket. A tudomány fejlődésével a létező, kialakuló, és újonnan megjelenő környezeti kockázatok száma folyamatosan nő, ezzel egy időben a társadalom kockázat-érzékelése is változik, az elmúlt bő két évtizedben a kockázatról alkotott vélemény átalakult (BECK, U. 2003). A fejlett, centrum térségbeli országok társadalmai egyre kevésbé türik az egyént és csoportjaikat fenyegető veszélyeket és kockázatokat, melyek kiszámíthatatlanságot és ismeretlenséget hoznak a mindennapokba. A környezeti kockázatokra és veszélyekre adott társadalmi reakciók olyan komplex térbeli, társadalmi-gazdasági feltételrendszer függvényei, mely lehetőséget teremt az egyenlötlen és igazságtalan helyzethez való alkalmazkodáshoz, az ellenálláshoz vagy a negatív hatások leküzdéséhez. Ez magában hordozza annak a lehetöségét is, hogy a környezeti ártalmakat áthárítsák, mely a kárvallottak körét megváltoztathatja ugyan, de a problémát nem feltétlenül oldja meg, ezáltal termelve újra térben akár eltérő helyen az igazságtalanságokat.

A környezet és az egészség fogalmai közel állnak egymáshoz bizonyos szempontból, nehéz őket látni, észrevenni, meghatározni, mérni. Gyakran megfeledkezünk róla, hogy mind a környezet, mind az egészség, mind az egészséges környezet állapota az intézményrendszerek és azok müködése által is meghatározott, befolyástól, hatalmi tényezőktől is függ. Szükséges ezért a környezet, az egészség, az egészséges környezethez való jog és annak biztosításának rögzítése.

Ennek értelmében az elmúlt évtizedekben a környezettel kapcsolatosan a jogalkotásban is megjelentek nemzetközi és hazai iránymutatások, jogi normák. Alaptörvényünkben a környezethez való jog (Magyaroszág Alaptörvénye 2011), mint harmadik generációs alapjog (SÁRI J. - SOMODY B. 2008) megjelenik. Ez alapján Magyarország elismeri és érvényesíti mindenki jogát az egészséges környezethez. Az alaptörvény az állam számára a környezet védelmével kapcsolatos intézményi és teljesítési garanciákat határoz meg, mint például a minőségi mutatók meghatározása, azok érvényesülésének törvényi feltételeinek megteremtése, ellenőrzése (NÉMETH L. 2012). A környezethez való jog jelenlegi formájában nem alanyi alapjog, hanem globális jellegü, megsértése általában nem érzékelhető közvetlenül és azonnal, a sérelem hosszabb távon fejtheti ki hatását (SÁRI J. - SOMODY B. 2008). Az egészséges környezethez való jog reciprocitáson alapul, hiszen az alaptörvény rendelkezése szerint aki a környezetben kárt okoz, köteles azt - törvényben meghatározottak szerint - helyreállítani vagy a helyreállítás költségét viselni.

A környezet tehát nem csupán a természeti értékei miatt, de az annak emberre gyakorolt hatása miatt is fontos, így igazságtalanságként nem csak a természetben okozott, de a társadalmi-gazdasági környezetben fennálló és kialakuló negatív állapotokat és folyamatokat is értelmezzük. A környezet és ember viszonyának újraértelmezése rávilágít, hogy a környezetben tapasztalt egyenlőtlenségek olyan struktúrákat alakítanak ki, melyek direkt vagy indirekt módon újra és újra befolyásolják életünket, társadalmi-gazdasági cselekedeteinket, politikai döntéseinket (WILLIAMS, R. W. 1999A) és a környezet állapotát. Az egyenlőtlenségek újratermelik az egyenlőtlen helyzeteket és társadalmi különbségeket. Ezek egyik legfőbb jellemzője, hogy térben is megjelennek és többléptékü földrajzi térben léteznek és leggyakrabban egészségügyi kockázatban, vagy életminőség romlásban nyilvánulnak meg (PÁL V.BOROS L. 2009).

\subsection{Az igazságosság értelmezési aspektusai a környezeti igazságosság-kutatásokban}

Az igazságosság kérdése az ókor óta kutatott és vitatott (JOHNSTON, D. 2011), az alapján, hogy a jog által biztosított igazság elosztáson vagy reciprocitáson alapul vagy milyen főbb dimenziók és irányelvek mentén alakul ki, például egyenlőség, fontosság, megfelelőség (WESTON, H.B. 2008) az igazságosságról többféle elképzelés létezik.

Arisztotelész bevezeti az ,arányos egyenlőség” fogalmát, mely szerint az azonos jogúakat azonosan, míg különböző jogúakat különböző módon kell bírálni (CAPEHEART, L. - MILOVANOVIC, D. 2007). Napjainkban a jogok különbözősége nem értelmezhető, így az azonosság fogalma sokkal inkább valamely társadalmi-gazdasági dimenzió(k) mentén kialakult társadalmi réteghez, csoporthoz, osztályhoz való tartozás alapján alkalmazható. Ez az elképzelés ebben az esetben a pozitív diszkrimináció és 
a körülmények figyelembevételére sarkall. Arisztotelész elképzelése alapján a jog és az igazságosság elosztáson alapul.

Rousseau (RousseAU, J. J. 2001; CAPEHEART, L. - MILOVANOVIC, D. 2007) szerint az igazságtalanság az emberek közösségében születik meg a lehetőségekhez mérten való egyenlőtlen birtoklás eredményeként, mely társadalmi konfliktust generál. Ennek felszámolását az állam és a társadalom által együttesen aláirt társadalmi szerződés teheti meg. Kant szerint az igazságosság csak az emberek kollektív akarataként születhet meg, (STEIGER K. 1997) mely alapján demokratikus jogalkotási folyamatot indítunk el, és a megszületö jogszabályok az összes ember akaratát tükrözik. MARX És ENGELS (1980) a Kommunista kiáltványban az igazságtalanságot definiálja, mint az igazság ellenpontját, azt állítják, hogy az igazságtalanságok kialakulásáert a kapitalizmus okolható. Ez az ideológia alapján az igazságosság és igazságtalanság bizonyos társadalmi-gazdasági berendezkedéshez és folyamathoz köthetők.

Az 1970-es években Rawls megalkotta az igazságosság elméletét, mely szerint az igazságosság minden személy sérthetetlen joga, mely nem feláldozható a társadalom egészének jóléte érdekében. Egyidejüleg fontos leszögezni, hogy mindenki azonos jogokkal és kötelezettségekkel van felruházva. Elfogadva Kant elképzelését, mely szerint az igazságosság a közösség által definiált fogalom Rawls azt állítja, hogy egy jól müködő társadalomban nem csak az a fontos, hogy a társadalom szereplői igazságosság elveit elfogadják, de az is, hogy az általuk létrehozott intézmények is megfeleljenek az igazságosság elveinek, vagyis az egyének között ne legyen megkülönböztetés és az emberek által, közvetetten az intézményeken keresztül életre hívott szabályok társadalmi egyensúlyt teremtsenek. Mindezt úgy, hogy közben hatékonyak, megfelelően koordináltak és stabilak, megbízhatóak maradjanak. Az igazságosság tehát a társadalom érdekazonossága, akiknek résztvevői kötelezően és együttesen ismernek el bizonyos magatartási szabályokat, azok alkalmazásában pedig az intézményrendszerek megadják a jogbiztonság feltételeit (RAWLS, J. 1977).

Azonban az igazságosság kollektív értelmezésében érdekellentét is felmerül, hiszen az egyén arra törekszik, hogy a legtöbből részesüljön, a társadalom is törekszik arra, hogy a lehető legtöbb ember vágya teljesüljön. Tehát Rawls szerint egy rendszer vagy egy folyamat akkor igazságos, ha úgy van kialakítva, ha az abban élők mindegyikének teljesülnek a vágyai. De az önmegvalósítás során létrehozott „egyéni vagy személyes igazságok” mások érdekeit sérthetik, mely egyenlötlenséget és konfliktust, igazságtalan helyzeteket szülhetnek (RAWLS, J. 1977). Felmerül a kérdés, hogy van-e, és ha van, akkor mi a határa az egyes egyének vagy csoportok érdekellentétének, mely még nem tekinthető igazságtalan helyzetnek?

A haszonelvüség szerint a társadalom akkor igazságos, ha a lehető legnagyobb tiszta egyenlegét éri el a megvalósult vágyaknak. A legfőbb jó a lehető legtöbb ember boldogsága, vagyis a morálisan helyes cselekvés és politika, mely a legnagyobb boldogságot eredményezi a társadalom tagjai számára (BUJALOS I. 2007). Az alapján ítéli meg a döntéseket, legyen az magánszemély vagy politikai, intézményi döntés, hogy az az érintettek boldogságát növeli vagy csökkenti. Még az alapvető emberi jogok is korlátozhatók vagy megsérthetők, ha ezzel egy magasztosabb, nagyobb jó célját szolgáljuk (BENTHAM, J. 1977; BUJALOS I. 2007; MÁLIK J. Z. 2013).

A kontextus-alapú értelmezést alapul véve az igazságosság fogalmat alkotó egyszerü kategóriák, mint a ,jó" és a ,helyes” egymástól függő fogalmak, vagyis csak akkor igazságos valami, ha az jó, és egyben helyes is, azonban mindenki számára mást jelentenek ezek a fogalmak. A haszonelvü igazságosság azonban ezt nem veszi figyelembe, nem tekinti mérvadónak, hogy az egyének a jóból hogyan osztoznak, egyetlen szempontot tart meghatározónak, hogy a társadalom egésze szempontjából a lehető legtöbb jó valósuljon meg. Az említett rendszert úgy kell kialakítani, hogy a benne lévő eszközökböl, a jogokból, a kötelességekből, kiváltásgokból, hogy a lehető legtöbben részesüljenek belőle (BUJALOS I. 2007), vagyis a hasznosságot nem esetről-esetre, hanem hosszútávon kell maximalizálni (MÁLIK J. Z. 2013). Ez azonban ellentmond az egyéni érdekekkel és azzal, hogy a társadalom minden tagja sérthetetlen, a haszonelvü igazságosság által alkalmazott összközösségi érdek sem lehet ezek felett. Így összegezni az egyének nyereségét és veszteségét nem elfogadható és nem igazságos. Ezért Rawls véleménye szerint a haszonelvű igazságosságot ki kell egészíteni, a társadalmi szerződés megalkotásakor figyelembe kell venni az egyén társadalmi helyzetét, az „eredeti pozícióját” (original posotion), mely 
részben, de akár teljes mértékben is determinál(hat)ja az egyén lehetőségeit, a jóról és rosszról, helyesről és tévesröl és így az igazságosról alkotott fogalmakat is (WALKER G. 1993).

Rawls ezzel az igazságossággal szemben támasztott kitételével figyelembe veszi az etnikai, vagyoni, nemi, státuszbeli különbségeket, hiszen minden egyén más-más eredendő helyzetből indul. Elfogadja, hogy mások a társalmi-gazdasági körülmények, a politikai berendezkedés által az egyénnek kínált lehetőségek. Ennek kiküszöbölése érdekében kifejezetten fontosnak tartja, hogy bármely környezetünket érintő döntést a ,tudatlanság fátyla” (veil of ignorance) alatt hozzanak meg. Vagyis az említett original position ismerete nélkül (de azt az alkalmazáskor figyelembe véve) választják ki a legmegfelelőbb elméleteket, szabályokat, így biztosítható a méltányosság, mert az ezáltal mentes lesz mindenféle társadalmi szerkezet (gazdasági-társadalmi körülmények és politikai berendezkedés) adta problémáktól, érdekellentéttől. Rawls egy olyan ideális és hipotetikus helyzetet teremt ezzel, melyben minden résztvevő racionális döntés alapján ideális nézőpontból alakítja ki a társadalmi igazságosság formális elveit (BALOGH I. 2006; BENCE Gy. 2007, KRÉMER S. 2017). A tudatlanság fátyla alatt mindenkinek azonos a helyzete, jogai pedig a rendszerből adódóan azonosak, egyenlők (RAWLS, J. 1977).

Mindemellett fontos lefektetni azt is, hogy nem feltétlenül az az igazságos, amely egyenlö, hanem az, ami méltányos. A méltányosságként felfogott igazságosság nem a társadalom által elfogadott helyes megfogalmazása nélkül határozza meg a jót és az igazságosságot, hanem azt figyelembe véve, egy előre elfogadott fogalom alapján. Ráadásul későbbi döntésekben alkalmazása csak akkor lehetséges, ha ismerjük az érintettek vélekedéseit, érdekeit, egymás közti viszonyait, választási lehetőségeit, mérlegelési eljárását. Rawls mini-max elmélete alapján a döntéseink úgy születnek, hogy minden alternatívát megvizsgálva azt választjuk, ahol a lehetséges legrosszabb szcenárió is jobb az összes többi alternatíva legrosszabb következményeinél (RAWLS, J. 1977; KRÉMER S. 2017). Ez persze feltételezi azt is, hogy a társadalom összes tagja tisztában van a legjobb döntésekkel, megérti és jóváhagyja azokat az elveket amikben korábban megegyeztek, ez azonban ütközik az eredeti helyzet elképzeléseivel. Ez az összeférhetetlenség (is) vezethet igazságtalan és méltánytalan helyzetekhez.

Rawls méltányos igazságossága és az említett haszonelvü igazságosság legfőbb kérdései közé tartozik, hogy a kevesek hátrányokkal való sújtása ellensúlyozható-e a mások számára nyújtott előnyökkel, illetve, ha azok összességében nagyobb hasznot generálnak, mint kárt okoznak. Napjaink globális gazdasági folyamatait is meghatározó neoliberális és hazánkban egyre inkább kiteljesedő neokonzervatív gazdaságpolitika gyakran veszi alapul a haszonelvü igazságosság illetve a Rawls által megfogalmazott méltányos igazságosság elveit. Mindkettő elképzelés szerint csak akkor valósulhat meg igazságtalanság, ha azzal még nagyobb igazságtalanságot előzünk meg, illetve ha az a közjó érdekeit szolgálja, és ha a vagyon vagy a hatalom egyenlőtlen eloszlása kárpótlásul előnyt teremt mindenkinek, főként a leghátrányosabb helyzetüek számára. Az igazságosság ebben az esetben szükségelvü és társadalmi egyenlötlenségek nem tekinthetök igazságtalannak, ha például egy jobb társadalmi helyzetủ csoport pozíciójánál fogva a rosszabb helyzetüeket segíti (RAWLS, J. 1977).

Kérdésként és kritikaként fogalmazható meg, hogy az efféle igazságosság-megközelítés túlságosan paternalista és elősegíti az eredeti pozícióból adódó különbségek által generált egyenlőtlenségek és egyenlötlen, igazságtalan viszonyok és helyzetek újratermelését. Más kritikusok szerint is az elképzelés túlságosan atyáskodó és szociális a vagyonosabbaktól áldozatot kíván, mely bár az egyenlőségre törekszik, mégis igazságtalan a gazdagabbakkal szemben (OKEREKE, C. 2006).

Egy másik kritika az említett igazságosság-fogalmakkal szemben, hogy az igazság normatív jellegéből adódóan, ahogyan a világról alkotott kép is változik, ugyanúgy változhat a környezetet meghatározó tényezők változásával, tehát az sosem tekinthető állandónak, annak ellenére, hogy számos olyan állandónak tekintett társadalmi és morális értékeket tartalmaz, melyek hosszú ideje változatlanok, így állandónak tünnek (4. táblázat). A normativitásnak egy másik fontos eleme a fogalomra, hogy igazságról alkotott elképzelés annak is függvénye, hogy az igazságtalansággal érintett vagy nem érintett lakosság alkotja-e meg. Ezért, ahogyan a tér is, maga az igazságosság is termelt és újratermelt, gyakorlott és vitatott (OKEREKE, C. 2006). 
4. táblázat: Az igazságosság különböző megközelítései. Forrás: saját szerkesztés

\begin{tabular}{|l|l|l|l|l|}
\hline $\begin{array}{l}\text { Haszonelvü igazsá- } \\
\text { gosság (utilitarian) }\end{array}$ & $\begin{array}{l}\text { Közösségelvü igazsá- } \\
\text { gosság (communitari- } \\
\text { anism) }\end{array}$ & $\begin{array}{l}\text { (Neo)Liberális } \\
\text { egyenlőség (Liberal } \\
\text { equality) }\end{array}$ & $\begin{array}{l}\text { Szükségelvü igazsá- } \\
\text { gosság (justice as } \\
\text { meeting needs) }\end{array}$ & $\begin{array}{l}\text { Méltányos igazsá- } \\
\text { gosság (justice as } \\
\text { fairness) }\end{array}$ \\
\hline $\begin{array}{l}\text { A lehetö legtöbb em- } \\
\text { bernek a lehető leg- } \\
\text { nagyobb jólétet és } \\
\text { boldogságot. } \\
\text { ókori bölcselök }\end{array}$ & $\begin{array}{l}\text { Elönyök és hátrányok } \\
\text { azonos arányban, cél } \\
\text { elkerülni az atomiszti- } \\
\text { kus társadalmak kiala- } \\
\text { kulását. Rousseau, } \\
\text { Kant, Marx és Engels }\end{array}$ & $\begin{array}{l}\text { Egyenlöség az alap- } \\
\text { vető jogokban, } \\
\text { egyenlötlenség a } \\
\text { közjó érdekében. } \\
\text { Rawls, Young }\end{array}$ & $\begin{array}{l}\text { Az elönyök és a hát- } \\
\text { rányok elosztása } \\
\text { egyenletes, az alap- } \\
\text { vető szükségleteket } \\
\text { kielégíti a rendszer. }\end{array}$ & $\begin{array}{l}\text { Az emberek eredeti } \\
\text { pozíciójuk szerint } \\
\text { élik meg az igazság- } \\
\text { talanságot, és ehhez } \\
\text { alkalmazkodón, Lefebvre } \\
\text { szükséges beavat- } \\
\text { kozni annak felszá- } \\
\text { molására Bullard, } \\
\text { Walker }\end{array}$ \\
\hline
\end{tabular}

Az igazságosság, mint fogalom többszempontú értelmezése hozzásegítheti a környezeti-igazságosság kutatásokat, hogy kritikusan, más- és más megközelítésekből is feltárják az adott témát. Az igazságosság fogalma, bármely megközelítésben normatívnak, kontextus-függőnek tekinthető, mindemellett nem elégséges pusztán igazságosságról beszélni, hiszen annak több aspektusú megnyilvánulása is megfigyelhető a környezeti igazságosságok szempontjából.

Az említett fogalmak közötti számos különbség miatt talán célszerủ az igazságosság-igazságtalanság, társadalomföldrajzi vizsgálat szempontjából fontos, két tartalmi különbségét figyelembe venni. Az adott igazságosság-igazságtalanság fogalom alkalmazható statikusan, állapotok leírásához és dinamikusan, folyamatok leírására. Az igazságosság állapot és a folyamat-központú értelmezéséhez három kulcsfontosságú tényezőt vizsgálok meg. Az egyik, mely a földrajzi gondolatvilághoz a legjobban kapcsolódik, az az egyes igazságtalanságot elöidéző tényezők térbeliségét vizsgálja, az elosztást és eloszlást (distribution). Ennek értelmében feltételezzük, hogy azon folyamatok vagy tényezők, melyek az igazságtalan helyzetet termelik vagy okozzák bizonyos térbeli mintázatot, állapotot hoznak létre. A második nézőpont szerint az igazságtalanság kialakulása folyamat eredménye (procedure / process), mely a mindennapi gyakorlatokból eredeztethetö. A folyamatigazságosság kérdésköre kiegészülhet az úgynevezett helyreállító igazságossággal (restorative) fogalommal is. Ez alapvetően az igazságtalanságot elöidéző folyamat utolsó szakasza, mely felszámolhatja, konzerválhatja vagy felerősítheti az igazságtalanságokat. A harmadik elképzelés mind az állapot, mind a folyamatot az érintettek szempontjából mutatja be a felismerés és elismerés (recognition) szempontjából.

1) Elosztás és eloszlás igazságtalansága (distributive injustice) az igazságtalanság (kockázat, szennyezés vagy akár a javak aránytalan elosztása stb.) elosztását, földrajzi eloszlását és azok mintázatában felfedezhető egyenlötlenségét és méltánytalanságát jelenti. Az elosztást ténylegesen (substantive theory) igazságosnak akkor tekinthetjük, ha a javak allokációja mindenki számára méltányos és egy közös döntésen alapuló, racionális társadalmi szerződés eredménye (RAWLS, J. 2011). A méltányosság mérhető, egyrészt egyenlőség (ugyanaz a jólét, erőforrások és lehetőségek), másrészt fontosság (mindenki számára a szükséges jogok biztosítva vannak), illetve a megfelelőség (mindenki számára elegendő módon biztosítottak a jogok) szempontjából (WESTONH.B. 2007.) A megközelítés fontos eleme, hogy a szerződő felek a jogok hordozói és a kötelezettségek vállalói között egyensúlyra törekszik. A kiterjesztett elosztási igazságtalanságban felelősség, nyilvánosság, hatások területegységek közti differenciákat is jelenti (WALKER G. 2012). Fontos, hogy nem szabad egyoldalúan az eloszlás igazságtalanságára koncentrálni, hiszen a mintázat alapján igazságosnak látszó helyzetekben is fennál a kialakult állapotokat előidéző eljárás és folyamat igazságtalansága (WESTON, H.B. 2007).

Ezen kérdések mentén egészül ki a térbeli igazságosság (spatial justice) koncepciója további vizsgálati tényezőkkel, melyek elfogadják azt, hogy az igazságosság sosem ugyanazon formában, hanem kontextus-függően jelenik meg, több dimenzióban, számos hatással, különböző felelőséggel és társadalmi-kulturális vonatkozásokkal. Leírható az emberek területi mintázata szociokulturális attribútumaik (nem, kor, etnikai szerkezet) alapján, de mintázata van az értelmezésnek és a jelentésnek is (poltikai, intézményi). Mindemellett a tér folyamatosan változó is, így az értelmezett igazságosságfogalom szükségszerüen változik a kontextus változásával, módosítva a mintázatot is. Az egyes igaz- 
ságosság-felfogások elfogadása más definíciók és elképzelések elnyomását eredményezi, így alapvetően az igazságosság-fogalomhoz hasonlóan az igazságtalanság is normatív, nézőpont kérdése. Emiatt szükséges a pluralista megközelítés, melyben megfigyelhetjük a mintázatok alapvető hasonlóságait és különbségeit. Az elosztás és az eloszlás igazságtalanságának kutatása bizonyítékokkal szolgál az igazságtalanságra, olyan kérdésekre választ adva, hogy kit, mivel kapcsolatban és milyen elvek, valamint fogalmak alapján ér igazságtalanság. Mindemellett a bizonyítékok felsorakoztatása szükséges, de nem elégséges feltétele az igazságtalan helyzetek bizonyításának, mely olyan egyéb tényezőktől is függ, mint sebezhetöség és érzékenység (vulnerability, sensitivity), melyet az érzékelés és felismerés megközelítéséből, valamint a kialakító folyamatok vizsgálatával is szükséges kiegészíteni.

2) Azigazságtalanság kialakulásának folyamata nem csak az egyenlötlen vagy méltánytalan elosztásból, de az igazságtalan döntéshozatali, kártérítési eljárásból, az „ügyrendiségböl” is eredhet. Ez az ügyrendiségből eredő egyenlötlenség nehezen bizonyítható, illetve több esetben vitatható. Az eljárás, intézmény és a folyamat igazságtalansága (procedural/process injustice) az eljárásban és a folyamatban valamint az abban való participációban tapasztalt igazságtalan, egyenlőtlen és méltánytalan helyzetek összessége. Azt mutatja meg, hogy az egyén, a csoport, az állam, a gazdasági szereplő stb. hogyan és milyen mértékben játszik szerepet térbeli „kirekesztési” folyamatban. A folyamat-központú igazság-megközelítés az átláthatóság és az elosztás folyamatának méltányosságát vizsgálja, főként az ügyintézés, és az intézményes gyakorlatok (administrative justice) szempontjából. Erre azért van szükség, mert számos esetben intézményi és rendszer-tényezők vezetnek az igazságtalan és méltánytalan helyzetek kialakulásához. Olyan alapelveket, mint méltányosság a szabályozásban, inkluzív döntéshozatal és hozzáférhetőség az információhoz kell meghatározni, melyek hiányában az adott folyamat igazságtalanná válik. HUNOULD, C. - YouNG, I.M. (2002) összefoglalják az eljárásrendhez, ügyrendhez kapcsolódó igazságtalanság legmeghatározóbb elemeket, mely eléréséhez szükséges a közigazgatási intézmények, a közszolgáltatások fair és egyenlő döntéshozatali mechanizmusa, mely mindenkire kiterjed.

Az inkulzivitás nem csupán a tájékoztatáson, hanem a részvételen és a bevonáson is alapul, érvényesülnek a praticipáció alapvelvei. Az elméletek alapján akkor igazságos a folyamat, ha az érintettek ténylegesen résztvesznek a döntéshozatali folyamatokban (WALKER, G. 2012). A kérdés azonban, hogy mi alapján határozzuk meg azt, hogy ki, és milyen szempont alapján érintett? További kritikaként fogalmazódik meg, hogy az érintettek körét pusztán területi alapon lehatárolni túlságosan leegyszerüsített, bár a szubszidiaritás elvét követi a helyi döntéshozatal, azonban hol húzódik a területegység határa, hogy elég nagy legyen, hogy minden érintett részt vehessen a döntéshozatali folyamatban, mégis kellően kicsi a lokális döntéshozatalhoz (WALKER, G. 2012)?

A változó globális környezetben egyre nagyobb szerepet kapnak az úgynevezett participáción alapuló alternatív vitarendezési módszerek, eljárások és a hozzájuk kapcsolódó helyreállítási igazságtalanság (restorative injustuce) is (SHERMAN, L.W.-STRANG, H. 2007). Ennek hátterében több tényező is szerepet játszik, az egyik legfontosabb az, hogy az egyes folyamatokban az aktorok és stakeholderek száma növekszik (GYŐRY Cs. 2009). Olyan új szereplők jelennek meg, melyek a hagyományos értelemben vett eljárásokban még nem szerepelnek, így több esetben az igazságosság elérése még összetettebb és bonyolultabb feladattá válik, egyre gyakrabban alakulhatnak ki igazságtalanságok. Egyrészt azért, mert az egyre több résztvevő egyre sokszínübb érdekkel lép fel. Másrészt azért, mert az egyes döntési mechanizmusokban az úgynevezett helyreállító szándék csak korlátozottan érvényesül a sok résztvevő miatt (SHERMAN, L.W. - STRANG, H. 2007). Harmadrészt BRAITHWAITE (2002) szerint a hagyományos döntéshozatalban minden helyreállítási folyamat kontextusfüggő (GYÖRY Cs. 2009), így hasonló cselekmények kapcsán is helyzettől függően eltérő súlyú és formájú szankcióban és jóvátételben állapodhatnak meg a résztvevők (BRAITHWAITE, J. 2002), ez azonban hátrányosan érintheti a deprivált csoportokat, így nem feltétlenül a jóvátétel és az egyenlőség elérése valósul meg, hanem inkább a meglévő állapotok konzerválása, vagy a hátrányos helyzetűek további marginalizálódása és periferizálódása. A helyreállítási igazságosság érvényesülésekor a helyreállítás a hátrányt szenvedő és a hátrányt okozó közötti egyezség (amennyiben lehetséges) alapvető fontosságú. Azonban a „helyreállító” nem csak a hátrányt szenvedő egyén, de a közösség érdekeit is figyelembe veszi, hiszen az okozott károkat társadalmi szinten próbálja kezelni. A helyreállító és a hátrányt szenvedők között azonban 
gyakran vélemény különbség lép fel az igazságtalanság felismerése és elismerése terén, ami konfliktusokat szül.

3) A felismerés és az elismerés igazságtalansága (injustice of recognition and perception) akkor áll elö, mikor az egyének és a csoportok eredeti helyzetükből adódóan akár iskolai végzettségük, akár testi-szellemi fogyatékosságuk vagy kiszolgáltatott, kirekesztett, deprivált helyzetüknek köszönhetően máshogyan értékelik az adott igazságtalan helyzetet. Ez adódhat egy lokális normarendszer alkalmazása miatt is. Az, hogy mi az adott kérdésben az a ,határérték”, mely cselekedetet vagy figyelmet vált ki az sok esetben az érintetteken kívülálló tényezők alapján meghatározott (MAGUIRE, K. - SHERIFF, G. 2011). A felismerés igazságtalansága többször összekapcsolódik a relativitással is, egyes csoportok relatív rossz megítélése más megvilágításba helyezi a tényleges problémát, egyes helyzeteket kiemelten fontossá, másokat pedig érdektelennek címkéz. Egyben tehát nem csak az igazságtalan helyzet felismerése válik nehézkessé, hanem annak elismerése és elismertetése is. A döntéshozóknak tehát el kell fogadni, el kell ismernie, hogy az adott helyzet igazságtalan, ezek alapján lehet csak igazi ténylegesen a helyzeten javító beavatkozást létrehozni. Amennyiben ez nem történik meg, az történhet szándékos figyelmen kívül hagyásból, vagy fel-nem-ismerésröl (LEWIS, T. - BENNETT, S. 2013). Ebben az esetben beszélhetünk a félreismerésről és a félreértelmezésről is. Bourdieu szerint a félreértelmezés és félreismerés (misrecognition) egy olyan cselekedet, értékítélet, diskurzus, gyakorlat melyet elviekben, elvárt módon, a normarendszernek megfelelően alkalmazunk, de valójában máshogyan cselekszünk, ítélkezünk, másfajta diskurzusban döntünk (JAMES, D. 2015). Ennek hatására az igazságtalanság nem csak eredmény, de a folyamat újbóli kiváltója is lesz, melynek hátterében a véletlen és a szándékosság is meghúzódhat. Utóbbi esetben diszkriminatív színezetet kap az igazságtalanság. Azonban mindennek nem feltétlenül jelentkezik explicit térbelisége. A felismerés és elismerés igazságtalansága gyakorta összekapcsolódik a folyamat igazságtalanságával és annak elosztásával is, azoktól nem élesen nem elkülöníthetö.

Mindhárom igazságosság-megközelítés összekapcsolója lehet a földrajzi tér és térbeliség, hiszen a tér mindhárom esetben, mind az elosztásban, mind a felismerésben és részvételben, mind az eljárásban meghatározó elem. Egyes esetekben a tér folytonossága, más esetekben a tér felszabdaltsága az, mely felhívja a figyelmet az igazságtalan helyzetek kialakulására és jelenlétére. Az említett három igazságtalanság bár külön is megnevezhető, csak teoretikusan különülnek el, mert az egyik hatással van a másikra. Ami összeköti öket, hogy többnyire egy adott földrajzi térben fejtik ki hatásukat, annak ellenére is, hogy esetleg nem is egy földrajzi térben keletkeznek.

Az említett igazságosság-megközelítések tekintetében a neoklasszikus közgazdaságtan egyik alaptétele többszörösen is visszatér, mely szerint a vállalatok, illetve tevékenységek a profitmaximalizálás és költségminimalizálás érdekében olyan telepehelyet választanak, ahol a legnagyobb hasznot realizálhatják a legkevesebb kiadással. Ebböl következik, hogy olyan helyre települnek, ahol a környezetben, illetve a társadalomban a legkevesebb kárt okozzák, hiszen ebben az esetben az állami regulációknak megfelelően kompenzációt kell fizetniük az okozott károkért. Ennek ellenére, azt tapasztalhatjuk, hogy számos esetben a kisebb társadalmi ellenállás és érdekérvényesítő képesség, valamint a gyenge jogi szabályozás az, amit kihasználnak egy-egy környezetkárosító tevékenység elhelyezésénél. Így azt mondhatjuk, hogy a kialakult igazságtalan helyzetek nagyban összefüggnek a döntéshozatali mechanizmussal. Nem csak környezeti hátrányok, de az elönyök egyenlötlen elosztása, a jogszabályok területenként eltérő végrehajtása a policy és a practice vagyis az elmélet és gyakorlat közötti eltérések is okozhatnak igazságtalan helyzeteket.

\subsection{A döntési mechanizmus szerepe a környezeti igazságtalanság kialakulásában, top- down és bottom-up megközelítések}

A környezeti igazságosság-kutatások egyik megközelítése a politikai és szakpolitikai döntések szerepét vizsgálja a környezeti igazságtalanságok kialakulásában. Ezen kutatások fö kérdéseként merül fel, hogy az állami szakpolitikák, jogszabályok, joggyakorlatok hogyan és milyen mértékben hatnak az igazságtalanságok kialakulására. Alapvető problémaként fogalmazódik meg, hogy az igazságtalanságok feltárását olyan rendszerben, struktúrában kell kimutatni és feltárni, melyek maguk is részt vesznek 
(részt vehetnek) ezen helyzetek kialakulásában vagy éppen kialakításában. Az intézményi keretek és gyakorlatok nagyban befolyásolják, hogy kik és kinek az érdekeit képviselhetik, hogyan történik, ha egyáltalán történik visszacsatolás és, hogy ki és hogyan szólhat bele az adott igazságtalanságról szóló diskurzusba. Mindezen tényezők hatással vannak a döntési folyamatokra, az abban alkalmazott normarendszerre és felvetik a kirekesztő állam kérdéskörét.

A környezeti konfliktushelyzetet az okozhatja, hogy a döntéshozatali eljárásokban a résztvevők számos dimenzió mentén különböznek, más kulturális háttérrel, iskolázottsággal, korral, nemmel, véleménnyel írhatók le. Ez azt eredményezheti, hogy például egyes szolgáltatások vagy akár az egészséges környezet egyesek - a hatalmi pozíciókban lévők - szerint egyértelmüen biztosítottak és könnyen elérhetők, míg mások - föként a deprivált rétegek - számára ugyanezek elérhetetlennek tünnek.

Már korábban szó esett a terek szerveződéséről, a léptékekről. Tudjuk, hogy minden tér további terekre tagolódik, melyek sok szempontból (etnikai, vallási, politikai) elkülöníthetők. Ezek a globális térszerveződési szinttől kezdve egészen az individuum szintjéig bonthatók, megjegyezve, hogy a szintekre bontás nem jelenti azok egymástól való függetlenségét, annak csak értelmezési kereteit változtatja. Az értelmezési keretek mellett a döntési jogkörök és a befolyásolás mértéke is változik a lépték és szintek változásával, egyes szereplők a hierarchiában magasabb térszerveződési szinten is rendelkeznek befolyással, míg mások befolyása sokkal korlátozottabb. Részben ez a fajta egyenlötlenség is elöidézhet hatalmi viszonyokból, döntéshozatali mechanizmusból eredeztethető környezeti igazságtalanságokat. Hiszen a döntések bár a hatályos jogszabályoknak megfelelnek, eljárásukban nem feltétlenül lesznek igazságosak. Ezért szükséges körültekintően elemezni, hogy mi vezetett a megfigyelt környezeti igazságtalanságok a kialakuláshoz, és az egyes szereplöknek milyen hatásuk, befolyásuk volt a folyamatra, vagy például az igazságtalanságot elszenvedők mennyiben érvényesítik/érvényesíthetik akaratukat, mennyire és hogyan nyilvánultak meg döntésekkel kapcsolatban, azt ellenezték vagy éppen támogatták-e.

A döntéshozatal alapvetően azt jelenti, hogy az egyén a különböző lehetőségek közül kiválasztja a számára legmegfelelőbbet a meghatározott (írott és íratlan) szabályok (rules) keretein belül bevetve a rendelkezésre álló értékeit (value) (anyagi és erkölcsi) és tudását (knowledge). Minden döntés egy adott kontextusba ágyazódik bele, mely tulajdonképpen a társadalmi - hatalmi struktúrák befolyásoló hatása a döntéshozatali mechanizmusra (CORNELL, S. ET AL. 2013, GORDDARD ET AL. 2016). Ez a kontextus, ahogyan a tér is folyamatosan változik, újra termelödik, átalakul, melyet a társadalmi mechanizmusok mozgatnak. A három említett tényezőböl (rules, values, knowledge) álló rendszer minden egyes eleme határokon belül tartja a lehetséges beavatkozások, gyakorlati lépések, döntések számát, „végessé” teszi a lehetőségeket, limitációt ad (GORDDARD ET AL. 2016). A szabályok, értékek és tudás hármasában értelmezett környezeti igazságtalanságok számos kérdést vetnek fel, mely a legtöbb esetben összekapcsolódnak a hatalomgyakorlás és az érdekérvényesítés lehetőségeivel. Az, hogy az egyén vagy csoport hogyan értelmezi és éli meg a kialakult igazságtalan helyzetet (recognition és perception) nagymértékben függ a létező intézményi keretektől és gyakorlatoktól, attól, hogy az igazságtalanságról szóló diskurzusba az érintettek milyen mértékben szólhatnak bele és mennyiben képviselhetik érdekeiket (CORNELL, S. ET AL. 2013; GODDARD, R. ET AL. 2016; GYURIS F. 2010). Ezek alapján lehet az igazságtalanság alulról tovagyürüző, bottom up, vagy felülröl irányított top down folyamat. Az utóbbi, más néven exogén igazságtalanság esetén, a helyspecifikusan tagolt és tagolódó térszerekben az igazságtalanság kialakulása egy felülről vezérelt folyamat eredménye. A bottom up, vagyis endogén igazságtalanság alulról induló, lokális döntésekben is gyökerező területi egyenlötlenség. Bizonyos döntések olyan hatásokat fejtenek ki, hogy azok egy felsőbb térszervezödési szinten is hatnak.

A döntéshozatali mechanizmus megértésével közelebb kerülhetünk az esetleges igazságtalanságok és egyenlötlenségek mérséklésére, megszüntetésére. Ehhez azonban szükséges az igazságtalanságot előidéző események és következményeinek szélesebb társadalmi kontextusba ágyazása, a résztvevő intézmények, az aktorok viselkedésének és felfogásának megismerése. Az aktorok a környezeti igazságosság szempontjából központi, lokális hatalmi szervekre és egyénekre valamint csoportjaikra oszthatók. Fontos szerepet kapnak ebben a rendszerben a gazdasági szerveztek, piaci szereplők is, akik harmadik pólusként jelennek meg bizonyos környezeti igazságtalanságokban. 
Az igazságtalanságokba való beavatkozások legtöbbször top-down folyamatok, melyek számos esetben nem vesznek tudomást a mindennapi gyakorlatokról, szokásokról és helyi adaptációs technikákról. Ez abban az esetben kifejezetten hátrányos lehet, ha cselekvő intézmények elfogadják és félreértelmezik a Rawls-féle eredeti helyzet (original position) felfogást, mely bizonyos kialakult rendszereket, akár hatalmi viszonyokat, pl. alá-fölé rendeltség, egyenlőtlenség stb. ezáltal stabilnak, megváltoztathatatlannak tekintenek (RAWLS, J. 2011). A döntéshozatali folyamatban a konfliktushelyzet akkor áll elö, ha az aktorok döntési és cselekvési mechanizmusa az eltérő tudás-érték-szabály komponensek okán meröben más döntéseket eredményeznek és az imént említett berögzött alá-fölérendeltségi hatalmi viszonyokat kívánják konzerválni vagy újratermelni. Így állhat elő a helyzet, hogy a kormányzati reakció nem találkozik a lakossági elvárásokkal. A kormányzat a helyi döntéshozatali kontextus részletes ismerete nélkül tudásdeficitben szenved, melynek eredményét a helyiek igazságtalan vagy méltánytalan helyzetként élik meg a beavatkozásokat. Ekkor a kialakult igazságtalan helyzetet top-down módon idézi elő a döntéshozó.

Környezeti igazságtalanság, természeti és ipari katasztrófák esetén az érintettek köre sajátos döntéshozatali mechanizmust alkalmaz. Minden aktornak léteznek helyzetükből adódó értékei/értékrendjei, tudásuk és írott, illetve íratlan szabályai, mely alapján cselekednek. Az íratlan szabályok gyakran egy közösen elfogadott normarendszerként funkcionálnak, melynek egyik elemeként értelmezhető az igazságosság felfogása is (RAWLS, J. 1977). Az írott szabályok megváltoztatása gyakran az íratlan szabályokba ütközhet. Az íratlan szabályok általános érvényüként kezelése részben megkönnyíti a mindennapi társadalmi együttmüködést, de sok esetben gátolhatja is. Azonban előállhat olyan helyzet is, amikor az említett íratlan szabályok valamely negatív jelenséghez kapcsolódnak (kirekesztés, depriváció), mely általános érvényüvé válása vagy annak kezelése tudatosan konzerválhat bizonyos negatív folyamatokat. Ebben az esetben a korábban ismertetett logika megfordul, és a tudásdeficit a lakosságnál lép fel, és a hiányos ismereteket kihasználva a döntéshozók tudatosan alakítanak ki igazságtalan helyzeteket. A top-down igazságtalanságok egyik példájaként említhető ha a top down beavatkozás okozta igazságtalanság az érintett csoportokat bőrszínük, életkoruk, vallási vagy etnikai hovatartozásuk, vagyoni helyzetük miatt éri negatívan, akkor nem csak a diszkrimináció, de a rasszizmus is felmerülhet (BULLARD, R. D. 1990).

Amennyiben az igazságtalanság kialakulásának döntési hátterét kívánjuk megérteni érdemes figyelembe venni Coase-elméletet (COASE, R. H. 1988). Ez egy ideálmodell, ahol a tranzakciós költségek nem léteznek, a területhasználat mindig úgy alakul, hogy az adott használattal a legtöbb profitot termelje, és a legkevesebb kárt okozza, mert így a legkisebb a kompenzációs költség is. Ez az elmélet azonban módosul az emberi „tényező” figyelembe vételével. Abban az esetben, ha a tervezett területhasználat egy vagy akár több lakost is zavar (pl.: egy gyár), megéri egy másik területre helyezni a beruházást, mert a „kollektív cselekedet”, ellenállás a gyár ellen nagymértékben megemeli a járulékos költségeket. Azonban nem feltétlenül minden lakóközösség elkötelezett, és összetartó, kollektívan mobilizálható egy adott kérdésben. Általában az alacsony képzettség és jövedelem korrelál az alacsony kollektív cselekvési hajlammal, illetve a környezeti elkötelezettség hiányával. Így inkább egy kevésbé aktív és mobilizálható közösséget keres a megvalósítás színteréül. Így kerül sor a deprivált, etnikai, vallási, szegény csoportok diszkriminációjára (HAMILTON, J. T. 1995), környezeti igazságtalan helyzetére ahol a társadalmi-gazdasági státusz kvázi telepítő tényezővé válik (COASE, R. H. 1988).

A folyamat kihagyhatatlan részese a helyi, illetve a felsőbb politikai elit is, hiszen egyes térségek hátrányt szenvednek egy döntési folyamat során, melyben az egyik kulcselem az információ- és tudásdeficit. Ez a megközelítés az egyenlőtlenséget az adott társadalmi-gazdasági fejlődés, illetve az állami törvényhozás szándékos vagy véletlen, egyénre és csoportra nézve pozitív, illetve negatív eredményéből eredezteti, ahol az egyes szociológiai mutatók befolyásolják az ép környezethez való jogot, hozzáférhetőséget (BULLARD, R. D. 1990). Ha a társadalmi csoportok között, a veszélyeknek való kitettségben tapasztalható egyenlőtlenségek elöre kigondolt, gazdasági okból eredeztethetők, szisztematikus környezeti diszkriminációról és rasszizmusról beszélünk (HAMILTON, J. T. 1995). BULLARD szerint a környezeti rasszizmus nem más, mint az elöítéletek és a hatalom egy társadalmi csoport általi felhasználása bizonyos csoportok kárára (BULLARD, R. D. 1990) a jogi, kulturális, vallási, oktatási, gazdasági, 
környezeti, katonai, társadalmi rendszer müködésének véletlen vagy tudatos eredménye. Ez egy intézményesült forma (BULLARD, R. D. 1990), politika, mely szándékosan céloz meg bizonyos csoportokat és különbözteti meg a környezetpolitikában, a végrehajtásban, a környezeti károk helyreállításában (CUTTER, L. S. 1995). Napjainkban számos vita folyik a környezeti igazságtalanság szándékos rasszista és diszkriminatív megvalósulásáról, de mind a környezeti rasszizmus, mind a környezeti diszkrimináció fennállhat a top-down döntéshozatal esetében (6. ábra).

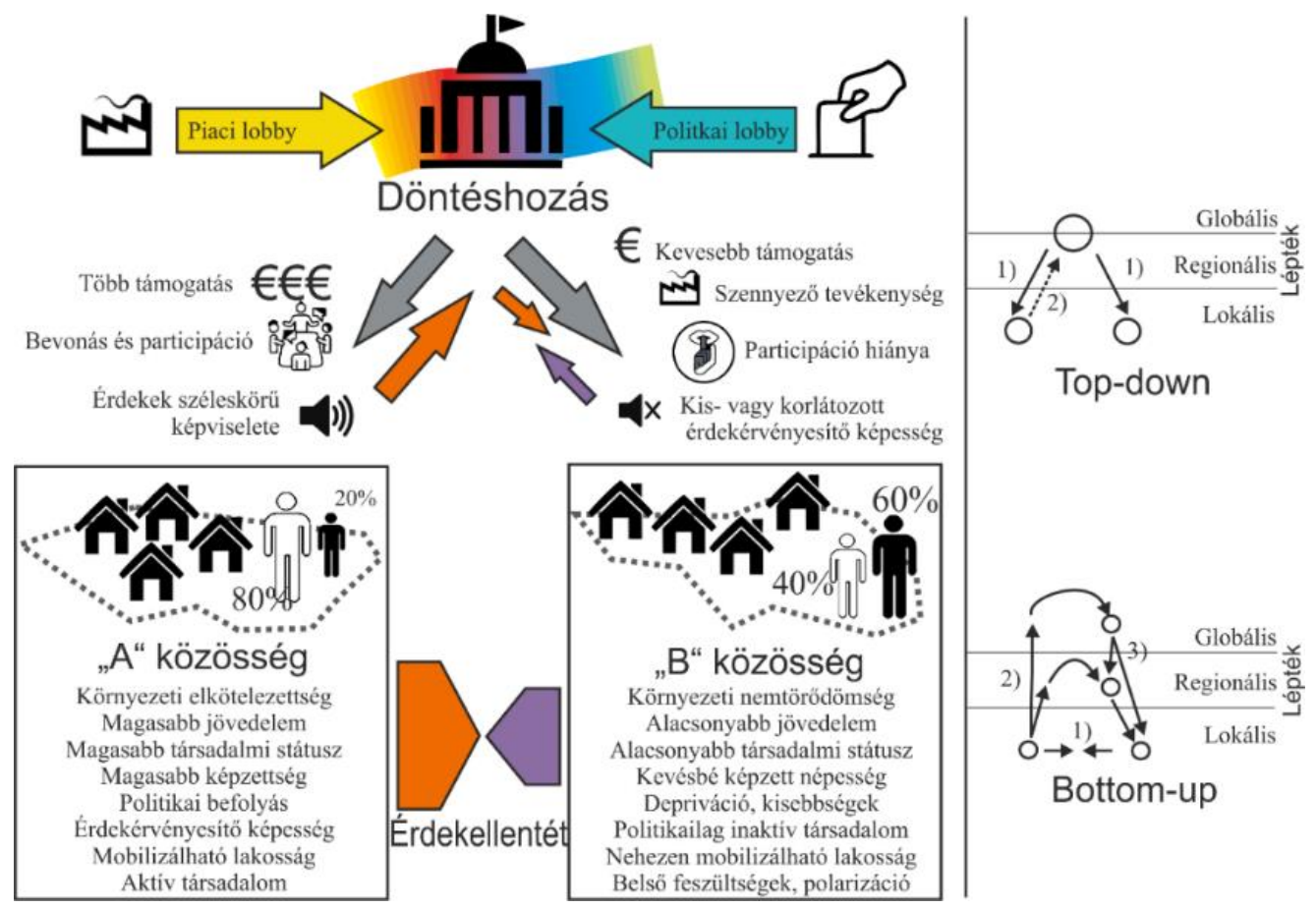

6. ábra: A top-down és bottom-up igazságtalanságok kialakulásának logikája. Forrás: saját szerkesztés

Ezekben az esetekben kívánatos lenne az iterációs döntéshozatal kereteit alkalmazni, mely apró lépéseken keresztül, az értékek, tudás és a szabályok megismerésével több fázisban eredeményez döntést, így az sokkal elfogadottabb, támogatottabb lehet (GODDARD, R. ET AL. 2016).

Elöfordulnak olyan lokális döntések, melyek az adott lokalitás/település/közösség pénzbeli helyzete, a területi lobbi, a politikai érdekek miatt meghatározzák nem csak saját maguk, de közvetetten környezetük területi fejlődését, mely a szubszidiaritás alulról építkező felfogásának megfelel, azonban a tényleges partnerséget felülírja a területi töke befolyása, mely környezeti igazságtalanságot szülhet. A politikailag nagyobb befolyású, esetleg vagyonosabb lakosság érdekei érvényesülnek a „gyengébbek" igényei felett, mely folyamatot HARVEY az igazságtalanság urbanizációjának nevezi (HARVEY, D. 1996), melyet bottom-up, endogén igazságosságnak tekinthetünk.

\subsection{A környezeti igazságtalanság érintettjeinek attitüdjei}

A döntéshozatali folyamattal való megelégedettség az információ-hozzáférés függvénye. Új tudáselem beépülése a társadalomba értékrendszer-változást okozhat, ezáltal a szabályok interpretációját, az igazságtalanságok szubjektív érzékelését is megváltoztatja. A különböző igazságtalanságokkal kapcsolatos attitüdök a településmarketingben is ismeretesek és használtak (GARAMHEGYI Á. - BOROS L. 2010). A disszertációban föként az egyes top-down döntésekhez és a környezetet potenciálisan szenynyező ipari tevékenységekhez és beruházásokhoz való lakossági hozzáállást értem az attitüdök alatt. Az egyes döntésekhez való lakossági hozzáállás és föként annak változása a helyi és központi hatalomgyakorlás függvénye is, mely nyomásgyakorlást, tudatos propagandát is mutathat. 
A döntéshozatalból való kimaradás, a participáció és a szubszidiaritás hiánya több esetben a döntéshozók és a tényleges stakeholderek közötti ellentéteket erösíthetik. Kezdetben az Egyesült Államokban, majd a környezeti igazságosság mozgalmak elterjedésével a világ számos pontján sorra derültek ki olyan esetek az elmúlt évtizedekben, amelyben egyes szennyező beruházások megvalósításáról olyan szervezetek, politikai döntéshozók hoztak döntést, akik nem voltak érdekeltek a civilek véleményének meghallgatásában, középosztályába tartozó, nem kisebbségiek voltak. Ennek következtében helyi lakosok gyakran szenvedtek hátrányt, melyet különböző beruházások által előidézett környezeti degradáció okozott. Ennek számos megnyilvánulási formája van a hulladékégetők (DAVIES, A. R. 2006; STEWART, J. A. ET AL. 2015), szeméttelepek (HigGS, G. - LANGFORD, M. 2009), mezőgazdasági üzemek (Bullers, S. 2005; MCClinToK, N. 2012; MAlin, A - DeMASTER Teigen, K. 2016), ipari létesítmények, bányák (MAN, P. - WAN, J. 2014; BOONE, C. ET AL. 2014; OSKARSSON, P. - BEDI, H. P 2018), raktárak (YUAN, Q. 2018) esetein át egészen az erőforrásokhoz való hozzáférés és hozzá nem férés (MethA, L. ET AL. 2014; ChAudHARY, S. ET AL. 2018; SCHNEGG, M. - KiAKA, D. 2018,) kérdésköréig bezárólag.

Ennek egyik következménye lett a helyi lakosok, lokálpatrióták tiltakozása a beruházások, tevékenységek ellen, melynek jelmondatává vált a „Not In My Backyard” (NIMBY) (VAN DER HORST, D. 2007). A lakosok környezeti érdekeik védelme érdekében megpróbálják megakadályozni a különböző beruházásokat, és azt kívánják elérni, hogy ne a közvetlen környezetükben valósuljon meg. A NIMBY tehát egyfajta protekcionista attitüd, mely a nem kívánt fejlesztés, beruházás, jelenség megjelenését ellenző csoportok taktikája annak meggátolására (DEAR M. 1992; WOLSNIK, M. 1994; BURNINGHAM K. 2000). A NIMBY attitüdhöz hasonló, annál talán kicsit elutasítóbb a BANANA attitüd, „Build Absolutely Nothing Anywhere Near Anything/Anyone" (GBANIE, S.P. 2013).

Abban az esetben, ha a lakosok úgy gondolják, hogy maga a beruházás fontos, megvalósulása kívánatos lenne, de nem az ő közvetlen közelükben, környezetükben az attitüdöt SOBBY-nak "Some Other Bugger's Back Yard" nevezzük (WALTER, L. 2014). Ezt a hozzáállást gyakran követi a PIBBY attitüd, mely a „Put In the Blacks Backyard” szavak kezdöbetüiböl keletkezett, és azt vallja, hogy a kisebbségek, az USA-ban föleg a színesbőrüek sokkal alacsonyabb igényüek a környezetükkel szemben, ezért a szennyező beruházásokat inkább helyezzék az ő közelükbe. Ez a hozzáállás etnikai alapú, diszkriminatív döntéshozatalt feltételez, melyben a befolyással rendelkező társadalmi csoportok előnyös helyzetüket kihasználva a döntéshozatali mechanizmust úgy torzítják, hogy az számukra kedvezőbb legyen, a környezeti terheket inkább a deprivált rétegek viseljék (BULLARD, R. D. 2008).

Ehhez kapcsolódik a NIABY, vagyis „Not In Anybody’s Backyard” attitüd az olyan eljárások, tevékenységek, beruházásokra irányul, melyek környezet- és egészségkárosító hatásuk miatt sehol nem megvalósíthatóak. A NIMBY és a NIABY-vel hasonló jelentéstartalmú, de nem fejlesztés-központú, hanem területhasználat alapú meghatározás a LULU, vagyis a „Locally Unwanted/Undesired Land Use". Jelentése szerint helyileg nem kívánatos területhasználatot takar, melynek kutatása a környezeti igazságosság mozgalom egyik meghatározó témája (BEEN, V. 1994; 1995. KAYA, I. A. - EROL, N. K. 2016).

A környezeti igazságosság kutatásainak nagy része vizsgálja a helyileg nemkívánatos földhasználatok (LULU-k) okozta környezeti egyenlötlenségek meglétét, azonban nem mutatják be, hogy a társadalmi-gazdasági helyzet, hatalmi viszonyok dinamikája hozzájárul-e, és ha igen, akkor hogyan a LULU-k kialakulásához. Mindez azért is kifejezetten fontos, mert a LULU tevékenységek gyakran LWLU-vá, vagyis „Locally Wanted Land Use”-á vállnak, ebben azonban a már említett társadalmigazdasági-hatalmi kontextus igen erőteljes szerepet játszik. Például ha az adott terület elmaradott, hátrányos helyzetü, nagy a munkanélküliség, leromlott az infrastruktúra, akkor a területre irányuló beruházás a helyiek szemében a közösség hasznára válhat. Kutatások szerint a szegényebb, elmaradottabb közösségek nehezen utasítják vissza az új létesülő munkahelyeket, és a térség kisebb gazdasági felpezsdülését okozó beruházásokat, annak ellenére, hogy azok környezet- és egészségkárosítóak lehetnek. Gyakran ezt a fajta hozzáállást az is előidézi, hogy a beruházók win-win (győztes-győztes) felállást hangoztatnak, hiszen munkahely létesül, az életszínvonal javul, a vállalat is jól jár. Előfordul, hogy a beruházást a tervezettnél környezetkímélőbbé teszik, így győzve meg a lakosságot arról, hogy a vállalat 
jót akar, s vásárolja meg az aktivistákat is, mondván így mindenki boldog. Ez azonban nem fogja kizárni a környezetszennyezés tényét. Az LWLU-val rokon értelmủ, a beruházást a közelben megvalósítani kívánó attitüd PIMBY, mely a „Put In My Backyard” szavakból keletkező mozaikszó. DAWsON J. (2001) példaként említi a lett orosz kisebbség helyzetét, mint a PIMBY és LWLU attitüd megvalósulását.

A Szovjetunió tagköztársaságából az 1990-es évek elején önálló állammá váló Lettországnak a rendszerváltó szocialista országoknál is keményebb gazdasági és társadalmi helyzettel kellett megküzdeniük. Bezáró gyárak, egekbe szökő munkanélküliség, növekvő infláció, összeomló szociális rendszer mellett domináns „többségi kisebbségi” terek jöttek létre a korábbi eloroszosítási politika hatására (DAWSON, J. 2001). A rendszerváltás időszakában a térségbe érkező bármely nyugati beruházás, szenynyező mértékétől függetlenül egy igazi gazdasági áldásnak volt tekinthető, így a beruházás megszerzése érdekében lobbi indult. Ennek következtében a várttal ellentétben a szennyező beruházás nem a legszegényebbeket, a legmarginalizáltabb csoportokat sújtotta, hanem éppen ellenkezöleg. A fejletlenebb térségek és az ott élők lobbi hiányában kimaradtak a LULU-ból LWLU-vá avanzsált beruházásokból, ezáltal a környezeti kockázatnövekedésböl is. Tehát míg a lett régiók közötti fejlettségi különbség tovább nött, addig a környezeti kockázat, ha nem is csökkent, de nem erösödött tovább (DAWSON, J. 2001).

Az egyes környezetet kockáztató események, tevékenységekkel kapcsolatos attitüdök idővel változhatnak, ez, mint már említettem sok esetben az információ birtoklásától, a döntéshozatalban való participáció mértékétől is függ. Több esetben az információellátás manipulatív és propaganda szerü, mely megváltoztatja az egyének és a közösség hozzáállását.

Példa lehet erre Bátaapáti, ahol az ősi gránitrög felszínre bukkanása, a terület geológiája lehetőséget adott a település területén a Paksi Atormerömüben keletkező kis- és közepes aktivitású radioaktív hulladékok elhelyezésére szolgáló felszín alatti tároló kialakítására. A projekt meghirdetésekor Magyarországon összesen 80 települést találtak alkalmasnak egy ilyen atomhulladék-tároló létrehozására, azonban csupán Bátaapáti vállalta, hogy teret ad a megvalósításnak. Aprófaluként az önkormányzat pénzügyi lehetőségei korlátozottak voltak, és a munkanélküliség is viszonylag magas volt. Mind a település vezetősége, mind pedig a lakosság a településfejlesztés egyik eszközének tekintették a veszélyeshulladék-lerakó megépítését, mely létesítéséért cserébe kompenzációt kaptak. A megvalósítás előtt, már 1997-ben létrehozták a TETT-et, a Társadalmi Ellenőrző Tájékoztató Társulást, melynek célja a Nemzeti Radioaktív- hulladék-tárolóval (NRHT) kapcsolatos tájékoztatási, ellenőrzési feladatok megvalósítása. A TETT nyolc tagja a lerakótól mért távolság függvényében pénzt kap a tájékoztatásért, mely évente 64-197 millió forintot jelent a települések számára ${ }^{2}$. 2005. július 10-én népszavazást tartottak a beruházásról, melyet a lakosság 75\%-os részvétel mellett 90\%-ban támogatott. A lakók saját maguk döntöttek a megvalósítás mellett, azonban nem tekinthetünk el a kontextustól, a település és a lakók kiszolgáltatott helyzetétől. A hulladéktároló működését 2008. október 6-án kezdte meg (NAGY GY.2011). Az egyéni és a térségi attitüdök változásának valószínűsége az ellenzés, illetve a támogatás mértékétől is függ, minél erősebb a kezdeti álláspont, annál nehezebb azt megváltoztatni (7. ábra).

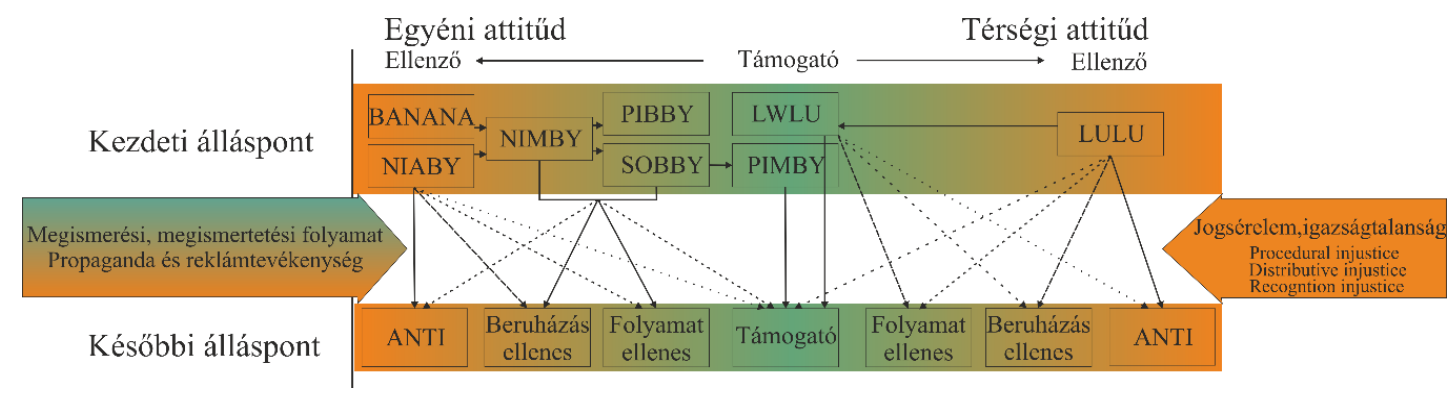

7. ábra: A környezetszennyező beruházásokkal kapcsolatos attitüdök típusai és változása. Forrás: saját szerkesztés

\footnotetext{
${ }^{2}$ http://nol.hu/archivum/archiv-355587-170352
} 
A tájékoztatás utáni, vagy már a megkezdődő beruházások közbeni vélemények maradhatnak támogatóak, azonban előfordulhat, hogy az érintettek bár az eredményt (beruházást) nem ellenzik, azonban az elérés módját, az eredmény megvalósításának folyamatát nem tekintik helyesnek, igazságosnak. Ez a procedural injustice megvalósulását is jelenteti. A későbbi álláspont a korábbi támogató álláspont ellenére nem csak a folyamat, de magát a beruházást, végeredmény ellenzését is hozhatja. Ez szintén köthető az eljárás és folyamat igazságtalanságához, de a hátrányok és az előnyök elosztásának igazságtalanságához. Az attitüd megváltozása köthető még az adott folyamatok szubjektív értékelésének megváltozásához, mely pedig a felismerés és elismerés igazságtalanságához köthető. Egyrészt az egyént vagy csoportot érő jogsérelem a döntéshozók által nem felismert vagy megismert, másrészt az egyén vagy a csoport felismerése megváltozik valamely információ(k) - ellenző mozgalmak, kutatási eredmények, tájékoztatók, rossz tapasztalat - hatására.

Az egyenlőség és az igazságosság nem csak a polgári demokráciák nélkülözhetetlen eszméje, de a fenntartható fejlödés elméletének is alapja. Minden embernek joga van olyan környezetben élnie, melyben az öt fenyegető veszélyek kockázata viszonylag alacsony, a környezet egy általános sztenderdnek megfelel, ha ezek a tényezők megvalósulnak, akkor nem csak egyenlő és fenntartható a fejlödés, de a környezeti igazságosság is beteljesül. A fenntarthatóság gondolatköre azért is meghatározó, mert a korábbi megőrző „,preserving” és konzerváló „,conserving” ideákon túlmutató környezetvédelmet hirdet, melyben nem csupán a természeti környezet (non human), de a környezet fogalomhoz méltóan az emberi értékeket (human artifacts), az ember-természet interakciókat is védelmezi. Ugyanis napjaink környezeti degradációjában nem azok „fizetik” a tevékenységek „árát”, akik ténylegesen okozzák azokat, hanem azok, akik társadalmilag alacsony státuszúak, gyakran marginalizálódottak. Igazságtalan, hogy ezek a csoportok viselik a legnagyobb kockázatot, hiszen társadalmi helyzetük alapján már eleve hátrányosak, így ezek a negatív externáliák csupán lejjebb sodorják őket a depriváció spiráljában (WESTRA, L 1996).

\subsection{A kockázatok lakossági értékelése és érzékelése}

A környezeti kockázatoknak és veszélyeknek való kitettség észlelt kockázata és a területi egyenlötlenségek összefüggését több tudományos munka is megerösíti. A környezetileg degradálódó helyszín sok esetben politikailag inaktív, gyenge érdekérvényesítő képességgel rendelkező helyi lakosok koncentrációját is jelenti. Ez többségi társadalom által nemkívánatos területfelhasználás megtelepítésére ad lehetőséget, hiszen az esetlegesen felmerülő aggodalmak ellenére többnyire ezek a csoportok valós és hatékony ellenállást nem mutatnak, így mind a gazdasági, mind pedig a politikai költségek alacsonynak tekinthetők. Több esettanulmány vizsgálata során két alapvető megnyilvánulást különíthetünk el a kockázatvállalással kapcsolatban (HAMILTON, J.T. 1995; LLURDÉS JC. ET AL. 2003; CAIN , N.L..-NELSON, H.T. 2013; LAURIAN, L. - FunDERBURG, R. 2014). Az egyik esetében a lakosság ténylegesen érdektelen a beruházással kapcsolatban, tájékozatlanságuk, alacsony képzettségük, egyéb, súlyosabb problémáik miatt nem tudnak vagy nem szeretnének a környezeti igazságtalansággal foglalkozni. A másik esetében a kezdeti aggályok és az észlelet környezeti kockázat és veszély mentén a lakosság szerveződni kezd, azonban ezek kezdetlegességét kihasználva a felszólalókat és az ellenző informális mozgalmat, szerveződést marginalizálják és kriminalizálják (DAVIES, P.A. 2008; DAVIES, A. 2009), ami elriasztja a területhasználat elleni formális ellenzéki intézmények kialakulását és fejlődését (FOLEY, M.W. - EDWARDS, B. 1996; DAVIES, P. A 2014). Az ellenállás kezdeti kudarcait követően letelepítik a nemkívánt területhasználatot, ami idővel növeli a környezeti kockázat elfogadottságát. A pénzbeli kompenzáció és egyéb kiegészítő tevékenységek hatására az elfogadottság tovább növekszik. Bullard ezt a folyamatot "környezeti zsarolásként" (environmental blackmailing) aposztrofálja (BULLARD, R.D.1992, FERREIRA, S. - GALlAGHER, L. 2010).

Az, hogy az egyén az adott, környezetében jelentkező kockázatot és veszélyt mennyiben érzékeli, fogja fel vagy fogadja el, számos tényező függvénye. A valós vagy vélt kockázat, potenciális veszély felismerése egy képesség, mely társadalmi-gazdasági státusz, családi körülmények, értékrend, kapcsolati háló, politikai aktivitás és még számos egyéb befolyásoló faktortól függ. A kockázatokat nem csak az egyén de a közösség is érzékelheti, észlelheti, mely az egyéni észleléshez hasonló tényezők által 
meghatározott. Azonban fontos elemmé válik a közösségen belüli kommunikáció és megértés. A közösség tagjai egyéni tapasztalatokat gyüjtenek, más kulturális és tudás-kontextusba helyezve. Bár a hagyományos megismerés folyamatában a társadalmi-kulturális és pszichológiai tényezők a hangsúlyosak, a környezeti igazságtalanságok esetében a kockázatértékelést befolyásolhatják gazdasági és hatalmi körülmények is. Az elsődleges egyéni megismerést követően a közösségen belül közös álláspontot alakítanak ki, mely tulajdonképpen egy attitüd-alakítási folyamat is, mely tükrözi a csoportok normarendszerét és világnézetét is (DAKE,K. 1991; 1992, PETERS, E. - SLOVIC, P. 1996).

A közösség által alkotott álláspont és kifejezett attitüd, azonban a legkevesebb esetben tükrözi a teljes közösség véleményét. Annak ellenére, hogy bizonyos igazságtalanságok esetében nem bizonyítható a tényleges veszélyhelyzet, azonban a félelem és a stresszhelyzet kialakulása tudományosan megfigyelt és leírt, mely ronthatja az egyén életminőségét és környezetének minőségével való elégedettségét (LimA, M.L. 2004; DownEy, L. - Willigen, M. 2005; SANTIAGO-RiverA ET AL.A. L. 2007; MARQUES, S. - LIMA, M.L. 2011). A környezeti terhek egyenlötlen elosztása a közjavak egyenlőtlen elosztásához hasonló hatást fejt ki, azonban itt fordítottan arányos.

További megfigyelés, hogy bizonyos nem látható, vagy ritkán tapasztalható kockázatok hosszútávú fennállása esetén az érintettek hajlamosak a kockázat és a veszély mértékét lebecsülni (FUNDERBURG, R. - LAURIAN, L. 2015). Hasonló folyamat figyelhető meg, ha a kockázat látható, azonban gyakorisága miatt megemelkedik a kockázatvállalók ingerküszöbe, így amit korábban veszélyesnek ítéltek meg, azt idővel már nem minősítik sem veszélyesnek, sem kockázatosnak (LIMA, L.M. 2004). További kutatások bizonyítják, hogy az alacsonyabb státuszúak között magasabb a kockázatérzet, mely a tájékoztatás hiányát vagy az intézményrendszerbe vetett hit hiányát mutathatja (KASPERSON ET AL. 1988; FUNDERBURG, L. - LAURIAN, L. 2015). A környezeti igazságtalanságoknak paradoxonja, hogy általában a környezeti ártalmakkal szemben mégis inkább a jómódúak, magasabb státuszúak azok akik fellépnek (MANSFIELD, C. ET AL 2001).

\subsection{A környezeti igazságtalanság időbelisége, ex ante és ex post igazságtalanságok}

A folyamatok vizsgálatakor a tyúk-tojás eset párhuzamán feltehetjük a kérdést, mi volt előbb, az igazságtalanságot okozó döntés, esemény, vagy már régebb óta fennállt az igazságtalanság, amelyre csupán felhívta a figyelmünket a radikális változást hozó esemény? Ezek alapján elkülöníthetünk ex ante, korábban kialakult, vagy ex post, később fellépő igazságtalanságokat.

A természeti környezetben zajló folyamatok emberi beavatkozás nélkül is igazságtalanságot generálnak (pl. árvíz, hurrikán), melyek többléptékü földrajzi térben léteznek (MÉSZÁROs R. 2010A; BOROS L. 2010B). Azonban nem elég a kollektíven elfogadott igazságosság-fogalomnak való megfelelöséget vizsgálni, az oda vezető folyamat és helyzetek azok, melyek az ex ante igazságtalanságokat definiálják. Hiszen az igazságtalanságot látszólag egy környezeti esemény eredményezte, azonban annak bekövetkezéséhez valójában a hatalmi struktúrák, társadalmi-gazdasági viszonyok vezettek, melyek hátterében gyakran rasszista vagy diszkriminatív szándék áll (CUTTER, L. S. 1995; HAMILTON, J. T. 1995). Például a környezetszennyező tevékenység letelepítését szándékosan a kisebb befolyással rendelkező, kevésbé aktív népesség által lakott területre telepítik. Vagy tudatosan költségmegkerülés érdekében nem valósítanak meg egy infrastrukturális beruházást bizonyos területeken, hiszen az kevésbé lenne jövedelmező. Ez azonban később, a katasztrofális esemény bekövetkezésekor fejti csak ki igazán negatív hatásait. Amikor az igazságtalan helyzet kialakulása a környezetet érintő esemény előtt kialakult már, ex ante, esemény előtti igazságtalanságról beszélünk (PASTOR, M ET AL. 2001). A területen mutatkozó etnikai-jövedelmi szegregáció nem feltétlenül intézményesült diszkrimináció és rasszizmus eredménye, bekövetkezhetett, ex post utólag is.

Az egyének saját megismerési folyamataik alapján másképpen érzékelik és értékelik a környezetükben jelentkező folyamatokat, így másféle válaszokat is fognak adni a felmerülő kérdésekre, máshogyan reagálnak a választási helyzetekben. Az ex post kialakult környezeti igazságtalanság esetében például egy szennyező beruházás megvalósulása vagy egy természeti katasztrófa után a környezetük iránt elkötelezettek, tehetősebbek, akiknek környezettel szemben támasztott igényei nagyobbak elhagyják a közösséget. A hátramaradottak nem törvényszerủen alacsonyabb minőségü környezeti igényüek, csak adott élethelyzeteik, vagyoni státuszuk, egyéb tényezök miatt nem képesek, vagy nem akarják 
elhagyni az adott területet. Ha a diszkrimináló munkaerőpiac alacsony jövedelmet biztosít a kisebbségeknek, akkor az alacsony jövedelem kényszeríti az alacsony környezetminőségi feltételekhez való hozzászokást, alkalmazkodást, hiszen az érintett nem rendelkezik a megfelelő forrásokkal a helyzet megváltoztatására. Ahogyan a jövedelmi helyzet, úgy a képzettség is befolyásolja az érintettek reakcióit, hiszen nem várható el senkitől pl.: egy zagytározó által előidézett kockázat önálló felbecslése.

Az igazságtalansággal érintett terület ingatlanpiaci és környezeti leértékelődése az esemény után megindul, melynek következményeként elérhetővé válik olyan egyének és csoportok - gyakran kisebbségi (HAMILTON, J. T.1995)- számára is, akik környezeti preferenciái alacsonyabbak, és rendelkezésre álló forrásaik alapján csupán egy olcsóbb ingatlanba tudnak befektetni. A folyamat a Johnston-féle filtrációs modellhez hasonló, ahol a folyamat végére az adott terület népessége kicserélödik (CSÉFALVAY, Z. 1994). A folyamatot a kockázatok elől való elmenekülésről „Riskscape”-nek nevezhetjük. Azt is mondhatjuk, hogy az alacsonyabb ingatlanárak adják a kompenzáció egy részét az adott területen lévő szennyező tevékenységért, azonban az árak nem tükrözik a teljes kockázat mértékét. A különbség ebben az esetben a mozgató faktorokban keresendő, hiszen ezesetben nem a város határában épülő új, jobb minőségü lakóparkok, vagy a szuburbanizáció hatására kezdődik meg a lakóhely megváltoztatásának folyamata. A környezeti igazságtalanságok esetében az egyén vagy a közösség fellépésének hiánya, a környezet minőségének megváltozása és a környezettel szemben támasztott elvárások azok, melyek alakítják a folyamatot. A szennyezés egyenlőtlen eloszlása a csoportok között az ingatlanpiaci folyamatokban csapódik le. PADGETT ÉS IMANI (1999) vizsgálata alapján a környezeti igazságtalanságok elszenvedőivel szemben gyakori az áldozat hibáztatás, a döntéshozók nehezen vagy egyáltalán nem értik meg a folyamat okát, az érintettek motivációit és belső, sajátos döntéshozási mechanizmusát.

Ha azonban a kitettség egyenlőtlensége nem a kollektív cselekvőképesség korábban emlegetett hiányából, hanem az adott csoport alacsonyabb környezeti és kompenzációs igényeiből, információhiányból vagy szándékos félretájékoztatásból fakad és önként fogadják be a szennyező tevékenységet, más a folyamat színezete. Ebben az esetben a magasabb kockázatvállalási hajlandóságért cserébe biztosított állami és vállalati kompenzáció a közösség fejlödését illetve előrejutását biztosíthatja, feltételezve hogy a kompenzáció elosztása a környezeti ártalmaknak való kitettség arányában, méltányosan és igazságosan történik. Ez az ex post környezeti igazságtalanság felvet számos új földrajzi vonatkozású problémát. Ilyen például a rasszizmus újszerü megközelítése (BENNETT, M. 2004), mely nem antorpológiai és kulturális jegyeken alapul, hanem térbeli attribútumokon. Kialakulása a nem megfelelö környezeti állapotokhoz, ingatlanpiaci szabályozáshoz, a társadalmi-gazdasági folyamatokhoz, szegregációhoz, deprivációhoz köthetők (8. ábra). 


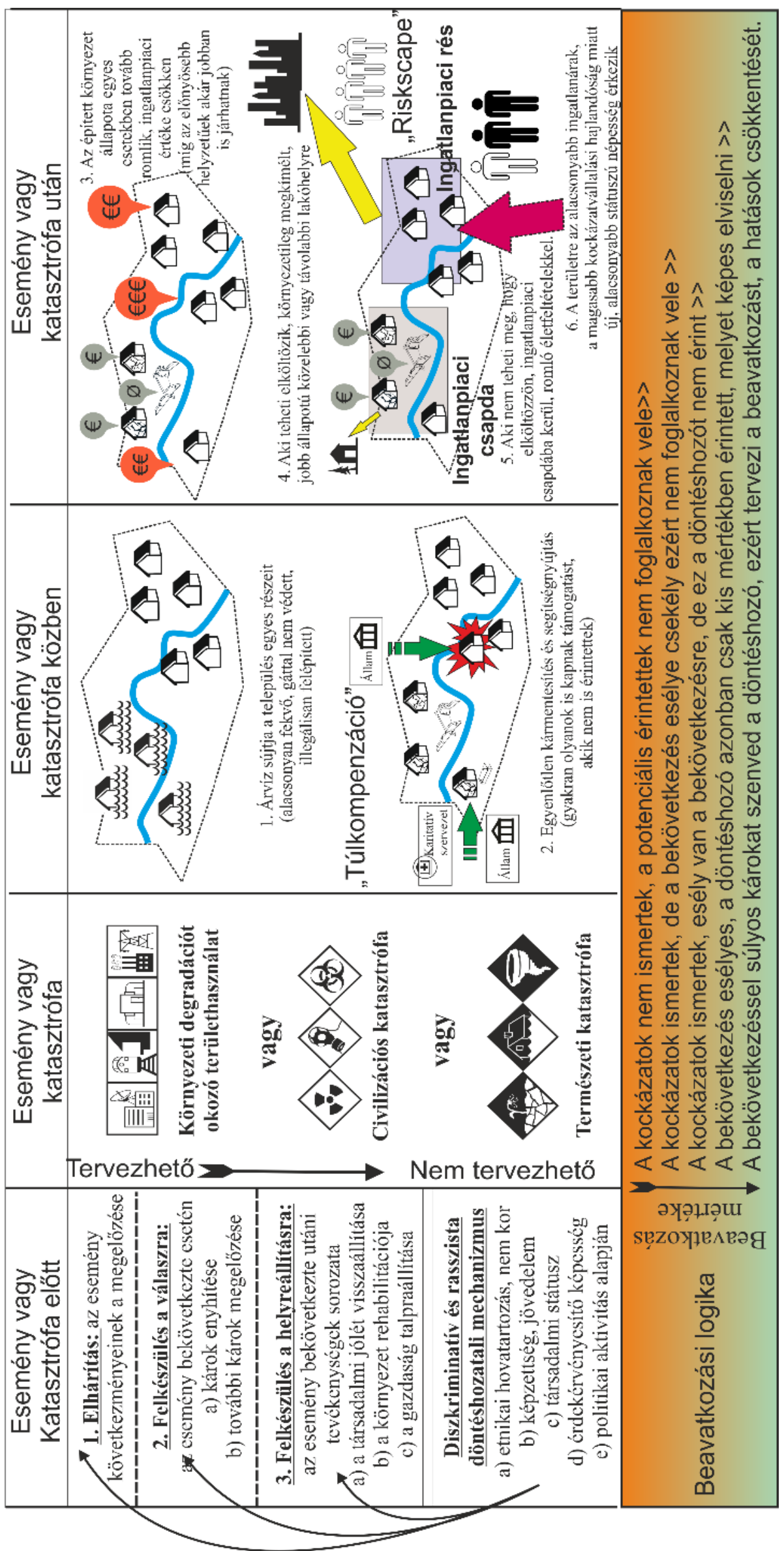

8. ábra: A környezeti igazságtalanságok időbeli vonatkozásai: Az ex ante és ex post igazságtalanságok és a beavatkozási logika. Forrás: saját szerkesztés 


\subsection{A lépték szerepe a környezeti igazságtalanságok vizsgálatában}

A környezeti igazságtalanságok számos formája ismert, melyek kialakulásának okai sokfélék, összetettek, ezért az igazságtalan helyzetek feltárására a szakirodalom számos módszert alkalmaz. Az eltérő kiváltó okok, az eltérő helyi társadalmi-térbeli rendszerek különbözőségből adódóan csak megközelítve és kontextus-függően mérik az ember-környezet kapcsolatban felmerülő zavarokat és rendellenességeket. Ezért a környezeti igazságosság-kutatásokban a problémák feltárása érdekében komplex módszertanra van szükség. Az említett módszertani összetettség mellett az igazságtalanságok földrajzi-térbeli kiterjedése miatt is nehéz a megfelelő vizsgálati módszert alkalmazni. A környezeti igazságtalanságot kiváltó folyamatok gyakran a vizsgálati keretet adó statisztikai/közigazgatási határokon túlmutatnak és ezért vizsgálatuk más-más megközelítést, más léptéket is igényelnek, akár egy időben.

A lépték megfelelő megválasztása kulcsfontosságú, erre mutat példát FABULA Sz. - TIMÁR J. (2016) kutatása, ahol a lépték a test és a háztartás, család nem pedig a hagyományosan értelmezett téregységek, mint a település, térség és nemzetállam. Ahogyan a test máshogyan reagál a szennyezésekre, úgy az egyén és a család is másképpen éli meg és reagál az adott eseményre, mely ezáltal sajátos társadalmi helyzet - életciklus, szociális státusz, nem, mentális állapot stb. - alapján meghatározott kontextusba ágyazódik be (FABULA Sz. 2013). Ahogy a családi háttér befolyásolja az események tapasztalását és a rá adott reakciókat, úgy a környezeti igazságtalanságok esetében is a háttér eredményezheti az egyes környezeti tapasztalatok, érzékelések, a sebezhetőség, felelösségérzet különböző perspektíváit. Ilyen szempontból a tértermelési- és értelmezési folyamatot környezetorientáltnak is tekinthetjük.

A lépték kérdése számos technikai jellegü problémát is felvet. Sok esetben a vonatkozó adatok csupán települési szinten állnak rendelkezésre, így a települési szint alatti, például népszámlálási körzet, háztömb vagy háztartási szintủ adatok nélkül csupán általánosított, nagyobb egységre, tömb vagy városrész/kerületre számított adatok elemzése lehetséges. Ezek nem tükrözik a tényleges kitettséget, egységesnek, homogénnek tekintik a vizsgált területegységeket, így minden lakost egyaránt és egyformán érintettnek tekintenek (HIGGS, G. - LANGFORD, M. 2009; FLOWERDEW R. ET AL. 2008; STAFFORD M. ET AL. 2008). Másodrészt, amikor a környezeti igazságosság kutatások pontszerü adatokat aggregálnak nagyobb területi egységekbe a területegység megválasztása alapvetően befolyásolhatja a kutatás eredményét. Az úgynevezett MAUP (modifiable areal unit problem), vagyis a területegység adatokra gyakorolt módosító hatása több esetben is ökológiai tévkövetkeztetésekhez vezethet (BOWEN, W. 2002; Swift, A. et al 2008; MAANTAy J. 2007; MAANTAY, J. - MAROKO. A. 2009; SAYRE N. F. - Di VitTORIO A. V. 2009; BOROS L. 2010A; MÉSZÁROS R. 2010) hiszen a terület aggregált adata nem minden egyénre vagy csoportra értendő érték, csupán azok együttes értéke, mely szükségszerüen az egyénekre vonatkoztatott adat részleges veszteségéhez vezet. A folyamatok és azok hatásának értelmezéséhez, ahogyan a társadalmi-gazdasági státusz egyedüli figyelembevétele, úgy a pusztán földrajzi távolságon alapuló vizsgálata sem célravezető, hiszen ha a területi beosztás nem megfelelö, az igazságtalanságok „megállnak” a vizsgálati határoknál (BOwEN, W. 2002).

A fentiek alapján tehát a kutatások során kulcskérdés a megfelelő földrajzi lépték megtalálása, amit viszont befolyásol, hogy honnan állnak rendelkezésre adataink. A rendszeresen gyüjtött és széles körben elérhető statisztikai adatok általában a közigazgatási térbeosztást követik, ugyanakkor ez a beosztás nem egyezik a folyamatok térbeli kiterjedésével - azaz az elemzési és folyamatlépték eltér egymástól. Így nehéz megtalálnunk a megfelelő társadalmi-gazdasági és területi indikátorokat, vagy éppen meghatároznunk a vizsgálatok megfelelö földrajzi léptékét.

A lépték segítségül szolgál az egyes jelenségek és folyamatok absztrakciójában, gyakorta azonban a lépték nem önmagában jelenik meg, más léptékekhez való viszonya vagy éppen a méretarány meghatározásához használatos.

MARSTON, S. ET AL. (2005) szerint a tér és társadalom közti dinamikus kapcsolat vizsgálata új térbeli nézőpontot igényel, hiszen olyan komplex kapcsolatrendszerről van szó, ahol a hely az emberi létezés helyszíne, helyhez kötött és nem helyhez kötött folyamatok tere, fontos és kevésbé fontos döntések és napi gyakorlatok egysége, miliő, kontextus, mely értelmezéséhez kerülni kell a statikus kategóriákat. A hasonló jelenségek együttes megjelenése adja a lehetőséget az egységek lehatárolására, tehát a gyakorlatban a lépték inkább kapcsolódik a térbeli folyamatokhoz, mint a térbeli kiterjedéséhez. 
Így hát a térbeli kiterjedés alapú település-járás-megye stb. léptékmeghatározás az egyes folyamatok feltárása ellen hat (MARSTON, A. ET AL. 2005). Mindemellett, a holisztikus megközelítés elkerülése érdekében, fontos hangsúlyozni, hogy a léptékeket alkotó objektumok, tevékenységek és folyamatok együttesen alkotják azt és nem függetlenek egymástól (COLLINGE, C. 2006).Az említett dimenziók a teret több szempontból fragmentálják és minden esetben más-és más értelmezéssel ruházzák fel, ezért ebben a többrétü térben különböző formában, különböző léptékben és konstruckióban jelennek meg az igazságtalanságok.

Összességében elmondható, hogy a környezeti igazságosság elmélete a különböző igazságosságmegközelítések, a sokszínủ megnyilvánulási formák igen szerte ágazóvá teszik a környezeti igazságosság kutatásokat. Meghatározónak tekinthetjük a kutatásokban az egyre felértékelö térbeliséget és a léptékek szerepét is. A hazai adaptálhatóság szempontjából a társadalmi és gazdasági struktúrák, a jogi szabályozási környezet hatása a társadalomra és a környezeti folyamatokra kiemelten elötérbe kerül.

A disszertáció további részében a kutatási kérdések megválaszolása érdekében elsődlegesen azonosítom a potenciálisan környezeti igazságtalanságokkal érintett térségeket, majd léptéket váltva az elméleti fejezetben leírt tényezőket vizsgálom meg. 


\section{A kutatás eredményei}

\subsection{Környezeti igazságtalanságokkal potenciálisan érintett területegységek lehatárolása}

A disszertáció egyik kérdése arra vonatkozott, hogy melyek azok a mintaterületek amik potenciálisan környezeti igazságtalansággal érintettek lehetnek. Ezen területek kimutatása érdekében a WHO ajánlásai alapján, a Magyarországon is elérhető adatokra elvégeztem a vizsgálatot. Összesen négy dimenziót, épített lakókörnyezet, társadalmi, természeti és gazdasági környezet, vizsgáltam meg az empirikus felmérés időpontjaihoz igazodva. Az adatok az adott dimenzióban a felmért legfrisseb adatokból képzett főkomponens-elemzés eredményeit reprezentálják. Az épített környezet értékelése alapján Borsod-Abaúj-Zemplén, az Ormánság, Zala megye határmenti térsége, illetve Belső-Somogy és a Szatmár és Szamoshát helyzete kifejezetten hátrányos (9. ábra).

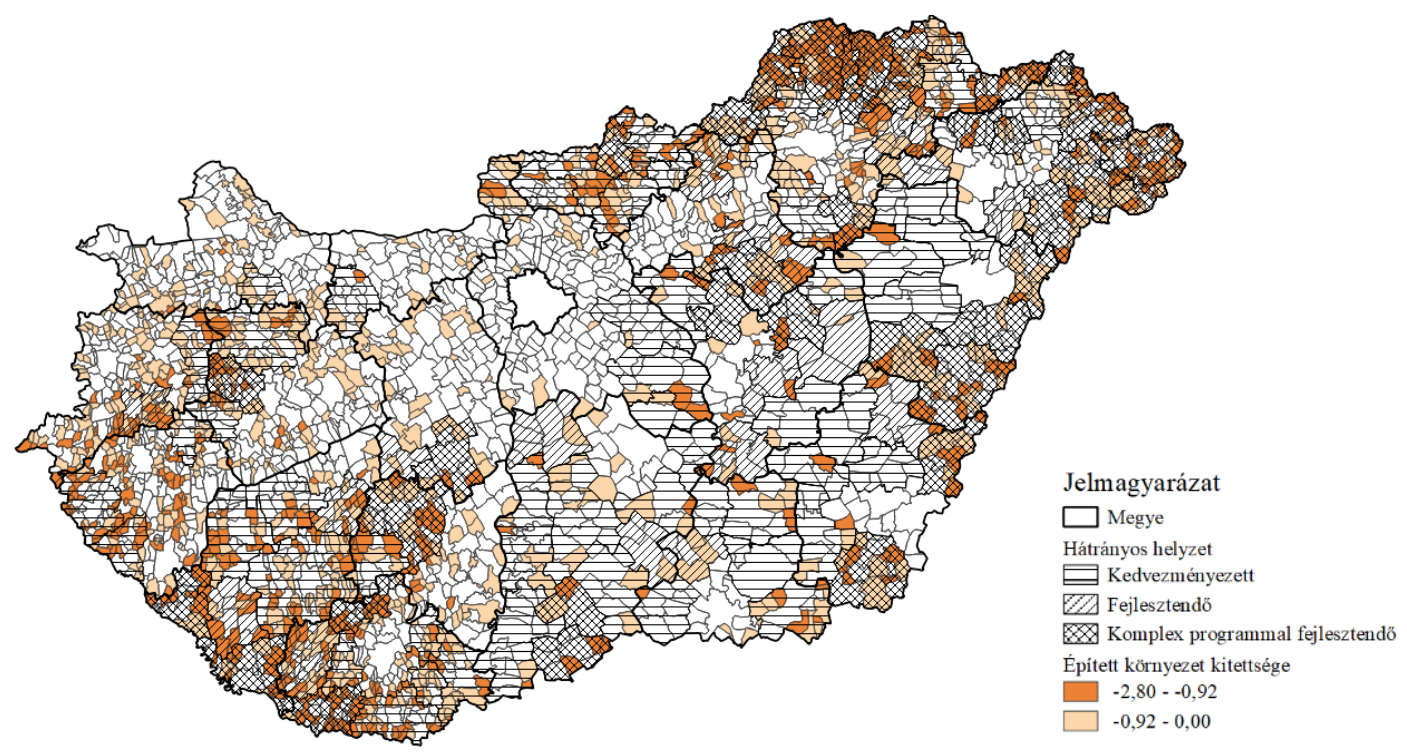

9. ábra: Az épített környezet dimenziója, a kitettség értéke. Forrás: KSH TEIR adatok alapján saját szerkesztés

A WHO másik indikátor dimenziója a környezet-okozta egyenlőtlenség, melyben a vizsgálatban a természeti tényezőket vizsgáltam. Az előző térképhez hasonlóan Borsod-Abaúj-Zemplén megye hátrányos helyzete szembetünő, ahol azonban főként a hegylábaknál található, völgyekben fekvő települések kitettebbek a mért környezeti kockázatoknak (10. ábra). Az Alföldön a Közép- és Alsó-Tisza vidéke föként az ár- és belvízveszély valamint az elégtelen ivóvíz miatt szintén az egyik legkitettebb terület. Komárom-Esztergom esetében a veszélyes hulladék, a belvíz és az árvíz okoz kockázatot. Heves megye déli részén az árvíz, illetve a veszélyes hulladék az, ami potenciális környezeti igazságtalanság kialakulásához vezethet. A kisebbséghez tartozók, az alacsony jövedelemmel rendelkezők, alacsony végzettségüek azok, akik a leggyakrabban elszenvedői az igazságtalanságoknak. Ök azok, akik pl. a megnövekedett közlekedési forgalom negatívumait, az ipari üzemekhez kapcsolódó veszélyeket és káros hatásokat, a növekvő ár- és belvízveszélyt a legnagyobb arányban elszenvedik. Ezen csoportok esetében jellemző, hogy nem jutnak egészséges ivóvízhez, vagy a környezeti katasztrófák az átlagosnál nagyobb mértékben fenyegetik őket (BEEN, V. 1994; CHAKRABORTY, J. -ARMSTRONG, M. P. 1997; DEREZINSKIET AL. 2003; HAMILTON, L 1995; KRIEG, E. J. 1995; MOHAI, P. - BRYANT, B. 1992; MORELLOFROSCH ET AL. 2001; SZASZ A. - MEUSER, M. 1997). Így a vizsgálatban a társadalmi környezetet meghatározó tényezőket, az infrastrukturális ellátottságot, a települések juvenilitását, illetve a lakónépességet is vizsgáltam. Ezek alapján az épített környezet dimenziójához hasonló eredményeket kaptam. 


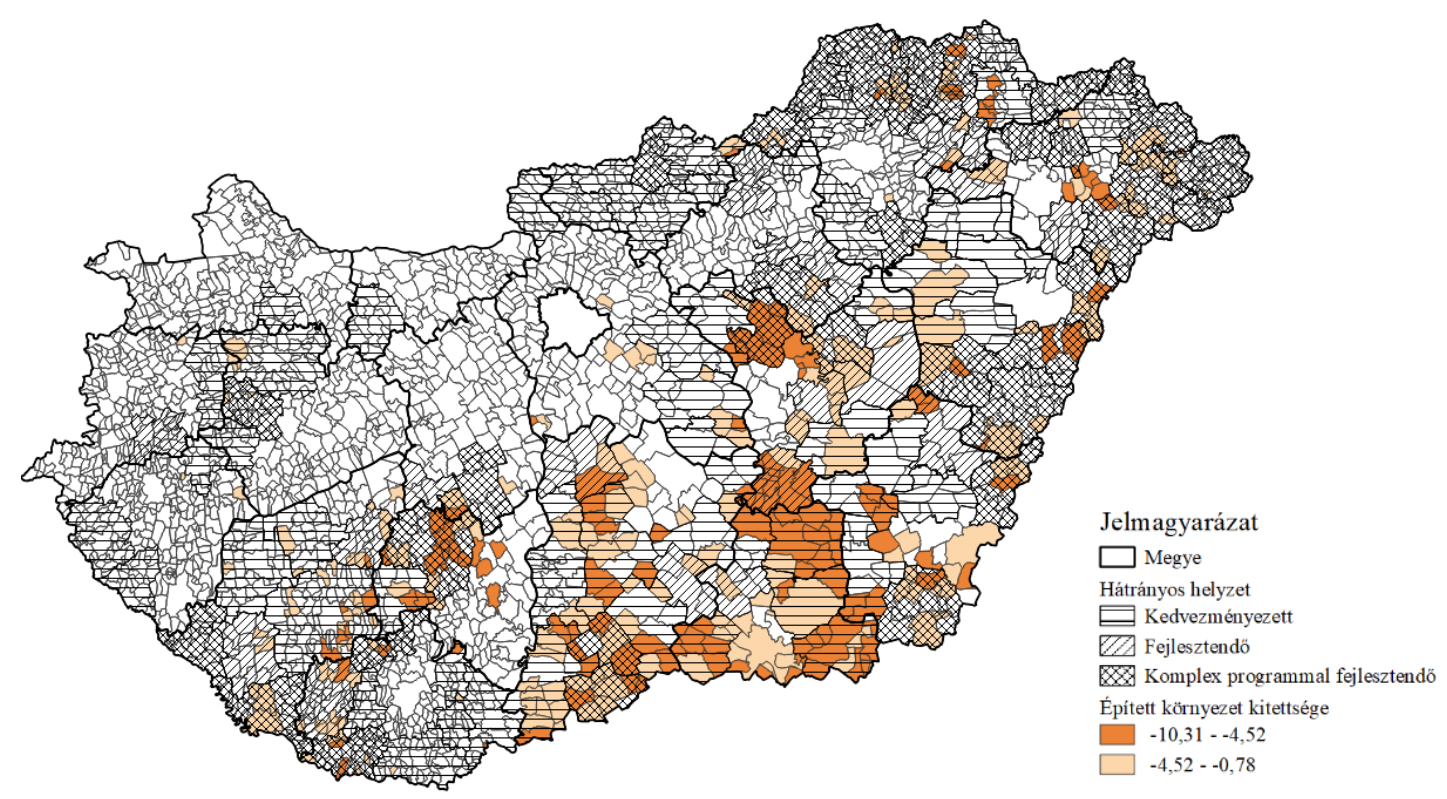

10. ábra: A természeti környezeti kitettség értékei, a természeti környezet állapotának dimenziója. Forrás: KSH TEIR adatok alapján saját szerkesztés

A gazdasági környezet dimenziója az eddig vizsgált dimenziók eredményeit megerősíti, és szintén Borsod-Abaúj-Zemplén megye hátrányos helyzetét bizonyítja. Azonban szembetünő az ország határmenti térségeinek elmaradottsága (11. ábra). Az Ormánság, a Szamoshát, Közép-Tisza vidék és Belsö-Somogy, valamint Salgótarján környékének hátrányos helyzete is megmutatkozik. Ráadásul ha egészségföldrajzi vizsgálatok eredményét is figyelembe vesszük, akkor megállapítható az is hogy Borsod-Abaúj Zemplén és Szabolcs-Szatmár-Bereg megyékben találhatjuk a legkedvezőtlenebb egészségi helyzetü lakosságot (ILLÉS, I. 1996; UzzOLI, A. 2001). Ez a kelet-nyugati megosztottság a 2009-es gazdasági válság idején tovább mélyült (UZzOLI A. - SzILÁGYI D. 2015). Mindez fokozott figyelmet irányít az északkelet-magyarországi megyékre.

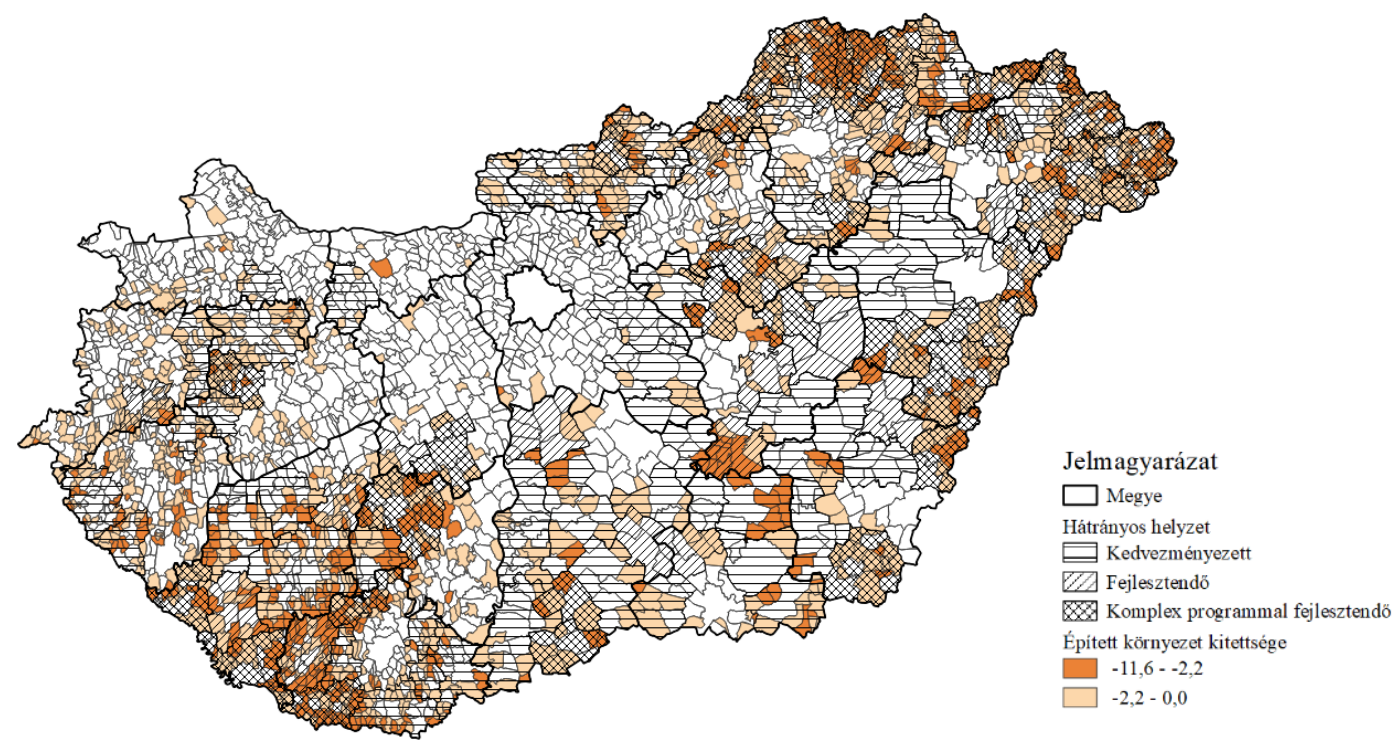

11. ábra: A gazdasági vizsgálati dimenzió értékei. Forrás: KSH TEIR adatok alapján saját szerkesztés

Az egyes dimenziók mentén Borsod-Abaúj-Zemplén megye szinte mindig az egyik leghátrányosabb helyzetü, ennél azonban fontosabb megállapítás, hogy számos olyan külső (Ormánság, Szamoshát és Bereg) és belső periférikus (Belső-Somogy, Közép-Tisza vidék) terület is található, melyre jelenleg a fejlesztéspolitikában kevesebb figyelem vetül (12. ábra). A hátrányos helyzet legtöbb esetben együtt mutatkozik a terület magasabb arányú roma lakosságával, azonban fontos leszögezni, hogy az igen 
összetett potenciális környezetileg igazságtalan helyzeteknek nem kialakítói, hanem elszenvedöi a romák, hiszen a legtöbb mutató külső tényezőket mutat, melyre az egyéneknek nincs, vagy csak korlátozottan van hatásuk. A vizsgálat során lehatárolt hátrányos térségek többnyire egybeesnek a jelenleg hivatalosan használt kormányrendelet besorolásával, azonban a hátrányos helyzet „súlyosságában” jelentős eltéréseket tapasztalhatunk. Ennek hátterében a jelenleg használatos jogszabály környezeti dimenziójának a hiánya, illetve statikus megközelítése áll.

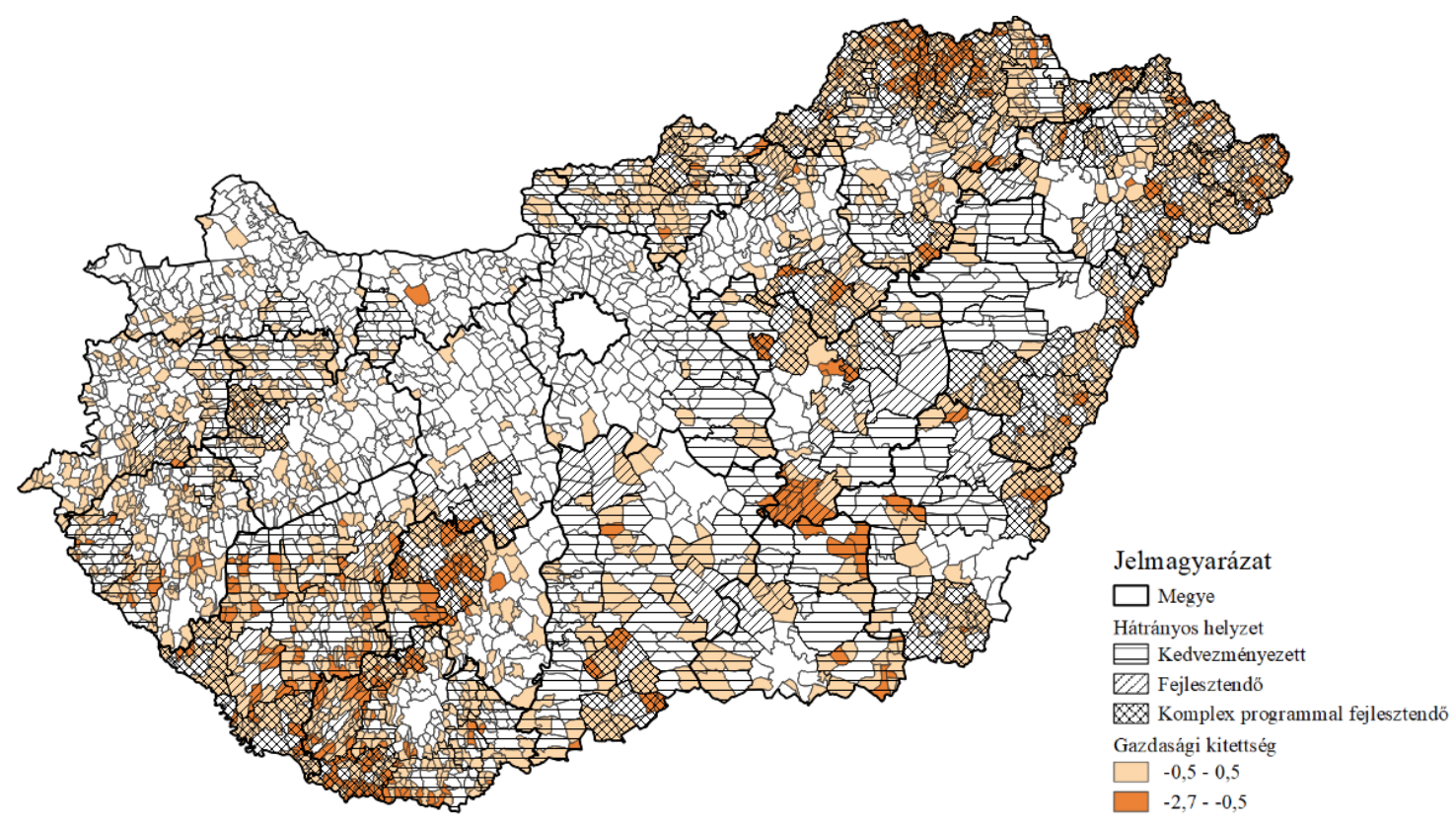

12. ábra. A környezeti igazságtalanság kialakulásának lehetősége 2015-ös adatok alapján. Forrás: KSH TEIR alapján saját szerkesztés.

Érdemes figyelmet fordítanunk a földrajzi léptékek kérdésére is, hiszen sok igazságtalanság a települési szintnél kisebb területegységen belül játszódik le, így a települési vagy annál nagyobb egységekre vonatkozó adatok elfedhetik az igazságtalanságokat. Számos esetben rosszul (netán önkényesen, manipulatív módon) kiválasztott településrészek vizsgálata olyan helyeken is igazságtalanságokat mutathat, ahol azok nem, vagy nem kimutatott formában vagy erősséggel jellemzőek. A lépték-kérdés mellett az időbeliség is meghatározó lehet, hiszen a változás dinamikáját így meghatározhatjuk. Ennek érdekében 2011, 2013 és 2015 évre is elvégeztem a statisztikai elemzéseket, így állapítottam meg potenciálisan környezeti igazságtalansággal veszélyeztetett zónákat. A jelenleg használt hátrányos helyzet besorolás a valóság pillanatnyi kimerevített képét mutatja, kevésbé dinamikusan alkalmazkodik a körülöttünk lévő világ változásaihoz. Ami azért is lenne kiemelten fontos, mert a globális klímaváltozás társadalmi-gazdasági hatásai is sokszínüek és dinamikusan változnak. Míg egyik évben az aszály teszi tönkre a terményeket, nagy gazdasági károkat okozva, addig a rákövetkező évben a belvíz nem csak a terméshozam romlását, de az épített környezet degradációját is okozza. Mindezek olyan hátrányok, melyekkel a jelenlegi statisztikai lehatárolás nem foglalkozik, ellenben egy térség jövőbeli sorsát nagymértékben befolyásolja akár igen rövidtávon is. A longitudinális vizsgálat eredményeként megállapítható, hogy az országban csökkent a környezeti igazságtalansággal potenciálisan érintett területek kiterjedése, a kiemelten jó helyzetü, gazdasági-társadalmi és környezeti szempontú besorolás alapján felső kategóriába került települések száma emelkedett (13. ábra). Ezek térbeli elhelyezkedése az Enyedi által lehatárolt ún. urbanizációs tengely mentén található (ENYEDI GY. 2010). 


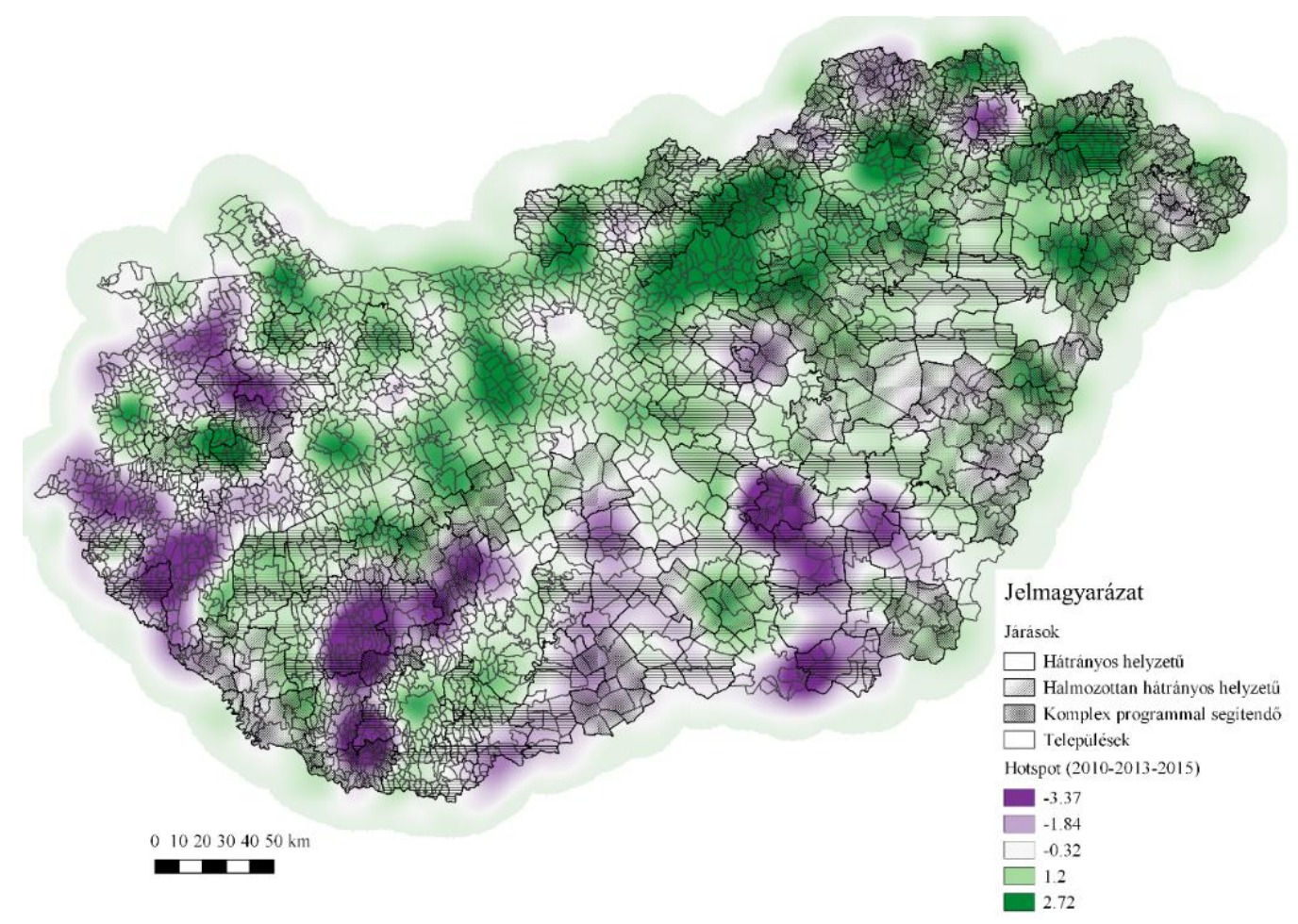

13. A vizsgált dimenziókból képzett összesített, 2011-2015 közötti évek kompozit képe. Forrás: saját szerkesztés

Ezzel párhuzamosan mélyült a hátrányos helyzetü települések és az átlagos és a jó helyzetü települések közötti távolság, erősödő polarizáció figyelhető meg 2010 és 2015 közötti időszakban. Ez föként a Dél-Dunántúlon, Baranya megyében az Ormánságban, Somogy megyében Külső-Somogy és Tolna megyében a Tolnai-dombság vidékén figyelhető meg. Itt az országos átlaghoz képest romló a tendencia. A regionális központok helyzeti előnye romlott 2010 és 2015 között. Ez leginkább Szeged és környékének példáján figyelhető meg, ahol a legjobb kategóriából a legrosszabba került több település is. Csongrád megye északi és keleti részén a jelentős belvíz, illetve az ivóvíz minőségének köszönhető a romló besorolás. Javuló helyzetet ért el a beregi térség, ahol a 2001-es árvizet követően egyre több fiatal értelmiségi jelent meg második otthonokat vásárolva. A korábban felújított árvízkárosult települések esetében pozitív folyamatok indultak el a települési környezet megítélése is sokkal pozitívabb. Hasonlóan javuló helyzete van a Devecseri járásnak, ahol a rekultiváció és a lakókörnyezet megújulása pozitív hatással volt a térségre. Érdekes folyamat, hogy míg a katasztrófával érintett területek helyzete javult, szomszédos térségük helyzete romlott (14. ábra).

A statisztikai adatok hosszútávú elemzése alapján, a területi koncentrációt is figyelembe véve az országban a környezeti igazságtalanságokkal érintett területek a következők: Ormánság, Belső Somogy, Kolontár-devecser környéke, Marosszög és Dél-Tisza vidék, Cserehát, Szamoshát, Bereg, Hajdú-határvidék. Az elérhető statisztikai adatok alapján a legtöbb esetben csak áttekintő képet kaphatunk a vizsgált folyamatokról, nem alkalmas a települési szint alatti belső folyamatok, struktúrák, hatalmi viszonyok feltárására. Ezért véleményem szerint szükség van a megfelelö léptéken végzett empirikus adatgyüjtésre is. 

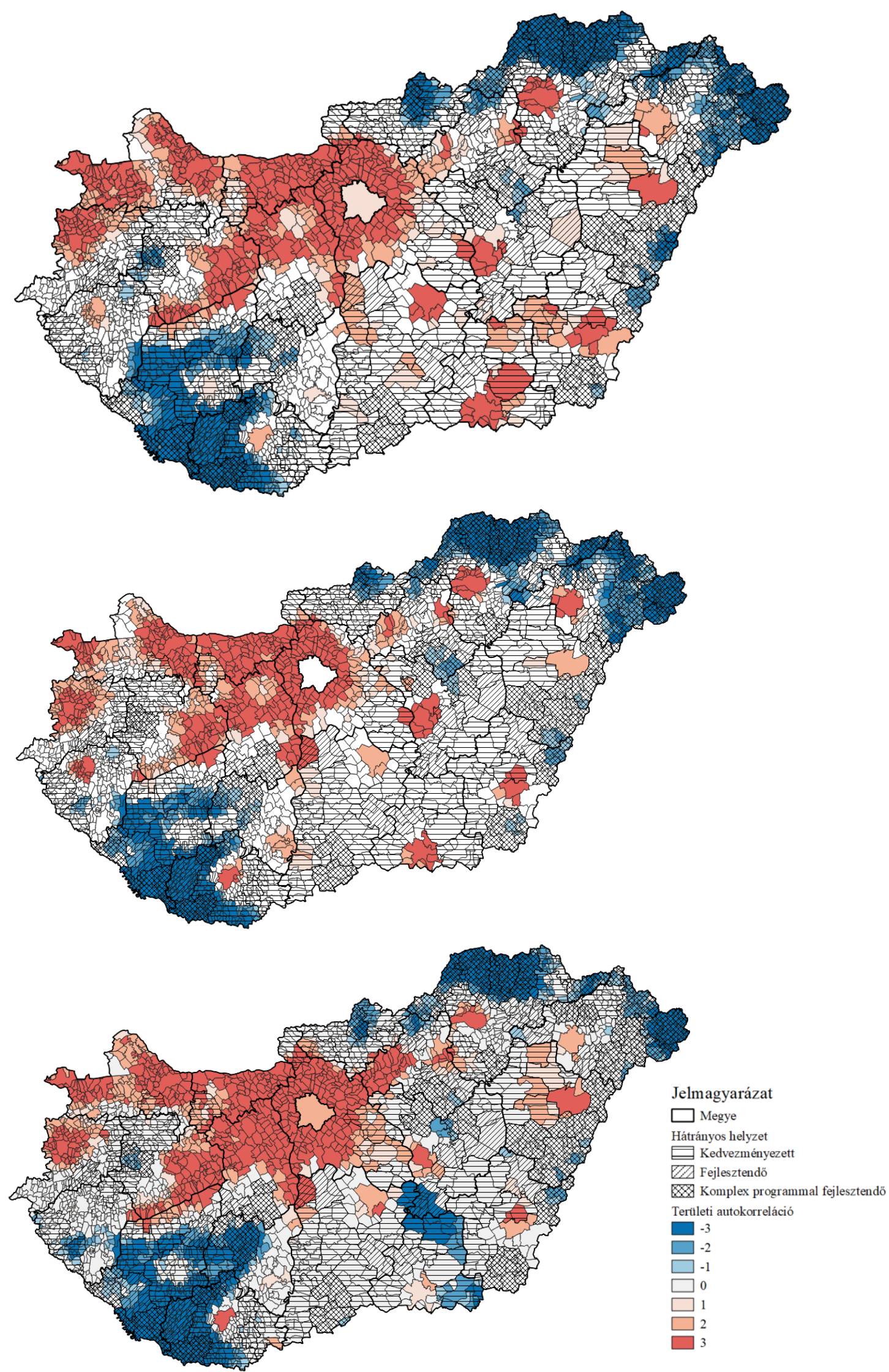

14. ábra: A vizsgált időpontokra $(2011,2013,2015)$ készített Getis-Ord módszerủ területi autokorreláció. Forrás: saját szerkesztés 


\subsection{A disszertáció kiválasztott mintaterületeinek a bemutatása}

\subsubsection{Az árvízzel érintett települések jellemzői}

Amint azt a bevezetőben kifejtettem, a globális klímaváltozás hatására az éghajlati szélsőségek következtében egyre többször kell számítani vízzel kapcsolatos katasztrófákra, a megváltozott időjárási viszonyok nem csak gyakoribb, de eddig ismeretlen veszélyhelyzeteket is teremthetnek (FARKAS ZS. JUHÁsZZ Z 2012 ). Az ország jelentős része érintett az időszakosan rendszerben megjelenő többlet vízmennyiség által, mely árvízként vagy belvízként jelentkezik. Jelenleg a Magyarországot fenyegető környezeti kockázatok közül az érintett népesség és az érintett települések száma alapján ezek tekinthetök a legmeghatározóbb környezeti konfliktusnak (MEZÖSI, G. 2011). A katasztrófákkal szembeni védekezés összetett feladat, mind állami, mind pedig közigazgatási szereplök együttes feladata, a többszintü szabályozás nélkülözhetetlen, azonban a párhuzamos, egymással ellentmondó vagy eltérő jogi szabályozás kerülendő (FARKAS Zs. - JUHÁSZ Z. 2012). Ez a jogalkotási alaptétel hazánkban több esetben sérülhet a különböző szereplők és szintek közötti nem megfelelő kommunikáció, esetleges rivalizálás miatt (KERTÉSZ J. 2012). Mindez a szintek és akár a szakterületek közt a katasztrófa-elhárítás hatékonyságát ronthatja (FARKAS Zs. - JUHÁSZZ. 2012), mindennek hatására a jogbiztonság veszélye állhat fenn. Mind az árvíz, mind pedig a belvíz olyan természeti katasztrófák, melyek csak közvetetten kapcsolhatók emberi tényezőkhöz. A disszertációban vizsgált két árvíz, a 2001-es beregi és a 2010-es borsodi árvizek is rávilágítottak arra, hogy a kárrendezéssel kapcsolatban nincs egységes joggyakorlat, hiszen a két árvíz kapcsán is eltérő volt a beavatkozási logika. Mindkét árvíz esetében kormányhatározatok és rendeletek születtek, melyek ad hoc jogi megoldást kínáltak (FARKAS ZS. - JUHÁsZZ Z. 2012). Tehát az árvízzel és a belvízzel kapcsolatos jogi- és szabályozási környezet jelenleg is kiforratlan, mely egyrészt a kárrendezést is gátolja, másrészt pedig a lakosság információ-ellátását is hátráltatja. Mindez a környezeti igazságtalanságok számos aspektuást, mint például kirekesztés, információellátás hiánya, hatalomgyakorlás és depriváció is felveti.

Az árvizes területeken felmerülő környezeti igazságtalanságok feltárása érdekében 2010 és 2011 között három mintaterületen, három szakaszban végeztem kérdőíves vizsgálatot a SZTE Gazdaság- és Társadalomföldrajz Tanszék hallgatóinak segítségével. Először 2010-ben a Borsod-Abaúj-Zemplén megyei Boldva település szegregált helyzetü cigány telepén $(\mathrm{N}=68)$, majd 2011-ben a 2001-es tiszai árvízben érintett kilenc beregi településen $(\mathrm{N}=411)$ és végül a 2010-es Sajó és Hernád és Bódva árvizeiben érintett öt borsodi településen ( $\mathrm{N}=443)$ zajlott kérdőives felmérés. Az árvízzel érintett településekröl így összesen 922 kitöltött kérdőív állt a rendelkezésemre. A kérdöíveket a mintaterületekre vonatkozó sajtóelemzés eredményei alapján állítottam össze, hogy az adott területre jellemző problémákra fókuszáljanak, így azok nem minden kérdésben egyeznek. Az eredmények összehasonlíthatóságát a kérdőívek meghatározott kérdésekben való tartalmi egyezése ad lehetőséget. A kérdőiv három fő részből állt, az első a környezetre, a második a politikai döntéshozatali befolyásra a harmadik pedig a személyes adatokra kérdezett rá. A kérdőíveket az 1. melléklet tartalmazza.

\subsubsection{Boldvai árvizes mintaterület bemutatása és a felvételezés módszertana}

Boldva a Bódva és a Sajó összefolyásánál fekszik, fokozottan árvízveszélyes területen, ráadásul a 2010-es árvizek által is érintett. A település sajátos, többszörösen szegregált településszerkezettel rendelkezik, mely társadalmi elkülönüléssel párosul. A Boldva lakosságának mintegy 20\%-át kitevő cigányság jelenleg a község központi területétől megközelítőleg 2 km-re, az Ördög patak mentén, a település legmélyebb pontján lakik, melyet csupán egyetlen, az Edelény felé vezető út köt össze a település többi részével. A telep szegregált helyzetét súlyosbítja, hogy a 94-es számú Miskolc-Tornanádaska vasútvonal töltése is elválasztja a központtól a lakosokat, ráadásul elősegíti az árvízi kockázat növekedését. Az államszocialista időszakban az országos területfejlesztési politika nagymértékben átalakította a forrásallokációt, az 1971-es OTK pedig számos hátrányos települést, köztük Boldvát is még hátrányosabb helyzetbe hozta (MOLNÁR E. ET AL. 2011). Ehhez kapcsolódott az 1965-ben elinduló telepfelszámolási program, mely a telepen lakó romákat kamatmentes kölcsönhöz juttatta. Ez ugyan felszámolta a telepek jelentős részét, de új területeken, főként az OTK által nem fejlesztendő aprófalvakban, melyek az iparvidékekhez közel találhatóak, újabb szegregációs formákat jelenített meg (KÖSZEGHY L. 
2007). Boldván, a romatelep jelenlegi területén az 1979-80-as években épültek fel a CS-házak, melyek a korábbi, úgynevezett „,putrisort” kívánták felváltani, de a Tanács által, a roma lakosok számára kijelölt terület ár- és belvízveszélyes volt. A terület fekvése által előidézett természeti kockázat mellett a politikai döntéshozatal is elősegítette a kialakult környezetileg igazságtalan helyzetet.

Az árvizek nem Boldva teljes területét, csupán a település egy részét, az elkülönülő cigánytelepet érintik - ráadásul azt sem azonos módon - így a szegregátumban lakó kisebbség, a település többi lakosához képest, az árvízi kockázatoknak való nagyobb kitettséget tapasztalhatja. Ez alapvetően befolyásolja az árvízi veszélyhelyzetekre adott lokális válaszokat. A 2010-es árvíz nem az első alkalom, amikor a telepet átszelő patak részben, vagy teljes egészében elárasztja. A 2000-es években legalább négyszer öntötte el a telepet, így nem egyszeri, hanem folyamatosan fennálló kockázati tényezőröl beszélhetünk. És bár a sajtó is több alkalommal beszámolt a boldvai árvíz hatásairól, annak etnikai vonulatáról és településrendezési hátteréröl, így nagyobb nyilvánosságot is kapott, azonban megfelelő válasz a mai napig nem született.

A kutatás megkezdése elött szükség volt a település részletes, mintavételezéshez szükséges térképét elkészíteni, mely a kutatás időpontjában elérhető legfrissebb, 2007-es Google felvétel alapján szerkesztettem Corel Draw program segítségével. A Google müholdfelvétel alapján, 2007-ben, a telep 132 házból állt. Az elkészített alaptérkép adatait terepbejáráson frissítettem, a 2010-es kettős áradás után hét ház lakhatatlanná roncsolódott és le kellett bontani, így a telep 2010 december 11-én, a felmérés időpontjában 125 házból állt (15. ábra).

A mintavétel 2010. december 10-11-én zajlott, melynek során a telep összes háztartását megkíséreltem két kutatótársam segítségével lekérdezni, azonban kilenc épület lakatlannak bizonyult. A telep teljes egészét érintő kérdöíves felmérés során 63 házban sikerült a lakosokkal kérdőívet kitöltetni, 53ban nem kívántak a kérdésre válaszolni. A válaszadók száma alapján a felmérés a házak (mely nem pontosan becsülhetően a háztartások számához közelít) 54,3\%-át lefedi. A háztartások számának meghatározása a mintaterület esetében módszertani problémát jelentett, hiszen a roma lakosságra jellemző, hogy egy házban akár több háztartás is él és a háztartások egymástól élesen nem feltétlenül különülnek el, hiszen a családok gyakran segítik egymást anyagilag a sajátos kulturális szokásoknak köszönhetően. A könnyebb érthetőség érdekében egy házat egy háztartásként értelmeztem.

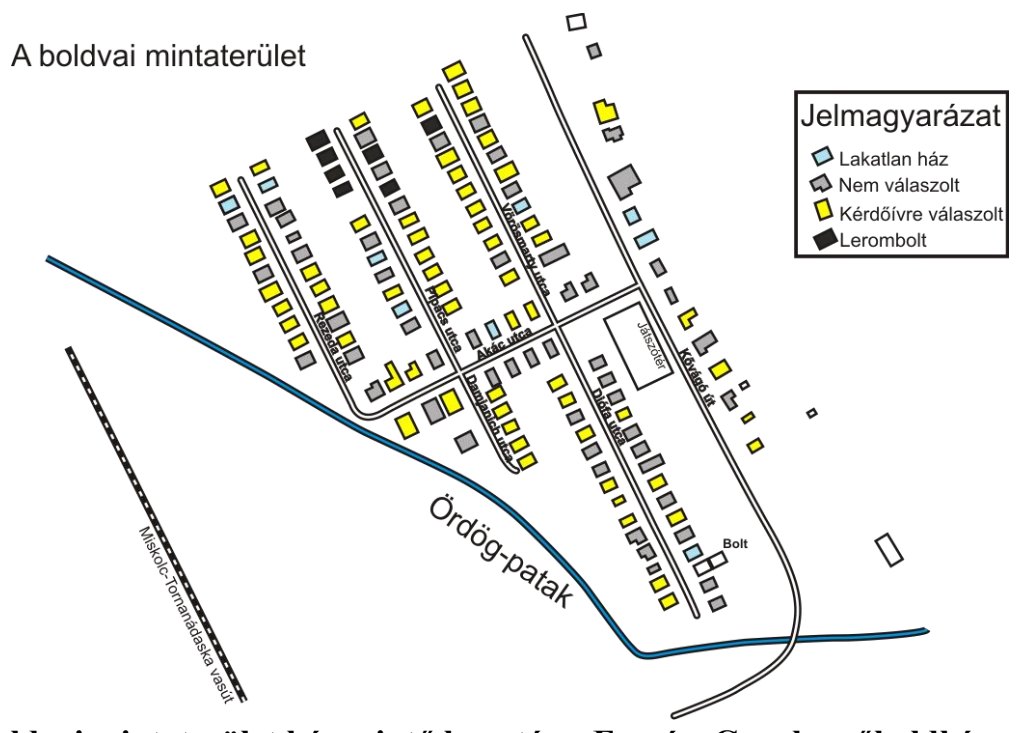

15. ábra: A boldvai mintaterület ház szintü leosztása. Forrás: Google műholdkép alapján saját szerkesztés

A telepen készült három félig strukturált interjú, kettő helyi lakossal, egy pedig a cigány kisebbségi önkormányzat vezetőjével, aki a telepen végig vezetve mutatta be a cigánytelep helyzetét, megvalósult fejlesztéseket és jövőbeli terveket, legfőbb problémákat. Az interjú kérdéseit két fö téma mentén füztem fel, az egyik a cigánytelep szegregált helyzetének bemutatására, az árvíz körülményeire, a másik pedig az árvizek utáni helyreállítási folyamatra vonatkozott. 


\subsubsection{A beregi Tiszamente és borsodi Sajó- és Bódvavölgy ${ }^{3}$ mintaterület módszertani jellemzői}

A beregi és borsodi esettanulmányok két, 2011-ben készült kérdőíves felmérés eredményeit dolgozzák fel. A mintaterületek kiválasztásának egyik indoka, mindkét terület nagyfokú árvízi kitettsége. Emellett mind a borsodi, mind a beregi térség az ország legelmaradottabb térségének tekinthető, társadalmi-gazdasági, infrastrukturális mutatói alapján is leghátrányosabb helyzetűek. Ráadásul mindkét mintaterület etnikai összetétele alapján az országos átlagnál magasabb roma népességet mutat (KoCSIS K. - KOVÁCs Z. 1991; PÉNZES J. ET AL. 2018) mely kapcsolatba hozható a kisebbségeket érintő környezeti igazságtalanságokkal.

Az első felmérés Szabolcs-Szatmár-Bereg megye országhatár és a Tisza által határolt beregi részen zajlott 2011. szeptember 29. és október 2. között, melyet a 2001-es Tiszai árvizek különösen súlyosan érintettek. 2001-ben a Szabolcs-Szatmár-Bereg megyét érintő árvízben 18 települést részben vagy egészben elöntött a Tisza, több ezer ház megsérült és/vagy megsemmisült (16. ábra). A gyors kormányzati beavatkozás következtében azonnali válasz érkezett a bajbajutottak megsegítésére, több település teljesen újjá épült egyentervek alapján, mely növelte az életszínvonalat, de konfliktusokhoz is vezetett.

A második felmérés a Borsod-Abaúj-Zemplén megyét érintő 2010-es Hernád, Sajó és Bódva folyókra kiterjedő árvizek által érintett településeken történt 2011. október 20-23. között. A kérdőíves felmérést egy, az árvízi érintettséget tartalmazó, TeIR adatokból felállított adatbázis vizsgálata előzte meg. A lakásállomány és az árvíz által megrongált és megsemmisített lakások aránya alapján határoztuk meg ${ }^{4}$ azokat a vizsgálandó településeket, ezeken a településeken belül pedig azokat az utcákat, melyeket legnagyobb mértékben érintett az árvíz. A mintába kerültek olyan utcák is, melyeket közvetlenül nem, vagy csak kis mértékben érintett az árvízi elöntés, ez adta a kontroll háztartásokat.

Mind a beregi, mind a borsodi kérdöív 76 kérdésből állt, mely a Boldvai kérdöívhez hasonlóan egyrészt az árvízzel való érintettségre, és az azt követő kompenzációs eljárásra, kártalanításra, másrészt a település társadalmi változásaira, harmadrészt pedig személyes adatokra fókuszált. A boldvai és az azt követő két vizsgálat kérdőíve azonban nem volt teljesen ugyanaz, mivel az első lekérdezések tapasztalatai alapján módosítottam a kérdések körén, megfogalmazásán, azok könnyebb érthetősége érdekében.

A mintavételi eljárás nem valószínűségi kiválasztással történt, a kérdőíves felmérés alapegysége ezúttal is a háztartás volt. A kérdezőbiztosok a településeken 2-3 fős csoportokat alkotva szisztematikusan járták végig az utcákat, és meghatározott mennyiségü kérdőívet (kvóta) kérdeztek le. Mindkét mintavétel esetében törekedtünk a lakosság legalább 1\%-át, és a háztartások legalább $10 \%$-át megkérdezni (5. táblázat). Edelény esetében ezek a feltételek nem teljesültek, azonban ennek oka, hogy az érintett népesség aránya kisebb volt, illetve a település népessége az összes vizsgált település közül a legnagyobb. Edelényben fókuszáltan a település azon területét kérdeztük le, melyet leginkább érintett az árvíz. Mivel a teljes településen az érintett háztartásoknak kisebb aránya, ezzel magyarázható a mintavételi stratégiától való eltérés. Szendrő tekintetében sem teljesült a 10\%-os mintavételi határ, itt szintén, az Edelényhez hasonló mintavételi stratégiát követtük, a település azon részét kérdeztük le nagyobb súllyal, melyet az árvíz nagyobb mértékben érintett. Szendrőn az önkormányzat árvízi kárrendezéssel kapcsolatos feladatok felelősével, illetve a segélyezésért felelős munkatársával készült félig strukturált interjú.

\footnotetext{
${ }^{3}$ A kutatás a TÁMOP-4.2.1/B- 09/1/KONV-2010-0005 azonosító számú, „Kutatóegyetemi Kiválósági Központ létrehozása a Szegedi Tudományegyetemen" címü projekt támogatásával készült. A kérdőíves felmérés a Szegedi Tudományegyetem Gazdaság- és Társadalomföldrajz Tanszék hallgatóinak közremüködésével valósult meg, akik kérdezőbiztosként segítettek a kérdőívek lekérdezésében.

${ }^{4}$ A TÁMOP kutatás kutatócsoportjában résztvevő kutató kollégák Dr. Bajmócy Péter és Dr. Boros Lajos segítségével
} 


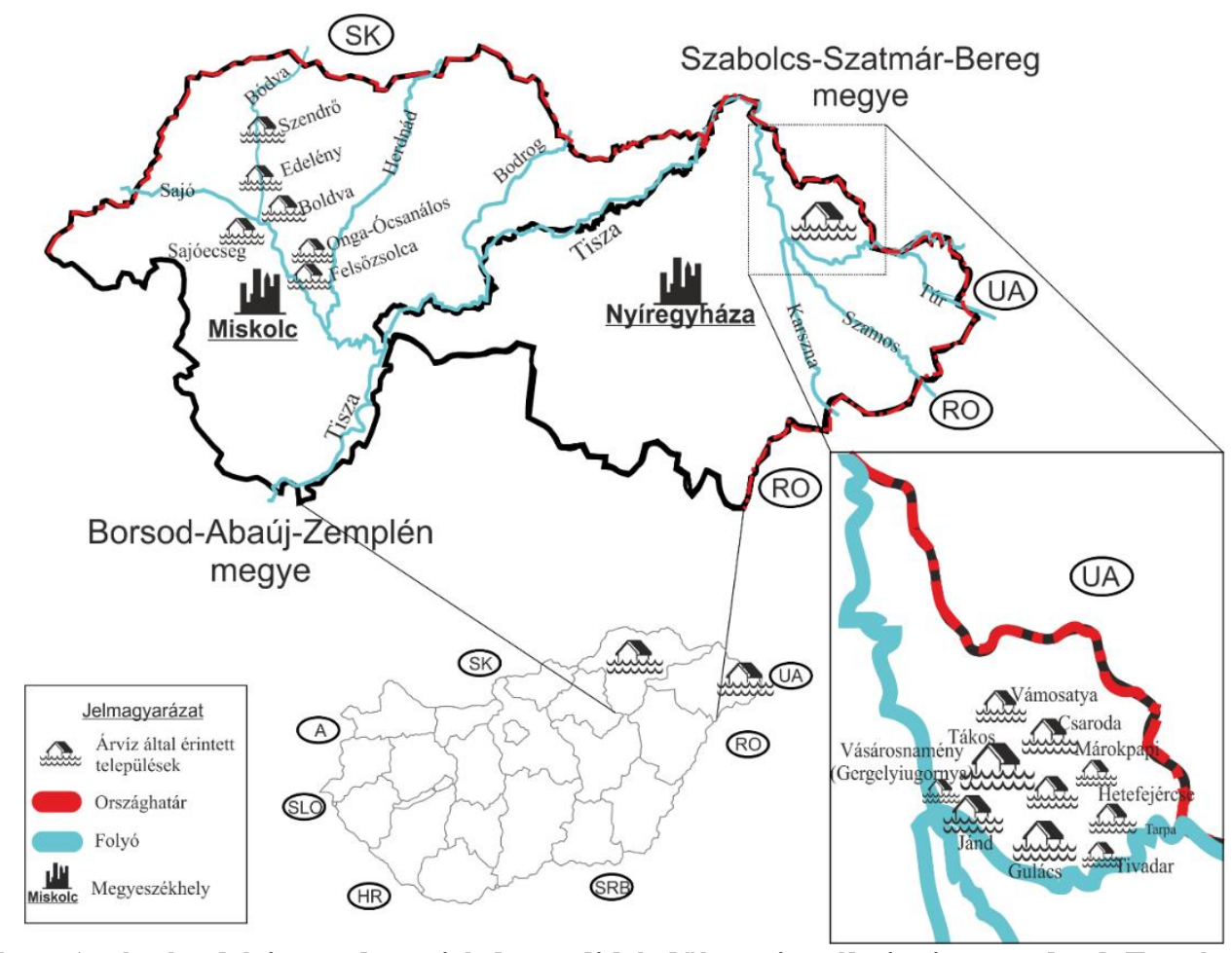

16. ábra: Az árvízzel érintett, beregi és borsodi kérdőíves vizsgálati mintaterületek Forrás: saját szerkesztés

5. táblázat: A beregi és borsodi mintaterület mintavételi adatai. Forrás: TeIR, kérdőíves felmérés, 2001es és 2011-es helységnévtár, saját szerkesztés

\begin{tabular}{|c|c|c|c|c|c|c|c|c|c|}
\hline 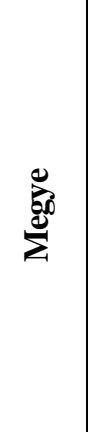 & 远 & 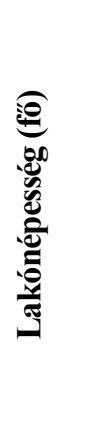 & 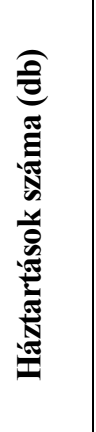 & 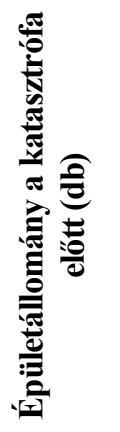 & 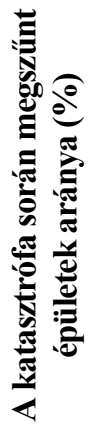 & 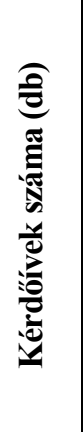 & 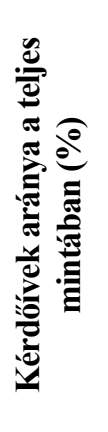 & 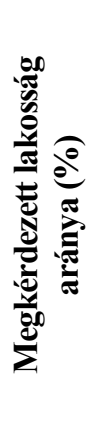 & 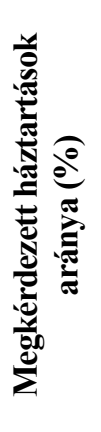 \\
\hline \multirow{9}{*}{ 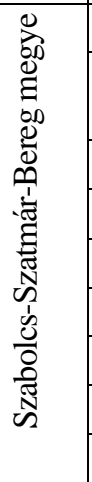 } & Csaroda & 548 & 217 & 334 & 30,8 & 42 & 4,9 & 7,7 & 19,4 \\
\hline & $\begin{array}{l}\text { Gergelyiugornya } \\
\text { (Vásárosnamény) }\end{array}$ & 1513 & n.a. & 668 & 11,9 & 63 & 7,4 & 4,2 & n.a. \\
\hline & Gulács & 874 & 326 & 558 & 41 & 61 & 7,1 & 7,0 & 18,7 \\
\hline & Hetefejércse & 330 & 99 & 190 & 24,2 & 17 & 2 & 5,2 & 17,2 \\
\hline & Jánd & 1007 & 294 & 416 & 38,9 & 42 & 4,9 & 4,2 & 14,3 \\
\hline & Tákos & 426 & 140 & 296 & 45,9 & 20 & 2,3 & 4,7 & 14,3 \\
\hline & Tarpa & 2138 & 840 & 1101 & 19,2 & 115 & 13,5 & 5,4 & 13,7 \\
\hline & Tivadar & 243 & 67 & 94 & 5,3 & 15 & 1,8 & 6,2 & 22,4 \\
\hline & Vámosatya & 592 & 242 & 324 & 21,9 & 36 & 4,2 & 6,1 & 14,9 \\
\hline \multirow{5}{*}{ 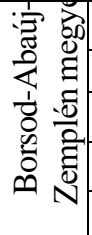 } & Edelény & 10096 & 3584 & 3575 & 0,8 & 94 & 11 & 0,9 & 2,6 \\
\hline & Felsőzsolca & 6716 & 2362 & 2358 & 7 & 229 & 26,8 & 3,4 & 9,7 \\
\hline & Ócsanálos (Onga) & 217 & n.a. & 103 & 5,8 & 19 & 2,2 & 8,8 & n.a. \\
\hline & Sajóecseg & 1056 & 426 & 440 & 1,4 & 57 & 6,7 & 5,4 & 13,4 \\
\hline & Szendrö & 4196 & 1455 & 1464 & 0,8 & 44 & 5,2 & 1,0 & 3,0 \\
\hline
\end{tabular}




\subsubsection{A belvízzel érintett területek jellemzői, Szeged-Baktó és Domaszék}

Az esetleges környezeti igazságtalansági helyzetek kialakulását hazánk árvíz melletti másik meghatározó környezeti problémájával, a belvízzel érintett területeken is vizsgáltam. A beépítettség növekedésével a csapadékvizek lefolyása és összegyülekezése is gyorsabbá vált az urbánus területeken, ezért ott, ahol korábban nem jelentkeztek belvízelöntéssel kapcsolatos problémák, ott is megjelentek (KozÁK P. 2003). Az 1990-2000-es években tapasztalható gyorsuló urban sprawl, főleg a városok szuburbán zónáiban (BAJMÓCY P. 2012; DöVÉNYIZ. - KOVÁCS Z. 1999; TIMÁR J. 1999; 2001) nem vette figyelembe a hidrogeológiai adottságokat, így több alföldi településen, pl. Domaszék, Kistelek, Mórahalom, Szeged belterületén is jelentős belvíz eredetü elöntések tapasztalhatók (BAUKÓ ET AL. 1981; KOZÁK P. 2003). A beépített területek kiterjedéséhez a vonalas infrastruktúra növekedése is hozzájárul, mely a belvízelöntés további fokozódásához vezet, hiszen az utak alapozása, töltése megakadályozza a felszíni lefolyást (BARTA K. ET AL 2011). Mindezeket a folyamatokat tovább súlyosbítja majd a klímaváltozás (BLANKA V. ET AL 2014).

A környezeti igazságosság szempontú kutatáshoz két mintaterületen, Domaszéken és SzegedBaktó városrészben kérdőíves felmérést végeztem ${ }^{5}$ a Szegedi Tudományegyetem Geográfus MSc hallgatói segítségével. A vizsgálatok mintaterültét a TeIR adatbázis belvízzel kapcsolatos adatai, illetve a 2000-2015-ös években megjelent, belvízzel kapcsolatos, az internetről elérhető sajtócikkek alapján választottam ki. A kereséshez a Szeged, belviz, Csongrád megye keresőszavakat használtam. A keresést a Google-ben kezdtem, majd az első öt találati oldal alapján leszükítettem a szegedma.hu, illetve a delmagyar.hu oldalakra a keresést, hiszen a legtöbb cikk ezekről az oldalakról származott. A Délmagyarország online felületén a felmérés időpontja elött összesen $68 \mathrm{db}$ cikk született a belvízröl, a szegedma.hu-n pedig $516 \mathrm{db}$. A cikkek tartalma alapján esett a szegedi Baktó, illetve a domaszéki mintaterületre a választás. A mintaterületek kiválasztásánál szerepet játszott Domaszék esetében a Szegedhez, mint nagyvároshoz való közelség, az egyéb projektekhez, valamint kutatásokhoz való kapcsolódás is ${ }^{6}$. A kiválasztott mintaterületek a Belvíz Info elnevezésü, GOP-1.1.1-2008 azonosítószámú projekt eredményeinek és a PÁLFAI, I. ET AL (2004) által szerkesztett Komplex Belvíz-veszélyeztetettségi Mutató által lehatárolt veszélyeztetettségi területeknek is megfelel. A felmérés ezen a kutatások eredményeit kívánja kiegészíteni a környezeti igazságosság szempontjából, társadalomföldrajzi megközelítésben. A két terület erősen-közepesen veszélyeztetett területnek minősül (17. ábra), a felmérések alapján (KoZÁK P. 2006; PÁLFAI I. 2011) az elmúlt évtizedekben ezeken a területeken a belvízelöntés száma meghaladta az ötöt (18. ábra).

A két kiválasztott mintavételi terület azért is különleges, mert földrajzilag közel találhatók egymáshoz, azonban jogállásuk és társadalmi folyamataik eltérőek. Míg Domaszék falusias jellegü, Szeged szuburbán települése, addig Baktó Szeged városrésze, a belső, közigazgatási határon belüli szuburbanizáció színtere. Mindkét vizsgált terület rendelkezik kiterjedt, korábban zártkerti besorolású területtel, melyek egy részén földművelés folyik, termőföldként hasznosul. Azonban nagyon sok olyan zártkerti ingatlan van, mely hétvégi házként és telekként is funkcionál, valamint egyre több állandó lakhatást szolgáló zártkerti ingatlan is létrejött az elmúlt évtizedekben, melyek azonban nem feltétlenül jogszerüen vannak telepítve. A hazai szuburbanizáció nem minden esetben követi a hagyományos szuburbanizációt, ahogyan arról DÖVÉNYI Z. - KOVÁCS Z. (1999) és TIMÁR J. (1999), VASÁRUS G. (2019) is beszámol, hiszen nem csak a jólét, de a szegénység is a közelebbi-távolabbi szuburbanizációs zónába való kiköltözést ösztönzi (19. ábra), mely ezeken a zártkerti településrészeken is tapasztalható folyamat.

\footnotetext{
${ }^{5}$ A vizsgálat a TÁMOP-4.2.1.D-15/1/KONV-2015-0002 azonosító számú, „Tudás-ipar igényeit kiszolgáló felsőoktatási szolgáltatások megalapozása a Dél-Alföldi régióban” címü projekt egyik alprojektjeként valósult meg.

${ }^{6}$ Hasonló kutatások valósultak meg a klímaváltozással, valamint a belvízzel kapcsolatosan a korábban említett TÁMOP-4.2.1/B-09/1/KONV-2010-0005 azonosító számú projekt keretében is, de föként természetföldrajzi megközelítésben.
} 


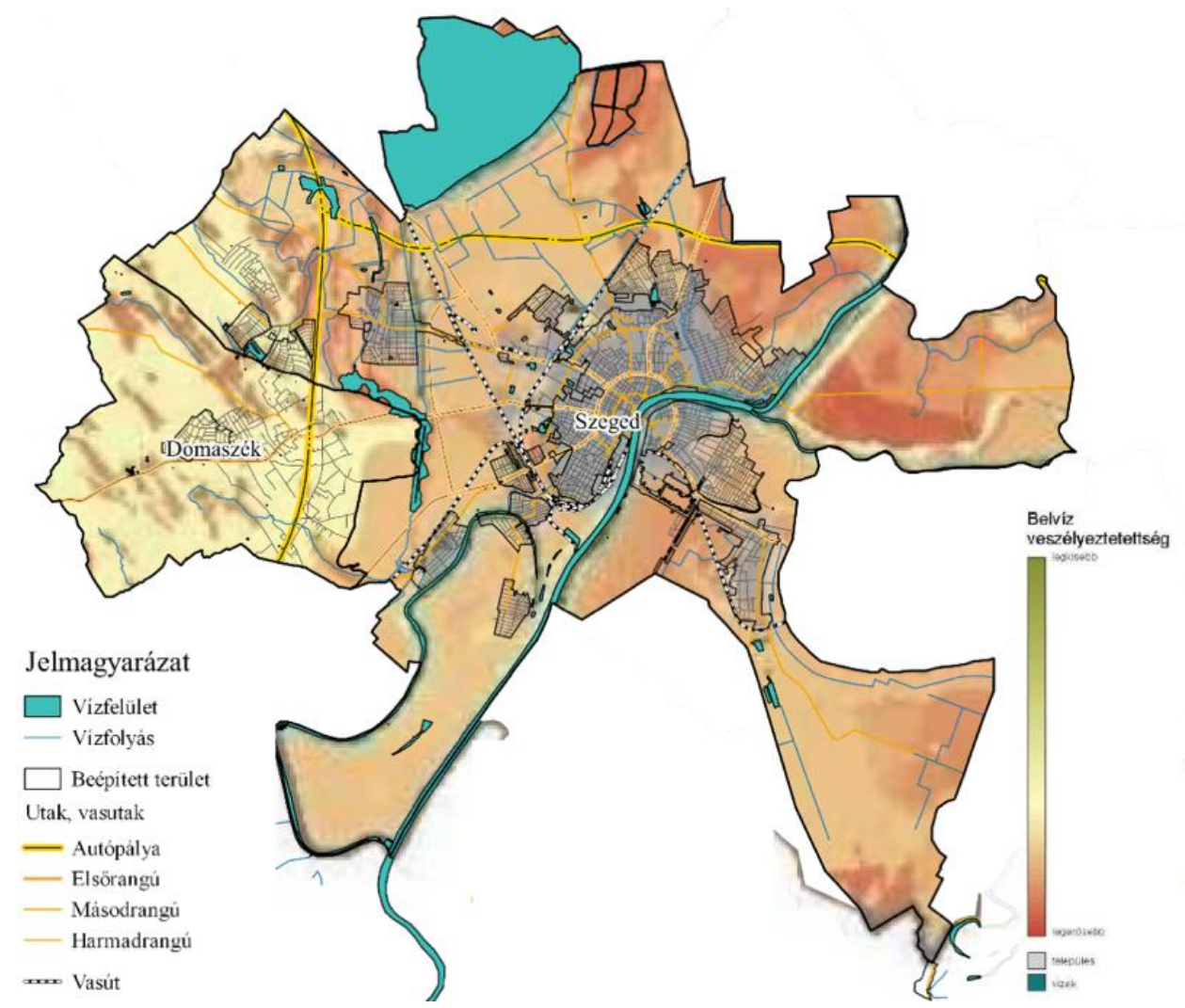

17. A belvízzel való veszélyeztetettség mértéke a kiválasztott mintaterületeken. Forrás: Körösparti et al. (2011) alapján saját szerkesztés

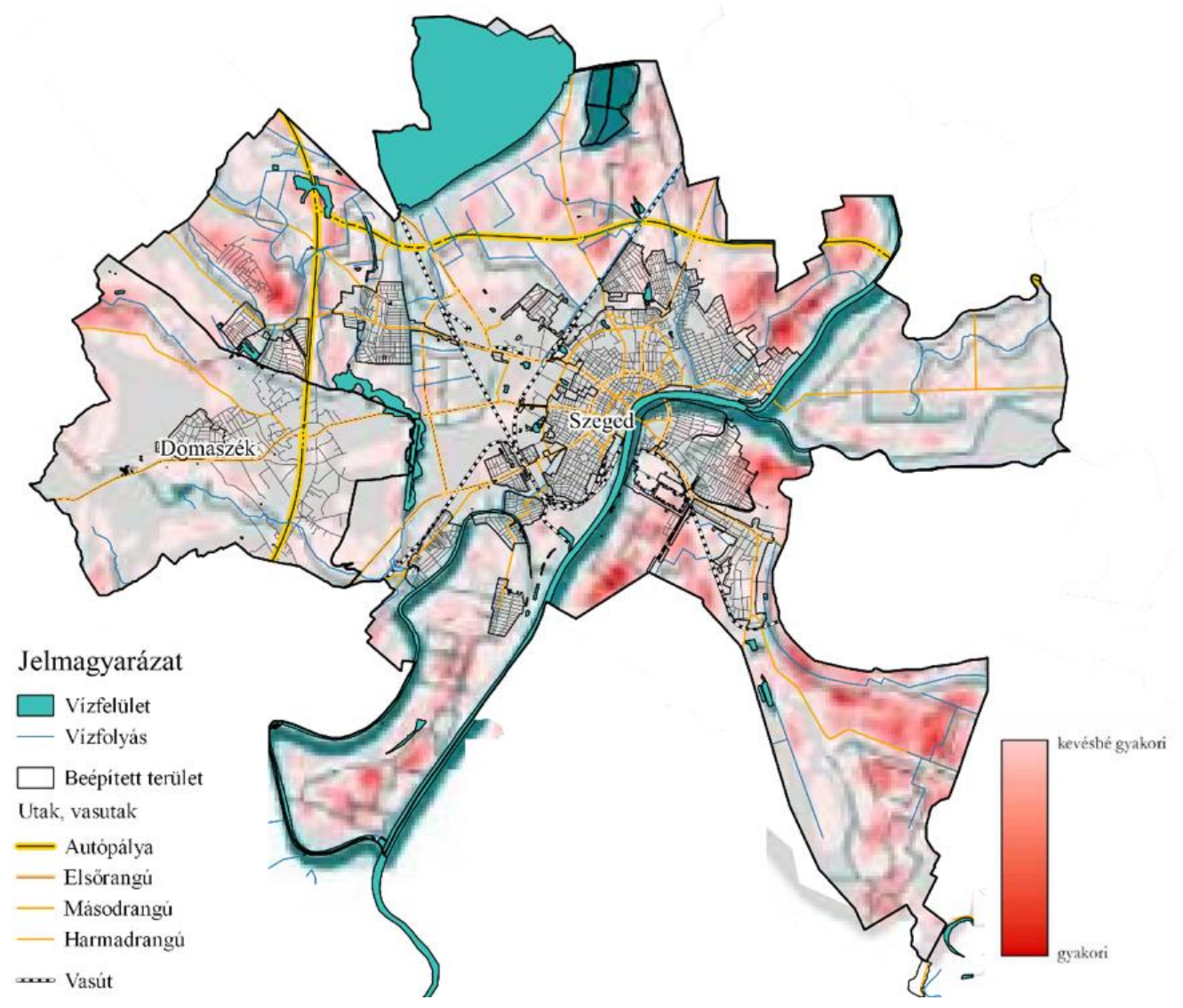

18. A belvízelöntés gyakorisága a kiválasztott mintaterületeken. Forrás: Körösparti et al. (2011) alapján saját szerkesztés 


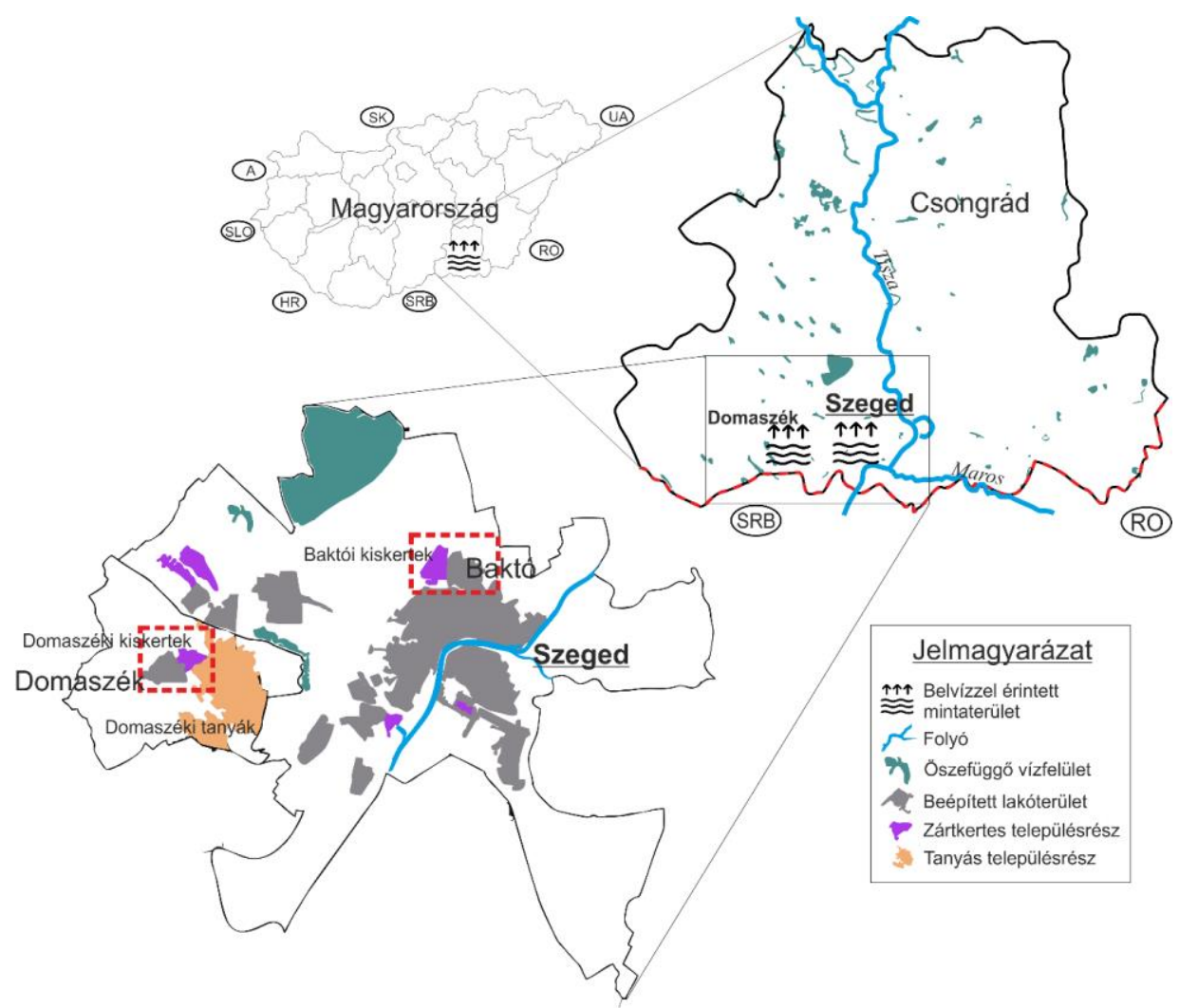

19. ábra: A belvízzel érintett mintaterületek elhelyezkedése és megosztott településszerkezeti jellege. Forrás: Saját szerkesztés

Domaszék alapvetően rossz vízgazdálkodású, homokos talajon alakult ki, az egykori tanyavilágból szerveződött településsé. A községben napjainkig is nagyarányú a külterületi népesség, kiknek körében gyakori az intenzív mezőgazdasági müvelés. Emellett a térség érintett Szeged szuburbanizációjának folyamatában is, melynek hatására fokozódott a település beépítettsége a bel- és külterületen, valamint a kiskertes zónában egyaránt ${ }^{7}$. Ezen természeti és társadalmi tényezők összessége elősegíti a belvizek kialakulását a településen és környékén. A község közvetlen közelében halad el az M5-ös autópálya is, ami szintén hatással van a felszíni és felszíni alatti vízáramlási folyamatokra (BARTA, K. -SZATMÁRI, J. 2010; BARTA, K. ET AL 2011; KUN, Á. ET AL. 2012), ezáltal belvíz kialakulását eredményezheti. Domaszék településfejlesztési koncepciójában is említésre kerül a település belvízzel való fokozott veszélyeztetettsége, mely leginkább az egykori zártkertes zónát és a külterületet érinti, a probléma megoldása fontos célként jelenik meg [1].

Szeged-Baktó többszörösen is megosztott, hiszen a városrész két markáns szerkezeti zónára tagolódik, a már említett zártkertes, külterületi és kertvárosias lakózónára. A belterületi rész sürün beépített, közmü-infrastruktúrával jól ellátott, burkolt utakkal, kiépített csatornarendszerrel, jó tömegközlekedési elérhetőséggel rendelkezik. Ezzel szemben a kiskertes terület közmüvekkel és közszolgáltatásokkal való ellátottsága rosszabb, a csapadék és szennyvízelvezetés jelenleg még nincs megoldva, ami maga után vonja a belvízzel való bizonyos fokú veszélyeztetettséget. Ez magában hordozza Baktó két területe közti feszültség lehetőségét és nagy társadalmi különbségeket is. További problémát jelent az életvitelszerüen itt élők növekvő száma, ami a településrész leértékelődésének veszélyét hordozza magában [2] (Szeged IVS, 2014).

A kérdőív alapját korábbi környezeti igazságtalansággal kapcsolatos kutatásokban használt kérdések adták (BorOS L. - NAGY GY. 2013; BOrOS L. - NAGY GY. 2014; NAGY GY. - JÁMBOR V. 2014; NAGY GY. - BoROS L. 2014), hogy az egyes eredmények összevethetősége biztosított legyen. A kérdések többsége a belvízzel való érintettségre, illetve ezen környezeti probléma megítélésére fókuszált, de a kérdőívben helyet kaptak az informáláshoz és az érdekérvényesítéshez kapcsolódó kérdések is, ame-

\footnotetext{
${ }^{7}$ Domaszék településfejlesztési koncepciója, 2012
} 
lyekből bizonyos mértékig következtetni lehet az információ, illetve az ahhoz való hozzáférés szerepére. A felmérés során összesen 250 személy került lekérdezésre a két mintaterületről, a Szegedi Tudományegyetem Gazdaság- és Társadalomföldrajz Tanszék MSc hallgatói közül kiválasztott kérdezöbiztosok segítségével. Egy háztartásból csak egy személyt kérdeztünk meg. A megkérdezettek kiválasztásához Domaszék esetében egyszerü véletlen mintavétel került alkalmazásra. A mintavétel randomszám-táblázat segítségével történt, amivel meghatároztuk a lekérdezés kezdőpontját, majd innen kiindulva a megadott terület utcáinak nagysága és háztartásainak száma alapján arányosan került lekérdezésre a megadott mennyiségü kérdőív. Abban az esetben, ha a kiválasztott háztartásban nem adtak választ, a mellette lévő házban kérdeztük le a kérdöívet.

Szeged-Baktón a településrész sajátos helyzete-belterület mellett kiskertes, nem minden esetben állandóan lakott részek - miatt nem alkottam konkrét mintavételi stratégiát. Az egyik fő szempont volt, hogy minél nagyobb területi lefedettséget biztosítsunk, vagyis a település legtöbb részéről rendelkezésre álljanak adatok. A másik fö szempont volt, hogy föként a potenciálisan belvízzel érintett utcákból adjanak választ a megkérdezettek, ezáltal bemutatva az esetleges környezeti igazságtalanságokat. A lekérdezendő utcák és háztartások lehatárolásához elsőként médiaelemzést végeztünk, amely során az interneten elérhető újságcikkeket alapul véve tártuk fel a belvízzel érintett utcákat. Ezt követően szisztematikusan végigjártuk a településrész összes utcáját belvízre utaló bizonyítékokat, „,nyomokat” keresve, a médiában nem megjelenő, de belvízzel veszélyeztetett területek felkutatásához. A terepbejárás során fotódokumentációt készítettünk, ami segítségünkre volt a lekérdezendő területek meghatározásához. Ahol belvizet tapasztaltunk, abban az utcában több kérdőívet töltettünk ki.

Domaszéken 167, Baktón 76 darab kérdöív került kitöltésre. Ez Domaszék esetében a háztartások 8,4\%-át, a lakosság megközelítőleg 3,4\%-át jelenti. Baktó esetében pontos statisztikai adatok nem állnak rendelkezésre a tényleges, állandó lakosok számának meghatározására, illetve az ott található lakások számára, mindemellett a Szeged Megyei Jogú Város Integrált Városfejlesztési Startégiája alapján az Északi Kertváros és Tápé városrész, mely tartalmazza Baktó kervárosias beépítésű lakóterületét és a Baktói kiskertek kertvárosias, falusias beépítésü hétvégi kertes területét összesen 4443 ingatlant számlál. Ebböl megközelítőleg 150 lakott ingatlan van a Baktói kiskertek területén, Baktó területén megközelítöleg 1500 lakott ingatlan áll, körülbelül 8500 fö népességgel. Így a mintavétel arányai pontosan nem meghatározhatóak, a háztartások nagyjából 4,6\%-át érinti.

\subsubsection{A vörösiszappal érintett Kolontár-Devecseri mintaterület felmérésének módszertana}

2010. október 4-én, Magyarországon korábban nem tapasztalt ipari katasztrófa történt az ajkai timföldgyár X. számú vörösiszap-tározójának gátszakadásakor. Ennek következtében 10 ember életét vesztette, több mint 700 hektár földterületet vált vörösiszappal elöntötté, 270 ház megrongálódott és több mint 40 milliárd forintos kárt keletkezett. A vörösiszap-katasztrófa, mint civilizációs, ezen belül is ipari katasztrófa egyedülálló a magyar történelemben. Vizsgálata azért is fontos, mert a természeti katasztrófákkal szemben az ipari katasztrófákból való „felépülési folyamat” (BOTYÁNSZKY A. 2012, P. 128) sokkal lassabb, és alapvetően változtatják meg a társadalmat és a gazdaságra is hosszútávú hatással lehetnek (DRABEK, T.E. 1986; EDELSTEIN, M.R. 1988), az egyik fontos tényező, hogy nem csak anyagi, de morális és erkölcsi szempontból is megrendül a térség helyzete (KÉMÉNCZY I. 1980). A természeti környezetre egyre nagyobb hatást gyakorló ipari tevékenység környezeti igazságtalanság kialakulását eredményezheti.

A katasztrófa hátterében több tényező is áll. A piaci érdekek, a jogi környezet hiányosságai illetve az emberi mulasztás - mind üzemeltetői, mind pedig lakossági részről - együtt vezetett a katasztrófához. A környezetvédelem jogisága hazánkban igen fiatalnak tekinthető, a jogharmonizációs folyamatok következtében a szubszidiaritás és a jóhiszemüség elve beépült a jogszabályokba (KERTÉSz J. 2012). Ennek értelmében a katasztrófák kezelésében, arra való felkészülésben a döntési szinteket minél közelebb helyezték el a helyi szervekhez, az állampolgárokhoz, ami nagyobb hatékonyságot eredményez (KERTÉSz J. 2012). Emellett vannak olyan feladatok, melyet csak az állam tud ellátni, annak hatalma és funkciói miatt. Az állam élet- és intézményvédelmi kötelezettsége keretében köteles a különböző katasztrófák, káresemények kezelésére, hatásainak mérséklésére, a mentés megszervezésére, a 
megfelelö jogi környezet kialakítására, azonban ez a védelem nem abszolút, mindenre kiterjedő (FARKAS Zs. - JUHÁSZZ. 2012) ezért szükséges bevonni az alacsonyabb szintü államigazgatási és közigazgatási szerveket a káresemények kezelésébe (FARKAS Zs. - JUHÁsZZ. 2012). A bevont szervek és szintek között jó kommunikációra és együttmüködésre van szükség, azonban hazánkban a decentralizációcentralizáció, a helyi és nemzeti szint közötti ellentétek nehezítik a konkrét és hatékony cselekvést (KERTÉSZ J. 2012). Ennek egyik következménye a vörösiszap katasztrófa.

Bár a vörösiszap katasztrófa előrelátható és megelőzhető lett volna (HAJNAL GY. 2008; KERTÉSZ J. 2012), sem a helyi, sem pedig az állami szinten nem számoltak ennek eshetőségével. A katasztrófavédelmi törvény szerint minden érintettet a hatóság von be a cselekvésbe, így a riasztáshoz elöször a hatóságot kell értesíteni, aki értesíti a további érintetteket (KERTÉSZ J. 2012). Bár Kolontárnak és Devecsernek volt katasztrófavédelmi terve arra, hogy mit kell tenni a tározó gátjának átszakadáskor, de nem volt riasztási lánc és nem tartottak gyakorlatokat sem, így a katasztrófa bekövetkezése utáni egy óra, mely a kritikus beavatkozás és az életek mentését szolgálta volna, a szervek közötti kommunikációs nehézségek, illetve a hatáskörök tisztázatlansága, valamint az adekvát cselekvés hiánya miatt, szinte tétlenül telt (KERTÉSZ J 2012).

A kommunikáció hiányára példaként szolgálhat, hogy például a sajátos építményfajták közül kikerültek egy korábbi jogszabálymódosítás nyomán a környezetvédelmi szempontból speciális építmények (mint például a zagytározók), tehát ennek telepítésének, építési engedélyeztetésének és ellenörzésének folyamatában a területileg illetékes jegyző volt, aki felelt. Azonban a jegyző megfelelő szakmai háttér nélkül nem tudja megfelelöen gyakorolni hatáskörét ezen épületek esetében (KAPRINAY E. 2012). Ráadásul a szabályozásban a tározókra vonatkozóan nem volt egyértelmü besorolás, így a jegyző sajátos építményfajtának minősítve azokat hatáskör hiányt állapított meg, míg a környezetvédelmi, természetvédelmi és vízügyi felügyelőség nem veszélyes hulladék tárolására alkalmas építményként definiálta az építményt, így azt általános - a jegyzőhöz tartozó - építésügyi hatósági eljárás keretében kívánta ellenőriztetni (KAPRINAY E. 2012). Kialakult egy negatív hatásköri összeütközés (HIDVÉGINÉ ERDÉLYI E. 2010), melynek feloldásában egyik fél sem volt érdekelt. A katasztrófa által érintett X-es számú kazetta kivitelezési, üzemeltetési, tervezési hiányosságait is megállapították a perben.

A helyzetet bonyolította, hogy a vörösiszap, mint hulladék minősítése sem az Európai Unió, sem pedig hazánk jogi szabályozásában nem volt egyértelmü a katasztrófa bekövetkezésekor, hiszen sem az Európai Hulladék Katalógus, sem pedig a hulladékok jegyzékéröl szóló 16/2001 KöM rendelet nem sorolta a veszélyes hulladékok kategóriájába (KAPRINAY E. 2012). Ennek oka, hogy alacsony sugárzási szintje és nehézfém-tartalma van, azonban erősen lúgos kémhatású, melyet nem vesz figyelembe a jogszabály. A vörösiszap mint hulladék a magyar szabályok szerint besorolható veszélyes hulladék kategóriájába, azonban ennek megállapítását a hulladék termelöje végzi. Ennek hiányában a besorolást a környezetvédelmi, természetvédelmi és vízügyi felügyelöség volt köteles megtenni. A felügyelöség 2006-ban elfogadta a MAL Zrt. általi minősítést és nem veszélyes hulladék lerakására és kezelésére kapott környezethasználati engedélyt (KAPRINAY E. 2012). Ennek hátterében anyagi megfontolások is állnak, hiszen a veszélyes hulladék kezelése és semlegesítése a nem veszélyes hulladékokhoz képest sokkal költségesebb. Mind a Katasztrófavédelemröl szóló törvény, mind a veszélyes anyagokkal kapcsolatos súlyos balesetek elleni védekezésről szóló kormányrendelet alapján az üzem nem minősült veszélyes ipari üzemnek (NAGY É. 2012). A katasztrófa előtt a MAL Zrt. nem a legjobb elérhető technológiát alkalmazta a hulladék kezelésére, hiszen a korábbi csurgalékvizes technológiáról való átállás a száraz ülepítésre szintén igen költséges lett volna. A katasztrófa után a cég átállt az említett száraz lerakásos technológiára (KAPRINAY E. 2012).

De nem csak a jogszabályi háttér tisztázatlansága segített hozzá a katasztrófa bekövetkezéséhez, hanem az emberi mulasztás is. Az építménnyel kapcsolatos ellenőrzések többször elmaradtak (JÁVOR B. 2011), illetve az azokat véleményező civileket nem vették komolyan, érveiket nem vették figyelembe. Az érintettek tehát a veszélyhelyzet fennállása ellenére nem avatkoztak be a katasztrófához vezetö folyamatba, és nem akadályozták meg annak bekövetkeztét sem. Mindemellett a lakosság egységes fellépése is hiányzott a már régóta tapasztalható környezetszennyezés (szivárgó tározó, vöröses színü patak) ellen. 
A katasztrófa bekövetkezése után a Kormány létrehozta a Magyar Kármentő Alapot, ennek élén a Kármentő Bizottság állt (252/2010 Korm. rend.), illetve a Kormányzati Koordinációs Bizottság vezetésével cselekvési tervet dolgoztak ki. A katasztrófát követően megindult a terület kármentesítése és az újjáéptés is. Ennek folyamata azonban több oldalról vitatható.

A kialakult helyzet után a felelősök keresése elindult, több évnyi pereskedés után a Veszprémi Törvényszék első fokon büncselekmény hiányában felmentette a vörösiszapper összes vádlottját a halált okozó gondatlan közveszélyokozás vétsége, a gondatlanságból elkövetett környezet- és természetkárosítás, továbbá a hulladékgazdálkodás rendje megsértésének vádja alól 2016. január 28-án. Ezt az ítéletet megtámadták, a vörösiszapper másodfokú tárgyalása 2017. január 23-án kezdődött a Győri Törvényszéken, 2019. február 4-én ítélet is született az ügyben a megismételt elsőfokú eljárás keretén belül [3]. A felelősség kérdése azért is érdekes, mert a katasztrófakor hatályos gazdasági társaságokról szóló törvény szerint a jogi személyiséggel rendelkezö társaságok tagjai nem tartoznak felelösséggel (AUER Á. 2012).

A tanulmány elkészítéséhez a vörösiszap által legjobban érintett három településen (20. ábra) 150 lakosnak tettünk fel a katasztrófával és az ahhoz kapcsolódó kártérítési és újjáépítési folyamattal kapcsolatos kérdéseket.

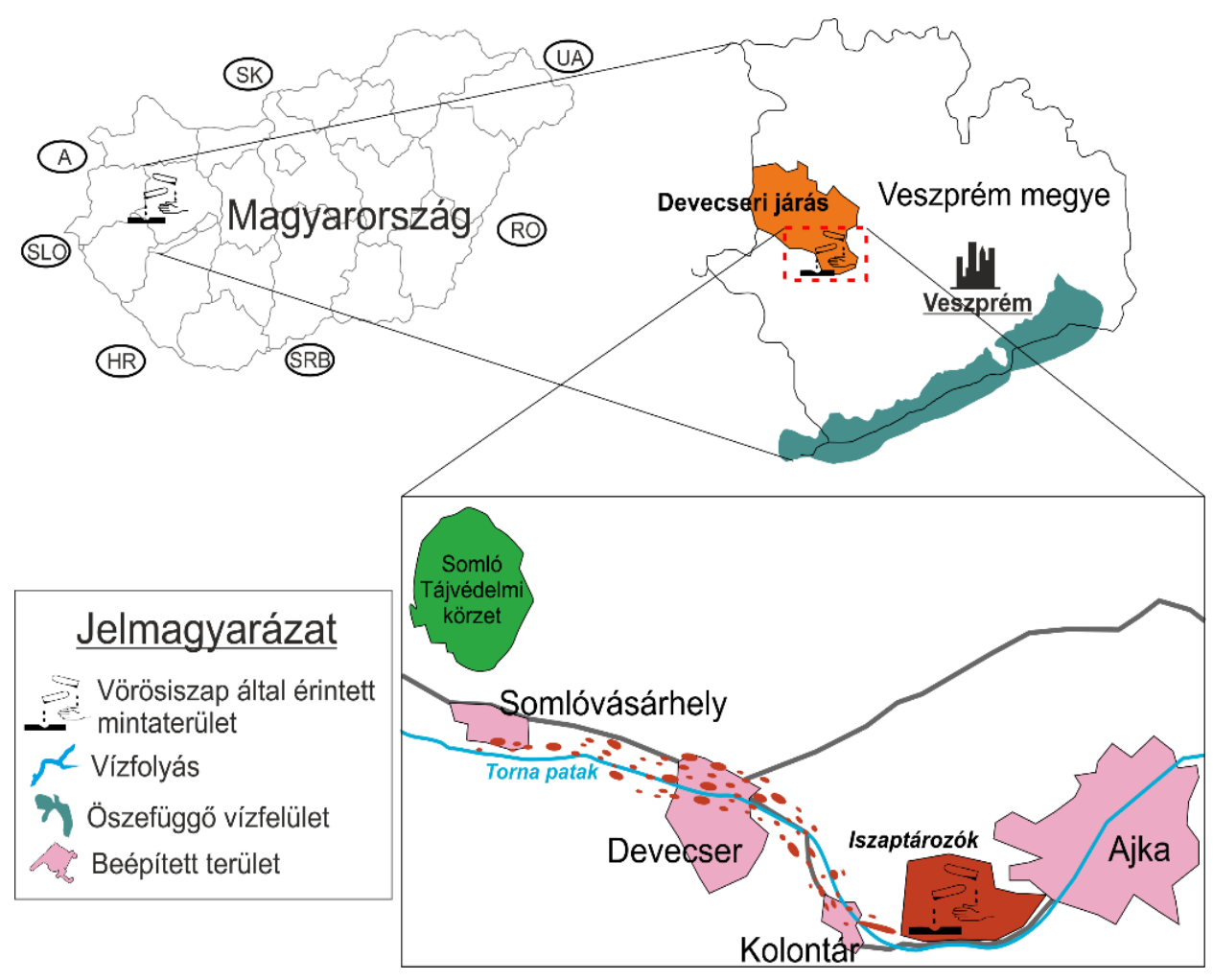

20. ábra: A vörösiszap-katasztrófa által érintett mintaterület elhelyezkedése Forrás: saját szerkesztés

A kérdőívezés 2014. február 28. és 2014. március 01. között zajlott, véletlenszám-táblázat segítségével, egyszerü véletlen mintaválasztási módszerrel. A kérdezőbiztosok a Szegedi Tudományegyetem Geográfus alap- és mesterszakos hallgatói voltak. Az egyes településeken a kérdőívek számát részben a népességszám és a katasztrófa általi érintettségtől függően alakítottuk ki (6. táblázat), így Devecseren és Kolontáron arányaiban több kérdöívet töltettünk ki, mint Somlóvásárhelyen. A lekérdezett kérdőívek közül végül 147 volt értékelhetö. A megkérdezettek 54,4\%-át közvetlenül is érintette a katasztrófa (6. táblázat). A következő fejezetben az empirikus eredményeimet mutatom be az elméleti keretekben meghatározott szempontok alapján. 
6. táblázat: A vörösiszap által érintett települések népessége, háztartásainak száma és a kérdő́vek települések szerinti megoszlása. Forrás: TeIR, kérdőíves felmérés, saját számítás alapján saját szerkesztés

\begin{tabular}{|c|c|c|c|}
\hline 2013. év & Devecser & Kolontár & Somlóvásárhely \\
\hline Lakónépesség (fö) & 4427 & 690 & 1153 \\
\hline Háztartások száma (db) & 1692 & 259 & 441 \\
\hline Épületállomány 2009 (db) & 1883 & 265 & 453 \\
\hline Megszünt épületek aránya (2010-11) (\%) & $11 \%$ & $10 \%$ & $0 \%$ \\
\hline Kérdőívek száma (db) & 93 & 39 & 15 \\
\hline A kérdőívek aránya (\%) & 63 & 27 & 10 \\
\hline Megkérdezett lakosság aránya (\%) & 2,10 & 5,65 & 1,30 \\
\hline Megkérdezett háztartások aránya (\%) & 5,50 & 15,06 & 3,40 \\
\hline
\end{tabular}

\subsection{A kutatás során vizsgált mintaterületek környezeti igazságosság-szempontú összeha- sonlító vizsgálatának eredményei}

A hátrányos, igazságtalan és méltánytalan helyzetek számos esetben pusztán objektív mutatókkal nem bizonyíthatók. A környezeti igazságosság vizsgálatok ezért az elméleti részben is említett módon nem pusztán az igazságtalanság tetten érhető bizonyítékait, hanem az azokat előidéző folyamatokat és az érintettek igazságtalanság-észlelését is vizsgálják. Az elmúlt években mind az árvizekkel, mind a vörösiszappal és a belvizekkel kapcsolatban is megjelent számos olyan tanulmány, sajtóhír, melyek az adott katasztrófák által érintett lakosság elégedetlenségéröl számolnak be. Ezeknek azonos szempontú, a környezeti igazságosság elvrendszerét felhasználó összehasonlító elemzése még nem született meg.

\subsubsection{A félelem-érzet hasonlóságai és különbségei a mintaterületeken}

Elsődlegesen az eseménytől és annak hatásaitól való félelem-érzetet vizsgálom meg. Általánosságban, a katasztrófával sújtott területek lakossága valamilyen formában tart egy esetleges újbóli bekövetkezéstől, vagy mindennapjaiban érzi az adott eseményt követő negatív externáliáit. A félelem-érzet és a katasztrófákkal kapcsolatos fenntartások feltárására fökomponens analízist végeztem. Az egyes mintavételek és a területek különbözösége miatt azonban a fökomponensek tartalma részben eltér. A belvizes és a vörösiszappal érintett mintaterületeken csupán egy állításban. Összesen 7 illetve 6 állítás ordinális válaszait vetettem össze a fökomponens-analízis korábban kifejtett, a rangsor-jellegü adatok elemzésére érvényes szabályainak megfelelően. A fökomponensben olyan alkomponensek kaptak helyet, mint a saját, valamint a család egészégének a veszélyérzete, a lakókörnyezet degradációjától való félelem (7. táblázat).

7. táblázat: A belvízzel és vörösiszappal érintett területek félelem-főkomponensének összetevői illetve azok legfőbb főkomponenst képző mutatói. Forrás: kérdőíves felmérés alapján saját szerkesztés

\begin{tabular}{|c|c|c|c|c|c|}
\hline & Mintaterület & \multicolumn{2}{|c|}{ Vörösiszap } & \multicolumn{2}{|c|}{ Belvíz } \\
\hline \multicolumn{2}{|r|}{ Állítások } & 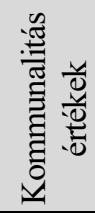 & 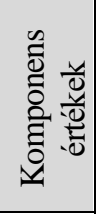 & 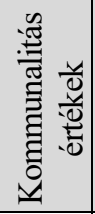 & 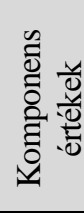 \\
\hline 1. & Aggódom saját és családom egészségi állapotáért & 0,680 & 0,824 & 0,734 & 0,539 \\
\hline 2. & Jelenleg féltem házam fizikai épségét & 0,627 & 0,792 & 0,616 & 0,379 \\
\hline 3. & Veszélyesebb itt élni, mint máshol & 0,617 & 0,786 & 0,581 & 0,337 \\
\hline 4. & Ismeröseim veszélyesnek tartják lakhelyem & 0,463 & 0,680 & 0,624 & 0,389 \\
\hline 5. & A belvíz megkeseríti az életünket & - & - & 0,783 & 0,613 \\
\hline 6. & Félek, hogy saját és családom egészsége veszélyben van & 0,531 & 0,729 & 0,820 & 0,672 \\
\hline 7. & Sokkal rosszabbul jártam, mint bárki a környéken & 0,235 & 0,485 & 0,714 & 0,509 \\
\hline & Variancia & \multicolumn{2}{|c|}{$49,2 \%$} & \multicolumn{2}{|c|}{$52,5 \%$} \\
\hline
\end{tabular}

Az árvizes területek esetében a más jellegü és időben eltérő mintavétel miatt a fökomponens az árvíz, mint a térséget fenyegető tényező és az emberek kiszolgáltatottsága került középpontba. 
A félelem főkomponensének megerősítése és elutasítottsága minden esetben mérhető a katasztrófával való érintettek és nem érintettek körében. Ezek alapján általánosan is beigazolódik, hogy mind a három típusú mintaterületen az érintettek szignifikánsan megerősítik a félelem főkomponensét, míg azok akiket közvetetten érintett a katasztrófa, azok elutasítják azt (8. táblázat). Mindez igazolja azon felvetéseket, hogy a bekövetkező környezeti igazságtalanság azok körében, akik közvetetten érintettek, hosszabb távon, akár 10-15 év távlatában is félthetik életüket, értékeiket. Mindez hosszútávon rányomhatja bélyegét az egyének mentális jóllétére és közvetetten jólétére is. Megfigyelhető, hogy a három mintaterület közül a belvizes mintaterületen élök válaszai különültek el a leginkább. Ez azzal magyarázható, hogy a belvíz, mint természeti jelenség - bár hatalmas vagyoni károkat okozhat a mezőgazdasági terményekben, épített környezetben - mégsem annyira kockázatos és veszélyes az emberéletre de egészségre gyakorolt negatív hatásai is föként csak közvetetten, több egyéb tényezővel együttesen jelenhetnek meg, ellenben a másik két katasztrófával. Így azok, akiket nem érintett a belvíz a vizsgált településeken, azok a belvíz problematikáját is sokkal kisebbnek értékelik, mint azon mintaterületek esetében, ahol a „nem érintettek” egyéni biztonsága sokszor csak a véletlen szerencse müve. Így ezekben az esetekben az árvízzel vagy vörösiszappal közvetlenül nem érintett válaszadókban a félelem érzet is nagyobb. A legkisebb mértékben a vörösiszap-katasztrófa által sújtott területen figyelhető meg a válaszok különbözősége, azonban a t-érték ebben az esetben is szignifikánsan bizonyítja a két válaszadói csoport különbségét. Ennek hátterében húzódhat, hogy bár a felmérés a katasztrófa után közel két és fél évvel készült a hosszasan elhúzódó környezeti remediációs folyamatok, illetve a jogi procedúra és felelős-keresés napjainkig tartó témát szolgáltat a településeken lakóknak.

\section{8. táblázat: a katasztrófában való érintettség és a félelem kapcsolata a vizsgált mintaterületeken}

\begin{tabular}{|c|c|l|c|c|c|}
\hline \multicolumn{3}{|l|}{$\begin{array}{l}\text { Érte-e árvíz vagy belvíz kár, vörösiszap-katasztrófa az } \\
\text { Ön háztartását az elmúlt évtizedben? }\end{array}$} & Elemszám & \multirow{2}{*}{ Átlag } & \multirow{2}{*}{ t-érték } \\
\hline \multirow{4}{*}{$\begin{array}{c}\text { Félelem } \\
\text { fökompo- } \\
\text { nense }\end{array}$} & Árvizes minteterület & Igen & 639 &, 0648485 & \multirow{2}{*}{3,965} \\
\cline { 2 - 5 } & Nem & 138 &,- 3040411 & \\
\cline { 2 - 5 } & \begin{tabular}{c} 
Belvizes mintaterület \\
\cline { 2 - 5 }
\end{tabular} & Igen & 83 &, 6181184 & \multirow{2}{*}{8,147} \\
\cline { 2 - 5 } & $\begin{array}{c}\text { Vörösiszappal érintett mintaterü- } \\
\text { let }\end{array}$ & Igen & 78 &,- 3772340 & \multirow{2}{*}{1,911} \\
\cline { 2 - 5 } & Nem & 57 &,- 1905333 & \\
\hline
\end{tabular}

Azonban a félelem fökomponensének mintaterületen belül is megfigyelhetö bizonyos mintázata. Azokon a településeken, ahol az érintettség nagyobb volt, hiszen nagyobb arányban találhatunk megrongálódott vagy megsemmisült épületeket, a fơkomponens megerősítését várnánk, azonban ez nem minden esetben teljesül.

A belvízzel érintett vizsgálati területek az érintettség meghatározásában némiképp eltérnek, hiszen a belvíz miatt megszünt vagy megrongálódott regisztrált lakóingatlanok száma elenyésző. Így ebben az esetben a korábbi kutatások eredményeire és empirikus valamint kvalitatív médiaelemzési módszerekre hagyatkozva állapítható meg a nagyobb érintettség. Mivel az árvizes területek több települést érintenek, az egyszerüség és a könnyebb összehasonlítás kedvéért beregi és borsodi csoportra különítettem el a településeket.

Az eredmények azt mutatják, hogy míg a belvizes települések esetében a rurális jellegü, de az urban-rural fringe zónában elhelyezkedő Domaszék válaszadói a félelem fökomponensét megerősítették, a Szeged részét képező, városias karakterü Baktó esetében elutasítják. Több esetben a belvizes területeken élők említették, hogy a belvíz egy természetes folyamat, és már hozzászoktak, így bár anyagi kár keletkezik, nem tartanak annak kialakulásától, sem egészségügyi hatásaitól. Az árvizes területek esetében a két terület közti különbség mérséklödik, míg a beregi településeken választ adók elutasítják az árvízzel kapcsolatos félelemérzetet, addig a borsodi válaszadók megerősítik azt (9. táblázat).

Azonban mind a megerősítés, mind az elutasítás mértéke igen kismértékü. Ez egyrészt a mintába bekerült települések eltérő válaszainak egymást kioltó hatásának tudható be. Másrészt kifejezetten fontossá válik, hogy a beregi mintaterületet a 2000-es évek elején érte árvíz, így a mintavétel idején (2011- 
ben) már több, mint 10 év telt el az árvíz óta, így annak az emlékei sokkal halványabban éltek az emberekben. Míg a borsodi mintaterület felmérési időpontja csak egy évvel az árvíz után volt. Így a szakirodalomban is leírt időtényező fontossága igazolódik a katasztrófa helyzetek érzékelésében és utólagos értékelésében is.

A legerősebben Tivadaron és Csarodán utasították el a félelem fökomponensét, mindkettő beregi település. Tivadar esetében a félelem fökomponenesének elutasítását okozhatja, hogy 2001-ben Tarpa és Tivadar közt szakadt át a gát, így az ár levonulása után a kárrendezés keretén belül az árvízi védmüvek teljesen megújultak. A magas elutasítás értéke lehet továbbá, hogy a település elemszáma alacsony. A leginkább Onga-Ócsanálos, Szendrő, Tákos és Hetefejércse településeken erősítették meg a félelem főkomponensét. A települések közül előbbi kettő Borsodból, utóbbi kettő pedig Beregből való. Így látható, hogy a félelem komponenesének megerösítése nem köthető egyértelmüen mintaterülethez és az idöhöz. Az említett települések közül Tákos volt az, mely szinte teljes mértékben elpusztult, majd újjáépült (9.1.2. Melléklet).

\section{9. táblázat: a félelem főkomponensének területi eltérései és azok tényleges eltérése az árvizes és belvizes mintaterületeken}

\begin{tabular}{|c|c|c|c|c|}
\hline & Település/Terület & $\begin{array}{l}\text { Elem- } \\
\text { szám }\end{array}$ & Átlag & t-érték \\
\hline \multirow{4}{*}{$\begin{array}{l}\text { Félelem fö- } \\
\text { komponense }\end{array}$} & Domaszék & 144 & 0,160 & \multirow{2}{*}{3,354} \\
\hline & Baktó & 75 & $-0,307$ & \\
\hline & Bereg & 332 & $-0,090$ & \multirow{2}{*}{2,443} \\
\hline & Borsod & 408 & 0,090 & \\
\hline
\end{tabular}

A vörösiszappal érintett mintaterület esetében a vizsgált három település közül Kolontár és Somlóvásárhely megkérdezett lakosai bár ellentétes irányú válaszokat adtak a t-próba alapján, azonban a különbségük nem szignifikáns, vagyis inkább hasonlítanak a települési válaszok, mint különböznek. Míg az említett két település elutasította, addig Devecser megerősítette a félelem fökomponensét (10. táblázat). Míg Somlóvásárhely település esetében a tényleges fizikai károk kismértéküek voltak, addig mind Devecser és Kolontár esetében emberéletet követelt és több, mint 300 ház teljes megsemmisülését okozta a vörösiszap. Így feltételezhető lenne, hogy e két település válaszadói hasonlóan vélekednek a fökomponensről. Ennek ellenére a felmérés alatt is tapasztalt társadalmi folyamatok igazolják a Kolontáron adott válaszok értékeit, hiszen a vörösiszap katasztrófa utáni mobilitási folyamatok nagyban megváltoztatták többek közt a településen élők összetételét is, az érintettek közül sokan elhagyták a települést és elköltöztek. A megkérdezettek közül többen arról számoltak be, hogy azok, akik tartottak egy esetleges újbóli katasztrófától már elköltöztek. Így a településen azok maradtak, akik kevésbé félnek a vörösiszaptól.

Devecser esetében a település patak menti házait egytöl-egyik elbontották, a lakosokat a város egy magasabban fekvő pontján épített lakóparban helyezték el (Melléklet 9.1.10, 9.1.11.). Az érintett lakosok többsége tehát nem feltétlenül költözött el a településről, ráadásul többen a katasztrófa után Kolontárról is a biztonságosabbnak vélt Devecserre költöztek. A félelem fökomponenesét Devecseren sokkal kisebb mértékben erősítik meg, mint utasítják el azt Somlóvásárhelyen vagy Kolontáron. Ennek ellenére mind a kolontári, mind a somlóvásárhelyi válaszadókkal szemben szignifikánsan eltér a devecseri válaszadók válasza. 
10. táblázat: a vörösiszap-katasztrófa által érintett települések félelem-főkomponens értékei. Forrás: kérdőíves felmérés alapján saját számítás

\begin{tabular}{|c||l|c|c|c||c|c|}
\cline { 2 - 7 } \multicolumn{1}{c|}{} & \multicolumn{5}{c||}{ t-értékek mátrixa } & \multicolumn{1}{c|}{} \\
\hline \multirow{3}{*}{$\begin{array}{c}\text { Félelem fö- } \\
\text { komponense }\end{array}$} & Települések & Somlóvásáhely & Kolontár & Devecser & Elemszám & Átlag \\
\cline { 2 - 8 } & Somlóvásárhely & -- & $-0,881$ & $-2,388$ & 14 &,- 4904601 \\
\cline { 2 - 8 } & Kolontár & $-0,881$ & -- & $-2,131$ & 37 &,- 2327141 \\
\cline { 2 - 8 } & Devecser & $-2,388$ & $-2,131$ & -- & 84 &, 1842484 \\
\hline
\end{tabular}

A félelem fökomponensének egyik meghatározó tényezője lehet Devecserben, hogy, míg a többi mintaterületen részben kiszámíthatatlan és ellenőrizhetetlen természeti tényezők idézik elő a katasztrófa-helyzeteket, ezzel szemben a vörösiszap katasztrófa civilizációs-katasztrófa jellegéből adódóan nagymértékben az emberi gondatlanságból eredeztethető. Bár a doktori dolgozat elkészítésekor már megszünt az ajkai timföldgyártás és a vörösiszapot veszélyes hulladékként új típusú, száraz deponálási módon tárolják, a tározók mindmáig az említett települések szomszédságában találhatók. Ezért érdemes feltárni, hogy a válaszadók körében a félelem fökomponensét mennyiben erösíti és gyengíti a tározó közelségének semleges/pozitív vagy negatív megítélése. A megkérdezettek számszerü többségét, 89 főt nem zavarja a tározó közelsége, míg 57 föt igen (11. táblázat). Azok a válaszadók, akiket zavar a tározó, szignifikánsan megerősítették a félelem fökomponensét, míg azok, akiket nem, elutasították azt. Annak érdekében, hogy a katasztrófával való direkt érintettség befolyásoló erejét mérjem, megvizsgáltam, hogy milyen mértékben utasítják el a fökomponenst az alapján, hogy zavarja-e őket a tározó közelsége vagy sem. Ezek alapján azok, akiket zavar a tározó, annak ellenére, hogy érintettek vagy sem, megerősítik a félelem fökomponensét. Ez az eredmény igazolja, hogy a környezeti igazságtalanságok érzékelése nem csupán az érintettség függvényei. A vélt vagy valós félelem egy adott környezeti tényezőtől is előidézhet méltánytalan és igazságtalan helyzeteket. Az érintett és nem érintett válaszadók között kismértékü a megerősítésben való eltérés, és azok, akiket nem érintett a katasztrófa közvetlenül nagyobb mértékben erősítették meg a félelem főkomponensét. Ennek oka lehet, hogy akik már megélték a katasztrófát, ismerik a következmények részleteit, így számukra az „ismeretlentől” való félelem kisebb mértékü.

11. táblázat: a félelem-főkomponens értékei a vörösiszap-tározó jelenléte és a katasztrófában való érintettség kereszttáblájában. Forrás: kérdőíves felmérés alapján saját számítás

\begin{tabular}{|l|c|c|c|c|c|}
\cline { 3 - 6 } \multicolumn{2}{c|}{} & \multicolumn{3}{|l|}{ Zavarja-e a vörösiszap-tározó közelsége? } \\
\cline { 3 - 6 } \multicolumn{2}{c|}{} & \multicolumn{2}{|c|}{ Igen } & \multicolumn{3}{c|}{ Nem } \\
\cline { 3 - 6 } & & Átlag & Elemszám & Átlag & Elemszám \\
\hline \multirow{2}{*}{ Érintette-ön közvetlenül a vörösiszap-katasztrófa } & Igen & 0,495 & 32 & $-0,124$ & 48 \\
\cline { 2 - 6 } & Nem & 0,572 & 25 & $-0,572$ & 41 \\
\hline
\end{tabular}

Azon válaszadók, akiket nem zavar a tározó közelsége és nem érintette őket a katasztrófa közvetlenül, azok majdnem olyan mértékben utasítják el a fökomponenst, mint az ellenkezö tábor. Akiket nem zavar a közelben található tároló, azonban érintett volt, sokkal kisebb mértékben utasítja el a félelem komponensét, nagyjából ötszörös a különbség. Több esetben a válaszadók azt említették, hogy kétszer ugyanott úgy sem lehet katasztrófa, ezért nem is tartanak tőle, valamint, hogy már gyermekkoruk óta a közelében élnek, így megszokták és nem érzik kockázatosnak a tározó jelenlétét.

A fentebbiek alátámasztására döntési fát készítettem a tározó közelség, a katasztrófával való érintettség és a költözési szándék változók félelem-főkomponenssel való kapcsolatának bemutatására. A döntési fa első elágazását a tározó jelenléte adta, mely után abban az esetben, ha a válaszadókat nem zavarta, a katasztrófa általi érintettségre kérdeztem rá (21. ábra) Azokat, akiket nem zavar a tározó jelenléte általánosságban a félelem főkomponensét elutasították attól függetlenül, hogy érintette-e őket a katasztrófa vagy sem. Az elutasítás mértékében van csak eltérés az érintettek és a nem érintettek közt, utóbbiak még erőteljesebben elutasítják a félelem főkomponensét. Azokat válaszadókat, akiket zavar a 
tározó közelsége, a költözési szándék befolyásolja elsődlegesen. Ha tervezi a költözést a válaszadó, ha nem, megerősíti a félelem főkomponensét, attól függetlenül, hogy érintette-e a vörösiszap katasztrófa vagy sem. Ebben az esetben is igazolódik, hogy azon válaszadók, akik közvetlenül érintettek voltak, de nem költöznének, sokkal kevésbé erösítik meg a fökomponenest, mint azok, akik közvetlenül nem voltak érintettek. Akik tervezik, hogy elköltöznek a településükröl, azok ha érintettek, ha nem közvetlenül megerösítik a félelem fökomponensét, mely szintén arra enged következtetni, hogy a vélt kockázat ugyanolyan félelmet kelthet és méltánytalan helyzetet teremthet, mint a tényleges kockázat a társadalom bizonyos csoportjaiban. Amennyiben a vizsgált mintaterületet települési szintekre bontjuk a korábban megfigyelt folyamatok igazolódnak.

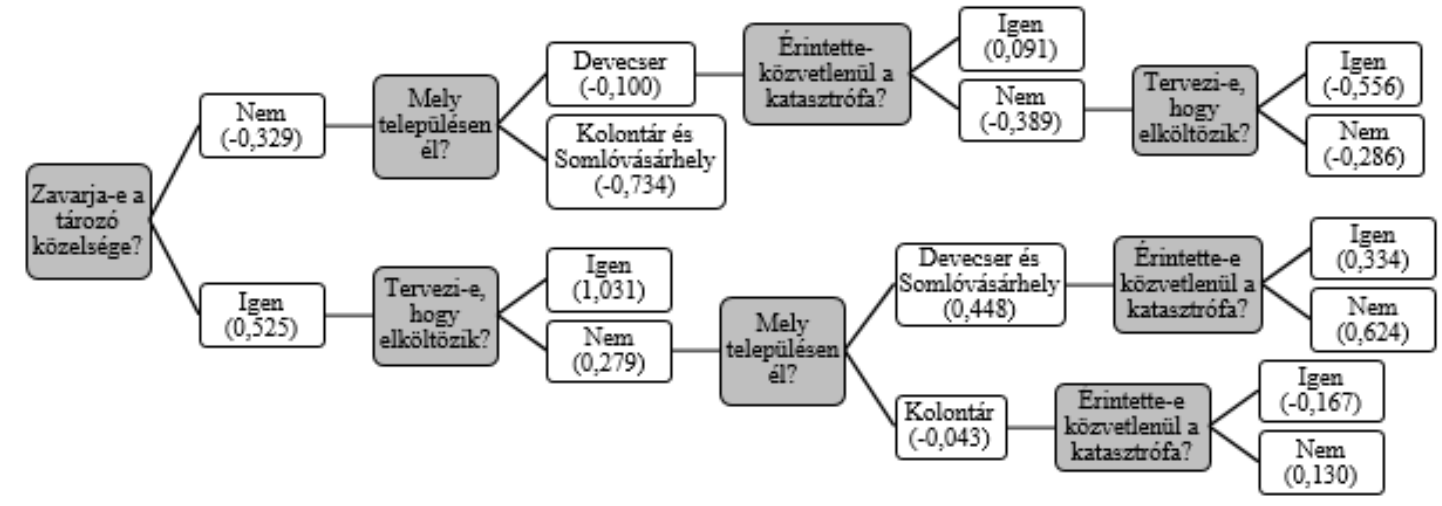

21. ábra: A vörösiszap-katasztrófa által sújtott mintaterület félelem-főkomponensének értékei és értelmezése a költözési hajlandóság, a lakóhely valamint a katasztrófa által közvetlenül érintett és nem érintett lakosság körében. Forrás: saját számítás

Az árvizes és belvizes mintaterületeken is lefuttatam a döntési fa elemzést. Általánosságban elmondható, hogy mindkét mintaterületen elutasítják a fökomponenst azok, akiket nem érintett katasztrófa, attól függetlenül, hogy elhagynák-e lakhelyüket vagy sem, ahogyan ez az elöbbi mintaterületen is jellemző volt. Azok, akiket érintett vagy az árvíz vagy a belvíz, és elköltöznének sokkal nagyobb mértékben fogadják el a félelem fökomponensét.

Az árvizes területeken romákat ért hátrányos helyzetet a félelem fökomponens esetében igazolni lehet, a döntési fa elkészitésekor a félelem szempontjából az etnikai hovatartozás alapján két csoportra bomlott a vizsgált minta, a romákra illetve a magyarokra (22. ábra).

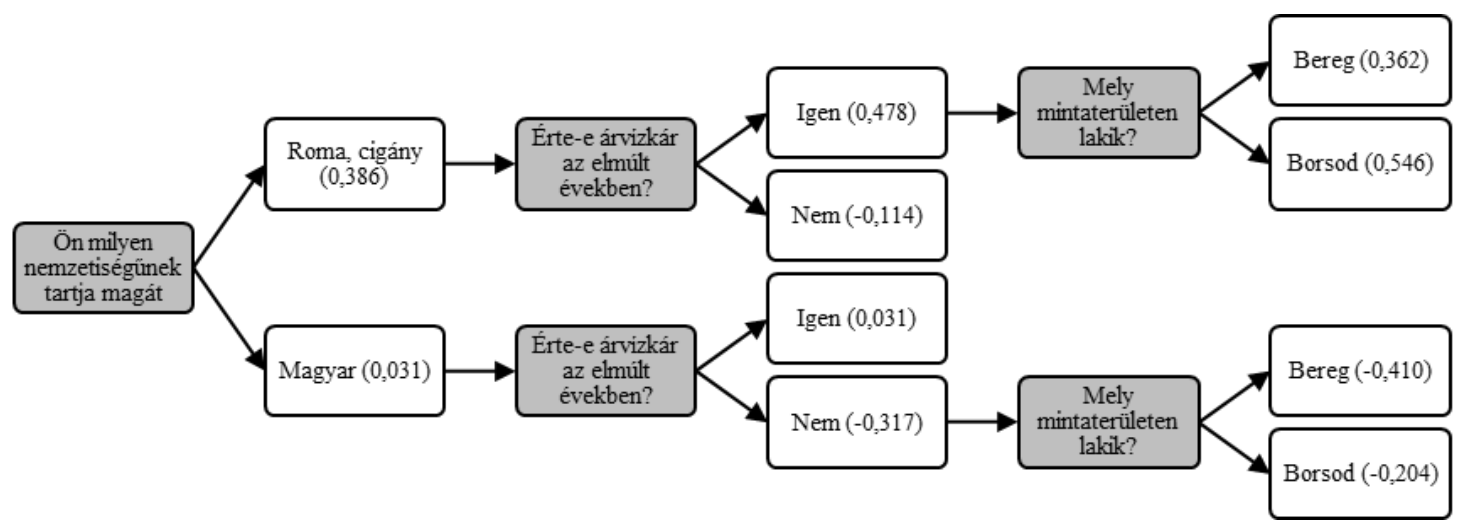

22. ábra: A roma és magyar lakosság a Beregi és Borsodi mintaterületeken felmért félelem-érzete az árvízi érintettség tekintetében

Míg a nem romák, magyarok kis mértékben ugyan, de elutasították, a romák megerősítették a főkomponenst. További bontásban azok a romák, akiknek árvízkár érte a házukat, még magasabb szkórt kaptak. Akiknek nem érte kár a házukat, azok viszont elutasítók voltak a fókomponenssel kapcsolatban. A magyar lakosság esetében a félelem fökomponensét árvízkártól függetlenül elutasították. Se a magyar, se a kisebbségi lakosok közt nincs különbség a két mintaterület közt, a magyarok elutasítják, a romák megerösítik a félelem főkomponensét, mindkét mintaterületen. A 
romák esetében Borsodban, ahol a felmérés időpontjához időben is közelebb volt a katasztrófa, illetve inkább a romák által lakott településrészeket érintette az ár, ott a félelem erösebb volt. Feltehetőleg a magyar lakosság körében, azok közt, akiket nem ért árvízkár a beregi térségben, a katasztrófa óta eltelt hosszabb idő miatt alacsonyabb a félelemérzet az árvizekkel kapcsolatban.

\subsubsection{A vizsgált települések társadalmi átalakulása}

A környezeti katasztrófák következtében számos esetben az érintett területek környezetében drasztikus változások állnak be, mind a társadalom, mind a természet, mind az épített környezet tekintetében. A változásokat azonban nem mindenki ugyanúgy érzékelte, mely az egyén vagy csoport más egyénekhez vagy csoportokhoz viszonyított relatív elégedettségét vagy elégedetlenségét is okozhatja. A változások érzékelésének feltárása érdekében létrehoztam mindhárom mintaterületen a változás értékelésének fökomponensét, ebbe olyan állítások kerültek bele, mint: a településnek a katasztrófa miatt nincs jövöje, vagy nehezebben lehet boldogulni a településen a katasztrófa óta, a település lakossági összetétele megváltozott a katasztrófa óta, illetve, hogy milyen irányban változott a település képe a katasztrófa után. A vizsgált települések esetében a félelem fökomponens értékeihez hasonló megoszlást tapasztalhatunk 0,853 és 0,604 korrelációs érték mellett. Azonban az árvizes mintaterületek esetében ellentétes irányú mozgást fedezhetünk fel, vagyis a korrelációs együttható értéke alapján, aki a félelem fökomponensét megerösíti, az elutasítja, hogy a település változott. Azonban az említett mintaterület kettőssége miatt parciális korreláció elvégzésére volt szükség. Ez alapján bebizonyosodott, hogy az ellentétesség nem szignifikáns. Ennek tükrében megvizsgáltam, hogy a két árvizes területen választ adók hogyan viszonyulnak a változás fökomponenshez. Ezek alapján a beregi települések öszszességében inkább megerősítik, míg a borsodi települések inkább elutasítják azt (23. ábra). Ebben az esetben érdekes azt is megvizsgálni, hogy a két mintaterületen belül, településenként hogyan oszalnak meg a főkomponens-szkórok. A változás főkomponenst Vásárosnamény-Gergelyiugornya település kivételével a 2001-es árvíz által érintett települések megerösítik, míg a borsodi mintaterület megkérdezettjei elutasítják azt.

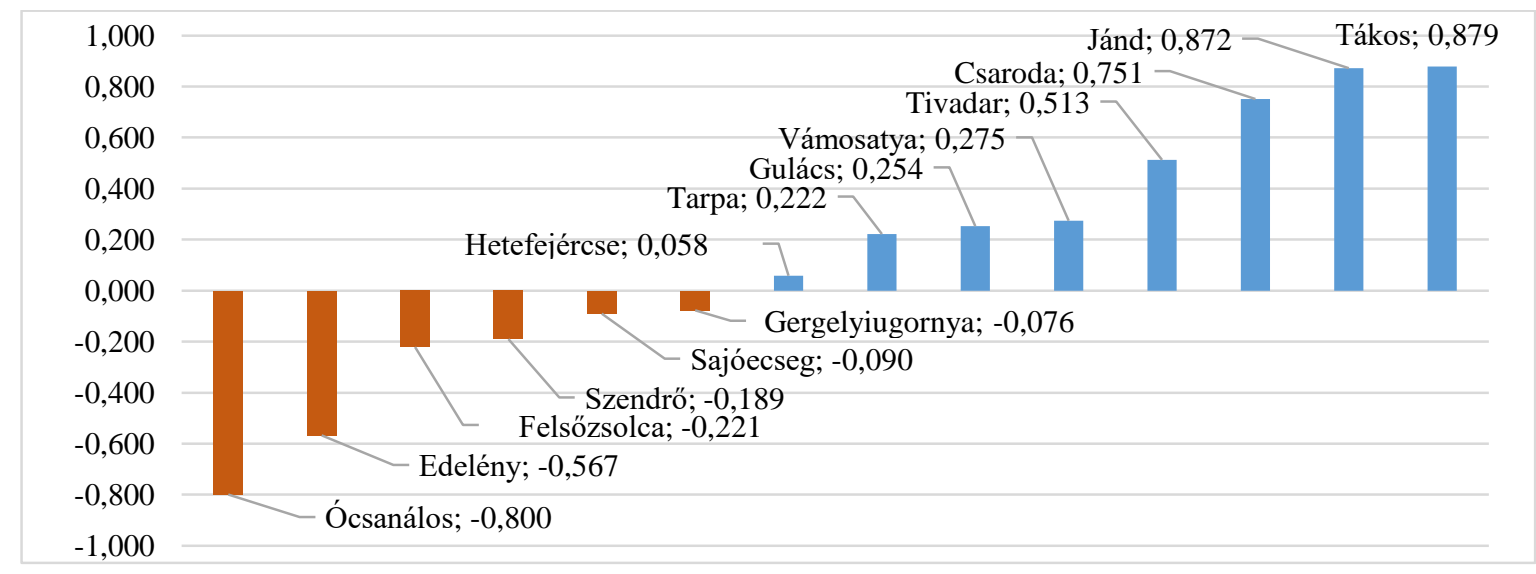

23. ábra: A változás-fökomponens értékei az árvizes mintaterület településein. Forrás: saját számítás

Ennek hátterében állhat, hogy a 2001-es árvízben legjobban érintett településeken a megrongálódott épületek aránya a teljes épületállomány $50 \%$-át is meghaladta, így több esetben az egyébként is alacsonyabb népességü apróbb falvakat újjá kellett építeni. Bár az újjáépítéshez a térségre jellemző építészeti stílust alkalmazó típustereveket használtak, a települések a korábbi építészeti karakterüket elvesztették (Melléklet 9.1.3). Míg a 2010-es árvíz idején az újjáépítés a magas számú és arányú megrongálódott ingatlan ellenére nem történt meg (Melléklet 9.1.6). Ennek hátterében a települések érintett lakosságának etnikai háttere is állhat. Míg a beregi árvíz többnyire romák által kevésbé, addig a borsodi árvíz romák által nagyobb arányban lakott településeket érintett. A beregi Jánd (Melléklet 9.1.1) vagy Tákos esetében például a legmélyebben fekvő területet pár évtizeddel korábban építették be (DÖVÉNYI Z. 2005). A beregi mintaterület esetében a leginkább érintett településrészek általában a cigánysorok és a helyiek által nevezett putrik voltak. Így az újjáépítés ezeken a területeken diszkriminatív módon nem, 
vagy nem teljeskörüen történt meg. Mindez felveti a diszkriminatív és rasszista, kirekesztő jellegü környezeti igazságtalanság lehetőségét. Ahogyan azt a félelem-fökomponense esetében megfigyelhettük, igazolódni látszik a romák hátrányos helyzete. Bár kevésbé egyértelmüen, azonban a romák és a magyarok közötti törésvonalak a települések változását mutató fókomponensben is megmutatkoznak. A megkérdezettek közül azok, akiket nem ért árvízkár általánosan megerösítik azt, hogy a települések képe megváltozott, a romák esetében a szkór 0,917, míg a magyaroknál csak 0,126. Ehhez kapcsolódik az az ellentétes jelenség, hogy azon romák, akiket a borsodi mintaterület településein ért árvízkár úgy érzik, hogy a települések egyáltalán nem, vagy csak kis mértékben változtak, erre utal a -1,127-es érték. A beregi településeken etnikai hovatartozástól függetlenül megerősítik a változás tényét. Ez a kettősség a környezeti igazságtalanságok szubjektív egyén és csoport alapú értékelését támasztja alá, melyben szerepet játszik a mintaterületeken a kormányzat eltérő beavatkozási stratégiája is. Míg a borsodi árvízkárosultak úgy érzik, hogy helyzetük változatlanul hátrányos, sőt rosszabb, a beregi területeken, ahol látványosan megújultak a települések sok esetben, például Jánd vagy akár Tákos korábbi cigány lakossága kényszerüen elhagyta a települést, hiszen őket áttelepítették közeli településekre, tehát nem csak az épített környezetben, de a társadalom összetételében is markáns változások következtek be. Mindezeket a helyi lakosság, ha elköltöztek a településről a romák, azért, ha beköltöztek, azért érzékelik jelentős változásként.

A borsodi mintaterületen hasonló folyamatokat nem, vagy csak sokkal kisebb léptékben lehet megfigyelni. A döntési fa elkészítésekor az SPSS a releváns és szignifikáns összefüggések figyelembevételével a települések két csoportját különíti el a változás-fökomponens értelmezéséhez. Ez majdnem megfelel a Borsod-Bereg felosztásnak, néhány kivétellel (24. ábra). Gergelyiugornya és Hetefejércse a Borsodi mintaterülettel mutat hasonlóságokat. Elöbbi Vásárosnamény településrésze, melynek meghatározó része üdülő, melyet a jogszabálynak nem megfelelöen vettek állandó lakásként igénybe tulajdonosaik. Így az ottani károkat a biztosító - ártérről lévén szó - nem, vagy csak töredékében fedezte. Illetve a nagyszabású újjáépítési programból is kimaradt a település. Hetefejércse alacsony elemszáma, illetve a többi településhez képest eltérö roma lakossági aránya alapján került ebbe a csoportba, azonban a válaszadók összesítve kis mértékben $(0,133)$, de megerösítik a változás tényét településükön. A beregi települések változás-értékelése még inkább elkülöníti a településeket, hiszen Jándon, Tákoson és Csarodán mind a romák $(1,318)$ mind a magyarok $(0,794)$ határozottan megerősítik a település változását, addig Gulácson és Vámosatyán a roma lakosság határozottan tagadja azt. Ezek voltak azok a települések, ahova többek közt Jándról kitelepítették a romákat. A harmadik településcsoport esetében lehet tehát a magyarok és a romák településsel kapcsolatos változás-érzékelésében különbséget felfedezni.

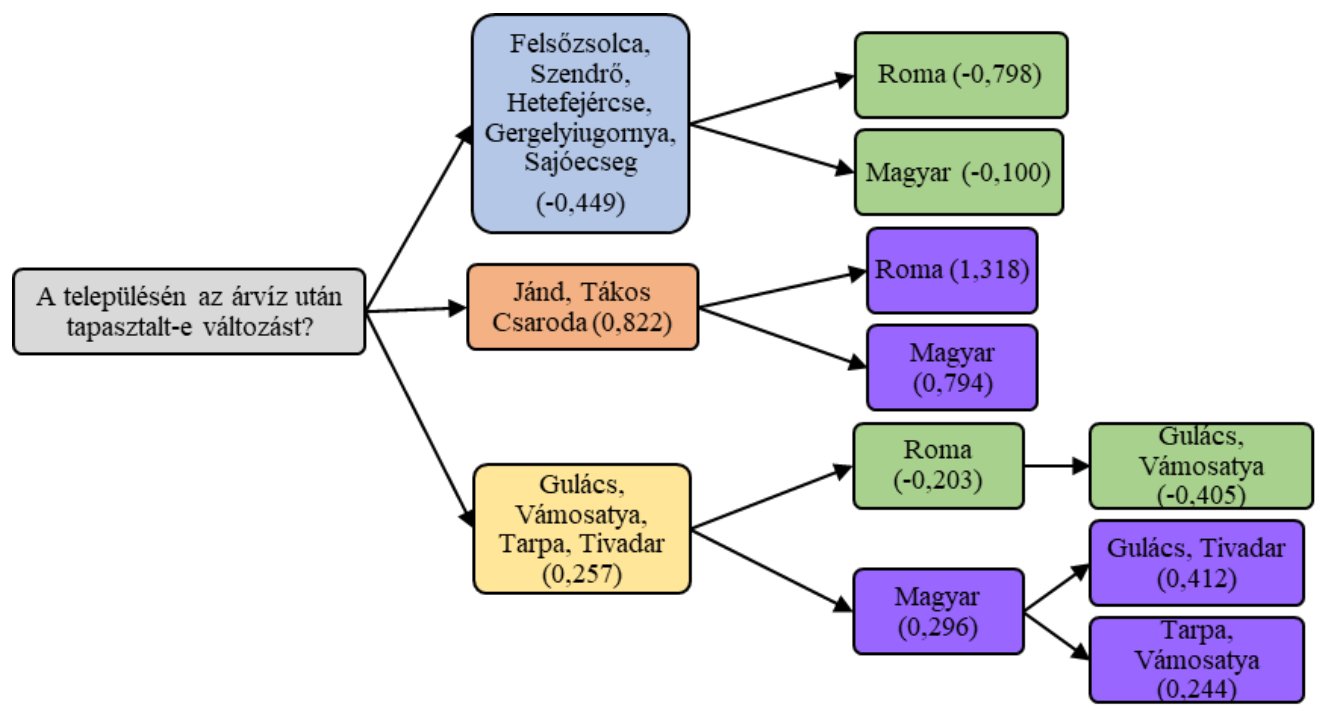

24. ábra: a változás főkomponens szkórok megoszlása a vizsgált komponenesek alapján statisztikailag egymásra leginkább hasonlító településcsoportok roma és magyar lakkosága körében 
Arra a kérdésre, hogy az adott településen a megkérdezettek milyen típusú változásokat tapasztaltak, eltérő válaszokat kaptunk mintaterületenként. Erre utal, hogy az adott fökomponensek, bár a lehetöségekhez mérten azonos elemeket tartalmaznak, azok kommunalitás- és komponens értéke eltérő. Azonban települések népesség-mozgásának és a társadalmi összetételének változását bizonyítja azt, hogy az összes mintaterületen a válaszadók több, mint 40\%-a úgy gondolja, hogy a településeken belül a társadalom átalakult és megváltozott. Nagy eltérések mutatkoznak azonban a mintaterületek között.

A vörösiszap katasztrófa által érintett mintaterület esetében az a komponens, hogy a katasztrófa megváltoztatta a település lakosságát 0,264-es kommunalitás értékkel és 0,513 komponens szkórral rendelkezett, a belvizes területekhez hasonló $(0,261 ; 0,511)$ értékkel, annak ellenére, hogy a belvízelöntések után szinte minimális újjáépítés illetve renováció történt és a belvízzel kapcsolatos népességcserét sem jegyeztek fel a vörösiszappal érintett településekkel ellentétben. A fökomponens szkórokkal ellentétes a válaszok százalékos megoszlása, hiszen a belvízzel érintett települések válaszadóinak közel 80\%-a úgy érzi, hogy egyáltalán nem változott meg a lakosság a katasztrófa következtében. Az árvízzel érintett települések esetében a vörösiszapos mintaterületek válaszadási arányait figyelhetjük meg, vagyis a lakosság megváltozását a válaszadók $65 \%$-a kisebb-nagyobb mértékben megerősítették. Az árvizes területek esetében ez az érték $50 \%$.

Abban az esetben, ha elválasztjuk a településcsoportokat az utóbbi mintaterületen, a Borsodi és Beregi válaszadók szinte teljesen ellentmondanak egymásnak. Míg a Borsodiak 64\%-ban úgy vélik, hogy a lakosság összetétele nem, addig a Beregiek 69\%-a szerint változott a települések társadalmi összetétele. A válaszok igazolják az azonos természeti katasztrófa eltérő hatását a társadalomra. Azonban ennek hátterében sokkal összetettebb, már említett folyamat áll, mely a kompenzációhoz kapcsolódik. Míg a Borsodi mintaterület a belvizes területek válaszadóinak mintázatához hasonló, addig a Beregi inkább a vörösiszapos mintázatot mutatja (25. ábra). A belvizes és vörösiszapos kérdöív a közösséggel kapcsolatos problémákra is rákérdezett, a korábbi kérdöívekben ezek a kérdések nem voltak benne. A válaszadók 57\%-a az utóbbi mintaterület esetében úgy vélik, hogy a közösségben tapasztalható konfliktusok száma megemelkedett, így a település lakosságának megváltozása negatív folyamatokat indított el. Ezt a belvizes mintaterületek válaszadóinak csak 9\%-a erösítette meg (25.ábra). Azonban azok válaszadók, akik úgy gondolták, hogy több probléma figyelhető meg a közösségben, mint a katasztrófa elött nem feltétlenül erösítették meg a lakósság összetételének megváltozását, vagyis korrelációjuk alacsony. A belvizes területek válaszadói inkább azt erösítették meg, hogy nem változott az összetétel és egyáltalán vagy inkább nem figyelhető meg több közösségi probléma. Azonban a korreláció itt is alacsony értékü $(0,201) 2 \%$-os hibahatár mellett.
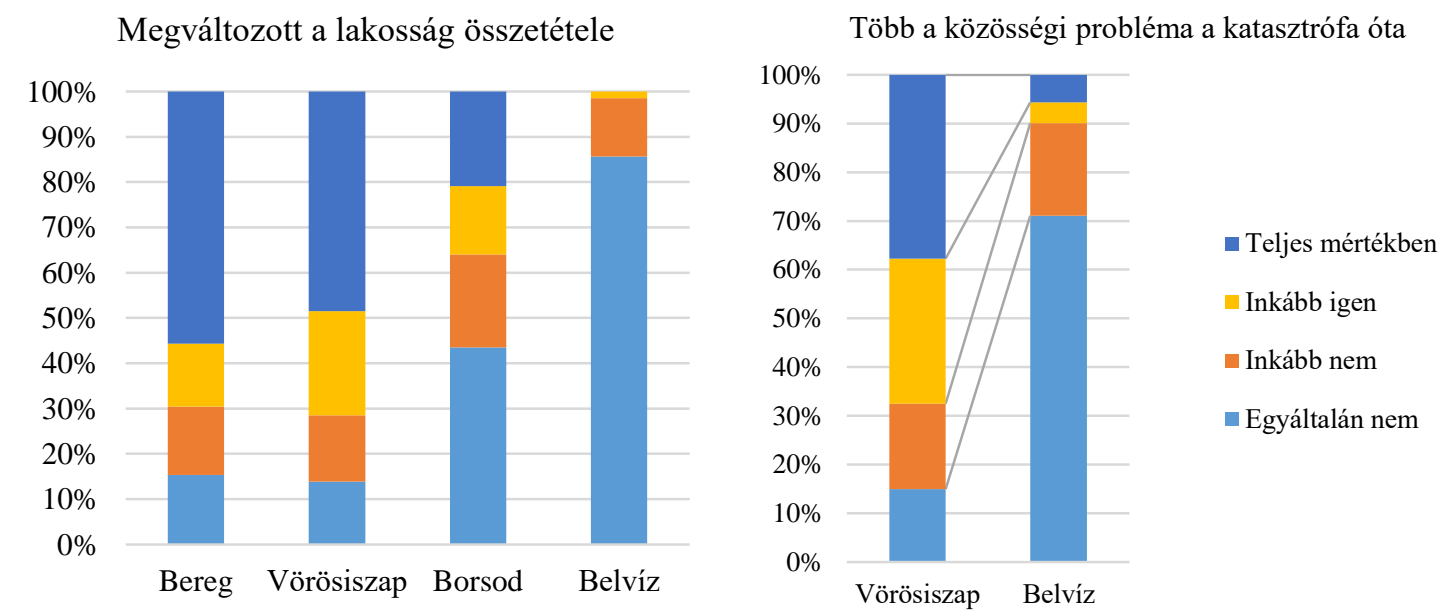

25. ábra: A lakosság összetételének megváltozása és a közösségi problémák számának változása a mintaterületeken. Forrás: kérdőíves felmérés alapján saját szerkesztés

A lakosság szerkezetének megváltozását különböző dimenziók mentén, mint például etnikai hovatartozás, vagyoni helyzet vagy életkor, értékelték a megkérdezettek. Ennek eredményei összhangban vannak az összetételre vonatkozó átfogó kérdés eredményeivel. Mind a beregi, mind a borsodi, mind 
pedig a vörösiszappal érintett mintaterületeken a válaszadók a népesség általános csökkenéséről számoltak be. A belvizes területek esetében a megváltozott népességre vonatkozó válaszok alacsony száma miatt ebből a kiértékelésből kihagytam a mintaterületet. Az eredmények alapján a vagyoni helyzet mentén nem lehet egyértelmüen állítani, hogy több szegény költözött volna a településekre, mint gazdag, hiszen a válaszadók többsége szerint vagyoni helyzettől függetlenül föként elköltöztek a településekről. Tehát az ex post jellegü környezeti igazságosság azon tétele, hogy a lakosság kicserélődése a társadalmi státusz csökkenését okozza, nem teljesül.

Mindezek ellenére a beregi és a vörösiszappal érintett települések esetében a válaszadók úgy gondolják, hogy több szegény költözött a településre, mint amennyi elköltözött volna. Szubjektív képük szerint tehát a nagymértékủ elvándorlás mellett relatíve megnött az alacsonyabb jövedelemmel rendelkező lakók száma. Ez a folyamat, amennyiben ténylegesen valós, erősíti és hozzájárulhat a települések imázsának romlásához és a térség ingatlanpiaci leértékelödéséhez is. Mindez a katasztrófa által sújtott és hátrányos helyzetbe sodort települések esetében a hátrányos helyzet halmozódását idézheti elő. A borsodi települések esetében a legnagyobb számban elköltözök a szegényebb, alacsonyabb jövedelmü társadalmi rétegek közül kerültek ki (26. ábra).

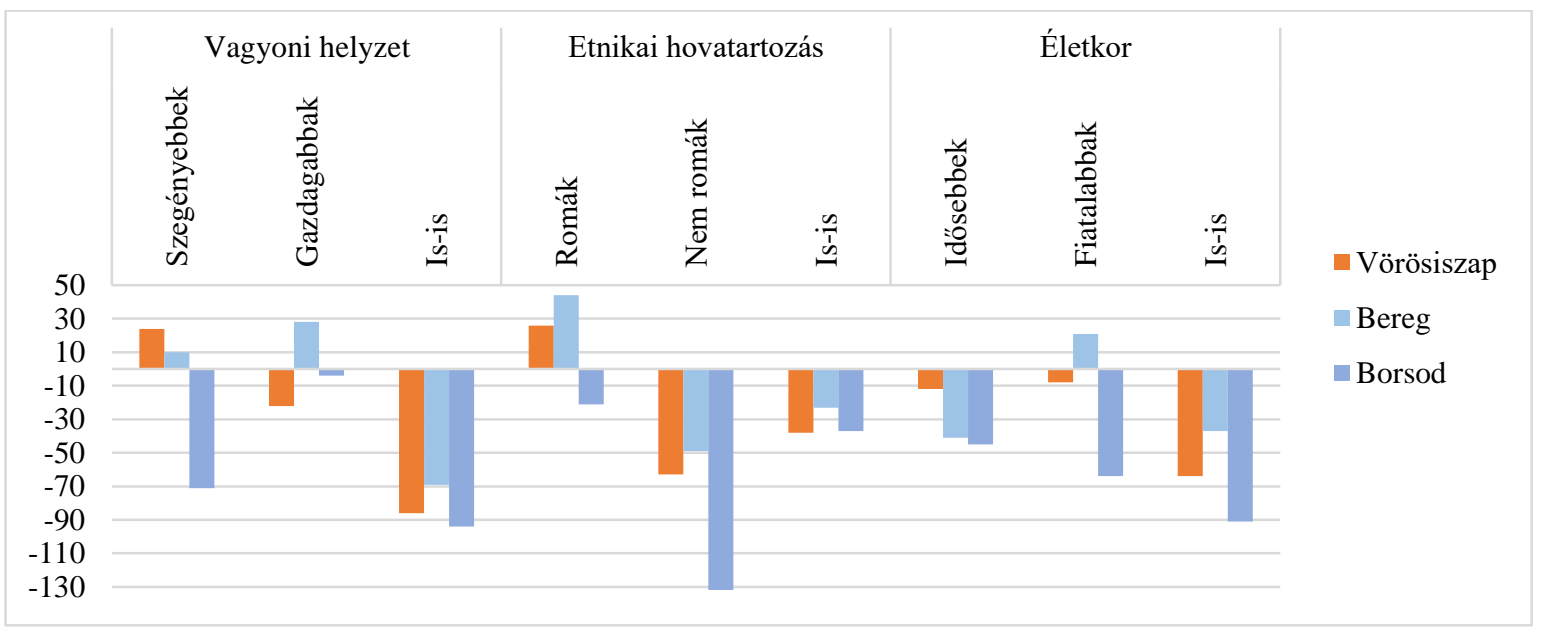

26. ábra: a mintaterületeken katasztrófát követő el-és beköltöző lakosság néhány társadalmi státuszt alakító tényező menti csoportosítása. Forrás: kérdőíves felmérés alapján saját szerkesztés

A beregi mintaterület esetében megfigyelhető folyamat, hogy a válaszadók szerint nem csak az alacsonyabb jövedelmüek közül jelent meg új lakos a településeken, de a tehetősebbek közül is. Ez az olcsón elérhető, jó minőségü újjáépített beregi otthonok második otthonná alakításával áll kapcsolatban. Ehhez kapcsolódhat az az eredmény is, hogy a mintaterületek esetében csak a beregi településeken nyilatkoztak úgy, hogy több fiatal költözött a településre, mint el onnan.Az alacsonyabb jövedelemmel rendelkező csoportok tagjai gyakran kisebbségi háttérrel rendelkeznek. Ennek vizsgálata érdekében a válaszadók az el- és beköltözők etnikai hovatartozását is megnevezték. A kitöltők szerint fơként nem roma származású lakók költöztek el a településekről a legnagyobb számban. Beregben és a vörösiszappal érintett településeken emellett úgy vélekednek a válaszadók, hogy több roma költözött a településekre, mint amennyi elköltözött volna. Bár a válaszadók többsége úgy gondolja, hogy nem határozható meg egyértelmüen, hogy romák vagy nem romák költöztek el többségében. Mindkét társadalmi csoportból van az el- és beköltözésre példa településükön. Ennek értelmében miközben a mintaterületekröl általánosan a romák és nem romák elvándorlása is egyidőben zajlott, addig bizonyos településeken az elvándorlással együttvéve is több roma jelent meg a válaszadók szerint, mint amennyien korábban voltak. 


\subsubsection{A településkép megváltozása}

Mindhárom mintaterületen a válaszadók többsége a településkép pozitív irányú változásáról számol be. A települések csoportjai közt azonban markáns különbség fedezhető fel az árvizes mintaterületek esetében. Azt tapasztaljuk, hogy a borsodi mintaterület válaszadóinak 60\%-a úgy gondolja, hogy inkább nem, vagy egyáltalán nem jó irányba változott a településkép az árvizet követően (27. ábra).

Jó irányba változott a településkép

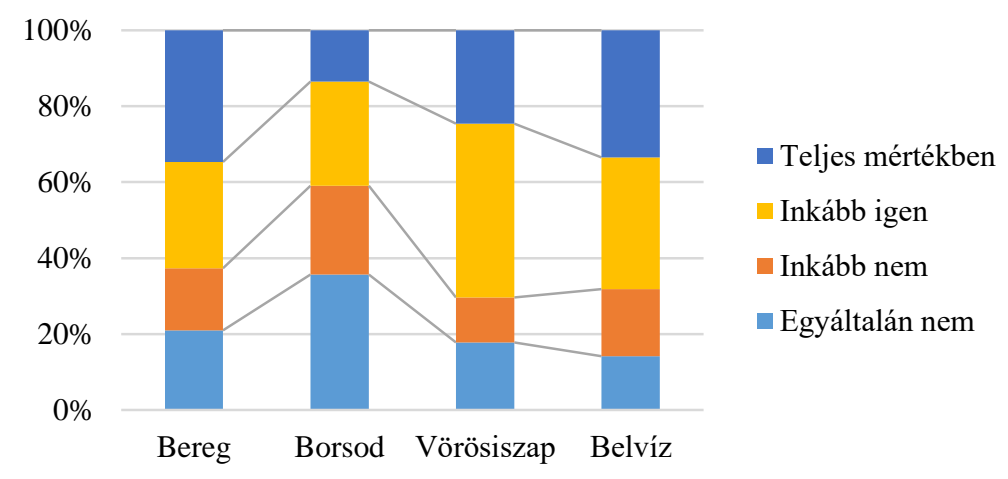

27. ábra: A településkép változásának megítélése a vizsgált mintaterületeken. Forrás: kérdőíves felmérés alapján saját szerkesztés

Mindez összefüggésben van a már említett folyamattal, miszerint a borsodi mintaterületeket a felmérés időpontjához közeli időpontban érintette a katasztrófa, másrészt pedig, hogy a kárpótlási folyamatot több esetben kifogásolták az érintettek, annak korruptságát és igazságtalanságát említve. Mindemellett fontos az a tényező is, hogy a 2010-es árvizek után nem indult egy olyan átfogó rekonstrukciós program, mint a 2001-es árvizeket követően volt. Erröl helyszíni terepbejárásunkat követően is meggyőződtünk kutatótársaimmal (28. ábra).

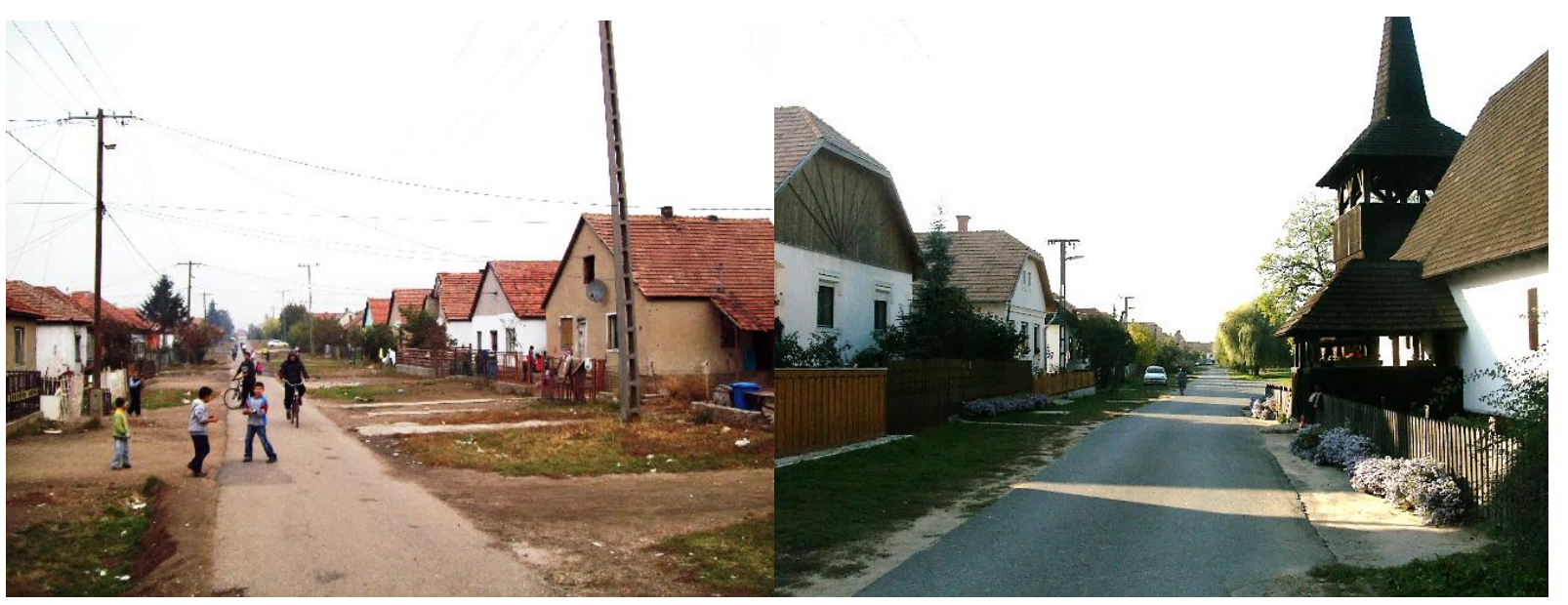

28. ábra: Nem megújult cigánysor Felsőzsolcán és újjáépült fổutca Tákoson. Forrás: saját fotó (2011)

A 2001-es árvíz erőteljesen hatott a lakásállományra: a statisztikák szerint a vásárosnaményi kistérségben összességében kb. 5\%-kal csökkent a lakásállomány, több, mint 3000 ingatlan megsérült, közülük 1000-et le is kellett bontani, mely jelentősen átformálta a települések arculatát (ALFÖLDI L. 2002). Ha azt vizsgáljuk, hogy természeti csapás miatt hány lakás semmisült meg 2001-ben, azt tapasztaljuk, hogy több településen is $20 \%$ feletti az arány, és a legrosszabb helyzetben Csaroda volt (BAJMÓCY P. ET AL. 2012). Természetesen az érintett ingatlanok aránya magasabb, ha figyelembe vesszük a „csupán” megrongálódott épületeket is. A károk felmérése után a Kormány kötelezettséget vállalt a beregi településeken közel 3000 megrongálódott ingatlan újjáépítésre, renoválására. Ezzel párhuzamo- 
san megkezdték a védmürendszerek megerősítését, korszerüsítését és a gazdálkodók kárát is megpróbálták mérsékelni, megtéríteni - ugyanakkor ennek mértékét és módját több kritika is érte (KUN I. 2004).

A lakóházak újjáépítése 17 típusterv alapján zajlott, a Kormány határozatban írta elő a legfőbb újjáépítési szempontokat. Az egyik legfontosabb eleme a lakóházak arculatára és a térség hagyományára való tekintet volt. „Az-újjáépités során a települések hagyományos szerkezetét és faluképét megörizve el kell érni azt, hogy a kor követelményeinek megfelelö infrastruktúra és élettér alakuljon ki" (1025/2001. (III.23.) Korm. hat.). Becslések szerint az árvíz elleni védekezés és a helyreállítás költségei meghaladták a 60 milliárd forintot. Az árvíz után a települések újjáépítése azok relatív felértékelődését eredményezte, az új házak korszerübbek, jobban felszereltek, minőségibbek lettek, mint elödjeik (DÖVÉNYI Z. 2005). A beregi újjáépítések és felújítások következtében a megkérdezettek háromnegyede ugyanolyan, vagy jobb minőségü lakásban él, mint az árvíz előtt. Kirajzolódik ugyanakkor egy éles különbség: azok, akiknek teljesen elpusztult az otthonuk, sokkal nagyobb mértékben számoltak be pozitív változásokról a lakáskörülményeiket illetően. Akiknek elpusztult vagy le kellett bontani a házát, kb. 70\%-uk jobbra értékelte a körülményeit, mint 2011 elött. Akiknek ki lehetett javítani a káraikat, csak 25\%-uk, akiket pedig nem ért kár, csak 15\%-uk él jobb lakáskörülmények között, mint az árvíz előtt. A vélemények alapján az újjáépítésekkel a településkép is pozitív irányba változott 2001 után: a válaszadók kétharmada részben vagy egészben egyetértett ezzel az állítással.

Míg a beregi újjáépítés kormányzati irányítással, központi szervezéssel zajlott, addig a 2010-es borsodi árvizek esetében a Kormány úgy határozott, hogy az önkormányzatokra hárítja az újjáépítés megszervezését. Ennek értelmében született meg a 1148/2010. (VII. 8.) Korm. határozat a 2010. májusjúnius hónapokban kihirdetett veszélyhelyzetek időszakában felmerült védekezési költségekről és károk enyhítéséröl. A Kormány ebben a jogi szabályozási eszközben határoz az árvízben elpusztult ingatlanok számáról és a kárenyhítés módjáról, melyek után az önkormányzat kártérítésre támogatást vehet fel. A mintaterület települései esetében Edelényben 24, Felsőzsolcán 173, Onga-Ócsalánoson 6, Szendrőn 17 ingatlan jelenik meg a határozatban mint ,teljes kárt szenvedett”. A határozat értelmében a „,megsemmisült, vagy helyreállithatatlanná vált lakóingatlanok tulajdonosai” jogosultak a támogatásra, melynek kiosztásánál „a károsultak egyedi szociális helyzetét és rászorultságát” is figyelembe kell venni. A támogatást igénybe vehette az, akik ,, a nem lakás céljára szolgáló lakóingatlanok (üdülö, nyaralóépületek)... a káreseményt megelözöen életvitelszerüen lakta”. Azonban a kormányhatározat az újjáépítés mellett a bontásról is rendelkezett, melynek költsége a károsultat terhelte. Amennyiben az érintett úgy rendelkezett, a támogatási összeg lakásvásárlásra is fordítható volt. A felsőzsolcai érintettek közül ötvenen választották ezt a lehetöséget, többnyire Miskolcra költöztek (RUDOLF M. 2012). Az állami támogatás károsultanként körülbelül 9 millió forint volt, melyet mind az újjáépítést kivitelezök, mind az önkormányzatok fóépítészei - akik feladata volt az újjáépítés elvezénylése - kevesellte. Felsőzsolca egykori fóépítésze többedmagával jelezte, hogy az újjáépítésre szánt támogatás költsége nem elegendő: , kértük, hogy összeadódhasson az állami segitségnyújtás az önerővel és a biztositótársaságok helytállásával. Kértük továbbá, hogy ne kérjen vissza az, aki ad: ne kelljen ÁFA-visszatéritéssel bajlódni." Azonban kérésüket nem hallgatták meg. Felsőzsolca képviselőtestülete liberalizálta az újjáépítést (RUDOLF, M. 2012), melyben a föépítész szerint nem fogadták meg az építészek szakmai véleményét. Ez a bevonás és a participáció hiányát mutatja az újjáépítési folyamatban. Tovább nehezítette a károsultak helyzetét, hogy a korábbi - beregi - gyakorlattal ellentétben az „öneröt... (és) biztositásból megtérülö károkat" (Korm. határozat) sem lehetett figyelmen kívül hagyni. Így azon károsultak, akik rendelkeztek biztosítással és költségeiket a biztosítók fedezték, arról értesíteni kellett az önkormányzatot. „,Nagyobb biztositási összegek lehívóinak a teljes öngondoskodást. Nekik kormányzati pénz nem járt" - emlékezik vissza a volt felsőzsolcai fóépítész. A településen 50 helyszínen elöre elkészült típustervek alapján építettek házat, az önerőből felépítendő házak közül csak három készült el, a hátrahagyott telkek azonban 7 évig elidegeníthetetlenné váltak (RUDOLF, M. 2012). Az elidegenítés ebben az esetben is egyfajta röghözkötést jelent, mely a katasztrófával érintett népesség ingatlanpiaci csapdahelyzetét erősíti, hiszen a kártárítési összeg több esetben nem volt elegendő egy városi (föként Miskolci) lakás megvásárlására a telek eladása nélkül. Az árvíz megközelítőleg 80 helyi építészeti emléket tüntetett el, 
tervek szerint az új épületek azonos, helyi építészeti karakternek megfelelő módon (kontyos tetőszerkezet, tornácos oldalfal stb.) épültek volna fel. Azonban a már korábban említett, nem központosított újjáépítés hatására nem valósult meg az azonos karakter kialakítása. Felsőzsolcán egységes utcakép csak részben alakult ki az Arany János utcában, ahol a típusterveknek megfelelően több ház is felépült. Azonban a település bizonyos érintett részei, mint például a cigánytelep egyáltalán nem újultak meg.

A vizsgált mintaterületek megkérdezettjeinek válaszadása azonban egy másik fontos szempont alapján is összehasonlíthatók. Ez pedig az érintettség szempontja. A környezeti igazságtalanságok esetében általánosan megfigyelt, hogy azok a válaszadók, akiket közvetlenül is érintett bármiféle igazságtalanság, hajlandóbbak negatívan nyilatkozni a bekövetkezett változásokról, mely tükrözi elnyomott és deprivált helyzetüket. Ennek érdekében megvizsgáltam, hogy a disszertáció mintaterületein a katasztrófák bizonyos típusaival közvetlenül és közvetetten vagy egyáltalán nem érintett válaszadó lakosság megerösíti-e vagy elutasítja a változások fökomponensét, és hogyan vélekedik a társadalmi és épített állományra vonatkozó változásokról.

Ennek eredményeként megállapítható, hogy a korábban megfigyelt Borsod-Bereg ellentét ebben az esetben is megerősíthető. Míg Borsodban elutasították, addig Beregben megerősítették a változás fökomponensét, mindemellett a beregi mintaterületen az érintettek és a közvetetten érintettek is megerősítik a változás főkomponensét. Borsod esetében azon válaszadók, akiket érintett az árvíz nagyjából hasonló mértékben, mint a beregi válaszadók, de elutasítják a változást. Tehát míg az alapvetően negatívabb, hátrányosabb helyzetben lévő érintettek Bereg esetében úgy vélik, hogy megváltozott a település képe és összetétele is, melynek iránya pozitív volt, addig Borsod esetében a hasonlóan érintett csoport úgy gondolja, hogy nem volt gyökeres átalakulás a településeken, és ami volt, az is negatívan érintette őket és szükebb környezetüket. Ezt a választ alátámasztja azon eredmény is, mely a lakosok kiszolgáltatottságára vonatkozik. A mintaterületek közül a beregi válaszadók azok, akik a legkisebb arányban érzik azt, hogy a lakosok kiszolgáltatottak lennének, megközelítőleg a válaszadók 30\%-a érzi úgy, hogy nem kiszolgáltatott a helyzete. A többi mintaterület esetében ez $15 \%$ alatti. Mindez összekapcsolódik a korábban említett újjáépítési programmal és az eltelt idővel is.

A beregi újjáépítéssel kapcsolatban az Országépítő c. építészeti folyóirat hasábjain jelent meg egy beszélgetés a tákosi és gulácsi újjáépítést vezénylö föépítészekkel. A lakosok kiszolgáltatott helyzetét ők is alátámasztják az interjúban. „Elöfordult, hogy valakit kiköltöztettek a házából és a kár mértékének megállapitásáig a kertben kellett laknia, sátorban, vagy jobb esetben a nyárikonyhában... Az embert kiköltöztetik a házából több hónapra, lehet, hogy 5 fok van éjszaka és sátorban kell lakni...egy idö után az ember megunja ezt... "'(ERHARDT G. 2001 P.2.). Emellett a kiszolgáltatottságra és a lakossági participáció hiányára is rávilágítanak az interjúalanyok, akik azonban ennek szükségességét hangsúlyozták, és azt, hogy az újjáépítésből végül a legtöbben pozitívan kerültek ki. „,Fél évig teljesen ki lettek zökkentve a megszokott életvitelükböl. A saját telkük felvonulási terület volt és nem tudták, hogy mikor mi történik ott" (ERHARDT G. 2001 P.2.). Arra a kérdésre, hogy mennyiben volt igazságos vagy méltányos az újjáépítési folyamat az interjúalanyok azt hangsúlyozzák, hogy az újjáépítés ,,nem igazságos, de abszolút korrekt" (ERHARDT G. 2001 P.4.) volt, hiszen akinek kis értékü, rossz állapotú ingatlana volt, az is új és jól felszerelt, ugyan négyzetméterben kisebb, épületet kapott cserébe, ugyanúgy, ahogyan azok, akiknek új vagy újszerü háza volt. A kiszolgáltatottság érzését növelheti az, hogy az érintettek újjáépített lakóházakkal kapcsolatos elfogadása időbe telik, mire kialakul. „, Ott volt a régi háza, abban született, abban lakott az apja, abban zajlott az élete. Most áll egy új házban, ami gyönyörû, de nem az öve’" (ERHARDT G. 2001 P.4.). Az idő múlásával tehát a vörösiszappal és egyéb katasztrófával érintett területeken élők kiszolgáltatottság érzése is csökkenhet, csakúgy, mint a beregi válaszadók esetében tapasztaljuk (29. ábra). 


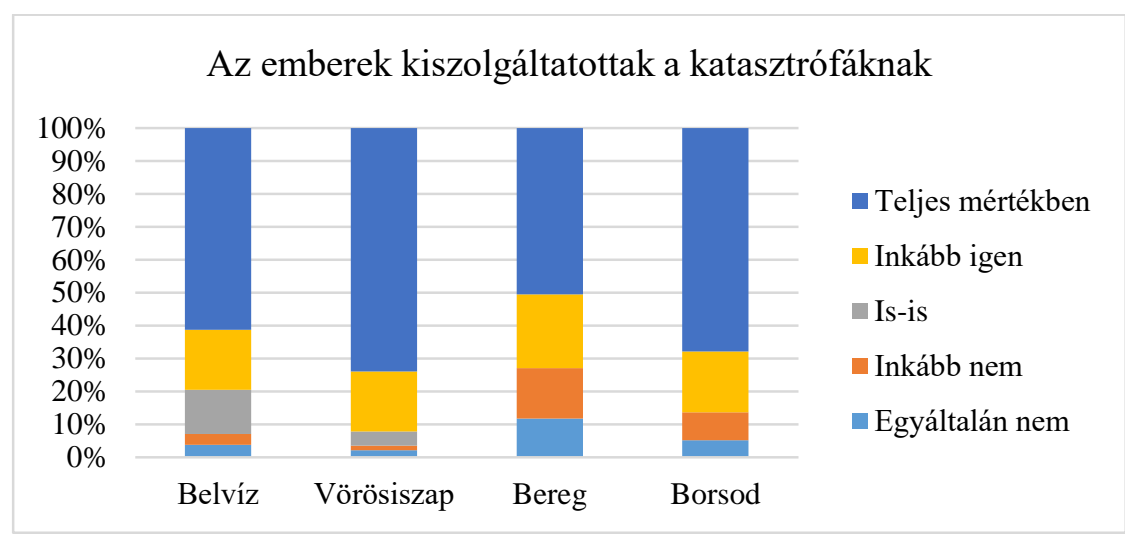

29. ábra: A válaszadók szubjektív kiszolgáltatottság-érzése a mintaterületeken. Forrás: kérdőíves felmérés alapján saját szerkesztés

A vörösiszap-katasztrófát követően a Kormány ismételten határozatban rögzítette a kárenyhítés folyamatát és a károsultak körét is. A 1221/2010. (XI. 4.) Korm. határozat a 2010. október 6-án kihirdetett veszélyhelyzet során keletkezett károk enyhítéséről és a helyreállításról rendelkezett. A katasztrófa esetében a borsodi újjáépítés mintáját követve a biztosítási költség esetében „a más forrásból megtérülö kárösszeget az állam javára visszafizetési kötelezettség terhelte”. Továbbá nem lehetett kártérítést igénybe venni „második károsodott lakóépület, valamint a nem lakás céljára szolgáló épületek, épitmények helyreállitásához és újjáépitéséhez" sem. Ahogyan a másik két mintaterület esetében is, a vörösiszap-károsultak esetében is elidegenítési tilalom került az új ingatlanokra. A Kormány határozatban a nem lakóépületekben keletkezett károk enyhítésére vonatkozó szabályozást is lefektette, ahol többek közt a gazdasági termeléshez szükséges eszközök, a mezőgazdasági termények, állatok, a ruhanemük, bútorok pótlására kitér. A katasztrófa után igazságügyi értékbecslést végeztek a károsultaknál, amellyel ha nem értettek egyet, akkor ismételt felmérést kérhettek. A vörösiszappal szennyezett házakat károsodott ingatlanok (364 db) és bontásra ítélt ingatlanok (286 db) csoportokra osztották (TuRI A. 2011). A bontást követően a támogatást többféle módon igénybe lehetett venni, készpénzes kárenyhítés, lakásvásárlás, állami lakásépítési programban való részvétel. A három érintett településen összesen 109 új épület épült fel, Kolontáron 21, Devecseren 87, Somlóvásárhelyen 1, szintén a Koós Károly Egyesülés típustervei alapján. A korábbi gyakorlattal ellentétben a vörösiszap-károsultak többször is lehetöséget kaptak a tervek apróbb változtatására. Háromhetente maguk is megtekinthették az építkezést. A felépült épületek ,, a bakonyi épitészet alapelemeit, arányrendszerét” (TURI A. 2011) tükrözik. Emellett figyelembe vették a mai kor igényeit is, gondoltak a melléképületek tájba illesztésére is, teljes inftastrukturális és zöldterületi helyreállítást is végeztek. Az építtetök szerint „,minden ház eltérö homlokzatú és alaprajzú a tulajdonos kérései szerint” Devecser központjában pedig az elbontott épületek helyén egy emlékparkot alakítottak ki, komplex tájrendezést végezve a településen (CsóKA, B. 2011; TURI A. 2011). Mindezek alapján a korábbi katasztrófák hibáit részben orvosolták a vörösiszap utáni újjáépítéskor. Javulás figyelhető meg a lakosság bevonásával kapcsolatban, hiszen a lakosok több alkalommal is beleszólhattak az épülő új otthonuk kialakításába is, ráadásul a központi terek kialakításába is volt beleszólási joguk. Nem egyetlen módon lehetett csak hozzájutni a támogatáshoz. Azonban az elidegeníthetetlenség megőrzésével a röghöz kötés megmaradt. Mindez továbbra is elösegíti az ingatlanpiaci csapdahelyzet kialakulását, annak ellenére, hogy a lakosság nagyobb szabadságot és betekintést nyert az újjáépítési folyamatba.

Bár a belvizes területek katasztrófája kevésbé drasztikus, azonban mint korábban említettem számos negatív hosszútávú egészségügyi hatása ismert. A belvíz, mint természeti katasztrófa a köztudatban kevésbé van jelen, annak ellenére, hogy a sajtóban szinte minden második évben olvashatunk arról, hogy az ország egyharmada belvíz elöntés alatt áll. Azonban ennek a katasztrófának föként a mezőgazdasági jelentőségére szokott koncentrálni a sajtó. Mindezek ellenére a mezőgazdasági területek elöntése mellett számos olyan település van Magyarországon, akár nagyvárosokban, mint Szeged, ahol a belvízkárok rendszeres anyagi károkat okoznak az épített környezetben. A vizsgált mintaterületen a belvízelöntés után a belvízzel érintett válaszadók úgy érzik, hogy történt változás a településen, ez pedig 
pozitív irányú volt (12. táblázat). Ez azért is jelentős, mert az összes vizsgált mintaterület közül itt a legnagyobb a változás-fökomponens megerősítésének értéke az érintettek körében. Külön kiemelendö, hogy a lakosok a károk enyhítésére és rendezésére többségében nem igényeltek semmilyen forrást és támogatást. Így saját maguk voltak kénytelenek megoldani a felújítást, ez viszont összekovácsolta a közösséget, hiszen a válaszadók közel $68 \%$-a szerint a szomszédok segítették egymást a helyreállításban. Azok a válaszadók szerint, akiket nem érintett a belvíz, a településeken nem volt nagy horderejü változás sem a település képét, sem pedig lakosságának változását tekintve. A két belvizes mintaterület között az érintettek és nem érintettek között nincs különbség válaszadásban. Hasonló mintázatot mutat a vörösiszapos mintaterület egésze, a válaszadók $76 \%$-a úgy véli, hogy a kiszolgáltatottság ellenére a lakosok segítenek egymásnak. Azonban míg Devecserben megerősítik, addig Kolontáron kis-, Somlóvásárhelyen nagymértékben elutasítják a változás főkomponensét (12. táblázat), azonban minden településen úgy vélekednek, hogy a szomszédok segítőkészek voltak, mely csökkentette a lakók kiszolgáltatottságát. Míg a borsodi válaszadók érintettségtől függetlenül közel $84 \%$-ban úgy gondolták, hogy nem igaz, hogy a szomszédok nem voltak segitőkészek, addig a beregi térség esetében ez csak 69\%, a megkérdezettek 31\%-a úgy véli, hogy szomszédaik nem voltak segítőkészek.

12. táblázat: A változás főkomponensének elutasítása vagy megerősítésének értékei az érintettség függvényében. Forrás: kérdőíves felmérés alapján saját számítás

\begin{tabular}{|c|c|c|c|c|c|c|c|c|}
\hline \multirow{3}{*}{$\begin{array}{c}\text { Mintaterület } \\
\text { Érintett? }\end{array}$} & \multicolumn{8}{|c|}{ Változás fókomponens } \\
\hline & \multicolumn{2}{|c|}{ Bereg } & \multicolumn{2}{|c|}{ Borsod } & \multicolumn{2}{|c|}{ Vörösiszap } & \multicolumn{2}{|c|}{ Belvíz } \\
\hline & Átlag & $\mathrm{N}$ & Átlag & $\mathrm{N}$ & Átlag & $\mathrm{N}$ & Átlag & $\mathrm{N}$ \\
\hline Igen & 0,339 & 294 & $-0,376$ & 375 & 0,266 & 77 & 0,709 & 77 \\
\hline Nem & 0,088 & 76 & 0,123 & 68 & $-0,33$ & 62 & $-0,447$ & 122 \\
\hline
\end{tabular}

A lakóhelyi épített környezet átalakulásáról eltérő véleménye van az árvizes mintaterületeken az árvízzel közvetlenül és közvetetten érintetteknek. Míg azok, akiknek háza megrongálódott vagy le kellett bontani sokkal drasztikusabbnak látják a települések épületállományának megváltozását, mint azok, akiknek ingatlanában nem keletkezett anyagi kár. Igaz, a válaszadók döntő többsége úgy érzi, hogy saját utcájában szinte minden vagy a házak több, mint a fele elpusztult vagy megrongálódott, a nem érintettek esetében többen úgy nyilatkoznak, hogy nem történt kár az ingatlanokban (30. ábra). Mindez az adott természeti katasztrófa szubjektív percepcióján alapul. Ez többek között környezeti igazságtalanság kialakulását is jelezheti, hiszen abban az esetben, ha a „hangadók és véleményformálók” többsége a nem érintettek közül kerül ki, akkor a segítségnyújtás is elmaradhat, vagy elbagatellizálódik. Több esetben a köznapi és politikai közbeszédet olyan megjegyzések uralják, melyek azt sugallják, hogy az árvíz miatt hátrányos helyzetbe került emberek legyenek hálásak és elégedettek, mert házaikat újjáépítik, ráadásul a korábbinál jobb komfortfokozatú lakásokat kapnak. Mindez részben igaz, azonban az árvízvédelem nem az egyén és közösség, hanem az állam feladata. Ennek hiányában kialakult katasztrófa helyzet utáni kompenzáció is így természetesen az állam feladata. A két árvizes mintaterület esetében markánsan kirajzolódik, hogy a borsodi mintaterület esetében a nem érintettek kevésbé látták drasztikusnak az árvíz okozta károkat. Mindemellett az árvíznek etnikai vonulata is volt, hiszen többnyire a települések szélén, az árvíz szempontjából legrosszabb helyen elhelyezkedő cigánytelepeket érte elsődlegesen az árvíz. 


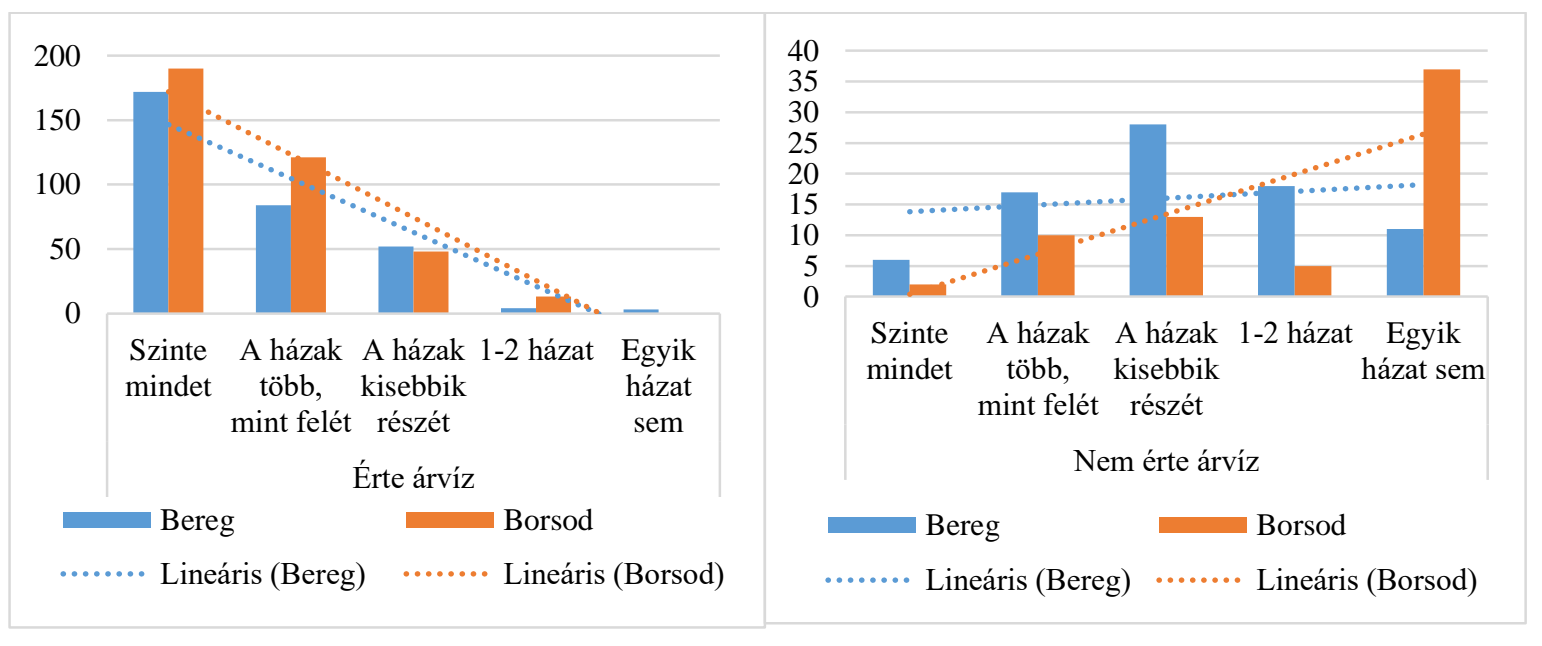

30. ábra: Az árvizes mintaterületek épületállomány-kárának szubjektív megítélése az érintettek és nem érintettek körében. Forrás: saját szerkesztés kérdőíves felmérés alapján

A lakókörnyezet és lakóhely minőségének változásában is különbségek figyelhetők meg az árvizes mintaterületeken. Míg a beregi települések esetében a válaszadók több, mint 38\%-a gondolja úgy, hogy jobb vagy lényegesen jobb a lakókörnyezete, addig borsodban ez csak 13\% körüli. Bár mindkét területen a többség úgy véli, hasonló a lakásának minősége, borsodban a válaszadók több, mint 42\%-a úgy érzi, hogy rosszabb vagy lényegesen rosszabb lakókörnyezetben él, mint a 2010-es árvíz elött (13. táblázat). Mindez összekapcsolódik a két árvizet követő helyreállítási munkák és állami beavatkozás mértékével.

13. A lakás minőségének megítélése az árvizes mintaterületeken Forrás: kérdőíves felmérés alapján saját számítás

\begin{tabular}{|c|c|c|}
\hline \multirow{2}{*}{ Hogyan értékeli jelenlegi lakásának minőségét az árvíz előttihez képest? } & \multicolumn{2}{|c|}{ Mintaterület } \\
\cline { 2 - 3 } & Bereg & Borsod \\
\hline Lényegesen jobb & $11,5 \%$ & $1,4 \%$ \\
\hline Jobb & $26,9 \%$ & $11,5 \%$ \\
\hline Hasonló & $37,4 \%$ & $45,1 \%$ \\
\hline Rosszabb & $21,5 \%$ & $35,4 \%$ \\
\hline Lényegesen rosszabb & $2,6 \%$ & $6,7 \%$ \\
\hline
\end{tabular}

Arra a kérdésre, hogy a lakókörnyezetben bekövetkezett változások hogyan hatottak a megkérdezettek életkörülményeire, illetve hogyan értékelik a katasztrófák utáni életminőségüket szinte minden mintaterületen azonos válaszok születtek. A katasztrófákkal érintett válaszadók szubjektív, saját életkörülményeire vonatkozó megítélését is megvizsgáltam. Feltevésem az volt, hogy azokon a településeken, ahol az érintettek nagyobb támogatást kaptak az életkörülmények javultak, vagy legalább is nem romlottak a katasztrófa előtthöz képest.

A válaszadók döntő többsége hasonlóan értékeli életkörülményeit. Ennek ellenére a mintaterületen választ adó, katasztrófával érintett népesség 34,9\%-a úgy érzi, hogy rosszabbul vagy lényegesen rosszabbul él, mint a katasztrófa előtt (31. ábra). Az árvizes mintaterületen élök nagyobb arányban - a válaszadók közel kétötöde - úgy érzi, hogy rosszabb vagy lényegesen rosszabb életkörülményeik vannak. Tehát a pozitív irányú településkép változás nem hozta magával az életkörülmények javulását ezeken a mintaterületeken. A válaszadók átlagosan 5-7\%-a érzi úgy, hogy életkörülményei javultak, Beregben ez az érték magasabb, 14\%. Mindez azonban a már említett indokokra, az eltelt időre illetve a kiemelt újjáépítési folyamatra vezethetö vissza. A mintaterületek közül a vörösiszap-sújtotta településeken vélekedtek a legnagyobb arányban úgy (közel 17\%), hogy lényegesen rosszabbak életkörülményeik a katasztrófa előtthöz képest, a vörösiszap-károsultak esetében ez az átlagostól további 8,5 százalékponttal magasabb értéket jelent. Mindezt annak ellenére, hogy szinte minden érintett egy újépítésü, lakóparki házat kapott Devecseren vagy Kolontáron. Mindennek értelmezéséhez nem elég azt 
elfogadni, hogy az érintettek szinte mindegyike magasabb komfortfokozatú, jobb minőségü házat kapott, de azt is szem elött kell tartani, hogy az új Makovecz-lakópark Devecser központjától több kilométerre, a város határában létesült. Ráadásul több esetben családi kötelékeket szakítottak szét, mely a roma családok esetében kiemelten nagy szereppel bír.

A mintaterületek közül a belvízzel érintett lakosok érzik úgy, hogy életkörülményeik hasonlóak, kevésbé változtak a katasztrófa hatására. Mindez annak fényében, hogy a változás fókomponenst pozitív irányban ezen mintaterület válaszadói erősítették meg leginkább, ellentmondásos (14. táblázat). Ez is alátámasztja, hogy az épített környezet átalakulása pusztán fontos, de nem egyetlen tényezője az életkörülmény és életminőség alakulásának.

14. táblázat: az életkörülmények szubjektív értékelése. Forrás: kérdőíves felmérés alapján saját szerkesztés

\begin{tabular}{|c|c|c|c|c|c|}
\hline & \multicolumn{5}{|c|}{ Válaszadók százaléka (\%) } \\
\hline Életkörülmény értékelése & Bereg & Borsod & Belvíz & Vörösiszap & Átlag \\
\hline Sokkal jobb & 2,52 & 0 & 0 & 1,41 & 1,00 \\
\hline Jobb & 11,48 & 5,01 & 6,52 & 5,63 & 7,38 \\
\hline Hasonló & 45,94 & 52,85 & 77,17 & 57,75 & 56,75 \\
\hline Rosszabb & 33,89 & 35,76 & 9,78 & 18,31 & 26,42 \\
\hline Lényegesen rosszabb & 6,16 & 6,38 & 6,52 & 16,9 & 8,44 \\
\hline
\end{tabular}

\subsubsection{A katasztrófákat követő segítségnyújtás szubjektív értékelése, az érdekérvénye- sítő-képesség megítélése}

Az életminőség és a lakókörnyezet javulásának a beavatkozásokhoz mérten alacsony aránya az elégedettlenség jele lehet az érintettek között. A kérdöíves felmérés keretein belül megkérdeztük a válaszadókat a segítségnyújtás és a kárenyhítés körülményeiről és módjáról. A mintaterületeken megkérdezettek közül nagy számban voltak azok, akik közvetlenül érintettek voltak bármely katasztrófával és nem kaptak semmiféle támogatást és kárenyhítést, azonban az érintettek százalékát tekintve sem az árvizes, sem a vörösiszappal érintett mintaterületen nem haladja meg a 25\%-ot (31. ábra). A belvizes mintaterületek esetében a megkérdezettek csupán 38\%-a volt közvetlenül érintett a belvízzel, azonban az érintettek valamivel több, mint 10\%-a kapott csak bármiféle segítségnyújtást a károk enyhítésében. Ez is mutatja, hogy bár mindhárom esetben jogszabályban rögzített természeti katasztrófáról van szó, a belvíz lakosságra és épületállományra gyakorolt hatásaival kevésbé foglalkozik a közbeszéd és ezáltal a kormányzat is (vagy fordítva).

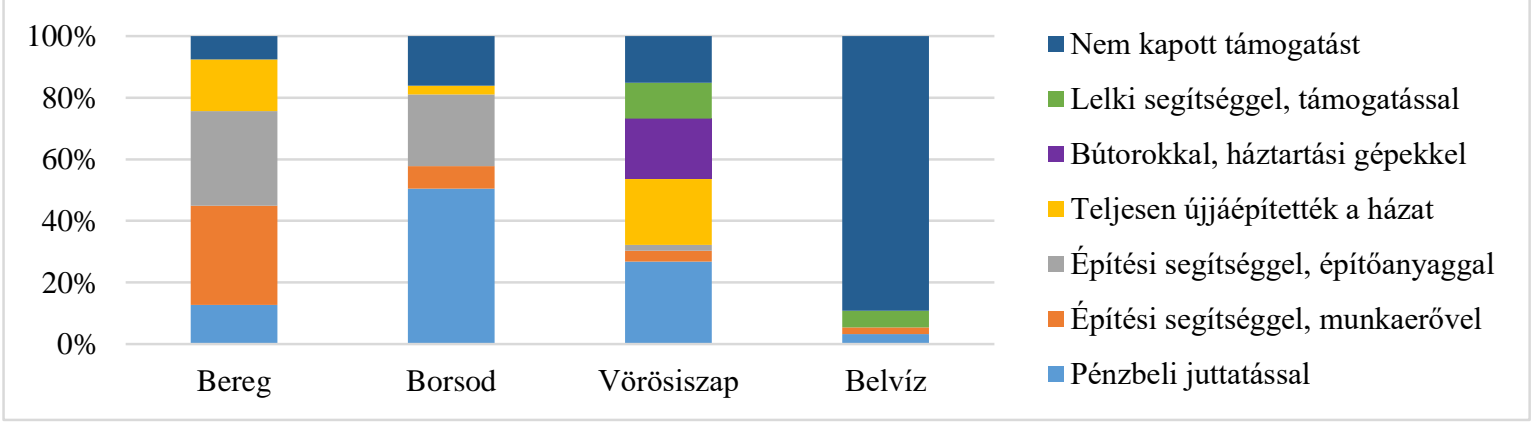

31. ábra: A kompenzáció és segítségnyújtás típusa Forrás: kérdőíves felmérés alapján saját szerkesztés

Az árvizes mintaterületek kárenyhítési eljárásának különbözősége megmutatkozik az érintettek kárpótlásának módjában: míg a beregi érintettek többsége építési segítséggel lett kárpótolva, addig a borsodi károsultak legnagyobb arányban pénzbeli juttatást kaptak. Az árvizes mintaterületek esetében nem volt lehetőség a bútor és háztartási gép, valamint a lelki segítség és támogatás válaszlehetőségek megjelölésére, ezek azért kerültek bele a későbbi kérdőívekbe, mert az árvizes mintaterületek felmérése során többen említették ezek fontosságát az újrakezdésben és újjáépítésben. A vörösiszap-károsultak 
voltak a legnagyobb arányban, akik új házat kaptak. Míg a belvízzel érintettek esetében a többség a már említett informális, morális segítséget tekintette a legfontosabbnak a segítség-típusok közül.

Arra a kérdésre is kerestem a választ, hogy a kapott segítséggel mennyire elégedettek az érintettek. A beregi mintaterület esetében egyértelmúen elégedettnek tekinthetjük a válaszadókat. Az ötfokozatú skálán a válaszadók többsége a középső, átlagos értéket jelöli, amikor semleges választ kíván adni. A borsodi és a vörösiszappal érintett mintaterületek esetében a bizonytalan válaszadók száma a legmagasabb. Ennek ellenére a vörösiszap által érintett válaszadók többsége elégedett a kompenzáció és segítségnyújtás mértékével. A borsodiak számszerüleg többségében elégedettek, azonban az elégedetlenek aránya jóval magasabb, $34,4 \%$ a másik kettő mintaterület $17,3 \%$-os és $24,5 \%$-os értékével szemben (32. ábra). Ennek hátterében az eltérő módú, „liberalizált”, helyi önkormányzatokra bízott kompenzációs feladatellátás állhat. Ez a fajta decentralizált támogatás a szubszidiaritás irányában hat, azonban az elmaradott, hátrányos helyzetü térségekben a helyi hatalom és alá-fölérendeltségi viszonyainak függvényévé teheti a támogatásokat. Ezek alapján feltételezésem volt, hogy a központosított újjáépítés esetében a helyi önkormányzat munkájával kevésbé elégedetlenek a lakosok, mint a liberalizált forgatókönyv esetében. Ennek érdekében megvizsgáltam, hogy a lakosok mennyiben tekintik a helyi önkormányzat, illetve az állam feladatának a katasztrófák megakadályozását és az általa okozott károk felszámolását.
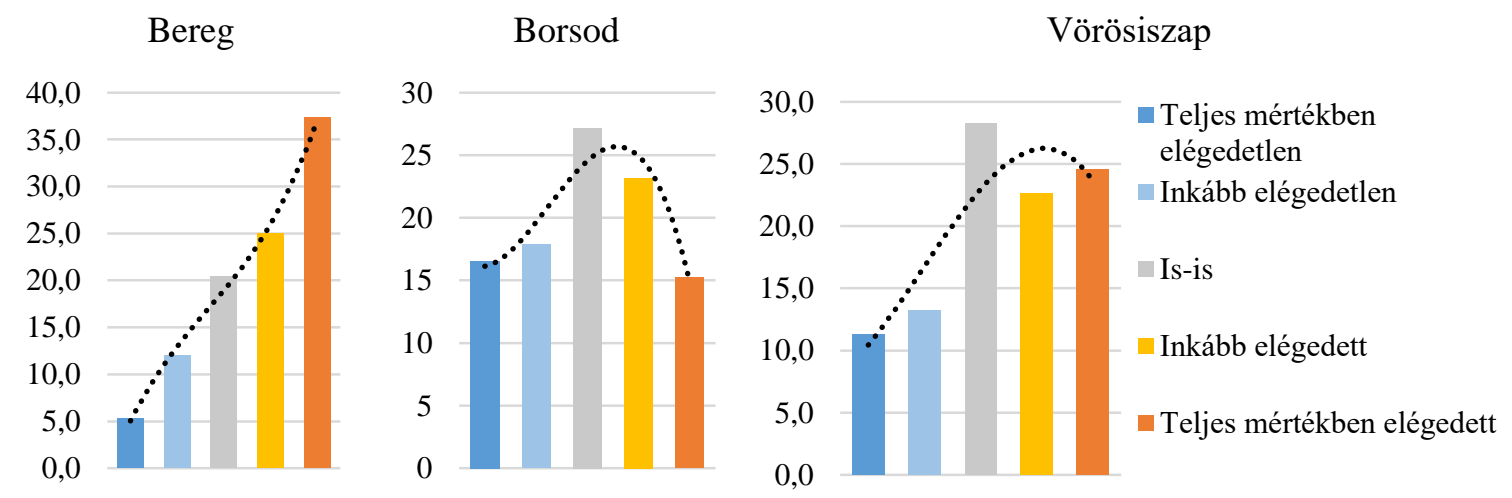

32. ábra: A kompenzációval való elégedettség a kiválasztott mintaterületeken. Forrás: kérdőíves felmérés alapján saját szerkesztés

A felvetés részben igazolódott, hiszen a központilag szervezett, a beregi, valamint a devecseri és kolontári újjáépítés és katasztrófa-elhárítás esetében a válaszadók 79,3\%-a, illetve 74,5\%-a gondolta úgy, hogy az önkormányzat mindent megtett, hogy segítsen a bajbajutottakon, a borsodi mintaterület esetében ez az érték csak 49,8\% (33. ábra). A polgármester helytállásáról hasonlóan vélekednek, $78,7 \%$, illetve $83,2 \%$ gondolta úgy, hogy a helyi vezető a maximális helytállást biztosította, a borsodi települések esetében a válaszadók 50,2\%-a gondolta így. Mindkét kérdés esetében a legtöbb borsodi érintett szerint sem a polgármester, sem pedig az önkormányzat nem tette meg a szükséges és kellő intézkedéseket a kárenyhítés érdekében. A belvizes mintaterületeken a borsodihoz hasonló folyamatokat figyelhetünk meg. Itt egyáltalán nem volt szervezett állami kompenzáció, az érintettek az önkormányzat és a biztosító megítélése alapján részesültek támogatásban, már, ha egyáltalán igényeltek bármiféle kártérítést. Azzal az állítással, hogy az állam minden segítséget megadott az újjáépítéshez a leginkább a beregiek, legkevésbé pedig a belvízzel érintettek értettek egyet. A belvíz, mint katasztrófa többitől való különbözősége, valamint az egységes állami kompenzáció hiánya okozhatja a nagymértékủ eltérést. Az állítással Beregben a válaszadók 93, Kolontáron, Devecserben és Somlóvásárhelyen 92, borsodban 58, míg Baktóban és Domaszéken a válaszadók csupán 27\%-a értett egyet (33. ábra). 


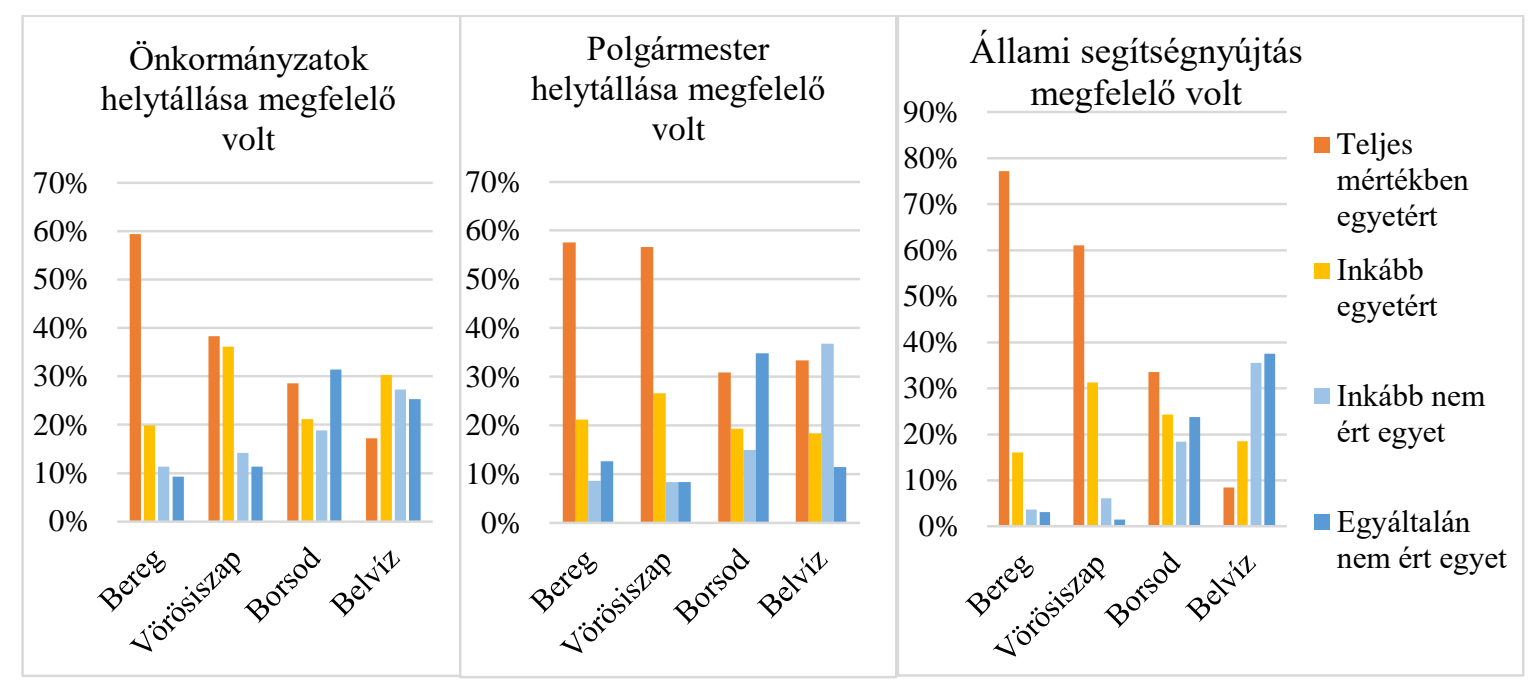

33. A helyi és központi hatalmi szervek helytállásának megítélése a mintaterületeken. Forrás: saját szerkesztés

Azt, hogy kizárólagosan az állam feladata lenne a katasztrófák okozta veszély elhárítása, a mintaterületeken élők másként látják. Az árvíz veszélyeztette mintaterületeken a válaszadók fele gondolja úgy, hogy az árvízvédelemért kizárólag vagy főként az állam tehet. Viszonylag magas azok aránya is, akik úgy vélik, hogy nem csupán az állam, de az önkormányzat és az emberek feladata is az árvízvédelem, mindez pedig a cselekvő társadalom irányába mutat, amelyben az egyén és a társadalom is aktívan kiveszi részesedését a felügyelet és a fenntartás munkáiból. Illetve a válaszadók kiemelték az önkormányzat szerepét is az árvízvédelemben. Jelenleg az önkormányzat közfoglalkoztatás útján tudja az árvízvédelmi létesítmények fenntartását elvégeztetni, ezáltal is statisztikailag csökkentve a munkanélküliséget.

Ennél magasabb, 84\%-os egyetértés mutatkozik a vörösiszappal érintett mintaterületen élők körében. Fontos megjegyezni, hogy az árvízvédelem jogszabály szerint is az állam feladata, azonban az ipari létesítmények biztonságáért nem az állam, hanem a tulajdonos a felelős, melyet az állam felügyel. Ennek ellenére a vörösiszap-károsultak úgy gondolják, hogy az állam kell, hogy akár egy szennyezö beruházás okozta kárt vagy veszélyt mérsékeljen. A válaszok alapján a jelenleg is meghatározó neoliberális és neokonzervatív gazdaságpolitika okozta környezeti feszültségek állami felszámolását, vagyis egy erősebb állami kontrollt kívánnak az érintettek az adott területen. Mindez olyan politikai és etikai kérdésekhez vezet, mely az állam gazdaságban való szerepvállalásának mértékéről szól. Felmerül a korábban említett kérdés, hogy az egyes piaci alapon müködő gazdasági aktorok etikusan fogják tevékenységeiket folytatni, hogy a legkevesebb kárt okozzák a környezetben, vagy olyan módon és ezzel párhuzamosan olyan helyen ténykednek, ahol a legkisebb társadalmi ellenállásba és állami kontrollba ütköznek. A vörösiszap-katasztrófa esetében utóbbi valósult meg, hiszen az évtizedek óta környezetszennyezően müködő MAL ZRt. a térség foglalkoztató-szektorában betöltött jelentős szerepét használta fel a környékben lakók hallgatása érdekében. Mindemellett a nem tisztázott jogi háttér adta kibúvókat is kihasználta, ezáltal minimálisra csökkentette a tározók ellenőrzését, a lehető maximális szinten tartva a környezetszennyezést és a veszélyhelyzetet. Mindezt nem a legkevesebb szennyezés, hanem a legmagasabb profit elérése érdekében tette. Bár látható, hogy az érintett lakosság a ,jó és paternalista állam" segítségét várja veszélyhelyzetekben, azonban a felelősség és az újjáépítés, valamint a kompenzáció is valójában a piaci szereplöket terheli, terhelné.

A belvízelöntéssel sújtott településeken élők gondolják legkevésbé úgy, hogy az állam feladata lenne a belvízvédelem, hiszen belvízelvezető árkok létesítésével és azok fenntartásával a lakosság is lehet a katasztrófahelyzet kialakulása ellen. Mindez ellentmond korábbi kutatások eredményeinek, melyek ugyan mezőgazdasági területek belvízmentesítésének feladatáról szólnak, a válaszadók $40 \%$ felett tartják úgy, hogy a kormány és az állam feladata a kármentesítése és belvíz elleni védelme. A válaszadók közel $30 \%$-a pedig úgy véli, hogy a helyi önkormányzatok, további $20 \%$ szerint a vízügyi hatóságok feladata (SZATMÁRI, J. - VAN LEEWEUN, B. 2013). 
A károk enyhítésében és kártalanításban nagy szerep jut a biztosító társaságoknak is. A teljes mintában a válaszadók többsége úgy véli, hogy a biztosítótársaságok nem fizettek kellő mennyiségü kártérítést a károk után. A belvízzel érintett települések esetében azonban többen megtagadták a válaszadást, mondván, hogy rájuk nem vonatkozik a kérdés, hiszen nem érintette őket a belvíz, vagy nem rendelkeznek biztosítással, ha mégis, akkor az belvízkárokra nem fizet. Az összes megkérdezett közül, akiket érintett a belvíz 53 fő nyilatkozott úgy, hogy bár őt érintette a belvíz, nem tudja megítélni, hogy megfelelő volt-e a kompenzáció mértéke, hiszen többségüknek nem járt biztosítás, vagy nem igényelt. Ez az összes megkérdezett közel egy ötöde. A biztosítással nem rendelkezök aránya ennél is magasabb, a megkérdezettek közvetlen érintettségtöl függetlenül 34\%-ának nincs biztosítása. A másik három mintaterület esetében ez az érték alacsonyabb, míg az árvizes területeken 106 fő nem tudta megítélni a biztosító által fizetett kompenzáció mértékét, főként mert nem rendelkezett biztosítással (12,5\%), a vörösiszappal sújtott települések esetében a válaszadók 10,9\%-a volt érintett közvetlenül a vörösiszap által és egyúttal nem rendelkezett biztosítással. Mindez tovább növeli a lakosok kiszolgáltatottságát a katasztrófákkal szemben. A katasztrófa után a biztosítás nélküli, illetve a biztosítással együttes állami kompenzáció több esetben helyi társadalmi feszültséghez vezet. Abban az esetben, amikor a károsult nem rendelkezik biztosítással konfrontálódik azokkal, akik rendelkeztek. Utóbbi csoport gyakran hangoztatja, hogy igazságtalan, hogy az öngondoskodók és előrelátók rosszabbul járnak. Előbbi csoport pedig azt hangoztatja, hogy akinek anyagi körülményei engedik, az duplán részesül kompenzációból. Ebben az esetben mind a helyi önkormányzat, mind az állam részéről a legfontosabb a szolidáris és főként méltányos igazságtétel, nem pedig a korábban már kifejtett egyenlőség-elvü igazságtétel. Mind az árvizes, mind a vörösiszappal érintett területeken volt olyan megkérdezett, aki az árvizet aranyárként, a vörösiszapot pedig aranyiszapként emlegette. Mindez utal a méltányos igazságtétel és kompenzáció egyenlötlenségére.

A kérdőívben a válaszadókat megkértük, hogy alkossanak véleményt a kompenzációs folyamatról. A belvizes mintaterületen összesen 9 fö gondolta úgy, hogy megfelelö mennyiségü pénzt kapott volna a károk felszámolására. Itt szintén a már említett okokra vezethető vissza az alacsony szám, hogy a lakosok többsége nem is igényelt kártérítést. A válaszadók közül többen említették, hogy a kártalanítási folyamat igazságtalansága abban rejlett, hogy például a mezőgazdasági károkat bérelt földekre nem térítették meg, így azok, akik nem tulajdonosai a területeknek de a tényleges termelő munkát végzik, azok jártak rosszul. Az érintettek közül többen tartják igazságosnak a kártérítés módját és mértékét (36 fö), mint ahányan nem (21 fö), viszont a válaszadók legnagyobb hányada nem tudott véleményt alkotni, mert vagy nem volt érintett, vagy nem rendelkezett biztosítással (187fó). Akik úgy gondolták, hogy nem volt igazságos a kártalanítási eljárás azért gondolják így, mert egyáltalán nem is tudnak ilyenről, ami alapvetően véleményük szerint igazságtalan. Van, aki arra panaszkodik, hogy nehéz a jogos pénzhez hozzájutni: „Nem mindenki kap kártéritést, ha mégis, akkor csak éves pereskedés után”. Mások szerint az, hogy kinek jár a kártérítés az a helyi hatalmi viszonyokon múlik: ,a hatalomhoz közel állók többet kaptak”, illetve a kárpótlás sem egyenlő: „mások többet kaptak hasonló kárral, nem volt megfelelö tájékoztatás” valamint az „újszerü házak megrongálódásakor nem kártalanitották megfelelöen az érintetteket".

A vörösiszap károsultak esetében a döntő többség úgy érzi, hogy nem kapott elegendő pénzt az újrakezdéshez ( 85 fö), miközben közel harmad annyian érezték úgy, hogy elégedettek a pénzbeli kompenzáció mennyiségével (28 fö). A kártalanítást megközelítőleg egyharmad-kétharmad arányban tartják meg,- illetve nem megfelelőnek (43 fö - 87 fö). Az elégedetlen válaszadók közül szinte mindenki (83 fö) kifejtette az elégedetlensége okát. A megjegyzések közül a legtöbb a kártérítési folyamat igazságosságát és igazságtalanságát méltatta. Egyesek úgy gondolták, hogy „,túlzott volt” a kártalanítás mértéke, mások pedig inkább azt emelték ki, hogy ,, valaki sokat kapott, valaki semmit, aránytalan volt a kártérités". Az aránytalanság érzete több okból ered a károsultakban. Egyrészt a válaszadók nehezményezték, hogy nem jutottak elegendő pénzhez, vagyis a részükre biztosított összeg nem fedezte a tényleges károkat. Másrészt az aránytalanság érzését fokozza, hogy vannak olyan károsultak, akik egyáltalán nem kaptak támogatást: „,Rohammentő vitt be, de nem kaptam kártéritést”. Bár a jogszabály rendelkezett az ingóságban és egyéb termelőeszközökben okozott károk felszámolásáról, annak teljeskörü teljesítése az érintettek egy része szerint nem valósult meg, így az egyenlötlen és igazságtalan 
elosztás érzete tovább erősödött az érintettek körében. Egyesek arra panaszkodtak, hogy több veszett oda, mint amennyi kompenzációt kaptak, hiszen ,,nem számoltak fel mindent, csak az eszközöket”, „,nem lett melléképület”, mert ezekre a kármentesítési eljárás nem terjedt ki. Egy válaszadó azért maradt ki a kompenzációból, mert nyugdíjas, így a munkagépeket neki nem fizették ki, mert nem aktív korú. Mások azt tartották problematikusnak, hogy „, az ingóság értékét és nem az elveszett dolgokat pótolták”, így az új eszközök megvásárlására nem jutott elég pénzük.

További elégedetlenséget szül a vörösiszap-kompenzáció esetében, hogy a jogszabály csak a közvetlenül érintett lakosok kártalanításáról rendelkezik. Azonban, ahogyan egy válaszadó említette a vörösiszap katasztrófa ,mindenkit ért, de nem mindenki kapott”. Vagyis a közvetetten érintettek semmiféle kárpótlást nem kaptak az államtól és a segélyszervezetektől, holott káruk a vörösiszap-katasztrófa közvetett eredménye. A remediáció és rekultiváció során a föbb utak mentén álló házak egy része a közlekedés okozta rezgéstöl megroskadtak, falaik megrepedeztek, azonban kártérítést ezért nem kaptak. Az egyik válaszadó szerint az egész katasztrófa mentálisan és fizikálisan is megterhelt mindenkit, a közvetlenül és közvetetten érintetteket is: „ez egy lelki terror, itt egész Devecser károsult, esély kell a tovább lépésre", és mindenkinek meg kéne adni a lehetöséget, hogy ezt feldolgozhassa. Nem feltétlenül csak anyagi eszközöket értve ez alatt.

A vörösiszap-katasztrófa utáni jogi procedúra a doktori disszertáció készítésének szinte minden fázisában új- és új fejleményekkel szolgált. A kérdőíves felmérés idejében, a katasztrófát követően három évvel már (a lakók szerint még mindig) zajló perek és vizsgálatok nehezítették a településeken élök és föként az érintettek mindennapjait. Többen a kompenzációs folyamat igazságtalanságának tartják, hogy „,perek vannak, ahol meg kell küzdeni a pénzü(n)kért. A legnagyobb problémát az jelenti, hogy a károsultak úgy érzik, hogy az eljárási idő hosszú, sokat kell várni a járandóságra, ,, a pereket ugyan megnyerik az emberek, de a pénz elfogyott", tehát mire a peres úton jogszerünek ítélt károk megtérítésére és kifizetésére kerülne a sor, addigra a rendelkezésre álló pénzösszeg már elfogy. Illetve félelmeiket fejezték ki azzal kapcsolatban, hogy „, az állam az első a bíróság elött, az ember az utolsó”, vagyis az érintettek attól tartanak, hogy az állammal szemben nem nyerhetnek. Mindez az egyén és az állam közötti alá-fölé rendeltségi viszonyt, a társadalmi bevonás és a jogállamiságba és igazságszolgáltatásba vetett bizalom hiányát jelezheti. Az ügy szempontjából fontos lehet az állam e narratívája, melyben ,az egyén” és ,,az állam” a független igazságszolgáltatás előtt nem egyenlő félként jelennek meg és felmerül az állami szervek hatalommal való visszaélésének lehetösége. Az állam szerepe és felelössége nem csak a vörösiszap-katasztrófában, de az árvizek esetében is megkérdőjeleződik, többen úgy gondolják az árvizes mintaterülteken, hogy az árvízi veszélyhelyzet megoldását jelenthetné, ha „,Parlament összetételének a megváltoztatása” megtörténne, olyan „,normális vezetöség” állna a védekezés és az újjáépítések élére, akik ,,szakképzett emberek, akik tudják mit kell tenni árviz idején”. Mások úgy vélik, hogy a katasztrófák esetén nem a politikai csatározásra és a politikai haszonszerzésre kellene fókuszálni, a ,pártok közötti megegyezés” ezekben az időkben elengedhetetlen kellene, hogy legyen, ezáltal ,,nem kellene a települést feláldozni” és ,,megszervezett [lehetne] a védekezés”.

Mindemellett nem csak az állam, de az önkormányzat tevékenységét is kritikával illették a válaszadók, föként azért, mert véleményük szerint az önkormányzat nem arra költötte a pénzt, amire kellett volna, nem állt ki megfelelően a lakosok és károsultak jogaiért. Egyesek szerint ,felületes volt a rekultiváció, az önkormányzat felélte a több milliárd forintot”. Az elégedetlen érintettek az alapvetö infrastrukturális és remediációs feladatokban is csak azt látták, hogy mindaz a pénz, amit elkölt az önkormányzat (melyre célzott, tehát csak az adott célra elkölthető támogatást kapott), azt nem a lakosok kártalanítására költik. „Autóbuszpályaudvar épült, de nem kompenzáltak” ráadásul ,,sok embert boszszantott, hogy inkább városszépitésre költötték el a pénzt” úgy, hogy például ,, az utak azóta sem lettek megcsinálva". A borsodi mintaterületen is hasonló vélemények merültek fel a pénz elosztásával és elköltésével kapcsolatban. A válaszadók egy része úgy gondolja, hogy priorizálni kell a fejlesztéseket, és elsődlegesen az árvízi védelemre kell fókuszálni. „,Megfelelő gátrendszer épitése, nem csak igérgetni. Nemcsak a kastélyt kéne felújítani”. A borsodi kártalanítás liberalizálása miatt az érintettek inkább az önkormányzatot hibáztatták, mint az állam felelősségét kérdőjelezték meg, egyesek úgy vélik, hogy „magasabb képzettségü szakemberek az önkormányzatnál” megoldhatták volna az árvíz idején felmerült problémákat. 
A kompenzációs folyamat egyenlőtlensége alapvetően társadalmi feszültséget szül, viszont az össztársadalmi érdeket tekintve a legkevésbé hagyja magára a társadalom depriváltabb rétegeit. A vörösiszap-katasztrófa utáni kompenzációs eljárásban többek ,, a logika hiányát”, ,, a másodlagos elosztás hiányosságait" hangsúlyozzák. Mindez véleményük szerint társadalmi igazságtalanságot és feszültséget keltett. Az elosztási logika az érintettek véleménye szerint a fentebb említett méltányosság és egyenlőség elv ellentmondásai miatt volt hibás, mert ,, annak, akinek rossz háza volt az újat kapott, akik dolgoztak rosszabbul jártak”, ,, akinek sok volt, az keveset kapott, mások vályogházért kaptak szép házat”. Az érintettek több esetben tehát a méltányosság helyett az egyenlöség elvét tartották volna helyesnek és igazságosnak a kompenzáció során. A kártalanítási folyamatban a roma-kérdés is többször felmerült. A károsultak egy része föként azt tartotta igazságtalannak, hogy a romák sokkal kevesebb értékkel rendelkeztek, mégis ugyanannyi kárpótlást kaptak. Az indulatokat és a feszültséget jelzi a vélemény kinyilvánításának módja: ,,aki dolgozott szarul járt, a romák bezzeg jól”. A mintaterületeken készült interjúkat és kérdöíveket is végigkíséri a romák és cigányok, mint etnikum munkanélküliséggel azonosítása, ,, a dolgozók, magyarok keveset, a romák sokat, ők nem dolgozók”, mindez azért aggályos és a környezeti rasszizmus jegyeit mutatja, mert a nem roma károsultak úgy gondolják, hogy az őket ért ipari katasztrófa utáni kompenzációjában nekik nem alanyi, hanem vagyoni és társadalmi-gazdasági státuszuk alapján több jár. A nem roma válaszadók e véleménye alapján arra következtethetünk, hogy a romák hátrébb valók a kárpótlási sorrendben, pusztán azért, mert kisebb értékü ingatlannal, kevesebb ingósággal rendelkeznek, vagy éppen mert nincs munkájuk. A kialakult helyzetben több károsult megjegyezte, hogy „, akinek volt bukott, akinek nem, az kapott 150 ezerböl igy lett 15 millió”, ,, a putrikat túlértékelték, a nagy házakat pedig alul”. Mindezek ellenére a disszertáció elméleti részében lefektetett igazságosság-definíció szerint a lefolytatott kártalanítási eljárásban a méltányosság elvét alkalmazták, mely bár egyenlőtlen, de igazságosnak tekinthető. Azonban a méltányos kárpótlás hátránya, hogy a társadalom pozitívan diszkriminált szeletét kirekesztik, illetve megszólják az érdemen és jusson felüli kárpótlás miatt, ezáltal növelve a korábban is létező társadalmi törésvonalakat. A katasztrófa után sajnos a kedélyek csillapítására és a társadalmi megbékélés elősegítésére a kellőnél kevesebb figyelem irányult, mely a radikalizálódás irányába hatott, mind politikai, mind pedig a mindennapi közbeszéd tekintetében. Az árvizes mintaterületeken, föként a Sajó és Bódva-völgyi települések válaszadói érezték a kialakuló roma-magyar ellentéteket, azonban kialakult egy másik törésvonal a közvetlenül és a közvetetten károsultak között.

A méltányos kárpótlással kapcsolatban probléma akkor merül fel, mikor a kompenzációs eljárásban a hatalommal való visszaélés tetten érhető. Ezt a vörösiszapos és a borsodi mintaterület esetében a vizsgálataink bebizonyították. A vörösiszap-katasztrófával érintettek közül többen arra panaszkodtak, hogy a kárpótlásra szánt pénzzel vagy egyéb juttatással (bútor, élelemiszer stb.) visszaéltek. A visszaélésnek több módja is lehetséges, egyrészt az egyén részéröl, másrészt pedig intézményesült formában, a hatalmi pozícióban lévők élnek vissza helyzetükkel. Az első esetben, az egyén a kárpótlás, vagy magasabb összegü kompenzáció megszerzése érdekében valótlant állít: „,sokan hazudtak és így kaptak pénzt, anyagot”, tehát a megkérdezettek egy része szerint „,nem volt jogosult sok ember”. A visszaélés nem egyéni, hanem intézményi oldalról történő megnyilvánulása lehetséges például a katasztrófával érintett területek átrajzolása, módosítása ,olyan utcákba adtak kártalanitást, ahol nem is volt iszap, a teherautók nem jártak”, vagy ,,romboltak le házakat, amiket nem kellett volna, nem mindig volt indokolt”, mindezt azért, hogy kártérítéshez jussanak vagy éppen attól elessenek adott lakosok. Mindez a hatalmi pozíciót tovább erősíti, a közfoglalkoztatási programokkal kapcsolatban több esetben említik, hogy a pozícióhoz a helyi vezetőséghez lojálisnak kell lenni, annak odaítélését a helyi önkormányzat vagy akár a polgármester mint „foúri kegyet” gyakorolja. A visszaélés másik módja az átláthatatlan kompenzációs folyamat során az „uram-bátyám” alapú pozitív diszkrimináció. Több érintett úgy gondolja, hogy ,, nem volt etikus [a pénzosztás], aki a tüzhöz közel volt, az nyert”, vagy, hogy a koordinátorok ,elosztották maguk között, nem osztották ki a segélyt”, vagy, ha kiosztották, ,a pénz pofára ment". Természetesen minden eljárásban elöfordul elégedetlenség, így nem állítható, hogy az érintettek állítása tény. Mindazonáltal, nem csak Devecseren, de a borsodi mintaterületen is akadtak olyan válaszadók, akik úgy gondolták, az eljárás nem volt teljesen igazságos, szerintük a folyamat egyenlőbb lehetne, ha „újabb felmérések [mellett], enyhitenék a károkat, [és] nem csak azokat támogatn[nák], 
akik közel voltak a tüzhöz. Éppen ezen vélemények miatt fontos az elégedetlenség okát feltárni, hiszen egy következö katasztrófa alkalmával tudatosan csökkenteni lehet az elégedetlenséget. A nem megfelelö és nem kellően átlátható kártalanítási folyamat tematizálhatja a közbeszédet és gyakran merülnek fel olyan vádak, hogy a kártérítést kezelők szereztek anyagi hasznot a folyamatban. Az olyan válaszok, mint az , elosztották maguk között, nem osztották ki a segélyt” vagy az ,elrakták a pénzt” nem bizonyítható, azonban az érintetteknek magyarázatként szolgálhat, hogy miért is nem lettek kártalanítva, legyen vagy sem bármiféle alapja a kijelentéseknek. A vörösiszappal érintett területeken felmerülö vádaskodások nem egyediek, hiszen például az árvizes mintaterületeken megoldási javaslatként merült fel az árvízi veszélyhelyzet mérséklésére, hogy „, ha a polgármester nem lopná el a pénzt, akkor lenne a töltés felújitására”. Amennyiben ténylegesen nem történt hatalommal való visszaélés (ilyen irányú bejelentés és vizsgálat nincs (és nem is volt) a katasztrófával kapcsolatban), úgy a kártalanítás során a megfelelő információ biztosításával átláthatóbbá és mindenki számára hozzáférhetőbbé, nyíltabbá lehet tenni a folyamatot, mely segítségével elkerülhetők az alaptalan vádaskodások. A nyílt és betekinthető eljárások nem csak növelhetik a lakossági bizalmat, de a korrupciót és a hatalommal való visszaélés lehetöségét is csökkentik. Az árvizes mintaterületen több válaszadó említette, hogy az árvíz-probléma megoldása az lenne, ha ,,jobb kommunikáció [lenne az] árvizkor”, és így a „megfelelö információ áramlás” segítene, hogy megfelelö időben ,megfelelöen lehessen lépni”.

Probléma eredhet abból is, hogy a helyi hatalmi viszonyokat felhasználva föként a depriváltabb, több esetben roma lakosság hátrányos helyzetét fokozta az önkormányzat pénzosztási és döntési mechanizmusa. Mindez egy ellensúlyozási folyamat eredménye. Interjúalanyaim közül többen is megerősítették a roma lakosság körében tapasztalt, a támogatási összegekkel és segélyekkel való visszaélést, melynek következtében a roma igényeket inkább alulbecsülték vagy nem vették komolyan. „, $A$ végén már nem lehetett nekik parancsolni. Volt ez a raktár, amit önhatalmúlag elkezdtek saját maguk kipakolni. Ennek véget kellett vetni. Meg kellene tanitani nekik, hogy nem minden jár".

Az elégedetlenséget növelheti, hogy a vörösiszap-katasztrófa kártalanítási folyamatában bár biztosítottak betekintést és módosítási lehetőséget a tervekbe, egyesek úgy érzik, hogy mégis kényszerpályára voltak állítva, nem volt tényleges választási lehetőségük. Erre utalhat az, hogy ,kikötötték, hogy hol lehet levásárolni azt az összeget, amit kaptak” illetve, hogy „,nem volt választási lehetöség, hogy hova" építsék újra az ingatlanokat. Azok, akik az ajánlott választási lehetőségtől eltértek, azok nem jártak jól, állítja a károsultak egy része.

Boldva esetében a környezet minőségét javító intézkedésekhez, például a vízelvezető rendszer kiépítéséhez igen érdekes a helyiek hozzáállása. A lakók szerint a beruházás csupán látszat keltése, tényleges jelentősége nincs. Ez a sok alkalommal elökerülő vélemény is mutatja, hogy a telep lakói nem feltétlenül értik meg a csatornázás hasznát, csak azt tapasztalják, hogy pillanatnyilag mindennapi életükben megzavarták őket, annak ellenére, hogy a program ténylegesen az életminőség javítását célozza. A lakók attitüdje folyamatellenes, mely a gátrendszer kiépítése után megváltozott, pozitív és támogatóvá vált. Ennek ellenére a kiépült gát épségére nem ügyeltek, pár hónappal később már ösvényeket tapostak a patakhoz.

A kompenzációval való elégedettségre vonatkozó kérdéseket összevontam egy fökomponensbe és megvizsgáltam, hogy Boldván, települési szint alatt, hogyan változik. A létrehozott fökomponens 52,4\%-os adatmegőrzéssel alkalmas volt a véleményekre vonatkozó kérdések adatredukciójára. Az így létrehozott fökomponens 0,472 és 0,581 közötti kommunalitás értékekkel jött létre. Az elégedettség lakóhely alapján is elkülönül, ́gy térbeli különbségeket mutat (34. ábra). Mivel a skála 10 osztályzatot tartalmazott, ezért a magasabb értékek az általános elégedettséget, míg az alacsonyak az elégedetlenséget tükrözik. Szembetünő, hogy az összes utcában tapasztalható középértékhez, inkább a semlegességhez való közelítés, melyből kivételt képez a Kővágó utca lakossága. Az utca a telep szélét jelenti, attól elkülönülten, egy domboldalon. Ezért ez a terület az áradások alkalmával nincs veszélyben. A legalacsonyabban a Damjanich, illetve a Rezeda utca fekszik, közvetlen az Ördög patak közelében, azonban a lakosok elégedetlensége kisebb mértékü, mint az Akác illetve a Vörösmarty utca lakóié, ugyanis míg 
az előbbi két utcában az összes ház támogatást kapott, addig utóbbiakban van olyan ház, mely lakhatatlanná van nyilvánítva, mégis lakják. Ezt az eltérést feltehetőleg az egyenlötlen segítségnyújtás eredményezi.

\begin{tabular}{|l|c|c|c|}
\hline \multicolumn{3}{|l|}{ A lakcím és az elégedettség fökomponens összefüggései } \\
\hline Lakcím & $\begin{array}{c}\text { Elége- } \\
\text { dettség }\end{array}$ & $\begin{array}{c}\text { Elem- } \\
\text { szám }\end{array}$ & Szórás \\
\hline Damjanich utca & $-0,1931$ & 5 &, 4258 \\
\hline Diófa utca & 0,0877 & 11 &, 9448 \\
\hline Akác utca & $-0,3424$ & 6 &, 8253 \\
\hline Pipacs utca & 0,2890 & 9 & 1,1517 \\
\hline Rezeda utca & $-0,0246$ & 12 & 1,0404 \\
\hline Kövágó út & 1,3016 & 5 &, 6215 \\
\hline Vörösmarty utca & $-0,4504$ & 15 &, 9114 \\
\hline Összesen & & 63 & \\
\hline
\end{tabular}

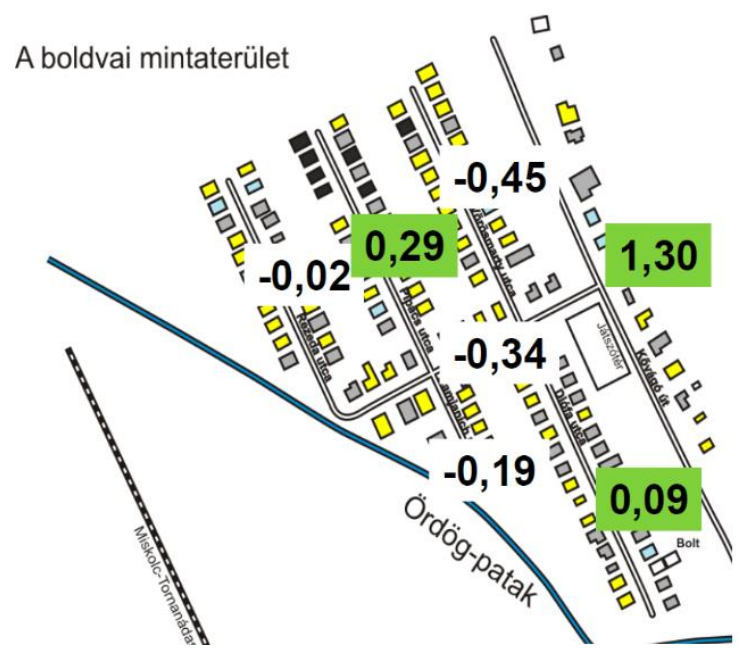

34. ábra: A lakcím és az elégedettség főkomponensének összefüggései. Forrás: kérdőíves felmérés alapján saját szerkesztés

Az egyenlőtlen támogatások a mikroközösségben is konfliktusokat generálnak, nehezítve az öszszetartást, bár az ellentétek szomszédsági szinten nem jellemzőek. A megkérdezettek 74,6\% szerint a környezet állapota akkor sem lenne jobb, ha mások lennének a szomszédjaik, azonban gyakran előfordult olyan megjegyzés, hogy „ez az utca rendes, a másik csinálja a bajt”, mely utal az utcák közötti nézeteltérésekre.

A környezeti konfliktusok hatása a fentebb említett példák mentén tapasztalhatóan politikai, szociális és gazdasági problémákkal ötvöződik, többszörösen összetett krízishelyzeteket idézve elő. Ezért a kialakult, komplex eseteket, kockázatokat, veszélyeket elemeiben szükséges vizsgálni, azokra egyedi, minden összetevője esetében gyakran különböző, egymással mégis összeegyeztethető módszerekkel kell kezelni, és/vagy felkészülni rá (NAGY GY. 2014). A kialakult krízishelyzetek a biztonságérzetre és ezzel párhuzamosan annak hiányára, a félelem észlelt dimenzióira is különbözöképpen hatnak. Ezért ennek elhárítása, vagyis a félelem-érzet csökkentése is az egyén és csoportok szubjektív véleményén kell, hogy alapuljanak. A félelem és a környezeti konfliktus közötti kölcsönkapcsolat gyakorta szinergikus, egymást erösítő hatással bír, minél nagyobb a környezeti konfliktussal kapcsolatos félelem, annál inkább fokozza a konfliktus minden dimenziójában tapasztalható elégedetlenséget. Korábbi árvízzel kapcsolatos hazai kutatásaink (KISPÁL J. - NAGY GY. 2016; KINCSES B. ET AL. 2016) bebizonyították, hogy az emberek félelem- és biztonságérzete nem feltétlenül a már meglévő, problémát megoldó fejlesztések alapján alakul ki, hanem föként a korábbi negatív tapasztalat útján, egyfajta imprintként megmarad az érintettekben. Ezért például akik már korábban éltek meg nagyobb árvizet, ők tisztában vannak az árvízi kockázatokkal, jobban tartanak tőle, azonban azok akik nem tartják veszélynek, valószínüleg a kiépült árvízvédelmi fejlesztés tükrében adták válaszukat. Ez okozhatja, hogy annak ellenére, hogy az árvizes, mind a vörösiszappal érintett mintaterülteken megtörténtek a szükséges beavatkozások a lakosok többsége szerint további beavatkozások lennének szükségesek, és több szakértöre lenne igény. Az árvizes mintaterületen 713 fő adott javaslatot az árvízi kockázat csökkentésére, melynek többsége ( $80 \%$ felett) a gátak megerősítését, további beruházások, víztározók létesítését stb. tartják a legfontosabbnak. Tették ezt annak ellenére, hogy a védmüvek megújultak, illetve több esetben újak is kiépültek (Melléklet 9.1.1). Azonban nemcsak a müszaki beruházások, hanem a kármentés és kártalanítás során a szakemberek hiánya is megjelenik a válaszadók véleményében, melyre több megoldási javaslat is született. Mindezt annak ellenére állítják, hogy a többség korábban úgy nyilatkozott, hogy a szomszédok segítették egymást a katasztrófa alatt, és hogy az illetékes hatóságok is többnyire helytálltak a körülményekhez képest. A lakosság által kínált megoldási javaslat az árvizes mintaterületeken 
több esetben arra épül, hogy az embereket nem szétválasztani kellene a kártalanítási eljárásokkal, hanem igyekezni kellene öket összefogni. Ehhez ,jobb vezetés, több odafigyelés, rátermettebb emberek kellenek, és hogy legyenek egymással megértöbbek az emberek.” Úgy gondolják a válaszadók, hogy leginkább „,pénzre és összefogásra lenne szükség, ehhez megfelelö embereknek kéne irányitani, részletes tervek kellenek”. ,Szakemberek kellenének, akik értik a dolgukat és össze kellene fognia az embereknek". Az odafigyelés és az emberi összetartás, a lakossági szolidaritás véleményem szerint azonban nem valósul meg, ha a katasztrófával sújtott területeken az információ áramlás nem teljeskörüen biztosított, ezáltal alapot ad mindenféle spekulációnak és alaptalan vádaskodásnak, mely a széthúzást erösítheti az érintettek közösségében vagy akár az érintettek és nem érintettek között is.

\subsection{5. Érdekérvényesítő képesség megítélése}

A környezeti igazságosság szakirodalma rendszerint kiemelten fontos tényezőként kezeli az érdekérvényesítő képességet, mivel a deprivált társadalmi csoportok, melyek általában a leginkább kitettek az igazságtalan helyzeteknek, az őket érintő hatalmi döntéseket kevésbé tudják befolyásolni, illetve az életüket közvetlenül meghatározó kérdésekbe is csak korlátozottan tudnak beleszólni (NAGY GY.BOROS L. 2015). Ezáltal az esetleges, alapvetően természeti okokra visszavezethető igazságtalanságokat társadalmi kontextusba lehet helyezni. A katasztrófákat követő helyreállítás és a kártalanítási folyamat igazságosságának megítélése függ az egyén személyes érdekérvényesítő képességétől. Minél erösebben tudja érvényesíteni akaratát a helyi döntésekben, annál valószínübb, hogy elégedett lesz a folyamattal. Fontos elem továbbá, hogy az egyént és érdekeit mennyire képes más, döntéshozói pozícióban lévő képviselni. Kiemelten fontos lehet például a kisebbségi csoportok esetében a képviselet kérdése.

A boldvai cigánytelepen a megkérdezettek átlagosan a helyi önkormányzat munkáját ítélték a legjobbnak, véleményük szerint viszont pont az érdekeiket képviselni hivatott szerv, a kisebbségi önkormányzat képviseli legkevésbé érdekeiket. A megkérdezettek között a megyei szint szinte ismeretlennek bizonyult, mint beavatkozási szint (20 hiányzó válasz). A lakók problémáinak megoldását elsődlegesen a helyi önkormányzattól várják. A kérdőívben 1-10 pontos skálázási lehetőség volt, azonban voltak megkérdezettek, akik kifejezetten kérték, hogy 0-ás értékelést adhassanak, így adták tudtomra elégedetlenségüket a helyi, illetve országos politikával szemben (15. táblázat). Megfigyelhetö, hogy mind a medián, mind az átlag értékek igen alacsonyak.

A válaszadók 23,8\%-a szerint csak helyi szinten, 34,9\%-a szerint helyi és országos szinten is ér a szavazata, és beleszólhat a döntéshozásba. 36,5\%-a vélekedik úgy, hogy nincs beleszólása a politikába, 4,8\% nem tudja vagy nem válaszolt a kérdésre (15. tábázat). Látható, hogy a megkérdezettek bíznak a szavazati jogukban, és hisznek annak változtató hatásában.

15. táblázat: Az önkormányzatok megítélése a megkérdezettek alapján

\begin{tabular}{|c|c|c|c|c|}
\hline & & $\begin{array}{l}\text { Mennyire képviseli } \\
\text { az ön érdekeit a ki- } \\
\text { sebbségi önkor- } \\
\text { mányzat? }\end{array}$ & $\begin{array}{l}\text { Mennyire képviseli } \\
\text { az ön érdekeit a he- } \\
\text { lyi önkormányzat? }\end{array}$ & $\begin{array}{l}\text { Mennyire képviseli } \\
\text { az ön érdekeit a } \\
\text { megyei önkor- } \\
\text { mányzat? }\end{array}$ \\
\hline \multirow{2}{*}{ Elemszám } & Érvényes & 58 & 61 & 43 \\
\hline & Hiányzó & 5 & 2 & 20 \\
\hline \multicolumn{2}{|c|}{ Átlag } & 2,57 & 5,26 & 3,95 \\
\hline \multicolumn{2}{|c|}{ Medián } & 1,00 & 5,00 & 2,00 \\
\hline \multicolumn{2}{|c|}{ Szórás } & 2,676 & 3,415 & 3,498 \\
\hline
\end{tabular}

Ez a környezeti igazságosság szempontjából különösen fontos, mert annak ellenére, hogy a környezeti állapot az áradások miatt igen rossz, a szubszidiaritás az emberek elméjében él. Ennek ellent mond azonban a képviselet értékelése, mely inkább rossz, mint átlagos, 3 közeli értékeléssel 10 fokozatú skálán, mely bizonyítja, hogy annak ellenére, hogy a megkérdezettek bíznak szavazatukban a kisebbségi, települési és a megyei önkormányzatoktól nem kapják meg a megfelelö beleszólást, hiszen elégedetlenek müködésükkel. 
A belvizes mintaterület esetében a megkérdezettek 52\%-a értékelte érdekérvényesítő képességét a településükön élőkéhez hasonlónak. Jellemzően ez tekinthető a legkézenfekvőbb válasznak a lakosok számára, amit az is mutat, hogy mindkét mintaterületen $50 \%$ körüli volt az így válaszolók aránya, ami a „középre húzás” attitüdjét jelzi (35. ábra).

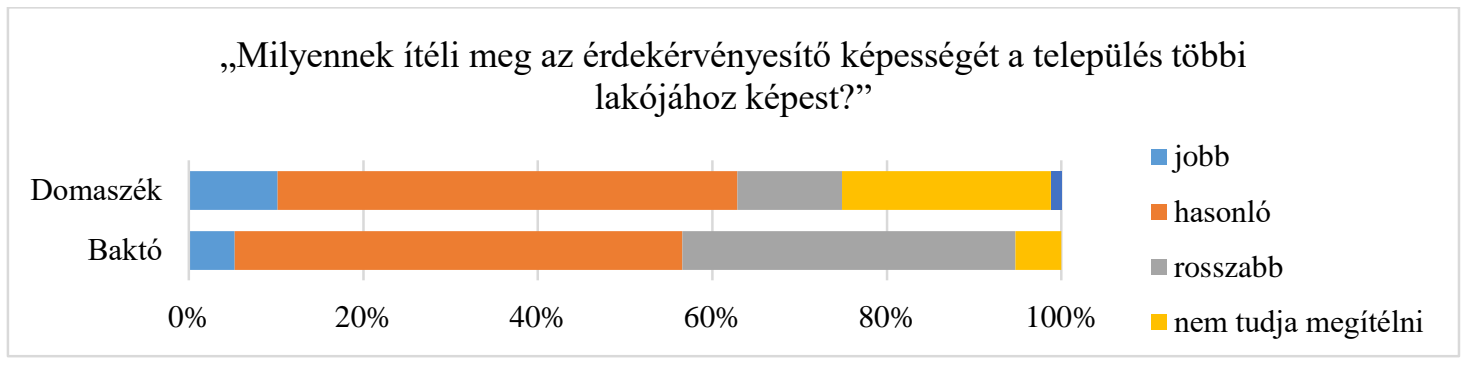

35. ábra Az érdekérvényesítő képesség megítélése a belvizes mintaterületeken, települési bontásban. Forrás: kérdőív alapján saját szerkesztés

A belvízzel való érintettség és az érdekérvényesítés megítélése közti kapcsolatról a teljes minta alapján kevésbé vonhatók le következtetések. A mintaterületek adatait külön megvizsgálva látszik, hogy a baktóin élők, akik érintettek a belvízzel, sokkal negatívabbnak értékelik saját helyzetüket, nagyobb arányban ítélik meg rosszabbnak a környezetük életébe való beavatkozás képességét, mint a problémával nem érintett lakosok (16. táblázat). Domaszéken szintén rosszabbnak értékelték a belvízzel érintettek saját érdekérvényesítési képességüket a nem érintettekhez képest, ám a Baktón tapasztalhatónál kisebb mértékben.

16. táblázat. Az érdekérvényesítés és a belvízzel való érintettség kapcsolata. Forrás: kérdőív alapján saját szerkesztés

\begin{tabular}{|c|l|l|l|l|}
\hline Milyennek ítéli meg érdekérvényesítő képességét a telepü- & \multicolumn{2}{|l|}{ Érintett-e Önt belvíz? } \\
\cline { 2 - 5 } lés többi lakosához képest? & \multicolumn{2}{|c|}{ igen } & \multicolumn{2}{|c|}{ nem } \\
\cline { 2 - 5 } & Baktó & Domaszék & Baktó & Domaszék \\
\hline jobb & $0 \%$ & $6 \%$ & $11 \%$ & $10 \%$ \\
\hline hasonló & $46 \%$ & $52 \%$ & $48 \%$ & $58 \%$ \\
\hline rosszabb & $54 \%$ & $35 \%$ & $14 \%$ & $10 \%$ \\
\hline nem tudja & $0 \%$ & $6 \%$ & $27 \%$ & $20 \%$ \\
\hline nem válaszol & $0 \%$ & $0 \%$ & $0 \%$ & $2 \%$ \\
\hline
\end{tabular}

Megjegyzendő, hogy míg a vidékies jellegü Domaszéken nagyobb fokú a belvízzel való érintettség, addig az érdekérvényesítő képességüket összességében jobbnak ítélik meg az itt élők. Ezzel szemben Baktó, amely térség az eredmények alapján Domaszékhez képest kevésbé érintett a belvízzel, sokkal rosszabbnak látja saját érdekérvényesítési lehetőségeit, ami utalhat depriváció jelenlétére. A belvíz egyik területen sem a legnagyobb problémaként azonosítható, viszont erre a problémára a domaszéki falusi közösség összetartóan, többnyire egymást segítve reagál, míg Baktó esetében inkább széthúzás figyelhető meg az adatok alapján.

\subsubsection{Tájékoztatás és információ-hozzáférés a mintaterületeken}

Korábbiakban bemutatott, az érintettek körében tapasztalt elégedetlenség a részben a kártalanítási folyamat átláthatóságának és a nyilvánosság hiányának is köszönhető. A környezeti igazságtalanságok kialakulásának egyik az elméleti részben is kifejtett eleme az információ és a tájékoztatás hiánya, mely nélkül az érintettek a rendelkezésre álló lehetőségek ismerete nélkül kénytelenek döntéseket hozni, cselekedni. Ennek következtében a katasztrófák következtében kialakult traumatikus állapotban, valamint a cselekvéskényszer hatására a deprivált rétegek hátrányos helyzetbe kerülhetnek. A mintaterületekn élőket megkérdeztük arról, hogy mit gondolnak a katasztrófa közbeni és az azt követő tájékoztatás minőségéről. Mennyire voltak beavatva, milyen mértékben tudták átlátni és követni a környezetükben zajló folyamatokat (36. ábra). 
A két belvizes mintaterületen a válaszadók összességében mintegy 50\%-a tartotta megfelelönek az informálást, ebből 32\% teljes mértékben, 18\% pedig többnyire megfelelőnek. A megkérdezettek közel negyede (26\%) volt ezzel ellentétes véleményen, illetve közel azonos arányban (24\%) voltak azok, akik nem tudták megítélni a kérdést, ők föként a belvíz által nem érintett válaszadók köréből kerültek ki. A domaszéki válaszadók sokkal inkább elégedettek a belvízzel kapcsolatos tájékoztatást illetően, 46\%-uk teljes mértékben, 23\%-uk többségében elégedett volt azzal. Ezzel szemben Baktón a válaszadók csupán 10\%-a volt valamilyen mértékben elégedett, 39\%-a pedig egyáltalán nem tartotta megfelelőnek az informálást. A baktói mintaterületen nagy arányban (51\%) voltak azok, akik nem tudták megítélni a tájékoztatás megfelelöségét.

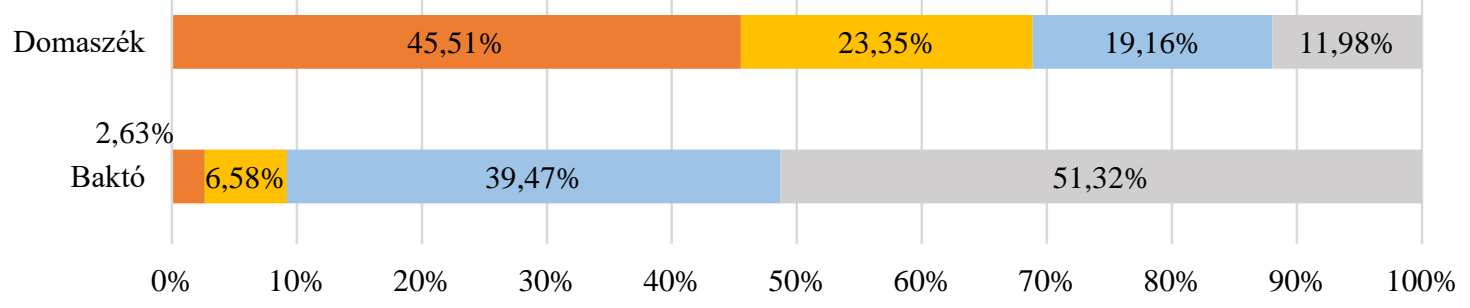

—Igen, mindig megfelelően tájékoztattak $\square$ Igen, de sok dologról nem tudunk $\square$ Nem $\square$ Nem tudja megítélni

\section{6. ábra: a belvizes mintaterületek válaszadóinak véleménye az információ-elérhetőségről. Forrás: sa-} ját szerkesztés

Akik nem voltak megelégedve az informálás mértékével, véleményük három fö szempont alapján csoportosítható. Egyrészt vannak olyanok, akik úgy gondolják, hogy a tájékoztatás mértéke nem volt megfelelö (1). Többen állítják, hogy a károsultaknak , lehetöségekről semmit nem mondtak, hazudtak a támogatásokról”. A válaszadók másik csoportja úgy véli, hogy a belvízelöntést követő kártalanítás szervezetlen és koordinálatlan volt (2). Az embereket és az illetékeseket felkészületlenül érte a belvízelöntés ,,nem volt terv arra, hogy ha belvízi probléma van, kihez tudunk fordulni”. A koordináció hiányát az okozhatta, hogy a válaszadók szerint „,nem volt olyan személy (?) aki átlátta volna a helyzetet”, illetve, hogy az illetékesek és érintettek ,későn, csak a végén intézkednek, amikor a baj van'. Nem volt összehangolt beavatkozás, nem tartottak falugyülést, sem fórumot. A válaszadók harmadik csoportja a kiszolgáltatottságot és az egyedüllétet (3) emelte ki a katasztrófa-helyzetben. A válaszadók úgy gondolják, hogy ,egyénileg kell megoldani a [belviz] problémát. Akit pedig nem érint, nem foglalkozik a problémával”. Az érintett lakosok így úgy érzik, hogy a lakosokat magukra hagyják, ráadásul a többi mintaterület esetében tapasztalt lakossági és szomszédsági kohézió sem valósult meg, mert ,,senki nem fogott össze, mindenki magát akarta menteni”. Mindemellett a baktói mintaterületen a megkérdezettek többsége nem értékelte nagy problémának az ilyen jellegü informálás hiányát, sokak szerint nem is lett volna rá szükség. Ez ugyancsak igaz volt a belvízzel jobban érintett kiskerti lakosokra. Az interneten elérhető cikkek alapján a baktói kiskertekben élők prioritásaként inkább a megfelelő utak kiépítését és a telkek nagyobb százalékú beépítésének kiharcolását tartják a legfontosabbnak a településrészen. A városi környezetben végzett kutatás eredményei így ellentmondanak korábbi Intézetünkben lefolytatott kutatás eredményeivel, ahol mind a vizsgált magyarországi, mind szerbiai területek megkérdezettjei közel 50\%-ban ,eléggé komoly” és nagyjából 27\%-ban „,nagyon komoly” problémának nevezték a belvízelöntést (SZATMÁRI J. - VAN LEEUWEN, B. SZERK. 2013). A vidékies jellegü Domaszék esetében a belvíz hangsúlyosabb problémaként jelentkezik, így az azzal kapcsolatos informálás igénye is nyomatékosabban jelenik meg, főként mert az érintettek közül nagyobb számban vannak mezőgazdasági termelők, akik számára jelentős károkat okozhatnak az elöntések. Az adatokból arra lehet következtetni, hogy Domaszéken jobban valósult meg az elöntésekkel kapcsolatos információ-átadás. Baktó esetében egyértelmüen kijelenthetö, hogy a belvízzel érintettek összességében nem voltak elégedettek a tájékoztatással, hiszen a megkérdezettek 69\%-a válaszolt nemmel a megfelelő informálás meglétére vonatkozó kérdésre, 23\%-a pedig nem tudta megítélni azt. Ezen a mintaterületen a problémával nem érintettek többsége szintén „,nem” (33\%) vagy „nem tudja megítélni” (57\%) válasz- 
lehetőségekkel válaszolt. Mindkét csoportban 10\% alatt volt azoknak a részaránya, akik szerint valamilyen mértékig megfelelö volt a tájékoztatás az elöntésekkel kapcsolatban. Domaszék esetében általánosan magasabb szintü elégedettség mutatkozik az informálást tekintve a baktói mintaterületen tapasztaltakhoz képest. A belvízzel érintettek 38\%-a teljes mértékben, 21\%-a pedig részben, elégedett a tájékoztatást tekintve, egyúttal a belvízzel nem érintettek 8\%-a, míg az érintettek 30\%-a szerint viszont nem volt megfelelő az informálás.

A belvízzel érintettek mintegy 10\%-a kapott valamilyen segítséget, elsősorban családtagoktól, barátoktól vagy ismerősöktöl lelki támogatás vagy építési segítség formájában, másodsorban az önkormányzattól vagy az államtól bizonyos mennyiségü pénzbeli juttatás keretében. Utóbbi igen kismértékü volt, és a pénzbeli támogatást kapók sem voltak maradéktalanul elégedettek a rendelkezésre bocsátott összeggel. A kárt szenvedett válaszadók többsége semmiféle támogatásban nem részesült. Ennek okaként legtöbbször azt említették a megkérdezettek, hogy meg sem próbáltak kártérítést igényelni, mivel „úgysem kaptak volna”. Jelentős számban voltak azok is, akik nem tudták, hogy hova lehet fordulni az ilyen jellegü igényeikkel. Ezek a vélemények egyértelműen mutatják, hogy a megfelelő információátadás a legtöbb esetben nem biztosított a lakosoknak, a hozzáférhető kártérítésekről nincs információjuk, amely, még ha nem is önmagában okozza, de hozzájárul az igazságtalan helyzet jövőbeni fennmaradásához. Hasonló eredmények tapasztalhatók a devecseri vörösiszap-katasztrófát közvetlenül és közvetetten megélők között (NAGY GY. - JÁMBOR V. 2014).

A vörösiszap-katasztrófa által érintett települések esetében a lakosok $41 \%$-a érezte úgy, hogy megfelelö tájékoztatást kapott, 53\%-a azonban úgy érezte, hogy nem rendelkezett a megfelelö információmennyiséggel az események alatt. Arra a kérdésre, hogy miért gondolják úgy, hogy nem volt megfelelő a tájékoztatást a megkérdezettek közel fele nem kívánt válaszolni. A válaszokat négy dimenzió mentén csoportosítottam, az elérhető információ mennyisége (1), a hatóságok katasztrófa alatt és a kártalanítás közben tanúsított helytállása és felkészültsége (2), az információ terjedésének módja és időbelisége (3), valamint helytállósága (4) alapján (37. ábra).
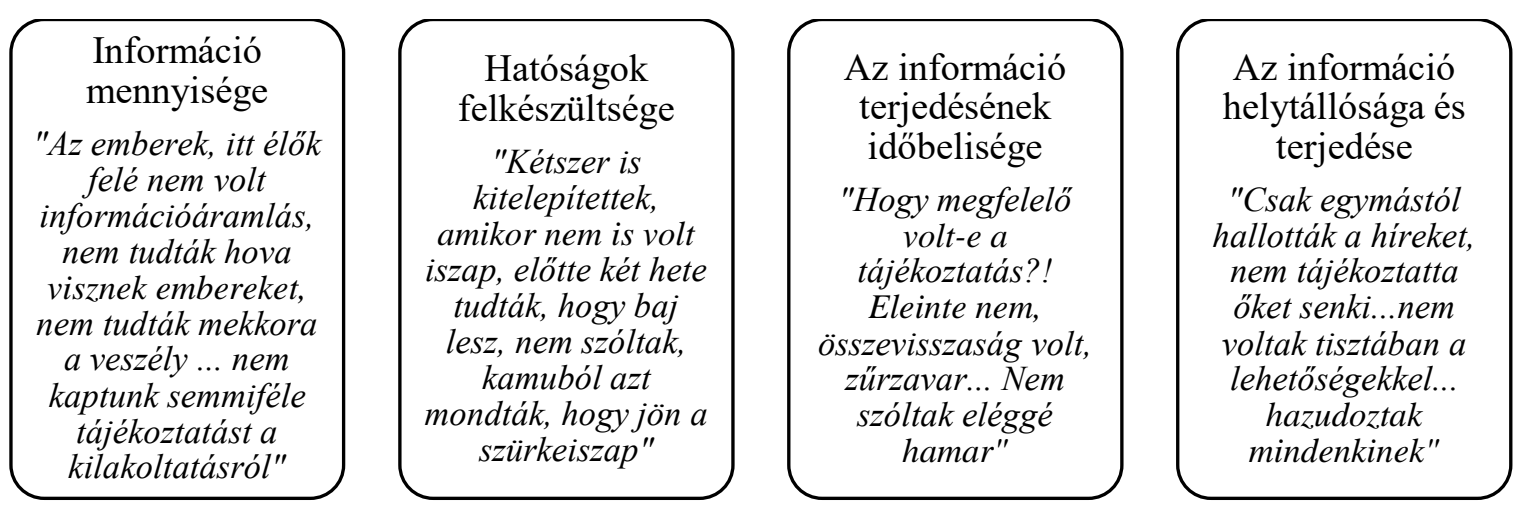

\section{7. ábra: az információ-ellátással való elégedetlenség indokainak vizsgálati dimenziói}

Az első csoport a hozzáférhető információ mennyiségével kapcsolatos. A csoportba került indoklások egyik fele azt állítja, hogy szinte semmiről nem tájékoztatták az érintetteket, megjegyezve azt is, ha bármit is mondtak volna a teendőkröl, akkor nem lett volna ekkora pánik. Az indoklások másik csoportja a hiányos információkat emeli ki. Egyesek szerint nem csak a katasztrófa közben, de az után sem volt megfelelő információáramlás a hatóságok és a lakosság között, mert „,nem tudták hova visznek embereket, nem tudták mekkora a veszély”, ráadásul a kártalanítási eljáráskor „,az adományokról sem tájékoztattak senkit”.

Az információszerzés nehézkes volt, mert „központi tájékoztatás nem volt, egymástól tudták meg” a híreket, amik „szájról szájra terjedt[ek]. Mindez a hatóságok felkészületlenségét is mutatja, mely az indoklások vizsgálatának második dimenziója. A válaszadók közül többen úgy vélik, hogy a hatóságok és az emberek is „,összevissza beszéltek, nem volt semmi konkrét”, mindez tovább fokozta azt a káoszt, amit az érintettek tapasztaltak, hiszen ,,sok információ sok felöl” jött. A szervezetlenséget jelezheti, hogy az egyik válaszadó szerint „,Veszprémben nem is tudták a kórházban”, hogy néhány kilométerrel távolabb három települést és több száz otthon elöntött a maró, lúgos vörösiszap. 
A harmadik dimenzió a katasztrófáról szóló hírek és információ időbeliségét vizsgálja. A válaszadók szerint „,az utolsó pillanatban értesültünk”, ráadásul nem csak ,,későn jött az információ, [de] pontatlanul [is] ” ezért ,, sok ember nem tudott reagálni”. Egy szemtanú szerint ,,az emberek tódultak ki az utcára, senki nem szólt [hogy maró hatású]'”. Az egyik érintett úgy értékeli az információ hiányt és időbeli megkésettséget, hogy az az eset egyedisége miatt történt így. Mások kiemelik, hogy az „elején ugyan káosz volt, de a vége felé sokat javult a helyzet".

A negyedik dimenzió a katasztrófa során keringő félinformációk és hivatalos tájékoztatások igazság-tartalmát vizsgálja. Több érintett úgy érzi, hogy ,félretájékoztatták a lakosokat”, ,,ködösitettek”, „,sok volt a titkolózás, valótlan állitás”, „, sokmindent elhallgattak a lakók elöl”. Többek között arról sem érkezett azonnali információ, hogy a vörösiszap maró hatású és hatása nem feltétlenül azonnal jelentkezik. Így a lakosok mindenféle óvintézkedés és védőfelszerelés nélkül azonnal elkezdték a kártalanítást. Egyesek úgy gondolják, hogy „,minden el volt tussolva, hogy ne legyen pánik”. Többen nehezményezik, hogy „,nem mondtak semmi konkrétat a gyerekekre való károsságról”, vagy, hogy „a légszennyezési adatok késve jelentek meg (2-3 nap), és a hirforrásokból nem ugyanazt az anyagot kapták meg", mindez kifejezetten ellentmondásos érzést keltett az érintettekben. A környezeti igazságtalanság meglétét jelzi, hogy a lakosok annak ellenére, hogy mindennapjaikat egy veszélyeshulladéklerakó közelében élték, szinte semmit nem tudtak annak negatív hatásairól, az esetleges katasztrófahelyzetben fontos teendőkről. Egy érintett szerint a lakosok azért ,nem tudták milyen lúgos a víz, mert már volt vörös árvíz a Torna patakból”. Ezen állítás a környezet korábbi, hosszú távra visszanyúló károsítását és az emberek állandó veszélyeztetését is jelenti. Az igazságtalan állapot tehát nem csak a katasztrófa után ex post, de már korábban alakult ki ex ante, feltehetőleg nem csak a lakosság, de a hatóságok és a termelőtevékenységet végző MAL Zrt. tudtával. Ebben az esetben felmerül a lakosság felelőssége is a katasztrófa kialakulásában, mely azonban elvetendő, hiszen nem álltak birtokában a megfelelő, a hulladék veszélyességére vonatkozó információknak (ahogy ez korábbi indoklásaikból kiderül), ráadásul a kiszolgáltatottság és a munkanélküliségtől való félelem, a MAL Zrt. által kínált munkahelyek meggátolták a tudatos, tevékenység elleni fellépést. Ezáltal egyfajta láthatatlan szerződést kötve az egészségük és anyagi biztonságuk esetleges feláldozásáról a munkalehetőségért cserébe. A munkahelyhez való kötődés többek között a lakosság mobilitásának egyik gátját is jelentette a térségben.

\subsubsection{Lakóhelyi mobilitás irányai és gátló tényezők}

A települések társadalmának átalakulását bár az egyes mintaterületeken eltérő mértékben támasztják alá, statisztikai adatok alapján a lakossági mozgások állandó elvándorlások tekintetében mind a négy mintaterületen tapasztalható népességváltozás. Ez három mintaterület esetében csökkenést, míg a belvizes mintaterület esetében kismértékü növekedést és stagnálást jelent, melynek föként az urbanizációs-szuburbanizációs folyamatok állnak a hátterében. A másik három mintaterület települései többségében hátrányos helyzetü, kedvezményezett besorolású járások települései, melyek társadalmi-gazdasági és infrastrukturális helyzetüknek köszönhetően válságtérségnek tekinthetők, így ezen területekről azt gondolnánk, hogy az elvándorlás az országos átlagnál nagyobb mértékü. Azonban, ha a 2001, 2011-es és a disszertáció megírásakor legfrissebb rendelkezésre álló TeIR adatbázis adatait vesszük figyelembe, akkor azt tapasztaljuk, hogy a hátrányos helyzetü mintaterületek közül csupán a Beregi az, ahol az ezer före jutó vándorlás rátája meghaladja az országos átlagos értékeket (38. ábra). Mindez azt sugallja, hogy a településeken a tényleges, mérhető elvándorlás alacsonyabb, tehát nagyobb a térségek népességmegtartó képessége. Ennek ellenére a szakirodalom ezen esetekben úgy vélekedik, hogy a katasztrófával sújtott területeken az alacsonyabb vándorlás kényszerü helyben maradás következménye, hiszen az érintetteknek nem áll a rendelkezésére megfelelő anyagi háttér ahhoz, hogy lakhelyüket megváltoztassák. Az érintettek ingatlanpiaci csapdahelyzetbe kerülnek, melyből külső segítség nélkül önállóan kikerülni nehéz. 


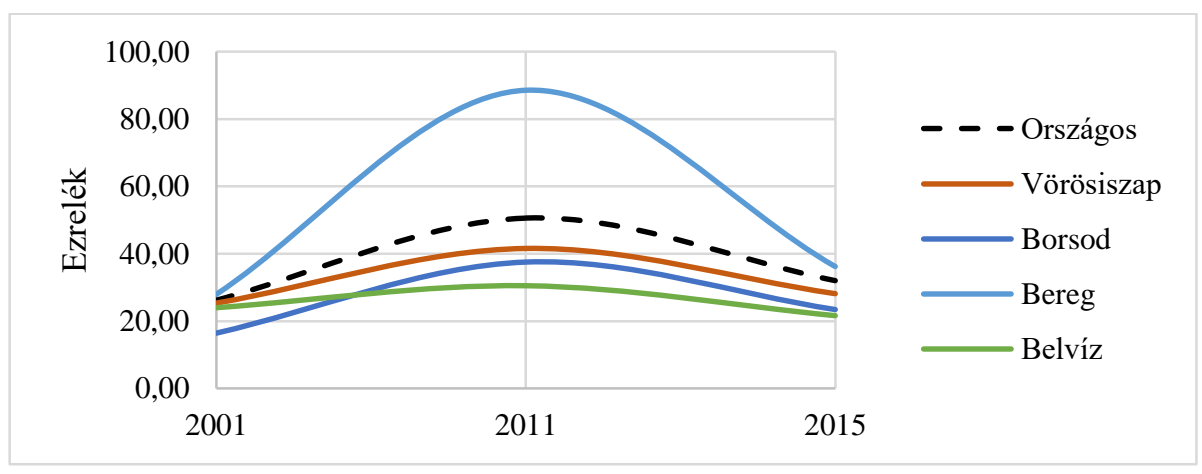

38. ábra: A vándorlási ráta településekre vonatkoztatott átlagos értékének változása a mintaterületeken a katasztrófák időpontját követően és napjainkban. Forrás: TeIR adatok alapján saját szerkesztés

A katasztrófával közvetlenül és közvetetten érintett lakosság költözési szándékait megvizsgálva, az tapasztalható, hogy mindhárom mintaterületen a lakosok döntö többsége nem kíván elköltözni, gondolkodik ugyan a költözésen, de nem tervezi, hogy elhagyja a lakhelyét (17. táblázat). A legnagyobb arányban a beregi mintaterület lakosai kívánják elhagyni a lakhelyüket a mintavétel időpontjában, a megkérdezettek 30\%-a gondolja így. A legkisebb arányban a belvizes mintaterület válaszadói kívánják elhagyni lakhelyüket, melynek hátterében számos indok húzódik.

17. táblázat: A költözési szándék megjelenése a mintaterületeken. Forrás: kérdőives felmérés alapján saját szerkesztés

\begin{tabular}{|c|c|c|c|}
\hline \multicolumn{4}{|c|}{ Tervezi-e, hogy elköltözik? } \\
\hline Mintaterület & Válasz & Elemszám & $\%$ \\
\hline \multirow{3}{*}{ Vörösiszap } & igen & 33 & 22,60 \\
\cline { 2 - 4 } & nem & 113 & 77,40 \\
\hline \multirow{2}{*}{ Belvíz } & igen & 15 & 11,03 \\
\cline { 2 - 4 } & nem & 121 & 88,97 \\
\hline \multirow{3}{*}{ Borsod } & igen & 94 & 21,32 \\
\cline { 2 - 4 } & nem & 347 & 78,68 \\
\hline \multirow{2}{*}{ Bereg } & igen & 112 & 30,68 \\
\cline { 2 - 4 } & nem & 253 & 69,32 \\
\hline
\end{tabular}

Azok, akik nem tervezik az ár- és belvízhez kapcsolódó költözést, három mintaterület esetében a megszokást jelölték meg legfőbb indokként. A válaszadók sok esetben életkorukra hivatkozva indokolták immobilitásukat. „,Ebben a korban már nem megyek én sehova” ", hetven évesen mit várjon az ember” „az egész életemet itt éltem le” kijelentésekkel és hasonló jelentéstartalmú mondatokkal indokolták válaszukat. A vörösiszap-katasztrófa után bekövetkezett áttelepítések a lakosok körében felértékelték a családi és baráti kapcsolatokat, több érintett számolt be a családok kényszerü elszakításáról a felújítás során. Így ezen a mintaterületen a megszokás csak a második legfontosabb indok volt a helyben maradásra (39. ábra). 


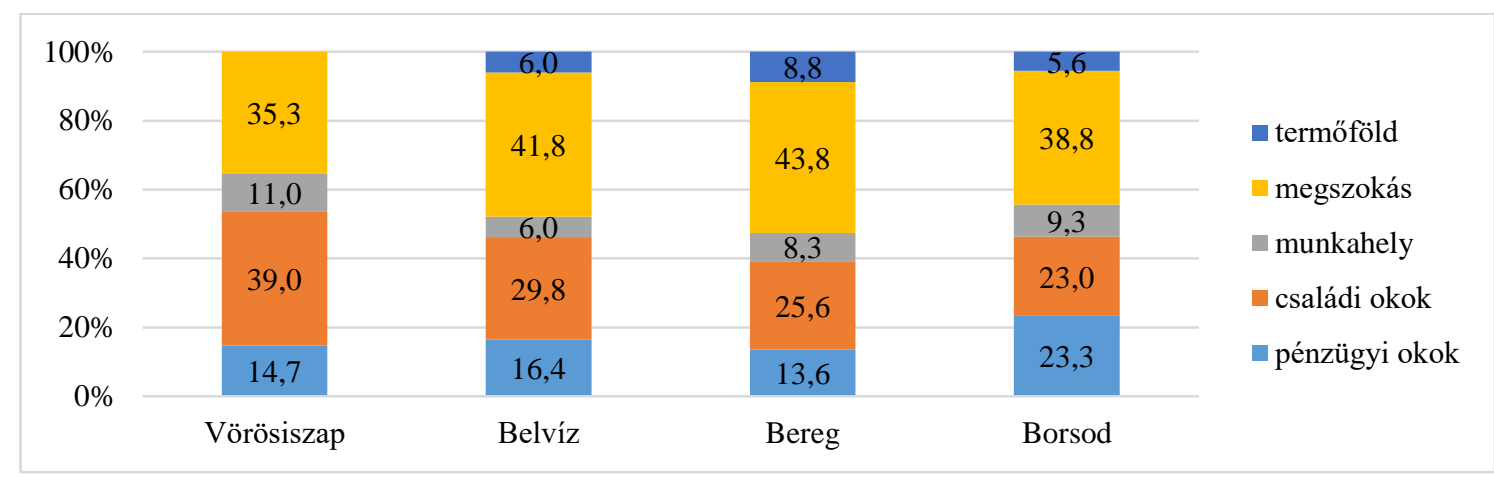

39. ábra: A helyben maradást elősegítő tényezők a mintaterületeken

A megkérdezettek közül a családi okok azok, melyek a három mintaterületen a második legtöbbet említették indokként. Ez azért is meghatározó tényező a vizsgált településeken, mert bizonyított, hogy a rokonok, illetve gyermekek és barátok közelsége a hátrányos helyzetü társadalmi csoportok között kiemelten fontos. Több tanulmány is bizonyítja, hogy bizonyos kisebbségek kulturális szokásához tartozik a többgenerációs család, illetve a hátrányos helyzetủ térségekben a szegényebb családok egyfajta túlélési stratégiáját adja az említett családmodell, melyet a katasztrófák megbonthatnak. Ezzel elgyökértelenedést is eredményezhetnek ezeknél a társadalmi csoportoknál (MÁLOVICS GY. 2012). A költözést több esetben gátolja az anyagi javak és megfelelő szociális és információs háttér hiánya. A mintaterületek közül Borsodban a legnagyobb az aránya azon válaszadóknak, akik csak azért nem terveznek elköltözni, mert anyagilag nem tehetik meg, ezen válaszadók az összes válaszadó nagyjából egynegyedét adják. Kis mértékben, de nagyobb visszatartó erőt jelent, mint a család (40. ábra).

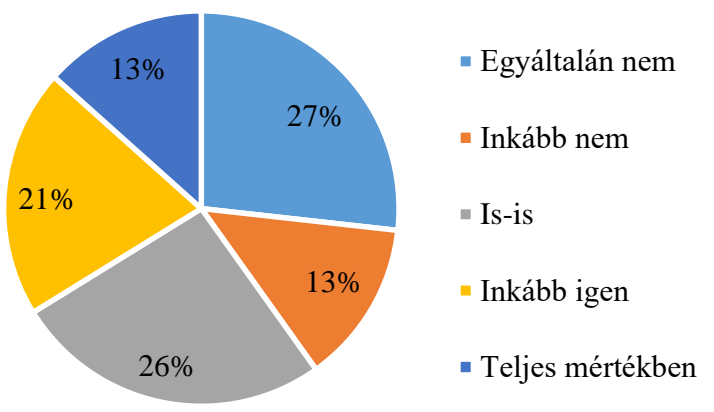

40. ábra: A család és a rokonok szerepe a helyben maradásban a vörösiszappal érintett mintaterületeken

A család és a rokonok szerepe igen meghatározó mobilitást gátló tényező, hiszen a válaszadók egyharmada úgy gondolja, hogy fontosabb a rokonokkal és a családdal egy településen élni, mint egészséges környezetben. Kifejezetten magas azok aránya, akik nem tudják eldönteni, hogy melyik a fontosabb, nagyjából azonosan ítélik meg az egészséges környezet és a rokonokkal azonos lakóhely fontosságát, a válaszadók több, mint egynegyede tartozik ebbe a csoportba (40. ábra).

A lakóhely megváltoztatásának igénye azonban alapvetően az egyéni és családi szándéktól, valamint a lehetöségektől is függ. Mindez összekapcsolódik az elméleti részben kifejtett ingatlanpiaci csapdahelyzet kialakulásával, mely szerint a borsodi mintaterület megkérdezett lakóinak egy része elköltözne, azonban hátrányos helyzetüket a katasztrófa tovább rontotta, és ezért nincs lehetőségük a lakóhelyváltoztatásra.

A mobilitást gátolja, hogy a megkérdezettek bizonyos mintaterületeken akár több, mint egytizede (41. ábra) félti jelenlegi munkahelyét, és amiatt nem hagyná el a katasztrófa sújtotta területet, mert tart attól, hogy máshol nem találna munkát. A legeröteljesebben a vörösiszappal érintett mintaterületen jelentkezik a munkahely visszatartó ereje (11\%), ahol arra a kérdésre, hogy meg kell-e szüntetni a szenynyező tevékenységet a válaszadók 44\%-a úgy gondolja, hogy semmiképpen sem szabad megszüntetni a timföldgyártást, összességében 69\%-a ellenezi, kisebb-nagyobb mértékben, a timföldgyártás felfüggesztését vagy befejezését. Mindezt úgy, hogy a kérdőíves felmérés időpontjában már csak csökkentett 
termelése volt a gyárnak, amit azóta már fel is számoltak. A legfőbb indok a timföldgyártás bezárása ellen a megkérdezettek szerint az volt, hogy ha megszünik a gyár, akkor a térségben rengeteg ember elveszíti munkáját és családok megélhetése szünik meg. Ennek ellenére a válaszadók 58\%-a gondolja úgy, hogy az egyén és a közösség egészsége a munkahelynél többet ér, a környezeti ártalmakat nem kell elviselni, csak azért, hogy munkája legyen az embernek. A környezeti igazságtalanság-kutatások több ízben utalnak arra, hogy az érintettek általánosságban elítélik az egészségkárosító tevékenységeket, azonban, ha az saját egzisztenciájukat érinti, akkor az ellenző attitüdből elfogadó vagy támogatóvá válnak, az úgynevezett BANANA-ból PIMBY-re váltanak.

A kérdöívben azt a felvetést, mely szerint az ipar megélhetést biztosít, így annak negatív hatásait el kell viselni a válaszadók többsége ugyan nem erősítette meg, azonban a kérdésre nemleges választ adók többsége nem ért egyet a timföldgyártás megszüntetésével (41. ábra), vagyis az első kérdésre adott válaszukkal ellentmondó választ adtak. Az első kérdéssel egyetértők, akik nagyobb környezeti kockázatot hajlandóak elviselni arányaiban nagyobb mértékben ellenezték a timföldgyártás megszüntetését is. Alapvetően két csoport különíthető el a válaszadók közt. Az előbbi, nagyobb elemszámú (93 fö) akik azonos választ adtak mindkét, ellentétes tartalmú kérdésre, míg utóbbi esetben (40 fó) akik ellentétes választ adtak (18. táblázat).

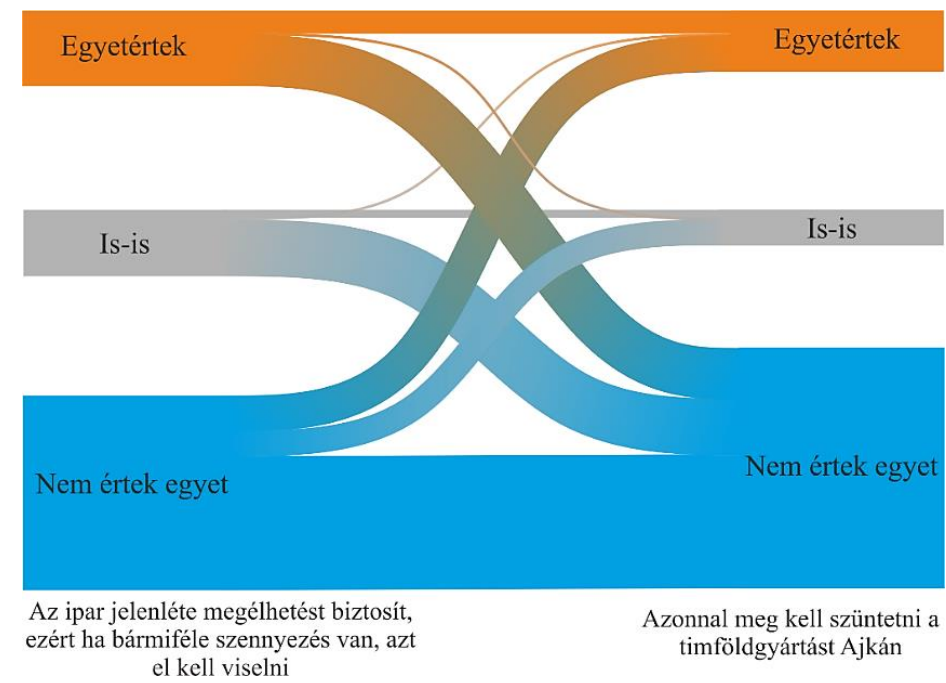

41. ábra: A szennyező beruházás kockázatviseléséhez és a timföldgyártás megszüntetéséhez kapcsolódó válaszadási mintázat változása. Forrás: kérdőíves felmérés alapján saját szerkesztés

18. táblázat: A válaszadók szennyező tevékenységgel kapcsolatos attitüdjének elkülönülő két csoportja. Forrás: Forrás: kérdőíves felmérés alapján saját számítás

\begin{tabular}{|l|c|c|}
\hline \multicolumn{1}{|c|}{ Kaszter } & $\begin{array}{c}\text { Egzisztenciális diffe- } \\
\text { renciált viszonyulók }\end{array}$ & Tényleges elutasítók \\
\hline \multicolumn{1}{|c|}{ Állítás } & \multicolumn{2}{|c|}{ Klaszterközép } \\
\hline $\begin{array}{l}\text { Az ipar jelenléte megélhetést biztosít, ezért ha bármiféle szennyezés } \\
\text { van, azt el kell viselni }\end{array}$ & $\begin{array}{c}\text { inkább nem ért egyet } \\
(2)\end{array}$ & $\begin{array}{c}\text { inkább nem ért egyet } \\
(2)\end{array}$ \\
\hline Azonnal meg kell szüntetni a timföldgyártást Ajkán & $\begin{array}{c}\text { egyáltalán nem ért } \\
\text { egyet (1) }\end{array}$ & $\begin{array}{c}\text { teljes mértékben } \\
\text { egyetért (4) }\end{array}$ \\
\hline Elemszám & 93 & 40 \\
\hline
\end{tabular}

A két csoport elkülönülését 6 lépésböl álló k-közép klaszterelemzés segítségével határoztam meg. Az első klaszterben a szennyezésre vonatkozó kérdésére a klaszterközép az ,,inkább nem ért egyet” válaszlehetőségre került és a gyártás megszüntetésre vonatkozó kérdésnél az ,egyáltalán nem ért egyet” lehetőségre. Míg a második klaszter az elöbbi kérdésre vonatkozó közepe az ,inkább nem 
ért egyet”, az utóbbi kérdés esetében pedig a „teljes mértékben egyetért” válaszra. A második klaszter válaszadói a környezetileg káros tevékenység tényleges elutasítói, vagyis a NIMBY vagy BANANA attitüd képviselöi, míg az első klaszterbe tartozó válaszadók egzisztenciálisan kiszolgáltatottak, a beruházáshoz differenciált, érdekekhez mérten változó viszonyulók, inkább a PIMBY attitüdhöz hasonlíthatóak.

\subsubsection{Az ingatlanpiaci csapdahelyzet kialakulása}

A vizsgált mintaterületeken a mobilitást gátló tényezők között ugyan nem vezető indokként, de erőteljesen megjelenik a vagyoni helyzet. A vagyoni helyzet értelmezésénél több tényezőt is figyelembe kell venni, melyek között kiemelt szempont a lakóingatlan megléte vagy hiánya. Alapvetően egy háztartás vagyoni helyzetét a következő tényezőkkel lehet leírni: lakóingatlan, egyéb ingatlan, jármüvek, egyéb ingóvagyon, pénzügyi vagyon, vállalkozói vagyon, adósságok (KOLOSI T. FÁBIÁN Z. 2016). A TÁRKI 2015-ös Háztartási Monitorja alapján az átlagos magyar háztartásban az összesített vagyon értéke 15,4 millió forint, melynél a medián közel négy millió forinttal alacsonyabb, 11,3 millió forint. A felmérésben igen nagy szórás tapasztalható, mely egy vagyoni tekintetben polarizált társadalom képét mutatja. Nagyjából a magyar háztartások 44\%-a tekinthető vagyon nélkülinek, akiknek nehezen mozgósítható vagyona van, és nem rendelkezik megtakarítással. A lakosság közel 95\%-a 70 millió forint értékü összvagyonnál kevesebbel rendelkezik. Egy ilyen társadalmi helyzetben az ingatlan tulajdon megléte alapvetően határozza meg a háztartás társadalomban elfoglalt pozícióját.

Azonban nem elég a lakóingatlan meg- és magántulajdonban léte, annak földrajzi elhelyezkedése és minősége is kritikus kérdés. Így hiába rendelkezik valaki ingatlannal, ha annak ingatlanpiaci értéke alacsony, vagy szinte meghatározhatatlan. A környezeti igazságtalanságok esetében ez kulcskérdés, hiszen az egyes katasztrófák gyakran okoznak nehezen javítható, vagy akár vissza nem fordítható károkat az ingatlanokban. Ekkor a családok, egyének vagyonuk jelentős, meghatározó elemét veszítik el, nem csak a katasztrófa miatt kerülnek hátrányos helyzetbe, hanem annak következményei is a társadalmi státuszukban jelentős, negatív irányú változásokat idézhet elő. Gyakorta ez a folyamat a gettósodási spirálhoz hasonlóan, vissza nem fordítható folyamat, föleg, ha az nem csak egy háztartást, hanem a térségen belül tömegesen, nagyszámú családot és egyént érint. Kiemelten hátrányosan érintheti ez a folyamat az alapvetően halmozottan hátrányos, társadalmi-gazdasági és földrajzi szempontból is szegregált helyzetü településrészeket, telepeket. A disszertáció boldvai mintaterülete települési szint alatti, mikro léptékủ ingatlanpiaci folyamatok, az ingatlanpiaci csapdahelyzet kialakulásának kíván példát állítani.

A település demográfiai viszonyai egy fiatalodó település képét rajzolják ki, amely rossz anyagi helyzettel párosul. Boldván az ezer före jutó adófizetők száma több mint 100 fövel kevesebb az országos átlagnál. Jelenleg a településen 177 fő nyilvántartott álláskereső, mely a teljes népességen belül közel 7\%-os érték, ez az országos aránynak nagyjából kétszerese. A munkavállalási korú népesség több, mint 10\%-a munkanélküli. Az országos relatív mutatóhoz képest ez még magasabb, 2,67-szeres értéket vesz fel. Külön probléma, hogy a településen a folyamatosan, vagyis 365 napnál régebb óta regisztrált munkanélküliek száma 60 fö. Rendszeres szociális segélyben (RSZS), illetve foglalkoztatást helyettesítő támogatásban (FHT) 87 fö részesül, emellett összesen 15 fö az, aki segélyt vagy valamiféle járadék típusú ellátást kap. A boldvai családok hátrányos helyzetét mutatja, hogy a hátrányos helyzetủ gyermekek száma és a gyermekvédelmi kedvezményben részesítettek száma 300 fö́t meghaladja a településen. Jelenleg 137 gyermek hátrányos vagy halmozottan hátrányos helyzetü (HH vagy $\mathrm{HHH})$ az általános iskolai tanulók közt, és ezzel egyidőben 55 gyermek HH vagy HHH az óvodában. 2016-ban közel háromezer alkalommal, több, mint 600 föt kellett települési támogatásban részesíteni, mely öszszességében 15 millió forint feletti értéket jelentett a település költségvetésében. Azonban ezek az adatok nem tükrözik a település megosztottságát, kettős arculatát. A cigánytelep az átlagos értéknél sokkal rosszabb helyzetben van, melyre a kérdőíves eredmények mutatnak rá. A megkérdezett háztartások nagyjából kétharmadában egyetlen eltartó sincs (40 háztartás), negyedében egy eltartó (16 háztartás) és

közel tizedében pedig két eltartó jut a családra. Mindeközben a családok kétharmada esetében ( 52 háztartás) három- vagy annál több az eltartott. A családok valamivel kevesebb, mint kétharmadában három, vagy annál több gyermek van a családban. 
A telep jövedelmi viszonyait tekintve nagy különbségek vannak a családok jövedelme között, az átlagos jövedelem igen alacsony, háztartásokként $80000 \mathrm{Ft} /$ hó. A jövedelmet kvartilisokra osztva a háztartások legalsó negyede maximum 56000 Ft-ból él, míg a felső negyed 106750 Ft-ot meghaladó összegből. A megemlített maximális érték 150000 Ft volt a felmérés időpontjában. A megkérdezett családok mindegyikében van olyan, aki részesül valamilyen szociális, segély jellegü juttatásban, általában egy családban két különféle segély is jár egyharmadában pedig három vagy annál több jogcímen jár segély jellegü juttatás.

Annak ellenére, hogy Boldva ingatlanpiaci helyzete, illetve lakásállománya tekintetében tipikusan a vidéki Magyarország képét mutatja, vagyis a lakások többsége 80 négyzetméter feletti, az épületek nagy része négyzetes alaprajzú, sátortetős családi háztípus, az úgynevezett Kádár-kocka. Mégis nagy számban találunk 60 négyzetméter alatti épületet is, melyek föként a telepen találhatók. A lakások életkora alapján a település lakásállománya egészen fiatalos, hiszen az összes lakás közel negyede 1980 után épült, vagyis nem régebbi 40 évnél. Ez azonban a szegregált helyzettel van összefüggésben. A település azon részei, melyet az árvizek érintettek több ízben újjáépültek, ráadásul maga a romatelep is az 1970-es évek után készült el (19. táblázat).

19. táblázat: Boldva lakásállományának méretbeli összetétele és kora 2016-ban Forrás: TeIR adatok alapján saját szerkesztés

\begin{tabular}{|l|l|}
\hline Méret & $(\mathrm{db})$ \\
\hline $30 \mathrm{~m}^{2}$-nél kisebb alapterületü lakások száma & 2 \\
\hline $30-39 \mathrm{~m}^{2}$ alapterületü lakások száma & 10 \\
\hline $40-49 \mathrm{~m}^{2}$ alapterületủ lakások száma & 68 \\
\hline $50-59 \mathrm{~m}^{2}$ alapterületủ lakások száma & 65 \\
\hline $60-79 \mathrm{~m}^{2}$ alapterületủ lakások száma & 158 \\
\hline $80-99 \mathrm{~m}^{2}$ alapterületü lakások száma & 225 \\
\hline $99 \mathrm{~m}^{2}$-nél nagyobb alapterületü lakások száma & 262 \\
\hline Összesen & 790 \\
\hline
\end{tabular}

\begin{tabular}{|c|c|}
\hline Időszak & $(\mathrm{db})$ \\
\hline 1946-ban és korábban & 87 \\
\hline $1946-1960$ között & 167 \\
\hline $1961-1970$ között & 111 \\
\hline $1971-1980$ között & 164 \\
\hline $1981-1990$ között & 144 \\
\hline $1991-2000$ között & 71 \\
\hline $2001-2005$ között & 15 \\
\hline 2006 - 2011 között & 31 \\
\hline Összesen & 790 \\
\hline
\end{tabular}

A telepen élők bár rendelkeznek lakóingatlannal, azok állapota a legtöbb esetben átlagon aluli. A kutatás során a kérdőívben rákérdeztem a házak komfortfokozatára. A válaszokból kiderült, hogy a telep építésekor bevezették az elektromos áramot, így az összes háztartás rendelkezik villanyáram hozzáféréssel. Egyéb infrastrukturális elemeket vizsgálva már rosszabb a kép: a 63 válaszadó házában csupán 14-ben van vezetékes víz, fürdőszoba, illetve vízöblítéses WC, 36 pedig teljesen komfort nélküli (20. táblázat). A lakások többsége önmagában elöirányozza a rossz életminőséget. A vezetékes vízzel nem rendelkező háztartások az Akácfa utca és a Rezeda utca sarkán található közkútból vödörrel viszik a vizet.

20. táblázat: A megkérdezettek háztartásának komfortja. Forrás: kérdőíves felmérés alapján saját számítás

\begin{tabular}{|c|c|c|}
\hline $\begin{array}{l}\text { Az alábbiak közül mivel rendelkezik az ön } \\
\text { háza? }\end{array}$ & $\begin{array}{l}\text { Háztartások } \\
\text { száma }\end{array}$ & Százalék \\
\hline Vezetékes víz & 6 & 9,5 \\
\hline Szennyvízelvezetés & 1 & 1,6 \\
\hline Fürdőszoba a házban & 1 & 1,6 \\
\hline Vezetékes víz + fürdőszoba a házban & 1 & 1,6 \\
\hline Szennyvíz + WC + fürdő & 1 & 1,6 \\
\hline Vezetékes víz + vízöblítéses WC + fürdőszoba & 3 & 4,8 \\
\hline Minden, kivéve gáz & 14 & 22,2 \\
\hline Egyik sem & 36 & 57,1 \\
\hline Összesen & 63 & 100,0 \\
\hline
\end{tabular}

Tovább súlyosbítja a helyzetet, hogy átlagosan 5 fó él egy szoba-konyhás házban, azonban a válaszok alapján a lekérdezett háztartások 35\%-ban 6-12 fó él, mely óriási zsúfoltságot jelent, emellett 
egészségügyi kockázattal is jár. A háztartások a teljes településen általában egy-kétszemélyesek, föként nyugdíjasok alkotják, míg a településen jellemző a másik véglet, hiszen nagy arányban, az országos értékeket meghaladóan találhatunk öt- vagy hatszemélyes, esetleg annál nagyobb családokat is (42. ábra).

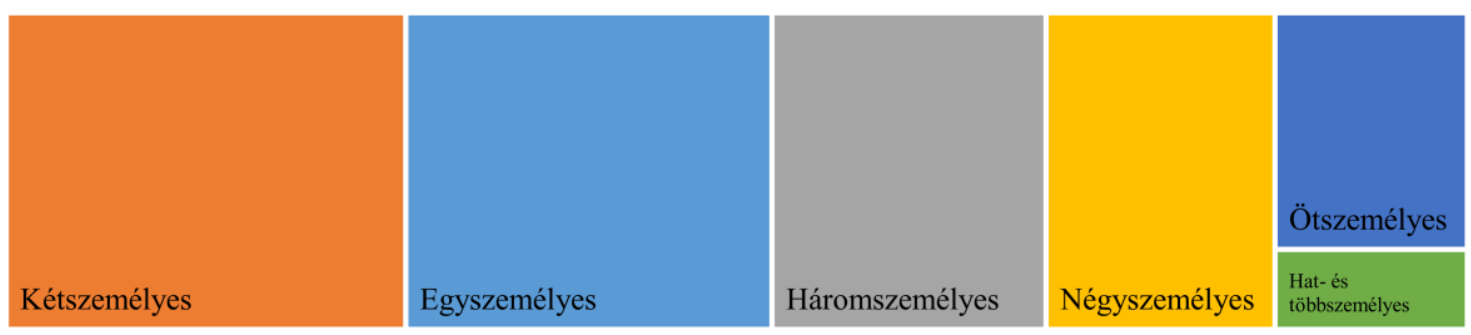

42. ábra: A boldvai családok tagjainak száma 2016-ban. Forrás: saját szerkesztés

A telep ingatlanjai csökkentett értékkel készültek el, a telep építésekor házakba a lakosok már az átadás elött beköltöztek, volt olyan ház, melynek teteje nem volt, illetve volt, amelyiken nem voltak nyílászárók, vagy éppen vakolat a beköltözés pillanatában. A rossz állapotú, alacsony színvonalon megépült házak mellett nagy problémát jelent a telep mellett elfolyó patak, hiszen áradások idején a megemelkedett vízszintü Boldvába és Sajóba nem tud a patak befolyni, mely így visszaduzzasztódik, ilyenkor elönti a meder melletti lapos területet, vagyis a cigánytelepet. A telep árvízveszélyes helyzetéhez társul, hogy alacsony fekvése miatt esős időszakokban erősen belvízveszélyes is, így ezekben az időszakokban a belvíztől szívják meg magukat a házak falai, salétromosodnak, felvizesednek és penészednek. Mindez csökkenti az ingatlanok értékét, melyek mind a felmérés időpontjában, mind napjainkban igen alacsonynak tekinthetők (21. táblázat).

21. táblázat: A boldván eladó ingatlanok átlagos értékének változása. Forrás: TeIR adatok alapján saját szerkesztés

\begin{tabular}{|l|l|l|l|}
\hline & Átlagár, ezer Ft/m² & Darab & Relatív szórás, \% \\
\hline 2008 & 92 & 7 & 28 \\
\hline 2009 & 62 & 4 & 44 \\
\hline 2010 & 62 & 6 & 27 \\
\hline 2011 & - & - & - \\
\hline 2012 & - & - & - \\
\hline Lakásár 2011 millió Ft/ingatlan & 4373415 & \\
\hline Lakásár 2015 Ft/ingatlan & 588888 & \\
\hline
\end{tabular}

Az árvizek, a belvízveszély és a szegregált helyzet miatt a telepet ingatlanpiaci leértékelödése is végbement, a lakosok többsége úgy véli, hogy a telkek és az ingatlanok többsége nem eladható, csupán a telep többi lakója között lehet üzletelni. Több megkérdezett is arról számolt be, hogy csupán távolabbi és közelebbi családtagok veszik meg az eladásra szánt ingatlanokat, azt is nyomott áron. Ez az ingatlanpiaci csapda lehetetlenné teszi a munkanélküli, segélyből élő, megtakarítással nem rendelkező romák kitörését a telepről. Az egyik interjú során kiderült, hogy házát 600000 Ft-ért adta el telekkel együtt, melyért cserébe csupán a telepen kapott másik házat. „,Aki egyszer a telepre bekerül nem csak, hogy nem tud, de nem is akar kiköltözni, mert ide köti mindene” - mondta a kisebbségi önkormányzati vezető.

\subsubsection{A lakossági mobilitás irányai}

A lakosság összetételével kapcsolatban a kérdőívben megfogalmaztunk egy olyan kérdést, mely arra vonatkozik, hogy a válaszadó hallott-e olyan családokról, háztartásokról, akik a katasztrófa következtében elköltöztek. Az összes beérkezett válasz alapján a megkérdezettek közel 63\%-a hallott már elköltözőkről, mely részben alátámasztja, hogy a települések társadalma megváltozhatott. A belvizes 
és a borsodi mintaterületek esetében azonban az eltérés igen markáns, hiszen előbbi esetében a lakók 88,5\%-a, utóbbi esetben 39,6\%-a nem hallott elköltözőkröl, mely részben alátámasztja a változás fökomponens mintaterületi megerősítését és elutasítását is (22. táblázat). A legtöbben a vörösiszappal érintett mintaterületen hallottak olyanokról, akik elhagyták a településüket a katasztrófa következtében. Azonban a település lakossági összetételének változása mellett kisebb-nagyobb mértékben a települések fizikai-müszaki struktúrája is átalakult a mintaterületeken.

22. táblázat: A mintaterületekről elköltözők érzékelése a helybenmaradók véleménye szerint. Forrás: saját szerkesztés

\begin{tabular}{|c|c|c|c|}
\hline \multicolumn{3}{|c|}{ Hallott-e olyan emberekről, akik a katasztrófa után másik településre költöztek? } \\
\hline Mintaterület & Válasz & Elemszám & $\%$ \\
\hline \multirow{2}{*}{ Vörösiszap } & igen & 138 & 95,83 \\
\cline { 2 - 4 } & nem & 6 & 4,17 \\
\hline \multirow{2}{*}{ Belvíz } & igen & 26 & 11,50 \\
\cline { 2 - 4 } & nem & 200 & 88,50 \\
\cline { 2 - 4 } & igen & 267 & 60,41 \\
\cline { 2 - 4 } Borsod & nem & 175 & 39,59 \\
\hline \multirow{2}{*}{ Bereg } & igen & 569 & 84,66 \\
\cline { 2 - 4 } & nem & 15,34 \\
\hline
\end{tabular}

A mintaterületekröl föként a környékbeli nagyvárosokba, illetve a szomszédos falvakba történt migráció. A vörösiszappal érintett települések esetében például Ajkára, Veszprémbe vagy Pápára költöztek a korábbi lakók a válaszadók tudása szerint. Az összes válasz 73\%-a kilenc környékbeli településre és Budapestre korlátozódik, további 3\% esetében nem volt megnevezés, csak a környékbeliséget emelték ki a válaszadók (43. ábra).

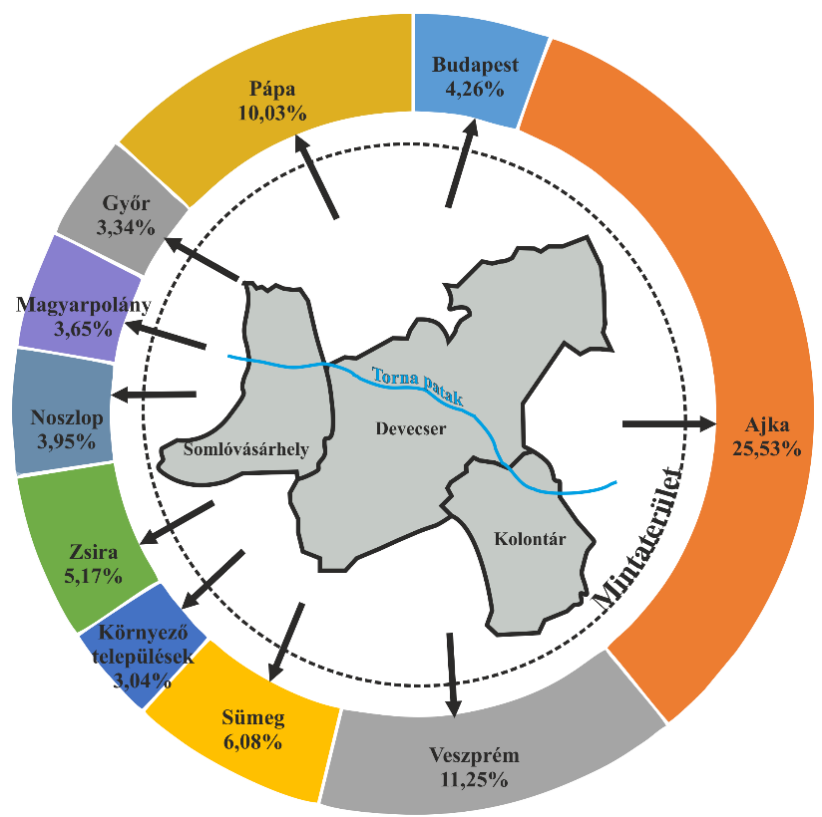

43. ábra: A főbb költözési irányok a vörösiszappal sújtott mintaterületekről.

A további megnevezett települések szinte egytől-egyig dunántúliak és a mintaterülettől nagyjából 50-60 km-es távolságban helyezkednek el. Mindezen adatok megfelelnek az általánosan megfigyelt migrációs trendeknek, mely szerint a költözni vágyók nagy része az általa ismert szükebb környezetben keres új lakóhelyet helyi kötődései miatt. Azok a megkérdezettek, akik a jövöben tervezik, hogy elköltöznek, többféle költözési irányban gondolkodnak. Alapvetően megfigyelhető, hogy a költözni vágyók a legközelebbi nagyvárosba vagy a környezö településekre költöznének legszívesebben. Mindez egyrészt köszönhetö annak, hogy családi és társas kapcsolataik a lakhelyükhöz kötik, másrészt több esetben 
a munkavállalót munkavégzési helye is köti a térséghez, ahogy ezt korábban kifejtettem. A megkérdezettek közül többen a fövárosba költöznének, azért mert úgy gondolják, hogy ott több lehetőségük van munkavállalásra és jobb életkörülményeket tudnak biztosítani saját maguknak és családjuknak is.

A borsodi mintaterület esetében, ahol a válaszadók majdnem fele gondolta úgy, hogy a lakosság összetétele nem változott meg, a többség mégis úgy nyilatkozott, hogy hallott olyan emberekröl, akik elköltöztek, mely részben magával vonja a terület lakosságának kicserélődését és átalakulását is. Bár a borsodi mintaterületről ténylegesen elköltözők, mint ahogy a többi megfigyelt mintaterületen, a környező településekre és a legközelebbi nagyvárosba költöztek, érdekes migrációs folyamatot figyelhető meg, hiszen a külföldi költözési desztinációk közt Kanada több, mint 5\%-ot tesz ki az összes költözési irányból. Ennek elözménye, hogy 2008-ban Kanada eltörölte a vízummentességet Magyarországgal szemben, így a kiutazás sokkal egyszerübbé vált és lehetőség lett helyben kérvényezni menekült státuszt. A 2008-as vízummentesség után azonban a Kanadába beérkező magyar menedékkérelmek csak az árvíz évében ugrottak meg, közel kétszeresére. Ez okozhatja az időszakban magasnak számító Kanada irányú kivándorlást. A Kanadába kiköltöző romák egy része gazdasági menekültént tekint magára, akik az árvízzel is érintett településen megélhetési küszöb alatti élet elől és az implicit rasszizmus elől menekülnek (DURST J. 2011; VIDA Z - VIRÁG T. 2012). A költözők egy része elköltözött korábbi lakóhelyéröl, azonban a településen maradt, ezzel próbálva a családi kapcsolatokat megtartani.

A másik indok a településen maradásra az ingatlanpiaci csapdahelyzet. A boldván készített interjús és kérdöíves felmérés alapján - melyek leképezik és tükrözik a többi árvízzel érintett települési folyamatokat az érintett településrészek, különösen a romák által lakott részek - ingatlanpiaci leértékelődése ment végbe. A válaszadók és interjúalanyok úgy érezték, hogy a telkek többsége nem eladható, csupán a telep többi lakója között lehet üzletelni velük. Ez az ingatlanpiaci csapda lehetetlenné teszi a munkanélküli, segélyböl élö, megtakarítással nem rendelkező romák kitörését a telepről vagy elköltözését a településről. Páran úgy vélik, hogy Boldván és a környező településeken az önkormányzat felvásárolta az üresen álló ingatlanokat, és azok árát mesterségesen olyan magasan tartja, hogy azt a romák ne fizethessék meg. Ezt azonban mind a polgármester, mind a kisebbségi önkormányzat vezetöje cáfolta. Arra a kérdésre, hogy hova költözne az, aki gondolkodott már vagy tervezi a költözést fóként Miskolcot jelölték meg, azonban a válaszadók második legnagyobb csoportja úgy nyilatkozott, hogy bárhová elköltözne, vagy legalábbis mindenképpen Borsod megyéből el. Utóbbi két állítás a térség és főként a választ adók deprivált és hátrányos helyzetét is bizonyítja (44. ábra).

A beregi mintaterület társadalmi átalakulásának egyik bizonyítéka lehet, hogy a 411 válaszadó közül 298 fő hallott olyan egyénről vagy családról, aki elköltözött az árvizet követően. A költözés célpontja, mint a másik két mintaterület esetében is a legközelebbi nagyváros volt. A válaszadók $30 \%$-a Vásárosnaményba költözött a válaszadók elmondása alapján, 28\%-a pedig távolabb, a megye központját, Nyíregyházát választotta lakhelyéül (45. ábra). A főváros vonzása e mintaterület esetében is érezhető, hiszen a válaszadók szerint a költöző népesség összesen 13\%-a Budapest vagy a Budapesti Agglomeráció valamely településére (pl. Érd, Gyál vagy Pécel) költözött. A válaszadók főként az agglomeráció keleti, illetve déli településeit nevezték meg, mely településekről korábbi lakhelyük könnyebben elérhetö. A mintaterület esetében is megjelent olyan válasz, ahol nem nevesítették a településeket, csak „nagyobb városokba”, vagy „,városokba” költöztek az érintettek. A migrációt a vizsgált településeken, a térségre jellemző rossz gazdasági mutatók okozzák, de emellett 2001-es árvíz is hatással volt a népesség számának alakulására (BEKÖL. ET AL. 2011). 


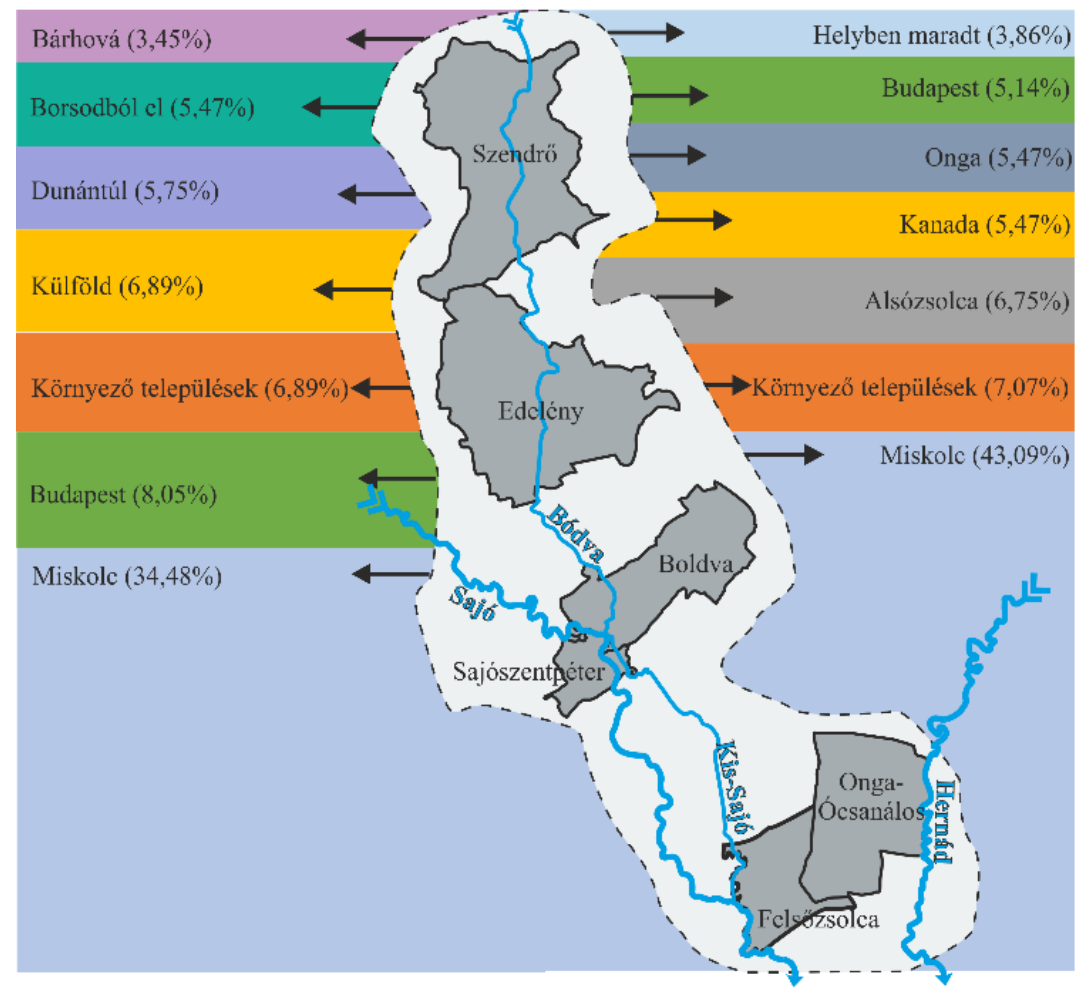

44. ábra: a Bódva-Sajó-völgyi mintaterület mobilitási jellemzői, az elköltözők és a költözni vágyók legfőbb célterületei alapján. Forrás: Kérdőíves felmérés adatai alapján saját szerkesztés

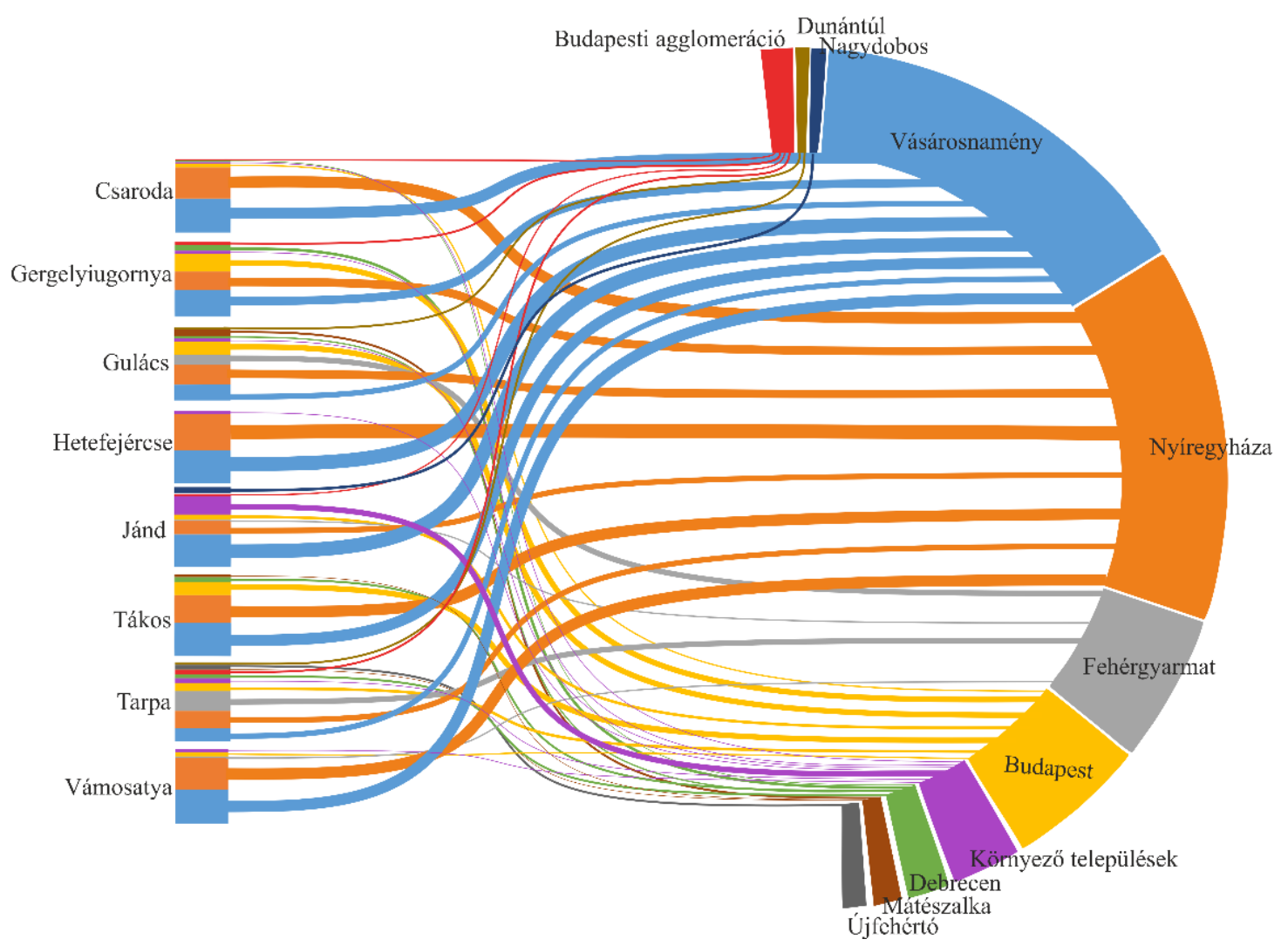

45. ábra: Legfőbb költözési irányok a beregi mintaterületen. Forrás: kérdőíves felmérés alapján saját szerkesztés 
Egy korábbi kutatás (BEKŐL. ET AL 2011) úgy találta, hogy Hetefejércsén, Csarodán és Tákoson a megkérdezetteknek mindössze 16\%-a szeretne elköltözni a településéröl, akik többsége fiatal. Jelen kutatás ennél nagyobb költözési hajlandóságot tárt fel, hiszen a megkérdezettek 28,9\%-a gondolkozott már vagy tervezi a költözést. A kérdőíves felmérés időpontjában a válaszadók átlagosan 52 évesek voltak, a költözni vágyók átlagosan 47 évesek, míg a maradni akarók átlagosan 54 évesek. A korábbi kutatással ellentétben a felmérés nem igazolta azt az állítást, hogy a költözni vágyók többsége fiatal, igaz, hogy az átlagéletkor tekintetében alacsonyabb értéket figyelhetünk meg a költözni szándékozók körében, azonban ez nem markáns különbség (46. ábra). A korrelációs mátrix felállítása után, a korrelációs koefficiens értéke alapján az a következtetés vonható le, hogy a beregi mintaterület esetében 0,175 nagyon gyenge ellentétes korreláció figyelhető meg (0,01-es szignifikancia szinten), vagyis a fiatalabbak inkább gondolkodnak költözésben, bár ez az érték ilyen magas elemszám mellett nagyon alacsonynak tekinthető. A borsodi mintaterületen a válaszadók $21,3 \%$ gondolkodott már költözésen. $\mathrm{E}$ mintaterület esetében a költözni illetve a lakóhelyüket elhagyni nem kívánók átlag és medián életkora is 51 év volt, tehát látszólag nem teljesül az az állítás, hogy a fiatalabbak szívesebben költöznek. Míg a borsodi mintaterület esetében a korreláció értéke 0 , vagyis nem figyelhető meg együttmozgás az életkor csökkenése és a költözési szándék megjelenése között.
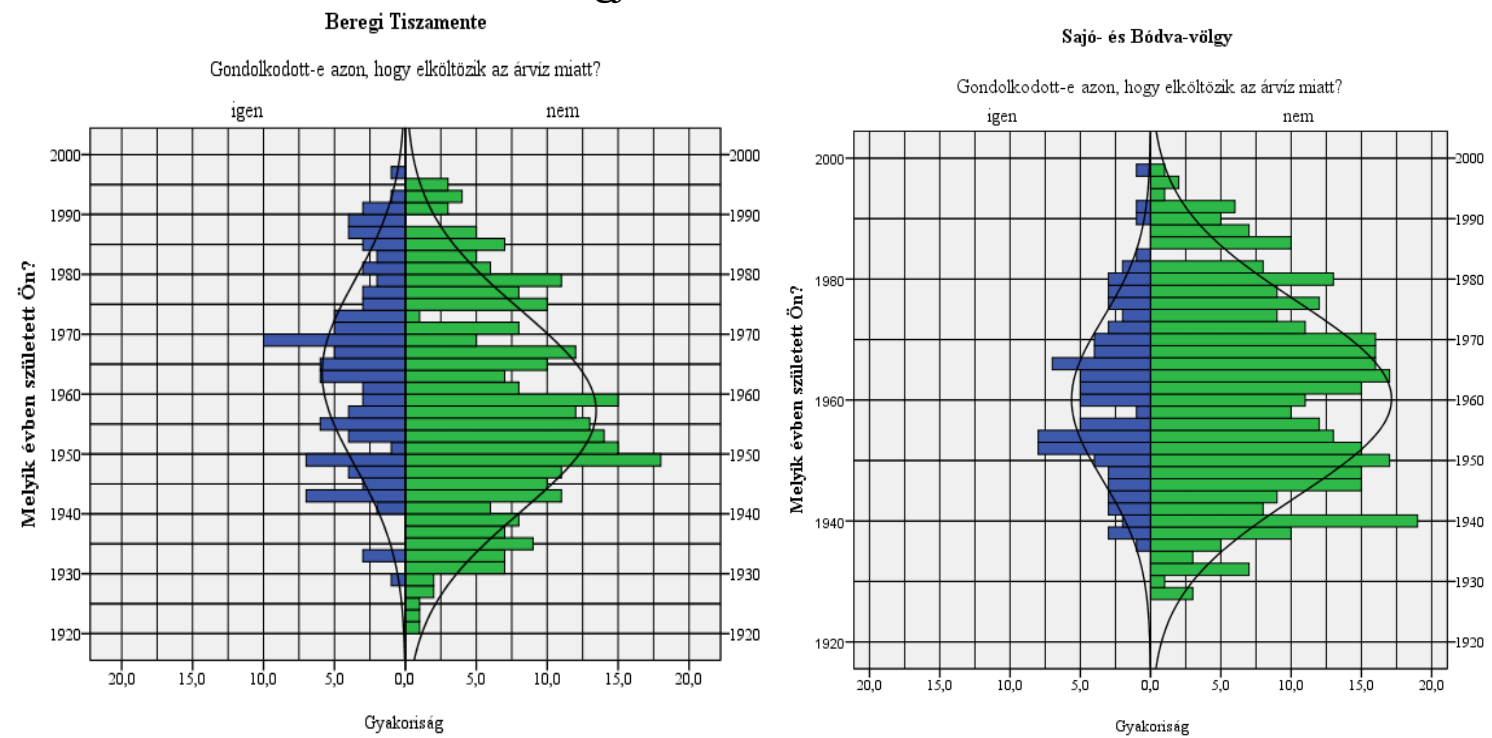

46. ábra: Az árvizes mintaterületek válaszadóinak költözési szándéka életkor szerinti bontásban. Forrás: kérdőíves felmérés alapján saját szerkesztés

Azok, akik gondolkodtak a költözésen hasonló költözési célpontokat neveztek meg, mint azon lakosok akik már korábban elhagyták a vizsgált településeket. A válaszadók legnagyobb része, egynegyede, a térség központját, Vásárosnaményt jelölte, valamint közel egyötöde (17\%) Nyíregyházára költözne legszívesebben. A többi mintaterülethez hasonlóan a beregi válaszadók esetében is megjelennek olyan nem nevesített költözési célok, melyek a térség hátrányos helyzetét fejezik ki. Ilyen például a „,mindegy, csak árvízmentes legyen” vagy a „,bárhova, ahol munka van”. Több válaszadó nagyobb városba költözne, vagy a közeli településekre, mindez a költözési irányok közel 15\%-át teszik ki (47. ábra). A beregi mintaterület részét képezte Gergelyiugornya, mely Vásárosnamény településrésze, ahol nagy számban üdülők találhatók. Azokban a városokban, ahol üdülőtelepek vannak, több esetben megfigyelhetö, hogy a lakosok a természeti környezet megkímélt állapota, vagy a természetközelség miatt kiköltöznek, nyaralóikat téliesítik és állandó jelleggel - a jogszabályoknak ellentmondóan - beköltöznek az üdülöterületre. Azonban nem csak a tehetősebb, természeti környezet közelségét kívánó felsöközép és középosztály az, aki lakhelyéül választja az üdülöterületeket. Sok esetben egyfajta megélhetési stratégiaként költöznek ki ezekre az üdülőterületekre a lakók, hiszen a közmüvesítés hiányában ritkított közszolgáltatásokkal (útkarbantartás, hulladékszállítás stb.) a havi költség sokkal alacsonyabb, mint a városban. 


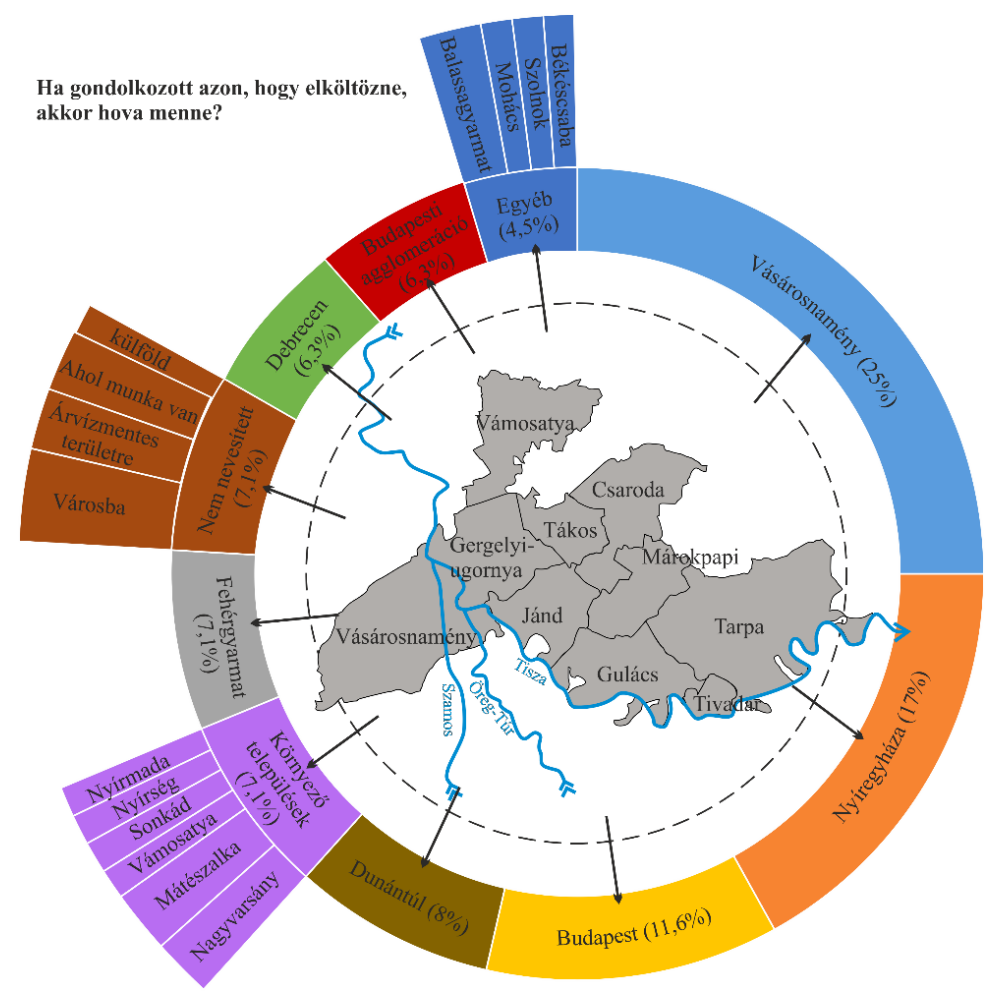

47. ábra: legfőbb költözési célpontok a beregi mintaterületen. Forrás: kérdőíves felmérés alapján saját szerkesztés

Ráadásul, mivel árvízveszélyes területen fekszenek az ingatlanok, így azok olcsóbbak is, mint az ármentesített oldalon. Hasonló okokból költöznek ki a lakók a korábbi zártkertekbe, ahol a megélhetési költségek csökkentése érdekében önkéntesen mondanak le közszolgáltatásokról (VASÁRUS, G. 2019). Így vállalva azt, hogy természeti kár esetén annak költségeit saját maguk vállalják, mint például Baktó vagy Domaszék esetében. Timár J. a folyamatot több alföldi településen megfigyelte, a társadalmi polarizáció egyik folyamataként identifikálta a szuburbanizáció eme formáját, melyet a szegények szuburbanizációjának is nevez (TIMÁR J. 2001; VASÁRUS G. 2019).

Mindez a stratégia, addig, amíg árvíz nem sújtja a lakókat müködőképes, azonban, mivel egyrészt jogszabályellenes állandó jelleggel üdülőterületen lakni, másrészt a biztosítótársaságok nem fizetnek árvízkárra, így a hátrányos helyzetü lakók fokozottan hátrányos helyzetbe kerülnek. Igen kettős folyamat, hogy bizonyos esetben kárpótolják az érintetteket, annak ellenére, hogy a területen élök tudatában voltak lakóhelyválasztásuk kockázataival. Ez azokban az esetekben történik meg, mikor az érintettek előbbi, nem megélhetési stratégiaként, hanem kellemből költöznek az árvízveszélyes területre, a hullámtérbe, azonban jövedelmük, politikai befolyásuk felhasználásával érdekeiket jobban képesek képviselni. Gergelyiugornya esetében nem csak az üdülőterület került veszélybe a 2001-es árvíz során, hiszen a tarpai gátszakadással a településrész 41-es úttól délre található része víz alá került. A kárpótlást azonban az üdülőterületen élő tulajdonosok nem, vagy csak részben kapták meg. Ez azonban nem egyedi eset a mintaterületen, hiszen nem csak az üdülöterületi lakosok azok, akik nem voltak elégedettek a kárpótlással.

Azok a családok, akik támogatásban, kártérítésben, kárenyhítésben részesültek sem voltak maximálisan elégedettek a segítségnyújtással. Ennek oka, hogy az újjáépített házak tulajdonosai a „modernkori röghöz kötés áldozataivá váltak" - állítja egy 2005-ös egyéni képviselői indítvány. A helyreállítás rendjéről és módjáról a 1033/2001. (IV. 12.) Korm. határozat úgy rendelkezik, hogy a megsemmisült vagy javíthatatlan lakóházakat csak az állam építhette újjá, illetve pénzbeli kártalanítást kérhettek a károsultak. A kártalanítás összege azonban a tényleges értéknél alacsonyabb mértékben került meghatározásra. A károsultak ezért „önként" választották a 15 éves „,öghöz kötést". Ennek következtében azonban 15 éves jelzálog került az ingatlanokra, mely eladhatatlanná tette azokat. Az érintett települések többsége azonban halmozottan hátrányos helyzetü, így az ingatlanok jelzálogban megállapított öszszege többszöröse a tényleges értékének, tehát azok szinte eladhatatlanok. Egy része a mai napig üresen 
áll, esetlegesen második otthonként funkcionál. KISS ALIDA kutatásában vizsgálta az érintett települések egy részének ingatlanpiaci helyzetét, tanulmányában állítja, hogy „, az átlagosan 18 millió forintért épült új házak, 4 millió forint körüli forgalmi értékkel rendelkeznek” (KISS, A. P. 102). Az ingatlanokra fordított költség és a valós piaci érték, valamint a szándékos röghözkötés, illetve az újjáépítési munkálatokba való lakossági bevonás hiánya a környezeti igazságtalanság jegyeit mutatja.

A belvizes területeken az elköltözni vágyók főként Szegedre és a szegedi belvárosba költöznének. A válaszadók egyötöde a Nyugat-Dunántúlra és a Balaton környékére költözne legszívesebben. A beregi válaszadók közel egynegyede a járás központjába, Vásárosnaményba költözne. A második legtöbb említést a megyeközpont, Nyíregyháza kapta, majd ezt Budapest követi. A borsodi mintaterületen Miskolc vonzó ereje és földrajzi közelsége megmutatkozik az adatokban, hiszen a költözni vágyók több, mint egyharmada a megyeszékhelyre költözne. A második legtöbbet említett desztináció Budapest, melynek történeti hagyományai is vannak, hiszen a térségböl közlekedtek a hírhedt-híres fekete vonatok, szállítva az alacsonyan képzett, gyakran cigány munkaeröt a fövárosba. A válaszadók 7\%-a a települése környékébe költözne a már korábban említett okok miatt. Érdekes folyamat figyelhetö meg a mintaterületen, hiszen a megkérdezettek jelentékeny, több, mint 13\%-a úgy gondolja, hogy mindegy, hogy hova, csak Borsodból, árvízzel érintett területtől elköltözzön. Ez a jelenség a vörösiszap-katasztrófa által érintett lakosság esetében hatványozottan jelentkezik, hiszen a válaszadók valamivel kevesebb, mint egynegyede gondolja úgy, hogy bárhova szívesen költözne, csak a mostani lakóhelyétöl távol legyen. Budapest és a Balaton térsége a második és harmadik legtöbbet megnevezett költözési célpont.

\subsubsection{A katasztrófák egészségügyi vonatkozásai az érintettek szemszögéből}

A korai környezeti igazságosság-vizsgálatok erősen kötődtek a környezeti károk okozta egészségkárosodáshoz. A doktori disszertációban kérdésként merül fel, hogy hazánkban, a nemzetközi tapasztalatokkal megegyezően az érintettek egészségkárosodásával számolhatunk-e. További kérdés, hogy az egészségkárosodásról, vagy annak kialakulási lehetőségéröl tudnak-e a katasztrófával érintettek. Abban az esetben, ha egészségi problémáik merülnek fel a katasztrófákkal kapcsolatban, a nemzetközi szakirodalom környezeti igazságtalanságról számol be. Azonban akkor is igazságtalan helyzetről beszélhetünk, ha az egészségkárosítás lehetőségéről nincs infomrációjuk a lakosoknak. Ennek érdekében minden vizsgált mintaterületen a válaszadók értékelték saját egészségi állapotukat a katasztrófa elöttihez képest, illetve beszámolhattak bármiféle egészségügyi problémájukról, valamint arról, hogy véleményük szerint származhat-e egészségügyi problémájuk a katasztrófából.

A vörösiszap-katasztrófával sújtott településeken a katasztrófa kiemelten egészségkárosító hatására tekintettel az egészségügyi problémákkal bővebben foglalkozó kérdőívet töltöttek ki a válaszadók. A kérdőív olyan kérdésekkel egészült ki, melyek egyrészt a mentális, valamint a fizikális egészségre is vonatkoztak, azok tüneteinek meglétére, illetve hiányára kérdeztek rá. A katasztrófákat követően gyakran a lakosok az elszenvedett anyagi és immateriális károk miatt depresszióssá válhatnak. A depresszió betegségnek leggyakoribb tünetei közt van a levertség, fáradékonyság, szomorúság és rosszkedv. Az eredmények azt mutatják, hogy akik magukon tapasztalható tünetként megjelölték a levertséget, azok nagy többségben és valószínüséggel a másik három tünetet is tapasztalták. A válaszokat megvizsgáltam az alapján is, hogy a katasztrófával közvetlenül vagy közvetetten és egyáltalán nem érintettek között a válaszadásban van-e bármi különbség. A kereszttábla-elemzés és a független t-próba eredményei alapján azonban nem fedezhető fel különbség az érintettek és nem érintettek közt. Összességében a megkérdezettek egynegyede tapasztalt levertséget, fáradékonyságot vagy rosszkedvet, az érintettek körében ez az érték valamivel alacsonyabb is (22\%). A fáradékonyság esetében tapasztalhatunk némi együttmozgást, azonban ez ellentétes a várttal, hiszen a saját bevallásuk alapján közvetlenül nem érintett megkérdezettek kevésbé érzik az említett tüneteket magukon (23. táblázat). 
23. táblázat: a depresszió tüneteinek megjelenése a megkérdezettek körében. Forrás: kérdőíves felmérés alapján saját számítás

\begin{tabular}{|c|c|c|c|c|c|c|}
\hline \multirow{3}{*}{$\begin{array}{c}\text { Érintette-e közvet- } \\
\text { lenül a vörösiszap- } \\
\text { katasztrófa? }\end{array}$} & \multicolumn{6}{|c|}{ Tapasztalja-e magán a következö tüneteket? } \\
\hline & \multicolumn{2}{|c|}{ Levertség, egykedvüség } & \multicolumn{2}{|c|}{ Fáradékonyság } & \multicolumn{2}{|c|}{ Szomorúság, rosszkedv } \\
\hline & igen & nem & igen & nem & igen & nem \\
\hline Igen & 18 & 63 & 15 & 66 & 21 & 60 \\
\hline Nem & 17 & 49 & 19 & 47 & 16 & 50 \\
\hline Total & 35 & 112 & 34 & 113 & 37 & 110 \\
\hline$\chi^{2}$ & \multicolumn{2}{|c|}{0,251} & \multicolumn{2}{|c|}{2,157} & \multicolumn{2}{|c|}{0,55} \\
\hline
\end{tabular}

A vörösiszap maró, lúgos kémhatása nedves, nyirkos közegben nem csak folyékony és iszapszerü, de levegőbe kerülő szemcseként is egészségkárosító lehet. A katasztrófa óta a vörösiszap száraz ülepítéssel depontált hulladék, a korábbi csurgalékvizes technológát felhagyták. Megkezdték a tározók remediációját, befedését. Azonban amíg a terület teljes felszínborítottsága nem megoldott nagyobb szélben az iszapból létrejövő por a légkörbe kerülve kockázatot okozhat, rosszabb esetben pedig komoly porviharokhoz vezethet. Annak ellenére, hogy a vörösiszap száraz, szilárd halmazállapotú lúgosságát nem veszíti el, így a légzőrendszerbe kerülve, illetve a börfelületeken irritatív hatású. Hosszútávú, nagy mennyiségü belégzése pedig egyéb, komolyabb betegségek, például asztma vagy légzőrendszeri daganat kialakulásához is vezethet. Ennek érdekében a kérdőíves felmérésben válaszadókat megkérdeztem, hogy tapasztalnak-e rohamszerü köhögést, száraz érzetet a torokban, mellkasi fájdalmat és légzési nehézséget, bőrirritációt és viszkető érzést, esetleg jelentkeznek-e börükön kiütések. A megkérdezetteket szintén két csoportra, az érintettek és nem érintettek körébe kategorizáltam. Az alacsony elemszám miatt a kiütések (összesen 4 fö jelölte meg) eredményei nem tekinthetők a khí-négyzet próba szerint szignifikánsnak és relevánsnak. Szintén alacsony az elemszám a bőrirritáció és viszkető érzés (16 megnevezés) tünetnek, azonban itt csupán egy cella (25\%) értéke nem haladja meg a minimálisat, így ez az eredmény szignifikánsnak tekinthető. A Khí-négyzet próba alapján a vörösiszap-katasztrófa érintettjei inkább küszködnek légzési nehézségekkel, száraz érzettel a torokban, bőrirritációval és rohamszerü köhögéssel (24. táblázat), mint a nem érintettek. Mindez természetesen nem bizonyíthatóan a vörösiszapnak köszönhetők. Mindemellett amíg a válaszadókban akár vélt vagy valós kockázat miatt fizikai tünetek alakulnak ki, úgy az az életminőségüket rontja. Mindemellett abban az esetben, ha a tapasztalt tünetek nem a vörösiszaphoz köthetök, akkor érdemes lenne a lakosságot tájékoztatni, rendszeresen értesíteni a jelenlegi környezeti állapotról, mellyel megnyugtathatók. Mindez elejét venné a spekulációknak is.

24. táblázat: A vörösiszap okozta potenciális tünetek megjelenése a megkérdezettek körében. Forrás: saját szerkesztés

\begin{tabular}{|c|c|c|c|c|c|c|c|c|c|c|}
\hline \multirow{3}{*}{$\begin{array}{l}\text { Érintette-e köz- } \\
\text { vetlenül a vörö- } \\
\text { siszap-kataszt- } \\
\text { rófa? }\end{array}$} & \multicolumn{10}{|c|}{ Tapasztalja-e magán a következő tüneteket? } \\
\hline & \multicolumn{2}{|c|}{ Kiütések } & \multicolumn{2}{|c|}{$\begin{array}{l}\text { Bőrirritáció, } \\
\text { viszkető érzés }\end{array}$} & \multicolumn{2}{|c|}{$\begin{array}{l}\text { Légzési nehézségek } \\
\text { és mellkasi fájda- } \\
\text { lom }\end{array}$} & \multicolumn{2}{|c|}{$\begin{array}{c}\text { Száraz érzet a } \\
\text { torokban }\end{array}$} & \multicolumn{2}{|c|}{$\begin{array}{l}\text { Rohamszerü köhö- } \\
\text { gés }\end{array}$} \\
\hline & igen & nem & igen & nem & igen & nem & igen & nem & igen & nem \\
\hline Igen & 3 & 78 & 13 & 68 & 22 & 59 & 24 & 57 & 26 & 55 \\
\hline Nem & 1 & 65 & 3 & 63 & 12 & 54 & 12 & 54 & 11 & 55 \\
\hline Total & 4 & 143 & 16 & 131 & 34 & 113 & 36 & 111 & 37 & 110 \\
\hline$x^{2}$ & \multicolumn{2}{|c|}{0,658} & \multicolumn{2}{|c|}{4,962} & \multicolumn{2}{|c|}{1,649} & \multicolumn{2}{|c|}{2,577} & \multicolumn{2}{|c|}{4,598} \\
\hline
\end{tabular}

Mindez azért is fontos lehet, mert a megkérdezettek arra a kérdésre, hogy a felsorolt tünetek közül van-e olyan, melyet csak a vörösiszap-katasztrófa után tapasztal, a válaszadók 47\%-a úgy érzi, hogy többségében a katasztrófa után alakult ki tapasztalt tünete. Emellett további 6,5\% érzi úgy, hogy az általa felsorolt tünetek közül néhányat érez a katasztrófa óta, a többsége már korábban is megvolt. Ösz- 
szességében elmondható, hogy a megkérdezettek többsége nem tapasztalta a felsorolt tüneteket, azonban bizonyos esetekben akár 20\%-ot is meghaladó lehet az egyes tünetek megjelenése, mely viszonylag magas értéknek tekinthető, mindemellett a Khí-négyzet próbák alapján csak bizonyos tünetek esetében szignifikáns a tapasztalás az érintettek és a nem érintettek között.

A válaszadókat arról is kérdeztük, hogy jelenleg van-e bármiféle egészségügyi problémája. A megkérdezettek közül 66 fö (44,9\%) nyilatkozott úgy, hogy orvos által regisztrált betegsége van, 72 fó (49\%) pedig, hogy nincs betegsége, 9 fö nem nyilatkozott. Arra a kérdésre, hogy okozhatja-e a betegségét a vörösiszap, a többség (46 fö - 74,2\%) nemmel válaszolt. Nincs szignifikáns különbség azon válaszadók közt, akiket közvetlenül érintett a vörösiszap és akiket nem, míg a betegség megléte kis mértékben együtt mozog az érintettséggel (khí=1,569), de nem tekinthető szignifikánsnak. Ezek alapján a környezeti igazságtalanságokkal foglalkozó kutatások egyik általános megállapítása, hogy a katasztrófa egészségkárosodáshoz vezet csak részben teljesül. Illetve fontos megjegyezni, hogy a vörösiszap okozta egészségügyi hatások indirektek, elöfordulhat, hogy csak egy vagy két évtizeddel az eset után lesznek felfedezhetők. A katasztrófa és a környezeti degradáció alapján a térségben a prognosztizálható betegségek légzőszervrendszeri (asztma, krónikus hörghurut vagy tüdőtágulat), valamint daganatos (bőr és légzőszervi) megbetegedések. A válaszadók önbevallása alapján a betegségeket a BNO kódoknak megfelelöen csoportosítottam.

Az eredmények alapján összesen 94 betegséget nevezett meg 66 válaszadó. A legtöbb betegség az országos statisztikának megfelelően szív-és érrendszeri megbetegedés volt a mintavétel időpontjában. A betegségek arányait a vizsgálat évében regisztrált egészségügyi adatokkal vetettem össze. Mind a nyers, mind az arány-értékekre elvégzett átlagpróba azt mutatta 0,01-es szignifikancia szinten, hogy a kérdőíves minta és a mintaterület három településén OEP által regisztrált betegségek megoszlása szignifikánsan eltér $(\mathrm{t}=4,680 \mathrm{df}=24)$ (25. táblázat). Tehát a mintában tapasztaltak nem képezik le a teljes település megbetegedéseit tehát a nullhipotézis, mely szerint a mintában szereplö lakosság - akik többségben a katasztrófa közvetlen érintettjei voltak - arányaiban másféle betegségekben szenvednek, beigazolódott. Mindez azonban annak figyelembevételét is szükségessé tette, hogy a vörösiszap-katasztrófa által érintett és nem érintett lakosok csoportja közt van-e különbség (25. táblázat).

25. táblázat: A teljes lakosság és a minta közötti hasonlóságok és különbségek alakulása a Vörösiszappal érintett mintaterületen. Forrás: OEP adatai és kérdőíves felmérés

\begin{tabular}{|c|c|c|c|}
\hline & $\mathrm{t}$ & df & $\begin{array}{c}\text { Szignifikancia } \\
\text { szint }\end{array}$ \\
\hline Teljes lakosság - Kérdöíves minta & 4,680 & \multirow{4}{*}{24} & 0,001 \\
\hline Teljes lakosság - Érintett lakosság (kérdőíves minta) & 4,677 & & 0,001 \\
\hline Teljes lakosság - Nem érintett lakosság (kérdőíves minta) & 4,676 & & 0,001 \\
\hline Érintett lakosság- Nem érintett lakosság (kérdőíves minta) & 3,241 & & 0,007 \\
\hline
\end{tabular}

Arra a kérdésre, hogy a kérdöíves mintában szereplök körében, az érintett és nem érintettek közt van-e különbség, bár alacsonyabb értékkel és kisebb bizonyossággal (99,3\%), de szintén bebizonyosodott a két csoport különbözösége. Ez azt jelenti, hogy az érintettek és a nem érintettek közt a regisztrált betegség típusokban, azok statisztikai eloszlásában különbözőség van. A szakirodalom és a katasztrófa alapján arra számíthatunk, hogy arányaiban nagyobb csoportot képeznek a légúti, illetve bőr betegségeit tapasztalók az érintettek körében. Ez részben igazolódik, hiszen a légúti megbetegedések aránya jóval magasabb az érintettek, mint a nem érintettek körében (15-3\%), azonban a teljes lakossághoz képest még így is két százalékponttal alacsonyabb a betegség előfordulása. A légúti megbetegedéseket említők közül kivétel nélkül az asztmát és az allergiát említették. A bőrbetegségek esetében olyan alacsony az előfordulás, mindössze 1 fö, és az sem köthető a vörösiszaphoz, hogy megállapítható, hogy a korábbi feltételezés, mely szerint nagyobb arányban szenvednek bör vagy légúti betegségekben megdőlt. Az orvos által regisztrált, feltételezhetően a katasztrófához köthető betegség lehet még a depresszió, melyet a mentális betegségek közé sorol az OEP. Az ebbe a körbe tartozó betegségek sokszínủek, számos mentális betegséget nyilvántartanak, erről a mintaterületre részletes adatok nem állnak 
rendelkezésre. Bár a mintában az érintett lakosság esetében alacsonyabb az e kategóriába sorolt betegségek részaránya, mint a teljes lakosság körében nyilvántartott (5 és 7\%), azonban a mintaterületen a depresszión kívül más betegséget nem neveztek meg és a nem érintettek nem számoltak be ilyen típusú betegségröl. Tehát feltételezhető, hogy a depresszió részaránya magasabb az érintettek körében, mint a teljes lakosságban (48. ábra).
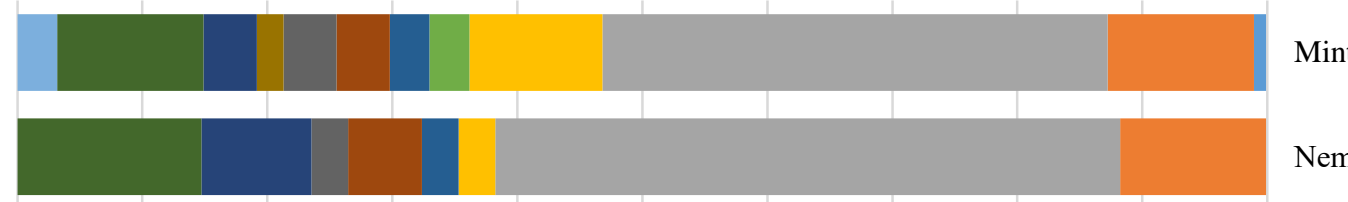

Nem érintett

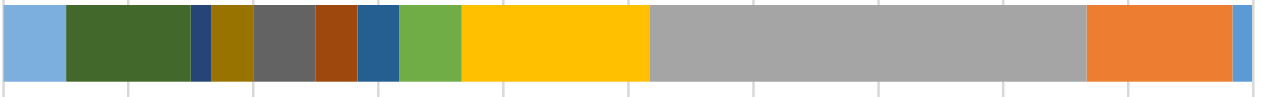

Érintett

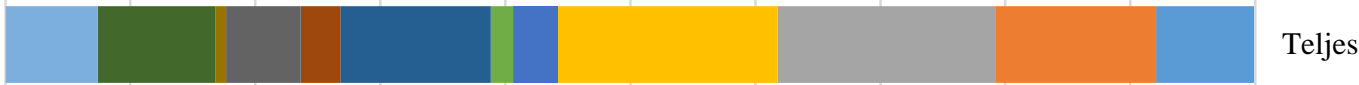

$\begin{array}{llllllllll}100 \% & 90 \% & 80 \% & 70 \% & 60 \% & 50 \% & 40 \% & 30 \% & 20 \% & 10 \%\end{array}$

- A bör és böralatti szövet betegségei

A csont-izomrendszer és kötöszövet betegségei

A keringési rendszer betegségei

A légzörendszer betegségei

- A szem és függelékeinek betegségei

- A vér és a vérképző szervek betegségei és az immunrendszert érintő bizonyos rendellenességek

- Az emésztőrendszer betegségei

- Az idegrendszer betegségei

- Az urogenitális rendszer megbetegedései

- Daganatok

- Egyéb

- Endokrin, táplálkozási és anyagcsere betegségek

- Mentális és viselkedészavarok

48. ábra: A vörösiszappal érintett települések BNO alapú betegség-megoszlása a teljes lakosság körében illetve a megkérdezett lakosság körében. Forrás: KSH adatok és kérdőíves felmérés alapján saját szerkesztés

A vörösiszappal érintett mintaterület mellet az árvizes és a belvizes területek is sajátos egészségügyi kockázatokat hordoznak magukban. Ennek felmérése, ismerete és a szükségszerü beavatkozások megtétele a környezeti igazságosság feltétele. Az árvizek emberre, és föként az emberi egészségre gyakorolt hatásait több tudományos munka is összefoglalja (REACHER, M. ET AL 2004; AHERN, M. ET AL. 2005; MoRGAN, O. ET AL. 2005; WALKER, G. ET AL. 2006; WHO 2011; FEYEN, L. - DuNKER, R. 2009). A környezeti igazságosság témakörét azonban a Kathrina hurrikán után kezdték összekapcsolni az árvizekkel, és azok hatásaival valamint a szegregáció, gettósodás és a környezeti degradáció együttes veszélyeivel (RYDIN, Y. 2006). Az árvizek által okozott károk sokfélék (26. táblázat), azonban legtöbbjük kellő mennyiségü pénzügyi forrás segítségével helyreállítható. A környezet károsodása, és az emberi életben bekövetkezett sérülések azonban sokkal nehezebben, vagy egyáltalán nem kompenzálhatók pénzzel, így a rawlsi értelemben vett igazságosság megvalósulásának lehetősége ebben az esetben nagyon korlátozott.

26. táblázat: Az árvízi károk tipizálása. Forrás: saját szerkesztés

\begin{tabular}{|c|c|c|}
\hline $\begin{array}{c}\text { Ingóságban és ingatlanban keletke- } \\
\text { zett kár }\end{array}$ & Egyénben keletkezett kár & Természetben keletkezett kár \\
\hline Megrongálódás & Megbetegedés, sérülés & Szennyeződés \\
\hline Megsemmisülés & Halál & Visszafordíthatatlanul károsodik \\
\hline
\end{tabular}

Árvíz okozta humán-egészségügyi kockázatok lehetnek direktek és indirektek. Utóbbi esetében föként a lakóingatlant ért károk közvetett következménye az egészségügyi probléma. A lakhatás az egyik legalapvetőbb emberi létfeltétel, a szociológusok és a társadalomföldrajzosok is az egyik megha- 
tározó alaptényezőnek tekintik, mely nem csak fizikai, de társadalmi-közösségi dimenzióval is rendelkezik. A lakhatás különböző dimenziói mellett annak minőségében is hatalmas eltérések vannak, mely a kultúrából, családi hagyományokból, vagyoni helyzetböl stb. ered. Az épületeknek létezik az a minimális követelményrendszere, mely alkalmassá teszi azokat lakhatásra, és megfelelö életteret biztosít a benne lakóknak, ezen alapfeltételeket jogszabályban rögzítik. Amennyiben ezek a feltételek nem teljesülnek a lakóhellyel kapcsolatban, akár akut és krónikus megbetegedéseket tapasztalhatunk a lakosok között. Abban az esetben mikor a katasztrófával érintettek a katasztrófához köthető ingatlanpiaci csapdázódás miatt nem tudnak változtatni lakókörnyezetükön, igazságtalan helyzet áll elő. A nemzetközi és ezt átvéve a hazai szakirodalom is nyilvántartja azokat az eseteket, mikor a nem megfelelő lakókörnyezet az, mely az egyén egészségét csorbítja és életminőségét rontja. Ez a jelenség a Beteg Épület Szindróma (Sick Building Syndrome), továbbiakban SBS (KREISS, K. 1990; BONNEFOY, X. 2007). Általánosan megállapított, hogy a legnagyobb arányban a hátrányos helyzetü, elmaradottabb valamint szegényebb országrészekben nagyobb arányban detektálható SBS (KREISS, K. 1990).

Az árvíz és föként a belvíz a beltéri penész kialakulásának egyik okozója lehet. A vízben álló épület nem megfelelő szigetelése miatt felvizesedik, penészesedésre hajlamossá válik. A penészgomba spórái a levegőben lebegnek, a nyálkahártyára kerülve allergizáló hatásúak, a hörgőkben allergiás náthát, a hörgöcskékben allergiás asztmát, a léghólyagokban gyulladást okozhatnak, de kialakulhat ekcéma vagy kiütés is. A penész jelenléte a lakásban kétszeresére növeli a bronchitis és az asztma kialakulását (EMBER I. 2007, RUDNAIP. 2007). Ezt a helyzetet súlyosbíthatja az ingatlan túlzsúfoltsága, ahol megnövekedett beltéri páratartalom segíti elő a penész kialakulását, ráadásul a levegőben terjedő vírusok, baktériumok is gyorsabban terjednek. A lakás belső hömérséklete és páratartalma fontos kérdés a penész kialakulásában, azonban a fütés problematikája is legalább ennyire fontos, hiszen további kockázatot jelent a lakosok számára, hogy a fütést fával oldják meg. A nem megfelelő szellőzés mérgezéshez vezethet, a füst, pernye, por, korom pedig irritálhatja a nyálkahártyát. Hazánkban, a téli időszakban családok gyakran egyetlen szobát fütenek be fával, itt tartózkodik az egész család. Emellett a vizsgált árvízzel érintett borsodi mintaterület légszennyezettsége az országos átlagnál magasabb (EMBER I. 2007). Boldván egy interjúalany elmondása szerint a köd és a füst együttes hatása miatt fél méteresnél is rövidebb látótávolságot észleltek egy hideg, párás decemberi éjszakán.

Az árvíz direkt hatása a fizikai behatás, melyben a vízzel való közvetlen érintkezés a legkockázatosabb, és ez hordozza magában a legnagyobb megbetegedési lehetőséget. Árvízkor megbetegedést okozhatnak az úgynevezett vírushordozók (pl.: szúnyogok), a vízbe kerülő szennyvíz is (EPINFO 2006; AHERN, M. ET AL. 2005). Utóbbi az árvizek talán leggyakoribb és legveszélyesebb fertőzés- és szenynyező-forrása (EMBER I. 2006), mely nem csupán egy típusú, hanem többféle fertőzés forrása is egyszerre. A szennyvíz szerves és szervetlen anyagokat, mikroorganizmusokat tartalmaz, és járványügyi szempontból kifejezetten veszélyesek. Ezek egy-egy árvíz során a felszínre kerülnek, kimosódnak, ingesztióval, vagy akár sérülésen keresztül is fertőznek. Bár a fizikai egészséget nagymértékben meghatározó mentális egészség kifejezetten fontos, mégis kevesebb hangsúlyt kap a látványosan terjedő és pusztító járványok kockázata mellett. Nem elhanyagolható, hogy egy-egy katasztrófa sokkhatása traumatikus, egész életet meghatározó lehet. A felnőtteknél a depresszióra való hajlam szignifikáns növekedést mutatott az árvizek után (REACHER ET AL. 2004; AHERN ET AL. 2005; MORGAN, O. ET AL. 2005). A vizsgálat során tehát egyrészt az árvíz és belvíz okozta indirekt egészségügyi hatásokat, másrészt pedig a direkt hatásokat tekintettem végig, kiemelt figyelmet szentelve a mentális egészség kérdéskörére.

A vizsgálat első lépéseként az árvizes mintaterületek esetében, a vörösiszapos mintaterülethez hasonlóan megvizsgáltam az érintettség és az egészségügyi problémák kapcsolatát. Kétféle megközelítést alkalmaztam ebben az esetben, egyrészt földrajzilag másrészt pedig a csoporton belül kerestem hasonlóságokat és eltéréseket. Megvizsgáltam, hogy melyek a vizsgált települések országos adatbázisban rögzített leggyakoribb betegségei, illetve hogy ez mutat-e eltérést a mintavétel során felmért betegségektől, vagy a minta a teljes lakosság eredményeit képezi-e le. Emellett azt vizsgáltam, hogy az érintett és nem érintett lakosság között van-e eltérés a tapasztalt betegségekben, másrészt pedig, hogy a borsodi és a bergi mintaterületek között tapasztalható-e különbség. 
A megkérdezettek $82 \%$-át közvetlenül is érintette az árvíz, akiknek azonban csak egyötöde nyilatkozott úgy, hogy véleménye szerint egészségügyi problémája eredeztethető az árvízből (27. ábra). Az érintettek és nem érintettek csoportjai közt szignifikáns eltérés van, abban, hogy származott-e egészségügyi problémája az árvízből adódóan. Az érintetteknek közel egyötöde, míg a nem érintetteknek csupán két százaléka gondolja úgy, hogy származott egészségügyi problémája az árvízből (Khí=33,359 $\mathrm{df}=1)$.

\section{Az árvízzel való érintettség és az egészségügyi problémák összefüggése Forrás: saját szerkesztés}

\begin{tabular}{|l|l|l|l|l|l|l|}
\cline { 3 - 7 } \multicolumn{2}{|c|}{} & \multicolumn{2}{l}{$\begin{array}{l}\text { Az árvízhez kapcsolódóan származott-e valamilyen egészségügyi } \\
\text { problémája? }\end{array}$} \\
\cline { 3 - 8 } \multicolumn{2}{|l}{} & Igen (fö) & $(\%)$ & Nem (fö) & $(\%)$ & Összes (fö) \\
\hline $\begin{array}{l}\text { Érte-e árvízkár az Ön házát az el- } \\
\text { múlt évtizedben? }\end{array}$ & Igen & 151 & 21,92 & 538 & 78,08 & 689 \\
\cline { 2 - 8 } & Nem & 3 & 1,96 & 150 & 98,04 & 153 \\
\cline { 2 - 8 } & Összes & 154 & 18,29 & 688 & 81,71 & 842 \\
\hline
\end{tabular}

A két mintaterület is szignifikánsan eltér egymástól a válaszadásokat tekintve, míg Bereg esetében a válaszadók tizede, addig Borsodban a negyede gondolja úgy, hogy az árvíz egészségét károsította. Az érintettek és nem érintettek viszonylatában is szignifikáns a különbség, az árvízzel érintettek körében a beregiek 14,5\%-a, a borsodiak 42\%-s érzi úgy, hogy az árvíz miatt egészségügyi problémái keletkeztek (28. táblázat). Az érintettek-nem érintettek mind a teljes árvizes mintaterületen, mind a mintaterületi bontást tekintve szignifikánsan eltérnek egymástól (Khí=31,118 df=1).

\section{Az árvízzel való érintettség és az egészségügyi problémák összefüggése mintaterületenkénti bontásban Forrás: saját szerkesztés}

\begin{tabular}{|c|c|c|c|c|c|}
\hline & & \multicolumn{4}{|c|}{ Érte-e árvízkár az Ön házát az elmúlt évtizedben? } \\
\hline & & \multicolumn{2}{|c|}{ Bereg } & \multicolumn{2}{|c|}{ Borsod } \\
\hline & & Igen & Nem & Igen & Nem \\
\hline \multirow{2}{*}{$\begin{array}{l}\text { Az árvízhez kapcsolódóan származott-e valamilyen egész- } \\
\text { ségügyi problémája? }\end{array}$} & Igen & 40 & 2 & 111 & 1 \\
\hline & Nem & 275 & 83 & 263 & 67 \\
\hline
\end{tabular}

Arra a kérdésre, hogy milyen típusú betegség származott az árvízböl összesen 184 válasz érkezett, egy fő akár több betegséget is megjelölt. Beregböl összesen 44, Borsodból pedig 140 betegséget jelöltek meg a válaszadók. Az országos átlagnál nagyobb arányú az említett két megyében a légúti megbetegedések aránya, mely részben köthető a már említett légszennyezettséghez, valamint az SBShez is. Éppen ezért a hipotézisem az volt, hogy a válaszadók nagyobb arányban nevezik meg majd a légúti megbetegedéseket. Ez a feltevésem megdőlt, hiszen az érintettek a teljes mintában mért $21 \%$ helyett csak 11\%-ban neveztek meg ilyen betegségeket. Mindezek ellenére kiemelendő, hogy a tüdögyulladás nagyobb számú említése mellett az asztma volt az a légzőrendszeri megbetegedés, melyet szinte a válaszadók 90\%-a említett, így bár alacsonyabb ezen betegségek aránya, mégis sokkal homogénebbnek tekinthető. Ráadásul az árvizekkel kapcsolatba hozható betegség összefüggést feltételez a természeti katasztrófa és a rossz lakókörnyezet között, mely környezi igazságtalanságként azonosítható attól eltekintve, hogy a kialakulása vélt vagy valósan kapcsolódik az árvízhez.

Alacsonyabb arányban fordulnak elő a Kolontár-Devecser mintaterülethez képest a keringési rendszer betegségei, azonban kiugróan magas az „egyéb” és a „mentális és viselkedési zavarok” aránya. Előbbi esetében a fertőző betegségek nagyjából az említések 95\%-át teszik ki, melyek általában sebfertőzések és az árvíz utáni járványok okozta megbetegedést foglalnak magukban. A mentális zavarokban a depresszió a megnevezett betegségek $41 \%$-át adja (49. ábra). Ez is igazolja, hogy a természeti katasztrófák közvetlen hatása nem csak fizikális, a mentális egészségre is igen nagymértékben hat, ezért erre is kiemelt figyelmet szükséges fordítani a katasztrófákat követő kompenzációkor. Összességében 
megállapítható, hogy az OEP adatok alapján a település egészére illetve a nagyobb arányban árvízzel érintettekre vonatkozó adatok szignifikánsan eltérnek egymástól $(\mathrm{t}=2,125 \mathrm{df}=12)$, vagyis statisztikailag is különböznek. Mindez az említett betegségek felülreprezentáltságának köszönhető.

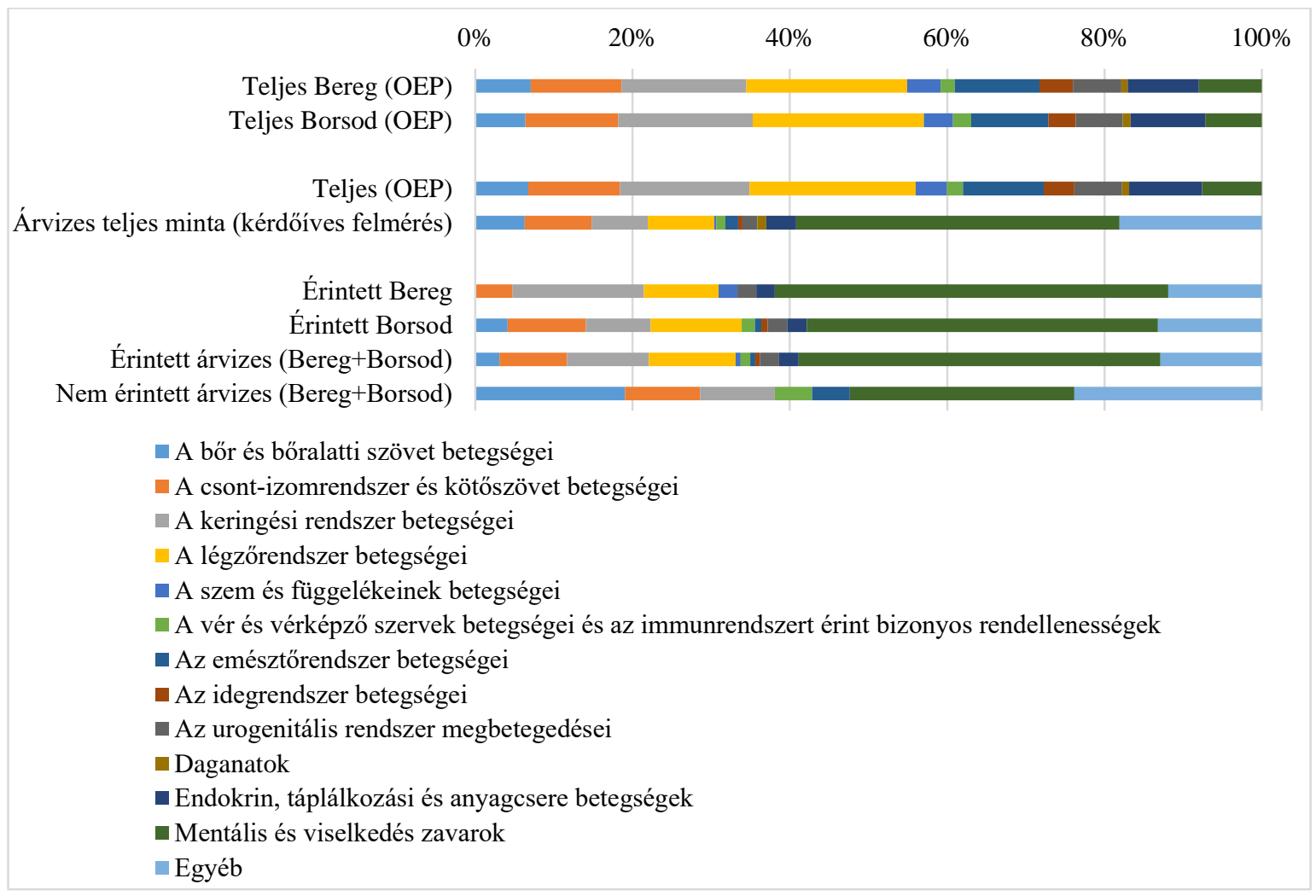

49. Az árvizes mintaterületek egészségügyi problémái Forrás: OEP adatok és kérdőíves felmérés alapján saját szerkesztés

Arra a kérdésemre, hogy van-e eltérés a tapasztalt betegségek összetételében és arányában a két árvizes mintaterületen a párosított t-próba eredményei alapján adtam meg a választ. A két mintaterület eredményei szignifikánsan eltérnek egymástól, mely a keringési és bőr-, valamint mentális betegségek arányainak eltéréséböl ered $(\mathrm{t}=2,426 \mathrm{df}=12)$. Azonban itt fontos megjegyezni, hogy az OEP adatok és a kérdőíves minta eredményei sokkal távolabb állnak egymástól, mint a két mintaterület adatai. Ennek hátterében az húzódik, hogy míg az OEP hitelesített adatforrás, orvosi diagnózison, addig a kérdőíves felmérés önbevalláson alapul. Az érintettek és nem érintettek esetében szintén statisztikai különbség van, az árvízzel közvetlenül nem érintettek kisebb arányban számoltak be mentális megbetegedésröl, mely ellentmond a vörösiszapos eredményeknek, míg nagyobb arányban tulajdonítottak az árvíznek egyéb betegségeket - föként fertőzéseket (24\%) és bőrirritációt, bőrbetegséget (20\%).

A boldvai telepen készült felmérés rávilágított arra, hogy az egészségügyi kockázatokat a hátrányos helyzet illetve, a nemzetközi szakirodalommal összhangban a kisebbségi lét súlyosbíthatja. A telepen fokozottan és halmozottan hátrányos helyzet alakult ki a felmérés időpontjában, mert a 2010-es tavaszi és nyári áradás a szennyvízelvezető hálózattal nem rendelkező telepen kimosta az ólak és az emésztőgödrök tartalmát, mely több napig áztatta a házakat kívülről-belülről. Az áradás közben a telepen sok hasmenéses, bakteriális megbetegedést regisztráltak, és hepatitis és vérhas ellen is oltották a lakosságot. A fertözésveszélyt növelte, hogy a nyári melegben a nedves környezetben a rovarok is megtelepedtek, melyek puszta jelenlétükkel, illetve csípéseikkel terjesztették a betegségeket. Az ár levonulása után több hétnyi fertőtlenítés sem oldotta meg a problémát, a kiszáradt föld fertőtlenítése ellenére továbbra is hordozta a fekália és egyéb bakteriális szennyeződéseket, melyek felporozva a bör irritációját okozták, fóként a gyermekeknél.

További probléma, hogy a lakosok alacsony képzettsége miatt az események összefüggéseinek felismerése nem történik meg (53 fö a 62-böl 8 általánost, vagy annál kevesebbet végzett). Annak ellenére, hogy 2010. július 9-én több hétre lakhatatlanná vált otthonuk, a válaszadók majdnem $50 \%$-a nem 
tud a környezetére, mint lakóhelyére, és annak szomszédságára káros folyamatról. A kérdésre, hogy jelenlegi lakhelyén érte-e egészségkárosító folyamat a válaszadók 73\%-a nemmel válaszolt, viszont ha azt kérdeztem, hogy természeti csapás fenyegeti-e lakhelyét az árvizet azonnal említették a megkérdezettek (29. táblázat). A megkérdezettek 88,9\%-a szerint veszélyezteti a környezetét természeti csapás, $\mathrm{s}$ az igennel válaszolók mindegyike említette az árvizet. Az árvíz gyakoribb meglétét többen a sok csapadékkal, az időjárással indokolták. A belvízveszély kevésbé volt emlegetett, mely azért különös, mert az év nyári időszakát kivéve a telep folyamatos belvíz-elöntés alatt van, így a szennyvízelvezetéssel és vezetékes vízzel nem rendelkező háztartások egészségügyi kockázata folyamatosan fennáll. A kerti WC-k ilyen esetben nem használhatók, így szükség esetén a lakosok a felsőbb térszínen lévő szomszédjaikhoz járnak. A megemelkedett talajvízszint áramlásai fekáliával szennyezik be a telep talaját, mely száraz időszakokban felporozva is bakteriális fertőzéseket eredményez.

29. táblázat: Az egészségkárosító hatás, környezeti folyamatok közötti kapcsolat.

Érte-e egészségkárosító hatás jelenlegi lakhelyén?

\begin{tabular}{|l|l|l|}
\hline & Háztartás & Százalék \\
\hline Igen & 17 & 27 \\
\hline Nem & 46 & 73 \\
\hline Összesen & 63 & 100 \\
\hline
\end{tabular}

Tud-e környezetére káros folyamatokról?

\begin{tabular}{|l|l|l|}
\hline & Háztartás & Százalék \\
\hline Igen & 32 & 50,8 \\
\hline Nem & 31 & 49,2 \\
\hline Összesen & 63 & 100 \\
\hline
\end{tabular}

Véleménye szerint veszélyezteti-e lakhelyét természeti katasztrófa?

\begin{tabular}{|l|l|l|}
\hline & Háztartás & Százalék \\
\hline Igen & 56 & 88,9 \\
\hline Nem válaszolt & 7 & 11,1 \\
\hline Összesen & 63 & 100 \\
\cline { 2 - 3 }
\end{tabular}

Arra a kérdésre, hogy a csapás minek a következménye, csupán egy válaszadó mondta a telep alacsony fekvését, föként a patak közelségét, a vízelvezetésének hibáit (13 említés) sok csapadékot (10 említés), az időjárást ( 9 említés), illetve a gátak hiányát ( 8 említés) vetették fel, hat válaszadó a globális klímaváltozás eredményeként vezette le az időjárás változását.

A Domaszék-Baktó mintaterületen a felmérés a belvízzel való érintettséget vizsgálta. A két mintaterületen összesítve a válaszadók mintegy 40\%-ának okozott kisebb-nagyobb mértékben problémát a belvíz az elmúlt években, annak ellenére, hogy a problémákat megnevező válaszadók csupán 12\%-a nevezte meg a belvizet, mint településen tapasztalható környezeti problémát. A domaszéki mintaterületen a megkérdezett személyek fele arról számolt be, hogy közvetlenül érintette a belvíz az elmúlt években. A legtöbbeknek, a problémával érintettek mintegy 77\%-ának mezőgazdasági földjében, terményében vagy kiskertjében keletkezett káruk. Sok esetben időszakosan az egész kert, vagy annak jelentős része víz alá került. A Domaszéken megkérdezett belvízzel érintettek 48\%-ának érte kár házát valamilyen formában, többségében a pince beázása volt tapasztalható, ami ideiglenesen használhatatlanná tette a helyiséget. A pincebeázás mellett a falak felázása és megrepedezése is gyakran említésre került a keletkezett károk között. Utóbbi a már említett módon közvetetten légúti megbetegedéseket idézhet elő. Domaszék esetében összesen két személy nyilatkozott úgy, hogy a belvíz miatt egészségkárosodást szenvedett. Baktón a kiskertes részen élők 24\%-a számolt be a belvízproblémával való érintettségéről, csupán egy személy számolt be olyan egészségkárosodásról, melynek kialakulását a belvíznek tulajdonította. Közvetlen összefüggés a belvíz és az egészségkárosodás között sem statisztikailag, sem orvosilag nem mutatható ki a mintaterületen.

A környezeti igazságtalanság-kutatások egyik meghatározó motívuma, hogy a katasztrófák során elszenvedett igazságtalanságokat a jövedelmi viszonyokkal illetve az etnikai hovatartozással hozzák összefüggésbe. A válaszok alapján mind a négy mintaterületen megvizsgáltam az említett változókat, azonban csupán az árvizes területeken kaptam eredményeket, hiszen mind a vörösiszappal, mind pedig a belvízzel érintett területek esetében 10 fö alatt volt a magát romának illetve cigánynak vallók száma, előbbi esetében 7 fö, utóbbi esetében 2 fö.

Összességében megállapítható, hogy a vizsgált minaterületeken egyértelműen nem bizonyítható a környezeti igazságtalansághoz kapcsolódó egészségügyi szempontú károsodás hosszútávon. Mindezek ellenére olyan markáns folyamatok sé törésvonalak rajzolódnak ki, melyek mindenképpen megfontolásra érdemesek a települések döntéshozóinak szemszögéből. 


\section{8. Összegzés}

A globális klímaváltozás, illetve a rendszerváltást követő társadalmi-gazdasági átalakulási folyamat több szempontból kihívások elé állította hazánk lakosságának jelentős részét, gazdasági szereplöit, közigazgatási intézményeit. A fellépő új problémákra eltérő válaszok érkeztek a különböző társadalmi csoportokból, gazdasági és politikai szereplőktől, eltérö földrajzi léptékben. Ezek a reakciók alapvetően a változásokhoz való alkalmazkodást, vagy az arra tett kísérletet jelentették. A 20. században környezetre nehezedő antropogén hatásokat a szocialista országokban megfigyelhető környezeti nihilista szemlélet tovább erősítette. Kiemelt jelentősége van, hogy az egyre növekvő emberi befolyás a természeti rendszerekben nem csak helyi, de léptékeken átívelő, komplex problémákat generál, melyek politikai, jogi, társadalmi és gazdasági következményekkel járnak. Ezek a következmények a társadalom eltérő csoportjait más-és más módon érintik, mely bizonyos csoportokat előnyösebb, másokat hátrányosabb helyzetbe hoz. Az így elóálló komplex kihívásokra csak megfelelő adaptációval válaszolhatunk, mely azonban lokális és globális hatalmi viszonyoktól, döntési mechanizmusoktól függ. Mindezek további feltételek, személyes vagy társadalmi tényezők, például érték- és normarendszer, elvek, szabályok és egyéni és társadalmi tudás függvényei. A környezetben zajló folyamatok alapvetően az ember-környezet és az ember-ember viszonyok együttes hatásaként értelmezhetök. Ezen rendszerek folyamatos átalakulásban és változásban vannak, melyek ,zavarai” egyenlőtlenségeket és igazságtalanságokat fognak generálni. Mindezeknek igen erőteljes térbeli vonatkozásai és földrajzisága van.

A disszertációban két fő és több alkérdésre kerestem a választ. A dolgozat első felében arról értekeztem, hogy (1.) Hogyan definiálható a környezeti igazságosság, illetve hogyan értelmezhetõek a természeti és társadalmi-gazdasági környezet kölcsönhatásából eredö igazságtalan helyzetek, milyen megnyilvánulási formái és gyakorlati vonatkozásai vannak ezen folyamatok feltárásának?

Ehhez kapcsolódóan elsődlegesen arra kerestem a választ, hogy (1.1.) a környezeti igazságosság, mint gondolati keret hogyan kapcsolódik a földrajztudományhoz, milyen kapcsolódási pontjai vannak a kritikai földrajzzal? A kérdésre röviden három fö tényező említésével találtam választ. A környezeti igazságosság és a földrajztudomány legfontosabb összekapcsolója a térbeli szemlélet, mely nem csak vizsgálati keretet ad a környezeti igazságosság-kutatásoknak, de a térben fellépő igazságtalanságok aktív alakítója, formálója is. Mindemellett a kibontakozó fenntartható fejlődés elmélete mind a földrajzba, mind pedig a környezeti igazságosság-kutatásokba és mozgalmakba is beépült, mely további kapcsolódási pontot jelent. További egyezőséget adhat a kritikai szemlélet, mely vallja a plurális értékalkotást és kutatási definíciókat, az egyes nézőpontok párhuzamos létezését és igazát is. A környezeti igazságosság egy olyan gondolati keret lehet a földrajzon belül, mely kihasználja a földrajz szintetizáló képességét és térszemléletét, emellett összeköti a társadalom- és természetföldrajzi kutatásokat, mindemellett kritikai szemlélettel közelít az egyes kutatási irányok felé.

Ezt követően a környezeti igazságosság- kutatások történetével foglalkoztam, azt vizsgáltam, hogy (1.2.) az elmúlt évtizedekben milyen meghatározó momentumok voltak, melyek a környezeti igazságosság koncepció kifejlödéséhez vezettek, illetve mi a jelenleg egyezményesen elfogadott és alkalmazott logikai keret? A környezeti igazságosság mint gondolati keret az 1960-as évek polgárjogi mozgalmával bontakozott ki, majd többszöri átalakuláson, a kutatási paletta bővülésén ment keresztül. A tudományos publikációk alapján a korábbi egyoldalú és egyfókuszú elosztás és eloszlás igazságtalansága (distributive justice) mellett ma már azonos hangsúlyt kap az igazságtalanságok kialakulását előidéző folyamatok (procedural justice) feltárása és az egyén szubjektív értékelése és érzékelése is (recognitional justice). A környezeti igazságosság-kutatások alapvetően három egymással kapcsolatos elemre helyezik a hagsúlyt, az igazságosságra, mint fogalomra, a folyamatra és a bizonyítékokra, melyek az igazságtalanságok vagy igazságosság megvalósulását tárja fel.

Az elméleti megalapozás érdekében megvizsgáltam, az igazságosság-fogalom etimológiáját, (1.3.) arra kerestem a választ, hogy a nemzetközi szakirodalomban milyen alkotóelemeket sorakoztatnak fel a fogalom tartalmával kapcsolatban, illetve (1.4.) milyen szerepet játszik a döntési mechanizmus, a különbözö attitüd, az egyéni percepció, az idöbeliség és a lépték. 
A környezeti igazságosság fogalma összetett, mely nem csupán a környezet és az igazságosság fogalomkettőséből áll. A fentiekben megvizsgáltam a kutatási keretet meghatározó kulcstényezőket, fogalmakat, melyekhez füződően a következő rövid megállapításokat kapcsolhatjuk (50. ábra).

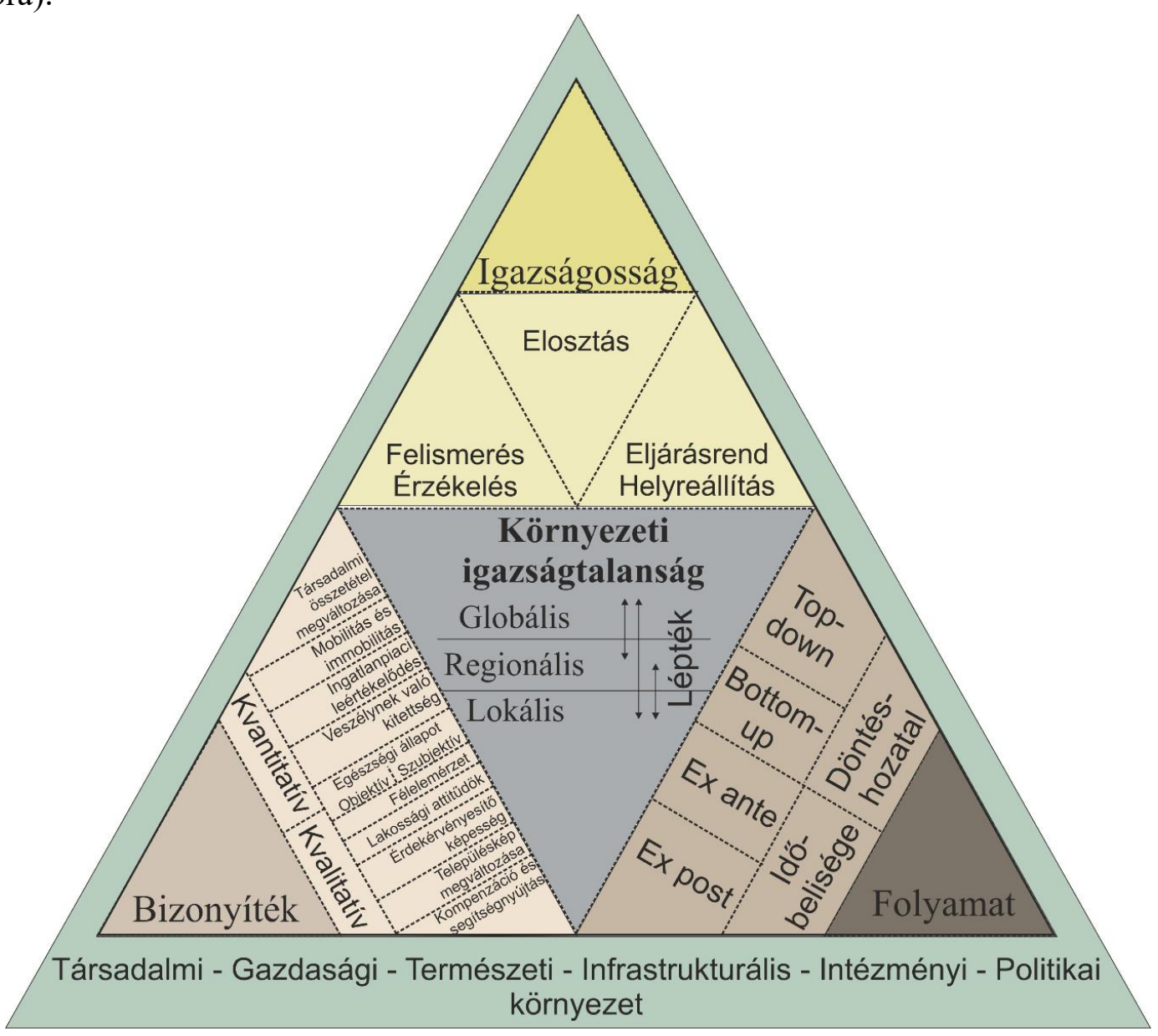

50. ábra: A környezeti igazságtalanság összetevői és egymáshoz való viszonyuk. Forrás: saját szerkesztés

A környezet fogalma többtényezős (1), mely egyben jelenti a körülöttünk lévő materiális világot, az épített és természeti környezetet, illetve az ahhoz kapcsolódó immateriális világot is, a saját és csoportunk, közösségünk mentális környezetét, illetve a kialakított társadalmi és gazdasági, politikai kapcsolatainkat. A természeti környezet kizsákmányolásából, a minőségi környezethez való hozzáférés csorbulásából fakadó egyenlőtlenségeket az egyes kritikák alapján nem a természeti környezet határossága és végessége, hanem a társadalmon belüli technológiai és igazságosságbeli hiányosságok okozzák, melyek nem képesek az erőforrások megfelelő kiaknázására és a hátrányok és előnyök megfelelő elosztására.

Az igazságosság fogalma három fó komponensből álló normatív fogalom (2), melyet a társadalmi szerződés keretében határoz meg a közösség. Az igazságosságnak létezik térbeli eloszlása és elosztása, mely folyamatfüggő. Az igazságtalanságok érzékelése az egyén és közösség szociokulturális és jövedelmi tényezői által befolyásolt.

Az igazságtalanságokhoz vezető folyamatok vizsgálhatók a döntések és az időbeliség szempontjából (3). Ezek alapján megkülönböztetünk top down és bottom up, valamint ex ante és ex post igazságtalanságokat. Hazánkban az igazságtalanságokba való beavatkozások legtöbbször topdown folyamatok, melyek számos esetben nem vesznek tudomást a mindennapi gyakorlatokról, szokásokról és helyi adaptációs technikákról. Ez abban az esetben kifejezetten hátrányos lehet, ha cselekvő intézmények elfogadják és félreértelmezik a Rawls-féle eredeti helyzet (original position) felfogást, mely bizonyos kialakult rendszereket, akár hatalmi viszonyokat, pl. alá-fölé rendeltség, egyenlőtlenség stb. ezáltal stabilnak, megváltoztathatatlannak tekintenek. A szakirodalom alapján megállapítható, 
hogy környezeti igazságtalanságok és ezen belül is föként katasztrófák esetén az érintettek köre sajátos döntéshozatali mechanizmust alkalmaz, hiszen minden aktornak léteznek helyzetükből adódó értékei/értékrendjei, tudásuk és írott, illetve íratlan szabályai, mely alapján cselekednek. A konfliktushelyzet akkor áll elö, ha az aktorok döntési és cselekvési mechanizmusai az eltérő komponensek okán merőben más döntéseket eredményeznek. Így állhat elő a helyzet, hogy a (feltételezhetően) segítő szándékú döntéshozók reakciója nem találkozik a lakossági elvárásokkal. A döntéshozók a helyi döntéshozatali kontextus részletes ismerete nélkül tudásdeficitben szenvednek, melynek eredményét a helyiek igazságtalan vagy méltánytalan helyzetként élik meg. A környezeti igazságtalanságok feltárásánál az időbeliség alapján nem vegytisztán elkülöníthető ex ante és ex post folyamatok azonosíthatók, azok keverednek. Ex ante igazságtalanság alakul ki, hogy ha a környezetben lezajló esemény (pl. katasztrófa) csak katalizátora az igazságtalanság felszínre törésének, kialakulásának háterében mélyebb és összetettebb társadalmi-gazdasági-hatalmi folyamatok húzódnak meg. Ex post egy igazságtalanság, ha a környezeti esemény következtében megindul a környezeti degradáció, a társadalmi depriváció és ezek egymást gerjesztő, lefelé tartó spirális folyamatot hoznak létre.

A környezeti igazságtalanságokkal szemben az egyéneknek és a csoportoknak is különféle attitủdjeik állhatnak fel (4), egészen a teljesen támogatótól (PIMBY) a teljesen elutasítóig (BANANA), de nem csak egyéni, hanem térségi szemléletben is (LULU és LWLU). Mindezek az attitüdök idő közben változhatnak külső tényezők (például egy tájékoztató kampány) hatására. Az attitüd megváltozása az adott folyamatok szubjektív értékelésének megváltozásához, a felismerés és elismerés igazságtalanságához is köthetö.

A könyezeti igazságtalanságok többléptékü földrajzi térben valósulnak meg, amelyben a léptékek és a különbözö téregységek is folyamatosan hatással vannak egymásra, kölcsönkapcsolatban vannak (5).

Az igazságtalanságok megnyilvánulása mind kvantitatív, mind pedig kvalitatív módon mérhető térbeli következményekkel jár (6), mely különböző léptékeken keresztül is érezhető. Ezek közül a szakirodalom alapján a legmeghatározóbbak:

- Az egyén vélt vagy valós kockázatoktól való félelme

- A lakossági attitüdök és elégedettség

- Érdekérvényesítő képesség megítélése

- A kompenzáció és segítségnyújtással való elégedettség

- A települési miliő megváltozása

- Az egyén szubjektív egészségi állapotának megítélése

- A település társadalmi összetételének megváltozása

- A lakóhelyi mobilitási mintázatok átalakulása

- Az ingatlanpiacra gyakorolt hatások, ingatlanpiaci csapdahelyzet

A disszertáció további részében a térbeli igazságtalanságok megnyilvánulási formáit vizsgáltam meg a kiválasztott mintaterületeken, két árvizes, egy belvizes természeti katasztrófa által súlytott területen, és egy vörösiszap-katasztrófa által érintett, civilizácós katasztrófa helyszínen. Az empirikus felmérés alapját kérdőíves felmérés jelentette, amely a mintaterületekhez alkalmazkodó mintavételi stratégiát alkalmaztunk a kutatást segítő kollégákkal. A kérdőíves felmérés eredményeit félig strukturált interjúval egészítettem ki (árvizes terület 6 fö, vörösiszapos mintaterület 4 fö), melyben volt döntéshozó, a károk rendezését segítö önkormányzati alkalmazott és károsult is.

A disszertációban statisztikai elemzéseket végeztem a kérdőív eredményeiből, illetve az elérhető statisztikai adatokból. Elsődlegesen a WHO ajánlásai alapján 4 dimenzió mentén megalkottam a Magyarországról szóló környezeti igazságosság területi potenciálját, amelyet térképen ábrázoltam. A 4 dimenzió mentén három vizsgálati időpontra $(2011,2013,2015)$ longitudinális, összehasonlító elemzést készítettem, GetisOrd módszer segítségével területi autokorrelációt számoltam. A kérdöíves adatok esetében szintén fökomponens-elemzést végeztem, majd a válaszok csoportosítására kis mélységü CRT döntési fákat rajzoltattam, K-közép klasztert számíttattam az SPSS programban. A statisztikai együttmozgást korrelációs számításokkal és Khi négyzet próbával mértem, a metrikus adatok különbözőségét és hasonlóságát pedig párosított t-próba segítségével tártam fel. A 
károsultak kompenzációja, a hatalmi viszonyok feltárása érdekében a felújításokkal kapcsolatos jogi hátteret elemeztem, illetve megjelent nyilatkozatok másodelemzését végeztem el.

Az említett módszerek felhasználásával válaszoltam meg hogy (2) Magyarországon a javak, a környezeti kockázatok, katasztrófák hatásainak egyenlötlen elosztásához kapcsolódóan milyen módszerekkel azonosíthatók a potenciális hazai környezeti igazságtalanságok, azoknak milyen térbeli sajátosságai vannak az érintettek szempontjából, milyen mechanizmusok vezetnek kialakulásához, az egyenlötlen helyzetek fenntartásához?

Arra a kérdésre, hogy (2.1.) milyen magyarországi terïletek határolhatók le, melyen potenciálisan környezeti igazságtalanságok alakulnak ki a társadalmi és környezeti változások tükrében, a korábbi társadalmi egyenlőtlenség és fejlettséggel, jólléttel foglalkozó kutatásokat vettem alapul (PÉNZES, J. 2018; NAGY, G. 2006; NAGY, E. ET AL. 2014). A dolgozat megállapításai közül a legfontosabb, hogy mindhárom vizsgált mintaterület a WHO ajánlások alapján és az elérhető KSH statisztikai adatok alapján potenciálisan környezeti igazságtalanság és egyenlötlenség kialakulásának területei. A disszertációban bővebben ugyan nem tértem ki a témára, de a négy mintaterület, Észak-Kelet Magyarország (Borsod, Bereg), Kolontár-Devecser, Dél-Tisza völgy mellett egy ötödik potenciális mintaterület is megjelent, a Hajdú-határvidék, melynek az ivóvíz-minőség problémáiról és leszakadó helyzetéröl NAGY, GY. ET AL. 2017 cikkben szerzőtársaimmal értekeztem. Ezen eredmények alapján a környezeti igazságtalanságok potenciális területei nagyvonalakban egybeesnek a „történeti” fejletlenebb térségekkel. Kiemelt fontosságú eredmény, hogy az alkalmazott módszertan erőteljesebben integrálja a természeti tényezöket, és longitudinális jellegü, dinamikus, változásorientált feltárást eredményez. Ezután (2.2.) arra voltam kíváncsi, hogy hogy a katasztrófák által közvetlenül és közvetetten érintett lakosság esetében vannak-e vélt vagy valós félelmek egy esetleges további katasztrófával kapcsolatban, valamint milyen változásokat észlelnek a társadalom vagy a településkép esetében? Összességében elmondható, hogy a külföldi szakirodalomban állítottakkal egybecsengő eredmények figyelhetők meg a vizsgált mintaterületek esetében, azonban több törésvonal mentén eltérő válaszok érkeztek a félelem és a változás kérdésére. A lakosság elsődlegesen felosztható közvetlenül és közvetetten érintett csoportra. Azt tapasztalhatjuk, hogy azok, akiket érintett bármilyen katasztrófa, azok hajlamosabbak megerösíteni a félelem és a változás főkomponensét, azonban ez nem ennyire egyszerü és egyértelmü, ugyanis az etnikai hovatartozás befolyásolja a válaszadást. Kutatásaim azt mutatják, hogy a romák hajlamosabbak a félelemérzet fökomonensének megerösítésére. Azonban emellett fontos megjegyezni, hogy az állítás a roma-magyar törésvonalra nem teljes érvényü, hiszen a mintaterületek és azok egyedi sajátosságai befolyásolják az egyének döntéshozatali mechanizmusát a félelem és a változás megítélésénél. Általánosságban elmondható, hogy a katasztrófákba való beavatkozási stratrégia az, ami igen szignifikánsan meghatározza azt, hogy az egyes csoportok az adott mintaterület sorsáról hogyan vélekednek. Mindez felveti a környezeti igazságtalanság lehetőségét, azon belül is a procedural, ügyrendi igazságtalanságét.

Ehhez kapcsolódóan a harmadik kérdésem arra vonatkozott, hogy (2.3.) a katasztrófákat követő segitségnyújtással, kompenzációval és az azzal kapcsolatos információ-ellátással mennyire elégedettek az érintettek? Általánosságban a kompenzáció módja befolyásolja az elégedettséget, úgy tünik, hogy hazánkban a top-down jellegü beavatkozást a lakosok és érintettek sikeresebbnek ítélik meg, mint a bottom up „liberalizált” kompenzációt, mely számos egyenlőtlenséget és visszaélést rejtett magában. A vörösiszapos és az árvizes területeken egyaránt használták az „,aranyárvíz” és az „,aranyiszap” elnevezéseket a megkérdezettek, mely a kompenzáció igazságtalanságára utal. Ennek ellenére egyik esetben sem tartják megfelelőnek a katasztrófákkal kapcsolatos tájékoztatást. Sem az információ terjedésének sebességével, sem az átláthatósággal, sem annak igazságtartalmával nem elégedettek a megkérdezettek.

A környezeti igazságtalanságok hosszútávon befolyásolhatják a térségről alkotott véleményt, gátolhatják a térségi mobilitást, így a kutatás azt is vizsgálta, hogy (2.4.) a mintaterületek esetében hogyan alakul a megkérdezett lakosság véleménye a helyben maradásról, elvándorlásról, a mobilitási lehetöségekröl, illetve, hogy a lokális egyenlötlenségek mérhetöek-e ingatlanpiaci adatokon keresztïl. A kutatások alapján igen erös differenciálódás és átalakulás indult meg a vizsgált területeken, mely nem csak az ingatlanállomány megváltozásában, tulajdonosi körében, de a lakossági mobilitásban is megmutatkozott. Elsődlegesen megindult a borsodi és beregi, valamint kolontár-devecseri területekröl 
a jobb módúak kivándorlása a katasztrófa után, melyet „riskscpae”-ként, vagyis a tehetősebbek kockázatok elöl való elmeneküléseként azonosíthatunk. Mindemellett megindult az ingatlanpiaci csapdahelyzet kialakulása is, bizonyos településeken a lakók úgy vélik, hogy az ingatlanok nem eladhatók, vagy ha igen, akkor nagyon nyomott áron. Nem segített ezen az állami kompenzációs beavatkozás, mely több esetben jogszerüen röghöz közötte a kártalanítottakat, ezáltal is gátolva a térségböl való elvándorlást. A helybenmaradást sok esetben a megszokás és a család vagy a munkahely megléte is elősegíti. Mindezek mellett a legfőbb mobilitási célpontoknak a közeli nagyvárosokat és térségközpontokat tekinthetjük az összes vizsgált mintaterület esetében.

Végezetül, a környezeti igazságtalanságok számos esetben egészségkárosodáshoz vezetnek, melyek fơként a kisebbségi, szegény, deprivált lakosságot érintik leginkább. Ehhez kapcsolódva a dolgozatomban megvizsgáltam, hogy (2.5.) a különféle katasztrófákkal sújtott mintaterületek esetében az. egyének szempontjából tapasztalható-e bármiféle, egészségre ható káros hatás, illetve, hogy az ehhez kapcsolódó statisztikai adatok alapján igazolható-e egészségkárosodás. A dolgozat statisztikai adatok, illetve kérdőíves szubjektív adatok alapján bizonyította, hogy az érintettek és a nem érintettek között megbetegedések tekintetében szignifikáns különbségek vannak. Kiemelkedően magas minden vizsgált térségben a mentális betegségek prevalenciája, ezen belül is a depresszió az, melynek tüneteivel is rendelkeznek a megkérdezettek. A vizsgált térségek esetében a légúti megbetegedések magasabb aránya lenne elvárható, azonban ez az országos átlagtól nem tér el. Annak ellenére, hogy számos válaszadó úgy érzi, hogy a környezeti igazságtalanságok okozzák megbetegedésüket, ez orvosilag nem bizonyítható, az összefüggés csak szubjektív.

Összességében a disszertációban vizsgált mintaterületek összehasonlító elemzése rávilágított, hogy a különböző jellegü mintaterületek között is vannak hasonlóságok, melyek a környezeti igazságtalanság fogalmába illenek. A mintaterületek vizsgálata alapján úgy tünik, hogy Magyarországon a helyi és állami beavatkozásoknak a nemzetközi szakirodalomban említetteken felül is nagyobb szerepe van, mely eredeztethető a korábbi rendszer paternalista hozzáállásából. Kiemelt figyelmet érdemes szentelni annak, hogy az említett igazságtalanságok súlyosbodtak a depriváció mértékének növekedésével. Bár az emúlt évtizedben csökkent a potenciálisan környezeti igazságtalanságokkal érintett területek kiterjedése, azonban a szakadék a legjobb és a legrosszabb területek között tovább mélyült, mely spirálisan lefelé tartó folyamat. A környezeti igazságtalanságok a hazai romák és cigányok, valamint szegények esetében súlyosabb következményekkel járnak, így azok felszámolásában külön figyelmet kell szentelni a kisebbségi és marginalizált csoportokra. Hazánkban a környezeti igazságtalanságok kialakulását negatívan befolyásolhatja a lakosság gazdasági és információs kiszolgáltatottsága, a tájékozatlansága és eredeti helyzete.

A disszertációban megfogalmazott gondolatok és helyzetfeltárások a jövőben esetlegesen bekövetkező környezeti katasztrófák közbeni és az azt követő beavatkozási folyamatok megértésében, megszervezésében nyújthatnak segítséget a döntéshozóknak. 


\section{Summary}

The global climate change and the subsequent socio-economic transition after the collapse of the socialist regime have posed a significant proportion of the population, economic actors and administrative institutions to a number of challenges in Hungary. Different responses were given on the emerging problems from different social groups, economic and political actors, on different geographic scales. These reactions have essentially been reported to adapt, or at least to attempt to adapt to the perceived changes. In the 20th century the environmentally nihilist approaches have further strengthened the often negative anthropogenic influences on the environment in the socialist countries. It is particularly important, that the growing human influence on the environmental systems generates complex problems that are cross-scale and not only locally observed, with several political, legal, social and economic consequences.

These consequences affect different social groups in different ways, which puts some groups at an advantage and others at a disadvantage. These complex challenges can be answered through proper adaptation, which, however, depends on local and global power relations and decision-making mechanisms. All of these are dependent on additional conditions, personal or social factors, such as the personal system of values and norms, principles, rules, regulations, individual and social knowledge. Processes in the environment are basically interpreted as the combined effect of human-environment and human-human relationships. These systems are in a state of constant transformation and change, and the "disturbances" of this system will result inequalities and injustices which have very strong spatial and geographical concerns.

In my dissertation I sought to answers to two main and several sub-questions. In the first part of the dissertation I discussed (1.) how can environmental justice be defined and how can natural and socio-economic environment connected unfair situations be explained. How are they manifested and how is it possible to explore these processes?

In this context, I have primarily sought to answer (1.1.) how environmental justice as a framework is related to geography, and what are its links with critical geography? I found the answer to this question briefly by mentioning three main factors. The most important link between environmental justice and geography is the spatial approach, which not only provides a framework for environmental justice research, but is also an active contributor to spatial injustice. In addition, the emerging theory of sustainable development has been embedded in geography as well as in environmental justice research and movements, providing an additional link. Further similarity can be given to the critical approach, which plurally recognizes different research definitions, the coexistence of individual viewpoints and truths. Environmental justice can be a framework within geography that exploits the ability of spatial synthesis of geography, connects socio-natural geographic research, and takes a critical approach to each research direction.

Next, I dealt with the history of environmental justice research, examining (1.2.) what decisive moments in the last decades have led to the development of the concept of environmental justice and what is the currently agreed and applied logical framework? Environmental justice as a conceptual framework emerged with the civil rights movement of the 1960's, and then underwent several transformations, expanding its research portfolio. Based on scientific publications, in addition to the former unilateral and single-focus distributive injustice research emphasis is now put on the exploration of procedural injustices and the subjective judgment, the individual recognition of injustices. Environmental justice researches nowadays focus on three interrelated elements, justice as a concept, a process, and evidence that reveals the evolution and existence of injustices.

For theoretical grounding, I examined the etymology of the concept of justice, (1.3) looking for the elements of the concept which it consists of, and (1.4) the roles played in defining it by decisionmaking, forming different social attitudes, individual perception, timeliness and scale.

The concept of environmental justice is complex, not just the dual concept of environment and justice. I have examined the key factors and concepts defining the research framework, to which the following brief statements can be related (Figure 51). 


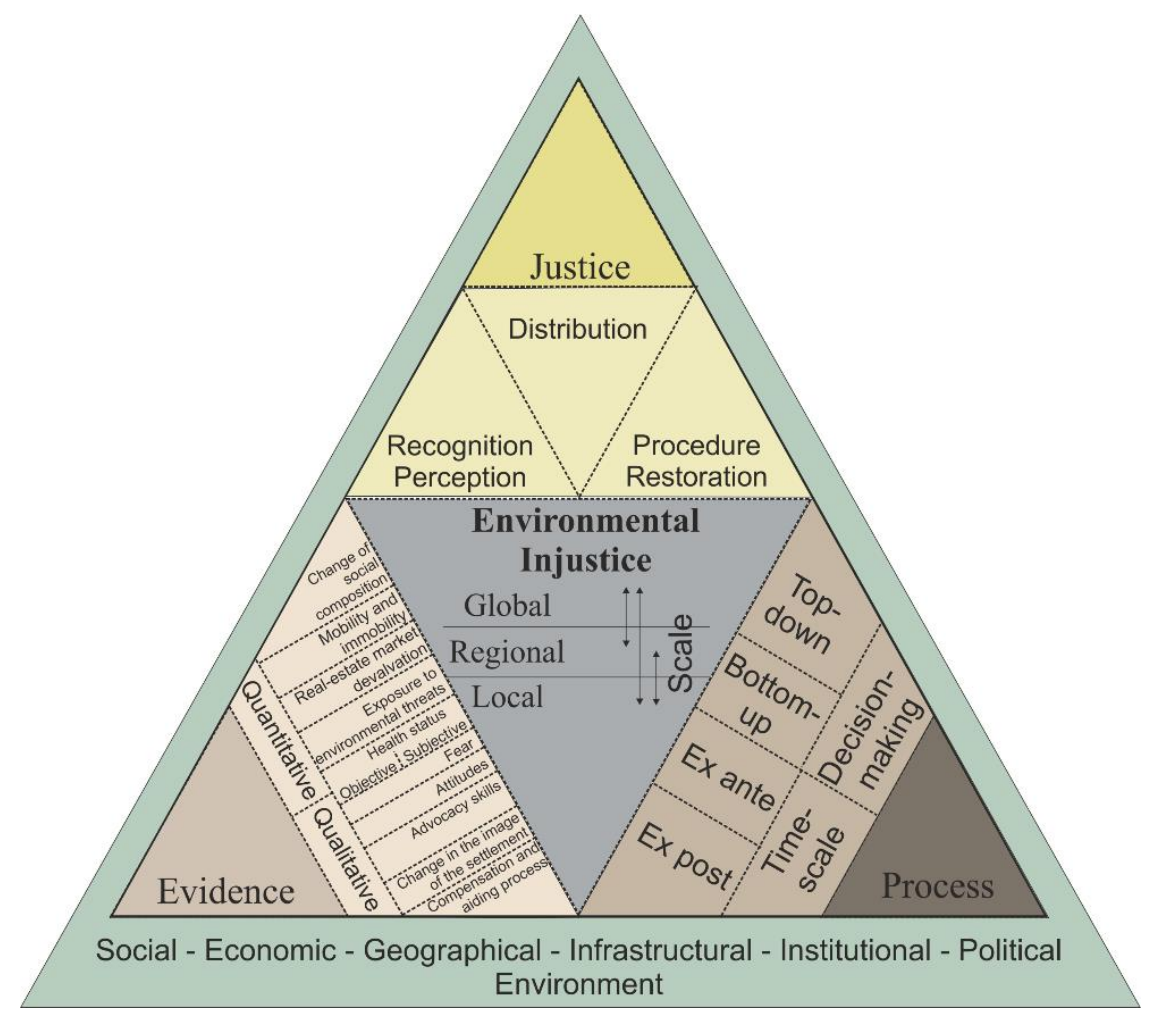

51. Figure: The components of environmental injustice and their relationship with each other. Source: own edition

The concept of the environment is multi-factoring (1), which means the tangible world around us, the built and natural environment, and the associated intangible world, the mental environment of our own and a group, a community, and the socio-economic, political relations. The inequalities connected to the unequal exploitation of the natural environment and the limited access to a quality environment are caused not by the finiteness of the natural environment, but by technological and justice deficiencies within society that are unable to properly exploit resources and the provided benefits.

The concept of justice is a normative concept consisting of three main components (2) defined by the community in the context of a social contract. There is a spatial distribution and distribution of justice that is process dependent. The perception of injustice is influenced by the socio-cultural and income factors of the individual and the community.

The processes leading to injustice can be examined in terms of decisions and time (3). On this basis, we distinguish top-down and bottom-up, ex ante and ex post injustices. In Hungary, interventions in unjust situations are mostly top-down processes, which in many cases ignore everyday practices, habits and local adaptation techniques. This can be particularly detrimental if the institutions adopting and misinterpreting Rawls's original position theory, through which existing power relations are stabilised. In the case of environmental injustices, especially in the case of disasters, the stakeholder groups use a specific decision-making mechanism, since each actor has own values, knowledge and norms and rules to act on. Conflict arises when the actors' decision-making and action mechanisms collide. This may result reactions and decision-making which do not meet expectations. Without adequate knowledge on the local context, decisionmaking will result unjust or unfair procedures.

When uncovering environmental injustices on the basis of time, ex ante and ex post processes can be identified distinct but mixed and coexisting. Ex ante injustice occurs when deeper and more complex socio-economic-power processes are present in the background of an environmental event (such as a catastrophe) that unfolds. Ex post is an injustice when an environmental event triggers environmental degradation, social deprivation, and creates a downward spiral process. 
Individuals and groups may have different attitudes about environmental injustices (4), from wholeheartedly supportive "PIMBY" to wholly dismissive "BANANA". But not only individually, but also regionally locatable attitudes can be distinct, such as Locally Unwanted Land Use or Locally Wanted Land Use (LULU and LWLU). All of these attitudes may change over time due to external factors (such as an information campaign). Changes in attitudes may also be associated with a change in the subjective values, or particular processes, recognition and recognition of injustice.Environmental injustices occur in a multidimensional and multiscale geographic space in which scales and different spatial units are constantly interacting and interacting (5).

The manifestation of injustice has spatial consequences that can be measured both quantitatively and qualitatively (6) and can be felt at different scales. According to the literature, the most important of these are:

- Fear of perceived or actual risks

- Attitudes and satisfaction

- Advocacy skills

- Compensation and aiding

- Change in the settlement milieu

- Subjective health of individuals

- Changes in the social composition of the settlement

- Transformation of mobility patterns

- Real estate market aspects, real-estate traps

In the dissertation I investigated the manifestations of spatial injustices in the selected sample areas according to the above mentioned aspects. The selected sample areas are consisting of two flood-affected areas, one inland excess water affected area, and a red mud-disaster-affected civilization catastrophe site. Empirical research was based on a questionnaire survey, which used different sampling strategy adapted to the features of the sample areas. The results of the questionnaire were supplemented with 10 semi-structured interviews, in which there was a decision-maker, a municipal employee assisting in the repair of the damage and stakeholder person. Statistical analyses were made based on the results of the questionnaire and the available statistical data. Primarily, based on WHO recommendations, I created the scale of territorial potential of environmental injustices for Hungary using four dimensions. Longitudinal comparative analysis was performed $(2011,2013,2015)$ along the 4 dimensions, and spatial autocorrelation was calculated using the GetisOrd method. In the case of the questionnaire data I also performed principal component analysis, then I drew low-depth CRT decision trees to group the answers and calculated a K-mean cluster in the SPSS program. Statistical correlation was measured and Chi-square tests were done. The difference and similarity of the metric data was revealed by using paired t-test. In order to understand the compensation and the aiding process of the victims and to reveal the power relations, I analyzed the legal background of the renovations and reanalysed the published papers, online news and journals on the topic.

Using the above mentioned methods I answered the second main question of my dissertation, which says (2) in Hungary, what potential environmental injustices can be identified and what are their spatial characteristics regarding the affected stakeholders and the mechanisms leading to unequal distribution of environmental risks, and effects of catastrophes?

As an answer on the second sub-question I delimited the (2.1.) areas of Hungary which are affected with potential environmental injustices. I have used previous researches on social inequality and development, well-being (PÉNZES, J. 2018; NAGY, G. 2006; NAGY, E. ET AL. 2014). The most important finding of the dissertation is that all study areas are potentially areas of environmental injustice. Although I did not elaborate on the topic in the dissertation, besides the sample areas, North-East Hungary (Borsod, Bereg), Kolontár-Devecser, South Tisza Valley, a fifth potential sample area appeared, the Hajdú-borderland, where the drinking water quality problems are paired with lower socio-economic status, as I discussed in the paper NAGY GY. ET 
AL. 2017. Based on these results, the potential areas of environmental injustice broadly coincide with the underdeveloped areas of Hungary.

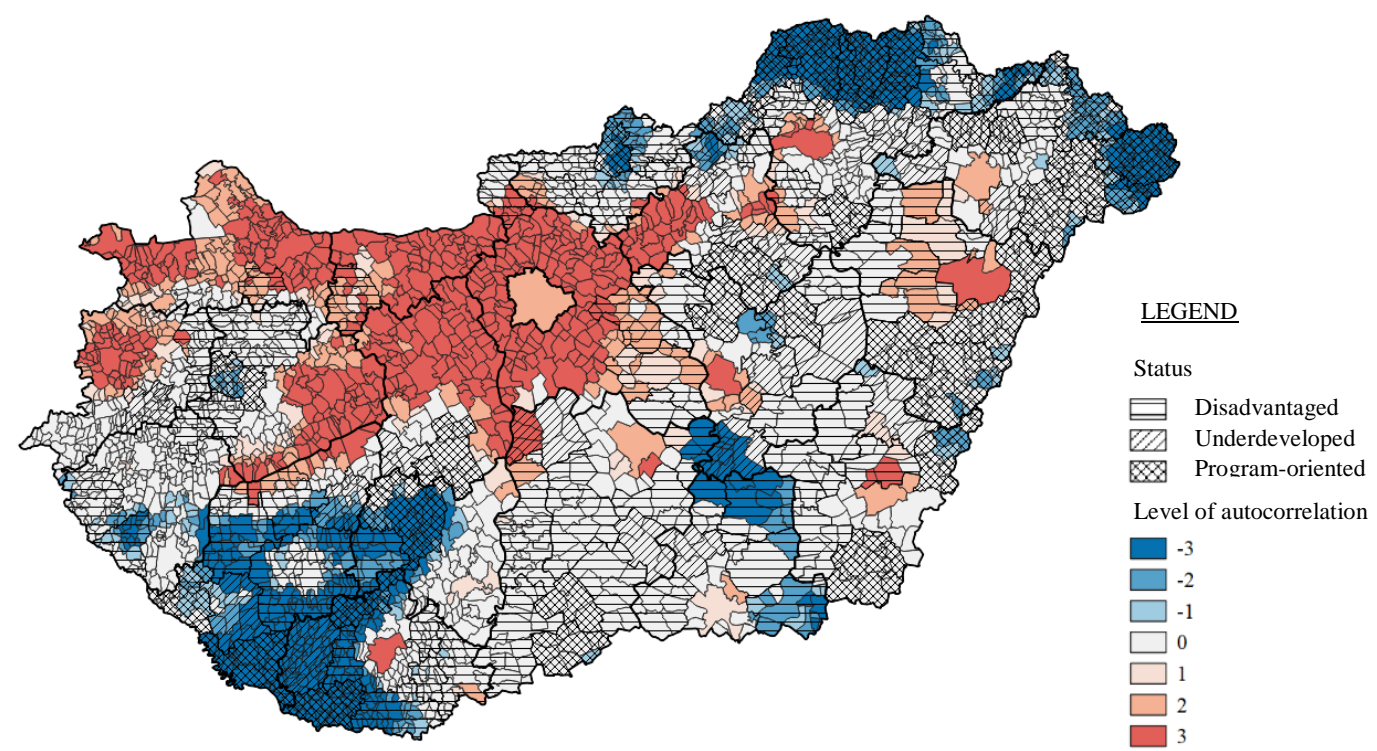

52. Figure: The components of environmental injustice and their relationship with each other. Source: own edition

Then (2.2), I examined if there was a perceived or real fear of a further catastrophe in the population directly and indirectly affected by the catastrophes. I also researched what changes were in the affected society, did the image of the affected settlements changed? Results are consistent with international literature. The population can be primarily divided into directly and indirectly affected groups, those affected by any disaster tend to reinforce the principle component of fear and change, but this is not as simple and straightforward as ethnicity influences the response. My research shows that Roma tend to reinforce the principle component of fear. However, it is also important to note that the assertion of the Roma-Hungarian fracture line is incomplete, since the sample plots and their unique characteristics influence individuals' decision-making mechanisms for judging fear and change. Generally speaking, it is the disaster-response strategy that determines significantly how each group views the recent situation and future of the sample areas. All this raises the possibility of environmental injustice, including procedural and procedural injustice.

In this context, my third question was (2.3) about, how satisfied are the stakeholders with the remediation process, the given compensation and information? In general, the way of compensation affected stakeholders' satisfaction, and it seems that in Hungary a top-down intervention is perceived by residents and stakeholders as more successful than bottom-up "liberalized" compensation, which had a number of inequalities and abuses. In both red-mud affected and flooded areas, the terms "gold flood" and "gold mud" were used, indicating injustice of compensation. Despite this, disaster information is not considered appropriate in either case. The respondents were not satisfied with the speed of the dissemination of information, the transparency or the truthfulness of the information.

Environmental injustices can influence the image of the area in the long run and hinder regional mobility, so the research also examined (2.4.) what is the opinion of the interviewed population about staying or migration, and whether local inequalities can be measured through real estate market data. According to the researches, a fast and visible differentiation and transformation has started in the examined areas, which has been reflected not only in the change of the real estate portfolio, but also in the mobility of the population. In the first instance, the exodus of the wealthier people from the Borsod, Bereg and Kolontár-Devecser areas after the disaster began, which can be identified as "riskscape", ie. the escape of the wealthier from the risks. In addition, the real estate market trap evolved, some believing that real estate cannot be sold or, if 
so, at very depressed prices. The state compensatory intervention, which in many cases legitimately clogged up the indemnified persons, did not help, thus preventing the exodus from the area. Staying in place is often helped by habit and by having a family or a job. In addition, nearby major cities and regional centres can be considered as the main mobility targets for each of the sample areas.

Finally, environmental injustices in many cases lead to health damage, mainly affecting the minority, poor, deprived populations. In connection with this, in my dissertation I examined whether (2.5.) in the case of the sample areas affected by various catastrophes any adverse effect on health can be experienced. And whether the related statistical data can justify the health damage. Based on statistical data and subjective data from the questionnaire, the dissertation proved that there are significant differences between the affected and non-affected stakeholders in terms of health status. The prevalence of mental illnesses, including depression, is particularly high in all of the regions studied, with symptoms also present in the respondents. Higher rates of respiratory disease could be expected in the studied regions, but this does not differ from the national average. Although many respondents feel that environmental injustices are causing their illness, this is not medically proven, but the relationship is only subjective.

Overall, a comparative analysis of the sample areas examined has shown that there are similarities between the affected areas. Based on the results, local and state interventions in Hungary appear to play a greater role than those mentioned in the international literature, which can be attributed to the paternalistic attitude of the former socialist system. It is worth noting that these injustices have worsened with the increase in deprivation. Although the area potentially affected by environmental injustice has diminished over the past decade, the gap between the best and worst areas has widened further, which is a spiraling downward process. Environmental injustices have more severe consequences for Roma and Gypsies and the poor, and special attention must be paid to minority and marginalized groups in the elimination of environmental injustices in Hungary. The development of environmental injustices may be negatively influenced by the economic and information vulnerability of the population, their ignorance, lack of knowledge and their original position.

The results presented in the dissertation can help decision-makers to understand and organize interventional processes during and after future environmental disasters. 


\section{Irodalomjegyzék}

1. ÁGH A. 2018: A neoliberalizmus rendszere és a „társadalom önvédelme. - Politikatudományi Szemle, 27.2. pp. 726.

2. Agyeman, J.-Ogneva-Himmelberger, Y. 2009: Environmental Justice and Sustainability in the Former Soviet Union. The MIT Press, Cambridge. 312 p.

3. Ahern, M - Kovats, S. R. - Wilkinson P. - FeW, R. - Matthies, F. 2005: Global Health Impacts of Floods: Epidemiologic Evidence. In: Epidemiologic Reviews, USA, John Hopkins Bloomberg Shool of Public Health. Vol 27. pp. 36-46

4. Alchmo, J. Et Al. 2007: Climate Change 2007. Adaptation and vulnerability. Cambridge, University Press. pp. 541-580

5. ALFÖLDI L. 2002: Felszíni és felszín alatti vizek. - In. Mészáros E.-Schweitzer F. (szerk.): Föld, víz, levegő. Magyar Tudománytár I. kötet Kossuth Kiadó, Budapest. pp. 207-256.

6. Antypas, A.-Atkins, L.-Borthwick, F.-CAHN, C.-FilCAK, R.-HARPER, K.-MAlbasic, I.-MEDAROVA-BERGSTROM, K. 2007: Making the case for Environmental Justice in Central and Eastern Europe. - In. STEGER, T. (ed.): The Coalition for Environmental Justice. CEU, Budapest. 58 p.

7. AUER Á. 2012: Felelősség a gazdasági társaság egzisztálása alatt: hiányzó tényállás vagy fortélyos bírói gyakorlat? - In. MEZEI P. (szerk.): Természeti és ipari katasztrófák: jogi aspektusok a 2010-es ajkai vörösiszap-katasztrófa fényében. SZTE ÁJK, Szeged. pp. 9-16.

8. BABBIE, E. 2008: A társadalomtudományi kutatás gyakorlata. - Balassi Kiadó, Budapest. 744 p.

9. BAJMÓCY P. 2012: Suburbanisation and Suburban Regions in Hungary After 1990. - In. Csapó T.-Balogh A. (eds.): Development of the Settlement Network in the Central European Countries. Springer, Berlin, Heidelberg. pp. $207-$ 221.

10. BALOGH I. 2006: Igazságosság és politika. - L'Harmattan, Budapest. 441 p.

11. BARNA I.-SzÉKELY, M. 2004: Túlélőkészlet az SPSS-hez. - Typotex kiadó, Budapest. 453 p.

12. BARTA K. - SZATMÁRI J. 2010: Antropogén hatások a belvíz-képződésben. Esettanulmány az M5 autópálya szatymazi szakaszának talajvízáramlásban betöltött szerepéről. - Hidrológiai Közlöny, 90. 2. pp. 23-25.

13. BARTA K.-SzATMÁRI J.-POSTA Á. 2011: A belvízképzödés és az autópályák kapcsolata. - Földrajzi Közlemények 135. 4. pp. 379-387.

14. BAUKÓ T.-DÖVÉNYIZ.-RAKONCZAIJ. (1981): Természeti és társadalmi tényezők szerepe a belvizek kialakulásában a Maros-hordalékkúp keleti részén. - Alföldi tanulmányok 5. pp. 35-60.

15. BECCHI, P. 2012: Our Responsibility Towards Future Generations. - In. MATHIS, K. (ed.): Efficiency, Sustainability, and Justice to Future Generations. Springer, Dordrecht. pp. 77-96.

16. BECK, U. 2003: A kockázat-társadalom - Út egy másik modernitásba. - Századvég Politikai Iskola Alapítvány. 336 $p$.

17. BeEN, V. 1994: Locally Undesirable Land Uses in Minority Neighborhoods: Disproportionate Siting or Market Dynamics? - The Yale Law Journal 103. 6. pp. 1383-1422.

18. BEGG, C. 2018: Power, responsibility and justice: a review of local stakeholder participation in European flood risk management. - Local Environment, 23.4 pp. 383-397.

19. BeLl, D. 2004: Environmental Justice and Rawls' Difference Principle. - Environmental Ethics 26. 3. pp. $287-306$.

20. BENCE GY. 2007: A politikai filozófia két gyökere Kantnál. - Phronesis 1. 1. pp. 3-10.

21. BennetT, M. 2004: Cities in the New Millenium: Environmental Justice, the Spatialization of Race, and Combating Anti-Urbanism. - Journal of African American Studies, 8. 1-2. pp. 126-141.

22. Berry, B. 1999: Sustainability and Intergenerational Justice. - In. Dobson, A. (ed.): Fairness and Futurity: Essays on Environmental Sustainability and Social Justice. Oxford University Press, New York. pp. 93-117.

23. Blacksell, M.-WAtKins, C.-Economides, K. 1986: Human Geography and Law: A Case of Separate Development in Social Science. - Progress in Human Geography 10. 3. pp. 371-396.

24. BLANKA V., LADÁNYI Zs., MEZÖSI G. 2014: A jövęben várható klímaváltozás a régióban. In: BLANKA V., LADÁNYI Zs. (szerk.): Aszály és vízgazdálkodás a Dél-Alföldön és a Vajdaságban / Suša i upravljane vodama u južnoj maÿarskoj ravnici i Vojvodini / Drought and water management in South Hungary and Vojvodina: Szegedi Tudományegyetem, Természeti Földrajzi Tanszék, Szeged, pp.142-151.

25. Blomley, N.K. 1994: Law, space and the geographies of power.- Progress in Human Geography, 20.1. pp- 137138

26. BONNEFOY, X. 2007: Inadequate housing and health: an overview. In: Inernation Journal of Environment and pollution (30) pp. 411-429

27. Boone, C. G.-Fragkias, M.-Buckley, G. L.-Grove, J. M. 2014: A long view of polluting industry and environmental justice in Baltimore. - Cities 36. 1. pp. 41-49.

28. Boros L. 2008: A depriváció térbelisége Szegeden. - In: SZABÓ V.-Orosz Z.-NAGY R.-FAZEKAS I. (szerk.): IV. Magyar Földrajzi Konferencia, Debrecen. pp. 362-368. 
29. Boros L. 2012: Szeged belső tagozódása a deprivációs indexek alapján. - In. RÁCZ A. (szerk) Város és vidéke. Belvedere Meridionale, Szeged. pp. 19-64.

30. BOROS L.2010: A globális gazdaság környezeti és társadalmi konfliktusai In: MÉSZÁROS R. —NAGY G. — NAGY E. - BOROS L. -PÁL V. (szerk.) A globális gazdaság földrajzi dimenziói. Akadémiai Kiadó, Budapest. pp. 276-306.

31. Boros, L- NAgY, Gy. 2014. The Long-term Socioeconomic Consequences of the Tisza Flood of 2001 in SzabolcsSzatmár-Bereg County, Hungary.In: BELVEDERE MERIDIONALE XXVI : 4 pp. 122-130.

32. Boros, L. - NAGY, GY. 2013: 2010-es árvízek hatásai és a környezeti igazságosság problematikája Borsod-AbaújZemplén megyében A FALU $28: 2$ pp. 43-54.

33. BosCO, F. 2014: Actor-Network Theory, Networks, and Relational Geographies. - In. AITKEN, S. C.-VALENTINE, G. (eds.): Approaches to Human Geography: Philosophies, Theories, People and Practices. SAGE Publication, Los Angeles, London. pp. 150-162.

34. BotyÁNSZKi A. 2012: Technológiai katasztrófák és a politika: Csernobil és a glasznoszty. - In. MEZEI P. (szerk.): Természeti és ipari katasztrófák: jogi aspektusok a 2010-es ajkai vörösiszap-katasztrófa fényében. SZTE ÁJK, Szeged. pp. 127-142.

35. BowEN, W. 2002: An analytical review of environmental justice research: what do we really know? - Environmental Management 29. 1. pp. 3-15.

36. BÖHM A.-PÁL L. (szerk.) 1988: Lehet-e közélet a lakóhelyen? - Kossuth Könyvkiadó, Budapest. 255 p.

37. Braithwaite, J. 2002: Responsive Regulation. - In. BRAithwaite, J.: Restorative Justice \& Responsive Regulation. Oxford University Press, New York. pp. 29-44.

38. BRAUBACH M. (2011): Environmental health inequailities in Europe. In: UMID Themenheft Umweltgerechtigkeit II. 2. pp. 47-51.

39. BRAUBACH, M.-FAIRBURN, J. 2010: Social inequities in environmental risks associated with housing and residential location--a review of evidence. - European Journal of Public Health. 20. 1. pp. 36-42.

40. Bujalos I. 2007: Az angol utilitarizmus a 19. században. - Magyar tudomány 167. 5. pp. 636-641.

41. Bullard, R. D. 1990: Dumping in Dixie: Race, Class and Environmental Quality. Westview Press, San Francisco. $234 \mathrm{p}$.

42. Bullard, R. D. 1994: Unequal Protection: Environmental Justice and Communities of Color. Sierra Club Books, San Francisco. 392 p.

43. Bullard, R. D. 2008: Dumping in Dixie: Race, Class and Environmental Quality. - Westview Press, San Francisco. $300 \mathrm{p}$.

44. Bullard, R. D.-Mohai, P.-SAHA, R.-Wright, B. 2008: Toxic wastes and race at twenty: Why race still matters after all of these years. - Environmental Law 38. 2. pp. 371-411.

45. Bullers, S. 2005: Environmental Stressors, Perceived Control, and Health: The Case of Residents Near LargeScale Hog Farms in Eastern North Carolina. - Human Ecology 33. 1. pp. 1-16.

46. BuRningham, K. 2000: Using the Language of NIMBY: A topic for research, not an activity for researchers. Local Environment 5. 1. pp. 55-67.

47. Butler, C. 2009: Critical Legal Studies and the Politics of Space. - Social \& Legal Studies 18. 3. pp. 313-332.

48. CAIN , N.L.. - NELSON, H.T. 2013: An integrated theoretical framework to explain infrastructure siting outcomes In. Journal of Land Use Policy 33. pp. 204-213.

49. Capeheart L.-Milovanovic D. 2007: Social Justice: Theories, issues, and movements. - Rutgers University Press, New Brunswick. 272 p.

50. CARSOn, R. 1962: The Silent Spring. - Houghton Miffin, New York. 368 p.

51. Chakraborty, J.-Armstrong, M.P. 2001: Assessing the Impact of Airbone Toxic Releases on Populations with Special Needs. - Professional Geographer 53. 1. pp. 119-131.

52. Chaudhary, S.-McGregor, A.-Houston, D.-Chettri, N. 2018: Environmental justice and ecosystem services: A disaggregated analysis of community access to forest benefits in Nepal. - Ecosystem Services 29. A. pp. 99-115.

53. Chavis, B. F.-LEE, C. 1987: Toxic waste and race in the United States (3rd). - United Church of Christ, New York. $69 \mathrm{p}$.

54. CheEsman S. J. 2012: The right to health: the state's international obligations. - In. MEZEI P. (szerk.): Természeti és ipari katasztrófák: jogi aspektusok a 2010-es ajkai vörösiszap-katasztrófa fényében. SZTE ÁJK, Szeged. pp. 74 82.

55. Christopher, A. J. 1997: Racial land Zoning in South Africa. - Land Use Policy, 14. 4. pp. 311-323.

56. Clough, E. 2018: Environmental justice and fracking: a review.- Current Opinion in Environmental Science \& Health, 3. pp. 14-18

57. CoAse, R. H. 1960: The Problem of Social Cost. - Journal of Law and Economics, 3. pp. 1-44.

58. Collinge, C. 2006: Flat ontology and the deconstruction of scale: a response to Marston, Jones and Woodward. Transactions of the Institute of British Geographers 31. 2. pp. 244-251. 
59. Cornell, S.-Berkhout, F.-Tuinstra, W.-TÀbara, J. D.-JÄGer, J.-Chabay, I.-Wit, B. D.-LAnglais, R.Mills, D.-Moll, P.-OTto, I. M.-Petersen, A.-PoHL, C.-KerKHOFF, L. V. 2013: Opening up knowledge systems for better responses to global environmental change. - Environmental Science \& Policy 28. 1. pp. 60-70.

60. Cushing, L.-Morello-Frosch, R.-WAnder, M.-PAStor, M. 2015: The haves, the have-nots, and the health of everyone: the relationship between social inequality and environmental quality. - Annual Review of Public Health 36. 1. pp. 193-209.

61. CutTer, S. L. 1995: Race, class and environmental justice. - Progress in Human Geography 19. 1. pp. $111-122$.

62. CutTer, S. L. 2006: Hazards Vulnerability and Environmental Justice. - Earthscan from Routledge, New York. 417 $\mathrm{p}$.

63. Cutter, S. L.-ScotT, M. S.-Hill, A. A. 2002: Spatial variability in toxicity indicators used to rank chemical risks. - American Journal of Public Health 92. 3. pp. 420-422.

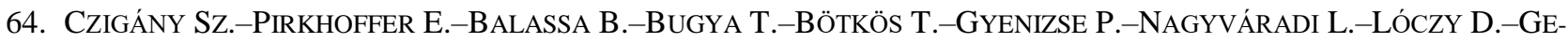
RESDI I. 2010: Villámárvíz mint természeti veszélyforrás a Dél-Dunántúlon. - Földrajzi Közlemények 134. 3. pp. 281-298.

65. CZIGÁNY, SZ.-PIRKHOFFER, E.-GERESDI, I. 2008: Environmental impacts of flash floods in Hungary. - In. SAMUEls, P.-Huntington, S.-Allsop, W.-HARrop, J. (eds.): Flood Risk Management: Research and Practice. Taylor \& Francis Group, London. pp. 1439-1447.

66. CSALOG Zs. 1993: A cigányság a magyar munkaerőpiacon. - Szociológiai Szemle, 1993. 1. pp. 19-33.

67. CSÉFAlvay Z. 1994: A modern társadalomföldrajz kézikönyve. - Ikva Kiadó, Budapest. 366 p.

68. CSÓKA B. 2011: Vörösiszap-ár után. - Országépítő 22. 2. pp. 6-11.

69. DAKE, K. 1991: Orienting Dispositions in the Perception of Risk: An Analysis of Contemporary Worldviews and Cultural Biases In. Journal of Cross-Cultural Psychology, 22(1), pp. 61-82.

70. DAKE, K. 1992: Myths of Nature: Culture and the Social Construction of Risk. In. Journal of Social Issues, Vol.48. Issue 4. pp. 21-37.

71. DARÓCZI E.-KovÁCS K. 2004: Halálozási viszonyok az ezredfordulón: társadalmi és földrajzi választóvonalak. KSH, Népességtudományi Kutatóintézet, Kutatási jelentés 77. Budapest. 212. p.

72. Davidson, P. Anderton, D.L. 2000: The Demographics of Dumping II: Survey of the Distribution of Hazardous Materials Handlers." In: Demography 37:461-66.

73. DAVIES, A. 2009: Environmentalism. - In: International Encyclopedia of Human Geography. pp. 565-570.

74. DAVIES, A. R. 2006: Environmental justice as subtext or omission: Examining discourses of anti-incineration campaigning in Ireland. - Geoforum 37. 5. pp. 708-724.

75. DAVIES, P. A. 2008: Looking out a broken old window: Community safety, gendered crimes and victimisations. Crime Prevention and Community Safety. In. An International Journal 10(4) pp. 207-225.

76. DAVIES, P. A. 2014: Green crime and victimization: Tensions between social and environmental justice In:. Theoretical Criminology, 18(3), pp. 300-316.

77. DAVIES, P.T. 2003: 'Systematic Reviews: How Are They Different From What We Already Do?', In ANDERSON, L. AND BennetT, N. (eds): Developing Educational Leadership for Policy and Practice’, London, Sage Publications.

78. DAWSON, J. I. 2001: Latvia’s Russian Minority: Balancing the Imperatives of Regional Development and Environmental Justice. - Politcal Geography, 20. 7. pp. 787-815.

79. DEAR, M. 1992: Understanding and Overcoming the NIMBY Syndrome. - Journal of the American Planning Association 58. 3. pp. 288-300.

80. Derezinski, D. D.-LACy, M. G.-Stretesky, P. B. 2003: Chemical Accidents in the United States, 1990-1996. Social Science Quarterly 84. 1. pp. 122-143.

81. Dixon, J.-Ramutsindela, M. 2006: Urban resettlement and environmental justice in Cape Town. - Cities, 23.2. pp. 129-139.

82. Downey, L. - WiLligen, M. 2005: Environmental stressors: the mental health impacts of living near industrial activity. In. Journal of Health Social Behaviour 46(3) pp. 289-305.

83. DÖVÉNYIZ. 2005: Az árvizek település- és településhálózat formáló hatása a Felső-Tisza-vidéken. - Földrajzi Értesítő 54. 1-2. pp. 85-109.

84. DövÉNYI Z.-KovÁCs Z. 1999: A szuburbanizáció térbeni-társadalmi jellemzői Budapest környékén. - Földrajzi Értesítö 48. 1-2. pp. 33-57.

85. DrabeK, T. E. 1986: Human System Responses to Disaster. - Springer, New York. 479 p.

86. DreIER, P. 1992: Bush to the Cities: Drop Dead. - The Progressive, 56. pp. 20-23.

87. EdELSTEIN, M. R. 1988: Contaminated communities: the social and psychological impacts of residential toxic exposure. Westview Press, Boulder, CO and London. 217 p.

88. EDEN, S. 2009: Environment. - In. International Encyclopedia of Human Geography. pp. 505-516.

89. EITZEN, D. S.-ZINN, M. B. 1994: Social Problems. - Allyn and Bacon, Boston. 620 p.

90. Elliot, S. J. 2009: Environmental Health. - In. International Encyclopedia of Human Geography. pp. 528-534. 
91. EMBer I. (SzERK) 2007: Népegészségügyi orvostan. Budapes - Pécs, Dialóg Campus Kiadó. 856p.

92. EMBER I. 2006: Környezet-egészségtan. Budapest - Pécs, Dialóg Campus Kiadó. 398p.

93. ENYEDI GY. 1996: Regionális folyamatok Magyarországon az átmenet időszakában. - Hilscher Rezső Szociálpolitikai Egyesület, Budapest. 138 p.

94. ENYEDI GY. 2004: Regionális folyamatok a posztszocialista Magyarországon. - Magyar Tudomány 49. 9. pp. 935941.

95. ENYEDI GY. 2010a: Regionális folyamatok Magyarországon. - In: BARTA GY.-BELUSZKY P.-FÖLDI ZS.-KOVÁCS K. (szerk.) 2010: A területi kutatások csomópontjai. - MTA Regionális Kutatások Központja, Pécs. pp. 307-316.

96. ENYEDI GY. 2010b: Társadalmi-területi egyenlőtlenségek és területi politika Magyarországon. - In: BARTA GY.BELUSZKY P.-FÖLDI ZS.-KovÁCS K. (szerk.) 2010: A területi kutatások csomópontjai. - MTA Regionális Kutatások Központja, Pécs. pp. 399-412.

97. ERHARDT G. (2001): Helyzetjelentés a Beregből. - Országépítő 12. 1. pp. 2-5.

98. FABER, D.-MCCARTHY, D. 2001: The Evolving Structure of the Environmental Justice Movement in the United States: New Models for Democratic Decision-Making. - Social Justice Research, 14. 4. pp. 405-421.

99. FABULA SZ. 2013: Body politics and urban spaces: disabled people's encounter with and resistance to disabling urban environments in Hungary. - In. ILIES, A.-KoZMA, G.-KovÁcs, Z.-POPA, N. (eds.): Regional development and cross border cooperation. Editura Universitatii din Oradea, Oradea. pp. 10-20.

100.FABULA SZ.-TIMÁR, J. 2016: A fogyatékosság mint társadalmi-térbeli viszony földrajzi vizsgálata. - In. UNGER J.PÁl-MolnÁR E. (szerk.): Geoszférák 2015: A Szegedi Tudományegyetem Földtudományok Doktori Iskolájának eredményei. SZTE TTIK Földrajzi és Földtani Tanszékcsoport, Szeged. pp. 89-111.

101.FARAGÓ, L. (SZERK.) 2018: Kortárs térelméletek közép-kelet-európai kontextusban. Budapest: Dialóg Campus. 398. p.

102.FARKAS ZS.-JUHÁSZ Z. 2012: Az állam objektív intézményvédelmi kötelezettsége a kasztrófahelyzetek kezelésével összefüggésben az általános ombudsman katasztrófavédelmi projektjének tükrében. - In. MEZEI P. (szerk.): Természeti és ipari katasztrófák: jogi aspektusok a 2010-es ajkai vörösiszap-katasztrófa fényében. SZTE ÁJK, Szeged. pp. 50-62.

103.FEINBERG, J. 1999: Társadalomfilozófia, Osiris Kiadó, Budapest, 188 p.

104.FERrEIRA, S. - GALlAGHER, L. 2010: Protest responses and community attitudes toward accepting compensation to host waste disposal infrastructure. In: Land Use Policy Vol. 27, Issue 2, pp. 638-652

105.FEYEN, L. DUNKER, R. 2009: Climate change impacts in Europe. Final report of the PESETA research project. Luxembourg, Publication Office of the European Union. pp. 45-50.

106.FILČÁK, R. 2007: Environmental Justice in the Slovak Republic. The case of the roma ethnic minority, Unpublished doctoral dissertation. - Central European University, Budapest

107.FisheR, J. B.-Kelly, M.-RoMM, J. 2006: Scales of environmental justice: combining GIS and spatial analysis for air toxics in West Oakland, California. - Health and Place 12. 4. pp. 701-714.

108.Flowerdew, R.-MANLEY, D. J.-SABEL, C. E. 2008: Neighbourhood effects on health: Does it matter where you draw the bounderies? - Social Science and Medicine 66. 6. pp. 1241-1255.

109.FODOR I. 1987: KGST együttmüködés a környezetvédelem társadalomtudományi kutatásaiban. -Tér és Társadalom, 1.2. pp.106-112.

110.FODOR L.-BARTA A.-FÓNAI M.-BÁNYAI O. 2016: Települési környezetvédelem Magyarországon: Egy kutatás előfeltevései. - Tér és Társadalom 30. 3. pp. 19-39.

111. FolEY, M.W. - EDWARDS, B. 1996: The paradox of civil society. Journal of Democracy, 7(3), pp. 38-52.

112.FreEdMAN, D.-PISANI, R.-PURVES, R. 2005: Statisztika. - Typotex kiadó, Budapest. 812 p.

113.FUNDERBURG, R.-LAURIAN, L. 2015: Bolstering environmental (in)justice claims with a quasi-experimental research design. - Land Use Policy 49. 1. pp. 511-526.

114.Gbanie, S. P.-Tengbe, P. B.-Momoh, J. S.-Medo, J.-KabBA, V. T. S. 2013: Modelling landfill location using Geographic Information Systems (GIS) and Multi-Criteria Decision Analysis (MCDA): Case study Bo, Southern Sierra Leone. - Applied Geography 36. 1. pp. 3-12.

115.GINELLI, Z. 2018: Decolonization and Semiperipheral Postcoloniality: Hungarian Experts in Nkrumah's Ghana.Letöltve:http://mezosfera.org/hungarian-experts-in-nkrumahs ghana/?fbclid=IwAR33il_xq9W5z_BX_aB6Z5QKHqzOqJFH634_q48IW9hSdJh5DOhmOD7TxE8 (2019. 04.04.)

116.GordDARD, R.-COLlofF, M. J.-WiSE, R. M.-WARE, D.-DunLOP, M. 2016: Values, rules and knowledge: Adaptation as change in the decision context. - Environmental Science \& Policy 57. 1. pp. 60-69.

117.GrundFest, E.-RIPPS, A. 2000: Flash floods. - In. PARKER, D. J. (ed.): Floods. Routledge, London and New York. Volume 1. pp. 377-390.

118.GuTTENSEN, R. 1996: On the Object and Subject of Geography. - Geografisk Tidsskrift 96. pp. 110-117.

119.GYŐRY CS. 2009: Egy pragmatikus idealista: John Braithwaite. - Jog, Állam, Politika 1. 1. pp. 108-128. 
120.GYURIS, F. 2010: Knowledge and Action — 9th Interdisciplinary Symposium on Knowledge and Space. - Tér és Társadalom 24. 2. pp. 153-160.

121.HABLICSEK L.-KOVÁCS K. 2007: Az életkilátások differenciálódása iskolázottság szerint, 1986-2005. - KSH, Népességtudományi Kutatóintézet, Kutatási jelentés 84. Budapest. 177 p.

122.HABLICSEK, L. - KovÁCs K. 2004:Az életkilátások differenciálódása iskolázottság szerint.—Központi Statisztikai Hivatal, Budapest. 177 p.

123.HAJDÚ O. 2010: Sajátértékek a statisztikában. - Statisztikai szemle 88. 7-8. pp. 773-788.

124.HAJDÚ Z. 2006:A szocialista természetátalakítás kérdései Magyarországon, 1948-1956. - In: KISS A., MEZÖSI G., SÜMEGHY Z. (szerk.): Táj, környezet és társadalom. Ünnepi tanulmányok Keveiné Bárány Ilona professzor asszony tiszteletére. SZTE Éghajlattani és Tájföldrajzi, Természetföldrajzi és Geoinformatikai Tanszék, Szeged. pp. $245-258$

125.Hamilton, J. T. 1995: Testing for Environmental Racism: Prejudice, Profits, Political Power. - Journal of Policy Analysis and Management 14. 1. pp. 107-132.

126.Hamilton, J. T. 1995: Testing for Environmental Racism? Prejudice, Profits, Political Power? - Journal of Policy Analysis and Managament, 14. 1. pp. 107-132.

127.HARPER, K.-STEGER, T.-FILČÁK, R. 2009: Environmental Justice and Roma Communities in Central and Eastern Europe. - Environmental Policy and Governance, 19. 4. pp. 251-269.

128. HARVEY, D. 1973: Social Justice and the city. - Univerity of Georgia Press, Athens. 356 p.

129.HARVEY, D. 1989: The condition of Postmodernity. - Blackwell, Oxford. 388 p.

130.HARVEY, D. 1996: Justice, Nature and the Geography of Difference. - Blackwell, Oxford 480 p.

131.HAVAS G. 1999: A kistelepülések és a romák. - In. GLATZ F. (szerk.): A cigányok Magyarországon. Magyarország az ezredfordulón. MTA, Budapest. pp. 163-204.

132.HeFFRON, R. J.-MCCAULEY, D. 2018: What is the 'Just Transition'? - Geoforum 88. 1. pp. 74-77.

133.HigGS, G.-LANGFORD, M. 2009: GIScience, environmental justice, \& estimating populations at risk: The case of landfills in Wales. - Applied Geography 29. 1. pp. 63-76.

134.Hillman, M. 2006: Situated justice in environmental decision-making: Lessons from river management in Southeastern Australia. - Geoforum 37. 5. pp. 695-707.

135.HunOlD, C.-Young, I. M. 1998: Justice, Democracy, and Hazardous Siting. - Political Studies 46. 1. pp. 82-95.

136.ILLÉS I. 1996: Az egészségügyi ellátás rendszere. - In: Perczel György (szerk.): Magyarország társadalmi-gazdasági földrajza. ELTE Eötvös Kiadó, Budapest. pp. 500-518.

137.JAMES, D. 2014: How Bourdieu bites back: recognising misrecognition in education and educational research. Cambridge Journal of Education 45. 1. pp. 97-112.

138.JÁNoSA A. 2011: Adatelemzés SPSS használatával. ComputerBooks, Budapest. p.376.

139.JÁVOR B. 2011: Kolontár-jelentés - A vörösiszap-baleset okai és tanulságai. - LMP - EGP, Budapest. 152 p.

140.JULESZ M. 2012: Médiademokrácia és szociális ökológia. - Információs társadalom 12. 4. pp. 125-133.

141.KANALAS I. - KISS A. 2006: Helyzeti (földrajzi) centrum-periféria viszony . - In: KANALAS, I., KISS, A. (szerk.): A perifériaképződés típusai és megjelenési formái Magyarországon. MTA RKK Alföldi Tudományos Intézet, Kecskemét. pp. 27-31.

142.KAPRINAY E. 2012: "Nem veszélyes" vörösiszap/veszélyes jogszabályi háttér. - In. MEZEI P. (szerk.): Természeti és ipari katasztrófák: jogi aspektusok a 2010-es ajkai vörösiszap-katasztrófa fényében. SZTE ÁJK, Szeged. pp. 94101.

143.KÁTAY Á.-SzALAi K.-HinEK M. 2013: A folyóvíz mint veszélyforrás, avagy az árvízi kockázat a hazai szálláshelykínálat és a belföldi turisták szemszögéből. - Földrajzi közlemények 137. 2. pp. 164-181.

144.KAYA, I. A.-EROL, N. K. 2016: Conflicts over Locally Unwanted Land Uses (LULUs): Reasons and solutions for case studies in Izmir (Turkey). - Land Use Policy 58. 1. pp. 83-94.

145.KÉMÉNCZY I. 1980: Tömegkatasztrófák pszichológiai hatásai. - Zrínyi Katonai Kiadó, Budapest. pp. 5-90.

146.KERTÉSZ J. 2012: Katasztrófavédelem a vörösiszap-katasztrófa tükrében. - In. MEZEI P. (szerk.): Természeti és ipari katasztrófák: jogi aspektusok a 2010-es ajkai vörösiszap-katasztrófa fényében. SZTE ÁJK, Szeged. pp. 63-72.

147.KINCSES, B, - KISPÁL, J. - NAGY, GY. 2016: Árvízvédelmi beruházások participáció szempontú vizsgálata Szegeden és Szolnok - összehasonlító elemzés In: KERESZTES, GÁBOR (SZERK.) Tavaszi Szél 2016. Tanulmánykötet. IV. kötet: Pszichológia- és neveléstudomány, sporttudomány, szociológia- és multidiszciplináris társadalomtudomány, történelem- és politikatudomány Budapest, Magyarország : Doktoranduszok Országos Szövetsége, pp. 242-254.

148. KisPÁL, J. - NAGY, GY. 2017: A biztonság, mint szubjektív tényező a városfejlesztésben: esettanulmány Szolnok város példáján In: KERESZTES, GÁBOR (SZERK.) Tavaszi Szél 2017 [tanulmánykötet] 3.Budapest, Magyarország : Doktoranduszok Országos Szövetsége, (2017) pp. 324-338.

149.KISS T.-FIALA K.-SIPOS GY. 2008: Altered meander parameters due to river regulation works, Lower Tisza, Hungary. - Geomorphology 98. 1-2. pp. 96-110. 
150.KoCSIS, K.-KovÁCS, Z. 1991: A magyarországi cigánynépesség társadalomföldrajza. - In: UTASI, Á.-MÉSZÁROS, Á. (szerk.): Cigánylét. MTA Politikai Tudományok Intézete, Budapest. pp. 78-105.

151.KolOSI T.-KELLER T. 2010: Kikristályosodó társadalomszerkezet. - In: KOLOSI T.-TÓTH I. GY. (szerk.) 2010: Társadalmi riport 2010. - Tárki, Budapest. pp. 105-138.

152. KolTAi Z. 2016: Városok vonzereje országos és regionális léptékben. - In: Lengyel I.-Nagy B. (szerk.): Térségek versenyképessége, intelligens szakosodása és újraiparosodása. - JATEPress, Szeged. pp. 272-289.

153.KOPP M.-SKRABSKI Á. 2009: Magyar lelkiállapot az ezredforduló után. - Távlatok 19. 86. pp. 32-52.

154.KovÁCs A. D. 2004: Környezeti problémák és konfliktusok a perifériákon. - In. Magyar Földrajzi Konferencia http://geography.hu/mfk2004/mfk2004/cikkek/kovacs_andras_donat.pdf Szeged, 2004. 09. 2-4.

155.KovÁCs Z. 2001. Társadalomföldrajzi Kislexikon, Müszaki Könyvkiadó, Budapest. p. 176.

156.KovÁTs B. (ford.) (2013): Városi politikai ökológia, igazságosság és léptékek politikája. In: JELINEK CS.-BODNÁR J.-CZIRFUSZ M.-GYIMESI Z. (szerk.): Kritikai városkutatás. L’Hartmann, Budapest. pp. 394-416.

157.KOZÁK P. 2003: Az alföldi belvizek jellemzése. In: Hidrológiai Közlöny 2003. 1. pp. 51-61

158.KozÁK, P. 2006: A belvízjárás összefüggéseinek vizsgálata az Alföld délkeleti részén, a vízgazdálkodás európai elvárásainak tükrében. Doktori értekezés, Szegedi Tudományegyetem, Szeged, 2006.

159.KÖRÖSPARTI J.-BOZÁN CS.-PÁSZTOR L.-KOZÁK P.-KUTI L.-PÁLFAI I. 2009: GIS alapú belvíz-veszélyeztetettségi térképezés a Dél-alföldön. Magyar Hidrológiai Társaság XXVII. Vándorgyülése. Konferencia Proceedings. Baja. 14 p. http://docplayer.hu/3422937-Gis-alapu-belviz-veszelyeztetettsegi-terkepe-zes-a-del-alfoldon.html

160.KÖSZEGHY L. 2007: A cigány és nem cigány lakosság lakhatási egyenlőtlenségeinek tényezői, in: Balogh Margit (szerk.) Diszciplínák határain innen és túl. Fiatal Kutatók Fóruma 2. - 2006 MTA Társadalomkutató Központ 2007 pp. 11-33.

161.KREISS, K. 1990:The Sick Building Syndrome: Where Is the Epidemiologic Basis? In: American Journal of Public Health. 80. pp. 1172-1173.

162.KRÉMER S. 2016: A késői Richard Rorty filozófiája. - JATEPress, Szeged. 333 p.

163.KRIEG, E. J. 1995: A Socio-Historical Interpretation of Toxic Waste Sites: The Case of Greater Boston. - The American Journal of Economics and Sociology 54. 1. pp. 1-14.

164.KUn, Á., BARTA, K., KATONA, O., 2012: Effects of the 2011-12 inland water on soils induced by the M43 motorway. VI. Magyar Földrajzi Konferencia. MERIEXWA nyitókonferencia és a Geográfus Doktoranduszok Országos Konferenciájának Tanulmánykötete. Szerk: Nyári Diána. 2012. Szegedi Tudományegyetem Természeti Földrajzi és Geoinformatikai Tanszék. ISBN 978-963-306-175-6

165.LACKÓ L. 1975: Magyarország elmaradott területei (Egy kutatás eredményei és tapasztalatai). - Földrajzi Értesítő, 24. 3. pp. 243-269.

166.LADÁNYI J.-VIRÁG T. 2009: A szociális és etnikai alapú lakóhelyi szegregáció változó formái Magyarországon a piacgazdaság átmeneti időszakában. - Kritika: társadalomelméleti és kulturális lap 38. 7-8. pp. 2-8.

167.LAURIAN, L. - FUNDERBURG, R. 2014: Environmental justice in France? A spatio-temporal analysis of incinerator location In: Journal of Environmental Planning and Management 57(3)

168.LeFEBVRE, H. 2003: The Urban Revolution. University of Minnesota Press, Minneapolis. 196 p.

169.LEHTINEN, A. A. 2009: Environmental Justice. In. International Encyclopedia of Human Geography. pp. 535-539.

170.LENGYEL I. 2010: Regionális Gazdaságfejlesztés. Akadémiai Kiadó, Budapest. 386 p.

171.LENGYEL I. 2012: Regionális növekedés, fejlődés, területi tőke és versenyképesség. - In: BAJMÓCY Z.-LENGYEL I.MÁLOVICS GY. (szerk.): Regionális innovációs képesség, versenyképesség és fenntarthatóság. - JATEPress, Szeged. pp. 151-174.

172.LENGYEL I.-SZAKÁLNÉ KANÓ I.-VAS Zs.-LENGYEL B. 2016: Az újraiparosodás térbeli kérdőjelei Magyarországon. - Közgazdasági szemle 63. 6. pp. 615-646.

173.LEWIS, T.-BENNETT, S. 2013: The juxtaposition and spatial disconnect of environmental justice declarations and actual risk: A new method and its application to New York State. - Applied Geography 39. 1. pp. 57-66.

174.LIMA, M.L. 2004: On the influence of risk perception on mental health: Living near an incinerator in Journal of Environmental Psychology 24(1) pp.71-84

175.LluRdes, JC. - SAURI, D. - CERDAN, R. 2003: Ten years wasted: The failure of siting waste facilities in central Catalonia, Spain In: in Land Use Policy 20(4) pp. 335-342

176.LŐCSEI H. - SZALKAI G. 2008: Helyzeti és fejlettségi centrum-periféria relációk a hazai kistérségekben. - Területi Statisztika, 3. pp. 305-314

177.LuX G. 2016: Az államszocialista iparpolitika területi következményei. - In: ERDŐs K.-KoMLÓSI É. (szerk.) Tanítványaimban élek tovább: Emlékkötet Buday-Sántha Attila tiszteletére. - PTE Közgazdaságtudományi Kar, Pécs. pp. 85-105.

178. MAANTAY, J. 2007: Asthma and air pollution in Bronx: Methodological and data considerations in using GIS for environmental justice and health research. - Health \& Place 13. 1. pp. 32-56. 
179.MaAnTAY, J.-MARoKo, A. 2009: Mapping Urban Risk: Flood Hazards, Race, \& Environmental Justice In New York. - Applied Geography, 29. 1. pp. 111-124.

180.MAguiRE, K.-SHERIFF, G. 2011: Comparing Distributions of Environmental Outcomes for Regulatory Environmental Justice Analysis. - International Journal of Environmental Research and Public Health 8. 5. pp. $1707-1726$.

181. MÁLIK J. Z. (n. é.): Etikai Tradíciók, Jeremy Bentham: Bevezetés az erkölcsök és a törvényhozás elveibe (részletek). Kézirat. pp. 6-9. - Letöltve: http://www.drmalikcikk.atw.hu/cikk/etikai tradiciok.pdf (2019.03.04.)

182. MÁLIK J. Z. 2013: Az utilitarizmus négy különböző paradigmájáról. - Jog, állam, politika 5. 3. pp. 3-17.

183. MALIN, S. A.-DEMASTER, K. T. 2016: A devil's bargain: Rural environmental injustices and hydraulic fracturing on Pennsylvania's farms. - Journal of Rural Studies 47. A. pp. 278-290.

184.MÁLOVICs GY. 2016: A környezeti fenntarthatóság statisztikai méröeszközeinek fejlesztésekor jelentkező operacionalizációs választások. - In: BAJMÓCY Z. - LENGYEL I. - MÁLOVICS GY. (szerk.) 2012: Regionális innovációs képesség, versenyképesség és fenntarthatóság. JATEPress, Szeged. 393 p.

185.MÁLOVICS GY.-BAJMÓCY Z. 2009: A fenntarthatóság közgazdaságtani értelmezései. In: Közgazdasági Szemle, LVI. évf., 2009. május pp. 464-483.

186. Málovics, Gy. - Crețan, R. - Tóth, J. - MÉreiné-Berki, B. 2018: Socio-Environmental Justice, Participatory Development, and Empowerment of Segregated Urban Roma: Lessons from Szeged, Hungary In: Cities: The International Journal of Urban Policy and Planning (In Press) 2019.04.08.

187.MÁLOVICS, GY. 2012: Környezetvédelem vagy társadalmi igazságosság? A környezeti igazságosság koncepciójának értelmezési lehetőségei és hazai jelentősége. In: KOVÁSZ - 2012. TAVASZ-TÉL pp. 3-31.

188. Mansfield, C.-Houtven, G. V.-Huber, J. 2001: The Efficiency of Political Mechanisms for Siting Nuisance Facilities: Are Opponents More Likely to Participate than Supporters? - The Journal of Real Estate Finance and Economics 22. 2-3. pp. 141-161.

189. MARQUES, S. - LIMA, M.L. 2011: Living in grey areas: Industrial activity and psychological health. In. Journal of Environmental Psychology 31 pp. 314-322

190.Marston, S. A.-Jones III, J. P.-WoOdWARD, K. 2005: Human Geography without Scale. - Transactions of the Institute of British Geographers, New Series 30. 4. pp. 416-432.

191.MArtin, A.-Gross-CAMP, N.-KeBEDE, B.-MCGuire, S.-MunYARUKAZA, J. 2014: Whose environmental justice? Exploring local and global perspectives in a payments for ecosystem services scheme in Rwanda. - Geoforum 54. 1. pp. 167-177.

192.MARX, K.-ENGELS, F. 1980: A kommunista Párt kiáltványa. Kossuth Könyvkiadó-Kárpáti Könyvkiadó, BudapestUzsgorod. $159 \mathrm{p}$.

193. MCAUSLAN, P. 1980: The ideologies of planning law. - Pergamon Press, Oxford. 279 p.

194. MCCLINTOCK, N. 2012: Assessing soil lead contamination at multiple scales in Oakland, California: Implications for urban agriculture and environmental justice. - Applied Geography 35. 1-2. pp. 460-473.

195.MehtA, L.-Allouche, J.-NICOL, A.-WALNYCKI, A. 2014: Global environmental justice and the right to water: The case of peri-urban Cochabamba and Delhi. - Geoforum 54. 1. pp. 158-166.

196.MÉSZÁROS R. (szerk.) 2010: A globális gazdaság földrajzi dimenziói. Akadémiai Kiadó, Budapest. 392 p.

197.MÉSZÁRos R. 2000: A társadalomföldrajz gondolatvilága, JATEPress, Szeged. 164 p.

198. MezŐsI G. 2011: Magyarország természetföldrajza. - Akadémiai Kiadó, Budapest. 393 p.

199. MoHAI, P. 2003: Dispelling Old Myths: African American. - Environment: Science and Policy for Sustainable Development 45. 5. pp. 10-26.

200.Mohai, P.-BRYANT, B. 1992: Environmental Racism: Reviewing the Evidence. - In: Bryant, B.-Mohai, P. (eds.): Race and the Incidence of Environmental Hazards. Westview Press, Boulder, CO. pp. 163-176.

201.Mohai, P.-Pellow, D.-RoberTs, J. T. 2009: Environmental Justice. - Annual Review of Environment and Resources 34. 1. pp. 405-430.

202.MOLNÁR E.-PÉNZES J.-RADICS Z. 2011: Az 1971-es OTK kiemelt alsófokú központjainak fejlődési pályája az elmúlt négy évtizedben. - In. CSAPÓ T.-Kocsis Zs. (szerk.): Az 1971. évi OTK hatása a hazai településrendszerre (szuburbanizáció, aprófalvak, településszerkezet). Savaria University Press, Szombathely. pp. 83-94.

203.Morello-Frosch, R.-PASTOR, M.-SADD, J. 2001: Environmental Justice and Southern California's "Riskscape": The Distribution of Air Toxics Exposures and Health Risks among Diverse Communities. - Urban Affairs Review 36. 4. pp. 551-578.

204.MORENO-JimÉNEZ A.-CAÑADA-TORRECILlA R.-VidAL-DOMÍNGUEZ M. J.-PALACIOS-GARCÍA A.-MARTÍNEZ-SUÁREZ P. 2016: Assessing environmental justice through potential exposure to air pollution: A socio-spatial analysis in Madrid and Barcelona, Spain. - Geoforum 69. 1. pp. 117-131.

205.MorgAN, O. - AHERN, M. - CAIRnCROSS, S. 2005: Revisiting the Tsunami: Health Consequences of Flooding. In: PLoS Med 2(6): e 184 
206.MuRDOCH, J. 1997: Inhuman/Nonhuman/Human: Actor-Network Theory and the Prospects for a Nondualistic and Symmetrical Perspective on Nature and Society. - Environment and Planning D: Society and Space 15. 6. pp. 731 756.

207.NAGY B. 2016: A magyar feldolgozóipar átalakulása 2008 és 2013 között: újraiparosodás vagy térbeli átrendeződés. - In: Lengyel I.-Nagy B. (szerk.): Térségek versenyképessége, intelligens szakosodása és újraiparosodása. - JATEPress, Szeged. pp. 45-66.

208.NAGY É. 2012: A vörösiszap-katasztrófa magánjogi felelősségi kérdései. - In. MEZEI P. (szerk.): Természeti és ipari katasztrófák jogi aspektusok a 2010-es ajkai vörösiszap-katasztrófa fényében. Szegedi Tudományegyetem Államés Jogtudományi Kar, Szeged. pp. 32-39.

209.NAGY E.-TIMÁR J.-NAGY G.-VELKEY G. 2015: A társadalmi-térbeli marginalizáció folyamatai a leszakadó vidéki térségekben. - Tér és társadalom, 29. 1. pp. 35-52.

210.NAGY, GY - PAPP, S. - MiKLós, B. 2017: Environmental Injustices in Border Regions: Case Study of Water Quality and Inland Excess Water In: Konstantin, Vasile-Toca; Ioan, Horga; Luminita, Soproni (szerk.) The evaluation of cross-border cooperation In Europe Oradea, Románia : Debrecen University Press, Oradea University Press, pp. 57 70.

211.NAGY GY. - JÁMBOR V. 2014: A környezeti igazságosság vizsgálata a vörösiszap-katasztrófa példáján In: CSISZÁR, I. - KöMÍveS, P. M. (szerk.) Tavaszi Szél / Spring Wind : III. kötet Debrecen, Magyarország : Doktoranduszok Országos Szövetsége, (2014) pp. 141-152.

212.NAGY GY. 2011: Környezeti igazságosság vizsgálati lehetőségei Magyarországon. OTDK DOLGOZAT 46P.

213.NAGY GY. 2012: A környezeti igazságosság fogalmi kérdései. - In: Pál V. (szerk.) A társadalomföldrajz lokális és globális kérdései: tiszteletkötet Dr. Mészáros Rezső professzor 70. születésnapja alkalmából. SZTE TTIK Gazdaságés Társadalomföldrajz Tanszék, Szeged. pp. 269-279.

214.NAGY J. ET AL. 2017: Hullámtéri feltöltődés mértéke és árvizek közötti kapcsolat az Alsó-Tiszán. - In. Földrajzi Közlemények, 141. 1. pp. 44-59.

215.NAGY, G. 2006: A gazdasági fejlettség minőségi indikátorai. - In: KANALAS, I., KISS, A. (szerk.): A perifériaképződés típusai és megjelenési formái Magyarországon. MTA RKK Alföldi Tudományos Intézet, Kecskemét. pp. 8697.

216.NAGY, GY - BoROS, L. 2015: A környezeti igazságtalanságok feltárásának térinformatikai módszerei In: Boda, J (szerk.) Az elmélet és a gyakorlat találkozása a térinformatikában : Térinfomatikai Konferencia és Szakkiállítás VI Debrecen, Magyarország : Debreceni Egyetemi Kiadó, pp. 293-306.

217. NeMES NAGY J. 2009: Terek, helyek, régiók. - Akadémiai Kiadó, Budapest. 350 p.

218.NÉMETH L. 2012: Az egészséghez és az egészséges környezethez való jog - In. MEZEI P. (szerk.): Természeti és ipari katasztrófák jogi aspektusok a 2010-es ajkai vörösiszap-katasztrófa fényében. Szegedi Tudományegyetem Állam- és Jogtudományi Kar, Szeged. pp. 83-92.

219.NewTon, D. E. 2009: Environmental Justice. - ABC Clio, Oxford. 307 p.

220.NYÍRI T. 2000: A filozófiai gondolkodás fejlödése. - Szent István Társulat, Budapest. 618 p.

221. OKEREKE, C. 2006: Global environmental sustainability: International equity and conceptions of justice in multilateral environmental regimes. - Geoforum, 37. 5. pp. 725-738.

222. OSKARSSON, P.-BEDI, B. P. 2018: Extracting environmental justice: Countering technical renditions of pollution in India's coal industry. - The Extractive Industries and Society 5. 3. pp. 340-347.

223.PAdGetT D.-IMANi N. O. 1999: Qualitative and Quantitative Assesment of Land-Use Managers' Attitudes Towards Environmental Justice. - Environmental Management 24. 4. pp. 509-515.

224.PÁL V.-BOROS L. 2010: The relationship between health policy and spatial justice - the case of Hungary. - Megatrend Review 7. 1. pp. 249-264.

225.PÁlfAi I. 2004: Az aszály definíciói, befolyásoló tényezői és mérőszámai. In: PÁLFAI I. (szerk.) Belvizek és aszályok Magyarországon. Hidrológiai Tanulmányok: Közlekedési Dokumentációs Kft., Budapest. pp. 255-263.

226.PÁLFAI I. 2011: Aszályos évek az Alföldön 1931-2010 között. In: RAKONCZAI J. (szerk.) Környezeti változások és az Alföld: Nagyalföld Alapítvány Kötetei 7., Békéscsaba. pp.87-96

227.PANELLI, R. 2009: Social Geography In: KITCHIN, R. -. THRIFT,N. (eds. in chief): International Encyclopedia of human geography (vol. 10). Elsevier, Oxford. pp. 185-195.

228.PASTOR, M.-SADD, J.-HIPP, J. 2001: Which came first? Toxic facilities, minority move-in, and environmental justice. - Journal of Urban Affairs, 23.1 pp. 1-21.

229.PEET, R. 2006: Modern Geographical Thought. - Wiley-Blackwell, Oxford. 342 p.

230.Peet, R.-Robins, P.-WATtS, M. J. 2010: Global Political Ecology. - Routledge, London - New York 464.p.

231.Pelletier, N. 2010: Environmental sustainability as the first principle of distributive justice: Towards a communitarian-based normative foundation for ecological economics. In Ecological Economics 69(10):1887-1894 
232.PÉNZES J. 2010: Az Észak-alföldi régió periférikus térségeinek tagoló tényezői a rendszerváltás után, különös tekintettel a területi jövedelemegyenlötlenségekre. - Doktori $(\mathrm{PhD})$ értekezés. Debreceni Egyetem, Természettudományi Kar, Földtudományok Doktori Iskola, Debrecen.

233.PÉNZES J. 2014: Periférikus térségek lehatárolása- Dilemmák és lehetőségek. Didakt Kft., Debrecen. 150 p.

234.PÉNZES J.-TÁTRAI P.-PÁSZTOR, I. Z. 2018: A roma népesség területi megoszlásának változása Magyarországon az elmúlt évtizedekben. - Területi Statisztika, 58. 1. pp. 3-26.

235.Peters, E. - Slovic, P. 1996: The Role of Affect and Worldviews as Orienting Dispositions in the Perception and Acceptance of Nuclear Power. In. Journal of Applied Social Psychology Vol.26 Issue16. pp. 1427-1453.

236.PIKÓ B. 1999: A társadalomtudományok illetékessége a biomedicina számára. —Valóság, 42.12. pp. 22-30

237.Platón 1989: Az állam. - Gondolat Kiadó, Budapest. 468 p.

238.PRUGBERGER T. (2001): A globalizáció és a környezetvédelem neuralgikus kérédsei a jogalkotás és a jogalkalmazás síkján. -Magyar közigazgatás,51.10 pp. 619-625.

239.PULIDO, L. 2000: Rethinking environmental racism: White privilege and urban development in southern California. - Annals of the Association of American Geographers, 90.1. pp. 12-40.

240.RABÓCZKY L. - POMÁZI I. - ZsıKLA GY. 1990: A környezet és a gazdaság kapcsolatának néhány kérdése (Problémák, feladatok, megoldási lehetőségek). - Földrajzi Értesítő, 39. 1—4. pp. 151-173.

241.RAKONCZAI J. 2003: Globális Környezeti problémák. - Lazi Kiadó, Szeged. 191 p.

242.RAWLS, J. 1971: A Theory of Justice. - Harvard University Press, Cambridge. 560 p.

243.RAWLS, J. 1993: Political liberalism. - Columbia University Press, New York. 435 p.

244.ReAcher, M. - MCKenzie, K. - LANE, C. - Nichols, T. - Kedge I. - IVERSEN, A. - Hepple, P. - Walter, T. LAXTION, C. - SIMPSON J. 2004: Health impacts of flooding in Lewes: a comparison of reported gastroinestinal and other illness and mental healt in flooded and non-flooded households. In: Communicable Disease and Public Health, Vol 7. No. 1. pp 1-8.

245.ReChNitZER, J.-SMAHÓ, M. 2011: Területi politika. - Akadémiai Kiadó, Budapest. 456 p.

246.RosLER, M. 1991: Fragments of a metropolitan viewpoint. - In. WALLIS, B.(ed.): If you lived here: The city in art, theory, and social activism. Bay Press, Seattle. pp. 15-44.

247.Rousseau, J. J. 2001: A társadalmi szerződés. - Kriterion Kiadó, Kolozsvár. 232 p.

248.RUDNAI P. (SZERK.) 2007: Lakás és egészség, Országos Környezetegészségügyi Intézet, Budapest, Nyilvános kiadvány

249.RUDOLF, M. 2010: Árvíz és újjáépítés Felsőzsolcán. - Országépítő, 21. 3. pp. 2-7.

250.RYDIN, Y. 2006: Justice and the Geography of Huricane Katrina. In: Geoforum (37). pp 4-6.

251.SAJTOS, L.-MiteV, A. 2007: SPSS kutatási és adatelemzési kézikönyv. - Alinea Kiadó, Budapest. 404. p.

252.SANTIAGO-RIVERA ET AL. 2007: Exposure to an environmental toxin, quality of life and psychological distress in Journal of Environmental Psychology 27(1) pp. 33-43

253.SÁRI J. - SOMODY B. 2008: Alapjogok, alkotmánytan II. Osoris Kiadó, Budapest, 419p.

254.SCHNEGG M. - KIAKA, R. D. 2018: Subsidized elephants: Community-based resource governance and environmental (in)justice in Namibia. - Geoforum, 93. pp. 105-115

255.SHERMAN, L. W.-STRANG, H. 2007: Restorative justice: the evidence. - Smith Institute, London. 96 p.

256.SMith, N. 2003: Jelszavak és könyörtelen kritika: marxizmus és nemzetközi kritikai geográfia In: Tér és Társadalom 17. évf. 2003/2. pp. 37-51.

257.SNEDDON, S. 2009: Environmental Studies and Human. - In: KITCHIN, R. -. THRIFT,N. (eds. in chief): International encyclopedia of human geography (vol. 3). Elsevier, Oxford. pp. 205-210.

258. SoJA, E. W. 2010: Seeking Spatial Justice. - University of Minnesota Press, Minneapolis. 280 p.

259. ŠPIRIĆ, J. 2018: Ecological distribution conflicts and sustainability: lessons from the post-socialist European semiperiphery.- Sustainability Science, 13.3. pp. 661-676

260.STEGER, T. (ed.) 2007: Making the case for environmental justice in Europe. - CEU Center for Environmental Policy and Law (CEPL), The Health and Environment Alliance (HEAL), The Coalition for Environmental Justice. 58 p.

261.STEIGER K. 1997: Bevezetés a filozófiába. - Holnap Kiadó, Budapest.

262.STEVAuX, J.C. -LAUTRUBESSE, E. 2010: Urban Floods in Brazil. - In: E. Latrubesse, (eds.):Geomorphology of Natural Hazards and Human Exacerbated Disasters in Latin America. - Elsevier, Amsterdam, pp. 245-266

263.STRATFORD, M. - DukE-Williams, O. - ShElON, N. 2008: Small area inequalities in health: Are we understanding them? - Social Science and Medicine. 67. pp. 891-899.

264.SÜLI-ZAKAR I. (szerk.) 2003: A terület- és településfejlesztés alapjai. - Dialóg Campus Kiadó, Budapest-Pécs. 468 p.

265.SwIFT, A. - LIU, L. - UBER, J. 2008: Reducing MAUP bias f correlation statistics between water quality and GI illness. - Computers, Environment and Urban Systems. 32. pp. 134-148.

266.Swyngedouw, E.- HeYen, N.C. 2003: Urban Political Ecology, Justice and the Politics of Scale In: Antipode Vol. 35 issue 5. pp. 898-918. 
267.SWYNGEDOUW, E.2004: Social power and the urbanization of water : flows of power, Oxford University Press, p. 209.

268.SzABÓ M. 2004: Piac, igazságosság, ökológia, Liberalizmus és környezetvédelem a XXI. század politikájában. Beszélö 12.9. pp. 10-20.

269.SZABÓ P.-FARKAS M. 2012: A fejlettség különböző felfogásai és mérései Európában és Magyarországon. - KözépEurópai közlemények 5. 1.pp. 86-101.

270.SZASZ A.-MEUSER, M. 1997: Environmental Inequalities: Literature Review and Proposals for New Directions in Research and Theory. - Current Sociology 45. 3. pp. 99-120.

271.SZÉKHELYI M.-BARNA I. 2008: Túlélőkészlet az SPSS-hez. - Typotex Kiadó, Budapest. 453 p.

272.SzILÁGYi D. - UzZOLI A. 2013:Az egészségegyenlőtlenségek területi alakulása az 1990 utáni válságok idején, Magyarországon.-Területi Statisztika,53.2. pp.306-322.

273.SZILÁGYi D.-UzZOLI A. 2013: Az egészség egyenlőtlenségek területi alakulása az 1990 utáni válságok idején Magyarországon. - Területi Statisztika 53. 2. pp. 130-147.

274.SZIRMAI V. ed. 2015: From spatial inequalities to social well-being. - Kodolányi János University of Applied Sciences, Székesfehérvár. 192 p.

275.SzOBOSZLAI Zs. 2006: Szegénység-marginalizáció-szegregáció. - In: KANALAS, I., KISS, A. (szerk.): A perifériaképződés típusai és megjelenési formái Magyarországon. MTA RKK Alföldi Tudományos Intézet, Kecskemét. pp. 116-134.

276.TAN, P. N.-STEINBACH, M.-KuMAR, V.2012: Bevezetés az adatbányászatba - Panem Kft., Budapest. 832 p.

277.TIMÁR J 2003: „Mi a teendő" a kialakulóban lévő kritikai geográfia számára Magyarországon?' In: Tér és Társadalom 17. évf. 2003/2. pp. 53-65.

278.TIMÁR J. 1999: Elméleti kérdések a szuburbanizációról, Földrajzi Értesítő 48. 1-2. pp. 7-32

279.TIMÁR J. 2001: A modern társadalomföldrajz szemlélete és módszerei. In: Nemes Nagy J. (szerk): GEOGRÁFIA AZ EZREDFORDULÓN. ELTE, Regionális Tudományi Tanulmányok 6. kötet

280.TIMÁR J. 2001: Mégis, kinek az érdeke? - Szuburbanizáció a kapitalizálódó Magyarországon. - Földrajzi Konferencia Szeged, 2001. 10. 25-27. - Letöltve: http://geography.hu/mfk2001/cikkek/Timar.pdf (2019.04.03.)

281.TIMÁR J. 2005: Városiasodás és szuburbanizáció. - In. TÖRÖK J. (szerk.): VII. Közmüvelödési Nyári Egyetem Tér-társadalom-kultúra. Csongrád Megyei Közmüvelődési Tanácsadó Központ, Szeged.

282. TimÁR J. 2009: Kritika és társadalomelmélet - Néhány érv a kritikai földrajz „védelmében". In: Tér és Társadalom 23. évf. 2009/4. pp. 225-231.

283.TóтH G.-DÁVID L.-BuJdosó Z. 2010: A hazai folyók által érintett települések társadalmi- gazdasági vizsgálata. Földrajzi Közlemények 134. 2. pp. 189-202.

284. То́тн J. (szerk.) 2001: Általános társadalomföldrajz I-II. kötet. - Dialóg Campus Kiadó, Budapest-Pécs. 519 p.

285.TURI, A. 2011: Az ajkai vörösiszap. - Országépítő 21. 2. pp. 14-23.

286.UZZOLI A. 2001: Társadalmi konfliktusok bizonyítása az egészségföldrajz eredményeinek felhasználásával. - Magyar Földrajzi Konferencia, Szeged 2001. október 25-27. - Letöltve: http://geography.hu/mfk2001/cikkek/Uzzoli.pdf (2019.04.03.)

287.UzzoLI A. 2013: A válság és egészség Magyarországon - Feltételezések és vélemények. - Egészségtudomány 57. 3. pp. $10-27$.

288.UZZOLI A. 2013:A válság és egészség Magyarországon - Feltételezések és vélemények.—Egészségtudomány, 57.3. pp. $10-27$

289.UzZOLI A.-VitRAi J.-BAKACS M.-GÉMES K.-KISS N.-KÖVI R. 2011: A lakóhelytől függ az esély a jobb minőségü ellátásra: Az ellátáshoz való hozzáférés területi egyenlőtlenségei Magyarországon. - Tér és Társadalom 25. 2. pp. 88-105., $18 \mathrm{p}$.

290.UZZOLI, A. - SZILÁGYI, D. 2015: A hazai egészség-egyenlőtlenségek alakulása válság idején. - In: HERVAINÉ SzABÓ GY. - BARÁTH, G. (szerk.): Inkluzív társadalom - Jól-lét - Társadalmi részvétel = Inclusive Society - Well-being Participation. Kodolányi János Főiskola, Székesfehérvár, pp. 78-84.

291.Uzzoli, A. - Vitrai, J. — BAKACS, M. — GÉMES, K. - Kiss, N. — KöVI, R 2011:A lakóhelytől függ az esély a jobb minőségü ellátásra: Az ellátáshoz való hozzáférés területi egyenlőtlenségei Magyarországon. — Tér és Társadalom, 25.2. pp. 88-105.

292. VAN DER HORST, D. 2007: NIMBY or not? Exploring the relevance of location and the politics of voiced opinions in renewable energy siting controversies. - Energy Policy 35. 5. pp. 2705-2714.

293. VÁRADI M. M. 2014: Szegénység és projektvilág. - In: NAGY E.-NAGY G. (szerk.): Polarizáció - függőség - krízis: Eltérő térbeli válaszok. - MTA KRTK RKI Alföldi Tudományos Osztály, Békéscsaba. pp. 10-17.

294. VÁRAdi M. M.-VIRÁG T. 2014: Faces and Causes of Roma Marginalization - Experiences from Hungary. - In: SzALAi J.-ZENTAI V. (szerk.): Faces and Causes of Roma Marginalization in Local Contexts: Hungary, Romania, Serbia. - Central European University, Budapest. 2014. pp. 35-66. 
295.VÁRADI M. M.-VIRÁG T. 2015: A térbeli kirekesztés változó mintái vidéki terekben. - Szociológiai Szemle 25.1. pp. 89-113.

296. VARGA CS.-KISS I.-EMBER I. 2002: The Lack of Environmental Justice in Central and Eastern Europe. - Environmental Health Perspectives, 110. 11. pp. A662-A663

297. VASÁRUS GÁBOR 2019: A lakossági szuburbanizáció szerepe a hazai vidéki agglomerációk külterületeinek átalakulásában. Doktori értekezés, Szegedi Tudományegyetem. (2019)

298. VÉDEGYLET 2010: Környezeti igazságosság Magyarországon. - Zárótanulmány, Budapest. Letöltve: http://kornyezetiigazsagossag.hu/zarotanulmany.pdf (2019.04.03.).

299. VELKEY G. 2014: Marginalizáció vidéken - sajátosságok és lehetséges beavatkozások. Tudáskészlet a magyar vidék fejlesztéséhez, Készült az MTA és Magyar Nemzeti Vidéki Hálózat együttműködésében, a Vidékfejlesztési Minisztérium vidékstratégiáját támogató komplex kutatási program keretében, a Nemzeti Agrárszaktanácsadási, Képzési és Vidékfejlesztési Intézet megbízásából. 18 p.

300. VIDA GY. 2016: A vidéki agglomerációk, agglomerálódó térségek és nagyvárosi településegyüttesek versenyképességének sajátosságai. - In: Lengyel I.-Nagy B. (szerk.): Térségek versenyképessége, intelligens szakosodása és újraiparosodása. - JATEPress, Szeged. pp. 204-222.

301. VIRÁG T. 2006: A gettósodó térség. - Szociológiai Szemle 16. 1. pp. 60-76.

302. VIRÁG T. 2010: Kirekesztve Falusi gettók az ország peremén. - Akadémiai Kiadó, Budapest. 266 p.

303. WAlker, G. - Burningham, K. - Fielding, J. - SMith, G. - Thrush, D. - FAY, H. 2006: Addressing Environmental Inequalities: Flood Risk. Science Report, Environmental Agency.

304.WALKER, G. 2006: Geographies of environmental justice. - Geoforum 37. 5. pp. 655-659

305.WALKER, G. 2012: Environmental Justice: Concepts, Evidence and Politics. - Routledge, London. 256 p.

306.WAlter, L. 2014: Move over Yuppies - the Magpies have arrived! https://dictionaryblog.cambridge.org/2014/03/05/move-over-yuppies-the-magpies-have-arrived/

307.WARF B.-ARIAS S. (eds.) 2009: The Spatial Turn,Interdisciplinary Perspectives. - Routledge, London. 256 p.

308.WeStOn, H. B. 2008: Climate Change and Intergenerational Justice: Foundational Reflections. - Vermont Journal of Environmental Law 9. 3. pp. 1-50.

309. WESTRA, L. 1996: Environmental integrity, racism and health. - The Science of the Total Environment 184. 1-2. pp. 57-66.

310.WILES, R. 1985: Field Duty: US. Farmworkers and Pesticides Safety. Study, World Recources Institute, Centre for Policy Research

311. WilliamS, R. W. 1999: Environmental injustice in America and its politics of scale. - Political Geography 18.1. pp. 49-73.

312. WiTHERICK ET AL 2001: A modern dictionary of geography, Oxford University Press; 4th edition p.293.

313.WolsinK, M. 1994: Entanglement of interests and motives: assumptions behind the NIMBY-theory on facility siting. -Urban Studies 31. 6. pp. 851-866.

314. Young, I. M. 1990: Justice and the Politics of Difference. - Princeton University Press, New Jersey. 286 p.

315. YUAN, Q. 2018: Mega freight generators in my backyard: A longitudinal study of environmental justice in warehousing location. - Land Use Policy 76. pp. 130-143.

\section{Források}

[1] DOMASZÉK TELEPÜLÉSFEJLESZTÉSI KONCEPCIÓ, 2012

[2] SZEGED MJV IVS, 2014

[3] https://24.hu/belfold/2019/02/08/vorosiszapper-katasztrofa-itelet/

[4] http://news.bbc.co.uk/2/hi/europe/8548417.stm

[5] https://www.dw.com/en/facets-of-ultranationalism-in-central-europe/g-38557548

[6]https://archive.nytimes.com/query.nytimes.com/gst/fullpage-

9C01E4D61038F930A35757C0A9669D8B63.html

[7] https://www.epa.gov/environmentaljustice

ANTIATOM 2008: Ma adták át a Bátaapáti melletti radioaktív hulladéktárolót. - Letöltve: http://antiatom.blog.hu/2008/10/06/ma_atadtak_a_bataapati_melletti_radioaktiv_hulladektarolot_reszlet__greenpeace_magyarorszag_egyesul (2012.10.3.)

ATV 2010: Derékig érő víz a nappaliban, romatelep az ártérben - borsodi (k)árhelyzet percröl percre. - Letöltve: http://atv.hu/belfold/20100520_borosdi_karhelyzet_percrol_percre (2012.09.10.)

BARBALACE, R. C. 2001: Environmental Justice and the NIMBY Principle. EnvironmentalChemistry.com - Letöltve: http://EnvironmentalChemistry.com/yogi/hazmat/articles/nimby.html (2012.10.15.) 
EPINFO 2006: Árvíz Európában. In: Epidemiológiai Információs Hetilap. Johan Béla Országos Epidemiológiai Központ. pp 201-203

HETEK 2005: Újabb vízözön - Borsodban. Letöltve:

http://www.hetek.hu/belfold/200507/a_gatemeles_gatja (2012. 09.10.)

HVG 2010: Vízhiány, szemét, telepek. - Letöltve: https://hvg.hu/hetilap.melleklet/201017_kornyezeti_igazsagtalansagok_magyarorszagon (2019.03.04.)

INDEX 2005a: Atomtemető: épülnek a kutatóaknák Bátaapátiban. - Letöltve: http://index.hu/belfold/hirek/223521/ (2012.10.3.)

INDEX 2005b: Bátaapáti, az atomfalu. - Letöltve: http://index.hu/bulvar/apati0729/ (2012.10.3.)

INDEX 2005c: Igent mondott Bátaapáti az atomhulladék-tárolóra. - Letöltve: http://index.hu/belfold/hirek/228777/ (2012.10.3.)

INDEX 2010: Sárban áll egész boldva. - Letöltve: http://index.hu/belfold/2010/05/23/sarban_all_egesz_boldva/ (2012.09.10.)

INDEX 2012: A magyaroknál persze porzik az utca. - Letöltve: http://index.hu/bulvar/telep0712/ (2012.09.11.)

ORIGO 2010: „A félelem tartja itt a zsákokat” - riport az elfelejtett árvízi faluról - Letöltve: http://www.origo.hu/itthon/20100723-boldva-az-arviz-utan-riport.html (2012. 09.10.)

MúLT-KOR 2009: A rendszerváltozás szimbólumává vált a Bős-Nagymaros elleni küzdelem. - Letöltve: http://www.mult-kor.hu/20090513_a_rendszervaltas_szimbolumava_valt_a_bosnagymaros_elleni_kuzdelem.

(2012.11.10.)

NETWORK 2008: Bátaapáti jövője. - Letöltve:

http://network.hu/beregszaszit/blog/t\%C3\%ADmea-blogja/bataapati_jovoje_atomtemeto-4791 (2010.10.3.)

ROMA SAJTÓKÖZPONT: Aláírásgyüjtésbe kezdtek az árvízkárosult boldvai romák. - Letöltve: http://www.sosinet.hu/2010/07/30/alairasgyujtesbe-kezdtek-az-arvizkarosult-boldvai-romak/ (2010. 09.10.)

ROMAPAGE: A boldvai cigánytelepet meglátogatta az Ördög. - Letöltve:

http://www.romapage.hu/hirek/hircentrum-forummal/article/75234/167/ (2012.09.10.)

ROMAPAGE: Gátrendszert terveznek Boldván. - Letöltve:

http://romapage.hu/hirek/hircentrum-forummal/article/106688/1464/page/16/ (2012.09.10.)

SolT E. 2010: A radioaktív hulladékelhelyezésének müszaki és társadalmi kérdései. A Magyar Tudomány Ünnepe, elöadás 2010.10.08. - Letöltve:

www.gdf.hu/TudNap2010/letoltes/12.pdf (2012.10.22.)

VITUKI 1990: Natural disasters in Hungary. - Letöltve: http://www.preventionweb.net/files/30484_hungarynaturaldisasters.pdf (2019.03.04.)

WALTER, L. 2014: Move over Yuppies - the Magpies have arrived! - Letöltve: https://dictionaryblog.cambridge.org/2014/03/05/move-over-yuppies-the-magpies-have-arrived (2019.04.03.)

WHO 2010a: Environment and health risks: a review of the influence and effects of social inequailities. - WHO regional Office for Europe, Coppenhagen - Letöltve: http://www.euro.who.int/_data/assets/pdf_file/0003/78069/E93670.pdf?ua=1 (2019.04.03.)

WHO 2010b: Towards Environmental Health Inequality Reporting. Development of a core set of indicators for reporting and assessing environemntal health inequalities in the WHO European Region. - WHO regional Office for $\quad$ Europe. http://www.euro.who.int/_data/assets/pdf_file/0013/130243/e94628.pdf?ua=1 (2019.04.03.)

Letöltve:

WHO 2011: Climate change, extreme weather events and public health - Meeting report. Bonn, Regional Office for WHO Europe. pp. 24. 


\section{Mellékletek}

\section{Fotódokumentáció}
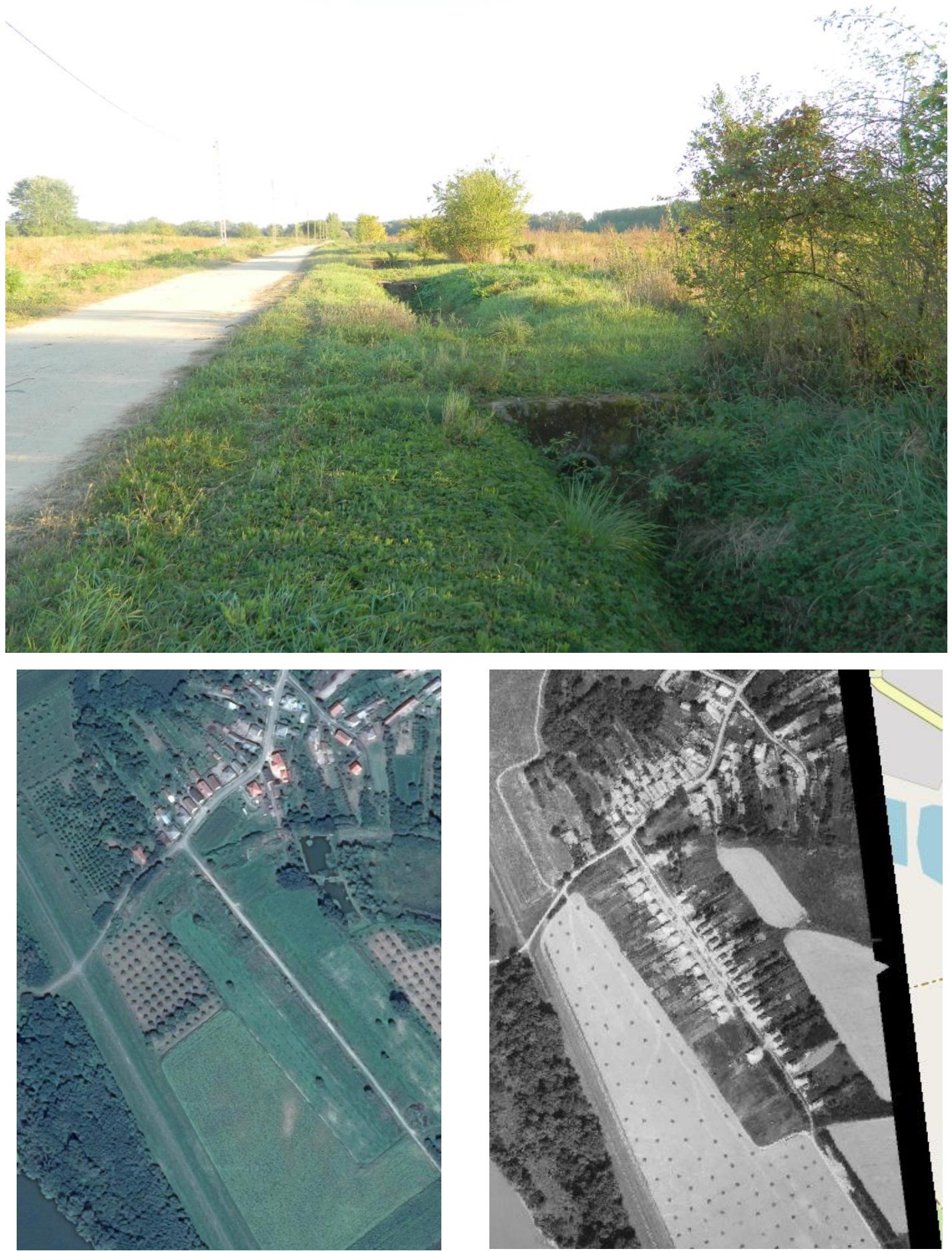

9.1.1. Egykori utca képe Jándon. Az utcában kb. 60-70 db közművesített, építési telek található, övezeti besorolása különleges beépítésre szánt szabadidő központ belterülete. A terület korábban lakott, beépített terület volt, azonban a legutolsó árvíz alkalmával a területet a Tisza elöntötte, a megrongálódott és megsemmisült házakat később elbontották. Forrás: Saját fotó (2011), Google Earth (2019), Fentrol.hu (1987) 

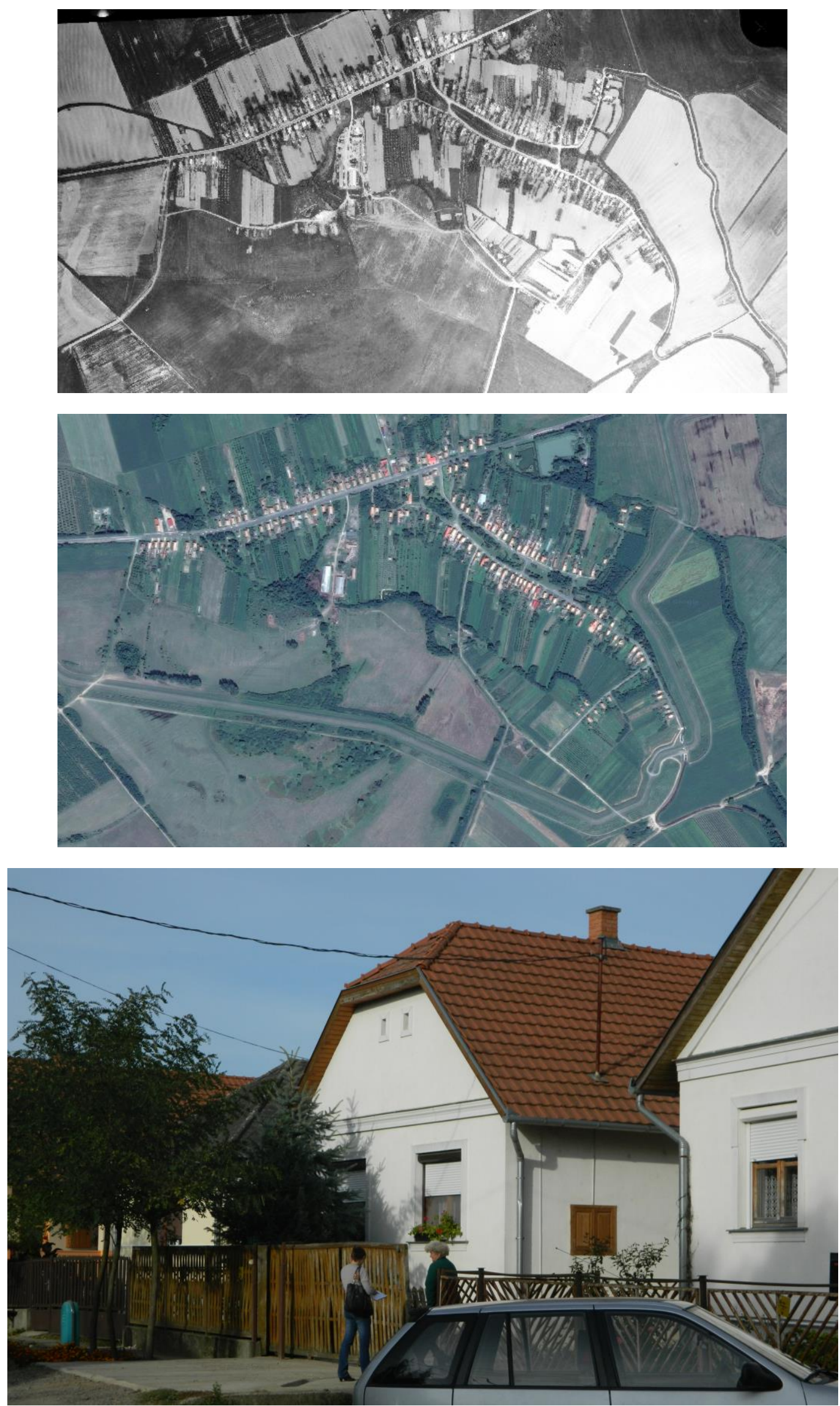

9.1.2. Tákos, az egyik leginkább érintett település volt a 2001-es árvíz során. Az árvizet követően kiépült az új árvízvédelmi rendszer, a település szerkezete ugyan nem változott, mégis gyökeresen átalakult a településkép az átalakításoknak köszönhetően. Fentrol.hu (1982), Google Earth (2019), Saját fotó (2011) 

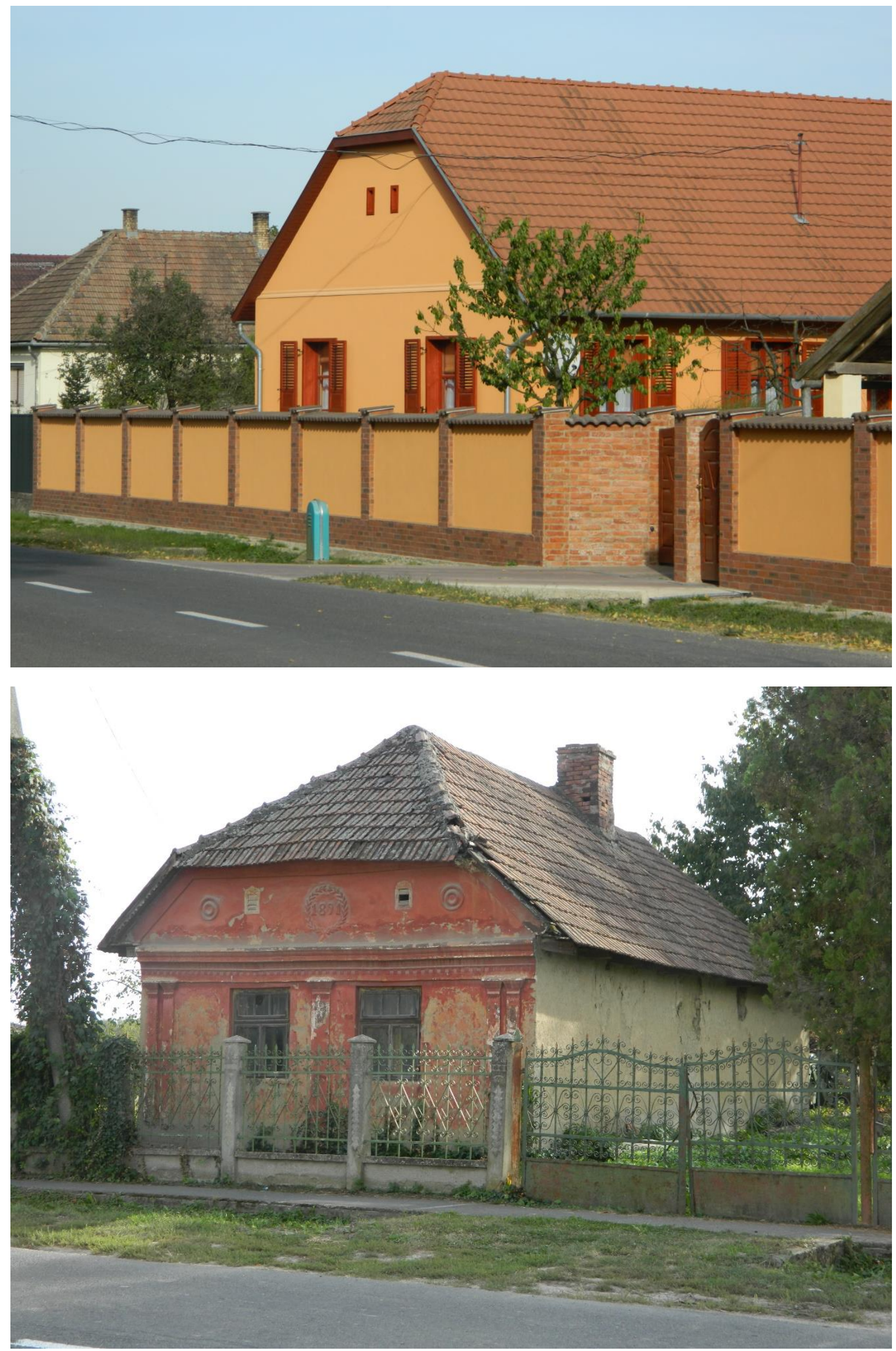

9.1.3. Az újonnan felépített házak a helyi stílust imitálják, idézik fel. A kontyolt nyeregtetős, magas oromzatú díszes házak a térségben élők egykori jólétéről árulkodik. Csupán pár eredeti lakóház élte túl az árvízi pusztítást a beregi térségben, Tákoson. Saját felvételek (2011) 

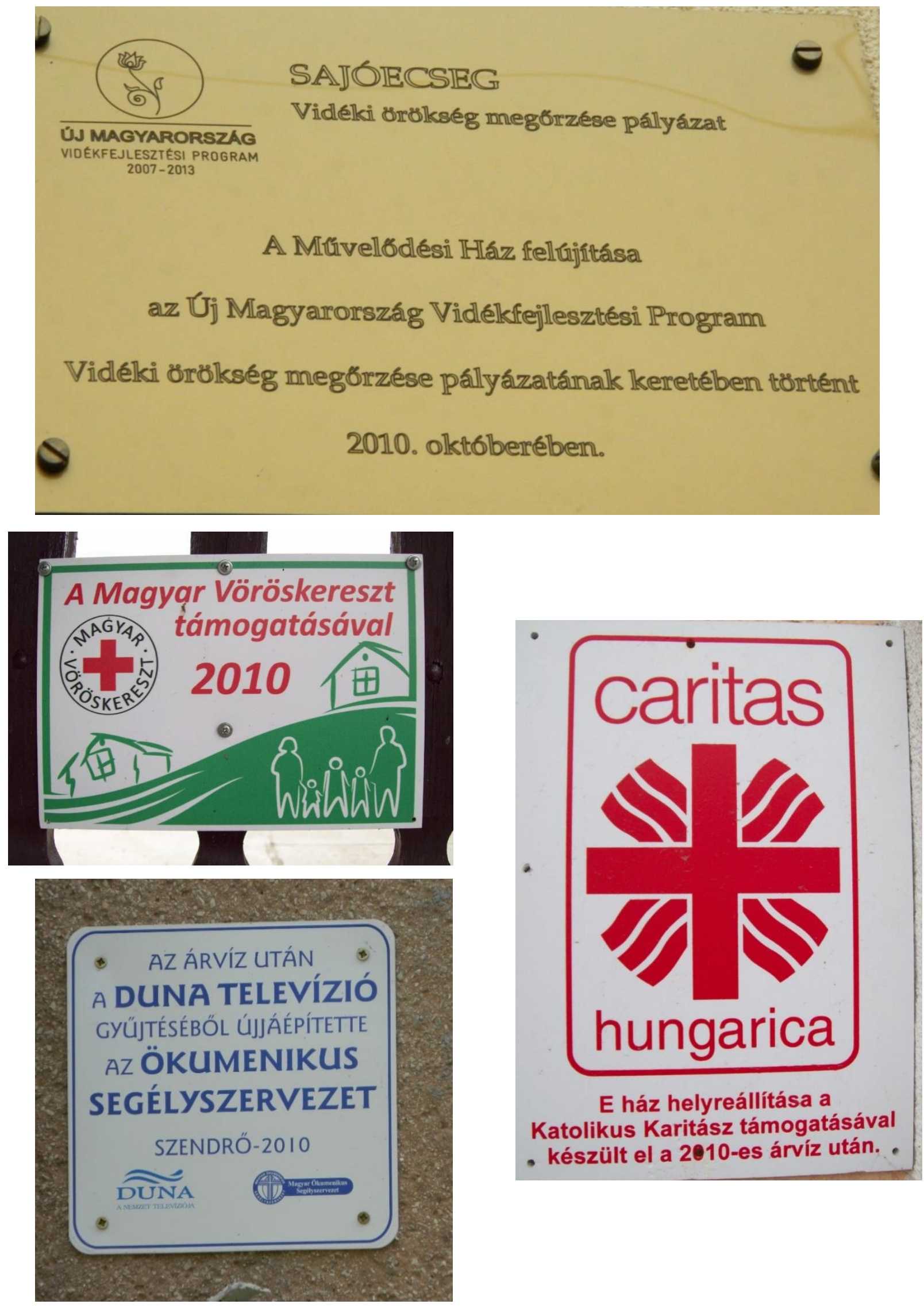

9.1.4. Segítségnyújtást jelző táblák. Az újjáépítés számos esetben közadakozásból, Európai Uniós pályázati forrásból, vagy karitatív szervezetek segítségével valósult meg. Saját felvételek (2011) 


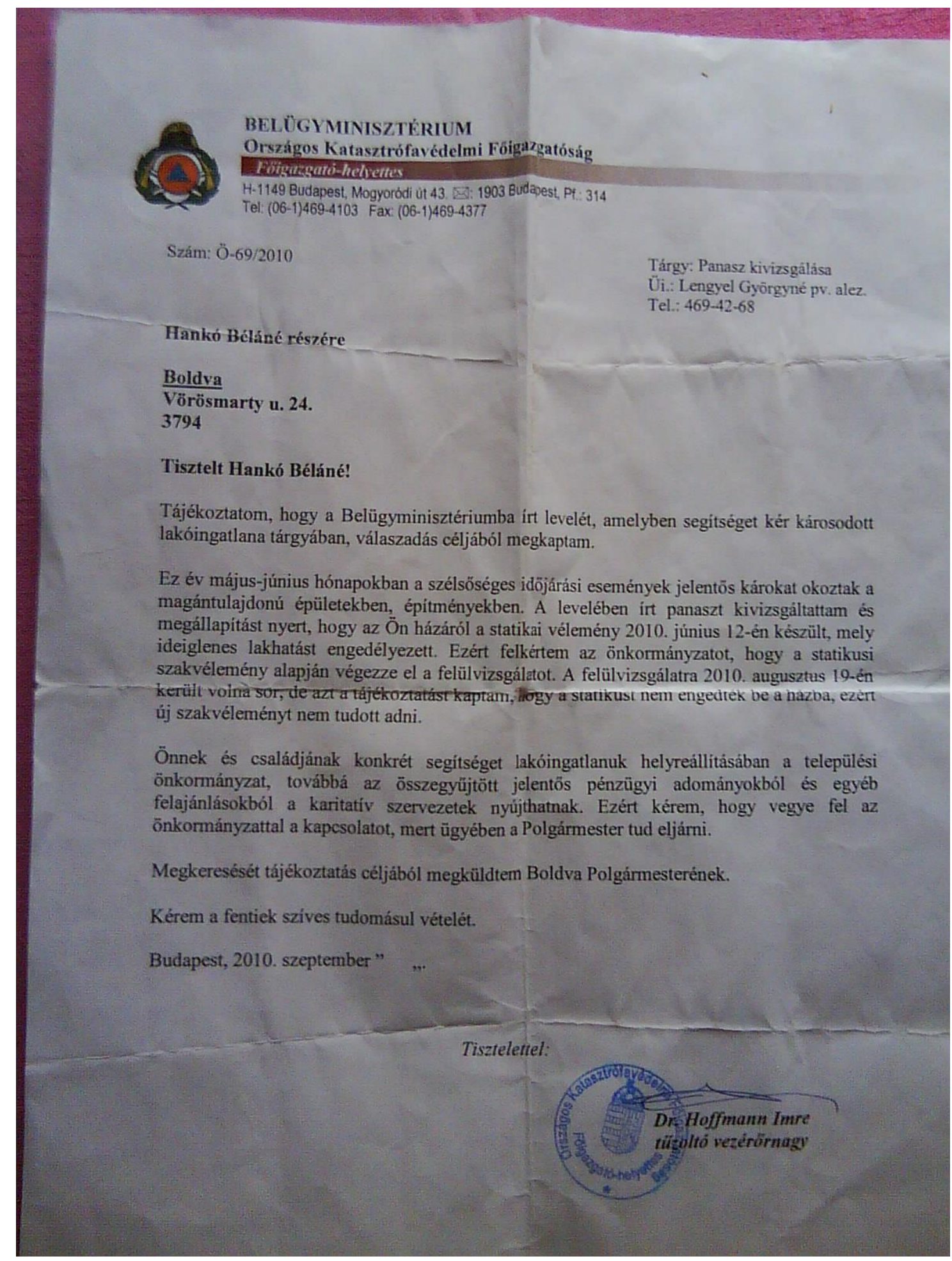

9.1.5. A Sajó és Hernád völgyében történt árvizek kárrendezése más jellegű volt, mint a beregi, így a településkép átalakulására másféle módon volt drasztikus hatással. Alapvetően a kárrendezés a települések bizonyos részein nem történtek meg, a segítséget kérő lakosokat arról tájékoztatták, hogy a segélyszervezetek azok, akik helyzetükben megsegítik majd az érintetteket. Saját fotó (2011). 

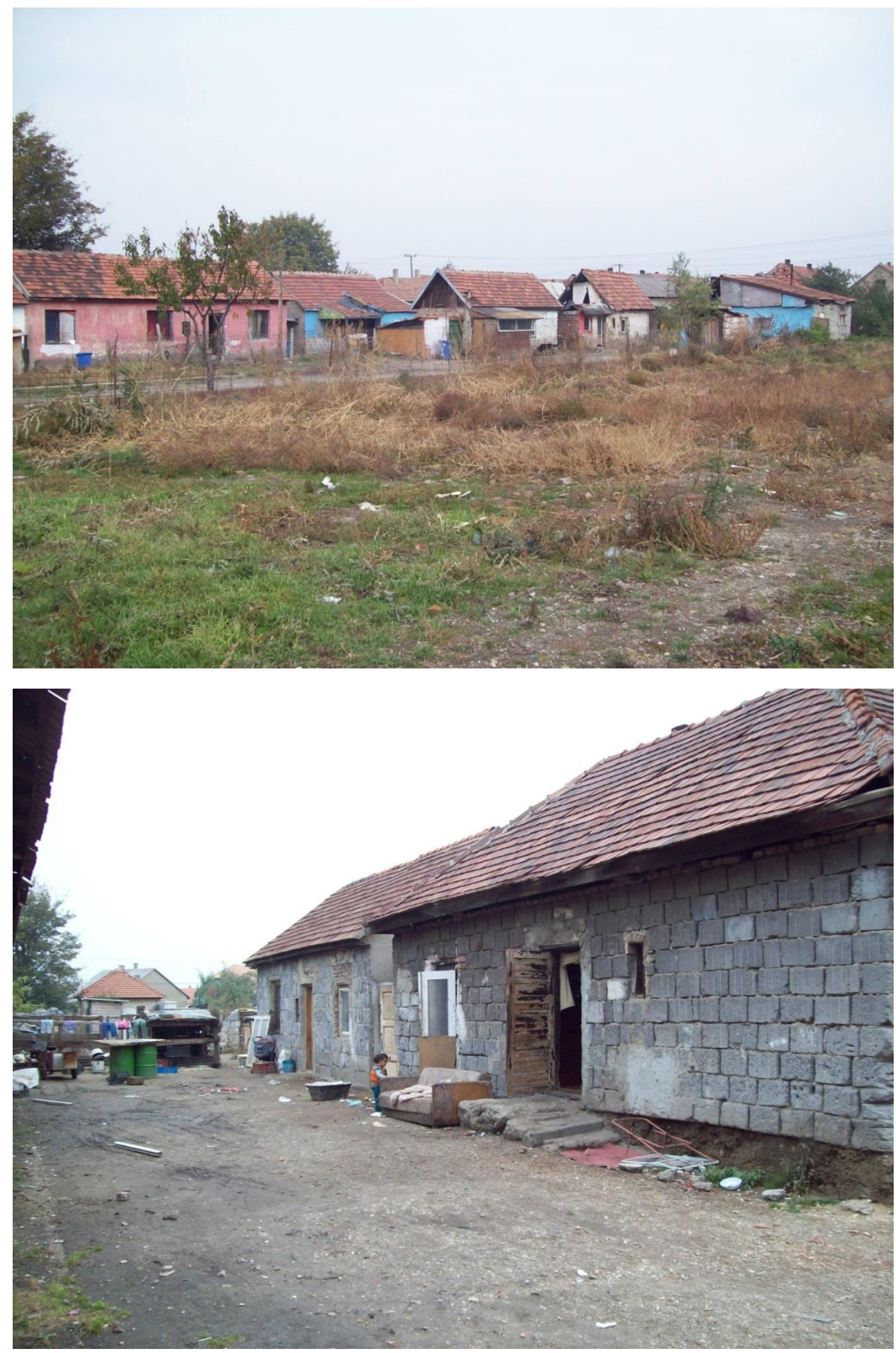

9.1.6. A megrongálódott épületek több esetben még napjainkban is felújítalanul állnak az érintett utcákban. Felsőzsolcán a romák és cigányok által lakott utcák jelentős részében látható az árvíz nyoma a mai napig is. 

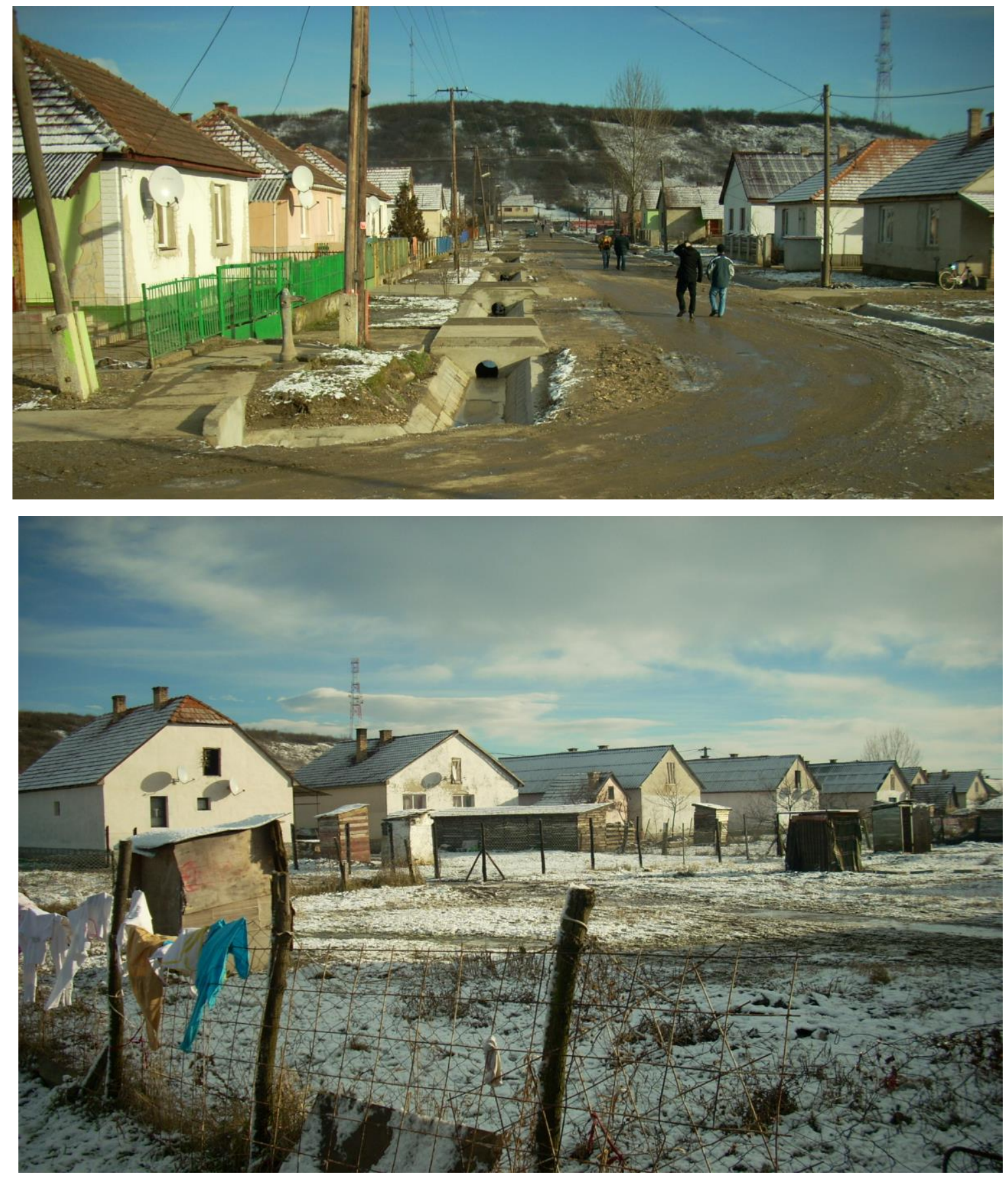

9.1.7. A boldvai cigánytelepen a felsőzsolcaitól eltérő állapotok uralkodtak a felvételezés időpontjában, hiszen itt a patakhoz közelebb fekvő házakat felújították, míg a távolabbiakat nem. A súlyosan megrongálódott épületek egy részét elbontották, azonban voltak olyan épületek, melyeket még annak ellenére is laktak, hogy azt életveszélyessé nyilvánították. 

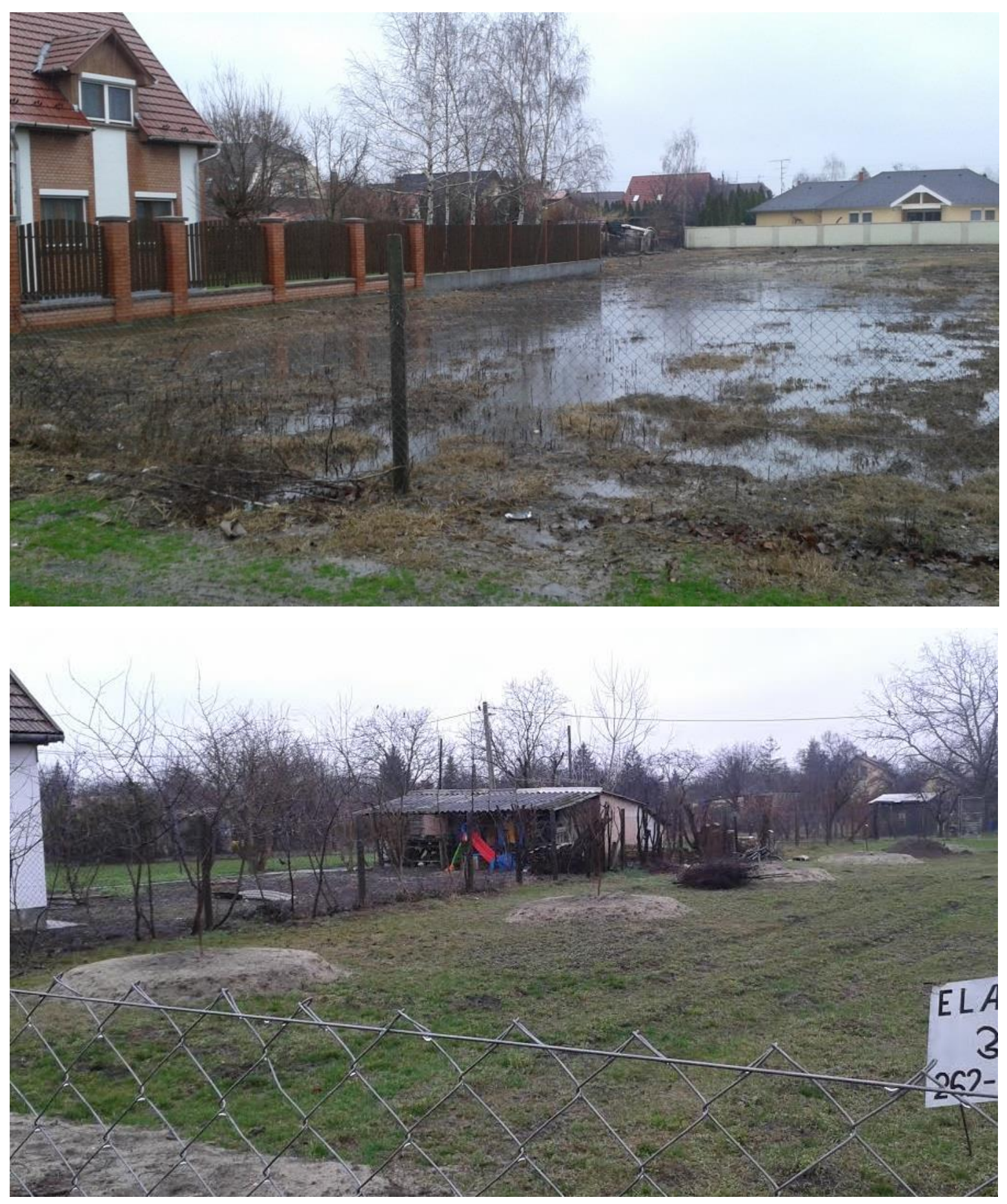

9.1.8. A baktói mintaterületen annak ellenére, hogy a lakosság nem tartja égetően súlyos problémának a belvizet, mégis terepbejáráskor a belvízre utaló nyomokat (megemelt ágyások), illetve belvizet találtunk a felmérést végző diákokkal. Saját fotó (2016) 

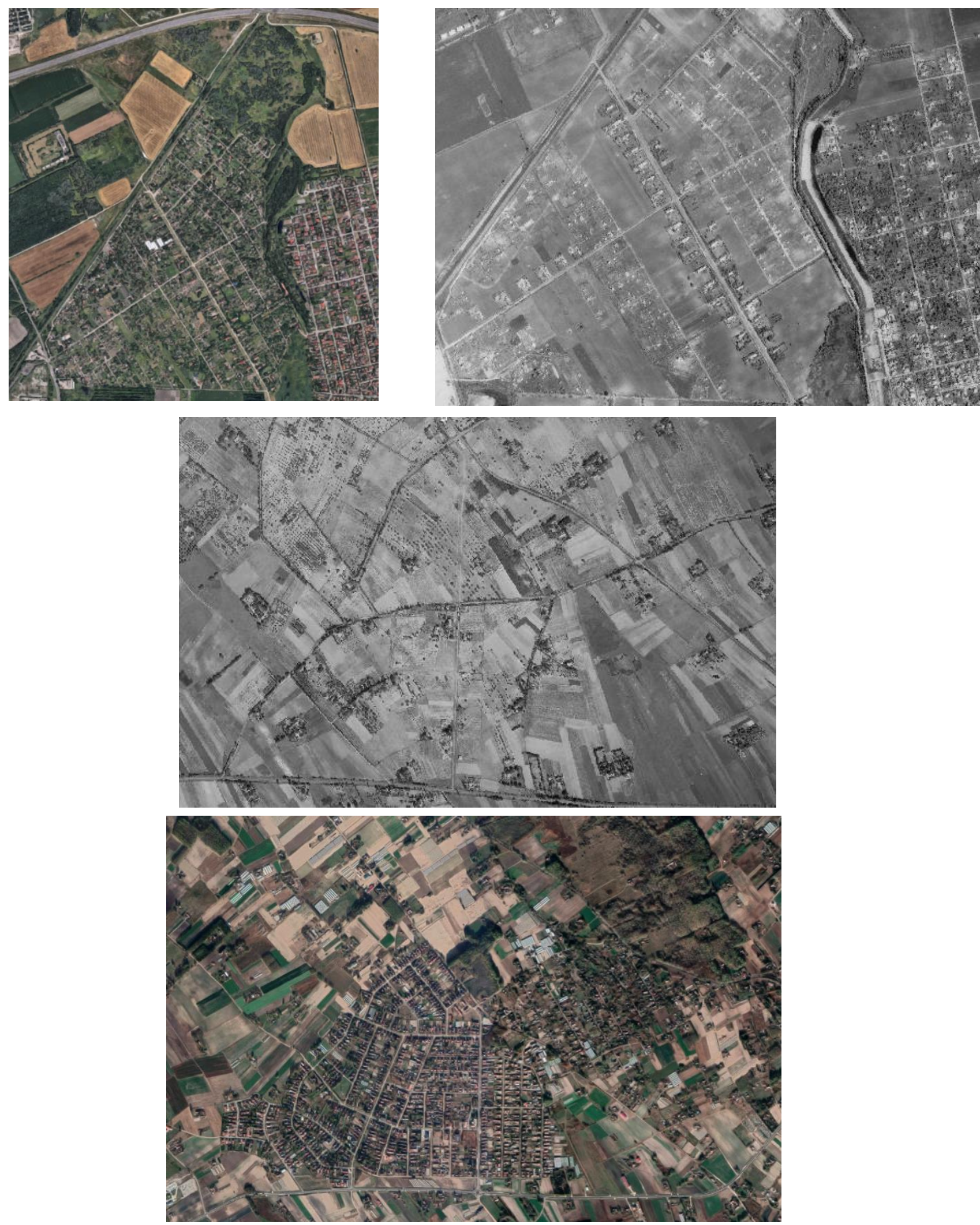

9.1.9. A belvízzel érintett területek egyik problémája, hogy mind Szeged városon belül, mind pedig annak szuburbán zónájában, Domaszéken igen intenzív beépülés indult meg az elmúlt évtizedekben, amely megváltoztatja a lefolyási viszonyokat, valamint feszültséget teremt a zártkertes „,külterületi” illetve a tőszomszédságban lévő „,belterületi” lakosok közt az eltérő városi szolgáltatások miatt. Szeged-Baktó Google Earth (2019), Google Earth (1975); Domaszék Fentrol.hu (1960), Google Earth (2019) 

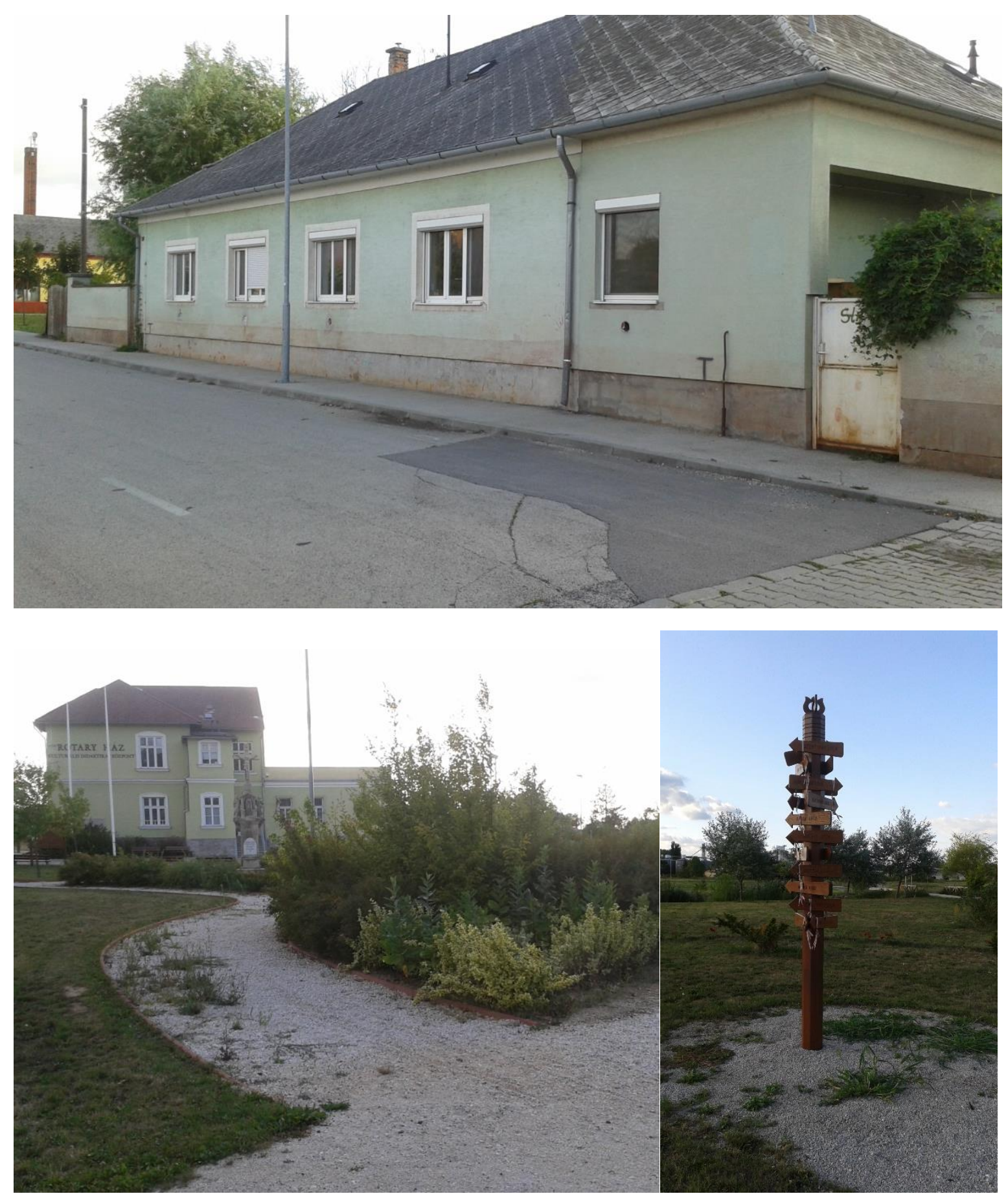

9.1.10. A Kolontár-Devecseri vörösiszap-katasztrófa nyomai még a mai napig is látszódnak egyes épületeken. Egyes épületeket mementóként megőriztek, Devecser teljes Torna-patak menti része megújult, átalakult, egy emlékparkot hoztak létre, ahol a megsemmisült utcák neveit iránytábla jelzi. Saját fotó (2017) 

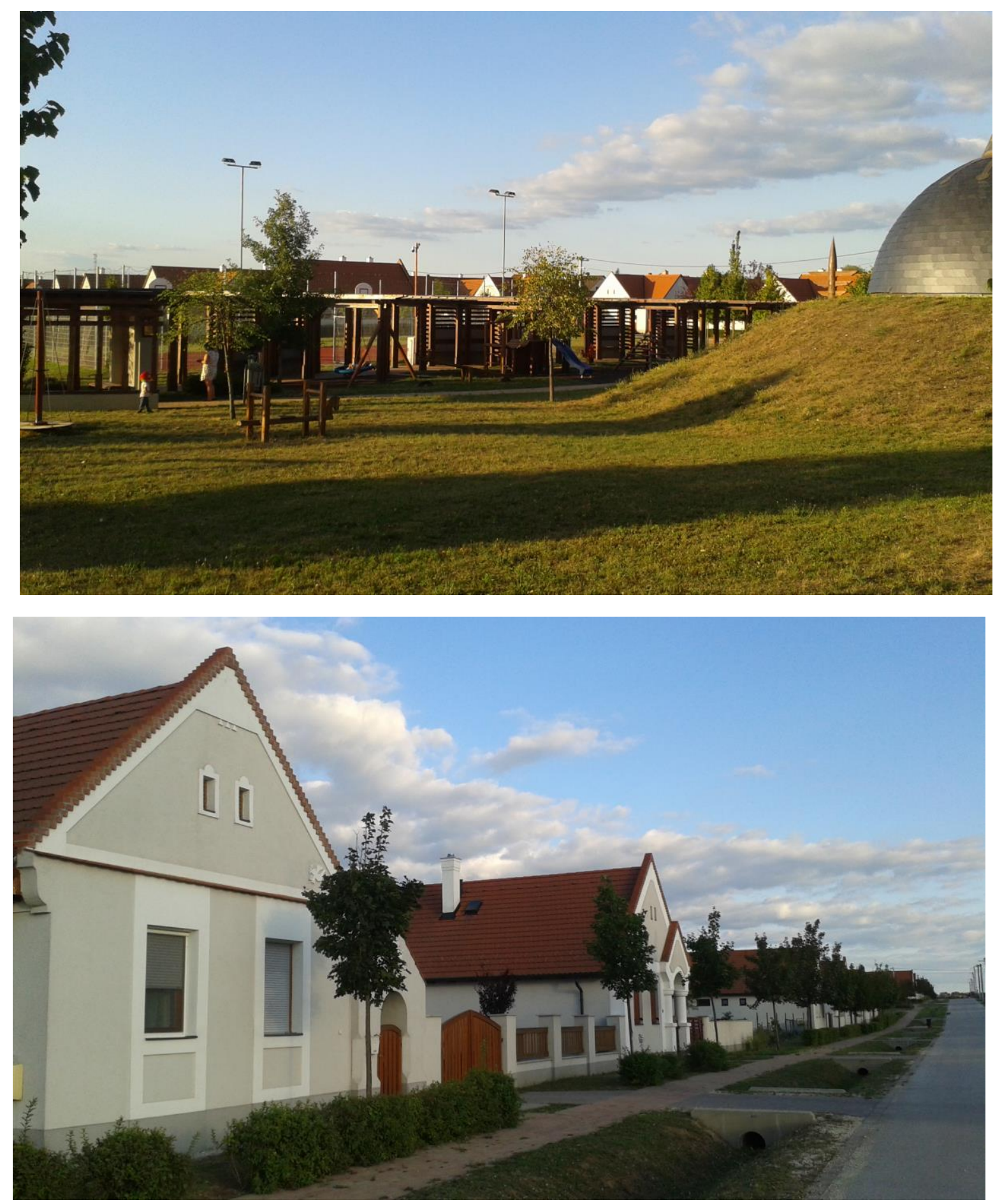

9.1.11. Devecser város egy magasabban fekvő térszínén épült meg a helyi sajátosságokhoz formavilágában és építészetében alkalmazkodó új lakópark, mely a kezdetekben (2013) még rideg és üresnek hatott, azonban a 2017-es ismételt visszatéréskor már élénk volt, az utcák nyüzsgők voltak, a kialakított főtéren gyerekek játszottak. 


\section{Árvízzel érintett területek kérdőíve}

Szegedi Tudományegyetem Természettudományi és Informatikai Kar Gazdaság-és Társadalomföldrajz Tanszék

\section{A GLOBÁliS KLÍMAVÁLTOZÁS TÁRSADALMI HATÁSAI}

1. Mióta lakik a településen? (év)

2. Honnan költözött a településre?
Kérdöiv száma:

Lekérdezés helye (település, utca)

99. Nem vonatkozik rá

88. Nem tudja (ugrás a 10. kérdésre)

99. Nem válaszol (ugrás a 10. kérdésre)

4. Egyéb, és pedig:

3. Érte-e árvízkár az Ön házát az elmúlt évtizedben?

1. Igen (tovább a 4. kérdésré)

2. Nem (ugrás a 10. kérdésre)

4. Ha igen, milyen jellegủ kár érte a házát?

1. Összedölt a ház

2. Megrongálódott, le kellett bontani

3. Megrongálódott, de ki lehetett javitani

77. nem vonatkozik rá

99. nem válaszol

5. Amennyiben kár érte a házát, kapott-e támogatást, segitséget az újjáépítésnél/javitásnál?

1. Igen (tovább a 6. kérdésre)

2. Nem (ugrás a 10. kérdésre)

77. Nem vonatkozilk rá (ugrás a 10.

kérdésre)

88. nem tudja, nem emlékszik (ugrás a 10 .

kérdésre)

99. nem válaszol (ugrás a 10. kérdésré)

6. Ha igen, milyen jellegút? (több válasz is megjelolhetô)

1. Pénzbeli juttatás

4. Teljesen újjáépítették a házat

2. Épitési segitség, munkaerövel

77. Nem vonatkozik rá

3. Épitỏanyaggal

99. Nem válaszol (ugrás a 10. kérdésré)

7. Kérem, osztályozzal-5-ig terjedô skálán, hogy mennyire elégedett a kapott segitséggel! (1-es ha egyáltalán nem elégedett, 5-ös ha teljes mértékben elégedett.) $\square \quad 77$. NVR $\quad 88 . N T \quad 99$. NV

8. Kérem, osztályozza, mennyire elégedett a segítségnyújtás mennyiségével! (1-es ha egyáltalán nem $\begin{array}{lllll}\text { elégedett, 5-ös ha teljes mértékben elégedett.) } & \square \quad 77 . \text { NVR } & \text { 88. NT } & 99 . \text { NV }\end{array}$

9. Kîtôl kapott a segítséget (több válasz is megjelölhetô)?

1. Önkormányzattól

2. Államtól

3. Karitatív szervezettôl

4. Egyháztól

5. Család, rokon, ismerõs

6. Egyéb, éspedig :

77. Nem vonatkozik rá

88. Nem tudja

99. Nem válaszol

10. Tudomása szerint az Önök utcájában a házak nagyjából mekksora részét érte kár az árvíz miatt?

1. Szinte mindet

5. Egyilk házat sem

2. A házalk tōbb mint felét

3. A házak kisebbik részét

4. 1-2 házat

88. Nem tudja

99. Nem válaszol 
Szegedi Tudományegyetem Természettudományi és Informatikai Kar Gazdaság-és Társadalomföldrajz Tanszék

11. Tudomása szerint az Önök utcájában a házak nagyjából mekkora részét érte kár az árvíz miatt?
1. Szinte mindet
5. Egyilk házat sem
2. A házak több mint felét
3. A házalk kisebbilk részét
88. Nem tudja
4. 1-2 házat
99. Nem válaszol

12. Hogyan értékeli jelenlegi lakásának minöségét az árviz elôttihez képest?
1. Lényegesen jobb
5. Lényegesen rosszabb
2. Jobb
3. Hasonló
88. Nem tudja megítélni
4. Rosszabb
99. Nem válaszol

13. Hogyan értékeli jelenlegi életkörülményeit az árviz elôttihez képest?
1. Lényegesen jobb
5. Lényegesen rosszabb
2. Jobb
3. Hasonló
88. Nem tudja megitélni
4. Rosszabb
99. Nem válaszol

14. Gondolkodott-e azon, hogy elköltözik az árviz miatt?

1. Igen (tovább a 14. kérdésre)

2. Nem (ugrás a 17. kérdésre)

99. Nem válaszol (ugrás a 17. kérdésré)

15. Ha gondolkozott, ałkkor hova költözött volna el?

1. Ugyanezen településen belül máshova

2. Máshova, éspedig :

77. Nem vonatkozik rá

88. Nem tudja

99. Nem válaszol

16. Miért nem költözött el a településrôl az árvíz után? (tōbb válasz is megjelölhetô)
1. Pénzügyi okok miatt
7. Az árviz után költözött ide
. Családi okok miatt
8. Egyéb, éspedig:
3. Munkahely miatt

4. Megszokásból, (mindig itt élt)

5. A földje ide köti

6. Gyerekek ide/a kōzelbe jámak iskolába

88. Nem tudja

99. Nem válaszol

17. Hallott-e olyan emberekrôl, akik elköltöztek innen (a faluból/városból) az árvíz után?
1. Igen (tovább a
2. Nem (ugrás a 21
kérdésre)
99. Nem válaszol
(ugrás a 21. kérdésre)

18. Ha ismer ilyen embereket, tudomása szerint melyik utcákban laktak?

77. Nem vonatkozilk rá

88. Nem tudja

99. Nem válaszol

19. Az alábbi szempontok közül válassza ki azokat, amelyek leginkább jellemzôek azokra, akik az árvíz után elköltöztek a településrổl! Kérem, mindegyik kérdéscsoportra próbáljon válaszolni!

\begin{tabular}{|c|c|c|c|c|}
\hline a,nemzetiség & b,anyagi & c, kor & d, iskolázottság & e, foglalkozás \\
\hline 11. roma & helyzet & 31. fiatal & 41. magasan iskolázott & 51. munkahelye volt \\
\hline 12. nem roma & 21. szegény & 32. középkorú & 42. alacsonyan iskolázott & 52 nem volt munkahelye \\
\hline 13. is-is & 22. gazdag & 33. öreg & 43. is-is & 53. is-is \\
\hline 77. NVR & 23. is-is & 34. is-is & 77. NVR & 77. NVR \\
\hline 88. nem tudja & 77. NVR & 77. NVR & 88. nem tudja & 88. nem tudja \\
\hline 99. nem & 88. nem tudja & 88. nem tudja & 99. nem válaszol & 99. nem válaszol \\
\hline válaszol & 99. NV & 99. nem válaszol & & \\
\hline
\end{tabular}


Szegedi Tudományegyetem Természettudományi és Informatikai Kar Gazdaság-és Társadalomföldrajz Tanszék

20. Tudomása szerint hova költöztek el innen leginkább? (Ha kömyékrôll, akkor mondjon példát)
77. Nem vonatkozik rá
88. Nem tudja
99. Nem válaszol

21. Ismer-e olyan embereket, akik az árvíz óta költöztek ide, a faluba/városba?

1. Igen (tovább a 22. kérdésre)

2. Nem (ugrás a 24. kérdésre)

99. Nem válaszol (ugrás a 24. kérdésre)

22. Az alábbi tulajdonságok közül válassza ki azokat, amelyek leginkább jellemzốek azokra, akik az árviz után költöztek a településre! Kérem, mindegyik kérdéscsoportra próbáljon válaszolni!

\begin{tabular}{|c|c|c|c|c|}
\hline $\begin{array}{l}\text { a, nemzetiség } \\
\text { 11. roma } \\
\text { 12. nem roma } \\
\text { 13. is-is } \\
\text { 77. NVR } \\
\text { 88. nem tudja } \\
\text { 99. nem } \\
\text { válaszol }\end{array}$ & $\begin{array}{l}\text { b, anyagi } \\
\text { helyzet } \\
\text { 21. szegény } \\
\text { 22. gazdag } \\
\text { 23. is-is } \\
\text { 77. NVR } \\
\text { 88. nem tudja } \\
\text { 99. NV }\end{array}$ & $\begin{array}{l}\text { c, kor } \\
\text { 31. fiatal } \\
\text { 32. középkorú } \\
\text { 33. öreg } \\
\text { 34. is-is } \\
\text { 77. NVR } \\
\text { 88. nem tudja } \\
\text { 99. nem válaszol }\end{array}$ & $\begin{array}{l}\text { d, iskolázottság } \\
\text { 41. magasan iskolázott } \\
\text { 42. alacsonyan iskolázott } \\
\text { 43. is-is } \\
\text { 77. NVR } \\
\text { 88. nem tudja } \\
\text { 99. nem válaszol }\end{array}$ & $\begin{array}{l}\text { e, foglalkozás } \\
51 \text {. munkahelye volt } \\
52 \text { nem volt munkahelye } \\
\text { 53. is-is } \\
\text { 77. NVR } \\
\text { 88. nem tudja } \\
\text { 99. nem válaszol }\end{array}$ \\
\hline
\end{tabular}

23. Tudomása szerint honnan költöztek ide leginkább? (Ha kömyékrôl, akkor mondjon példát)
77. Nem vonatkozik rá
88. Nem tudja
99. Nem válaszol

Kérem, a következö kérdések megválaszolásakor 1-10-ig pontozzon, ahol az l-es a legrosszabb, a $\underline{10 \text {-es a legjobb helyzetet jelenti }}$

24. Hol helyezné el magát a társadalomban, JŌVEDELMÉT tekintve?

99. NV

25. Hol helyezné el magát a társadalomban, BEFOLYÁSÁT tekintve?

99. NV

26. Hol helyezné el magát a társadalomban, EGÉSZSÉGI ÁLLAPOTÁT tekintve? $\square \square \quad 99$. NV

28. Hol helyezné el magát a társadalomban, MEGBECSÜL TSÉGÉT tekintve? $\square \square \quad 99 . \mathrm{NV}$

29. Véleménye szerint mi lehetne a megoldás a település árvizveszélyes helyzetére?
2. Nincs ilyen
88. Nem tudja
99. Nem válaszol

30. Véleménye szerint az árvízveszély mekkora problémát jelent a térségben?

1. Nagyon nagy problémát jelent

2. Nagy problémát jelent
3. Problémát jelent, de nem jelentôs
4. Semmilyen problémát nem jelent

88. Nem tudja megitélni

99. Nem válaszol 
31. Ön szerint mennyire befolyásolja a munkavállalását, elhelyezkedését az árvízveszély?

1. Nagyon megneheziti

2. Inkább nehezít

88. Nem tudja

3. Kis hatása van ra

99. Nem válaszol

4. Egyáltalán nem nehezíti

32. Az árvízhez kapcsolódóan származott-e valamilyen egészségügyi problémája?

1. Igen (tovább a 33. kérdésre) $\quad 88$. Nem tudja (ugrás a 34. kérdésre)

2. Nem (ugrás a 34. kérdésre)

99. Nem válaszol (ugrás a 34. kérdésre)

33. Ha igen, akkor mi volt ez:
77. Nem vonatkozik rá
88. Nem tudja
99. Nem válaszol

34. Tud-e másról a településen, akinek az árviz miatt egészségügyi problémája volt?

1. Igen (tovább a 35 . kérdésre)

77. Nem vonatkozilk rá

2. Nem (ugrás a 36 . kérdésre)

88. Nem tudja (ugrás a 36 . kérdésre)

99. Nem válaszol (ugrás a 36 . kérdésre)

35. Ha igen, akkor mi volt ez:
77. Nem vonatkozik rá
88. Nem tudja
99. Nem válaszol

\section{Mennyire ért egyet a következö állitásokkal?}

36. Az árviz megváltoztatta a település lakosságának összetételét.

37. Az árvíz után jó irányban változott meg a településkép

38. Az uzsorások kihasználták az árvízben megszorultakat

39. A biztosítók teljesitették a szerzõdésekben leirtakat.

40. A biztosítók nem megfelelô mennyiségü kártéritést fizettek

41. Az önkormányzat mindent megtett, hogy segitsen a bajba jutottakon

42. A polgármester maximális helytállást tanúsít minden veszélyhelyzetben

43. Az állam minden segitséget megadott az újjáépitéshez.

44. Az állam kizárólagos feladata az árvizveszély elhárítása

45. A szomszédok nem segítettek egymásnak a munkálatokban

46. A bankokban nem éltek vissza az árviz okozta nehéz helyzettel

47. Az árvízveszély miatt az emberek kiszolgáltatottak

48. A hiradások és a média helytállóan számol be az árvizröl, megfelelóen mutatta be az eseményeket

49. Az embereket nem nagyon érdeklik az árvízrôl szóló hírek

50. Az árvizveszély mindenki számára fenyegetettséget jelent a kömyéken.

51. A természeti folyamatokat az emberek is befolyásolhatják. 
Kérem, a következö kérdések megválaszolására 1-10-es skálán pontozzon, az 1-es teljesen elégedetlen, egyáltalán nem, 10-es teljesen elégedett.

52. Mennyire elégedett KÖRNYEZETÉNEK SZÉPSÉGÉVEL?

53. Mennyire elégedett INGATLANA FIZIKAI MINÓSÉGÉVEL?

54. Mennyire elégedett KÖRNYEZETÉNEK ÁLLAPOTÁVAL, MINÖSÉGÉVEL?

55. Részt vett-e a legutóbbi helyi önkormányzati választáson?
1. Igen
88. Nem válaszol
2. Nem
99. Nem tudja

56. Részt vett-e az országgyülési választásokon?
1. Igen
88. Nem tudja
2. Nem
99. Nem válaszol

57. Véleménye szerint számít-e a szavazata?
1. Igen
88. Nem tudja
2. Nem
99. Nem válaszol

58. Véleménye szerint van-e beleszólása a környezetében zajló folyamatokba?
1. Igen
88. Nem tudja
2. Nem
99. Nem válaszol

59. Történt-e mostanában olyan folyamat, beruházás, fejlesztés a környéken, ami Önt negativan érintette?

1. Igen (tovább az 60. kérdésre)

88. Nem tudja (ugrás a 61. kérdésre)

2. Nem (ugrás a 61. kérdésre)

99. Nem válaszol (ugrás a 61. kérdésre)

60. Ha volt ilyen, mi volt az?

77. Nem vonatkozik rá 88 . Nem tudja 99 . Nem válaszol

61. Véleménye szerint 1-10-ig osztályozva mennyire képriseli jól az ön és közössége érdekeit a helyi önkormányzatl-10-es skálán?

(1, ha egyáltalán nem,10 ha a maximálisan).

Személyes kérdések következnek, a válaszadás továbbra is önkéntes!

62. A válaszadó neme:
1. Férfi
2. Nõ

63. Melyik érben született Ön?

99. nem válaszol

64. Mi az Ön legmagasabb iskolai végzettsége?
1. 8 osztálynál kevesebb
5. föiskola
2. 8 általános
6. egyetem
3. középiskola
99. nem válaszol

65. Van-e jelenleg munkahelye?

1. Van (tovább a 66. kérdésre)

2. Nines (ugrás a 68 . kérdésre)

99. Nem válaszol (ugrás a 71. kérdésre) 
Szegedi Tudományegyetem Természettudományi és Informatikai Kar Gazdaság-és Társadalomföldrajz Tanszék

66. Ha van, akkor mi a foglalkozása: (minél pontosabb megnevezés)

67. Hol, melyik településen dolgozik?

68. Ha nincs, akkor mely állitások igazak önre?
1. 3 hónapnál kevesebb ideje munkanélküli
2. tartósan, 3 hónapnál több ideje munkanélküli
3. nyugdijas
4. nem munkaképes
5. nem munkaképes korú
77. nem vonatkozik rá
99. nem válaszol

69. Mik a munkanélküliségnek a körülményei? (több is megjelölhetố!)
1. keres munkát, de nem talál
2. véleménye szerint képzetlen
5. már a rendszerváltás óta munkanélküli
3. véleménye szerint kiközösitiv
88. nem tudja
99. nem válaszol

4. feladta a munkakeresést, mert reménytelen

70. Mennyi pénzböl gazdálkodik az ön esaládja egy átlagos hónapban?
$\square . \square \square \square . \square \square \square \mathrm{Ft}$
99. NV

71. Milyen szociális juttatásokban részesül? (több válasz megjelölhetö)
1. semmilyen
2. GYES, GYED
3. munkanélküli segély
4. családi pótlék
5. ápolási dij
6. rokkantnyugdij
7. árvaellátás
8. rendszeres szociális segély
9. fogyatékossági ellátás

10. egyéb juttatások, mégpedig:

72. Ön milyen nemzetiségünek tartja magát?
1. Magyar
2. Román
3. Szlovák
4. Roma/cigány

5. Egyéb, éspedig:

99. Nem válaszol

73. Hány 18 évnél fiatalabb gyermek él önökkel egy háztartásban (közös kasszán)?

74. Összesen hányan élnek egy kasszín?

fo

fo

75. Hány eltartó van a családban (munkahelyen pénzt keres)?

fo

99. Nem válaszol

76. Milyen tulajdonban van a ház/lakás, amiben lakik/laknak?
1. saját tulajdon
2. ōnkormányzati bérlakás
3. albérlet

4. egyéb:
8. nem tudja
99. nem válaszol

\section{Köszönjük a segítségét!}




\section{Vörösiszappal érintett területek kérdőíve}

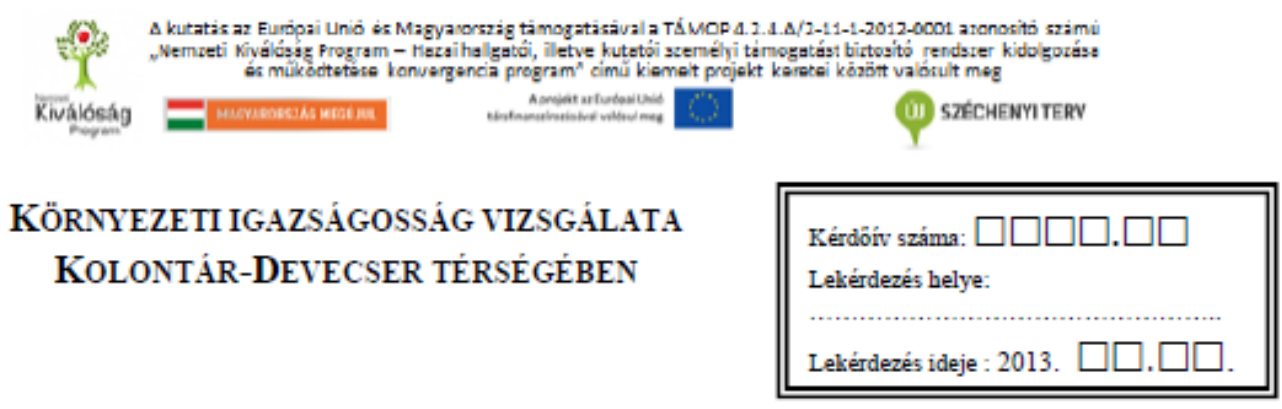

1. Mennyire szeret Ōn településén élni? Kérem, értékelje, 1-5 slálán (ahol=1 egyailtalán nom, $5=$ nagyon)!

2. Tudomása szerint van-e a településen bármilyen környezethez lköthetố probléma?

1. Igen

2. Nem

3. Nem tud róla

4. NV

3. Melyik évben költözött Devecserre / Kolontárra? $\square \square \square \square$ 2. Szilletése óta 88. NT. 99. NV.

\begin{tabular}{|c|c|c|}
\hline 4. Kérem, értélvelje, mennyire elégedett .... & & 1. Teljes mértékben \\
\hline 1. Kōrnyezete szépségével, tájképpel? $\square$ & 5. A levegô tisztaságával? & 2. Inkább igen \\
\hline 2. Ingatlanának (házánal) állagával? $\square$ & 6. A vizek tisztaságával? $\square$ & $\begin{array}{l}\text { 3. Is-is } \\
\text { 4. Inkább nem }\end{array}$ \\
\hline 3. Házának szépségével? $\square$ & 7. A talaj tisztaságával? $\square$ & 5. Egyáltalán nem \\
\hline 4. Környezete állapotával, minōségével? $\square$ & 8. A település tisztaságával? $\square$ & $\begin{array}{l}\text { 88. Nem tudja megitélni } \\
\text { 99. NV. }\end{array}$ \\
\hline
\end{tabular}

5. Van-e Önnelk bármiféle betegsége, tünete mellyel nem fordult orvoshoz?

1. Igen 5.1 . Ha igen, alkkor mi?

2. Nem

88. Nem tudja

99. NV.

5.2. Ha igen, mióta tapasztalja?

1. Kevesebb, mint egy éve

2. 1-2 éve

4. 4 évnél régebb óta

3. $2-4$ éve

88. Nem tudja

5.3. Véleménye szerint mi olsozza/okozhatja?

6. Van-e családjában bármiféle betegség, tünet, mellyel nem fordulnalk orvoshoz?

1. Igen 6.1 . Ha igen, alkkor mi?

2. Nem

88. NT.

99. NV.

6.2. Ha igen, mióta tapasztható?

1. Kevesebb, mint egy éve 4 . 4 évnél régebb óta

2. 1-2 éve

88. Nem tudja

3. 2-4 éve

99. NV.

6.3. Véleménye szerint mi olkozza/okozhatja?

7. Kérem, osztályozza 1-5 skálán (ahol 1 a legrosszabb és 5 a logjobb) a többi lalkoshoz képest milyen az Ön...
1. Egészségi állapota $\square$
2. Érdekérvényesitō képessége, befolyása
3. Megbecsültsége $\square$
4. Jôvedelme $\square$ 


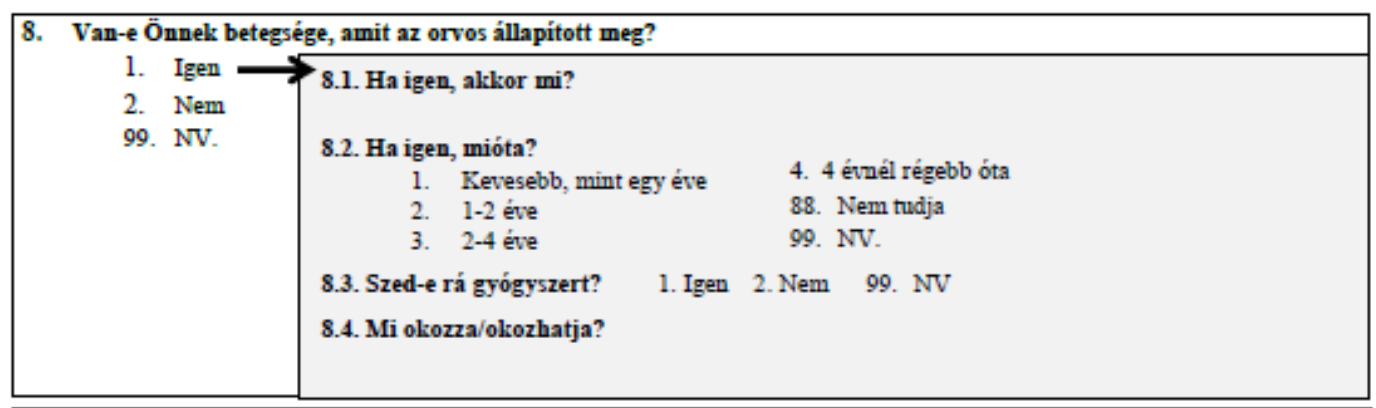

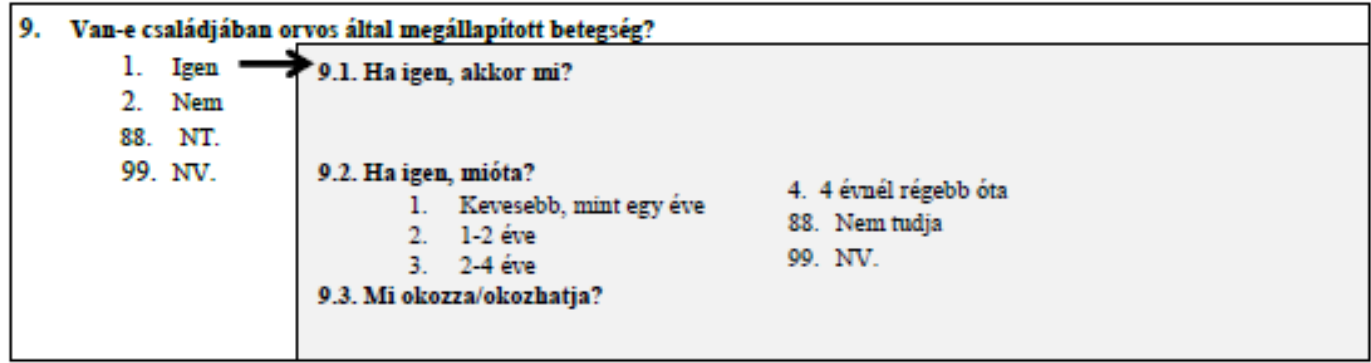

\begin{tabular}{|l} 
10. Mennyire ért egyet a következõ állításokkal? \\
1. $\square$ aggódni kell saját és családja egészségi állapota \\
miatt \\
2. $\square$ nem kell félteni otthona fizikai épségét \\
3. $\square$ veszélyesebb itt élni, mint máshol \\
4. $\square$ ismerốsei nem tartják veszélyesnek lakhelyét \\
5. $\square$ esélyes egy katasztrófa bekōvetkezése lakhelyén \\
6. $\square$ Ha tehetné, nem kōltoozzne el \\
7. $\square$ nagy problémát jelent a telepilésen az ipar \\
okozta környezetszennyezés
\end{tabular}

8. $\square$ az ipar jelenléte megélhetést biztosit, ezért a szennyezést el kell viselni

9. $\square$ Nem tudja érdekeit, akaratát érvényesíteni a településen

10. $\square$ Véleményét szabadon hangoztathatja demonstráció, kōnyezetvédelmi akciók során

11. $\square$ A korrupció nem játszott kōzre a katasztrófa bekövetkezésében.

2010 októberében sajnálatos módon bekövetkezett vörösiszap katasztrófa sok kárt okozott a környéken lakóknak. Az Ön véleménvére is kíváncsiak vagyunk a történtekkel kapcsolatban, ezért a következố kérdések erre vonatkoznak!

11. Véleménye szerint megfelelö volt-e a környezet kártalanítása, a kár felszámolása katasztrófa után?
1. Igen
11.1. Miért?
88. Nem tudja megítélni

12. Véleménye szerint megfelelö volt-e a lakosok kártalanítása, a károk enyhítése a katasztrófa után?
1. Igen
12.1. Miért?
2. Nem
88. Nem tudia megitélni

13. Véleménye szerint megfeleló volt-e az információ ellátás a katasztrófahelyzet alatt?
1. Igen
13.1. Miért?
2. Nem
88. Nem tudja megitélni

14. Tudomása szerint volt-e bármilyen jellegú probléma, összetúzés a kártalanítás alatt?
1. Igen
14.1. Ha igen, alkkor mi?
2. Nem
19. 
88. Nem tudja

15. Gondollsodott-e azon a katasztrófa után, hogy ellköltözilk?

1. Igen, már elköltōztem $\longrightarrow$ 15.1. Honnan?

2. Igen, tervezem

3. Nem 15.2. Hová?

15.2. Ha nem, alkkor miért nem? (több válasz is megjelölhetō)

1. Pénzïgyi okok miatt

2. Családi okok miatt 5. A termófold ide köti

3. Munkahely miatt 6. Gyerekek/család kōzelben van

4. Megszokásból 7. Egyéb:

16. Hallott-e olyan emberelcröl, alik a katasztrófa miatt (szintén) elköltöztek?

1. Igen $\longrightarrow$ 16.1. Ha igen, alklor hova?

17. Zavarja-e a vörösiszap-tározó közelsége?

1. Igen $\longrightarrow$ 17.1. Ha igen, miért?

2. Nem

88. Nem tudja megitélni

18. Mennyire ért egyet a következó állításolklcal?

1. $\square$ A katasztrófa megváltoztatta a település lakosságának összetételét.

2. $\square$ A katasztrófa után jó irányban változott meg a településkép.

3. $\square$ Az uzsorások kihasználták a katasztrófában megszorultakat.

4. $\square$ A biztosítók teljesítették a szerzödésekben leirtakat.

5. $\square$ A biztosítók nem megfelelö mennyiségú kártérítést fizettek.

6. $\square$ Az ōnkormányzat mindent megtett, hogy segitsen a bajba jutottakon.

7. $\square$ A polgármester maximális helytállást tanúsított minden veszélyhelyzetben.

$\square$ Az állam minden segitséget megadott az uijaépitéshez.

9. $\square$ Az állam feladata az ilyen jellegũ katasztrófak: elhárítása.

1. Teljes mértékbe

2. Inkább igen

3. Is-is

4. Inkább nem

5. Egyáltalán nem

88. Nem tudja megitélni

$99 . \mathrm{NV}$.

10. $\square$ A szomszédok nem segítettek egymásnak a munkálatokban

11. $\square$ Az emberek kiszolgáltatottak az ilyen jellegî katasztrófáknak

12. $\square$ A híradások és a média helytállóan számol be az eseményekröl]

13. $\square$ A vōrösiszap mindenki számára fenyegetettséget jelent a környéken

19. Az vörösiszaphoz lapcsolódóan származott-e valamilyen egészségügyi problémája?
1. Igen -
2. Nem
19.1_Milyen jellegú lárosodást szenvedett?
3. NV.

20. Érintette-e önt a vörösiszap-lkatasztrófa?

1. Igen 20.1 Érte-e kár az ön házát?

2. Nem

1. Igen $\longrightarrow$ 19.1.1. Ha igen, alklkor milyen jellegũ?

2. Nem 1. Lakhatatlanná vált az ingatlanom, le kellett bontani

2. Megrongálódott az ingatlanom, de ki lehetett javítani

3. Összedölt 4. Egyéb:

99. NV.

19.1.2. Mennyi volt a becsült lár?

20.2. Érte-e kár mezốgazdasági foldjét, terményét?

1. Igen 19.2.1. Ha igen, alkkor lkb. melklora területet érintett?

2. Nem

19.2.2. Mennyi volt a becsült kár?

20.3. Hogyan értékeli jelenlegi életkörülményeit, életminōségét a katasztrófa elôttihez

képest?

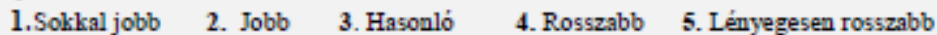

88.Nem tudom megitélni 99. NV. 
20.4. Kapott-e támogatást, segitséget az újjáépitésnél/javitásnál?

1. Igen 20.4.1. Ha igen, alckor milyen jellegü segitséget? (több válasz is megjelölhetô)

2. Nem 1. Pénzbeli juttatás

99. NV.

2. Épitési segitség munkaerôvel

3. Épitési segitség épitõanyaggal

5. Bútorokat, háztartási gépeket kaptam

4. Teljesen újjáépitették a házat

6. Egyéb:

99. NV.

20.4.2. Mennyire elégedett a lsapott segitséggel? Kérem, osztályozza 1-5 skálán!

20.4.3. Kitôl lapott segitséget (több válasz is megielölhetô)

1. Önkonnányzattól

6. Család, rokon, barát, ismerós

2. Államtól

3. Karitatív szervezettōl

4. Vörös kereszttōl

5. Eqyháztól

21. Részt vett-e a legutóbbi választásokon?

1. Igen 2. Nem

22. Véleménye szerint számít-e a szavazata?

1. Igen 2. Nem

88. Nem tudja

7. Egyéb:

88. Nem tudja

99. NV

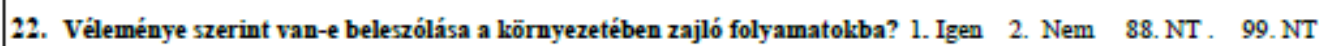

23. Kérem, 1-5-ig osztályozva mennyire képviseli jól az ön és közössége érdelseit a helyi önkormányzat? $\square$

24. A válaszadó neme: 1. Férfi 2. Nö

25. Melyik évben született Ōn? $\square \square \square \square$

88. NT

99. NV.

26. Mi az Ön legmagasabb islvolai végzettsége?

27. Van-e jelenleg munkahelye?

1. Van

27.1. Ha van, alklcor mi?

2. Nincs 27.2. Melyils településen?

99. Nem válaszol

27.3. Ha nincs, akkkor mely állitások igazak önre?

1. 3 hónapnál kevesebb ideje munkanélküli

2. Tartósan, 3 hónapnál több ideje munkanélkūli

3. GYES/GYED

4. Nyugdijas

5. Nem munkaképes

6. Nem munkaképes kori

99. NV.

28. Mennyi pénzbôl gazdállkodik az ön családja egy átlagos hónapban ? $\square . \square \square \square . \square \square \square \mathrm{Ft}$

29. Összesen hányan élnek egy kasszán? $\square \square$ fó 99 . Nem válaszol

30. Hány 18 évnél fiatalabb gyermek él önölkkel egy háztartásban (közös kasszán)?

fo

31. Hány eltartó van a családban (munkahelyen pénzt keres)? $\square \square$ fó 99 . Nem válaszol

32. Milyen szociális juttatásolkban részesül? (több válasz megielölhetô)

\begin{tabular}{lll} 
1. semmilyen & \multicolumn{2}{c}{$5 . \quad$ ápolási dij } \\
2. GYES, GYED & 6. rokkantmyugdij \\
3. munkanélküli segély & 7. árvaellátás \\
4. családi pótlék & 8. & rendszeres szociális segély
\end{tabular}

33. Ön milyen nemzetiségünek tartja magát?

34. Milyen tulajdonban van a ház/lakás, amiben lakilk/aknak?

1. saját tulajdon

2. önkormányzati bérlakás

3. albérlet

4. Egyéb:

88. Nem tudja

99. Nem válaszol

9. fogyatékossági ellátás

10. Egyéb juttatások:

99. Nem válaszol

álaszadást! 


\section{Belvízzel érintett területek kérdőíve}

\section{A BELVIZZ TELEPÜLÉSI HATÁSAI KÖRNYEZETI IGAZSÁGOSSÁG SZEMPONTÚ MEGKÖZELÍTÉSBEN \\ Kérdöiv száma: $\square \square \square \square . \square \square$ \\ Lekérdezés helye: \\ "TUDÁS-IPAR IGÉNYEIT KISZOLGÁLÓ FELSÕOKTATÁSI SZOLGÁLTATÁSOK MEGALAPOZÁSA A DÉL-ALFŌLDI RÉGIÓBAN"

CíMŨ, TÁMOP-4.2.1.D-15/1/KONV-2015-0002

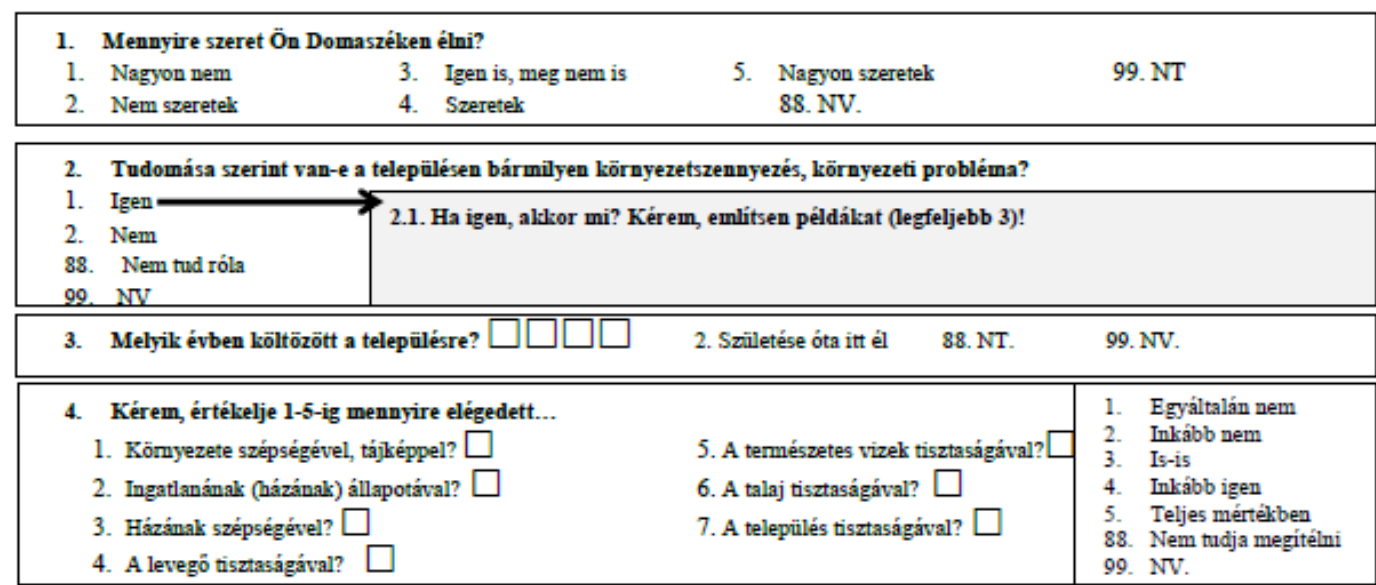

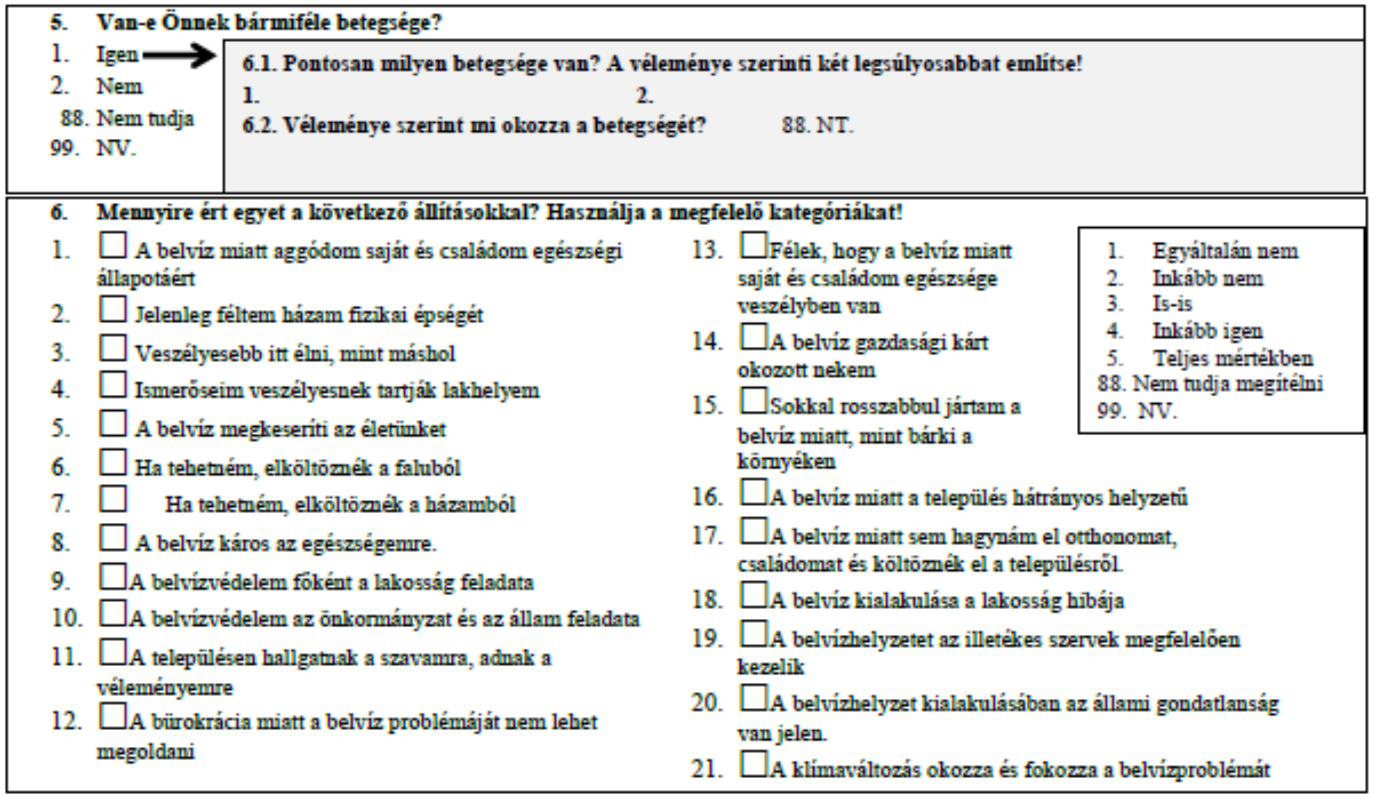

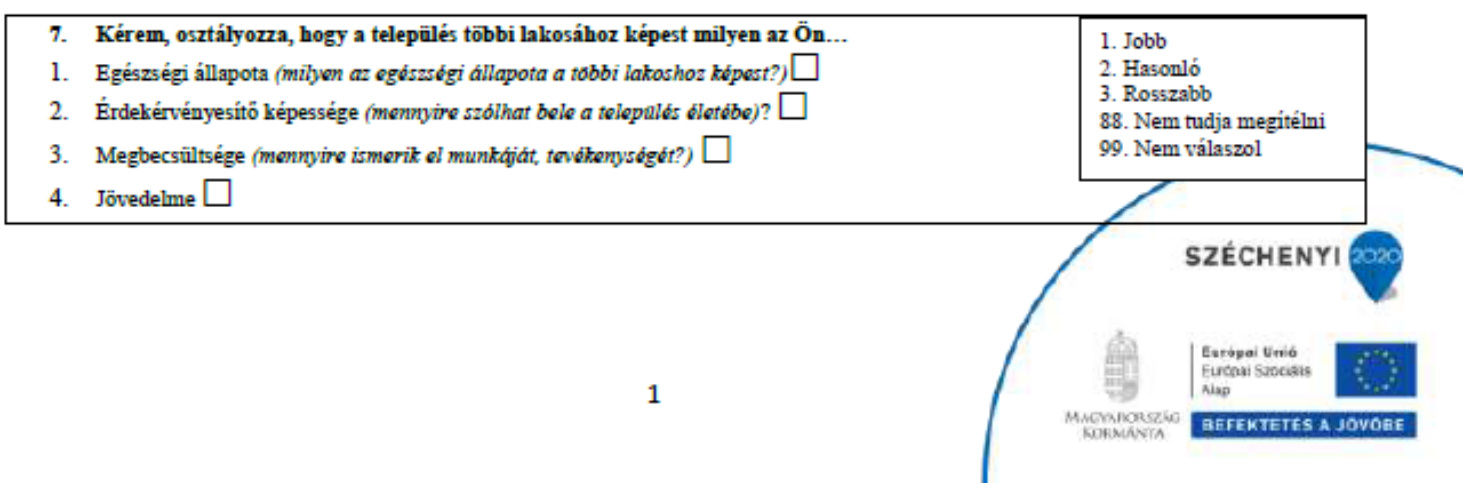


8. Véleménye szerint megfelelỗ volt-e lakosok informálása a belvízelöntés(els) alatt a teendổklkel, védelsezéssel kapcsolatban?

1. Igen, mindig megfelelöen tájékoztatnak 13.1. Ha nem, aldkor miért?

2. Igen, de sok dologról nem tudunk

3. Nem

88. Nem tudja megítélni

9. Véleménye szerint Ön kapott-ẹ elegendō pénzt a károk enyhítésére? 1. Igen

10. Véleménye szerint megfelelô volt-e a környezeti, természeti kár felszámolása a katasztrófa után?

1. Igen

2. Nem

12.1. Ha nem, alklsor miért?

88. Nem tudja megítélni

11. Véleménye szerint megfelelô, igazságos volt-e a lakosok kártalanitása a katasztrófa után?

1. Igen

2. Nem

88. Nem tudja megítélni

13.1. Ha nem, alklkor miért?

12. Hallott-e olyan emberelkrôl, alkil a belvíz miatt másilk településre költöztelk?

\begin{tabular}{l|l} 
1. Igen & 15.1. Ha igen, aldror hová? (3 leggyakoribb telepuilés) \\
2. Nem &
\end{tabular}

88. Nem tudja

13. Érintette-e közvetlenül a belvíz az elmúlt években, vagyis egészsége, ingatlana, termófoldje, terménye megrongálódott, esetleg odaveszett?

1. Igen $\rightarrow$ 16.1. Érte-e egészséglvárosodás a belviz miatt?

1. Igen $\rightarrow$

16.1. Milyen jellegú károsodást szenvedett?

16.2. Érte-e leár az ön házát?

1. Igen

2. Nem 16.2.1. Milyen jellegü volt a kár?

16.2.2. Mennvi volt a becsült laír?

16.3. Hogyan értékeli jelenlegi életkörülményeit az elmúlt évelz belvízelöntései elōttibez képest?

$\begin{array}{lllll}\text { 1. Sokkal jobb } & \text { 2. Jobb } \quad \text { 3. Hasonló } & \text { 4. Rosszabb 5. Lényegesen rosszabb }\end{array}$

88. Nem tudom megitélni 99. NV.

16.4. Véleménye szerint a belvizelöntés hozzájárult-e, abhoz, hogy életliörülményei romoljanak?

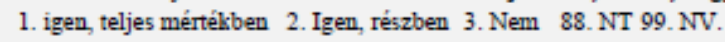

16.5. Érte-e kár mezōgazdasági földjét, terményét, liskertjét?

1. Igen $\longrightarrow 16.5 .1$. Ha igen, alklkor lkb. melklkora területet érintett?

2. Nem

16.5.2. Mennyi volt a becsült kár? (Ft)

16.6. Kapott-e támogatást, segitséget az újjáépitésnél/javitásnál?

1. Igen $\longrightarrow \quad 16.5 .1$. Ha igen, alklor milyen jellegú segítséget? (több válasz is megjelölhetô)

1. Pénzbeli juttatás

2. Épitési segítség munkaerôvel

5. Bútorokat, háztartási gépelet kaptam

3. Épitési segitség épitóanyaggal

6. Lelki segitséget és támogatást

4. Teljesen újjáépitették a házat

7. Egyéb:

99. NV.

16.5.2. Mennyire elégedett a kapott segitséggel? Kérem, osztályozza 1-5 skálán!

16.5.3. Kitōl kapott segitséget (több válasz is megjelölhetō)

1. Ōnkormányzattól

2. Államtól

3. Karitatív szervezettōl

4. Vörös kereszttõl

5. Egyháztól

6. Család, rokon, barát, ismerốs

7. Egyéb:

88. Nem tudja

99. NV

2. Nem $\longrightarrow$ 16.6.4. Miért nem kapott?

99. NV. 
14. Alktivan tagia-e valamilven civil szervezetnek? 1. Igen, többnek is 2. Igen egynek 3. Nem 88. NT 99.NT

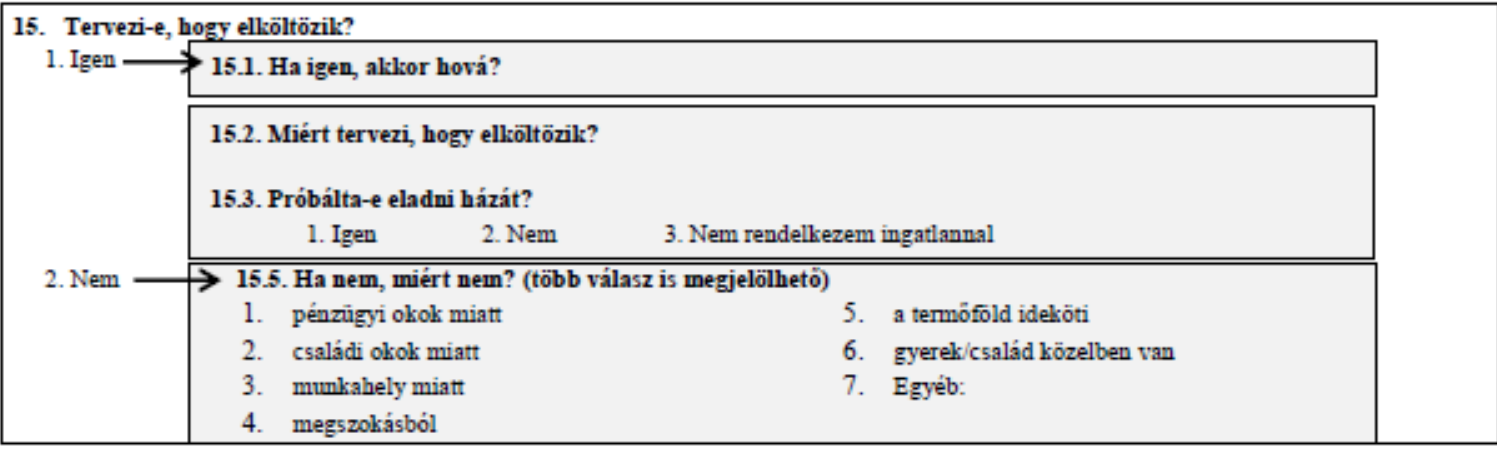

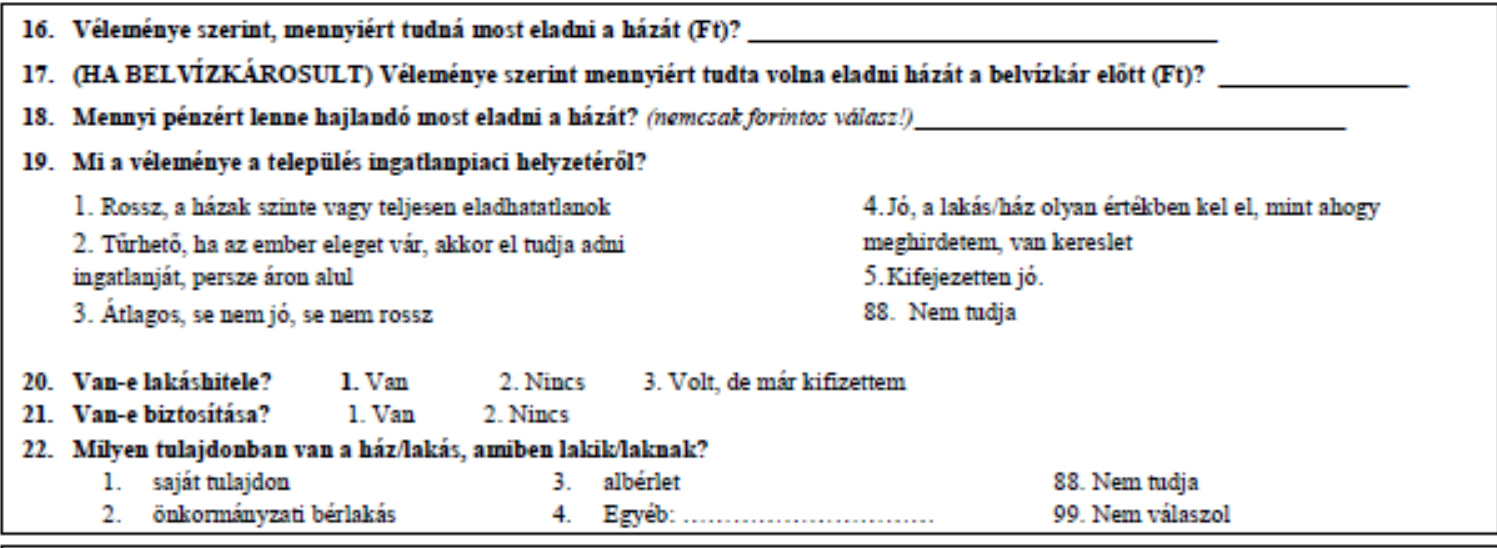

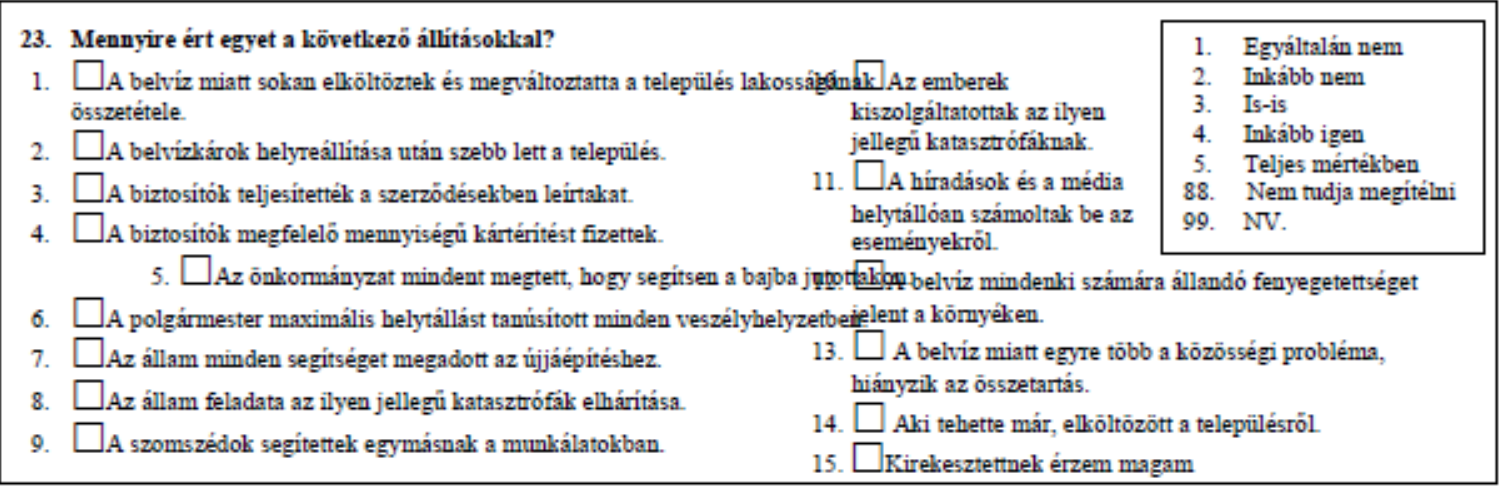

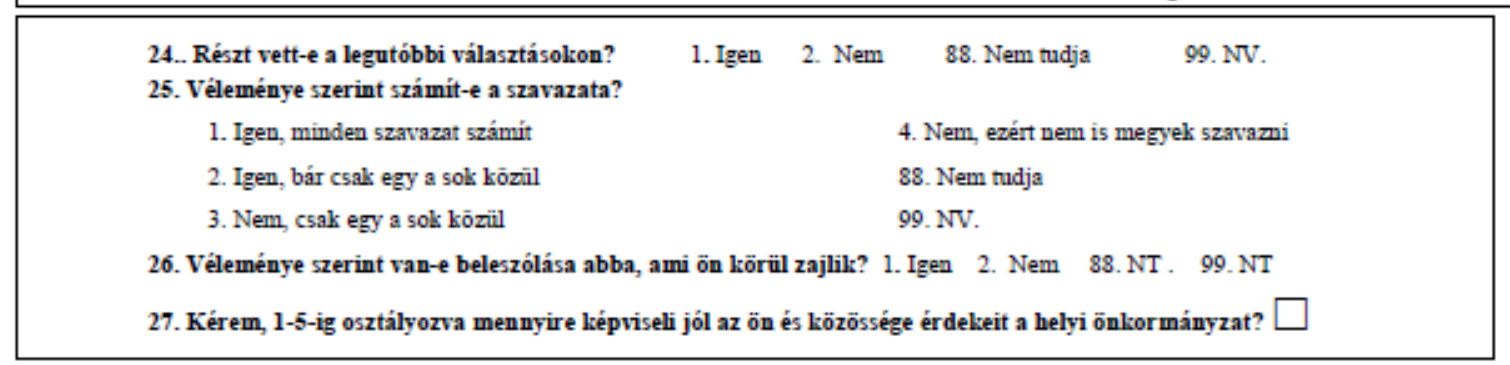




\section{$\underline{\text { Személves kérdések }}$}

\begin{tabular}{|c|c|}
\hline 28. A válaszadó neme: $\quad$ 1. Férfi $\quad 2$. Nö & \\
\hline 29. Melyik évben született Ön? $\square \square \square \square$ & 99. NV. \\
\hline 30. Mi az Ön legmagasabb iskolai végzettsége? & \\
\hline 1. 4 osztály vagy annál kevesebb (elemi) & 6. fóiskola \\
\hline 2. 8 osztály & 7. egyetem \\
\hline 3. $5 z a k$ mmunkás & 8. Egyéb: \\
\hline 4. szakiskola & 99. NV. \\
\hline 5. gimnázium & \\
\hline
\end{tabular}

\begin{tabular}{|c|c|c|}
\hline \multicolumn{3}{|c|}{ 31. Van-e jelenleg munkahelye? } \\
\hline $\begin{array}{l}\text { 1. Van }- \\
\text { 2. Nincs }\end{array}$ & $\begin{array}{l}\text { 31.1. Mi a munkalköre neve? } \\
\text { 31.2. Melyilk településen? }\end{array}$ & \\
\hline 99. Nem válaszol & $\begin{array}{l}\text { 31.3. Ha nincs, akkor mely állitások igazal önre? } \\
\text { 1. } 3 \text { bónapnál kevesebb ideje mumkanéllküli } \\
\text { 2. Tartósan, } 3 \text { hónapnál tôbb ideje munkanélküli } \\
\text { 3. GYES/GYED } \\
\text { 4. Nyugdijas }\end{array}$ & $\begin{array}{l}\text { 5. Nem mumkaképes } \\
\text { 6. Diák } \\
\text { 7. Egyéb } \\
\text { 99. NV. }\end{array}$ \\
\hline
\end{tabular}

32. Mennyi pénzbổ gazdálkodil az ön családja egy átlagos hónapban (figyelembe véve a szociális juttatásolkat, maszelsolást, ösztöndijat, melyeket a háztartásban élölk összesen keresnelk)? $\square . \square \square \square . \square \square \square$ Ft $\quad 99$. NV.

33. Összesen hányan élnek egy kasszán? $\square \square$ fo 99 . Nem válaszol

34. Hány liskorú (18 év alatti) él önölkkel egy háztartásban (közös kasszán)? $\square \square$ fó 99 . NV.

35. Hány eltartó van a családban (munkahelyen pénzt keres)? $\square \square$ fo 99 . Nem válaszol

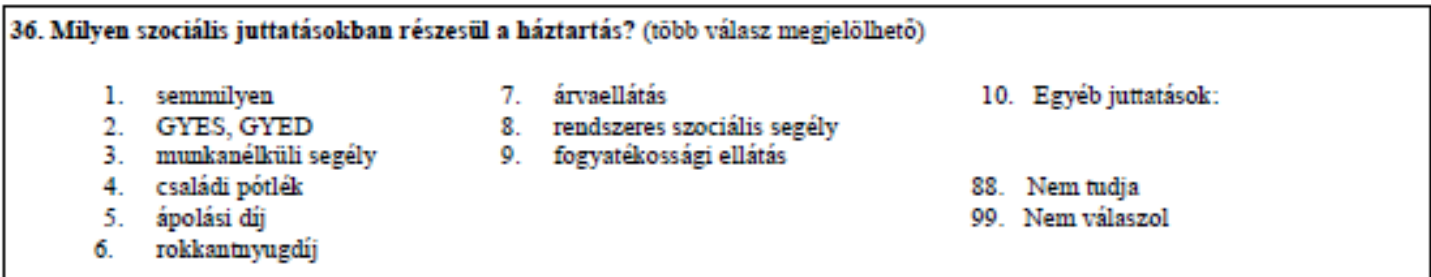

44. Ön milyen nemzetiségünel tartja magát? $\quad 99$. Nem válaszol

45. Ön szerint lia a felelốs a belvíz miatt?

99. Nem válaszol

\section{Köszönjük a segítségét!}

Bồvebb információ: Nagy Gyula +3630-424-3214 


\section{A felméréseknél használt randomszám-táblázat}

\begin{tabular}{|c|c|c|c|c|c|c|c|c|c|}
\hline \multirow[b]{2}{*}{$k=$} & \multicolumn{9}{|c|}{ minden $\mathbf{k}$-adik } \\
\hline & 2 & 3 & 4 & 5 & 6 & 7 & 8 & 9 & 10 \\
\hline & 2 & 2 & 6 & 5 & 8 & 8 & 2 & 8 & 6 \\
\hline & 1 & 4 & 3 & 3 & 1 & 11 & 3 & 10 & 4 \\
\hline & 3 & 3 & 6 & 3 & 9 & 3 & 9 & 9 & 12 \\
\hline & 1 & 4 & 6 & 3 & 2 & 9 & 5 & 9 & 12 \\
\hline & 2 & 3 & 6 & 7 & 4 & 9 & 7 & 5 & 1 \\
\hline & 1 & 4 & 1 & 8 & 7 & 7 & 13 & 14 & 14 \\
\hline & 2 & 5 & 3 & 6 & 11 & 5 & 4 & 7 & 16 \\
\hline & 3 & 4 & 5 & 4 & 1 & 2 & 2 & 8 & 17 \\
\hline & 3 & 2 & 3 & 5 & 5 & 3 & 1 & 15 & 15 \\
\hline & 2 & 4 & 7 & 4 & 4 & 8 & 6 & 12 & 6 \\
\hline & 2 & 4 & 5 & 1 & 5 & 11 & 13 & 15 & 2 \\
\hline & 2 & 2 & 1 & 3 & 9 & 1 & 7 & 5 & 2 \\
\hline & 2 & 4 & 6 & 4 & 6 & 6 & 13 & 15 & 3 \\
\hline & 2 & 2 & 7 & 5 & 7 & 6 & 8 & 15 & 18 \\
\hline & 2 & 5 & 3 & 4 & 3 & 4 & 14 & 7 & 4 \\
\hline & 3 & 3 & 6 & 3 & 4 & 7 & 3 & 13 & 12 \\
\hline & 3 & 3 & 6 & 2 & 7 & 9 & 12 & 3 & 16 \\
\hline & 1 & 4 & 3 & 5 & 7 & 9 & 13 & 16 & 16 \\
\hline & 2 & 5 & 5 & 4 & 7 & 10 & 5 & 5 & 10 \\
\hline & 2 & 2 & 1 & 2 & 5 & 12 & 10 & 2 & 3 \\
\hline & 1 & 2 & 6 & 6 & 8 & 8 & 6 & 11 & 12 \\
\hline & 2 & 3 & 1 & 8 & 11 & 10 & 15 & 6 & 4 \\
\hline & 3 & 2 & 6 & 5 & 1 & 6 & 14 & 11 & 15 \\
\hline & 2 & 1 & 5 & 2 & 1 & 9 & 3 & 14 & 7 \\
\hline & 1 & 2 & 1 & 6 & 11 & 3 & 14 & 4 & 4 \\
\hline & 2 & 3 & 5 & 1 & 9 & 3 & 4 & 7 & 8 \\
\hline & 2 & 2 & 4 & 2 & 8 & 8 & 8 & 11 & 1 \\
\hline & 1 & 4 & 3 & 8 & 11 & 12 & 9 & 2 & 15 \\
\hline & 2 & 4 & 7 & 2 & 8 & 4 & 2 & 4 & 9 \\
\hline & 3 & 2 & 4 & 4 & 3 & 8 & 6 & 7 & 12 \\
\hline & 1 & 1 & 6 & 2 & 10 & 12 & 6 & 8 & 7 \\
\hline & 2 & 2 & 6 & 9 & 8 & 3 & 7 & 4 & 11 \\
\hline & 3 & 2 & 1 & 3 & 5 & 9 & 15 & 12 & 7 \\
\hline & 2 & 4 & 6 & 5 & 9 & 6 & 4 & 17 & 18 \\
\hline & 3 & 5 & 3 & 8 & 7 & 7 & 5 & 15 & 11 \\
\hline & 2 & 4 & 2 & 1 & 5 & 5 & 14 & 15 & 19 \\
\hline & 2 & 5 & 4 & 6 & 7 & 13 & 12 & 2 & 17 \\
\hline & 3 & 1 & 3 & 9 & 2 & 7 & 4 & 14 & 17 \\
\hline & 3 & 3 & 7 & 3 & 7 & 9 & 11 & 2 & 17 \\
\hline & 2 & 2 & 4 & 6 & 2 & 11 & 1 & 6 & 5 \\
\hline & 2 & 5 & 6 & 8 & 9 & 12 & 12 & 11 & 13 \\
\hline & 1 & 4 & 6 & 6 & 2 & 7 & 2 & 8 & 16 \\
\hline & 3 & 5 & 6 & 1 & 2 & 9 & 5 & 5 & 12 \\
\hline átlag: & 2,1 & 3,2 & 4,4 & 4,5 & 6,0 & 7,5 & 7,7 & 9,0 & 10,4 \\
\hline
\end{tabular}

